


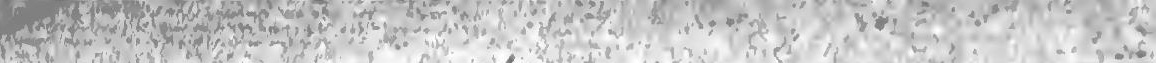

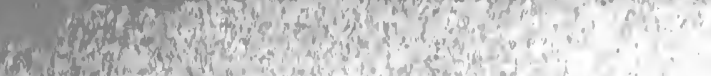

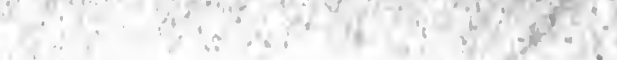
11 (1)

1.

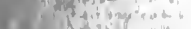

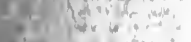

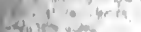

1.:

nith

.

and

$x$ 



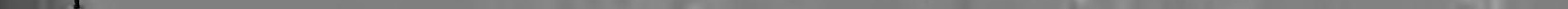





\title{
THE ADMINISTRATION OF DEPENDENCIES
}

\author{
A STUDY OF \\ THE EVOLUTION OF THE FEDERAL EMPIRE, \\ WITH SPECIAL REFERENCE TO AMERICAN \\ COLONIAL PROBLEMS
}

BY

JV5110 Sy-001 ALPHEUS H. SNOW

G. P. PUTNAM'S SONS NEW YORK AND LONDON Tbe Iknickerbocker $\mathbb{D r e s g}$ 1902 


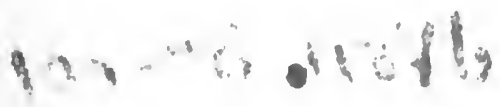

Copyright, igoz

BY

G. P. PUTNAM'S SONS

Published, September, rgoz 


\section{PREFACE}

$\mathrm{T}$

HE study here undertaken was suggested by a conversation two years ago, on the problems arising from the recent acquisition of our Insular Possessions, in which it was emphasized that there is one clause of the Constitution of the United States-the clause by which Congress is given power "to dispose of and make all needful rules and regulations respecting the territory or other property belonging to the United States"-to which the Supreme Court has never attached a definite and certain meaning. Believing that the authors of the Constitution, in framing that instrument, almost simultaneously with the enactment, by the American Congress, of an ordinance for the administration of the Northwest Territory as a dependency of the American Union, must have intended the only clause on this subject to express the true principles of the administration of dependencies, as they believed them to be, I attempted to ascertain the correctness of this belief.

The inquiry necessitated a careful examination of the issues of the American Revolution, and, as a knowledge of the theory and practice of the administration of the American Colonies is essential to the understanding of these issues, my investigation extended back to the inception of the American Colonies in I584. As a result of the inquiry, I found my belief fully corroborated-the clause in question in fact containing a statement of the principles of the administration of dependencies in a Federal Empire. I then examined the American, British, and European theory and practice from the adoption of the Constitution until the present time, to discover to 
what extent the principles embodied in the clause had been recognized and followed, and what the result had been. The whole inquiry thus became a study of the evolution of the Federal Empire-a form of political organism which, though commonly believed to be of modern origin, was in fact more clearly understood by our Revolutionary leaders than by any other statesmen before or since their time, and which was recognized by them as being not only necessary and proper, but also beneficent in its operation, and hence desirable, for America as well as for other States.

A. H. S.

Washington, May, Igo2, 


\section{CONTENTS}

CHAPTER

INTRODUCTION

PAGE

I. French Administration, I600-I787 . . II

II. English Administration, $1584-1606$ • 24

III. The American Charter of i606 . • . 36

IV. Imperial Councils, I606-1625 • • • 49

V. Imperial Councils, I625-I750 • • . 66

VI. Imperial Nomęnclature, I625-I750 • . 9I

ViI. The American Constitution of i750 • • ili

VIII. Realm OR EMPIRE, 1750-I765 • • • I 28

IX. The Stamp ACt Congress, i765 • • . I5I

X. Plans of Setţlement, I765-I767 . . . . I69

XI. Imperial Unity, I768 • • • • • • I9I

XII. The Imperial Secretariat, i768. • . 208

XIII. America's Position Criticised, i769 • • 224

XIV. Realm,一NOT EMPIRe, I769-1774 . • . 24I

$\mathrm{XV}$. The Federal Empire Defined, 1774 • . 26I

XVI. America's Ultimatum, I774 • . • . 280

XVII. British Propositions, 1775 . . . . 294

XVIII. The Final Issue, I775-I776 . . . . 318

XiX. The American Empire Planned, 7776 . 350

XX. The American Empire Declared, i778 • 374

XXI. The Dispositive Power, I779-1783 • . 400 
$\mathrm{vi}$

Contents

CHAPTER

PAGE

XXII. The Regulative Power, I783-I 787 • • 419

XXIII. The Imperial Power, I787 • • • • 445

XXIV. European Administration, i787-1902. $\quad 474$

XXV. British Administration, i780-r902 • 498

XXVI. American Administration, i787-igo2 • 537

XXVII. Imperial Obligations . • • • $\quad 57 \delta$ 
THE ADMINISTRATION OF DEPENDENCIES 



\section{THE ADMINISTRATION OF DEPENDENCIES}

\section{INTRODUCTION}

C OVERNMENT may be conceived of either as the expression of the popular will or as a science. Regarding it as the expression of the popular will, there are no principles which determine the decision of its problems other than those which are commonly accepted as such by the people, and each question, as it arises, is to be decided by the light of such ordinary knowledge and capacity for reasoning as the people may happen to have at the moment when the decision is to be made. Regarding government as a science, the problems which arise are decided according to principles which can only be ascertained by study and experience, and which, if properly applied, will lead to a right, as distinguished from a wrong solution. In this view, the depositary of governmental power is required to bring to each problem a knowledge of historical and economic facts and of social, political, and economic principles, a faculty for scientific and judicial investigation, and a trained capacity for reasoning.

Government so constituted that the depositaries of governmental power are persons of ordinary common sense, without expert knowledge and experience, is popular government. Government so constituted that 
the depositaries of governmental power are qualified to decide the problems by expert knowledge, investigation, and reasoning, and actually do so decide them, is expert government.

Popular government implies an absence of conditions concerning the manner of action. No such conditions are possible in the nature of things. A body of men elected to express the will of the people of the State acts necessarily after deliberating concerning facts which are of common knowledge among the people. The power exercised is absolute power, and the persons subject to popular government are subject to mere human will.

Expert government necessarily implies a condition imposed by the people relating to the manner of the exercise of the power granted by them to their governmental agents. The condition is that the depositaries of governmental power shall exercise their power according to the political and economic necessity in each case, as that necessity shall be determined by expert knowledge and scientific investigation.

Popular government is abominable in theory, being a government "by men, not principles," and hence a form of slavery tempered only by the fact that each individual is supposed to participate in his own mastery; but it works well for some purposes, because it encourages each individual to interest himself in the government of the State and calls into play individual initiative. Expert government-government "by principles, not men" -is ideal in theory, but the frailty of man makes this form of government impracticable, and it has the disadvantage of discouraging individual initiative.

The possibility of the government being wholly popular or wholly expert exists in every kind of State. A monarchical State, with which, perhaps, the idea of expert government is usually associated, may be under popular or expert government according as the monarch 
habitually reflects the will of the people or exercises his power according to the expert knowledge of himself and his advisers. A republican and democratic State may evidently be under either popular or expert government, according as its elected depositaries of power habitually bring to the decision of all governmental problems the common knowledge and ability and a purpose to merely reflect the will of the people, or an expert knowledge and an ability for scientific investigation. What is true of the monarchical and republican State is plainly also true of the oligarchical State. Nor does it make any difference whether the power of the governmental agencies is centralized or decentralized - the depositaries of power may plainly either reflect the will of the people or may act expertly. In the Federal State, where the people, by their written Constitution, divide the supreme power between the Central Government and the Governments chosen by the Member-States, all these Governments may evidently either reflect the will of the people or may act expertly. Nor does it make any difference whether the spheres of governmental power within which the governmental agencies in the State act are definitely limited by written Constitution or are left with indefinite limits under an unwritten Constitution; - the depositaries of power in either case may either reflect the will of the people or may act expertly. In determining whether their governmental agents shall be obliged to reflect the popular will or shall be obliged to act expertly, the people of each State are actuated by considerations wholly separate and apart from those relating to the form of government which they may have chosen to adopt. The condition that all governmental action shall be based on expert knowledge and investigation will be omitted or imposed by them according to the theory as to the nature of all government which prevails among them. If they regard government as merely the expression of the popu- 


\section{The Administration of Dependencies}

lar will, they will omit the condition; if they regard it as wholly or in part a science, they will impose the condition.

As matter of fact, no States do commit themselves wholly to the theory that government is the expression of the popular will or wholly to the theory that it is a science. They recognize that it is not exactly either the one or the other, but is a combination of both-that although there are principles, they are never capable of exact application, and that their application must vary to some extent according to the common will and sentiment of the people to whom they are applied. The efforts of modern statesmanship are directed therefore toward preserving the two conceptions in the State side by side, and towards providing instrumentalities according to which the conclusions arrived at by examining from each standpoint each question as it arises may be formulated and the one conclusion used to correct the other. Hence in the modern State, by its Constitution, written or unwritten, conceived of as emanating from all the people of the State, the Government is divided into two parts or branches, one of which is so organized as to reflect the will of the people and the other so organized as to decide questions of government expertly. By one or the other of these two great branches of the Government, in the last analysis, all the powers of the State, of whatever kind, must be exercised.

The people of a State may require those two branches to be related to each other in any way they see fit. The powers of government may therefore be divided between these two agencies, so that they are independent coagents, each having a distinct sphere of action. The legislative power-the power of changing the law, - the judiciary power-the power of interpreting the law,and the executive power-the power of executing the law,-may thus be divided between the two branches so 
that the popular branch shall be the Legislature and Judiciary and the expert branch the Executive, or so that the popular branch shall be the Legislature and Executive and the expert branch the Judiciary, or so that the popular branch shall be the Executive and the Judiciary and the expert branch the Legislature; or so that the expert branch shall be the Legislature and the Judiciary and the popular branch the Executive, or so that the expert branch shall be the Legislature and the Executive and the popular branch the Judiciary, or so that the expert branch shall be the Judiciary and the Executive and the popular branch the Legislature. The last is the usual arrangement.

The people of a State may also divide the governmental power among their governmental agents on the principle that the one of the two branches shall exercise all the powers of government-legislative, judicial, and executive - and the other shall superintend it. All powers of government may thus be conferred on the expert branch of the Government, and the popular branch may superintend; or all powers may be conferred on the popular branch and the expert branch may superintend; or a part of the powers of government may be conferred on one branch subject to the superintendence of the other and the other powers remain divided so that each branch as respects them is independent of the other.

The superintendence may occur in many different ways -by advice given before the act or after the act is formulated and before it becomes final, by negativing the act, by re-examining the whole subject and making a new decision, by refusing money supplies necessary to carry out proposed action, or by impeaching and removing from office the official who has performed, or who threatens to perform, the act disapproved by the superintending body.

Though it is said that the popular branch of the Gov- 
ernment of the modern State is independent of the expert branch, and vice versa, this is in fact never the case, but each exercises some supervision over the other. The expert branch, though having no legislative power, advises the popular branch concerning proposed changes to be made in the law and refuses to recognize such changes if after careful interpretation they conflict with the fundamental law which the people have made unchangeable by the Legislature. The popular branch controls the Executive by impeachment, and by refusing to supply money by taxation. Division of powers between the popular and the expert branch and mutual superintendence are equally interwoven in the Constitutions of modern States.

A State is a person, having a body and personality composed of specific lands and the populations inhabiting them. As respects these specific lands and populations, the power of the State is undoubtedly to be classified in the usual manner as legislative, judicial and executive. But the lands and populations which constitute the body and personality of the State are not the only lands and populations over which it may exercise power. It is a fact that the State may and does exercise power over lands and populations which are not, and cannot, in the nature of things, be a part of the body and personality of the State, and that it may be in a permanent relationship to these lands and populations of such a kind that it must exercise power over them permanently. External lands and populations may be recognized, by the State, as States foreign to itself, with which it may contract; and it may, therefore, recognize itself as under an implied contract by which it is obligated to the external populations which are permanently under its control. Under such express or implied contracts, the State may be obligated to render permanent services to these populations. Such services may be of any kind whatsoever, and do not necessarily involve the doing of acts which can be cer- 
tainly described as either legislative, judicial, or executive acts of the State. In the performance of such functions, the agents of the State are not changing the law of the State, nor interpreting it, nor executing it. They are wielding the power of the State as if the State were a person. They represent the State, as a political person, in the performance of services towards another State, as a political person. The acts of the State done in the performance of those services are all legislative, judicial or executive acts, but they are legislative, judicial or executive acts done not by the State for itself, but by the State for another State. As all agencies of the State belong either to the popular or the expert branch of the Government, the State, in performing such services, necessarily acts either through the popular or the expert branch exclusively, or through one superintended by the other.

All lands and populations subject to the power of a State, but not so related to it that they form by common consent an integral part of the body and personality of the State, which are called the dependencies of the State, are, therefore, capable of being viewed, in their relations to the State, in two different ways. They may be regarded as mere prolongations of the soil of the State, and its powers over them may be regarded as mere extensions of the legislative, judiciary and executive powers of the State. In this view, all inherent political personality of the dependencies is denied. They are not States, but mere extremities of the body and personality of the State, in which the heart-action of the State is less strong than at the centre. They may also be regarded as States distinct from and external to the State. In this view every dependent population within specific territorial limits determined by the natural circumstances and conditions is regarded as, by the nature of things, a State, whether it has the capacity to establish and the power to 
maintain a distinct Government for itself as a State, or not. On this conception, it is evident that the theory that the power exercised is a mere prolongation or extension of the legislative, judicial, and executive power as it is exercised by the State within itself is not applicable. The State does not exercise its power directly upon the individual inhabitants of the dependencies. There is an intervening personality - a State - between the State and each individual inhabitant of the dependencies, and the State substitutes itself, by its own will or by contract express or implied, for this intervening personality, and exercises within the dependency the legislative, judicial, and executive power in substitution for this personality.

It is even possible to go so far in regarding dependencies as naturally States, as to regard the State as acting within the dependencies wholly by their permission. Such a permissive power is plainly different in character from the legislative, judicial, and executive powers which the State exercises within itself.

A State and its dependencies, in whatever light the latter are regarded, constitute, according to the accepted public law of the civilized world, an Empire. The old conception of an Empire as a Kingdom composed of Kingdoms, and of an Emperor as a King who rules over other Kings, is passing away, and in its stead has come the conception of the Empire as a State composed of distinct and often widely separated populations or States, of which a State is the Central Government or Emperor. The State so acting as the Central Government or Emperor-whatever may be its inner constitution, whether monarchical, oligarchical, republican, whether federal or unitary-is called the Imperial State. The study of the administration of dependencies is in fact, therefore, the study of the form and nature of the modern Empire.

The problem of the administration of dependencies in- 
volves, first of all, reaching a definite conclusion on the point whether dependencies are prolongations of the soil of the State, or whether they are, in the nature of things, within territorial limits determined by natural circumstances and conditions, States in permanent relationship with the State. Even if it be granted that they are States, it must be settled whether they are in a noncontractual or a contractual relationship, and if in a contractual relationship, whether under an implied or an express contract. If it shall be concluded that dependencies are essentially States in a permanent contractual (that is, federal) relationship with the State, the question will arise whether the power which the State exercises over its dependencies is in its essence strictly legislative, judicial, or executive, or a power distinct from, though inclusive of, all these powers, and whether the power can best be exercised by the popular or the expert branch of the Government of the State, and in what manner the one should act and the other superintend. If it shall be concluded that the administration of dependencies is a kind of governmental work which can be best performed through the expert branch of the Government under the superintendence of the popular branch, it will be necessary to consider the form which the instrumentalities of expert Government must take, in order to best fulfil the functions and obligations of the Imperial State.

This requires a study of the whole administration of dependencies by States from the time that the personality of States began to be recognized and it was possible to distinguish between the State and its dependencies,that is, from the beginning of the seventeenth century. Starting at this point, it is necessary to select out of the multitude of acts and documents those which have, by the common consent of the successors of the actors of them, had an effect in formulating opinion concerning the relationship of the State to its dependencies and 


\section{ıo The Administration of Dependencies}

concerning the character and extent of its power over them; and to study these acts and documents in the light of modern political science. France and England furnish the earliest examples of States consciously recognizing themselves as legal and political persons, and as such entering into a permanent relationship with external dominions and countries and endeavoring to maintain the relationship unbroken. The experience and thought of these States, therefore, naturally demand first attention. 


\section{CHAPTER I}

FRENCH ADMINISTRATION, I6OO-I 787

DOR eight centuries before the French Revolution, the $\mathrm{King}$, in exercising the supreme power, stood, according to the theory of French jurisprudence, in a fiduciary relation to the people, being regarded as under an obligation to decide problems of government scientifically and judicially. No written Constitution had ever been dreamed of. No system of popular elections was considered desirable. Yet there was, until the seventeenth century, at least, a good and orderly government. France was a great nation and successfully governed throughout a great domain until the middle of the eighteenth century.

Vicomte d'Avenel, in his Richelieu et la Monarchie Absolue, published in 1895, speaking of the Constitution of France during the period of the traditional monarchy, - from 987 to 1620 , - quotes with approval the saying of Bodin in his treatise De la République, published in I 580:

The royal or legitimate monarchy is that in which the subject obeys the laws of the monarch and the monarch the laws of nature, leaving to the subjects their natural liberty and their private property.

Vicomte d'Avenel, in the course of his remarks on the way in which these principles were worked out during the traditional monarchy, says:

The relationship between the King and the subject differed from that between lord and vassal, in that the King was the 
only lord in France who made oath to his vassals. . . There were in France sovereign laws, which were supreme over the power of the King, and according to which he was obliged to direct his political life; in his private life, the King was only a private citizen before the proper courts.

The fundamental laws of the Kingdom were nothing but legal usages, which were binding on the monarchs themselves. Whether written or unwritten, whether enacted by a previous King or deriving their force from tradition only, these laws were regarded as unchangeable. "They have been observed for so long," says Seyssel, in 1519, in his book La Grande Monarchie de France, " that the Kings do not undertake to interfere with them, and when they wish to do so, no one obeys their commands." . . . Although the King possessed the legislative power, nevertheless if he saw fit to change, by edict, certain ancient arrangements (dispositions) ratified by public opinion, he was reproached with having violated the laws of the State, as if the consecration of time had given them an indestructible force. This regard for tradition appears incessantly in the writings and public discourses of the period. Under Louis XIII. [from I610 to I643, during which time, under the influence of Richelieu, the traditional monarchy ceased to exist except in theory], writers and public speakers were in the habit of citing freely, as authorities, the acts, the charters, or the bulls of the first Capetian Kings, and even those of earlier date. In the books, when a subject was examined, the author went back to the times of the Greeks and Romans. . . . In the matter of taxation, the right of the King was remarkably limited. The States-General not only discussed the necessity of the aide, but also determined the manner in which it should be levied and collected. . . . The principle that taxes are not legal except by consent of the people who pay them was violated more than once before the time of Louis XIII., but it had not ceased to be recognized even then. It was the doctrine of Old France. Every one knows what happened later on, but no one, in those old days, could have imagined the "taillable et corvéable à merci" of Louis XIV. 


\section{French Administration, I600-I 787 I 3}

From the beginning of the Capetian monarchy, we observe two distinct kinds of legislative acts of the King; one relating to the domains of the King, in which he speaks in his own name; the other relating to the whole of France, emanating from the united action of the King and Barons, - often even from that of the King and the people. . . . Seyssel thinks that "it is necessary the important affairs of the Kingdom should be consulted upon by a Council of personages drawn from the different Estates, both ecclesiastical and secular." Bodin regards it as less dangerous to have a bad King, guided by a good Council, than a good King, guided by a bad Council.

Throughout the existence of the traditional monarchy, the King acted by the advice of expert counsellors, some of whom acted as his Ministers.

During this period, this theory of government became crystallized in the French language, and the study of the words they used to express the exercise of the supreme power is, in fact, a study of the unwritten Constitution of France. The two words which expressed the exercise of the supreme power were the verbs ordonner and disposer. Of these the latter was the more strictly generic, though the former was used also in a generic sense. The Grand Vocabulaire François of 1770 treats the words as synonymes, defining ordonnance (ordinance) as a disposition (disposition).

Vattel, writing of the general public law in 17.58 , in his great work, The Law of Nations, said of the power of the state:

Le pays qu'une nation habite . . . est l'établissement de la nation; elle y a un droit propre et exclusif.

Ce droit comprend deux choses: I. Le domaine, en vertu duquel la nation peut user seule de ce pays pour ses besoins, en disposer et en tirer tout l'usage auquel il est propre. 2. L'empire, ou le droit du souverain commandement, par lequel elle ordonne et dispose à son volunté de tout ce qui se passe dans le pays. 


\section{I4 The Administration of Dependencies}

A translation of which is:

The country which a nation inhabits . . . is the establishment of the nation; in this country it has a proprietary and exclusive right.

This right includes: 1 . The domain, by virtue of which the nation may exclusively use the material resources of the country for its needs, may dispose of them, and may draw from them every kind of utility which pertains to them. 2 . The empire, or the right of supreme command over persons, by virtue of which it orders and disposes, according to its will, of the whole intercourse and commerce of the country.

Every act of the depositary of the supreme power in a State, therefore, according to Vattel, whether it relates to the partition of the soil or other arrangements concerning it, or to the use by the State of private property for public uses, or to grants of governmental authority over persons, or to the control of the action of persons by legislative action, was properly described, in 1758 , by the expression " $a$ disposer de" - " to dispose of."

Vattel's definition of the right of the depositary of the supreme power in the state is called " classic" by the editor of the great French Encyclopædia of Law (Dalloz, Répertoire de Législation, de Doctrine, et de Furisprudence).

The verb disposer (our word " dispose") and the expression disposer de (our expression " dispose of ") carried with them the idea, brought over from the Latin word " dispono," of conforming things to a certain order in the ends of propriety and justice, and implied that in each case there was some orderly and proper course of action, as contradistinguished from all other possible courses, and that the person who " disposed of " the particular case occupied himself with ascertaining, either from expert knowledge or by a new investigation, the orderly and proper course, and, having discovered it, applied it in the particular case. His action was called a 
" disposition of " the matter. He " disposed of " problems of motion or action; he " disposed" things or actions by setting them in their proper order.

The word disposer and the expression disposer de were, therefore, those which were peculiarly appropriate to express the exercise of supreme power which was required by the Constitution to be exercised expertly. They had no reference to the extent or the sphere of the power. The sphere or extent might be small or great, with specific limits or with indefinite. If the power within the sphere of action was exercised expertly, it was regarded as disposition. Distinguished from disposition was législation, which implied the making of commands according to the mere will of the depositary of the supreme power-that is, without the recognition of any condition as to the manner of the exercise of the power. The word juridiction was more commonly used to describe supreme power exercised by way of disposition, and quite properly, when the literal meaning of the word"the declaring of the right in the particular case"-is considered. The supreme power exercised within the state was spoken of as juridiction, as distinguished from the supreme power exercised outside the state and with reference to international questions, which was called souveraineté. The word juridiction was used to express the exercise of the power, the word disposition to describe the power itself. The King in exercising the power of disposition was said to have juridiction over the land and things concerning the transfer of which, and the persons concerning the actions of whom, disposition was made.

The French for many centuries past have commonly used the expression les dispositions des lois, where we should say "the provisions of the laws." Doubtless both expressions are relics of the conception of the moral obligation attached to the exercise of the supreme power requiring that it shall be exercised not according to mere 
will, but according to principles carefully ascertained and properly applied.

Although the legislative acts of the King, as compared one with another, were classified as ordonnances, which were fundamental laws or laws of great importance, édits (edicts), which were acts of ordinary legislation to meet changing circumstances, and déclarations (declarations), which were interpretations or explanations of existing laws, they were all called, as distinguished from the acts of subordinate officers and tribunals, ordonnances. All acts of subordinate officers and tribunals were called réglements (regulations). Dispositions made by the King usually related to matters of public concern, while those made by subordinate officers and tribunals usually related to matters of private concern-that is, directly affected individual life, liberty, or property. Hence, in process of time, the acts of the King relating to matters of private or particular concern came to be called réglements; and thus the acts of the King became divided into two kinds, ordonnances and réglements.

The power of disposition of the King extended, of course, to everything that was recognized as within the power of the State. The King, therefore, "disposed of" what Vattel called "the domain" and "the empire" of the State. Dispositions of the domain were the partition of unoccupied land for the purpose of settlement and determinations of the right of partition or ownership of settled lands; and, as the domain included the power not only over the land, but of every product or division of the land, the disposition of it included power over all private property exercised by way of seizure for public use (expropriation), or for the support of the government (taxation). Dispositions of the empire were the partition of governmental power over the actions of persons to officers, tribunals, and subordinate governments of municipalities and administrative districts. The Local 
Assemblies were called Parlements (Parliaments), Cours (Courts), or Conseils (Councils), and were consultative and advisory bodies only, with the right to offer criticism, remonstrance, or protest against any proposed disposition by way of ordonnance or réglement before registering it on their journals, but not to obstruct the execution of a law after the King had heard and acted upon the remonstrance.

The power of the King over the dependencies seems never to have been doubted, and it was considered to be subject to the same moral obligation as in France itself. Thus, M. Emilien Petit, writing in 1778 , when the question as to the character and extent of the power of the metropole over its dependencies was the burning question of the day, carefully refrains, in his Dissertations sur le Droit Public des Colonies Françoises, Espagnoles et Angloises, from claiming unlimited and unconditional power for the King, but contents himself with specifying what the King may do in the dependencies. He says:

The government of the French colonies is entirely in the hands of the King. To his Majesty belongs the command of the military and naval forces; the nomination of local administrators, governors and intendants; the choice ofjudges and provision for them; the fletermination of the respective powers of officials; the defence and protection of the colonies; the power to cause their inhabitants to dwell together peaceably and religiously; the maintenance of their governments; the security of their commenes the reformation of fudgments rendered by administrati sef cials or by local councils; and the power of ordaining or permitting the levy of taxes.

These objects of the exercise of the sovereign authority by our Kings are announced to the colonists by the regulation of $167 x$, by the edict of 1674 , and by subsequent laws regarding the administration and government of the colonies, derived from these two ordinances.

The Constitution and laws of France were regarded as in force in the dependencies except in so far as they were 
rendered inapplicable by the local circumstances and conditions. The King, in his expert management of the dependencies, took care to see that this principle was enforced, and the difficulty and delicacy of the problems growing out of the adjustment necessitated by the application of this principle were fully recognized-the greatest statesmen of the time giving their personal attention to the subject. Richelieu and Colbert, for instance, during the seventeenth century, devoted a great part of their eminent abilities to the solution of colonial problems, with the result that the connection between France and its colonies was kept harmonious, that the relationship was at the same time profitable to it and beneficial to them, and that France attained to a high position among the powers of Europe.

In the beginning of French colonization, this process of adjustment between France and its dependencies was clearly apparent. The original French colonizing schemes took the form of the creation of companies by royal ordinance for the purpose of transporting persons to the region to be colonized and developing its resources, the consideration for their agreement to transport being the grant of large tracts of land which they were at iberty to sell to the colonists. The companies were legally located in France and were as much subje to the Constitution, laws, and customs of France in carrying on their business as were any other corporationsen the Realm. From the necessities of the case, they given jurisdiction over the soil, things, and persons the colony, sufficient to enable them to keep order and to protect the settlements from attack. Sometimes a representative of the $\mathrm{King}$ in the colony was provided. The revenue from the mere sales of land proving inadequate, theme was soon granted to these companies the monopoly of buying the products of the colonies and of selling them in France. From these grants of the privileges of government 
and of monopoly, these companies were called " privileged companies" (compagnies privilégiées).

The charters, and hence the privileges, were usually granted for a term of years, and at the expiration of the term the King was at liberty to resume the powers granted or to grant them again on the same or other conditions, so that, from time to time, adjustments were made in which the respective interests of France and the dependencies were considered.

Later, when the monopolies began to grow very valuable, and the colonies began to complain of enriching private individuals when the services of protection for which they were demanding tribute were really performed by the French Government, the charters were not renewed on their expiration, and the French Government substituted itself to all the rights and obligations of the colonizing company and took the whole disposition of the property and affairs, formerly administered by the company, into its hands. Thus, after this change, there was still no question but that the Constitution, laws, and customs of France were in force in the colonies to the extent that they were not rendered inapplicable by local circumstances and conditions. The theory of the French Government that all governmental power was to be exercised expertly and scientifically stood France here in good stead. The adjustments and readjustments between the French Constirion, laws, and customs on the one hand and the local om umstances and conditions on the other were made judiciously and advantageously. The chief need of the colonies was physical protection against outside interference, not only from the native tribes, but from civilized foreign States. The cost of such protection was much more than it would have been had the colony been an integral part of France. The method of collecting payment for such protection by process of taxation which prevailed in France was impracticable for 
many reasons, and so it was considered equitable that this extra expense should be compensated for by indirect taxation by way of imposts. Certain obligations were therefore imposed on the dependencies calculated to return to France indirectly this extra expense. The trade between France and its dependencies was treated as coasting trade and obliged to be carried in French vessels, thus allowing the French ship-owners to make an extra profit. The manufacturing by the colonists of their raw materials was forbidden, and this manufacture was required to be done in France, thus giving French manufacturers an extra profit in this way, and the colonists were forbidden to buy anything which could be manufactured in France except from the French manufacturers, thus giving them a profit in another way. The colonists were obliged to sell all their products in France, and the whole French people thus enabled to derive a profit by the saving in price over that which it would have been had the colonists been able to sell in the dearest market; but, in order that the colonists might have the best chance possible in the French market, they were given an advantage with their products over foreign States by differential duties imposed against the foreign products.

All this complicated adjustment, necessitated by the fact that the Constitution, laws, and customs of France regarding taxation were inapplicable by reason of the local circumstances and con thens, was given the name of "the colonial pact" (le pacterolonial). Because it was a system of mutual restrictions to some extent, and because it involved the doing of something on the one side and the doing of something on the other in return, the arrangement has some of the outward form and appearance of a contract, but it was never inferred from this resemblance that the powers of France over its dependencies were rights growing out of a treaty or an express contract between them. The "pact," so-called, was really the 
recognition of a mutual obligation growing out of an established relationship. The expression, "the colonial pact," implied that the mutual restrictions and obligations were such as arose from the definition of the terms of the relationship, and grew out of the balancing of the respective interests of the parties-the Constitution, laws, and customs of the Imperial State on the one side against the local circumstances and conditions of the dependencies on the other.

The principle of "the colonial pact" was evolved by France after a long and extensive experience in the administration of dependencies. The French Colonial Empire of the seventeenth century was as wonderful for its day as is the British Empire for the present time. Between 1603 and 1664 , privileged companies were organized for the colonization of Canada, Acadia, Sumatra, Java, Molucca, the East Indies, Madagascar, Guinea, and Africa. Between 1664 and 1718 , similar companies were organized on expiration of the former charters, for colonizing and exploiting the East and West Indies, Senegal, Guinea, Acadia, San Domingo, the Hudson's Bay region, China, and Canada. Many of these ventures came to nothing, but, on the other hand, some succeeded. In I750, the Colonial Empire of France included Canada, Acadia, Louisiana, several islands in the West Indies, Guiana, Senegal, and a number of islands near Africa and Australia. The French Colonial Empire of $\mathrm{I} 750$ is said to have included a region four million five hundred square miles in extent.

A theory developed out of this enormous and diversified experience by a State having so just and moderate a conception of the character and extent of governmental power is certainly deserving of serious and careful consideration. When closely examined, it is to be noticed that by the use of the word " pact" to describe the bond between France and its dependencies, it was necessarily 


\section{The Administration of Dependencies}

implied that the dependencies were legal and political persons-that is, States-distinct from the State of France, since a pact, like every other form of contract, necessarily implies two persons, as parties to the contract, each of whom is capable of contracting. It was implied in the whole expression, "the colonial pact," that the terms of the relationship were such that the stronger party recognized itself as under a moral obligation to the weaker party to see that the relationship was on the same terms as if they had been equal in strength, though it was to judge what such terms ought to be. The conception of the relationship between France and its dependencies as one arising out of a "pact " was therefore a conception of the dependencies as States in a federal union with the State of France.

According to this theory, there existed an implied contract between the Imperial State and its dependencies, which determined the relations between them, and according to which the Imperial State agreed to render services for the dependencies in the way of physical protection and political guidance, and they agreed to pay for those services by means of restrictions on their trade and commerce for the benefit of the Imperial State. Just what services were to be rendered, and just what payment was to be made for the services, the Imperial State determined, but in making such determinations or dispositions, it consulted the wish of the dependencies and regarded their interests.

It has often been claimed that the theory of "the colonial pact" was invented as a means of covering up oppression of the dependencies by France. It seems, however, that it was rather the conception of a wise statesmanship, which foresaw that remote and scattered dependencies could not in the long run be held by force, and that they must be regarded as being to some extent political persons, or States, in a relationship with France. 
resembling a federal union.

As the French Colonies developed to a point where their populations were capable of expressing their will in an organized manner, they were given the right to have Local Councils, of the same kind as those of the Provinces of France itself, whose advice was carefully considered by the King and his Council before any acts of the King became final.

The same author from whom we have quoted above, M. Émilien Petit, in his Droit Public ou Gouvernement des Colonies Françoises, published in I77I, gives many examples of French colonial charters and commissions in which the duty of the colonists to observe the ordinances and regulations of the King and the judgments of the courts in accordance with the custom (common law) of Paris is stated, but in which it is recognized that the local circumstances and conditions of the colonists are entitled to be considered. He shows that where colonies were given the right to have Local Councils, these Councils had the right of remonstrance against ordinances or regulations proposed by the $\mathrm{King}$, of substantially the same kind as the Local Councils or Parlements of the Provinces of the Realm, one of the grounds of remonstrance permitted being "that the proposed law would cause inconvenience."

The great part of the French Colonial Empire was lost in the war with England between 1756 and 1763 . French India became British India and French Canada became British Canada in 1756 and 1757 , and the conquests were secured to Great Britain by the Treaty of 1763 -Louisiana passing by cession, at the same time, to Spain. The loss of the Colonial Empire was due to the weakness of France itself caused by the denial to the people of the expression of the popular will which had been allowed under the traditional Constitution, and was not in the least degree due to the theory or practice in the adminis- 
24 The Administration of Dependencies

tration of its dependencies. French colonists were loyal to France and French methods in India were adopted by the British. The underlying principles of "the colonial pact" were sound. Colonies connected with France by "pact" occupied a dignified position in the political world. As to them, France was a State to some extent foreign, which was their Sovereign, under obligation to protect and guide them by its ordinances and dispositions, but at the same time under obligation not to act except as might be necessary for these purposes. 
ENGLISH ADMINISTRATION, I584-I606

$\mathrm{W}^{\mathrm{1}}$

ILLIAM THE CONQUEROR, in 1066, brought with him into England the French theory of governmental power. In his coronation oath, he promised among other things:

To rule over the whole people subject to him justly and with royal providence: to enact and to preserve right law, and strictly to forbid violence and unjust judgments.

. By this oath, he recognized that the power which he exercised was conditioned and limited, and that it was exercised under a supreme law which it was his duty to adjudicate and execute.

In the course of a century and a half, Anglo-Saxon influence had predominated, and King John claimed that the power which he exercised was unconditional and unlimited, and that there was no law except his will. Magna Charta, granted by him in 1215 , purported to be a gift of privileges from him to the people of England. The enumeration of the privileges granted was preceded by the following words of gift and conveyance :

We have granted moreover to all free men of our Kingdom, for us and our heirs forever, all the liberties written below, to be had and holden by themselves and their heirs from us and our heirs.

There was contained in this a repudiation of the theory that the governmental power, which the King then 


\section{6 The Administration of Dependencies}

exercised, was a power of ordinance or disposition. It was regarded as a power of commanding according to mere will. The people of England were regarded as subjects of the Government of England, except in so far as it had "granted liberties" to them.

This claim on the part of the King forced the people of Englard to combine against him for the purpose of extorting concessions from him. By I249, during the reign of Henry III., they had succeeded in having inserted in the enacting clause of all laws the statement that they were enacted "by the authority" of the Lords and Commons, as well as by their "consent," thus laying the foundation for the subsequent claim made by the Lords and Commons, and afterwards by the House of Commons, of absolute and unconditional power.

At the same time, the practice of the English monarchy in exercising governmental power continued to follow along the lines of the French monarchy. Though the King claimed unconditional and unlimited power, he acted, as did the King of France, by the advice of a Council composed of men expert in statecraft,called the Privy Council, who were in continuous attendance upon him, who enjoyed his closest confidence, and with whom he advised concerning every act of government. Acts of State done by the King by the advice of his Privy Council were called acts of the King in Council. The Privy Council of the King thus became opposed to the Great Council of the Kingdom, consisting of the House of Lords and the House of Commons, but the real issue was not changed nor greatly obscured by reason of the existence of the Privy Council and the House of Lords, and there was a continual struggle between the King and the House of Commons, each claiming to be the rightful Sovereign of England.

Queen Elizabeth's policy was to recognize the House of Commons as an existing and necessary institution, to 
endeavor to ascertain the part which it ought to play in the Government of England as the representative of the people, and to confine it to the sphere of action to which she thought it properly belonged.

Her idea seems to have been that the Parliament (in which, though legally composed of King, Lords, and Commons, the House of Commons was the controlling factor) ought to have only the power to negative the acts of the King in certain cases. When the Speaker of the House demanded, as usual, liberty of speech for the Commons, she replied that liberty of speech they should have, but that that liberty consisted in the privilege of saying yes or no. She admitted that the Parliament had the supreme power with respect to changing the law, but claimed that it could not initiate legislation and could only negative legislation proposed by her. She also admitted that the House of Commons had full control over the supplies.

The Parliament of Elizabeth's time was therefore essentially a popular assembly with strictly limited powers. The Queen exercised certain powers to the exclusion of Parliament, both because it was recognized that these powers could be better exercised by an expert body than by a representative body elected by the people, and because Elizabeth, by her remarkable personality and ability, had succeeded in establishing a modus vivendi between herself and the House of Commons, by which, in consideration that she admitted that they had a power for certain specific purposes to supervise, and negative her acts, they agreed for all other purposes to leave the whole government in her hands.

Perhaps no English monarch brought out more clearly than did Queen Elizabeth the distinction between the King, as the expert part of the Government-the Crown -and the Parliament, as the popular part. Under this conception, the King, in his official capacity, was the 
depositary of all governmental power, except that which had been appropriated by Parliament or surrendered by Charter. Though Elizabeth recognized that Parliament had appropriated to itself the power of changing the laws and of raising money, and that under Magna Charta the King was bound by the judgments of his Judges given in causes in which the private rights of individuals were involved, she, like all her predecessors, considered that all powers which Parliament had not expressly claimed and insisted upon were vested in her, as the Crown or Head of the English State. As Parliament had never claimed the right of disposition of the public lands of the State, she regarded herself as holding the title to all lands discovered, ceded, or conquered, as trustee for the State, with full powers in the matter of disposing of them.

England of the days of Elizabeth was not without its experience in managing an Empire. Jersey and Guernsey had been dependencies of England at least since the reign of King John (1215), and had been treated as States having their own internal life over which England exercised such power as was thought necessary through the King, who was represented in the Islands by a Governor appointed by him. It had exercised power at various times over many of the French and German States and Provinces as the result of conquest. The power thus exercised resembled rather a military occupation and had not been treated as permanent. Ireland had been a dependency since 1495. During the period from I495 to I 584 the affairs of Ireland had been administered by the King in Council, but Parliament had not invariably held its hand. While it does not appear to have ever attempted to enact specific legislation applicable only in Ireland, it had in some cases made some laws effective both in England and Ireland.

When the question arose of colonizing America, Queen Elizabeth did not hesitate to take the position that this 
was a subject within her power to regulate by royal charter. It was recognized as being the function of the King to grant charters of incorporation to inhabitants of the Realm, to grant by charter the lands belonging to the State, and to wield the external power of the State in pursuance of treaty or for redress of wrong done by foreign States. In the Charter which Elizabeth granted to Sir Walter Raleigh for Carolina in 1584 , she recognized the supremacy of the statutes of the Realm, but she regarded herself as having the exclusive power over the whole subject of the disposition of the lands and populations in America which might by discovery or conquest be brought within the power of England. The Charter gave Raleigh the title to the lands he should discover and occupy and the power of governing them. The provisions having reference to the political relationship between England and the countries so discovered and occupied were as follows:

And for uniting in more perfect league and amity such countries, lands and territories, so to. be possessed and inhabited as aforesaid, with our Realms of England and Ireland . . . we do by these presents grant and declare that all such countries, so hereafter to be possessed and inhabited as aforesaid, shall henceforth be of the allegiance of us, our heirs and successors.

We, for us, our heirs and successors, are likewise pleased and contented, and by these presents do give and grant to the said Walter Raleigh, his heirs and assigns forever, that he and they, and every of them, shall and may from time to time forever after, within the said remote lands, and countries in the way by the seas thither and from thence, have full and mere power and authority to correct, punish, pardon, govern and rule by their and every of their good discretions and policies, as well in causes capital or criminal as civil, both marine and other, all such our subjects as shall . . . at any time inhabit any such lands, countries or territories as aforesaid 
- . according to such statutes, laws and ordinances, as shall be by him, the said Walter Raleigh, his heirs and assigns, and every or any of them, devised or established for the better government of the said people as aforesaid, . . . so always as the said statutes, laws and ordinances may be, as near as conveniently may be, agreeable to the form of the laws, statutes, government or policy of England, and also so as they be not against the true Christian faith, now professed in the Church of England, nor in anywise withdraw any of the subjects or people of those lands or places from their allegiance to us, our heirs and successors, as their immediate Sovereign under God.

This Charter made Carolina a Province of England, under Raleigh as Lord Proprietor. The method of colonization thus employed was evidently an application of the method of disposition of the public lands which had been employed in England for centuries, according to which the King granted to those who had deserved well of the State such portions of the public lands as he tnought proper, with certain rights of lordship, and the inhabitants of the land became tenants of the Lord Proprietor, who was himself a tenant of the King-that is, of the State. The very full powers of government granted to Raleigh over the inhabitants of Carolina were evidently an extension of the powers (almost entirely judicial or military) of Lords Proprietors in England over their tenants, and were evidently given, from the necessity of the case, on account of the remoteness of the lands.

According to the theory of this Charter, the regions in America to be discovered and occupied were external to the State of England- "remote lands and countries"related to that State by a contractual and constitutional bond-a "union.". The power of both King and Parliament over the countries was taken for granted. The provision that Raleigh and his successors should make their statutes, laws, and ordinances "as near as con- 
veniently may be, agreeable to the form of the laws, statutes, government or policy of England" implied that the remote lands and countries were political entities distinct from the State of England, whose government was to be made as nearly as practicable like that of England. It was implied that England would not interfere with the inner life of these countries unless Raleigh and his successors failed to preserve a sufficient degree of uniformity. The power of England over the external life of these countries was regarded as based on the allegiance (that is, the contract) between the King and the individual inhabitants of the countries.

The question of the character and extent of the power which England might justly exercise over its various kinds of dependencies was much discussed between 1603 and 1607, when King James, as King of both England and Scotland, was trying to unite the two Kingdoms. The hostility among the common people of England to the Scotch was so great that the House of Commons would not agree to the Scotch having any more rights in England than the existing common law gave them. It was agreed that the common law gave no rights in England to any one born in Scotland before King James came to the throne of England-that they were aliens until naturalized by Act of Parliament. The question, therefore, concerned only those born after King James came to the throne, who were hence called the postnati. A great hearing was had in Parliament in 1603 , the eleven highest judges of England sitting as a tribunal, and members of the House of Commons arguing the case before them, some presenting the case from the standpoint of the law of nature and of nations, some from the standpoint of historical precedent, some from the standpoint of civil law, and some from that of the common law.

While the case was, of course, one of mere personal union through a common Chief Executive, as we should 
say now, that situation was not so apparent in those days, when the principles of the general public law were yet in process of formation; and in the arguments and opinions, the powers of the English Government over the dependencies were fully discussed, and it was agreed, both by the judges and the members of the House who acted as counsel, that the power of Parliament over the dependencies was the same as its power in England. In I607, a test case was made up, known as Calvin's Case, in which the same issues were raised. It was heard before all the high judges of England, under a practice which permitted all to sit in cases deemed of exceptional public importance, and the same ground covered in the argument and opinions, and the same conclusions reached.

While the Case of the Postnati and Calvin's Case did not, as has been seen, necessarily involve the question whether Parliament had power over the dependencies, yet, on account of the solemnity of the hearings, and the unanimity between court and counsel on that point, the matter was then finally settled as a part of the Constitution of England. Dependencies were defined to be " parcel of the Realm in tenure" which, after being merged in the Realm by union and incorporation, became " parcel of England in possession" or "parcel of the body of the Realm." " Parliament," it was said, might " make a statute to bind in [a dependency], if [the dependency] were specially named, but without special naming, it does not bind." In this statement, the Court recognized that a dependency, from its nature, demanded a special treatment by the State in the interests of the State itself; and a corollary from this was, of course, that Parliament might make special laws for the government of particular dependencies.

This statement was made with especial reference to Ireland, and with full consideration of the facts, which 
were mentioned by the Court, that Ireland did not send representatives to the English Parliament, and that it had its own Lords and Commons which constituted a Parliament with the King of England or his Deputy, " whereat they have made divers particular laws concerning that Dominion." The real point of the decision, though it is not very clearly expressed and can only be made out by inference, is that Scotland was either a petty kingdom subordinate to England, and subject to the will of Parliament, or was merely a foreign friendly State, and that no community external to England could ever be constitutionally related to England through the King except as a dependency,- - that equal or even unequal union with another state could be accomplished only by express and unmistakable Act of Parliament.

The power of Parliament over all the petty kingdoms and dominions belonging to England having been thus declared, by dictum of the highest judges of England, the power of the King was, by their dictum, declared to be as follows:

In the case of any Christian country under the dominion of England, to which the laws of England had been given by the King or by Parliament, the King could not "alter the laws" any more than he could "alter" the laws of England, in England. This merely meant that the King could not legislate contrary to the laws of England so given, but that he could legislate in any way not inconsistent with them.

In the case of countries (necessarily Christian) coming to the King by inheritance, the King could not " change" the laws of the country. "Change," in this connection, meant the same as "alter" - that he could not legislate contrary to them, but that he could legislate in any way not inconsistent with them.

In the case of a conquered Christian country, the laws of the conquered country remained until the King 


\section{The Administration of Dependencies}

changed them, which he might do at his pleasure. It was evidently considered unnecessary by the Court to say that the King in changing them would make them conform, as nearly as possible, to the laws of England.

In the case of a conquered infidel country, the laws of the conquered country were abrogated ipso facto by the conquest, " for that they be not only against Christianity, but against the law of God and of nature, contained in the Decalogue," and the King " by himself and such judges as he shall appoint, shall judge them and their causes according to natural equity . . . until certain laws be established amongst them," that is, until Parliament made a local code or until the conquered population organized themselves into a dependent State and established its own local laws. The use of the word " judges" to describe both the administrative and judicial officers in a dependency of inferior race and civilization is noticeable. It expressed the expert and judicial character of the power exercised by the King in the dependencies, and emphasized the judicial character even where the power was exercised for purely administrative purposes.

As the American Colonies were all dominions of England to which the laws of England had been given by their charters, the principle that the King could not legislate inconsistently with the laws of England so given to them, or afterwards given to them by Parliament by an Act in which they were specially named, was the only one of the principles announced in Calvin's Case which applied to them.

The Parliamentary hearing, called the Case of the Postnati, occurred just three years before the first American colonial charter was granted. Sir Francis Bacon was the leader of the counsel appointed by the House of Commons to argue the case before the Judges, and introduced the various counsel-among whom was Sir 


\section{English Administration, I 584-1606}

Edwin Sandys-who took the different parts in the argument. It was doubtless the careful consideration then given to the whole question of the relation of England to all the external communities related to it, which led Bacon to take such an interest as he did in the schemes for colonizing America, and which enabled Sandys to do his magnificent work as Treasurer of the Virginia Company. 


\section{CHAPTER III}

\section{THIE AMERICAN CHARTER OF I606}

\section{$\mathrm{T}$}

HE American Charter of 1606 , or the Virginia Charter, so-called, was a regulative act for two purposes; first, to grant to certain persons, who were to settle and reside in America and form there two political communities dependent upon Great Britain, —one to be called "The First Colony of Virginia" and the other "The Second Colony of Virginia" - the title to the land adjacent to their first settlements for a space one hundred miles square ; and, second, to establish a Central Council in England for the superintendence of the affairs of all the American dependencies, and a Local Council in each Colony to advise with the Governor of the Colony.

At the time this Charter was granted, everything was most favorable in England for the adoption of a just plan of colonial administration. King James had come to England from Scotland, and was trying to consolidate the two Kingdoms. English jurisprudence and politics were being studied by some of the most able and publicspirited men that England has ever produced, and the King was, at this time, acting on their advice. The Charter is said to have been drawn by Lord Chief Justice Popham, who was one of the most distinguished of the Chief Justices of the King's Bench. It doubtless was in part the product of the mind of Sir Francis Bacon.

Mr. Hugh Edward Egerton, in his History of the Colonial Policy of Great Britain, published in 1897, says that the Central Council established by this Charter was " a new Privy Council for Colonial Purposes." While 
this statement is correct so far as it goes, it does not fully state the character of this Council. The Privy Council was a purely consultative body - that is, it had, apart from the King, no powers of administration. Though there was nothing, and of course could have been nothing, in the Charter to prevent the King from treating the Central Council established by it as a merely consultative body and personally managing the affairs of the Colonies, yet, if he did not choose to do so, the Council could administer the affairs of the Colonies without his concurrence,-which the Privy Council, as such, or a committee of it, could not have done. It was therefore a new Privy Council for Colonial Purposes and more, -it was an Imperial Council and an Imperial Secretary of State. It was directly subordinate to the King, and had actual administrative powers subject to the King's visitorial and superintending power.

This Imperial Administrative Council, called "Our Council for Virginia," in contradistinction to the Council resident in each Colony for the purposes of local administration, which was called " the Council of the Colony," was thus described in the Charter:

There shall be a Council, established here in England, which shall consist of thirteen persons, to be for that purpose appointed by us, our heirs and successors, which shall be called our Council for Virginia; and shall, from time to time, have the superior managing and direction, only of and for all matters that shall or may concern the government, as well of the several Colonies as of and for any other part or place, within the aforesaid precincts of four and thirty and five and forty degrees above mentioned.

The Charter, by creating this Imperial Administrative Council, contained a recognition of the distinction between the functions of the King acting within the State, and his functions when acting for England as the Imperial 
State constituting the Head of the British Empire. The underlying thought was that the existence of colonies of England necessarily implied that England was related to them as their Imperial State; that the functions of the State acting upon communities or corporations outside itself were distinct in character from its functions when acting upon communities or corporations within itself ; and that the body of persons appointed to advise and act for the King in the performance of his duties as a part of the government of the State, when the State was fulfilling its functions toward communities and corporations within itself, ought to be distinct from the body appointed to advise him when the State was fulfilling its functions toward communities and corporations outside itself.

It is noticeable that this Imperial Administrative Council was not limited to the superintendence of the affairs of the two Colonies mentioned in the Charter, but was to have the superintendence of " any other part or place within the aforesaid precincts of four and thirty and five and forty degrees above mentioned "-that is to say, between the northern boundary of South Carolina as at present established, and the present city of Eastport, Maine, and extending westward to the Pacific Ocean. The power was large enough to place within the charge of this Council all the Indian tribes which should be conquered or should place themselves under the protection of England, and all settlements of foreigners which should be conquered or should submit to dependence on that State. Instead of being called "Our Council for Virginia,", it would more properly have been called "The Imperial Administrative Council in Charge of the Relations between England and the Dependencies in America."

By the King's Orders and Instructions of November 20, 1606 , the powers of the Council in England (called "the King's Council for Virginia") were thus defined: 
They shall have full power and authority, at the pleasure and in the name of his Majesty, his heirs or successors, to give directions to the Councils resident in America, for the good government of the people there, and for the proper ordering and disposing all causes within the same, in substance as near to the common law of England, and the equity thereof, as may be.

In these Instructions the word " dispose" is used with the word "order" as describing the power which the Council were to exercise " at the pleasure and in the name of "the King, - that is to say, to describe the power of the King.

It will be advisable, in view of the important part which the word "dispose" plays in the clause of the Constitution of the United States which relates to the administration of dependencies, and in the Acts of Congress preceding the adoption of the Constitution, to ascertain at this point the exact meaning of that word.

The word " dispose". was the word commonly used in the public acts of the time to express the exercise of governmental power which was held under a condition that it should be exercised expertly and according to just principles, just as the word disposer was the most appropriate in the French language to express the same idea. Contemporary examples of this use are the following :

For the handling, ordering and disposing of matters and affairs of greater weight and importance, and such as shall or may in any sort concern the weal public and general good of the said Company and Plantation, as, namely, the manner of government from time to time to be used, the ordering and disposing of the lands and possessions, and the settling or establishing of a trade there, or such like, there shall be held and kept every year . . . four Great and General Courts. (Charter of the Virginia Company of $16 \mathrm{Ir}_{\mathrm{s}}$ ) 
The said Governor and Assistants shall apply themselves to take care for the best disposing and ordering of the general business and affairs of, for and concerning the said lands and premises hereby mentioned to be granted, and the plantation thereof and the government of the people there. (Charter of the Massachusetts Bay Company of 1629 ; also Charter of Rhode Island of 1663 .)

The Commissioners shall have power and authority to provide for, order and dispose all things which they shall, from time to time, find most advantageous for the said Plantation. . . . Always reserving to the said Commissioners power and authority for to dispose the general government of that Plantation, as it stands in relation to the rest of the Plantations in America, as they shall conceive, from time to time, most conducing to the general good of the said Plantation, the honor of his Majesty, and the service of the State. (Charter of Providence Plantation of 1644 .)

The said General Assembly shall have full power and authority . . . to elect and constitute such officers as they shall think fit and requisite for the ordering, managing and disposing of the affairs of the said Governor and Company, and their successors . . . and to establish laws for the directing, ruling and disposing of all other matters and things, whereby our said people, inhabitants there, may be peaceably, civilly and religiously governed. (Charter of Connecticut of I662.)

The word " dispose" was peculiarly appropriate to express this idea, whether it be considered from the standpoint of its derivation or of its usage in general literature.

The first meaning of the word "dispose" is "to place apart," and,- -as placing things apart implies a purpose in so doing, - to dispose objects, physical or mental, soon came to mean to place them apart for the purpose of setting them in some predetermined order or arrangement. In military science, it is proper and usual to speak of disposing troops, or disposing of troops, so as to put them in a certain order or arrangement. The 
same usage continues at the present time in the science of architecture, where the arrangement of different parts of a structure with reference to each other is spoken of as the "disposition" of the different parts.

Of " disposition" the Century Dictionary gives for the first meaning " a setting in order; a disposing, placing, or arranging; arrangement of parts; distribution": as, " the disposition of the infantry and cavalry of an army; the disposition of the trees in an orchard; the disposition of the several parts of an edifice or of figures in painting; the disposition of tones in a chord or of parts in a score." As a very ancient example of this use, it quotes the following from Sir T. Wilson's Essay on Rhetoric (I 553):

"Disposicion is a certain bestowing of thinges, and an apt declaring what is meete for every part, as tyme and place doe beste require."

Dr. Johnson, in his great dictionary, published in I775, gives the following illustration of this meaning of "disposition" from Dryden (I680):

"Under this head of invention is placed the disposition of the work, to put all things in a beautiful order or harmony, that the whole may be of a piece."

From this meaning, of placing in a certain order or arrangement, the word " dispose" soon came to have the meaning " to regulate or govern in an orderly way; to order, control, direct, manage, command," as the new Oxford Dictionary informs us. This dictionary gives the following quotations, as illustrating the meaning: From Trevisa (1398): "Angels have under theym the orders of men, and ordeyne and dyspose theym." From Savile (I58I): "Otho disposed the affaires of the Empire." From Chapman (16I8): "They were such great fools at that age that they could not themselves dispose a family." From Milton (I667): "Be it so, since hee Who is now Sovran can dispose and bid what shall be right." From Hale (1677): " A regent principle, which 
may govern and dispose it as the soul of man doth the body."

One meaning of "disposition" given by the Century Dictionary is, "guidance and control; order; command; decree: as, the dispositions of the statute." It gives the following illustrations of this meaning: "I putte me in thy proteccioun, Dyane, and in thi disposicioun (Chaucer, I390); "Who have received the law by the disposition of angels" (Acts vii. 53); "Appoint (i.e., arraign) not heavenly disposition, father" (Milton, r67I).

Another meaning which the word " dispose" had, according to the Oxford Dictionary, was " to make arrangements; to determine or control the course of affairs or events; to ordain, appoint." Under this meaning is given the proverb, "Man proposes but God disposes," and also a quotation from Hall's Chronicles (I 548): "To dispose for the nedes of the foresaid realme."

Other examples of the use of the word with this meaning are :

"There were in these quarters of the world, sixteen hundred years ago, certain speculative men, whose authority disposed the whole religion of those times" (Hooker, 1595); and "Who hath disposed the whole world ?" (Fob xxxiv. I3).

The Oxford Dictionary gives as one meaning of " disposal," " the act of disposing things, or parts of a thing, according to some method, good or bad, or the state or manner of being so disposed; arrangement; order; distribution."

In the Century Dictionary one meaning given of "disposal," is, " regulation, ordering, or arrangement, by right of power or possession; dispensation." An example which it gives of this meaning is the sentence, "Tax not divine disposal " (from Milton, I67I). The same dictionary also gives, as another meaning of "disposal," "power or right to dispose of or control," and gives as an 
example: "Are not the blessings both of this world and the next in His disposal?" (Bishop Atterbury, I720).

The word "disposer" was recognized in English and American literature up to the beginning of the nineteenth century as the one which was peculiarly appropriate to characterize the Deity, thus being treated as a word most appropriate to signify the widest and most complete power, exercised for the ends of order and justice. The Century Dictionary gives the following examples of this use :

"Forget not those virtues which the great Disposer bids thee to entertain" (Sir Thomas Browne, 1646); "Leave events to their Disposer" (Boyle, I715).

Dr. Johnson, in his dictionary, as an example of this meaning of the word " disposer," gives: "All the reason of mankind cannot suggest any solid ground of satisfaction, but in making that God our friend, who is the absolute Disposer of all things." Other examples of this same sense of the word " disposer" applied to human beings, given by Fohnson's Dictionary and the Century Dictionary, are:

"Would I had been disposer of thy stars, Thou shouldst have had thy wish and died in wars" (Dryden, I665); " The Gods appoint him The absolute disposer of the earth, That has the sharpest sword" (Fletcher, I620).

Other examples of the same meaning in the derivatives " disposure " and " dispositive" are:

"In His disposure is the orb of earth, The throne of kings, and all of human birth," and: "They quietly surrendered both it and themselves to his disposure" (Sandys, $16_{30}$ ); " Whilst they murmur against the present disposure of things, they do tacitly desire in them a difformity from the primitive rule and the idea of that mind that formed all things best" (Sir Thomas Browne, I646); " W'ithout His eye and hand, His dispositive 


\section{The Administration of Dependencies}

wisdom and power, the whole frame would disband and fall into confusion and ruin" (Bates, I685).

Grotius, in his Peace and War (book i., chapter iii., sec. $2 \mathrm{I}$ ), says of the distinction between the words "to dispose " and "to command" (the translation being that of Rev. William Evats, made in I682):

Isocraies, commending that excellent conduct of the ancient Athenians, in the managing of their social wars, saith, that they took care for all, without intrenching upon the liberty of any. It is well worth our observation that what the Latins express by the word imperare, to command, the Greeks more modestly express by the word $\tau \dot{\alpha} \sigma \sigma \varepsilon \imath \nu$, to dispose or set in order.

The expression "dispose of " was used interchangeably with the verb " dispose." In this sense, as in the former, it was frequently coupled with the word " order." An example of the use of the expression " dispose of " in this sense is found in the preamble of the Fundamental Orders of Connecticut of 1638 , which read:

Forasmuch as it hath pleased the Almighty God by the wise disposition of his divine Providence so to order and dispose of things that we, the inhabitants and residents of Windsor, Hartford and Wethersfield are now cohabiting and dwelling in and upon the River of Connecticut and the lands thereunto adjoining; and well knowing, where a people are gathered together, the word of God requires that to maintain the peace and union of such a people there should be an orderly and decent government established according to God, to order and dispose of the affairs of the people, etc.

Also in the Charter of Rhode Island of 1663 :

The said Governor and Company shall have full power and authority . . . to direct, rule, order and dispose of all other matters and things, as to them shall seem meet, whereby our said people and inhabitants may be religiously, peaceably and civilly governed. 
Another example of this usage occurs in the Charter of the Province of Massachusetts Bay of 1691 :

We do give and grant that the said General Court or Assembly shall have full power and authority . . . to dispose of matters and things whereby our subjects, inhabitants of said Province, may be peaceably and civilly governed, protected and defended.

The preposition " of," in the expression " dispose of," evidently has the meaning of specifying the particular object of the act of disposing. The Oxford Dictionary calls attention to the fact that instances are found where the prepositions " upon" and "on" and also "with" are used with the word " dispose." To " dispose upon" something, or to "dispose on" something, would plainly mean, if used to-day, to adjudicate upon something for the purpose of determining the proper and orderly arrangement in regard to it and making the arrangement so determined upon. To " dispose of " something evidently has the same meaning. The Oxford Dictionary gives as the first meaning of the expression "dispose of," "to make a disposition or arrangement of; to do what one will with; to order, control, regulate, manage"; and, as an illustration of this meaning, quotes from Shakespeare, Henry $V$., iii., 3, 49: "Enter our gates; dispose of us and ours ; For we no longer are defensible."

The Century Dictionary defines " dispose of " as meaning " to exercise control over; direct the disposal or course of : as, "They have full power to dispose of their possessions." "As examples of this meaning it gives the following:

"The lot is cast into the lap; but the whole disposing thereof is of the Lord" (Prov. xvi. 33); "This brow was fashion'd To wear a comely wreath, and your grave judgment Given to dispose of monarchies" (Fletcher, 


\section{The Administration of Dependencies}

I622); "A planet disposes of any other which may be found in its essential dignities" (W. Lilly, I670).

In the original form of the word, " dispone," it was used both transitively and intransitively, and the word " of," when used with it, plainly meant " upon, respecting, concerning." This is evident from the two quotations from Chaucer, given by the Century Dictionary: "Syn God seth every thing, out of doutance, And hem disponeth through his ordinaunce" and: "Of my moble (i. e., belongings) thou dispone Right as the semeth best is for to done."

The conception of the King as the "disposer" of the affairs of the dependencies was the conception of him as the Imperial Judge and Ruler, under a condition to exercise his powers by expert advice according to just principles, and not beyond what the necessity, in each case, required.

In the Instructions occurs a clause in which the King declares his power in the dependencies to be superior and the power of Parliament to be supreme, which reads:

That as the Colonies shall, from time to time, increase in plantation, the King, his heirs and successors, will ordain and give such order and further instructions, laws, constitutions and ordinances as by them shall be thought fit and convenient: Provided always that they be such as may stand with and be consonant to the laws of England, or the equity thereof.

"Consonant to the equity of the laws of England" meant, of course, " not repugnant, but agreeable, as nearly as may be, considering the local conditions and circumstances."

Excellent as the Charter was in the respect that it assured the Colonies an intelligent fulfilment of the functions of the Imperial State toward them, it was objectionable because it did not admit any right in the Colonies to be treated as States for any purposes. It did 
not say that they had not this right, but simply left the whole matter indefinite. There was to be a Council in each Colony, but how these Local Councils were to be constituted or what their duties were to be was not stated. This was left to future determination by the King, presumably though not necessarily following the advice of the Imperial Administrative Council. These Local Councils were thus described:

Each of the said Colonies shall have a Council, which shall govern and order all matters and causes which shall arise, grow or happen, to or within the same several Colonies, according to such laws, ordinances and instructions as shall be, in that behalf, given and signed with our hand or sign manual, and pass under our Privy Seal of our Realm of England; each of which Councils shall consist of thirteen persons, to be ordained, made, and removed from time to time, according as shall be directed or comprised in the same instructions.

The Instructions, though so careful as to the powers of the Council in England, not only denied all statehood to the Colony, but required the colonists for five years to bring all their products into hotchpot, thus converting the Colony into a mere farm or factory, out of the product of which the colonists, as farmers or workmen, got their living merely. The Instructions did not specify what was to be done after the expiration of the five years. Not only was statehood and private property denied, but the President and Council were given powers without the limitation provided in the English Constitution, even jury trial being permitted only in certain specified cases.

This un-English system of local administration was naturally most galling to the colonists. They refused to allow the President and Council to carry out the Instructions, and a state of anarchy ensued. It was to these Instructions, which were a perversion of the Charter, and 


\section{The Administration of Dependencies}

not to the Charter itself, that the unpopularity of it was due.

This Imperial Constitution for the American dependencies, as it might be called, containing so many excellent ideas and capable of such good results had it been supplemented by Instructions securing to the colonists a just share in their own government, was revoked after being in existence only three years, and a new charter granted on entirely different principles. 


\section{CHAPTER IV}

IMPERIAL COUNCILS, I606-25

$\mathrm{T}^{\mathrm{T}}$

HE year 1606 marked the beginning of systematic colonization not only in Virginia, but in Ireland. After the rebellion in Ulster in 1605 , the whole Province was practically depopulated and confiscated to the Crown. This situation furnished an opportunity for the English to gain a new foothold in Ireland by colonization, and James, in his eagerness for his own aggrandizement, was not slow to take advantage of it. One of the persons who was consulted concerning the proper methods to be employed, or who at least felt at liberty to offer his advice, was Sir Francis Bacon. That it was acceptable is shown by the fact that the King appointed him Solicitor-General the next year. The advice so given is preserved in the form of a tract entitled Certain Considerations touching the Plantation in Ireland, which, though not dated, shows on its face that it was written after the Virginia Charter of 1606 had been granted.

In order to appreciate the purport of Bacon's advice, it is necessary to consider the methods of administration of the dependencies then prevailing. Ireland, the Channel Islands, and the Isle of Man, were each administered by the King in Council through a royal Governor assisted by a royal Council, with the concurrence of an Assembly representing the people. The Governor of Ireland was called the King's Deputy or Viceroy, it being thus recognized as a petty kingdom, that is, a State which had formerly been a Kingdom, but which was now a dependency, 
retaining its royal organization to some extent. Since 1495, when the law called Poynings' Law was enacted,so called because suggested by Sir Edward Poynings, the King's Deputy, upon his pacification of Ireland,-no Parliament could be held in Ireland without the King being officially informed of it, and no Acts could be introduced in an Irish Parliament without having previously received the approbation and license of the King under the Great Seal. The Irish Parliament was thus a merely deliberative and registering body, like the French parlements.

Sir Francis Bacon, after referring to the fact that the plan for the colonization of Ulster, which had already been partly formed, provided for a local Commission in that Province, suggested:

That your Majesty would make a correspondency between the Commission there, and a Council of Plantation here; wherein I warrant myself by the precedent of the like Council of Plantation for Virginia; an enterprise in my opinion differing as much from this as Amadis de Gaul differs from Cæasar's Commentaries. But when I speak of a Council of Plantation, I mean some persons chosen by way of reference, upon whom the labor may rest to prepare and report things to the Council of State here that concern that business. For although your Majesty have a grave and sufficient Council in Ireland, from whom and upon whom the Commissioners are to have assistance and dependence; yet that supplies not the purpose whereof I speak. For considering that upon the advertisements as well of the Commissioners as of the Council of Ireland itself, there will be many occasions to crave directions from your Majesty and your Privy Council here, which are busied with a world of affairs, it cannot but give greater expedition, and hence better perfection unto such directions and resolutions, if the matters may be considered of aforehand by such as may have a continual care of the cause. And it will be likewise a comfort and satisfaction to some principal undertakers, if they may be admitted of that Council. 
Bacon evidently here suggests the institution of a Permanent Commission, or "Council in England," for the affairs of Ireland, standing in the same relation to the King in Council as did a referee in chancery to the Chancellor, - that is, having the duty to ascertain and report the facts in each case of complaint or request from the colonists or any persons interested in the colonies, and their conclusions on the facts, for the information of the King and the Privy Council.

In this there would have been implied a criticism upon the plan of American government contained in the Virginia Charter of 1606 , had he not differentiated America from Ireland, since the "Council in England for Virginia" was, as has been said, in no sense a mere referee of the Privy Council, but was itself an Imperial Administrative Council,- - that is, a body with greater powers than the Privy Council, without the concurrence of the King, could exercise. That he did differentiate the case of America and Ireland shows his remarkable sagacity. Ireland was a dependency destined by nature for ultimate incorporation into the body of the Realm of England. America was a dependency destined by nature never to be so incorporated. The affairs of Ireland, though essentially affairs of the Empire, were so closely connected with the affairs of the Realm, that Bacon thought they should be managed by the King in Council assisted by a referee body. The affairs of America were strictly affairs of the Empire, and, as such, were, as he thought, properly in the hands of a Council separate from the Privy Council, and which could act in the first instance, subject to the superintendence of the King.

The kernel of the whole matter lay in the last sentence: "And it will be likewise a comfort and satisfaction to some principal undertakers, if they may be admitted of that Council." In order to appreciate this proposition, it is necessary to consider the circumstances under which 


\section{The Administration of Dependencies}

colonization, at that time, had to be carried on. Emigration was then a new idea, and when it was broached, the dangers of the enterprise deterred all except those persons of small means who were willing to undergo the risk in order to better their financial condition, or who were influenced by religious or missionary motives. Such emigration had to be encouraged by pecuniary assistance. King James had not money enough to pay for the luxuries he insisted upon having. The House of Commons could not be asked to grant taxes for colonization purposes,- to be expended, necessarily, under the King's supervision,-when it was already objecting to his requests for money. It was necessary, therefore, to adopt a plan which would attract private contributions. There were two classes of persons who would be likely to be interested in colonization,- - one made up of those who had capital to invest for the sake of profit, and the other of those who were willing to contribute for the public good or for religious or missionary reasons, without regard to return or profit. The character of colonial administration had, as it then appeared to Bacon, to be adjusted to the existing circumstances so as to allow capitalists and religious and missionary enthusiasts to share in it with the public authorities. This required that the enterprise should be partly private and partly public, and the form which naturally and inevitably suggested itself for the purpose was that of a guild or privileged private com. pany, the members of which, when it was organized for objects external to its own membership, were called " undertakers."

Although privileged private corporations are little known at the present day, being used almost entirely for colonizing operations in uncivilized regions, they were very common at that period, and their rights and status were well and even commonly understood. The guilds practically controlled the city of London. The accepted 
definition of a guild is, " a voluntary association for mutual protection, for common mercantile aims, or for religious worship." In the mercantile guilds of the fifteenth, sixteenth and seventeenth centuries, these three objects were combined. The characteristic of a guild was that it might admit or exclude any persons it saw fit. It was this characteristic which distinguished a guild from a municipal corporation. A guild could not exercise any jurisdiction outside its own membership except by way of protection of its members. By grant from the King or the Parliament, it could, however, receive any governmental privileges whatever, but it did not, by so doing, lose its power to admit persons to the freedom of the company and exclude persons from its freedom. The members of the guild were called "brethren" or "freemen"; its meetings were called "Courts." The officers were originally elective by the members, and were called by various names-the head officer being more usually called " the Master" and his Council being called "Wardens." The law-making body was composed of the Master and Wardens and representatives of the whole membership called "Assistants." The meetings at which all the guild-associates were present, as, for instance, for the purpose of election of officers, were called " the General Courts." The English mercantile and trading guilds organized for colonizing purposes were exactly like the French privileged companies which began to be formed at about the same time. Any governmental privileges conferred by royal charter to exercise jurisdiction beyond the membership of the guild were, in contemplation of law, held at the will of the King, and could be resumed by him at any time without his showing special cause, and the long continuance of the guilds in the use of these privileges did not interfere with the King's rights. It mattered not with how great governmental privileges they were endowed, they were essentially private 


\section{The Administration of Dependencies}

corporations and, in the exercise of their governmental privileges, were under the immediate control of the officers of the district, province, county, or municipality in which they were situated. They could exist without in. corporation, but could not hold real estate till they were incorporated.

The guild, endowed by royal charter with limited governmental privileges, was a convenient instrumentality for the management of colonizing operations which required the raising of money by private subscription, even when the freemen of the guild elected its presiding officer and board of directors, since, in case of contumacy or mismanagement, the King could immediately resume all the governmental powers which it held in trust. When the King appointed the board of directors of a guild, as James I. did whenever he could after his contests with the people began, his control over it was, theoretically, complete. The great London guilds succeeded in keeping the election of their governing boards in their own hands, in spite of all efforts to the contrary, for many years after the granting of the Virginia Charters.

When the Virginia enterprise was reorganized in 1609 , the new organization was, therefore, given the form of a guild. That this should have been done appears the more natural when it is remembered that the Virginia Company of 1609 and the Ulster colonization scheme of the same year were both, under the precept of the King, promoted and very largely contributed to by the London guilds, and that of the seven hundred and twenty-eight persons and corporations (among them Sir Francis Bacon) named as " adventurers" of the guild incorporated by the name of "The Treasurer and Company of the Adventurers and Planters of the City of London, for the First Colony in Virginia," fifty-six were London guilds.

The Charter of 1609 followed the usual form of guild 
charters. It created a private corporation, located in England, to own land and carry on farming and trading operations in Virginia. The Imperial Administrative Council and the Council in Virginia created by the Charter of 1606 were both abolished, as it was quite within the discretion of the King to do, since no private corporate rights had been created by that Charter. The whole enterprise, theretofore public, became essentially private, but with a public aspect.

It was, of course, entirely consistent with the management of the colonizing, trading, and missionary operations in Virginia being in the hands of a guild, that there should be a Council in England for Virginia, wholly public in its nature and distinct from the guild, though containing among its members " undertakers" of the guild; and this is evidently what Sir Francis Bacon meant when he recommended, in reference to the Ulster Colony, that "some of the principal undertakers" should "be admitted of "the Council in England for Ulster. The Charter of 1609 went beyond this, and provided a Council in England for Virginia which was wholly composed of " undertakers" in the enterprise.

The Board of Directors of the guild was composed of fifty-two persons and was called "Our Council for the Company of Adventurers and Planters in Virginia." It was appointed by the King and was self-perpetuating. All the members of the Council were adventurers in the Company - that is, those who held the Company's " bills of adventure." It was both a Board of Directors for the private Company and the Imperial Administrative Council in Charge of the Affairs of Virginia. Among the members of this Board were the Earl of Southampton, Sir Francis Bacon, and Sir Edwin Sandys. The Charter proceeded upon the assumption that there would be General Assemblies or General Courts of the whole membership of the Company which would control the Council in 


\section{${ }_{5} 6$ The Administration of Dependencies}

its legislative action, but made no special provision for the summoning of such General Courts.

The Company had power to admit or expel members, to refuse admission as freemen to any persons considered undesirable, and to exercise jurisdiction over those persons who were on the land granted to the guild and who were not freemen of the Company, as if they were its servants. The Charter, like those of the guilds of the Realm, proceeded on the assumption that the Company was subject to all laws of Parliament, all orders and regulations of the Crown, and all regulations of any municipal organization which should be instituted by the King or Parliament for the local government of the region in which the Company was allowed to carry on its operations. It was given power to govern the English colonists

according to such orders, ordinances, constitutions, directions and instructions, as by our said Council shall be established; and in defect thereof, in case of necessity, according to the good discretion of the said Governor and officers respectively; - . . so always as the said statutes, ordinances and proceedings, as near as conveniently may be, be agreeable to the laws, statutes, government and policy of this our Realm of England.

The Governor of the Colony appointed by the Council of the Company was given the powers of a Lord-Lieutenant in a county of England. The Council was still called "Our Council "- that is, the King's Council-and its acts were, therefore, theoretically, the acts of the King.

The system provided by the Charter of I609 proved an utter failure. The Council appointed by the King was ineffective and unsatisfactory to all concerned, and after a short time it became evident that another plan would have to be adopted.

The Virginia Charter of I6I I was granted partly in or- 


\section{Imperial Councils, 1606-25}

der to extend the jurisdiction of the Colony so as to include the Bermuda Islands, but principally because of the mismanagement of its affairs. The London guilds which were adventurers evidently insisted that the Company should be given the same powers of self-government as they had, and were successful, so that the freemen of the Company were given full power of managing all its affairs.

In the Charter of 16 I I, the words appropriate to guilds are uniformly used. Those who had become adventurers in the Company since the granting of the Charter of I609 were declared to be "brethren and free members of the Company." The business meetings of the Company were called "Courts," and these courts, as in the case of guilds, were divided into Ordinary Courts and General Courts. The Ordinary Courts were to be held as often as the Company might think proper, and to consist of the Treasurer, any five or more members of the Council, and any fifteen of the freemen of the Company. The General Courts were to consist of the Treasurer and all the freemen of the Company and were to be held four times a year on the next to the last Wednesday of the Hilary, Easter, Trinity, and Michaelmas terms, and to be called "The Great and General Courts of the Council and Company of Adventurers for Virginia." The Ordinary Courts were to have a superior jurisdiction, being granted power

"for the handling and ordering and dispatching of all such casual and particular occurrences and accidental matters, of less consequence and weight, as shall from time to time happen, touching and concerning the said Plantation."

The General Courts were to have a supreme jurisdiction, being granted power

for the handling and disposing of matters and affairs of greater weight and importance, and such as shall or may, in any sort, 


\section{$5^{8}$ The Administration of Dependencies}

concern the weal public and general good of the said Company and Plantation, as namely, the manner of government from time to time to be used, the ordering and disposing of the land and possessions, and the settling and establishing of a trade there, or such like.

The Company assembled in "General Court" was authorized :

To ordain and make such laws and ordinances, for the good and welfare of the said Plantation as to them, from time to time, shall be thought requisite and meet: So always as the same be not contrary to the laws and statutes of this our Realm of England.

In addition to this full grant of legislative powers over the Colony, the power of appointing the Governor and other officers to manage the local affairs of the Colony was taken out of the hands of the Council and vested in the Company assembled in General Court; so that the whole Company, so far as it was granted governmental powers, was the deputy of the King, for the time being, to administer both the English interest in the Colony and the Colony itself, subject to the right of the King to withdraw the commission at any time, and substitute another form of agency. Its "Courts" were "the Council in England for Virginia," the so-called "Council" of the Company being simply its Board of Directors.

The Colony in Virginia languished under the bad and arbitrary management of the "Courts" of the Company, abusing their powers as the de facto Council in England for Virginia, until I6I9, when Sir Edwin Sandys, one of the great lawyers and patriots of England, was elected Treasurer (i.e., President) of the Company. He was assisted by the equally public-spiritec and capable Earl of Southampton. By the influence of these two men and their friends in the Company, the Courts of the Company performed the functions of a true Council in England for 
Virginia, and a most satisfactory administration was given to the Colony. The functions of the Courts, as the Council in England, were separated from the functions of the Local Government and each confined to its proper sphere of action. The consent of the King was after a time secured to the admission of this principle, and on August 3, 1621, the General Court, by the King's consent, granted to the freemen of the Colony, then called burgesses, the right to participate by their Representatives in the management of the affairs of the Company, by an ordinance entitled "An Ordinance and Constitution of the Treasurer, Council and Company in England, for a Council of State and General Assembly." By this Ordinance, a Council of State in Virginia, appointed by the Company in England, was created, which was the Privy Council of the Governor. The Governor in Council was given full governmental powers except that he could not act contrary to the expressed will of either the General Assembly of the Colony, the General Court of the Company, the King in Council, or Parliament. The General Assembly, which consisted of the Governor, the Council, and Representatives from every " town, hundred or particular plantation," was the General Legislature of the Colony. It was permitted to hold only one session in each year, except on occasions of emergency, and was given full powers of legislation except that it could not act contrary to the expressed will of either the General Court of the Company, the King in Council, or Parliament.

This Ordinance did not purport to be granted under the terms of the Charter, but by special authority from the King- " by authority directed to us from his Majesty under the Great Seal." It was a strictly political instrument, having no characteristics whatever of a guild charter, and on its face negating the possibility of its ever being claimed to be such, since it included all inhabitants 
of the Colony, present and future. It was not only an Ordinance, but a Constitution, since it showed on its face that the arrangements which it made were intended to be permanent. It recognized the Courts of the Company as the Imperial Administrative Council for Virginia. The legislative acts of the Company were called "Orders of Court," following the practice when the Council for Virginia existed, the acts of which were called "Orders of Council." The most remarkable part of this Ordinance is, however, the arrangement by which, after the government of the Colony should be settled, no law or ordinance enacted by a Court of the Company was to be valid in Virginia unless ratified by the General Assembly of the Colony. As none of the acts of the General Assembly were valid unless ratified by a Court of the Company, this would have left matters, after the government was settled, so that the acts of the Courts of the Company - that is, the acts of the Imperial Council-would have been only co-ordinate in authority with the acts of the General Assembly of the Colony, consisting of Governor, Council, and Representatives, and so that all laws or ordinances would have had to be agreed upon by the General Courts of the Company in England and the General Assembly of the Colony in Virginia. In case of a dead. lock, the King would undoubtedly have been obliged to settle the matter by an Order in Council. The special authority granted by the King to the Company to enact this Ordinance, or Constitution, was, in effect, a complete alteration of the plan of administration laid down in the Charter of $16 \mathrm{I}$. It was practically a return to the plan of the Charter of 1606 , according to which there was to be an Imperial Administrative Council in England and a Local Administrative Council in Virginia. The differences were that the King, instead of insisting upon his right of appointing the Council in England, allowed the whole Company, composed of persons pecuniarily in- 


\section{Imperial Councils, I6o6-25}

terested in the Colony, to act as the Council, and that he renounced his claim of right to exclude the people of the Colony from a just share in their local government.

The connection with England was kept through the fact that the Governor and his Council were appointed there, and that the Governor had the veto power; and particularly by the following restriction upon the power of the Local Government:

The General Assembly shall have free power to treat, consult and conclude, as well of all emergent occasions concerning the public weal of the said Colony and every part thereof, as also to make, ordain and enact such general laws and orders for the behoof of the said Colony, and the good government thereof, as shall from time to time appear necessary or requisite; whereas in all other things we require the said General Assembly, as also the said Council of State, to imitate and follow the policy of the form of government, laws, customs and manner of trial, and other administration of justice, used in the Realm of England, as near as may be, even as ourselves by his Majesty's Letters Patent are required.

The years that Sir Edwin Sandys held or controlled the Treasurership of the Company-from I619 to 1624were the most prosperous the Company and Colony had ever had and the most prosperous that the Colony had for many years afterwards. Though Sandys had, in fact, converted the Courts of the Company into an Imperial Administrative Council for the Colony, it was most difficult to hold such assemblages of persons interested in exploiting the Colony up to their obligations as an Administrative Council. They were non-experts and made Sandys's life a burden in trying to get him to protect or further their short-sighted schemes of exploitation. Stith, in his History of the Early Settlement of Virginia, written in I 747, says : 


\section{The Administration of Dependencies}

Although Sir Edwin Sandys was much wronged in the execution of his office, and even sought to be deterred by threats of blood, they could in no way turn him from a vigorous prosecution and inquiry into the late disorders in Virginia.

In the performance of his duties, he even had the King's officers prosecuted for seizing some tobacco belonging to the Company under orders of the King, and was successful in having the tobacco restored. With the Company nagging him on the one hand, and the King opposed to him and demanding that he should not be re-elected, he retired in favor of the Earl of Southampton, but on account of his close relations with the Earl he retained the actual control until the end of the Company. The destruction of the settlements in the Indian raid of 1622 , and the forfeiture of the Charters by the Court of King's Bench in I624, on application by the King, brought to an end the experiments under the Charters of I609 and I6II. The forfeiture of the Charters did not, of course, revoke the Ordinance of $\mathrm{I} 62 \mathrm{I}$, which had been granted by special authority of the King, and it was allowed to stand as the Constitution of the Dominion of Virginia, so that that Dominion was put on a substantial equality with the most favored of the other dependencies of English race, and was given greater legislative liberty in the first instance than Ireland had. Necessarily, upon the revocation of the Charters, the Imperial administrative power reverted to the King in Council.

In 1620 , James tried another experiment in the organization of a Council in England for the Colonies distinct from the Privy Council, which exhausted all the possibilities. He had started, in 1606 , with an Imperial Administrative Council of small size, appointed by himself. This was not satisfactory, because it did not attract capital. In I609, he created a self-perpetuating Board of Directors 
of a private corporation his Council for this purpose. In I6I 1 , he created this whole private corporation, assembled in meetings or courts, his Council. In 1620 , these Councils having proved unsatisfactory, he created a "close corporation,"-that is, a small body of persons incorporated with powers of self-perpetuation, as his Council. This he did by his charter to the Council for New England, located in Plymouth, England, consisting of forty persons named by the King, who were incorporated by the name of "The Council Established at Plymouth, in the County of Devon, for the Planting, Ruling, Ordering, and Governing of New England, in America," and were obliged to take the oath of Councillors of the King. This Council was self-perpetuating and had full governmental powers subject to the condition that its acts and proceedings should be " as near as conveniently may be, agreeable to the laws, statutes, government and policy of this our Realm of England." Such a "Council" was an impotent body. It had no power to grant charters to the colonists conferring governmental powers. It did not attract capital, and, as its members were appointed or elected for life and had to govern as best they could without money and without help from the King, it really never did much except to make grants of land. After an inglorious existence, it voluntarily surrendered its franchises to the King.

Lord Bacon, in his Essay on Plantations, written probably about the time of the revocation of the Virginia Charters, expressed the conclusions at which the thinking people of England had arrived at that time. He said:

For government, let it be in the hands of one, assisted with some counsel: and let them have commission to exercise martial laws, with some limitation. . . . Let not the government of the Plantation depend upon too many counsellors, and undertakers, in the country that planteth, but upon a temperate 


\section{The Administration of Dependencies}

number: And let these be rather noblemen and gentlemen, than merchants; for they look ever to the present gain.

The result of these experiments was to convince the English Government that a private corporation with governmental powers was an ineffectual instrumentality for administering dependencies like the American Colonies, whose popuiations had a will and a juridical conscience of their own which they were capable of expressing by combined action. All experiments in this direction relating to the American Colonies practically ended in 1624 , upon the revocation of the Virginia Charters, though the Charter of the Council for New England was not surrendered until some years later.

James I. died April 6, 1625, while a Commission to investigate the affairs of Virginia was still sitting. On May 23, 1625, Charles I., after consultation with Sandys, who was a great friend of his and who had joined in an argument before the Commissioners in favor of a new charter to the old Company, stated his intention in a Proclamation " to resume the government," so that

there should be one uniform course of government throughout all our whole monarchy; That the government of the Colony of Virginia shall immediately depend upon ourself, and not be committed to any company or corporation, to whom it may be proper to trust matters of trade, but cannot be fit or safe to communicate the ordering of state affairs, be they of never so mean consequence.

The Proclamation stated that he intended to establish a royal Council in England and another in Virginia. He in fact did so, but he left the Virginians their representation in the General Assembly.

The effect of this Proclamation was to establish two principles of the administration of the American Colonies: First, that, to an orderly administration it was necessary that there should be an Imperial Council located 


\section{Imperial Councils, $1606-25$}

in England, composed of expert persons appointed by the King, which should be a consultative body for the King when he was exercising the Imperial power on behalf of England, and which might also have administrative powers; and second, that the Colonies, being separated by distance so that they could not be incorporated into the body of the Realm, were to be regarded as States for some purposes. 


\section{CHAPTER V}

\section{IMPERIAL COUNCILS, I625-I750}

JTIL the year 1750, at least, there continued to be an Imperial Council in England for America,usually assisted by a referee Council,-which, with the King, represented England or Great Britain as the Imperial State.

Charles I., for nine years after his accession, administered personally the affairs of the American Colonies, acting with the advice of his Privy Council. Under this arrangement, the Charter of the Massachusetts Bay Company was granted in 1629 , by which the persons named in it were incorporated as a guild or private company, having governmental privileges but also full power to admit or exclude. The officers of the guild were a Governor and Assistants, elected by the members at a "General Court." The members were called "freemen." No place was specified in which the guild should be located, though it was granted land in New England.

In 1632 , Charles I., by Charter, granted the region called Maryland to Lord Baltimore as Count Palatine and Lord Proprietor. The region and its inhabitants were incorporated by the name of "The Province of Maryland." The object doubtless was to keep alive, among the colonists, the idea of allegiance to the person of the King, and to secure the personal responsibility of a Proprietor.

By Commission of April 28, 1634, Charles I. appointed as "Lords High Commissioners for the Plantations," the Archbishop of Canterbury (William Laud), the Arch- 
bishop of York, the Lord Keeper, the Lord High Treasurer, and eight other Officers of State-thus showing that the administration of the dependencies was regarded as a matter of very great importance and that the office of Lord High Commissioner for the Plantations was regarded as one of great dignity. These Commissioners constituted an Imperial Administrative Council, and not merely a Privy Council for Colonial Purposes. They were given power to make laws and orders for the government of the Colonies, with the King's assent; to impose penalties and imprisonment for offences in ecclesiastical matters; to remove governors and require an account of their government; to appoint judges and magistrates and establish courts; to hear and determine all manner of complaints from the Colonies; to have power over all charters and patents, and to revoke those " surreptitiously and unduly obtained."

This last power was doubtless given with reference to the Massachusetts Bay Charter, under a claim that, in moving the whole administration of the Company to New England, an improper advantage had been taken of the omission in the Charter to limit the location of the Company to some place in England, and that this action was evidence of fraudulent intent in obtaining the Charter. This claim was evidently unfounded and made without sufficient investigation, since Governor Winthrop states that the omission was intentional, and that the Company refused to take the Charter unless it were unlimited in the matter of location.

Under the administration of the Lords High Commissioners for the Plantations, the region called Maine was, in 1639, granted to Sir Ferdinando Gorges as a County Palatine and a Proprietary Province by the name of "The Province of Maine."

The establishment of the Province of Maine, modelled exactly after the Province of Maryland, in which, though 
the Lord Palatine was required to act by the advice and consent of the freeholders, he was permitted to determine to what extent they should participate in the government,- the one immediately north of Virginia and the other immediately north of Massachusetts Bay,-made the Lords High Commissioners exceedingly unpopular in the old Colonies. In Massachusetts Bay, the antagonism to them was increased by a judgment obtained by their efforts in 1635 , declaring the Charter forfeited, and by the appointment, in 1637, of Sir Ferdinando Gorges as Governor-General of New England. The objection of the colonists was not, however, to the Imperial Council because it was such, but to the acts and beliefs of the men who composed the Council.

The Commission to the Lords High Commissioners for the Plantations was revoked in 1639 , and from that time until 164I the troubles of England within itself and with Scotland and Ireland made it impossible for much attention to be given to the affairs of the American Colonies. The administration of the Colonies reverted to the charge of the King, who acted under the advice of a Committee of the Privy Council for Foreign Plantations.

The Lords and Commons of England, during the first two years of their contest with King Charles, after his flight from London in $164 \mathrm{I}$, seem to have been inclined to treat the Colonies as if they were integral parts of the Realm. They suggested that the Colonies send representatives to Parliament, but the Colonies refused; and, in 1643, the Massachusetts Bay Colony and the Providence Plantations sent Agents to England to present their matters of dispute to the Lords and Commons for disposition, Roger Williams representing the Providence Plantations. After conference between the Colonial Agents and the leaders of the Lords and Commons, there was no more talk of the Colonies being represented in Parliament. They had realized that their interests lay in the direction 
of dependence on England as the Imperial State, not in the direction of merger with England.

The Lords and Commons, on November 2, 1643, by an Ordinance "for Regulating the Plantations," appointed a Board of Commissioners for the Plantations, which was an Imperial Council with full powers, even to the granting of charters. This Ordinance was the first legislative act emanating from the English Government relating to the American Colonies not enacted by the King in Council or by the King's authority. It was enacted at a time in English history when the English Government was sanely democratic and republican, and was in the hands of men of eminent ability and standing. It is, for this reason, so pertinent to the present situation in the United States, that a quotation of it may be useful. It read as follows, after the preamble:

The Lords and Commons, finding it of great importance both to the safety and preservation of the aforesaid natives and subjects of this Kingdom, as well from all foreign invasions and oppressions as from their own intestine distractions and disturbances, as also much tending to the honor and advantage of his Majesty's dominions, have thought fit, and do hereby constitute and ordain Robert Earl of Warwick, Governor in Chief and Lord High Admiral of all those Islands, and other Plantations inhabited, planted, or belonging to any of his Majesty's the King of England's subjects, or which hereafter may be inhabited, planted, or belonging to them, within the bounds and upon the coasts of America: And, for the more effectual, speedier, and easier transaction of this so weighty and important a business, which concerns the well-being and preservation of so many of the distressed natives of this and other his Majesty's dominions, the Lords and Commons have thought fit, that Phillip Earl of Pembroke, Edward Earl of Manchester, William Viscount Say \& Seale, Phillip Lord Wharton, John Lord Roberts, Members of the House of Peers, Sir Gilbert Gerrard Knight and Baronet, Sir Arthur 
Haselrig Baronet, Sir Henry Vane Junior, Knight, Sir Benjamin Rudyer Knight, John Pym, Oliver Cromwell, Dennis Bond, Miles Corbett, Cornelius Holland, Samuel Vassall, John Rolls, and William Spurstowe, Esquires, Members of the House of Commons, shall be Commissioners, to join in aid and assistance with the said Earl of Warwick, Chief Governor and Admiral of the said Plantations, which Chief Governor, together with the said Commissioners or any four of them, shall hereby have power and authority to provide for, order, and dispose all things which they shall from time to time find most fit and advantageous to the well-governing, securing, strengthening, and preserving of the said Plantations, and chiefly to the preservation and advancement of the true protestant religion amongst the said planters and inhabitants, and the further enlargement and spreading of the Gospel of Christ amongst those that yet remaineth there in great and miserable blindness and ignorance: And, for the better advancement of this so great a work, it is hereby further ordained, by the said Lords and Commons, That the said Chief Governor and Commissioners shall hereby have power and authority, upon all weighty and important occasions which may concern the good and safety of the aforesaid planters, to call unto their advice and assistance therein any other of the aforesaid planters, owners of land or inhabitants of the said Islands and Plantations, which shall then be within twenty miles of the place where the said Commissioners shall then be; and shall have power and authority to send for, view, and make use of, all such records, books, and papers, which do or may concern any of the said Plantations: And because the well-settling and establishing of such officers and Governors, as shall be laborious and faithful in the right governing of all such persons as be resident in or upon the said Plantations, and due ordering and disposing all such affairs as concern the safety and welfare of the same, is of very great advantage to the public good of all such remote and new Plantations, it is hereby further ordained and decreed, That the said Robert Earl of Warwick, Governor in Chief and Admiral of the said Plantations, together with the aforesaid Commissioners, Phillip 
Earl of Pembroke, Edward Earl of Manchester, William Viscount Say \& Seale, Phillip Lord Wharton, John Lord Roberts, Sir Gilbert Gerrard Knight and Baronet, Sir Arthur Haselrig Baronet, Sir Henry Vane Junior, Knight, Sir Benjamin Rudyer Knight, John Pym, Oliver Cromwell, Dennis Bond, Miles Corbett, Cornelius Holland, Samuel Vassall, John Rolls, and William Spurstowe, Esquires, or the greater number of them, shall have power and authority, from time to time, to nominate, appoint, and constitute all such subordinate Governors, Councillors, Commanders, officers, and agents, as they shall judge to be the best affected, and most fit and serviceable for the said Islands and Plantations; and shall hereby have power and authority, upon the death or other avoidance of the aforesaid Chief Governor and Admiral, or any the other Commissioners before named, from time to time to nominate and appoint such other Chief Governor and Admiral, or Commissioners, in the place and room of such as shall so become void; and shall also hereby have power and authority to remove any of the said subordinate Governors, Councillors, Commanders, officers, or agents, which are or shall be appointed to govern, counsel, or negociate, the public affairs of the said Plantations, and in their place and room to appoint such other officers as they shall judge fit: And it is hereby ordained, That no subordinate Governors, Councillors, Commanders, officers, agents, planters, or inhabitants whatsoever, that are now resident in or upon the said Islands or Plantations, shall admit or receive any other new Governors, Councillors, Commanders, officers, or agents whatsoever, but such as shall be allowed and approved of under the hands and seals of the aforesaid Chief Governor and High Admiral of the said Plantation, together with the hands and seals of the aforementioned Commissioners or any six of them, or under the hands and seals of such as they shall authorize thereunto: And whereas, for the better government and security of the said Plantations and Islands, and the owners and inhabitants thereof, there may be just and fit occasion to assign over some part of the power and authority granted in this Ordinance to the Chief Governor and Commissioners aforenamed unto the 
said owners, inhabitants, and others, it is hereby ordained, That the said Chief Governor and Commissioners before mentioned, or the greater number of them, shall hereby be authorized to assign, ratify, and confirm so much of their aforementioned authority and power, and in such manner, and to such persons, as they shall judge to be fit for the better governing and preserving the said Plantations and Islands from open violence and private disturbance and distractions.

And lastly, that whosoever shall do, execute, or yield obedience to any thing contained in this Ordinance, shall, by virtue hereof, be saved harmless and indemnified.

Under this Ordinance a Charter was granted to Providence Plantations in March, I644, which was open to criticism, if at all, only for excess of liberality. This Charter, after a long preamble in which the Ordinance of November 2, I643, was set out, read:

In due consideration of the said premises, the said Robert Earl of Warwick, Governor in Chief and Lord High Admiral of the said Plantations, and the greater number of the said Commissioners, whose names and seals are here underwritten and subjoined, out of a desire to encourage the good beginnings of the said planters, do by the authority of the aforesaid Ordinance of the Lords and Commons, give, grant and confirm to the aforesaid inhabitants of the Towns of Providence, Portsmouth and Newport, a free and absolute charter of incorporation, to be known by the name of the Incorporation of Providence Plantations, in the Narragansett Bay, in New England, together with full power and authority to rule themselves, and such others as shall hereafter inhabit within any part of the said tract of land, by such a form of civil government, as by voluntary consent of all, or a greater part of them, they shall find most suitable to their estate and condition; and, for that end, to make and ordain such civil laws and constitutions and to inflict such punishments upon transgressors, and for execution thereof, so to place and displace officers of justice, as they, or the greater part of them, shall 
by free consent agree unto. Provided, nevertheless, that the said laws, constitutions and punishments, for the civil government of the said Plantations, be conformable to the laws of England so far as the nature and constitution of the place will admit. And always reserving to the said Earl and Commissioners, and their successors, power and authority for to dispose the general government of that, as it stands in relation to the rest of the Plantations in America, as they shall conceive, from time to time, most conducive to the general good of the Plantations, the honor of his Majesty, and the service of the State.

The passage of this Ordinance by the Lords and Commons shows that, at the moment in the history of England when the feeling for constitutional liberty was most intense, and when the Lords and Commons were most jealous of their own constitutional rights, they recognized that, from the nature of things, they were not fitted to administer the affairs of the dependencies, and that it was their duty to place this branch of government in the immediate, active, and continuous control of a self-perpetuating Council of experts, reserving to themselves only a superintendence of the action of the Council so as to keep it within proper bounds and so as to direct its policy on questions of great national or international importance.

The Ordinance shows also that the administration of the affairs of the dependencies was regarded as a matter of the greatest importance and as requiring the attention both of the most distinguished statesmen, expert in the general art of government, and of persons who were familiar with the circumstances and conditions of the Colonies. Pym was the leader of the Lords and Commons, and was interested in the Providence Islands Company chartered in 1630 . Sir Henry Vane, Junior, the son of the Sir Henry Vane who was one of the Lords High Commissioners for the Plantations under Charles I., was one of the most conspicuous men in the 
Lords and Commons, and largely controlled the most important business. He had emigrated to Massachusetts in 1635 , to avoid religious persecution. He was elected Governor of the Colony in 1636 , and gave it for a year a singularly energetic and wise administration, when, having offended the people by his advocacy of universal toleration, he was defeated for re-election and returned to England. In December, I643, after the death of Pym, he became the leader of the House of Commons. The Board of Commissioners thus contained in its membership two of the greatest statesmen of the times, one of whom had had actual experience in colonial administration. Others of the Commissioners had, through personal or family interest in the Council for New England, the Virginia Company, and the Providence Islands Company, a knowledge of the affairs of the Colonies. The Ordinance was, therefore, in effect, a declaration that the transmarine dependencies of England were constitutionally entitled to administration through a Council of experts located in the metropole.

At this time Charles had left London, but the Lords and Commons still considered him as King. In appointing the Commissioners, they regarded themselves as substituted, from the necessity of the case, to the rights and powers of the King over the Colonies. They did not consider themselves at that time as Parliament, since they still believed that a Parliament could constitutionally exist only by the concurrence of King, Lords, and Commons. The Board of Commissioners thus established differed, as an Imperial Council, from that instituted by King Charles in 1634, only in the fact that it was on a more liberal basis.

The Massachusetts Bay Colony could undoubtedly have obtained from the Commissioners a Charter equally as free as that of Providence Plantations, but it merely secured from them a recognition of the Charter of 1629 , 
and an extension of boundaries toward Rhode Island. The power of the "freemen" of the Company to admit or exclude they would not yield, since only by the possession of that power could their religious discipline be maintained.

This system of administering the dependencies continued until the establishment of the Commonwealth, in January, I649. One of the first acts of the Parliament (then consisting only of the House of Commons) was to appoint a Council of State of forty-one members, to serve as the Executive part of the Government. This was done by Act of February 13, 1649, which not only contained the Commission to the Council, but also the Instructions of Parliament governing its action. Among these Instructions was the following:

You are hereby authorized to use all good and lawful means for the securing, advancement and encouragement of the trade of England and Ireland and the dominions to them belonging; and to promote the good of the Foreign Plantations and Factories belonging to this Commonwealth or any of the natives thereof.

When the year for which this Council was commissioned expired, on February 13, 1650, the Commission and Instructions were renewed by Act of the Parliament, and a new Instruction added, which read:

You have also hereby power to appoint Committees or any other person or persons, for examinations, receiving of informations and preparing of business for your debates or resolutions.

On March 6, 1650, the Council of State made an order which provided that the whole Council or any five of them should be a Committee for the Plantations, and in August, 1650, the Parliament passed an Act "for the 


\section{The Administration of Dependencies}

Advancing and Regulating the Trade of the Commonwealth," by which there was created "a standing Council for the regulation of trade," which was an under-Council for the affairs of the Colonies. This Council was known as "the Council of Commerce."

One of the Instructions given by the Act required the Council :

To advise how the English Plantations in America or elsewhere may be best managed; and how the commodities thereof may be so multiplied that those Plantations alone may supply the Commonwealth of England with whatsoever it necessarily wants."

The Parliamentary History says of this under-Council for Trade :

These Commissioners were empowered not only to receive proposals from any persons of experience and ability in matters of trade, but had also anthority to send for the officers of the Exchequer, Mint, Customs and Excise, for their assistance; also to view all books, records, \&c., for their further information; and the result of their inquiries, with their opinion thereupon, was required to be laid before the Parliament or Council of State.

Under this arrangement, Parliament declared the American Colonies to be "subordinate and dependent upon England" (in the Act of October 3, 1650, "for reducing Barbadoes and Virginia"), and, on October I9, I65 I, passed the first Navigation Act, restricting the trade of the Colonies to England. The establishment of the Council of Commerce evidently had the immediate effect to lead to a distinct understanding and statement of the relation of the Colonies to England, and to cause the adoption, by the Council of State and the Parliament, of a strong and definite colonial policy.

The Instructions to the Council of State above quoted were repeated in the Instructions given by Act of Parlia- 
ment of November 30, 1652 , and also in the Act of the Little Parliament of July 9, 1653 .

On December 16, 1653, the Council of State was abolished, and there was substituted for it, under the Instrument of Government, the Lord Protector's Council, composed of not less than thirteen nor more than twentyone persons. This Council, with the Lord Protector, formed the Imperial Council, the Lord Protector being granted "the chief magistracy and the administration of the government over the Commonwealth of England, Scotland and Ireland, and the dominions thereunto belonging, and the people thereof," which power he was to exercise with the assistance of his Council,_- "assistance" being defined by a subsequent clause in the Instrument of Government which gave the Lord Protector power "to govern the said countries and dominions in all things by the advice of the Council and according to these presents and the laws."

The Council for Trade appointed by Parliament continued to exist as an under-Council for the Lord Protector's Council until Cromwell dissolved Parliament on January 22, 1655 .

On March 2, I655, the Lord Protector's Council appointed from its own number a Committee for the Foreign Plantations, and on November I, I655, the Lord Protector, by an Ordinance in Council, constituted a "Council of Commerce," consisting of forty persons, among whom, as the Parliamentary History states, were Cromwell's son Richard, the Commissioners of the Great Seal, all the members of the Council, the Judges, several Sergeants at law, and Aldermen of London, York, Bristol, Newcastle, Lynn, Yarmouth, Dover, Southampton, and Exeter. Any seven members were to constitute a quorum.

The Parliamentary History thus describes the powers of this Council: 


\section{The Administration of Dependencies}

The Council were authorized to take into consideration all ways and means for advancing, encouraging and regulating the trade and navigation of the Commonwealth; for which purpose they were empowered to receive such propositions as should be made to them, and to send for the officers of the Excise, the Customs, and the Mint, or such other persons whom they should deem capable of giving advice upon this subject. They were to examine the books and papers of the late Council of Commerce, and all other public papers which might afford them necessary information. Whatever proposals were laid before these Commissioners which they judged to be for the advantage of trade and commerce, were to be certified to the Lord Protector and his Council, who were to give the necessary orders therein.

It appears also that a similar Council for Trade was appointed by Parliament on March 4, 1657, which was a referee body for the Lord Protector's Council, in matters relating to trade and plantations.

After the acceptance by Cromwell, on May 25, I657, of the Petition and Advice, the relations with the Colonies remained in charge of the Lord Protector in Council (the Council being given the old name of the Privy Council), until Cromwell's death on September 3, 1658.

After Parliament had deposed Richard Cromwell, it placed the Executive part of the Government again in the hands of a Council of State. This Council of State consisted of thirty-one persons, any nine of whom (six of the nine being members of Parliament) constituted a quorum. Among the Instructions given by Parliament to this Council of State were the following:

You are to try to advance the trade in England, Scotland and Ireland, and promote the good of our Foreign Plantations and Factories, and watch the State's interests in foreign parts.

You are to consult on matters of public concernment, and report your opinion to Parliament. 
You are to send for whomever you wish to bear witness or give advice.

You may send for any public written documents you wish to consult, on matters in agitation before you.

You may, on emergency, administer an oath for the discovery of the truth.

You may appoint committees or persons to take examinations, receive informations, or prepare business for your debates or resolutions.

This Council of State appointed a Committee for the Foreign Plantations from among its own members, which had charge of the relations with the Colonies.

Thus it appears that during the time England had been without a King, there had been no change in that principle of the English Constitution as it existed before the Commonwealth, according to which the management of the relations between England and the Colonies was in the hands of the Crown.

Charles II., on November 7, I660, shortly after his restoration, appointed a Council of Trade, and, on December I, I660, also appointed an Imperial Council called "The Council for Foreign Plantations." This Imperial Council was composed in part of high officials and dignitaries of the English State and Church and other members of the Privy Council, and in part of members of the trading guilds. It originally consisted of forty persons. While it had administrative powers within a somewhat indefinite sphere, it was also an Under-Council or Committee of Reference, which was to ascertain the facts concerning complaints or propositions regarding the Colonies, and report the facts, with their conclusions, to the King in Council. The Instructions to this Council were as follows:

I. You shall inform yourselves, by the best ways and means you can, of the state and condition of all Foreign Plantations, 
and by what commissions and authorities they are and have been governed and disposed of ; and are to procure, either from such persons as have any grants thereof from the Crown, or from the records themselves, copies of all such commissions or grants, to be transcribed and registered in a book provided for that purpose, - that you may be the better able to understand, judge and administer such affairs as by your commission and instructions are intrusted to your care and management.

2. You shall forthwith write letters to every Governor for the time being of all our English Plantations, and to every such person or persons who, by any letters patent from us or any of our predecessors, claims or exercises the right of government in any of the said Plantations; in which letters you are to inform them of our gracious care and provision in their behalf, both in erecting a general Council of Trade wherein their concernments are mingled and provided for with [those of] the rest of our dominions, and especially [in erecting] this particular Council, which is applied only to the inspection, care and conduct of Foreign Plantations.

3. You are in the said letters to require the said Governors and persons above-mentioned, to send unto you in writing, with the advice of the Council of every of the said Plantations respectively, a particular and exact account of the state of their affairs, of the nature and constitution of their laws and government, and in what model and frame they move and are disposed, what number of men, what fortifications and other strengths and defences are upon the places, and how furnished and provided for.

4. You are to order and settle such a continual correspondence that you may be able, as often as you are required thereunto, to give to us an account of the government of each Colony, of their complaints, their wants, their abundance of their several growths and commodities, of every ship trading there and its lading, and whither consigned, and what the proceeds of that place have been in the late years; that thereby the intrinsic value and the true condition of each part and of the whole may be thoroughly understood, whereby a most steady judgment and balance may be made for the 
better ordering and disposing of trade and of the proceeds and improvement of the Plantations, that so each place within itself and all of them being collected into one view and management here, may be regulated and ordered upon common and equal ground and principles.

5. You are to apply yourselves to all prudential means for the rendering those dominions useful to England and England helpful to them; and for the bringing the several Colonies and Plantations within themselves into a more certain, civil and uniform way of government and for the better ordering and distributing of public justice among them.

6. You are to inquire diligently into the several governments and counsels of colonies, plantations and distant dominions belonging to other Princes or States, and to examine by what conduct and policies they govern or benefit them; and you are to consult and provide that, if such counsels be good, wholesome and practicable, they may be applied to the use of our Plantations, or if they tend or were designed to the prejudice or disadvantage thereof or of any of our subjects or of trade or commerce, then they may be balanced or turned back upon them.

7. You are to call to your assistance from time to time, as often as the matter in consideration shall require, any well experienced persons, whether merchants, planters, seamen, artificers etc.

8. You are to take especial care and inquire into the strict execution of the late Act of Parliament entitled an Act for the Encouragement and Increasing of Shipping and Navigation; that, as much as in you lies, none of those good ends and purposes may be disappointed for which the said Act was intended and designed.

9. You are to take into your consideration how our several Plantations may be best supplied with servants, that neither our Colonies-especially such as are immediately under our commissions-may be unprovided in so essential an assistance, nor any of our good subjects may be forced or enticed away by any unlawful or indirect way; and how such as are willing to be transported thither to seek better fortune than they can 
meet with at home may be encouraged thereunto; and how such a course may be legally settled for the future that vagrants and others who remain here noxious and unprofitable may be so transplanted, to the general advantage of the public as well as to the particular commodity of our Foreign Plantations.

ro. You are most especially required to take an effectual care of the propagation of the Gospel in the several Foreign Plantations, by providing that there be good encouragement settled for the invitation and maintenance of learned and orthodox ministers, and by sending strict orders and instructions for the regulating and reforming the debaucheries of the planters and servants, whose ill example doth bring many scandals upon Christianity and deter such as yet are not admitted thereunto from affecting or esteeming it. And you are to consider how such of the natives [as are servants or slaves], or such as are purchased by you from other parts to be servants or slaves, may be best invited to the Christian faith, and be made capable of being baptized thereunto,-it being to the honor of our Crown and of the Protestant Religion that all persons in any of our dominions should be taught the knowledge of God and be made acquainted with the mystery of salvation.

I I. You are lastly required and empowered to advise, order, settle and dispose of all matters relating to the good government, improvement, and management of our Foreign Plantations, or any of them, with your utmost skill, direction and prudence; and in all cases wherein you shall judge that further powers and assistance shall be necessary, you are to address yourselves to us or our Privy Council for our further pleasure, resolution and direction therein.

Under this Council for Foreign Plantations a Charter was granted to Connecticut in 1662 , under which the Colony and State lived for one hundred and fifty-six years-until I818; and another to Rhode Island in 1663 , under which the Colony and State lived for one hundred and seventy-nine years-until I 842. While these Colonies were both allowed the right to elect their own Governor, 
Assistants and Representatives, and while no provision was made in the Charter for the Crown having an appointed representative in the Colony, this was evidently permitted as a special régime, since under this Council there were granted, in 1664 , the Patent to the Duke of York, who succeeded Charles II. as King, covering nearly the whole region north of Maryland not included in previous charters, by which the Duke of York was created Lord Proprietor and in which there is no mention of any participation of the people in the government, and, in 1665, the Charter of Carolina, which created a County Palatine in which the Lords Palatine were required only to advise with the representatives of the people.

By Instructions given to this Council for Foreign Plantations in July, 1670 , the Council was required

To give strict order to our several and respective Governors that if any of the Indian nations shall at any time desire to put themselves under the protection of our Government, that they receive them, and that they do by all means seek firmly to oblige them, and that they do direct or employ some persons purposely to learn the languages respectively of them, and that they do not only carefully protect and defend them from. other Indians, and from any that are the adversaries of them, but that they more especially take care that none of our own subjects, nor any of their respective servants, do, at any timein any way harm them, and that if any shall dare to offer violence to them in their respective persons, goods or possessions, the said Governors do severely punish the said injuries: agreeable to justice and right.

On September 16, I672, Charles II. abolished both the Council for Trade and the Council for Foreign Plantations, and by Letters Patent formed a " Select Council to take Care of the Welfare of the Colonies and Plantations, and of the Trade and Navigation of the King's Dominions, Domestic and Foreign, and of his Colonies." 
This Council was known as "The Council for Trade and Plantations." It was a referee body for the King in Council, being required "to certify the result of their resolutions on any propositions submitted to them by the King for consideration and determination.'

This was not a sufficient centralization of power for Charles II. The Council for Trade and Plantations was too much inclined to advise measures which would have given the dependencies a just and expert government. On March I2, I675, he abolished the Council, and placed the administration of Imperial affairs in the hands of himself advised by a Committee of the Privy Council, called the "Lords of Trade and Plantations."

Under this arrangement the Charter was granted in I68I to William Penn, of the Province of Pennsylvania, to be held and governed by him as Lord Proprietor. Under this arrangement, also, the Charters of Massachusetts Bay and Connecticut were adjudged forfeited on quo warranto proceedings in the Court of King's Bench-the former in 1684, and the latter in 1687,--and Sir Edmund Andros was made Governor-General of New England in I686, and of both New England and New York in I688. Had the plans of Charles II. been carried out, New England and New York together would have been formed into a single federal or unitary dominion, according as the English Government had or had not respected the right of the Colonies so consolidated to statehood.

William III. came to the throne under a constitutional settlement by which he agreed with the Lords and Commons that he was to be the King of England and of " the dominions thereunto belonging." This was, in effect, a declaration that England was the Imperial State on which the American Colonies were dependent, and that his powers as King were the powers of the official representative of the Imperial State. None of his royal predecessors had made any such admission. 
The Stuart Kings regarded the Colonies as belonging to themselves rather than to the State of England. In view of the careful and deliberate thought which was given to the ascertainment of the true principles of the Constitution of the Realm and of the Empire at the time of the accession of William III., the methods of administering the dependencies which were used by him deserve the most careful attention. It is fair to assume that such of the methods as were brought over from the times of the Stuarts were retained because they were approved by the most distinguished constitutional lawyers of England.

For six years after his accession in I688, William III. managed the affairs of the Empire by the advice of a Committee of the Privy Council, and it was under this arrangement that the Charter of the Province of Massachusetts Bay was granted in I69I, seven years after the forfeiture by quo warranto instituted by order of Charles II. of its Charter of 1629. By this Charter, it became a Province, with a royal Governor, but with the rest of its government elective. The five years during which Massachusetts Bay had been under the immediate administration of Governor Andros, with all his arbitrariness, and under the superintendence of Charles II., with all his ideas of absolutism, had somehow made the people of the Colony willing to give up their guild form of organization and to become a Province under the empire of the State of England.

In 1696 William III. returned to the plan originated by Charles II. and instituted a " Board of Commissioners for Trade and Plantations," composed of high officers of State and men expert in colonial affairs. The idea of this Council seems to have originated with the House of Commons, not with the King. On January 31, 1696, after the House of Commons had been sitting as a Committee of the Whole on the State of the Nation with Re- 
spect to Trade at various times ever since December 14, I695, it came to the following resolutions in Committee of the Whole:

I. Resolved, That it is the opinion of this Committee that a Council of Trade be established, by Act of Parliament, with powers for the more effectual preservation of the trade of this Kingdom.

2. Resolved, That it is the opinion of this Committee, that the Commissioners constituting the said Council of Trade shall be nominated by Parliament.

3. Resolved, That it is the opinion of this Committee that none of the said Commissioners be of this House.

8. Resolved, That the said Commissioners be likewise empowered to consider the Plantation Trade and all other trades and manufactures; and the best methods for securing and improving the same.

The third resolution was defeated, but the others passed.

The sixth resolution, which was adopted, read:

Resolved, That it is the opinion of this Committee that the said Commissioners do send their directions for the protection of trade to the Lord High Admiral of England or the Commissioners for executing that office; which directions are to be controllable by his Majesty under his sign manual.

Burnet, in his History of His Own Times, says of the debates on these resolutions:

The creation of this Council of Trade by Act of Parliament, was opposed by those who looked upon it as a change of our Constitution in a very essential point. They urged that the Executive part of our Government was in the King, so that the appointing any Council by Act of Parliament began a precedent of their breaking in upon the execution of the law, in which it could not be easy to see how far they might be 
carried. It was indeed offered that this Council should be much limited as to its powers; yet many apprehended that if the Parliament named the persons, how low soever their powers might be at first, they would be enlarged every session; and, from being a Council to look into matters of trade, they would next be empowered to appoint convoys and cruisers. This, in time, might draw in the whole Admiralty, and that part of the revenue or supply which was appropriated to the Navy; so that a King would soon grow to be a Duke of Venice. And indeed those who set this on most zealously did not deny that they designed to ingraft many things upon it.

The King was so sensible of the ill effects which this would have that he ordered his Ministers to oppose it as much as possibly they could.

The fear that if the King were deprived by Parliament of the function of administering the relations with foreign States and with the dependencies, he might " grow to be a Duke of Venice," was a fear that he might grow to be a mere figurehead,-the government of the Venetian Republic being then so largely in the hands of Administrative Boards that the Doge had no powers whatever. The underlying thought of the opponents of the measure was, that it was contrary to the nature of things that Parliament, led by the House of Commons, as the popular part of the Government, should perform the functions of the State with respect to foreign States and the dependencies, and that such action would be a usurpation, by the House of Commons, of power which, in the nature of things, belonged to the King.

The House of Commons yielded to the King's wishes and the resolutions were not pressed.

It seems the more probable that the functions of this Council, had it been created, would have been extended to the administration of the American Colonies, when it is considered that, at the very time these resolutions were adopted, the House of Commons was considering a Bill 
which became an Act in March, 1696, "for Preventing Frauds and Regulating Abuses in the Plantation Trade," known as the Navigation Act of 1696.

The grant of powers by William III. to the first Council for Trade and Plantations is thus summarized by Mr. Thomas in his History of Public Departments :

The commission was for promoting the trade of the Kingdom generally, and inspecting the Plantations in America and elsewhere; and for this latter purpose, they were directed to take under their care all records, grants, and papers, remaining in the Plantations office, or thereto belonging: to inform themselves of the present condition of the Colonies, as well with regard to administration of the government and justice in those places as in relation to the commerce thereof; to look into the usual instructions given to Governors of Plantations, and to see if anything might be added or omitted; to take account yearly, by way of journal, of the administration of Governors; to consider of proper persons to be Governors or Deputy Governors, . . . in order to present their names to the King in Council; to weigh all Acts of the Assemblies of the Plantations as shall be sent to England for the King's approbation; the Commissioners to report their proceedings from time to time to the King or Privy Council.

The system thus established by William III. was followed with slight changes, actually until the year I750, and nominally until the year 1782 . Under it the Crown, in 1729 , bought out the Proprietors of Carolina and erected the two parts of it into separate Provinces by the names of North Carolina and South Carolina. Under it also, in 1732 , a Charter was granted to a guild or privileged company known as "The Trustees for Establishing the Colony of Georgia in America," under the control of a President and Common Council elected by the members of the corporation, in accordance with which the corporation was to have the sole power of legislation in 
the Colony under the supervision of the Board of Trade and Privy Council, for twenty-one years. To the Board of Commissioners for Trade and Plantations, throughout the whole period from 1695 to 1750 , were referred all colonial questions except some of those arising in the administration of Crown Colonies, which were under the direct control of the King through a Secretary of State. The Board reported the facts and its conclusions to the Committee of the Privy Council for Plantation Affairs. and they determined the matter and reported to the King, who, though of course at liberty to accept or reject their conclusions, did as matter of fact accept them in practically every instance.

The Colonies sent their "Agents" to present the considerations growing out of the local circumstances and conditions at the hearings before the Board of Trade and Plantations and before the Committee of the Privy Council for Plantation Affairs. The practice of keeping an "Agent" permanently at the English Court seems to have been originated about the year 1670 , by the Province of Virginia. From that time forward, this practice seems to have been quite commonly adopted by the Colonies. An "Agent," in the nature of things, fulfilled in part the functions of a public and diplomatic representative of his Colony, and in part the functions of an attorney-at-law for the Colony before the Administrative Tribunals having in charge the dispositions of colonial affairs to be made by England as the Imperial State.

Thus had grown up a complete system of Imperial administration, under which the relations with the dependencies (that is, the affairs of the Empire) were separated from the affairs of the Realm, and placed in the hands of Imperial Councils, composed of experts in finance and economics and of high administrative officials of the Realm, before which, as before High Administrative Courts, or Tribunals of International Arbitration, the 


\section{The Administration of Dependencies}

Colonies could come, in one sense as suitors, but in another sense as distinct political personalities, or States, having rights which were to be ascertained and declared according to principles to which they had consented. 


\section{CHAPTER VI}

\section{IMPERIAL NOMENCLATURE, I625-I750}

$\mathrm{A}^{\mathrm{s}}$ the system of administration of the Colonies became more and more fixed along certain lines, the nomenclature became fixed accordingly. The name " colony" was the generic name for any distinct region and community in America, controlled by the English inhabitants and independent of all external power except the power of the State of England or Great Britain. It was a name which, from its origin, conveyed no necessary implication that the community called by that name had any political status whatever. Settlements were called " colonies" equally when they were little more than farms or factories, and when they had arrived at an organization so complete that they resembled half-sovereign States.

Sir George Cornewall Lewis, in his Essay on the Government of Dependencies, published in I84I, says of the word "colony":

The colonice were settlements of Roman citizens in Italy, who occupied a conquered town, divided the whole or a large part of the lands belonging to its citizens among themselves, and became the coloni or cultivators of the lands thus appropriated.

Colonia was formed from colonus; and colonus was formed from colo, and signified a cultivator. Colonia had also the sense of a farm. Compare the modern word "plantation," which means both a farm and a settlement. The idea of cultivation, and not of military occupation, was therefore contained in the word colonia. 


\section{The Administration of Dependencies}

The word colonia was, however, used in the Latin language, and the word "colony" in the English, to signify not only a community located in a region for the purpose of developing and cultivating it and its inhabitants, but also to signify a community which had been detached from the body of a State, and was, by reason of this fact, related to the State not only by ties of race and kindred, but also politically or semi-politically. The Oxford Dictionary says of this use of the word "colony" :

The Roman writers used the word colonia to translate the

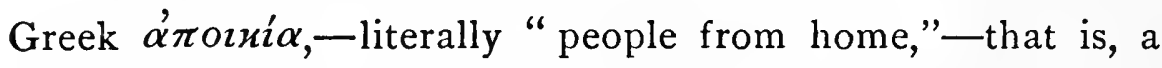
body of emigrants who settled abroad as an independent selfgoverned $\pi o^{\prime} \lambda 25$ or State, unconnected with the $\mu \eta \tau \rho o ́ \pi \circ \lambda \imath$ (metropolis) or mother-city, save by religious ties.

The word "plantation" had this same double meaning of a settlement of planters and a settlement planted by a State. Thus Lord Bacon, in his Essay on Plantations, said :

Plantations are amongst ancient, primitive and heroical works. When the world was young, it begat more children; but now it is old, it begets fewer : For I may justly account new Plantations to be the children of Kingdoms . . . Planting of countries is like planting of woods ; for you must make account to lose about twenty years' profit, and expect your recompense in the end . . . The people wherewith you plant ought to be gardeners, ploughmen, laborers, smiths, carpenters, joiners, fishermen, fowlers, with some few apothecaries, surgeons, cooks, and bakers.

The use of the word " colony" to describe every form of political community external to a State and constitutionally related to it probably arose from the practice of regarding the natives of the State who emigrated, and their associates and descendants, as alone constituting the political community. This conception still prevails to 


\section{Imperial Nomenclature, I625-1750 93}

some extent, especially in France, the native and foreign populations of dependent regions being regarded as so many individuals without status as members of a political community. Thus, M. Arthur Girault, in his Principes de Colonisation et Législation Coloniale, says:

One perceives, upon examination, a double civilizing action on the part of those who emigrate for colonizing purposes, exercised at the same time towards the material resources and towards the people of the region.

First, towards the material resources. The emigrants improve the harbors, build roads, clear and cultivate the soil, exploit the mineral wealth -in a word, utilize all the resources which the native inhabitants have drawn on only to a partial extent.

Secondly, towards the people of the region. Efforts are made to raise the natives to our civilization, to put an end to barbarous customs. Missionaries try to convert them to the religious beliefs prevailing among civilized peoples. Commercial agents, in quest of new markets for their products, engender new wants among them.

It is this civilizing action, this double culture of the soil and its inhabitants, which constitutes the work of colonization properly so-called. Moreover this sense corresponds to the original etymology of the word, "colonize" being from the same root as colere, to cultivate.

There is thus implied in the name "colony," as applied to inhabited regions acquired by cession, conquest, or occupation, a social and economic superiority, on the part of the dominant State, over the related and dependent communities. Political superiority, however, by no means necessarily implies social and economic superiority. A community which, in the beginning of the relationship, is socially and economically inferior to the dominant State, may, with the passage of time, come to equal or surpass the dominant State in civilization, 


\section{The Administration of Dependencies}

without changing its relationship of political subordination. It is even conceivable that a political community of higher civilization than that of the State to which it is external and related might, from the very beginning of the relationship, be in a condition of political subordination to this State and might remain in such a condition indefinitely. The name "colony" applied to such a community would be a palpable misnomer.

Giving the word "colony" its widest meaning, it seems to be the proper word only when the connection between the dominant State and the external related community is viewed from the social and economic standpoint, and when the external related community is on a lower scale of civilization than the dominant State, and so loosely organized that the power of the dominant State may be systematically applied, through an organized body of its own citizens who emigrate for the purpose, toward the civilization of the natives and toward the proper exploitation of the natural resources of the region. It seems, therefore, that the word "colony" can never properly be adopted as the generic word to describe the communities external to a State and under its political control or superintendence.

The word "mother-country" to denote the Imperial State, and the word "colonies" to denote its dependencies,-that is, to describe the political relationship, were, however, in 1750 , in almost universal use in Great Britain and America. The political relationship had not been carefully distinguished from the social and economic relationship.

The first American Charter in which an American Colony was recognized as having a political status was that of Maryland of 1632 , granted to Lord Baltimore. In that Charter, Maryland was declared to be a " Province," and its relations to the State of England were declared to be exactly those which the County Palatine of Durham held 
to that State. A county palatine differed from an ordinary county in that the count palatine exercised some royal functions and was regarded as the representative of the person of the King. The County Palatine of Durham was a border county between England and Scotland and on that account had, under the Bishops of Durham as Counts Palatine, enjoyed a semi-independence, having almost complete statehood, though being subject to the superintendence of the King and Parliament of England. Lord Baltimore, as Count Palatine and Lord Proprietor of Maryland, was the representative of the person of the King, - the King's Deputy, who exercised the same powers as the King might have exercised if he had been present, subject, however, to the King's ratification or disapproval by order in Council.

The name " province," as applied to such a political community as the inhabitants of Maryland formed, seems to have been taken from the public law of Rome relating to the administration of dependencies. Perhaps the provinces of the Realm of France, as they then existed, may also have suggested its use.

Mr. C. P. Lucas, in an appendix to the I89I edition of Sir George Cornewall Lewis's Essay on the Government of Dependencies, has this to say concerning the meaning of the word "province":

Provincia is derived by Festus from pro and vincere, according to which etymology it would mean "a country formerly conquered." This etymology has been adopted by the moderns, with no other modification than that suggested by Vossius, viz., that pro should be taken not for ante, but for procul. Provincia would thus signify " a country conquered at a distance." This etymology, however, seems objectionable on two grounds: I. Provincia is not formed by a proper analogy from vinco; it ought rather to be formed from a past tense or participle, like victor, victoria. 2. The derivation from vinco does not satisfactorily explain the other meaning of provincia, 


\section{The Administration of Dependencies}

viz.: "function," "department," "business"; which it appears to have had at an early period, since this usage occurs in familiar language.

It seems to me therefore most probable that provincia is contracted from providentia, and originally meant "that which a person had to look after, to attend to, to care for" ; that its primitive meaning was "business," "function," "department"; and that it acquired the secondary sense of "a foreign dependency" of Rome, because the management of the district was the department of one of the consuls or prætors.

The contraction of provincia from providentia is not greater than in other similar words; and the change of $t$ into $c$ after $n$ has nothing remarkable. Concio from conventio affords a parallel to both changes.

A " province," in the American and British public law of I750, was a species of " colony," which had, as a part of its constitutional settlement with Great Britain, a representative of the State of Great Britain residing within it, who participated in the government.

Provinces were of two kinds-those over which the Crown (that is, the State) of England or Great Britain had granted to individuals, as Counts Palatine and Lords Proprietors, full powers of government, which they held, to themselves and their heirs, subject to the conditions and trusts specified in the Charter in favor of the State of Great Britain and the inhabitants of the province; and those immediately dependent on the Crown, in which the King was represented by a Governor, appointed by the King in Council and holding office during his pleasure, who was the agent of the King, and the public and diplomatic agent of England or Great Britain, and the Chief Executive of the province.

Under grants to individuals as Counts Palatine and Lords Proprietors, the inhabitants were allowed to participate in the government only to such extent as the Lords 
Proprietors saw fit. This resulted usually in the inhabitants being represented only in the House of Representatives. When the $\mathrm{King}$ created a province immediately dependent upon himself, the invariable purpose of the English and British Government was to have not only the Governor, but also his Council (which was at the same time his Privy Council and the Upper House), appointed by the King. When only the Governor was appointed by the King, it was because the demand of the inhabitants of the province for statehood to the highest extent possible was so strong as not to permit the Council to be an appointed body.

The acceptance, by the various communities on and near Massachusetts Bay and on the coast above, of the Charter of I69I, by which all these communities were united into a province, under the name of "The Province of Massachusetts Bay," marked a great advance in the political thought of both England and America. It had been realized that the establishment of a region as a province was a recognition of it as a State in a relationship of constitutional (and hence of conditional and limited) dependence upon the Imperial State, and that the provincial form of government solved the problem how to justly and fairly maintain this constitutional dependence.

Perhaps one of the causes which led to the willingness of Massachusetts Bay, in I69I, to accept a Charter by which it became a province, was the position taken by England with regard to Ireland. Though William and Mary had been declared to be King and Queen of "England, Scotland and Ireland and the dominions thereunto belonging," nevertheless, when Ireland, in 1690, presumed to put itself on an equality with England, claiming to be an independent State, in personal union with England through the King, by its Lords and Commons holding what they called a Parliament in Dublin and purporting to 


\section{The Administration of Dependencies}

recognize King William as King, English troops at once reduced it to subjection, and it was constitutionally settled to be a province, with a royal Governor and Council, a hereditary House of Peers, and an elected House of Commons. Thenceforward, it was evident that the constitutional settlement of 1689 between King and people had not operated to convert the colonies of England into independent States, and that the highest grade of constitutional relationship attainable by any political community external to England and subject to the control of that State, was that of a province with a large degree of statehood. After Massachusetts Bay had taken the lead, there was no reason for the other Colonies to refuse to occupy the same kind of position in the Empire. All the other Colonies had become provinces before 1750 , except Connecticut and Rhode Island; and, as before said, they were guilds or privileged companies and hence rightfully subject to be converted into provinces at any time, by mere resumption by the Crown of its rights. That no advantage was taken by William III. of the surrender of the Rhode Island Charter to Governor Andros and of the judgment of forfeiture rendered by default against Connecticut in 1687, was doubtless due to the fact that these Colonies gave no special cause for forfeiting their franchises as guilds, and that, had the King resumed the government without special cause, however legal his action might have been, it would have been regarded by these Colonies as a violation of their constitutional rights. Maryland and Pennsylvania were under a merely nominal control of Lords Proprietors and were hence royal provinces in fact, though proprietary provinces in name.

The form of words by which provinces were created was in every case such as to show that the province was dependent, for its rights of statehood, upon the recognition and disposition of the State of England, as an ex- 
ternal Sovereign having power to adjudicate concerning the degrees of statehood which its dependencies ought properly to enjoy. Thus in the Charter of Maryland of 1632 the words used by Charles I. were "do erect and incorporate into a province." In the Charter of Maine of 1639 , his words were "do create and incorporate into a province." In the Charter of Carolina of 1662 the expression used by Charles II. was "do erect, incorporate and ordain into a province." In the Charter of Pennsylvania of I68I, Charles II. " erected" Pennsylvania "into a province." In the Charter of Massachusetts Bay of $\mathrm{I} 69 \mathrm{I}$, the regions specified were, by William III., " erected, united and incorporated into a province." The usage in this respect has a peculiar interest, because the words " erect" and "create" were used in resolutions offered in the Constitutional Convention of 1787 to describe the power of Congress over the "new states" (that is, the dependencies) which were expected to be formed in the Northwest Territory.

By the practice which prevailed between the years 1700 and 1750 , any region and community was considered a "province" of which the King, on forfeiture of a charter under which it had existed as a guild or a county palatine, had resumed the government by Proclamation or Letters Patent through an appointed Governor or an appointed Governor and Council, without granting a new charter formally "erecting" the region and community into a province. Under this practice, Virginia, which before I700 was called a "Dominion" was called a " Province."

The name "province" by no means implied absolute power on the part of the Imperial State over the population erected into a province. Indeed, if Mr. Lucas's derivation be correct, the word " province" contained, in itself, a recognition that the Imperial State was under an obligation in making its adjudications concerning 


\section{Ioo The Administration of Dependencies}

the degree of statehood to which the province was entitled, to adapt the form of government to the local circumstances and conditions to the extent that they could be met consistently with the higher obligations which required it to act for the general welfare. It did not imply any lack of consent of the population of the province to the form of government under which they were, or an absence of participation by them in their own government. It assumed that a constitutional relationship existed between the Imperial State and the province as a dependent State, and implied that the power of the Imperial State was a power of disposition as distinguished from a power of legislation.

Besides the words "colony" and "province," the words "dominion" or "dominions" and "territory" or "territories" were used to describe the American Colonies as related to England and Great Britain.

In the Virginia Charters of 1606,1609 , and 1611 , the "Colonies" or "Plantations" in Virginia were uniformly treated as a part of the "dominions" of the King. Thus in both the Charter of 1606 and that of 1609 it was provided that:

All and every the persons being our subjects, which shall dwell and inhabit within every or any of the said Colonies and Plantations, and every of their children which shall happen to be born within any of the limits and precincts of the said Colonies and Plantations, shall have and enjoy all liberties, franchises and immunities within any of our other dominions, to all intents and purposes as if they had been abiding and born within this our Realm of England, or any other of our said dominions.

The same provision is found in the other Colonial Charters with the addition that children born at sea to English or British subjects going to or returning from the Colonies were given the same privileges. 
The word "dominion" of course means literally the power which the head of a household (domus) exercises over it.

In the civil law, to quote the words of Mr. Gordon Campbell, in his Treatise on Roman Law:

Dominium gives to him in whom it is vested the power of applying the subject to all purposes, except such as are inconsistent with his relative or absolute duties.

The Century Dictionary defines "dominion" in the civil law as "the ownership of a thing, as opposed to a mere life interest, to an equitable right, to a merely possessory right, or to a right against a particular person."

In this wide sense, the same dictionary defines "dominion" as "a territory and people subject to a specific government or control."

Up to the time of the Commonwealth, the word " dominions" seems to have been used in this large meaning. Then, however, there seems to have arisen a doubt whether the word "dominions" was wide enough to cover all the region under every form and in every degree of connection with the State of Great Britain. In the Act of May I7, 1649, abolishing the office of King, Charles I. is spoken of as "Charles Stuart, late King of England, Ireland, and the territories and dominions thereunto belonging," and in the Act of May 19, I649, establishing the Commonwealth, the expression, "the people of England and of all the dominions and territories thereunto belonging," is used. In the Instrument of Government of 1653, the expression used, however, is "the Commonwealth of England, Scotland and Ireland, and the dominions thereunto belonging." Though Cromwell was by this Act declared to be "Lord Protector of the Commonwealth of England, Scotland and Ireland, and the dominions thereunto belonging," his title was afterwards changed by the addition of the words "and 


\section{The Administration of Dependencies}

territories" after the word "dominions," and his son Richard was given the title in this enlarged form.

Thus there was made a division of the "dominions" of the English State into two classes, the dominions of and within the State, and the dominions belonging and external to the State.

After the restoration of Charles II., a question arose as to the proper title of Virginia, which, in its Articles of Surrender to the army of the Commonwealth, in $165 \mathrm{I}$, had agreed that it should "be and remain in due obedience and subjection to the Commonwealth of England." In the Acts of the Colonial Assembly, during the period from I660 to I666, Virginia was described as " the Country of Virginia." In I666, Charles II. took Virginia under his direct government by Letters Patent, in which it was "declared and granted" that all the King's subjects inhabiting within the Colony should " have their immediate dependence upon the Crown of England, under the rule and government of such Governor or Governors as we, our heirs or successors, shall from time to time appoint in that behalf." Thenceforward Virginia was called "the Dominion of Virginia," and in 1682 , upon the reorganization after Bacon's Rebellion, the General Assembly adopted this name as the description of the Colony.

When James II., in I686, converted New England and New York into a single Government by means of a commission to Sir Edmund Andros as Governor-General, the region and its inhabitants were officially styled "The Territory and Dominion of New England," and were commonly called "The Dominion of New England."

It thus appears that a "dominion" was a specific part of the dominions "belonging to" England, which differed from a "province" merely in the fact that it had not been "erected " or "created" or "incorporated" as such. A dominion was, in fact, a province arising by rec- 
ognition of the Crown, and not by express grant. The title of Virginia as the "Old Dominion" is justified from the fact that its relationship to the State of England did not legally change between I625, when Charles I. resumed its government, and the Declaration of Independence, so that as it was a "Dominion" in I682, it was a "Dominion" from 1625 to 1776 , and hence entitled to the credit of having attained in advance of all the other Colonies to the ultimate type, later called a " province."

$\mathrm{Up}$ to the time of the Commonwealth, the word " territories," when used in the Colonial Charters, seems to have no certain meaning. It is used in such a way that it may be taken as meaning land under government, or outlying land, or vacant land, or settled land external to England, or land occupied by barbarous tribes, and perhaps with other meanings. In the time of the Commonwealth it seems to have been used with a specific meaning, though exactly what that meaning was, it is somewhat difficult now to determine.

The etymology of the word "territory" has been disputed from the earliest times. Grotius, in his Peace and War (book iii., chapter vi., sections 3 and 4), and Barbeyrac, his commentator, in his notes to the passage, go extensively into the question, and M. Pradier-Foderé, in his very recent Traite de Droit International Public (vol. ii., section $6 \mathrm{I} 2$ ), also considers it with some care. The derivation which Grotius, writing in 1625 , adopted, on the authority of Flaccus, Frontinas, and Pomponius, all Latin writers of the classical period, in which he was followed by " the learned " Crronovius, and which seems necessitated by the rules of the Latin language, is from the Latin verb terreo, meaning " to hold in subjection by terror or excessive fear,"'the double suffix torium giving the whole word territorium in Latin the literal meaning of " a place pertaining to a person who holds in subjection through terror or excessive fear," - that is, through awe or dread, 


\section{I04 The Administration of Dependencies}

creating obedience, respect, and reverence,-and the derived meaning of " a place subject to the exclusive control of a person or a political community."

The first writer who ever attempted to define the word, Marcus Terentius Varro, a friend of Cicero's, who wrote about 20 B.C., defined territorium as colonis locus communis, qui prope oppidum relinquitur - that is, " a place common to the farmers (or colonists) which is left near a town." In the passage from which this is taken he derives the word from the Latin verb terere, to wear away (by rubbing, that is, by frequent working over or by frequent footsteps). This derivation seems impossible, as the derived substantive would, under the rules of the Latin language, have been tritorium. Assuming, therefore, that Varro was correct as to the meaning of the word in his time (to doubt which would be rationally impossible), but that he was mistaken concerning the derivation (which is by no means improbable), the character of the early Roman colonization makes it possible to trace a close connection between Varro's definition and the verb terreo. The first Roman colonies were, to use the language of Sir George Cornewall Lewis, " garrisons of Roman citizens placed in conquered towns of Italy, the colonists retaining their full rights as Roman citizens." Niebuhr, in his History of Rome, informs us that all the towns of Italy, in the ancient days, had common land outside the town, and that in case of conquest by Rome, the practice was for the conquerors to confiscate one third of both the town land and the common land, and to allot to each member of the colony sent there to act as a garrison a quantity of Jand inside the town sufficient for a garden, but insufficient for the support of a family, so that the colonists had, in order to support life, to cultivate the common land and share in its product. Such "land common to the farmers (or colonists) left near the town" may very well have been called terri- 


\section{Imperial Nomenclature, I625-I750 105}

torium, because the old population and all foreigners who were inclined to the side of the old population were kept out of it, or held in subjection while in it, by fear. Such a region was, as we say, "commanded" by the garrison.

Assuming that the word "territory" is derived, as it seems necessary to conclude, from the Latin terreo, and to mean a place held in subjection by terror, it is the one word which, when without qualifying language, expresses the idea of a region and people under the unlimited and unconditioned power of an external human will. Of course a region held in subjection through terror might at the same time be governed according to just principles, and therefore a power over " territory" dependent on a State, to dispose of it and make all needful rules and regulations respecting it, is not objectionable to the most advanced political thought.

One of the meanings which has at all times been attached to the word "territory" has been that given by Varro, of a region adjacent to an organized community and dependent upon it for its government, though not forming a part of the personality of the community.

The derived meaning of "territory,"-" all the space in which the depositaries of the public authority are able to execute the will of the Sovereign by the employment of the force at their disposal " (Pradier-Fodére), or, "the extent of land and water which depends exclusively from the supreme power of a State" (de Martens), - doubtless arose from regarding the depositaries of the supreme governmental authority as the supreme power in the State, so that the town, city, or State itself, and its territorium or dependencies, were regarded as constituting a single territorium over which they were supreme.

A possible explanation of the use of the word "territories" with "dominions" in the time of the Commonwealth is that at that time publicists doubted whether a State, as such, could be said to have "dominions," 


\section{Io6 The Administration of Dependencies}

since the existence of "dominions" implied a person who was the dominus or lord of the region under dominion. A State was not at that time recognized by all publicists as a person. The institution of the Crown, in which the title to property belonging to the State of England was vested, was due, in part, to the fact that the State of England, as such, was supposed not to be a legal corporate person capable of holding and managing real estate. If it had not sufficient legal personality to hold real estate, it was doubtless argued that a fortiori it was not a moral person, charged with the moral obligations which are implied in the word " dominion," and that consequently the power of England over regions external to itself arose from the fact that these regions were merely appurtenances " belonging to " the State or " territory," or parts of the whole body of "territories," subject to the power of the State, as its " property."

Another meaning which "territory" or "territories" seems sometimes to have had in the literature of the period, was that of unsettled or wild lands. The use of the word in this sense perhaps arose from the supposition that it was derived from the Latin terra, " land," for which the authority of Cujas and Barbeyrac may be cited, but which seems impossible under any recognized rules of the Latin language. This meaning, however, seems never to have been given to it to any considerable extent. The word "territories" was used over and over again in many American public acts and proceedings where it necessarily meant an organized settled region dependent upon an American Province.

The "Lower Counties" of Pennsylvania, so-called, (which afterwards became the State of Delaware), ceded by James, Duke of York, to William Penn, a few months after the Charter of Pennsylvania was granted to him, which were given a separate Assembly but were put under the charge of the Governor and Council of Penn- 


\section{Imperial Nomenclature, I625-I 750 107}

sylvania, with a representation in the Council, were uniformly spoken of, until they obtained statehood under the Governor of Pennsylvania, as the "territories belonging to" Pennsylvania. The invariable expression throughout the public acts of the period was "The Province of Pennsylvania and the territories thereunto belonging."

From the year I686 until the American Revolution, the Governor of New York was commissioned as " Governor in and over the Province of New York and the territories depending thereon, in America," and the same practice prevailed in New Jersey from 1738 until the Revolution.

As there were both settled and unsettled regions depending upon the Provinces of New York and New Jersey, and as the regions depending upon Pennsylvania were settled, it appears that the word "territories" had no reference to unsettled or vacant or common land, but rather to any region which was adjacent and appurtenant to a province and immediately dependent upon it for its government. The original meaning of " territory" given by Varro seems to have been adopted in the English and American public law, except that that which he called "common to the colonists or farmers" was regarded as subject to the "town" or province, and dependent upon it for its government-a characteristic which such common land as Varro described must necessarily have possessed.

In the Charter of Massachusetts Bay of I69I, the alternative designation "Territory" is used with the word "Province," the expression used throughout the Charter being "Province or Territory." The same is true of the supplementary Charter of Carolina of 1665 . It is noticeable that in both cases the Charter annexed a region of country to a previous grant, and brought the whole under one provincial government. Thus, in the Charter of 


\section{I08 The Administration of Dependencies}

Massachusetts Bay, "the Territories and Colonies commonly called or known by the names of the Colony of Massachusetts Bay and Colony of New Plymouth, the Province of Maine, the Territory called Acadia or Nova Scotia and all that tract of land lying between the said Territory of Nova Scotia and the said Province of Maine" were erected, united, and incorporated into a "Province or Territory." In the Charter of Carolina of 1665 , the unsettled region between the twenty-ninth and thirty-first degrees of north latitude (now a part of Florida) was annexed to the Province of Carolina. There was nothing in either Charter which gave authority to the Provincial Government to treat the annexed region as a dependency of the Province. It has already been noticed that when $\mathrm{New}$ England and New York were brought under one government in $\mathrm{I} 686$ by commission to Andros as Governor-General, the alternative designation "Territory" was used with the title "Dominion." The conclusion seems necessary that the Crown lawyers doubted the power of the Crown, independent of Act of Parliament, to annex part of the Crown lands, or a province, to a province or to a colony formed under a guild charter, so as to create the whole into a single province; and that the words "or territory" were added in such cases, out of precaution, so that, in case it should be decided that the Crown had not the power of annexation or consolidation as respects the dependencies, the whole region would remain under the power of the Crown as a part of the " territory (or territories) belonging to England." This is the more probable, since it was settled that the King could not revoke a Charter, but that it could only be annulled for cause after a judicial determination in a high court of the Realm.

Still another word which was beginning to come into use in the British and American public law of 1750 to express the idea of a political community in relationship with an Imperial State was the word " dependency." 


\section{Imperial Nomenclature, I625-I 750 I09}

It will have been noticed that the expression "territories thereunto belonging" and "territories thereon depending" were used with the same meaning. Other examples of this are found in the Acts of the Parliament of the Commonwealth. The "dominions and territories belonging to England" mentioned in the Acts of 1649 abolishing the office of King and declaring the Commonwealth, were spoken of in the Act of $165 \mathrm{I}$, authorizing the sending of Parliamentary troops and vessels to quell the revolt in Virginia, as "dependent upon England." In the last-mentioned Act, it was declared that all the Colonies and Plantations in America " are and ought to be subordinate and dependent upon England, and hath ever since the planting thereof been, and ought to be, subject to such laws, orders or regulations as are or shall be made by the Parliament of England." The expression " dependent upon" and the word "dependency" were continuously, from the time of the Commonwealth, in use in the English public law. There is contained in the expression "dependent upon" an idea of protection and support which is absent from the expression " belonging to." The Century Dictionary gives as the first meaning of dependence "the relation of a hanging thing to the support from which it hangs"; and as one of its derived meanings: "The state of deriving existence, support, or direction from another; the state of being subject to the power and operation of some extraneous force; subjection or subordination to another or to something else." There is thus contained in the word "dependence" a meaning of mutual obligation. Nothing hangs from anything else unless by mutual attraction, or some other form of mutual binding or obligation, and hence "dependence" has the meaning of "reliance, confidence, or trust ; or a resting on something," and a relationship of dependency is a relationship of trust and confidence by the person who depends on the other person. If it be 


\section{Io The Administration of Dependencies}

granted that a State is a moral person and that any political community external to a State and related to it is likewise a moral person, so that a State is regarded as capable of undertaking and fulfilling a trust and confidence towards a political community under its control, the word "dependency" is properly the generic name by which to describe a political community external to a State and subject to its superintendence and control. The Oxford Dictionary admits this generic sense of the word when it defines a dependency as "a country or province subject to the control of another country of which it does not form an integral part." These propositions had not, however, received general acceptance in I750, and the expression "dependent upon" a State, by which the political community so characterized was recognized as an actual or inchoate State, was used interchangeably with the expression "belonging to" a State, which contained no express recognition of the statehood of the community, but simply declared its externality to the State to the control of which it was subject.

The fact that the expression "territories belonging to" a State was used in the sense of "territories dependent upon" the State is of peculiar interest because it seems to determine the meaning of the words "territory or other property belonging to the United States," in the clause of the Constitution relating to the administration of dependencies, and require that they be construed as meaning " territory or other property dependent upon the United States." 


\section{CHAPTER VII}

\section{THE AMERICAN CONSTITUTION OF I750}

$\mathrm{D}$

URING the period from I606 to I750, there was going on a continual process of unification of the British Colonies in America. Though their populations were separated by local interests and jealousies, they were all of one race, and, whatever the beginnings of their political organization, they all tended toward a single form-that of a province, which was recognized as a political organism distinct from the Realm of England or the Realm of Great Britain, and as entitled to the largest degree of statehood consistent with the welfare of the whole Empire.

Thomas Pownall, who was Governor of Massachusetts in I757 and of New Jersey in I759, in the fourth edition of his book The Administration of the Colonies, published in 1768, gives an ingenious and plausible reason for James I. having admitted the Virginians to a share in their own government. He says:

It was a most fortunate thing for the American Colonies that the Island of Jersey had, by its constitution, a right to hold a convention or meeting of the three orders or estates of the island, in imitation of those august assemblies, known by that or some other name, in great kingdoms and monarchies, a shadow and resemblance of an English Parliament, in which the King's Governor, or Lieutenant, had a negative voice; the great business of which meetings was the raising money to supply public occasions. "For" (Mr. Falle says), " as in England money cannot be raised upon the subject but by authority 


\section{2 The Administration of Dependencies}

of Parliament, so here it is a received maxim that no levies can be made upon the inhabitants but by their own consent, declared by their representatives assembled in Common Council." It was fortunate, I say, for our Colonies, that this was the case of Jersey; for there can be no other reasonable account given, how our Colonies preserved this essential right of Englishmen, but that it happened to be also a constitutional right of his Majesty's foreign French-Norman subjects.

But whether England conceded to the dependencies political personality to the greatest extent possible because it found that they could not be administered except on this basis, or because the French-Norman subjects of the King in the Island of Jersey had previously obtained it by constitutional settlement, or because the English sentiment for political liberty responded to and helped on the desire of the colonists for political personality for their communities, is immaterial for the present purposes. That the right of the people in the subordinate parts of the English and British Empire to participate in their own local government existed from the year I62I, as a principle of the Constitution of the Empire, is beyond doubt. The Imperial Constitution was the aggregate of the dispositions made by England and Great Britain concerning the extent to which statehood ought justly to be conceded by it to the respective dependencies in the interests of the whole Empire composed of England, as the Imperial State, and its dependencies. The adjustments and readjustments necessary to preserve a just balance between the interests of the metropole and the dependencies, which the French called the " colonial pact," required the exercise of expert and diplomatic powers. The problem for England was vastly complicated by the fact that the case was really that of the population of one political community treating with the population of another, and not, as in France, the King treating with the influential persons in each Colony. 


\section{The American Constitution of I750 I I 3}

Upon the King, therefore, as a part of his diplomatic functions, the duty was cast of determining, under the advice of experts, what ought justly to be the extent of the participation of the people of the dependencies in the government of them, as States, and of establishing those determinations by means of constitutional settlements made by Proclamations or Charters.

But, although there was a general recognition of the King's functions in this respect, there was at no time prior to 1750 any thought of denying to Parliament a visitorial and superintending power superior to that of the King. Even in 1630 , Charles I. issued a Patent to a guild for the colonization of the Providence Islands in the West Indies with a proviso that it should not take effect as a Charter until confirmed by Parliament, and the granting, confirmation, or amendment by Parliament of Charters of colonizing guilds was not uncommon. In I698 a Charter was granted, by Act of Parliament, to the English Company Trading to the East Indies, as a joint-stock company, which was, by Acts of Parliament of 1707 and I7II, consolidated with the original East India Company, the Charter of which was granted by Queen Elizabeth in 1600 , and renewed in 1658 by Cromwell, and in 1662 by Charles II. By the operations of this United Company, the foundation of the British Empire in India was laid.

The Colonies, from the outset, claimed that the power of Parliament, when sitting as the Parliament of the Empire, was different from its power when sitting as the Parliament of the Realm.

In 1646, when Dr. Child and others petitioned the Commissioners of the Lords and Commons for Foreign Plantations for a regulation permitting religious freedom in Massachusetts Bay, claiming that the Colony was only a guild and hence was subject to Parliament like all the corporations of the Realm, the General Court of the 


\section{4 The Administration of Dependencies}

Colony thus stated its views of the power of Parliament in the Empire:

I. That there is a difference between subjection to the laws in general, as all that dwell in England are, and subjection to some laws of State, proper to foreign plantations;

2. That we must distinguish between corporations within England and corporations of, but not within, England; the first are subject to the laws of England, yet not to every general law, as the City of London and other corporations have divers customs and by-laws differing from the common and statute laws of England. Again, though plantations be bodies corporate (and so is every city and commonwealth), yet they are also above the rank of an ordinary corporation.

In the Act of Parliament of 1649 , declaring the estabishment of the Commonwealth, the power of Parliament was declared in language which did not differentiate its powers when sitting as the Parliament of the Realm from its powers when sitting as the Parliament of the Empire. The Act read:

Be it declared and enacted by this present Parliament, and by the authority of the same, that the people of England, and of all the dominions and territories thereunto belonging, are and shall be, and are hereby constituted, made, established, and confirmed, to be a Commonwealth and Free State, and shall from henceforth be governed as a Commonwealth and Free State by the supreme authority of this nation, the representatives of the people in Parliament, and by such as they shall appoint and constitute as officers and ministers under them for the good of the people, and that without any King or House of Lords.

Virginia, however, after its revolt from the authority of the Commonwealth, procured its constitutional relationship to England, - and incidentally the constitutional relationship of all the Colonies, - to be thus expressed in the Articles of Surrender of March I2, 165I : 


\section{The American Constitution of I $75^{\circ}$ I 15}

First: It is agreed that the Plantation of Virginia, and all the inhabitants thereof, shall be and remain in due obedience and subjection to the Commonzealth of England, according to the laws there established, and that this submission and subscription be acknowledged a voluntary act not forced nor constrained by a conquest upon the country, and that they shall have and enjoy such freedoms and privileges as belong to the free born people of England.

Second: That the Grand Assembly as formerly shall convene and transact the affairs of Virginia, wherein nothing is to be acted or done contrary to the government of the Commonwealth of England and the laws there established.

Seventh: That the people of Virginia shall have free trade as the people of England do enjoy to all places and with all nations according to the laws of that Commonwealth; and that Virginia shall enjoy all privileges equal with any English Plantations in America.

Eighth: That Virginia shall be free from all taxes, customs and impositions whatsoever, and none to be imposed on them without consent of the Grand Assembly, and so that neither forts nor castles be erected or garrisons maintained without their consent.

This constitutional settlement, by which it was agreed that Virginia was in a relationship of "due obedience and subjection" to the State of England (that is, in a relationship of such obedience and subjection as was due and proper on just principles of free Imperial government) necessarily implied that Parliament had only the powers which the State of England could exercise by virtue of this constitutional settlement.

The language used in the English statutes shows that from the time of the accession of William III., at least, the King was regarded as the King of the dominions and territories because England was the Imperial State on which these dominions and territories were dependent 


\section{i 6 The Administration of Dependencies}

and of which he was the representative, under the control and supervision of Parliament, for the performance of those duties requiring expert and diplomatic knowledge and action.

In the Coronation Oath established by the Act of $\mathrm{I} 688$, the King was obliged to make oath

To govern the people of this Kingdom of England and the dominions thereunto belonging, according to the statutes in Parliament agreed on, and the laws and customs of the same.

In the Oath of Allegiance established by Act of I707, the person taking the oath was obliged to swear:

That our Sovereign , is lawful and rightful King (or Queen) of this Realm, and of all other his (or her) Majesty's dominions and countries thereunto belonging.

This last expression is noticeable as showing that though the dependencies were then regarded as "belonging to" Great Britain, they were also regarded as "'his Majesty's" dominions-that is, they were regarded as dependencies of the State of Great Britain, in the immediate charge of the King.

In the Navigation Act of 1696 (For Regulating Frauds and Preventing Abuses in the Plantation Trade) Parliament took occasion to declare its power over all the dependencies in Asia, Africa, and America by enacting that

All laws, by-laws, usages or customs at this time or which shall hereafter be in practice or endeavored or pretended to be in force or practice in any of the said Plantations which are in anywise repugnant to . . . this present Act or to any other law hereafter to be made in this Kingdom, so far as such law shall relate to and mention the said Plantations, are illegal, null and void to all intents and purposes whatsoever.

This was an admission that the dependencies were entitled to a special régime distinct from that of the Realm, 


\section{The American Constitution of I 750 i I 7}

accompanied by a claim that Parliament might determine the character of the régime in each particular instance.

The statehood of the Colonies was evidenced and declared by the manner and form of their political and corporate action. Their Local Governments "enacted" their "laws." In the Colonies, the General Court or the General Assembly enacted the laws; in the Provinces, the Governor or the Lord Proprietor, by the authority of the General Assembly, enacted them. There were occasional and temporary forms of enactment used which, if continued, might have given ground for claiming that the King was a part of the Provincial Government. Thus, in Maryland, from 1654 to 1658 , the form of the enacting clause was: "It is enacted in the name of his Highness the Lord Protector, with the consent and by the authority of this present General Assembly." This form of enactment, which might have contained an admission that Maryland was a commonwealth co-ordinate with England and not a province belonging to and dependent upon England, was stopped in 1658 when Lord Baltimore was restored as Lord Proprietor, and the old form, "Be it enacted by the Lord Proprietary by and with the consent of the Upper and Lower House of the General Assembly," was again used until the Revolution.

In I682, immediately after Bacon's Rebellion, the form of enactment in Virginia was: "Be it enacted by the King's most excellent Majesty, by and with the consent of the General Assembly." This was stopped after two years and in 1682 the form was adopted which was not changed until the American Revolution: " Be it enacted by the Governor, Council and Burgesses of the General Assembly and it is enacted by the authority aforesaid."

After Lord Baltimore was deprived of his proprietorship of Maryland in 1692 , the form of the enacting clause was: "Be it enacted by the King's most excellent Majesty, by and with the advice and consent of this present 


\section{8 The Administration of Dependencies}

General Assembly, and the authority of the same." This continued until I7I6, when the proprietorship was restored to the heirs of Lord Baltimore. Thenceforth the form of the enacting clause was: "Be it enacted by the right honorable the Lord Proprietary, by and with the advice and consent of his Governor and the Upper and Lower Houses of Assembly and the authority of the same."

These temporary exceptions, however, only serve to prove that it was the theory of the public law that the public acts in the American Colonies were to be enacted in the name of the Local Government, and not in the name of the King or of the Home Government. The practically universal form of the enacting clause, by which the Governor of the Province enacted "by and with the advice and consent of the Upper and Lower House of the General Assembly and by the authority of the same," shows that, in the public law of the British Empire, the Colonies were recognized as having statehood, and the State of Great Britain, as having a visitorial and superintending power over them.

It was thus established as the fundamental principle of the Constitution of the British Empire for the American Colonies that they were political persons, - that is, States, in the generic sense of that word,-subject, under constitutional conditions and limitations, to the State of Great Britain as the Imperial State or metropole of the Empire; that the King was the representative of Great Britain as the Imperial State, and that Parliament was also its representative, superior to the King. As between the Imperial State and the dependencies, the functions of the Imperial State were to determine the constitutions of the dependencies and to legislate for the Imperial defence and welfare; the function of the dependencies was to legislate for their local interests. Whatever the King consented to as a proper function of the Local Governments, 
the Colonies naturally considered to be a concession made by the Imperial State, and to be a part of the Imperial Constitution. Theoretically, perhaps, such concessions were regarded as in suspense for a time, so that if Parliament objected, the concessions would fail, but no opportunity ever arose to put such a theory in force, because Parliament left substantially the whole administration of the Colonies, except with regard to their foreign trade, to the King in Council.

Some of these concessions had come without any effort. The American Colonies had never been troubled by any attempts of English trading companies to monopolize their trade, but all chance of this was cut off by the declaration by the House of Commons by resolution in 1692 , against the power of the King to create monopolies by charter for trading in the dependencies. Thenceforward all monopolies had to be created by Act of Parliament, and Parliament granted none in America.

The concession by the King in Council in I735 that the Colonies should have the right of taxation, however, came as the result of a long struggle.

The Navigation Act first enacted by the Parliament of the Commonwealth in $165 \mathrm{I}$, which gave England and English ships the monopoly of the trade with the American Colonies, was re-enacted under Charles II. in I663, and a more elaborate statute covering the same ground was enacted under William III., which carried out the principles of the "colonial pact" and the "mercantile system" to the full. These Acts, of course, made it impossible for the King to make any concessions in this direction. Parliament had covered the ground with respect to the regulation of the external trade of the Colonies, and so long as these statutes existed, he could make no regulation inconsistent with them. The Colonies strenuously objected to the Navigation Acts until 


\section{I20 The Administration of Dependencies}

the time of William III. Thenceforward they acquiesced in them, apparently being convinced, as the result of the very careful consideration which all constitutional questions received in England upon the accession of William III., that the mercantile system involved no violation of their constitutional rights, and that the levying of imposts for the purposes of the trade and navigation of the Empire was a different thing from the levying of taxes for the ordinary purposes of defence and welfare.

Though the question of the right of England, as the Imperial State, to levy taxes in the Colonies was raised in the earliest times, the first general agitation of the question throughout the Colonies was initiated by the Province of Massachusetts Bay in 1692, which refused, under claim of authority given in its charter to levy taxes and direct the appropriation of the proceeds, to grant a permanent salary to the Governor. It claimed it had the right to pay him what it chose, by an annual grant. The English Government objected, both because this implied the exclusive power of the Colony to legislate by way of local taxation, and because it made the Governor dependent on the favor of the Legislature. Other Colonies followed the example of Massachusetts Bay, and by 1725 the practice of paying the royal Governors such sums as the General Assemblies (that is, the Houses of Representatives) saw fit, had become common. The House of Commons, on petition from the Legislature of Massachusetts Bay in 1732 requesting that they consent to this arrangement, refused in a brusque resolution which declared the request to be "frivolous" ; but nevertheless the King in Council yielded the point in I 735, and no further attempt was made to tax the Colonies or to dictate to them how they should tax themselves for nearly thirty years, they deciding, on requisition made by the King in Council, the amount, manner, and time 


\section{The American Constitution of 1750 I 2 I}

of payment, and enacting the law providing for the necessary taxation.

Other rights which the Colonies claimed were adjusted by a compromise or left unsettled as being so close to the border-line as to require adjudication in each case as it arose.

The Colonies had during all this period objected to all interference of the English and British Government in affairs that they regarded as properly of local importance and interest. When the Post Office establishment was extended to the Colonies in I707, they almost uniformly took upon themselves to regulate the manner in which the post-riders and postmasters should conduct themselves. When the British Government tried to enforce the Act of Parliament of I7IO, which made it a penalty to cut or injure pine trees suitable for ships' masts growing on land not appropriated to private ownership, they made prosecution and punishment so difficult that the law became a dead letter. When the British Government tried, in $\mathrm{I} 74 \mathrm{I}$, to stop the issue of bills of credit by the Colonies, by compelling Massachusetts Bay to tax itself to pay off all its bills then outstanding, the situation was made so difficult that the British Government allowed the matter to drop.

That the individual in the American Colonies had all the rights, privileges, and immunities as against the Government that every inhabitant of England or Great Britain had, was undoubted. The right was secured by every Colonial Charter, and the Charters were regarded as merely declaratory of the existing law.

The British Imperial Constitution for the American Colonies and Provinces, as it existed in 1750, may, therefore, thus be summarized:

Ist. Concerning the political relationship between Great Britain and the Colonies:

It was adjudged and declared by Great Britain and 


\section{The Administration of Dependencies}

assented to by the Colonies that they were dependent on Great Britain, and that Great Britain, as the Imperial or Sovereign State, and the Colonies, as dependencies, or constitutionally subject States, constituted a single political organism known as the British Empire; that Great Britain, acting through the King in Council or Parliament, had power to make constitutions for or constitutional settlements with the Colonies, respecting their wishes as far as it deemed consistent with the common interests. In the infancy of the Colonies the inhabitants were little consulted, as it was usually impossible for them, owing to their lack of homogeneity and the sparseness of their settlements, to have any definite ideas as a community on the subject of their government: As the Colonies increased in compactness of organization, the form of government was established by Charters or Proclamations, which evidenced the constitutional settlements made from time to time between the King in Council and the Agents or General Assemblies of the Colonies.

$2 \mathrm{~d}$. Concerning the respective spheres of jurisdiction of the Imperial State and the Colonies:

It was adjudged and declared by Great Britain and assented to by the Colonies that Great Britain, through its King, represented the whole Empire in the matter of making war and peace, and in all dealings with foreign States; and that Great Britain, through the King in Council, or through Parliament, or through any other governmental agency specially appointed for the purpose, had power to administer the common interests of the whole Empire, and that the Colonies had the exclusive power to administer their local interests in those respects in which they did not conflict with the interests of the Empire, under the condition that their local administration should conform to the equity of the laws of Great Britain - that is, should not be repugnant to it, but 
should be consistent with it as nearly as the local circumstances and conditions would permit; that Great Britain, through the King in Council, or through Parliament, had powers of administration reasonably incidental to the preservation of the common welfare, even though such administration extended to subjects which would ordinarily be within the sphere of jurisdiction of the Colonies, provided that such dispositions should not be repugnant, but agreeable, as nearly as might be, considering the circumstances and conditions of the whole Empire, to the laws and customs prevailing in the Colonies; that, for the purpose of preventing the intrusion of the Colonies into the sphere of jurisdiction of Great Britain, it was to be represented in the Colonies by a royal Governor with power of veto and sometimes by a royal Council, and that the King in Council should also have the power to veto Colonial legislation; and that, for the purpose of preventing intrusion by Great Britain into the sphere of jurisdiction of the Colonies, the petitions of their General Assemblies were to be considered and adjudicated upon by the King in Council and by Parliament, and the Agents of the Colonies were to be heard by the Board of Trade and Plantations and the Committee of the Privy Council for Plantation Affairs, before any action affecting the local interests of the Colonies became final.

The power to legislate in the common interests included the right to regulate foreign trade and the trade with the Indians, and probably also the right to regulate intercolonial trade (though this latter power seems not to have been exercised after the time of Charles II. and James II., owing to the prevalent belief in England that the dependence of the Colonies on England could be secured only by keeping them divided and fostering their jealousy of each other); to coin money and regulate its value, and fix the standard of weights and 


\section{24 The Administration of Dependencies}

measures; to establish an Imperial postal service; to constitute Imperial and Colonial Courts, unless the right to establish Colonial Courts were granted to a Colony in its Charter; to establish a Supreme Court of Appeal in England for the Colonies (the Court being a Judicial Committee of the Privy Council, which was evidently regarded as the proper body to hear Colonial causes, since such causes had to be decided not by the laws of England but by the equity of those laws); to define and punish piracies and felonies on the high seas and offences against the law of nations; to declare war, grant letters of marque and reprisal, and make rules concerning captures on land and water; to provide and maintain an army, navy, and fortifications for the Imperial defence, and to have power over the militia of the Colonies when raised by the Colonies for the Imperial defence; to regulate the mode of proof of the acts, records, and proceedings of a Colony, in another Colony; and to provide for the extradition of criminals from one Colony to another.

Among the matters of common interest concerning which the Colonies could act when authorized, were the entering into treaty, alliance, or confederation with other Colonies; granting letters of marque and reprisal; coining money; emitting bills of credit; or making anything other than gold and silver coin a legal tender in payment of debts.

The right to tax for the Imperial defence and welfare had never, up to 1750 (or until I764), been exercised by Great Britain. Its rights in this respect had, up to that time, been confined to an adjudication by the King in Council, after hearing the Agents of the Colonies, of the amounts of money or the numbers of troops which ought justly to be supplied by each Colony, and to making requisitions upon the respective Colonies, which responded through action taken by their General Assemblies for raising the money or troops. 


\section{The American Constitution of I $75^{\circ}$}

3d. Concerning the rights of individuals in the Colo. nies against the Imperial and the Colonial Governments.

It was adjudged and declared by Great Britain and assented to by the Colonies that neither the Imperial nor the Local Governments were to deprive the citizens of the Colonies of the equal protection of the laws (and hence were not to grant any monopoly except for patents, copyrights, etc.) or deprive any person of life, liberty, or property without due process of law. Due process of law, as against the Imperial Government, consisted in the Colonies being heard, through their Agents, acting both as diplomatic representatives and as attorneys at law, by the Board of Trade and Plantations and the Committee of the Privy Council for Plantation Affairs, before any action of the State of Great Britain depriving them, or any of their inhabitants, of life, liberty, or property, became final.

Under this Constitution, Great Britain and the Colonies were Member-States of a Federal Empire, in which Great Britain was the Imperial State and Central Government which adjudicated upon the limits of its own jurisdiction and concerning its action within these limits, after advising with the Colonial Agents, who acted as the representatives of the Colonies at the Court of the Imperial State. The usual instrumentality through which Great Britain made these adjudications or dispositions was the King, assisted by the Committee of the Privy Council for Plantation Affairs as a Secretarial Board or Chancellery, and by the Board of Trade and Plantations as an underSecretarial Board or sub-Chancellery, but the adjudications of the King were reviewable and controllable by the Parliament, composed of King, Lords, and Commons, acting in conformity with the conditions and trusts which rested upon the State.

The whole political organism composed of Great Britain and the Colonies was a Federal Empire, and not a 


\section{26 The Administration of Dependencies}

Federal State, because the Central Government was a State and not an elected body of men. The powers of Great Britain as the Imperial State and Central Government of the Federal Empire were essentially conditional,- the condition being that it should adjudicate the limits of its own jurisdiction, and act only within the limits so adjudicated. It occupied a position of trust of the highest nature, as does every Imperial State in its Federal Empire.

It cannot be said that the existence of the Federal Empire was ever admitted. It could not have been, since the Federal Empire and the Federal State had not yet been recognized and named. Writers on the general public law had not advanced beyond calling such political organisms "Systems of States." It can be said, however, that the Federal Empire existed in fact and that the Constitution above described was, in fact, its fundamental law. That there were acts of the English and British State and its Government during this period which were inconsistent with this Constitution is undeniable, but they were few in comparison with the great body of acts which were explicable only on the theory of the existence of such a Constitution.

The Constitution as it existed in 1750 continued in force unchanged until the close of the French War in I763. In all the negotiations between the Colonies and Great Britain preceding the Revolution, when a claim was made by or in behalf of the Colonies that they be restored to their constitutional situation, it was invariably the situation as it existed at the close of the war in 1763 that was intended. In speaking of the harmony and good feeling which it was hoped might be restored as the result of the negotiations, it was the harmony and good feeling which existed at the close of the war in 1763 to which the words referred. It would seem, therefore, on first glance, that the pre-Revolutionary Constitution 
of the British Empire in America ought to be called the Constitution of 1763 , and not the Constitution of 1750 . Inasmuch, however, as the acts on both sides which were regarded, in the time of the Revolution, by each of the contending parties, as attempted infractions of its constitutional rights, began in the year 1750 , it seems more proper to describe the Constitution as of the last year before any alleged infractions of it took place.

In the year 1750, the Constitution of the British Empire in America reached its greatest efficiency. During the period from I 735 to 1750 , the relations of the Colonies with Great Britain were better than they had been at any previous time; and, though seeds of discord were sown between 1750 and $17 \sigma_{3}$, yet the close fellowship and the pursuit of a common end during the war with France drew tighter the bonds of friendship. The Colonies were devoted to the connection with Great Britain,-which was, to all intents and purposes, a connection with England,-and no one appears to have dreamed that there was anything which was not dignified, just, and proper in their relationship to that State. 


\section{CHAPTER VIII}

\section{REALM OR EMPIRE, I750-I765}

\section{A}

FTER the passage of the Act of Settlement of 1689, the King, as a part of the Parliament, consisting of King, Lords, and Commons, was still looked up to by the people as the leader of political thought and action. It was equally repugnant to the ideas of William III. and of the people that the power of the King over legislation should be reduced to a mere power to veto bills that had passed both Houses. It was agreed by all parties that the King ought not only to have a part in the enactment of legislation, both constitutional and ordinary, but that he ought, as the expert part of the Government, to have the power of initiation and an equal voice with each of the two Houses in the framing of enactments. In the actual working of the system established by the Act of Settlement, it was necessary to the maintenance of the King's leadership that he should succeed in persuading the House of Commons to adopt any new measures of legislation initiated by him-the House of Lords acting usually with the King, but also checking both the King and the Commons. He could no longer ignore the Commons, or force them to act as a mere deliberative and registering body.

Legislation, therefore, had to be a matter of agreement between the three parties, - King, Lords, and Commons, - and, in order to consummate the agreement, there was need of the services of a body of persons, skilled in government and in party politics, whose 
function it was to devise measures on which all the three parties might unite, and to carry the measures through to agreement, by argument and persuasion. There was at first no open recognition of this body, and it was called the Cabinet Council,-that is, the inner and confidential Council which met in the Cabinet, or private apartment of the King, to devise measures of legislation and arrange for carrying them through both Houses, as distinguished from the Privy Council, which met in the Council Chamber, and deliberated concerning the purely executive acts of the King. The members of the Cabinet Council were called the King's Ministers, that is, the King's Servants. Later on, when it was realized that this body was an absolutely necessary means to consummate the necessary agreements concerning legislation between the King, Lords, and Commons, it came to be recognized as an institution, and received the abbreviated name of "The Cabinet." Though the members of the Cabinet were always Privy Councillors, the functions of the two bodies were so different-the Cabinet being organized to actually take part in and control legislation, while the Privy Council existed only to advise the King in his purely executive acts-that the two bodies were entirely distinct and separate from one another. As the functions of the Cabinet were expert and confidential to all the three parties,-King, Lords, and Commons, - it followed that unless it could devise measures on which an agreement could be reached, the only way was for the parties to discharge it and appoint another. If, however, one of the parties could dictate when it should be discharged, that party, in effect, could dictate legislation.

Shortly prior to I750, the House of Commons had claimed that it had the right to discharge the Cabinet when the measures advanced by it did not meet the approval of a majority of the House, and the Cabinet had 


\section{30 The Administration of Dependencies}

begun the practice of resigning under such circumstances. It was thus on the way to become simply the consultative Council of the House of Commons, to prepare measures agreeable to that House and to carry them through with the King and the House of Lords by persuasion and argument. As things stood in 1750 , the signs of the times pointed to a complete revolution of exactly this sort, which, when accomplished, would substitute for government by King, Lords, and Commons, the government of the House of Commons in Council, checked by the King and the House of Lords, who would, however, have little more than deliberative and registering functions.

$\mathrm{Up}$ to the time of the death of George II., in I760, no definite trial of strength had occurred between the King and the Commons. George III., however, determined to bring the question to an issue, and undertook to oppose the threatened attachment of the Cabinet to the House of Commons by fair means or foul, and to establish a government by $\mathrm{King}$ in Cabinet, not like that of the King in Council either in the traditional sense or in the sense of the Stuarts, who honestly believed that they had the right to legislate as well as to execute the statute and the unwritten law, but by rewarding his allies and ostracizing his opponents. No doubt he and the whole Tory party were alarmed to see the reins of government slipping out of the hands of the Crown, as the expert part of the English and British Government, and being caught up by the House of Commons, the popular and non-expert part. Perhaps his and their position may best be described as one which they considered to be necessitated by the fact that the House of Commons, in claiming the right to discharge the Ministry when it disapproved any measure proposed by them, was in a state of revolution against the Government, that there hence existed a state of political warfare between the King and that House, and that all was fair in war. 
If the Government of Great Britain was to be a government by the King, it logically followed that the inhabitants of the Realm of Great Britain and the inhabitants of the dependencies must constitute a single political organism. The House of Commons being, in the estimation of George III., a mere deliberative and registering body, at least so long as the warfare between him and them continued, there appeared to him to be no reason why the American Colonies should not be satisfied with the theory that the power of Parliament in the Colonies was unlimited and unconditional, since Parliament, in his view, was merely himself, assisted by the House of Lords and the House of Commons, as deliberative and registering bodies. But, if the Colonies were not satisfied, the exigencies of the political situation at home were such that he could not pay any attention to their complaints. An admission by him that the popular Assemblies of the Colonies had the right to control their Governments would have been an admission that the British House of Commons had the right to control the British Government. It was a logical necessity for the King and the Tory party, in the political situation then existing in England, in case the Colonial Assemblies claimed any other power than that of mere registration of the measures instituted by the King and deliberated and registered by the Lords and Commons, to reduce the Colonies to subjection by force.

On the other hand, the antagonism between the King and the House of Commons led the advocates of the claims of that House to be very jealous of all its prerogatives, so that many of the members who were opposed to the claims of the King vehemently upheld the unlimited and unconditional power of Parliament over the American Colonies. Thus the Colonies were between two contending factions in the British Government, both 


\section{32 The Administration of Dependencies}

working together to annul all the claims of the Colonies which could possibly interfere with the prerogatives claimed by either of them.

Both factions listened eagerly, therefore, to any argument, however specious, which went to show that the power of the King and Parliament was exactly the same in the American Colonies as in the Realm of Great Britain, and there were not wanting advocates who were ready to present arguments in favor of this theory.

The proposition that the powers of the King and Parliament were the same in the Colonies as in Great Britain meant, however, that the position which the English Government had taken in the time of the Com: monwealth, and in which it had persisted for a century and more, that the Colonies were "dominions and territories belonging to England or Great Britain," in the sense of being external to and dependent upon the body and personality of that State, was a mistake, that the old distinction between the Realm and the Empire was unfounded,-that there was no British Empire,- -and that there was only a British Realm, of which Great Britain was an integral part and the American Colonies another integral part.

On this theory, it was necessary to prove that the nonrepresentation in the British Parliament of the inhabitants of the Colonies, or the impossibility, by reason of natural conditions, of their being effectively represented, did not differentiate their political status from that of the inhabitants of Great Britain. The advocates of the theory argued that the people of the Colonies were no worse off than the disfranchised men of Great Britain (of whom there were many at that time, owing to the crude and unsystematic arrangements established by statute relating to the representation in the House of Com. mons), and the women, children, idiots, convicts, and paupers of Great Britain, who were "virtually repre- 
sented" by the Parliament, composed of King, Lords, and Commons.

The first Act of Parliament which showed signs of the tendency of Parliament to treat the American Colonies as parts of the Realm, and to deny the obligation toward them to which Great Britain was justly subject as the Imperial State on which they were dependent, was the Act of 1750 , by which, upon the inadequate consideration of admitting pig iron and bar iron from the Colonies into Great Britain free of duty, the erection, in any of the Colonies, of any " engine for slitting or rolling iron, or any plating forge to work with a tilt-hammer, or any furnace for making steel " was forbidden. A penalty of two hundred pounds was provided for violation of the Act, and any mill, furnace, or forge erected in violation of its provisions was declared a common nuisance which it was made the duty of the Governor to abate. This Act was doubtless justified, by those who believed in the existence of the Empire, as a proper adjustment of the terms of the "colonial pact" as the French called it, or as necessary under the "mercantile system," as it was then understood. All the European metropoles took upon themselves to treat their Colonies in this way. If the metropole restricted itself in any way, this was regarded as a justification for almost any restriction of the dependency in favor of which the metropole restricted itself.

But even if the Act of 1750 be conceded to be somewhat ambiguous concerning the theory on which Parliament legislated for the American Colonies, there is less doubt about the Act of I75 I, by which the Colonies of Massachusetts, Rhode Island, Connecticut, and New Hampshire were forbidden to issue bills of credit except to meet the current expenses in anticipation of taxes or in case of emergency, or to make any bills of credit a legal tender. That this Act was not based on the theory 


\section{34 The Administration of Dependencies}

that the Colonies could not constitutionally issue money is clear from the fact that it applied only to certain of them, and that Parliament, after having enacted in $176_{3}$ an Act forbidding any Colony to make its bills of credit a legal tender, passed another Act in 1770 , which allowed New York to issue bills of credit on loan paper and make them a legal tender.

Both these Acts were, of course, open to explanation as legislation of the Imperial State for the common welfare, since one purported to be a regulation of trade and the other a regulation concerning the currency; but they were both arbitrary measures (the Colonies not being consulted), and were local as well as general, in their effect; and hence might be claimed as precedents for the exercise of unconditional and unlimited power. For this reason, they provoked and alarmed the Colonists.

Almost at the same time that Parliament, by thus dictating to the Colories regulations respecting their manufactures and internal commerce, began to treat them as integral parts of the Realm, "virtually represented " in Parliament, George II. began to act on the same principle. In 1752 , by his order in Council, the Lords of Trade sent out instructions to all the Colonial Governors requiring them to submit full reports on all subjects and especially on all matters in which the Colonies were claimed to be violating the rights of the King or Parliament, and their recommendations concerning the action. which ought to be taken.

While the answers of the Colonial Governors to these instructions were under consideration by the British Government, the war with France broke out, and, as it was evident that the British possessions in America would be attacked, it became important to Great Britain to keep the good-will of the Americans and of the Indian tribes which occupied the region between the French and the British possessions. Consequently all thought 
of bringing the Colonies into the proper subjection of persons "virtually" represented had to be given up, and measures had to be taken to induce the Colonies to put themselves in a position to effectually co-operate with Great Britain in negotiating with the Indian tribes and in defending the American frontier. In order to accomplish this, the British Government instructed the Colonial Governors to have the Colonies send representatives to the meeting with the Indian chiefs appointed to be held at Albany in July, I754, who should assist in making a treaty of alliance with the Six Nations, and take measures for the general defence. Massachusetts Bay, Pennsylvania, New York, Connecticut, Rhode Island, and New Hampshire were represented. The delegates so met, all of whom were men of prominence in their respective Colonies, apparently without the least thought that they were acting in any way in violation of the purpose for which they were assembled, agreed upon a "Plan of Union," which proposed to the different Colonies " that humble application be made for an Act of the Parliament of Great Britain, by virtue of which one General Government may be formed in America, including all the said Colonies, and under which Government each Colony may retain its present constitution, except in the particulars wherein a change may be directed by the said Act."

The Plan of Union related to only two subjects-the administration, as dependencies of the American Colonies, of the Indian tribes and the settlements of whites in the Western country; and the defence of the Colonies. There was to be a President-General, to be appointed and supported by the Crown, and a Grand Council of delegates from the Colonies, appointed by their General Assemblies. The power of the President-General and Grand Council to enact laws (subject to the approval of the King in Council) and to levy taxes was thus worded: 


\section{36 The Administration of Dependencies}

That the President-General with the advice of the Grand Council, hold or direct all Indian treaties in which the general interest of the Colonies may be concerned; and make peace or declare war with Indian nations. That they make such laws as they judge necessary for the regulating of all Indian trade. That they make all purchases from Indians for the Crown, of lands not now within the bounds of particular Colonies, or that shall not be within their bounds when some of them are reduced to more convenient dimensions. That they make new settlements on such purchases by granting lands in the King's name, reserving a quit-rent to the Crown for the use of the General Treasury.

That they make laws for regulating and governing such new settlements, till the Crown shall think fit to form them into particular Governments.

That they raise and pay soldiers, and build forts for the defence of any of the Colonies, and equip vessels of force to guard the coasts and protect the trade on the ocean, lakes, or great rivers, but they shall not impress men in any Colonies without the consent of its Legislature. That for these purposes they have power to make laws and lay and levy such general duties, imposts or taxes, as to them shall appear most equal and just, considering the ability and other circumstances of the inhabitants in the several Colonies, and such as may be collected with the least inconvenience to the people, rather discouraging luxury, than loading industry with unnecessary burthens.

At the same time that the Plan of Union was adopted, the delegates also adopted a "Representation on the State of the Colonies."

In the Representation it was proposed:

That the bounds of these Colonies which extend to the South Sea, be contracted and limited by the Allegheny or Appalachian Mountains ;

That measures be taken for settling from time to time Colonies of His Majesty's protestant subjects, westward of the 
said Mountains, in convenient cantons to be assigned for that purpose; and

That the patentees or possessors of large unsettled territories be enjoined to cause them to be settled in a reasonable time on pain of forfeiture.

The plain purpose of both the Representation and the Plan of Union was that, as soon as the limits of the American General Government should be fixed by the order of the King in Council or by Act of Parliament, the American General Government should administer the settlements in the Western region as its dependencies. It is true that the Plan of Union provided that this power was to exist only until the Crown should think fit to form the new settlements into particular Governments; but the important thing is that it should have been proposed to the British Government that an American General Government should constitute the Imperial Government of the Western dependencies, even for the purposes of temporary administration.

If there is any doubt that the framers of the Plan of Union intended that the new Colonies in the transmontane region should be American, and not English Colonies, it is removed by what Franklin, the author of the plan, in his pamphlet, published in 1754, entitled Reasons and Motives on which the Plan of Union was Formed, said about the provisions which permitted the Governor in Council to make new settlements on land purchased from the Indians. His words were:

It is supposed better that there should be one purchaser than many; and that the Crown should be the purchaser, or the Union in the name of the Crown. By this means the bargains may be more easily made, the price not enhanced by numerous bidders, future disputes about private Indian purchases, and monopolies of vast tracts to particular persons, (which are prejudicial to the settlement and peopling of the 


\section{38 The Administration of Dependencies}

country), prevented; and the land being again granted in small tracts to settlers, the quit-rents reserved may in time become a fund for the support of government, for defence of the country, ease of taxes, etc.

Strong forts on the Lakes, the Ohio, etc., may at the same time that they secure our present frontiers, serve to defend new Colonies settled under their protection; and such Colonies would also mutually defend and support such forts, and better secure the friendship of the far Indians.

A particular Colony has scarce strength enough to extend itself by new settlements, at so great a distance from the old; but the joint force of the Union might suddenly establish a new Colony or two in these parts, or extend an old Colony to particular passes, greatly to the security of the present frontiers, increase of trade and people, breaking off the French connection between Canada and Louisiana, and the speedy settlement of the intermediate lands.

The power of settling new Colonies is, therefore, thought a valuable part of the plan.

Referring to the provision in the Plan of Union authorizing the President-General and Council " to make laws for regulating and governing such new settlements, till the Crown shall think fit to form them into particular Governments," Franklin said:

The making of laws, suitable for the new Colonies, it was thought, would be properly vested in the President-General and Grand Council, under whose protection they must, at first, necessarily be, and who would be well acquainted with their circumstances, as having settled them. When they are become sufficiently populous, they may by the Crown be formed into complete and distinct Governments.

The Plan of Union plainly provided for the establishment of an American Empire, dependent on the Imperial State of Great Britain, that is to say, for the establish- 
ment of an imperium in imperio, or sub-Empire. The twelve Colonies then existing (Delaware being then a dependency of Pennsylvania) were to constitute the subImperial State or the sub-metropole. As a plan for establishing an American sub-Empire, it was " complete in itself," to quote the sarcastic language of the Lords of Trade in their report upon it to the Privy Council, because it gave the General Government complete powers for the administration of the dependencies in the Western country. As a plan for a General Government for all the common purposes of the Colonies, however, it was incomplete, since the General Government was given no powers to legislate for the common convenience and welfare except as regards the administration of dependencies and the common defence. Had the Plan been adopted, the separate Colonies would have had to make such arrangements regarding all other matters of common interest as could be brought about by diplomatic negotiation between them, subject to the approval of the King in Council.

The words used to describe the power which the Gen: eral Government, composed of the President-General and Grand Council assembled as the Legislature of the sub-Empire, was to have in the administration and government of the dependencies of the sub-Empire, are noticeable. They were to be given power by Act of Parliament to make laws "for regulating and governing such new settlements," till the Crown should think fit to form thern into particular Governments.

That they were to have this power only till the Crown acted, shows that they were to act in lieu of the Crown, and therefore, in the same way and under the same obligations as the Crown would have acted. But if the power had been granted permanently instead of temporarily, the expression " for regulating and governing such new settlements" would have made it certain that 


\section{I40 The Administration of Dependencies}

they were to act in lieu of the Crown and under its obligations and restrictions.

The word " regulate" had, at this time, come into considerable, though not universal use in the English public law to describe the supreme power in the State, when exercised expertly. In the first English translation of Vattei's Law of Nations, made in 1760, the passage relating to the power of the State, the original of which is quoted above on page 13 , is thus rendered:

The country inhabited by one nation . . . is the settlement of the nation, and it has a proper and exclusive right to it.

This right comprehends two things: $\mathrm{x}$. The domain, in virtue of which the nation alone may use this country for the supply of its necessities, and may dispose of it in such a manner and derive from it such advantages, as it thinks proper. 2. The empire, or the right of sovereign command, by which the nation ordains and $" e g$ gulates at its pleasure everything that passes in the country.

By comparing this translation with the original, it will be observed that the expression disposer de is translated "dispose of " when it refers to what Vattel calls " the domain " of a state, and "regulate" when it refers to what he calls " the empire." A " regulation," therefore, in the view of the translator, was evidently a disposition relating to the actions of persons, as distinguished from a disposition relating to land or things. Just how the distinction arose can only be surmised. A reason which is at least plausible is that the expression " dispose of " had by process of derivation come to be used in such a way as made its meaning somewhat ambiguous, as applied to persons and their actions. One of these meanings (which the expression still has) was that of transferring control or ownership by will, by sale, or by gift. Evidently this meaning was derived from a supposed re- 


\section{Realm or Empire, I750-1765}

semblance between a disposition of property by will and an alienation of the title to property. A will is a disposition of property in the sense of a setting one's property in order for death, but as it also works a transier of the title, the two ideas seem to have become confused, so that it has become customary, in ordinary usage, to speak of disposing of property when one means merely selling or giving it away, and intends to convey no idea of setting his affairs in order by the transaction. Besides this meaning, also, it came to have, by derivation from its meaning of disposing or adjudicating upon problems relating to human action, the meaning of "determining the fate of " persons, and by still further derivation of " destroying the existence of " persons or " getting rid of "them. These curious changes of meaning had never been allowed in the public law, but they had evidently become so well fixed in popular usage in 1760 that the word " regulate" was preferred by some writers on the public law as applied to the power of the King over the actions and affairs of persons, natural and corporate, instead of " dispose of." While the usage was not fixed, the acts of the Crown or Parliament relating to land and things, or to communities when regarded as objects without personality, seem generally to have been spoken of as " dispositions," and the acts relating to persons, and to communities when regarded as legal and political persons, as "regulations."

By the Treaty of Paris of February 10, 1763, Canada and all the region east of the Mississippi and certain islands of the West Indies were ceded to Great Britain. By Proclamation in Council, of October 7, 1763 , George III. " erected . . . four distinct and separate Governments, styled and called by the names of Quebec, East Florida, West Florida and Grenada," which covered every part of the region ceded or relinquished by the Treaty which was unmistakably outside the charter 


\section{42 The Administration of Dependencies}

limits of any of the American Colonies, and, after so erecting these Governments, forbade the Colonies to make or allow any settlements in the remainder (which they claimed was within their charter limits) beyond the heads of the rivers which emptied into the Atlantic-that is, beyond the ridge of the Allegheny or Appalachian Mountains. As the Atlantic slope of this range has a maximum width of two hundred miles, and a minimum width (near New York) of only a few miles, it is evident that this restriction of the boundaries of the Colonies was a very serious matter. Added to this, the new Governments erected by the Proclamation were without selfgovernment and under the immediate control of the Crown, from which it was natural to suppose that all other Governments erected by the Crown in the Western country would, at the outset, at least, be of the same kind.

Thus the American scheme for a sub-Empire was annulled, and George III. declared that there should be only one Realm or Empire, and that the Realm or Empire of Great Britain.

This Proclamation incidentally established the policy of the British Government respecting the treatment of the Indian tribes. They were described as "the several nations or tribes of Indians, with whom we are connected and who live under our protection." The lands occupied by them were described as "parts of our dominions and territories reserved to them, as their hunting grounds." They were thus declared to be dependencies of Great Britain. The method of administration of these uncivilized dependencies outlined in the Plan of Union as the course proper to be followed by the General Government of the American sub-Empire was adopted as the method to be pursued by the Central Government of the British Empire. Purchases by private persons from the Indians or from Indian tribes were forbidden: trade with them, though free to any one who chose to engage 
in it, could be carried on only under a royal license issued by a royal Governor and upon giving security for the observance of "such regulations as we shall at any time think fit, by ourselves or commissaries, to be appointed for that purpose, to direct and appoint for the benefit of the said trade." All purchases of Indian lands were to be by the Crown. This was an excellent policy for the Indian tribes, but it was, in the opinion of the Americans, a violation of their constitutional rights as parts of the British Empire, secured to them by their Charters, to administer the affairs of these tribes as if they were dependencies of the Colonies.

In the Annual Register of ${ }_{17} \sigma_{3}$, which is said to have been edited by Edmund Burke, the following comment is made upon this part of the Proclamation, which is interesting as showing the difficulty which even the best informed people of England had in understanding its full purport, or at least their unwillingness to assume that the Proclamation was a part of a design of the British Government to alter the constitutional status of the American Colonies. The passage is interesting, also, because it describes the power of the Crown over the Western region as a power of "disposition." It was as follows:

The reader will observe, and possibly with some surprise, that in this distribution, much the largest, and perhaps the most valuable part of our conquests, does not fall into any of these Governments.

Many reasons may be assigned for this apparent omission. A consideration of the Indians was, we presume, the principal, because it might have given a sensible alarm to that people, if they had seen us formally cantoning out their whole country into regular establishments.

Another reason, we suppose, why no disposition has been made of the inland country, was, that the Charters of many of our old Colonies give them, with very few exceptions, no other bounds to the westward but the South Sea. 


\section{I44 The Administration of Dependencies}

On April 5, 1764, Parliament, by the procurement of the King and the Ministry, enacted the Tariff Act of I764, imposing duties on sugar, molasses, syrups, indigo, coffee, wines, cambrics, lawns, silks, silk stuffs, and calicoes, imported into the Colonies, with a proviso that the net proceeds of the duties should

be paid into the receipt of his Majesty's Exchequer, and entered separate and apart from all other moneys paid or payable to his Majesty, his heirs or successors; and be there reserved to be, from time to time, disposed of by Parliament towards defraying the necessary expenses of defending, protecting and securing the British Colonies and Plantations in America.

The Tariff Act of $176_{4}$ followed the old form of tax statutes, brought over from the thirteenth century, according to which the Commons of Great Britain "gave and granted " to the King " the several rates and duties hereinafter mentioned." This form of expression necessarily implied that the King was a personality apart from the people, exercising power by virtue of his prerogative and not by virtue of his being a governmental agent, between whom and the people a relationship existed which permitted of contracts and conveyances between him and them ; and that the House of Commons was essentially all the people of Great Britain, assembled by their representatives, who gave and granted a part of their property to the King.

The preamble of the Tariff Act of I $7 \sigma_{4}$ read:

Whereas it is expedient that new provisions and regulations should be established for improving the revenue of this Kingdom, and for extending and securing the navigation and commerce between Great Britain and your Majesty's dominions in America, which by the Peace have been so happily enlarged; and whereas it is just and necessary that a revenue should be 
raised in your Majesty's dominions in America, for defraying the expenses of defending, protecting, and securing the same: we, your Majesty's most dutiful and loyal subjects, the Commons of Great Britain, in Parliament assembled, being desirous to make some provision, in this present session of Parliament, towards raising the said revenue in America, have resolved to give and grant unto your Majesty the several rates and duties hereinafter mentioned.

As the House of Commons of Great Britain could not, by any stretch of the imagination, be considered as the meeting together of the people of Great Britain and the people of the American Colonies, since the people of the Colonies sent no representatives to that House, the giving and granting of a tax by the Commons of Great Britain on the property of the people of the American Colonies was a plain case of the people of Great Britain giving away the property of the people of America.

The language of the Tariff Act denied both limits and conditions upon the power. The people of Great Britain, assembled in the House of Commons by their elected representatives, - that is, the State of Great Britain, since the people of that State, acting through the House of Commons, were the ultimate power of that State, -it was claimed, had power over the property of the people of America without specific limits of extent and without specific conditions on the manner of its exercise. He who has power to "give and grant" property has unlimited and unconditional power over it, in a legal sense.

Undoubtedly, however, it will not do to lay too much stress on these words. They were a mere formula. By the constitutional settlement of 1689 , the Kings of England became governmental agents of the people and participants in legislation with the Lords and Commons. All that either of the three parties to legislation could thereafter claim for itself was the right of initiating 


\section{I46 The Administration of Dependencies}

certain kinds of legislation. The Commons, because of the old theory according to which they "gave and granted" taxes to the King, claimed the right to initiate all tax legislation,-or, to use the common phrase, to "originate money bills," and the old form of words was continued as evidencing this right. Had Parliament passed an Act with the simplest form of enacting clause imaginable, imposing the duties specified in the Act on imports into the American Colonies, the case would not have been altered in the least.

This Act also contained the following provision:

All the forfeitures and penalties inflicted by this or any other Act or Acts of Parliament relating to the trade and revenues of the said British Colonies or Plantations in America, which shall be incurred there, shall and may be prosecuted, sued for, and recovered, in any court of record, or in any Court of Admiralty, in the said Colonies or Plantations where such offence shall be committed, or in any Court of Vice-Admiralty which may or shall be appointed over all America, (which Court of Admiralty or Vice-Admiralty are hereby respectively authorized and required to proceed, hear and determine the same), at the election of the informer or prosecutor.

This extension of the jurisdiction of the Admiralty to customs and revenue cases was the extension of the system of trial without a jury which had hitherto been in force only with respect to causes of action arising on the sea, to cases arising on the land. The Lord High Admiral, or the Lords of the Admiralty when the office was held by a Board of Commissioners, had charge of the British interests on the seas. Upon the enactment of the Navigation Acts for regulating the trade between Great Britain and foreign States and between it and its dependencies, the jurisdiction of offences against these Acts seems to have been considered as vested in the 
Courts of Admiralty. The first recognition of this jurisdiction seems to be in the Act of I670, "to Prevent the Planting of Tobacco in England and for Regulating the Plantation Trade," in which it was provided that ships violating the Navigation Acts should be forfeited " in any of the said Plantations, in the Court of the High Admiral of England or of any of his Vice-Admirals." In some of the Colonies Vice-Admiralty Courts were established by the Crown, which had jurisdiction of offences against the Trade and Navigation Acts by ship-captains and mariners landing in the Colonies. Where such courts were not established, Colonial Courts were, by Colonial statutes, given admiralty jurisdiction. The procedure in the Admiralty Courts was by way of libel and seizure of the vessel, and the case was determined without a jury. Offences against laws imposing duties on importation of goods into the Colonies were, of course, committed on land, since the duties did not attach until the goods were landed, and hence such offences were not within the jurisdiction of the Court of Admiralty. Cases arising from the non-payment of import duties were revenue cases, in which the State sued in a civil or criminal action. In England, such suits were brought in the Court of the Exchequer; in the Colonies they might be brought in any court of general jurisdiction. They were triable by court and jury. To confer jurisdiction of such cases on the Courts of Vice-Admiralty in the Colonies was to treat the Colonies as if they were English ships at sea,- that is, as if they had no political status whatever, but were mere outlying appendages of the soil of Great Britain subject to the unlimited and unconditioned will of Parliament.

This Act mentioned "a Court of Vice-Admiralty which may or shall be appointed over all America." It was evidently the intention of the British Government to place the whole admiralty jurisdiction in all the Colonies 


\section{I48 The Administration of Dependencies}

in one court, to be called the Court of Vice-Admiralty to distinguish it from the British Court of Admiralty, which would undoubtedly have had branches in each Colony, and the judges of which would all have been appointed by the Crown. On this Court it seems to have been the intention to confer such jurisdiction as might be deemed from time to time necessary, for the protection of the Imperial interests. Had such a Court of Vice-Admiralty as proposed been established, it would have been, in fact, an Imperial Court, as distinguished from the Colonial Courts.

On March 22, I765, Parliament passed the Stamp Act. This Act, like the Tariff Act of 1764 , purported to "give and grant" the rates and taxes authorized by it. The duties, which were imposed on every kind of business instrument or document, newspapers, pamphlets, calendars, almanacs, advertisements in newspapers or pamphlets, playing-cards, and dice, were more troublesome than those authorized by the Tariff Act of the previous year, because they had to be paid in piecemeal by the user and not in bulk in the first instance by the importer, and later on by the consumer in an increase of price of the commodity. The same provision as in the Tariff Act of 1764 regarding the payment of the net proceeds into the Imperial Treasury and using them for the Imperial defence in the American Colonies was inserted in the Stamp Act.

The Stamp Act contained a provision similar to that of the Tariff Act of 1764 , giving jurisdiction of customs cases arising under it or other Tariff Acts to the Courts of Admiralty or to the Imperial Court of Vice-Admiralty, and also gave the right of appeal in customs cases to the Imperial Court of Vice-Admiralty, to any party aggrieved by the decision of a Colonial Court having admiralty jurisdiction, or by the decision of any existing Court of Vice-Admiralty in the Colonies. 
The Stamp Act, based expressly, as it was, on the claim that Parliament had unconditioned and unlimited power in the Colonies, and affecting, as it did, every transaction between individuals in the Colonies, squarely raised the question whether the Colonies were integral parts of the British State or component parts of the British Empire. If the Colonies were integral parts of the British State, Parliament had undoubtedly the same unconditioned and unlimited power over them and their inhabitants that it had over the Counties of the Realm and their inhabitants. If, on the other hand, the Colonies were political persons external to the British State, in constitutional relationship with that State, the power of Parliament over them was measured by the power of the State of Great Britain over them, and the conditions and limitations of that power were to be determined by the constitutional adjudications and settlements (dispositions) made by Great Britain, through the branch of its Government having charge of its Imperial relations, for and with the Colonies, on principles of just Imperial government. If the Colonies had acquiesced in the claim that Parliament had power to pass the Stamp Act, the British Empire would have ceased to exist and in its stead there would have existed a British Realm including all America. When the Americans opposed the Stamp Act, they were upholding the statehood of the Colonial communities, as component parts of the political organism composed of Great Britain as the Imperial State, and the Colonies as its dependencies, known as the British Empire,-a political organism which they believed to be right in principle and necessary and proper for their own welfare as well as for that of Great Britain. In a word, it may be said that when the Americans opposed the Stamp Act, they were upholding the British Empire, and that the real Revolution occurred when Great Britain, by passing the Stamp Act 
I50 The Administration of Dependencies

and thus claiming for itself unconditioned and unlimited power over the Colonies, denied their member-statehood and hence the existence of the British Empire. 


\section{CHAPTER IX}

\section{THE STAMP ACT CONGRESS, I 765}

$\mathrm{T}$

$\mathrm{HE}$ claim of Great Britain of the right to tax the Colonies was based upon two grounds: First, that Great Britain and the Colonies formed one political organism, and that all parts of the same political organism ought to contribute to its support according to laws established by the Central Legislature and enforced by the Central Executive; and second, that it was unjust to Great Britain that it should expend the money for the common defence and welfare and receive nothing, or only so much as the Colonies chose voluntarily to contribute, for so doing. Both these propositions were met by writers of great ability in the Colonies.

The first in the field was James Otis of Massachusetts, who had already made himself famous by resigning the office of Prosecutor for the Crown when the duties of the office required him to uphold the writs of assistance attempted to be issued by the courts, as general searchwarrants, in aid of the customs officers, and by appearing, in opposition to the Crown, to dispute the constitutionality of the writs.

In I764, he published a pamphlet entitled The Rights of the Colonies Asserted and Proved, in which he endeavored to prove that the power of Parliament, whether exercised in the Realm or in the Empire, was the same, but that it was conditioned and limited by the principles of natural justice-which merely meant that the courts of the Realm and of the Colonies should 


\section{52 The Administration of Dependencies}

determine the validity of Acts of Parliament. He said :

The question is not upon the general power of Parliament, but whether it is not circumscribed within some equitable and reasonable bounds. It is hoped that it will not be considered as a new doctrine that even the authority of the Parliament of Great Britain is circumscribed by certain bounds, which, if exceeded, their acts become those of mere power without right, and consequently void.

In support of this proposition, he quoted dicta of Lord Coke and Lord Hobart, which, however, had never been followed by the English courts. Nothing was better settled than that there were no constitutional conditions or limitations upon the power of Parliament when exercised within the Realm of Great Britain, and as he did not differentiate the Realm from the Empire, his argument did not help to elucidate the great question,- - which was, how the rights and liberties of the Colonies and of their inhabitants could be preserved consistently with the Colonies remaining in a relationship of dependency on Great Britain as their Imperial State,-but led, by an inevitable tendency, directly to independence, as must every argument based on the proposition that communities which Nature has made dependencies of a state are not dependencies, but integral parts of its body and personality.

Otis's pamphlet was referred to with approval in a remonstrance against the Stamp Act sent by the Massachusetts Legislature to the Board of Trade in 1765 , and produced much ill-feeling in England. It was one thing to claim that the powers of Parliament were conditioned and limited in the dependencies because the powers of Great Britain as the Imperial State over its dependencies were conditioned and limited and the powers of Parliament were only those of the Imperial State, and quite 
another to say that the powers of Parliament were in all cases conditioned and limited. The first position raised the question of the political personality of the Colonies and their relationship as political persons to the State of Great Britain; the other attacked the Constitution of the State of Great Britain.

Daniel Dulany, of Maryland, in his Considerations on the Propriety of Imposing Taxes on the British Colonies, published in 1765 , made a decided advance toward the soiution of the problem of constitutional dependency. Taking as fundamental the proposition that Great Britain was the Imperial State, to which the Colonies were constitutionally related as political persons, or States, he endeavored to define the character and extent of the power of Parliament in the Empire-or, what is the same thing, of the power of the Imperial State, acting through Parliament. He was the first to describe the power of the Imperial State as a power of "superintendence," that is, a power limited by the necessity of its interference in each particular case as it arose. He said:

The Colonies are dependent upon Great Britain, and the supreme authority vested in the King, Lords and Commons may justly be exercised to secure or preserve their dependence, whenever necessary for that purpose. This authority results from, and is implied in the idea of the relation subsisting between England and her Colonies; for considering the nature of human affections, the inferior is not to be trusted with providing regulations, to prevent his rising to an equality with his superior. But, though the right of the superior to use the proper means for preserving the subordination of his inferior is admitted, yet it does not necessarily follow that he has a right to seize the property of his inferior when he pleases, or to command him in everything, since, in the degrees of it, there may very well exist a dependence and inferiority, without absolute vassalage and slavery. In what the superior may rightfully control, or compel, and in what the 


\section{I54 The Administration of Dependencies}

inferior ought to be at liberty to act without control or compulsion, depends upon the nature of the dependence and the degree of the subordination; and these being ascertained, the measure of obedience and submission and the extent of the authority and superintendence will be settled.

May not then the line be distinctly and justly drawn between such acts as are necessary or proper for preserving or securing the dependence of the Colonies, and such as are not necessary or proper for that very important purpose?

When credit comes to be given to those great men who were responsible for the clause in the Constitution of the United States relating to the government of depen-. dencies, Dulany must receive his share of honor for having suggested the principle which underlies the phrase " and make all needful rules and regulations."

In I765, Stephen Hopkins, of Rhode Island, a man of great prominence in that Colony, who had filled its highest offices and had been one of its delegates to the Albany Congress of 1754 , in his pamphlet The Grievances of the American Colonies Candidly Examined, supplemented the suggestion of Dulany that the power of Parliament in the Empire was limited by the necessity of its interference in each particular case, by suggesting that its power was also conditional upon an expert investigation as a preliminary to all its action. He said:

Although each of the Colonies hath a Legislature within itself, to take care of its interests and provide for its peace and internal government, yet there are many things of a more general nature, quite out of the reach of these particular Legislatures, which it is necessary should be regulated, ordered and governed. One of this kind is, the commerce of the whole British Empire, taken collectively, and that of each Kingdom and Colony in it, as it makes a part of that whole. Indeed, everything that concerns the proper interest and fit govern- 


\section{The Stamp Act Congress, I 765}

ment of the whole Commonwealth, of keeping the peace, and subordination of all the parts towards the whole, and one among another, must be considered in this light. Amongst these general concerns, perhaps money and paper credit, those grand instruments of all commerce, will be found also to have a place. These, with all other matters of a general nature, it is absolutely necessary should have a general power to direct them; some supreme and overruling authority, with power to make laws and form regulations for the good of all, and to compel their execution and observation. It being necessary some such general power should exist somewhere, every man of the least knowledge of the British Constitution will be naturally led to look for and find it in the Parliament of Great Britain. That grand and august legislative body must from the nature of their authority and the necessity of the thing, be justly vested with this power. Hence it becomes the indispensable duty of every good and loyal subject, cheerfully to obey and patiently submit to all the acts, laws, orders and regulations that may be made and passed by Parliament, for directing and governing all these general matters.

Here it may be urged by many and, indeed, with great appearance of reason, that the equity, justice and beneficence of the British Constitution will require that the separate Kingdoms and distinct Colonies, who are to obey and be governed by these general laws and regulations, ought to be represented, some way or other, in Parliament, at least whilst these matters are under consideration. Whether the Colonies will ever be admitted to have representation in Parliament-whether it be consistent with their distant and dependent state-and whether, if it were admitted, it would be to their advantageare questions we will pass by; and observe, that these Colonies ought in justice, and for the very evident good of the whole Commonwealth, to have notice of every new measure about to be passed, by which their rights, liberties or interests may be affected. They ought to have such notice that they may appear and be heard by their Agents, by counsel, or written representation, or by some other equitable and effectual way.

The Colonies are at so great a distance from England that 


\section{I56 The Administration of Dependencies}

the members of Parliament can generally have but little knowledge of their business connections and interests, but what is gained from people who have been there; the most of these have so slight a knowledge themselves that the informations they can give are very little to be depended on, though they may pretend to determine with confidence on matters far above their reach. All such informations are too uncertain to be depended on in the transacting of business of so much consequence, and in which the interests of two millions of free people are so deeply concerned. There is no kind of inconvenience or mischief can arise from the Colonies having such notice and being heard in the manner above mentioned; but on the contrary, very great mischiefs have already happened to the Colonies, and always must be expected, if they are not heard before things of such importance are determined concerning them.

Had the Colonies been fully heard, before the late Act had been passed, no reasonable man can suppose it ever would have passed at all in the manner it now stands. For what good reason can possibly be given for making a law to cramp the trade and ruin the interest of many of the Colonies, and at the same time lessen in a prodigious manner the consumption of the British manufactures in them?

To Hopkins, therefore, must be given the credit for the suggestion of the principle which underlies the expression "to dispose of " in the clause of the Constitution of the United States relating to the administration of dependencies.

The second proposition of the British Governmentthat it was unjust to Great Britain, and unfair on the part of the Colonies, that Great Britain should expend the money for the common defence and welfare and receive nothing for so doing or only so much as the Colonies chose voluntarily to contribute-was answered by John Dickinson, of Philadelphia, the leading lawyer and statesman of Pennsylvania, in a pamphlet published in 


\section{The Stamp Act Congress, I 765 I57}

I765, entitled The Late Regulations Respecting the British Colonies on the Continent of America. In this pamphlet, he discussed the whole economic situation as between Great Britain and the American Colonies, and showed that the Colonies had, by the mercantile restrictions under which they had been placed, been made to contribute to the wealth of Great Britain many times more than Great Britain had ever expended for their benefit in its administration of the British Empire, so that the proposition for taking money by taxation in addition to the wealth which was taken from them and the money which was drained from them and transferred to Great Britain under the existing economic conditions, was so far from being justifiable as a repayment by the Colonies for money expended by it for them, that it was really an adding to the debt which Great Britain already owed to them. Of course, this argument related merely to the particular situation then existing, and while it made a great impression, it plainly did not cover every kind of economic situation which might exist between an Imperial State and its dependencies, and required some general rule to supplement it.

This general rule Dickinson proceeded to lay down, in the resolutions adopted by the Pennsylvania Legislature, September 21, I765, which were drafted by him, by making a distinction between internal and external taxes, -internal taxes being, according to his view, within the exclusive jurisdiction of the Colonial Governments, and external taxes exclusively within the jurisdiction of the British Government, acting as the Imperial Government. The second resolution (which followed his draft verbatim), read:

Resolved: That in the opinion of this House, it is inseparably essential to a free constitution of government that all internal taxes be levied upon the people with their consent. 
Of course, if Great Britain, as the Imperial State, had the exclusive power of external taxation, it followed, on the principle that the greater includes the less, that it had power to enact all other kinds of legislation relating to the external affairs of the Colonies, and to represent them in their external relations.

When the Stamp Act Congress met in New York on October 7, 1765 , to consider the measures to be taken in opposition to the Stamp Act, which, though passed on March 22, I765, was, by its terms, not to go into effect until November I, of that year, the thought of the country may be thus summarized: Otis, in Massachusetts, denied that Great Britain was the Imperial State, and sought to remedy the existing evils by changing the character of Parliament to that of a constitutionally conditioned and limited legislature, both in Great Britain and in the Colonies. This would have meant a revolution in Great Britain. In Rhode Island, Hopkins had recognized that Great Britain was the Imperial State and, without considering whether its powers were limited or not, had claimed that they were conditional, so that the Colonies were entitled to have these powers exercised by an expert tribunal acting on principles of justice, in which the Colonies could be heard by their diplomatic agents, before any legislation affecting them became final. In Maryland, Dulany had recognized also that Great Britain was the Imperial State, and had advanced the proposition that its powers were conditioned and limited so that it could exercise only such power as was necessary and proper for securing the dependence of the Colonies, on principles of justice and liberty. In Pennsylvania, Dickinson, also recognizing that Great Britain was the Imperial State, had taken the position that it had, as such, the power to legislate concerning the external affairs of the Colonies, and to represent them in the management of these affairs. 
The resolutions adopted by the Congress on October I9, I765, will be found, on careful examination, to be divisible into five parts, and to contain,-first, a statement of the character of the political relationship between Great Britain and the Colonies, in which Great Britain is recognized as the Imperial State and the Colonies as its dependencies; second, a statement of the sphere of jurisdiction of Great Britain and the Colonies respectively, under the existing Imperial Constitution; third, a statement of the rights of the individual inhabitants of the Colonies against the Imperial and Colonial Governments under the existing Imperial Constitution; fourth, a statement of the violations by Great Britain of the constitutional rights of the Colonies as political persons by intrusion of the Imperial State into the sphere of jurisdiction of the Colonies and by violation of the constitutional rights of individuals; and fifth, a statement of the violations by Great Britain of the constitutional rights of the Colonies, by enacting laws which, though within the sphere of jurisdiction of Great Britain, were not according to the principles of justice, considering the Colonies as political persons, or States, entitled to just and fair treatment by the Imperial State as component parts of its Empire.

The first part of the resolutions-that containing a statement of the character of the political relationship between Great Britain and the Colonies-was contained in the first resolution, which read:

I. That his Majesty's subjects in these Colonies owe the same allegiance to the Crown of Great Britain that is owing from his subjects born within the Realm, and all due subordination to that August Body, the Parliament of Great Britain.

This resolution seems to be in part taken from the decision in Calvin's Case, in which it was held by ali the 


\section{The Administration of Dependencies}

high judges of England that allegiance was to the person of the King and was due equally from the inhabitants of the Realm and the inhabitants of the dependencies, and in part from the constitutional settlement made between the Commonwealth of England and Virginia by the Articles of Surrender of $165 \mathrm{I}$, in which it was agreed that Virginia and all its inhabitants should "be and remain in due obedience and subjection to the Commonwealth of England according to the laws there established," which, as has before been noticed, left the whole question of the character and extent of the obedience and subjection to be determined according to what one or both the parties, or some tribunal, considered to be "due" and proper under the circumstances.

Dickinson had made the original draft of these resolutions, and the subject-matter of this resolution of the Congress had been covered by the first two resolutions of his draft, which read:

I. That his Majesty's subjects in these Colonies owe the same allegiance to the Crown of Great Britain, that is due from his subjects born within the Realm.

2. That all Acts of Parliament, not inconsistent with the principles of freedom, are obligatory on the colonists.

According to the theory of Dickinson's original resolutions, all Acts of Parliament were to be judged by certain principles of government, assumed to be capable of scientific determination, and, if found to be inconsistent with such principles, were to be annulled. It left it uncertain by what party-Great Britain, the Colonies, or a third party or tribunal-the adjudication should be made. The resolution in its final form, in claiming that the inhabitants of the Colonies owed "all due subordination to Parliament," proceeded upon exactly the same theory, but was more diplomatic, respectful, and proper, since it 


\section{The Stamp Act Congress, I765 I6I}

contained the implication that Parliament was endeavoring in all cases to act on principles of freedom judicially and expertly ascertained, and that hence its Acts were presumptively binding.

The resolutions, both in their original and final form, plainly and definitely claimed that the Colonies were not integral parts of the Realm. In both the distinction was carefully drawn between "the Colonies" and "the Realm." The colonists were described as " his Majesty's subjects in these Colonies," and were distinguished from " his Majesty's subjects born within the Realm"; and the position taken was that, though they all owed "the same allegiance" to the King, "his Majesty's subjects in these Colonies" owed obedience to such Acts of Parliament only as were " not inconsistent with freedom," or, in other words, " owed all due subordination to Parliament."

The main reason advanced in the resolutions against Parliamentary taxation therefore was, that the relations of the Colonies were, in the first instance, relations between them and the State of Great Britain, and that the powers of the Crown and Parliament over them were such and such only as were necessary to the maintenance, at the highest point of efficiency, of this political connection between the Colonies as political organisms and Great Britain as another political organism acting as protector and governor.

Indeed it may be doubted whether this was not, when the resolutions are examined, the whole basis on which they rested, because the resolutions absolutely repudiated any possibility of a settlement on the basis of the Colonies being represented in Parliament, on the ground that such representation was contrary to the nature of things and hence out of the question. This repudiation was contained in the fourth resolution, which was adopted verbatim from Dickinson's draft, and which read: 


\section{The Administration of Dependencies}

Iv. That the people of these Colonies are not, and from local circumstances cannot be, represented in the House of Commons of Great Britain.

This was no more than to say that the Colonies were not, and from local circumstances could not be, parts of the Realm, but that they were, and from local circumstances must always be, so long as they were constitutionally related to Great Britain, parts of the Empire of that State.

In the second part of the resolutions-the part relating to the respective spheres of jurisdiction of the Imperial and the Colonial Governments-it is undoubtedly true that the Congress made a distinction between legislation for the purposes of levying and collecting taxes and legislation for all other purposes, which, if it had stood alone, would have laid them open to the claim that they had admitted that other kinds of legislation except legislation for taxing purposes might constitutionally be enacted by Great Britain, as the Imperial State, without the consent of the Colonies.

The resolutions of the Stamp Act Congress on this subject were as follows:

III. That it is inseparably essential to the freedom of a people, and the undoubted right of Englishmen, that no taxes be imposed on them but with their own consent, given personally, or by their representatives.

$\mathrm{v}$. That the only representatives of the people of these Colonies are persons chosen therein by themselves, and that no taxes ever have been, or can be constitutionally imposed on them, but by their respective Legislatures.

vi. That all supplies to the Crown being free gifts of the people, it is unreasonable and inconsistent with the principles and spirit of the British Constitution, for the people of Great Britain to grant to his Majesty the property of the colonists. 
As, however, the Congress, under the lead of Dickinson, had placed their claims on the wide ground that their subordination to Great Britain was "due" subordination, in which qualification it was necessarily implied that they had at least the right to be heard concerning the justice and propriety of any legislation affecting them before it became final, these resolutions were really a specification under the general claims contained in the first, second, and fourth resolutions.

No distinction was made by the Congress in their resolutions, based on the purposes for which the taxes were to be levied. They placed in the same category taxation for local administration and taxation for the defence and welfare of the Empire of which they admitted themselves to be subordinate parts. Great Britain had, however, raised no constitutional question of this sort, because though, in the Tariff Act of I $7 \sigma_{4}$ and the Stamp Act, it had declared that the proceeds of the taxes thus imposed should be kept apart as funds of the Empire, to be used for the Imperial defence in the Colonies, it had not based its right to tax the Colonies on this ground, but had simply left matters so that the proceeds of the taxes should be used for the Imperial defence in the Colonies until Parliament should will otherwise.

That this provision was absolutely ignored by the Congress was doubtless due principally to the fact that they did not consider that they were called upon to answer a proposition of Parliament which merely stated its intentions regarding the exercise of power. Still, even if Parliament had in these statutes declared its power to tax to be limited, the words used were objectionable. The proceeds were "to be from time to time disposed of by Parliament towards defraying the necessary expenses of defending, protecting and securing the said Colonies and Plantations." Had it been proposed by Great Britain to levy taxes for the defence and welfare of the 


\section{I64 The Administration of Dependencies}

Empire in the Colonies, attention might have been called to the considerations which differentiate such taxation from all other kinds, and the discussion might have turned on the proper methods of taxation for the Imperial defence and welfare. At that time, however, the conception of the modern Empire, in which a state is the constitutional Emperor, and other states the constitutional subjects, was perhaps too dim to enable either party to the discussion to perceive any distinction between the defence, by the State of Great Britain of its Empire, in that part of it called the American Colonies, and the defence, by the Parliament of Great Britain, of the American Colonies, as appendages or appurtenances of the Realm of Great Britain.

The third part of the resolutions-that relating to the constitutional rights of the individual inhabitants of the Colonies against the Imperial and Colonial Governments -was contained in the first, second, seventh, and thirteenth resolutions, which read:

I. That his Majesty's subjects in these Colonies owe . . . all due subordination to that August Body, the Parliament of Great Britain.

II. That his Majesty's liege subjects in these Colonies are entitled to all the inherent rights and liberties of his naturalborn subjects within the Kingdom of Great Britain.

viI. That trial by jury is the inherent and invaluable right of every British subject in these Coionies.

xiII. That it is the right of the British subjects in these Colonies to petition the King, or either House of Farliament.

The fourth part of the resolutions-that which set out the grievances which were unconstitutional because invasions of the sphere of jurisdiction of the Colonies and of the constitutional rights of the individual inhabitants of the Colonies to life, liberty, and property, as distinguished from those which were unconstitutional because 
oppressive and injurious in their operation-was as follows:

viII. That the late Act of Parliament, entitled "An Act for Granting and Applying Certain Stamp Duties, and Other Duties, in the British Colonies and Plantations in America," \&c., by imposing taxes on the inhabitants of these Colonies, and the said Act, and several other Acts, by extending the jurisdiction of the Courts of Admiralty beyond its ancient limits, have a manifest tendency to subvert the rights and liberties of the colonists.

The "extension of the jurisdiction of the Courts of Admiralty beyond the ancient limits of the Admiralty," was the extension of the system of trial without a jury to cases which, in their nature, arose on the land, since duties cannot properly be said to attach to goods imported until they are landed and the importation is complete.

The fifth part of the resolutions-that relating to violations by Great Britain of the constitutional rights of the Colonies and their inhabitants by enacting tariff laws which, though within the sphere of jurisdiction of Great Britain, were not based on just and scientific principles, but were ill-considered, unjust, and oppressive to the Colonies as political persons and to their inhabitantswas contained in the ninth, tenth, eleventh, and twelfth resolutions, which were:

Ix. That the duties imposed by the several late Acts of Parliament, from the peculiar circumstances of these Colonies, will be extremely burthensome and grievous; and from the scarcity of specie, the payment of them absolutely impracticable.

$x$. That as the profits of the trade of these Colonies ultimately center in Great Britain, to pay for the manufactures which they are obliged to take from thence, they eventually 


\section{I66 The Administration of Dependencies}

contribute very largely to all supplies granted there to the Crown.

XI. That the restrictions imposed by several late Acts of Parliament on the trade of these Colonies will render them unable to purchase the manufactures of Great Britain.

xII. That the increase, prosperity and happiness of these Colonies depend on the full and free enjoyment of their rights and liberties, and an intercourse with Great Britain mutually affectionate and advantageous.

There was contained in these resolutions a plain suggestion that these matters of tariff should be adjusted by diplomatic agreement between Great Britain and the Colonies, which could have been accomplished only by. the recognition of the Colonial Agents as diplomatic representatives of the Colonies. This would have necessitated that they should be received at Court and should be allowed to negotiate terms with the King's Secretary or his Secretarial Board appointed for the purpose, subject to the final determination of the King, made after advising with his Secretary or Secretarial Board.

In the conclusion of the resolution the Congress recognized again the allegiance of the colonists to the person of the King and the connection of the Colonies, as political persons, with Great Britain as the Imperial State, in the following language:

Lastly, it is the indispensable duty of these Colonies to the best of Sovereigns, to the Mother-Country, and to themselves, to endeavor, by a loyal and dutiful address to his Majesty and humble applications to both Houses of Parliament, to procure the repeal of the Act for Granting and Applying Certain Stamp Duties, and of all clauses of any other Acts of Parliament, whereby the jurisdiction of the Admiralty is extended as aforesaid, and of the other late Acts for the restriction of American commerce.

The Congress said, in its "Address to the King ": 


\section{The Stamp Act Congress, I 765}

Our connection with the British Empire we esteem our greatest happiness and security, and humbly conceive it may now be so established by your royal wisdom, as to endure to the latest period of time.

In its "Address to the House of Commons" it said:

We esteem our connections with, and dependence on Great Britain as one of our greatest blessings, and apprehend the latter will appear to be sufficiently secure, when it is considered that the inhabitants in the Colonies have the most unbounded affection for his Majesty's person, family, and Government, as well as for the Mother Country, and that their subordination to the Parliament is universally acknowledged.

In the "Address to the King," the grievances of the Colonies were thus stated:

Our subordinate Legislatures are in effect rendered useless by the late Acts of Parliament imposing duties and taxes on these Colonies and extending the jurisdiction of the Courts of Admiralty beyond its ancient limits, - statutes by which your Majesty's Commons in Britain undertake absolutely to dispose of the property of their fellow-subjects in America without their consent, and for the enforcing whereof, they are subjected to the determination of a single judge in a Court unrestrained by those wise rules of the common law, the birthright of Englishmen, and the safeguard of their persons and liberties.

In the "Address to the House of Commons," the Congress adopted the ideas of Dulany, Hopkins, and Dickinson, in the following language:

It is submitted that it is extremely improbable that the honorable House of Commons should at all times be thoroughly acquainted with our condition, and all facts requisite to a just and equal taxation of the Colonies.

It is also humbly submitted whether there be not a material distinction, in reason and sound policy, between the necessary 


\section{I68 The Administration of Dependencies}

exercise of Parliamentary jurisdiction in general Acts, and the common law, and the regulations of trade and commerce through the whole Empire, and the exercise of that jurisdiction by taxing the Colonies.

The proposition that the power of Parliament in the Empire was in the nature of things different from its power in the Realm, being only such as was necessary to preserve, in an orderly manner, the Empire exercised by the State of Great Britain over the Colonies, was the fundamental proposition on which all the resolutions of the Congress rested. Once this was admitted, the question of the proper terms of the constitutional relationship between Great Britain and the Colonies resolved itself into a question of the character and extent of the power which Parliament ought to exercise over the Colonies on principles of justice, regardless of the character and extent of the power which it exercised in the Realm. 


\section{CHAPTER $\mathrm{X}$}

\section{PLANS OF SETTLEMENT, I $765-1767$}

SHORTLY after the dissolution of the Stamp Act $\bigcirc$ Congress, Sir Francis Bernard, who was then the royal Governor of Massachusetts, in letters to friends in England who were high in authority as members of the Board of Trade and the Privy Council, made suggestions concerning the course which he thought it necessary for Great Britain, as the Imperial State, to follow, if it was to maintain itself at the head of the Empire. These letters were published in 1774 , in a volume entitled Select Letters on Trade and Government of America. In them, he proposed that the British Government should call together a Constitutional Convention composed of delegates from Great Britain and the Colonies, to frame a written Constitution for the parts of the . Empire situated in America and the West Indies, which should define the relationship between Great Britain and these Colonies (declaring it to be the Imperial State and they its dependencies), the conditions and limitations upon the powers of the Imperial State and the Colonies respectively, and the rights of the individuals inhabiting in the Colonies against the Imperial and Colonial Governments. In a letter of November 23, I765, he said:

It is my opinion, that all the political evils in America arise from the want of ascertaining the relations between Great Britain and the American Colonies. Hence it is, that ideas of that relation are formed in Britain and America so very repugnant and contradictory to each other. In Great Britain, 


\section{70 The Administration of Dependencies}

the American Governments are considered as corporations, empowered to make by-laws, existing only during the pleasure of Parliament; which hath never yet done anything to confirm their establishments, and hath at any time a power to dissolve them. In America, they claim (I mean in the public papers) to be perfect States, no other wise dependent upon Great Britain than by having the same King; which, having complete Legislatures within themselves, are no way subject to that of Great Britain; which, in such instances as it has heretofore exercised a legislative power over them, has usurped it. In a difference so wide, who shall determine? The Parliament of Great Britain? No, say the Americans (I mean the violent of them); that would be to make them judges in their own cause. Who then? The King? He is bound by Charters, or Constitutions equal to Charters, and cannot declare against his own grants. So, at this rate, there is no superior tribunal to determine upon the rights and privileges of the American Colonies.

But the general plea of the Americans against the Stamp Act is, that they are not represented in Parliament, and therefore not liable to be taxed by it: to which it has been answered in England, that they are virtually represented in Parliament. Each of these pleas tends to expose its own cause. If the Americans rest their defence upon their not being represented, it is in the power of Parliament, by admitting representatives from America, to take away all pretence of their not being bound by its Acts: on the other side, if the notion of the Americans being virtually represented should be falsified in fact, the plea of the Americans will remain in its full force; whereas the right of the Parliament of Great Britain to make laws for the American Colonies is founded upon its being the Supreme Imperial Legislature, to which all members of the Empire, whether represented or not, are subject in all matters and things, and in manner and form, as shall be judged most convenient for the whole.

But though the Parliament of Great Britain does not stand in need of a real or virtual representation to ground its authority over the Colonies, it may now be worth considera- 
tion, whether admitting representatives from the Colonies may not be a proper expedient for the present exigencies.

Two years ago, a proposal of this kind would not have borne a hearing: but so much is America altered by the late financial Acts, that a new system of policy, and of a more refined kind than was wanted heretofore, is now become needful. The patch-work government of America will last no longer: the necessity of a Parliamentary establishment of the Governments of America upon fixed constitutional principles, is brought on with a precipitation which could not have been foreseen but a year ago; and is become more urgent, by the very incidents which make it more difficult. The circumstance of the Americans justifying their disobedience by their not being represented, points out a method to enforce their obedience upon their own principles. Take them at their word; let them send representatives for the present time, and for the present purposes; thirty for the Continent, and fifteen for the Islands, would be sufficient. In this Parliament, the Colonies being actually represented, let the affairs of the American Governments be canvassed to the bottom; and let a general, uniform system of American Governments be formed and established by Act of Parliament, by which the Americans, according to their own principles, will be bound; and let the relation of America to Great Britain be determined and ascertained by solemn Recognition: so that the rights of the American Governments and their subordination to that of Great Britain, may no longer be a subject of doubt and disputation. When this great work is done, the American representatives may be dismissed, and left to attend their own Legislatures, which will then know the bounds of their own authority; or may be continued, as shall be most advisable.

The civil policy of America is composed of temporary expedients, all derived from the Crown only; not one of the American Governments has that sanction which none of them ought to be without, a Parliamentary establishment. And, until the Parliament shall establish the American Governments 


\section{72 The Administration of Dependencies}

upon a constitutional bottom, and ascertain the limitations and extensions of their Legislatures, it must be expected that the Governments will be continually subject to disturbance, whenever the Americans think fit to complain of innovations upon, and infringements of, their rights; that is, whenever anything is required of them which they don't like.

In a letter of December I4, I765, he said:

The chief arguments of the Americans against their being subject to Acts of Parliament which impose inland taxes (and it will hold equally good against all other Acts of Parliament for the regulation of their internal policy) is, that they are not represented in Parliament. This is the Palladium of their cause: but they have of late discovered, that this is a dangerous argument; for if the Parliament should allow them to send representatives, they are concluded, and must then be bound by Acts of Parliament, according to their own principles. Therefore of late, when they use this argument, they add, that such a representation is impracticable. Now it certainly is not strictly impracticable; though it may be difficult, inexpedient or improper. But it seems to me, that it is both expedient and proper for the present time and purposes. The Parliament must now interpose for regulating the policy of America, or else all things will run into confusion. But if they proceed to such regulations, whilst the Americans dispute their authority, what can be expected but an enforced obedience, whilst the seeds of opposition lie ready to shoot up in proper season?-whereas, if the Parliament first removes the pretence for the Colonies not being subject to it, there can be no pretence for their disobedience afterwards.

Besides, if the Parliament should undertake so important a work as the new modelling of the Governments in America, which seems to me to be at this time unavoidable, it appears reasonable that the Colonies should have their deputies in the House, both to hear and to speak upon the subject relating to them. If they were allowed this liberty, (even though they did not accept it, as probably some of them would not), they could not complain of their rights being disposed of without their 
being heard, as they do now. For a liberty of sending representatives would conclude them, whether they sent them or not. And this leads me to say that I do not propose American representatives as a perpetual establishment, but only as a temporary ordinance. When the business is done, the Governments new modelled, their Legislatures established upon constitutional principles and a permanent bottom, and a Recognition of the supremacy of the Parliament of Great Britain passed by the new Legislatures as a first and conditional Act, there will be no longer occasion for American representatives; they may return and serve in their own Assemblies, which then may be as separate from that of Great Britain as that of Ireland.

Bernard's scheme made no impression either in Great Britain or the Colonies. Not only was it full of practical difficulties, but it was completely overshadowed by the plan of settlement advocated by William Pitt (afterwards Lord Chatham) during the debate in the House of Commons on January 14,1766 , on the bill for the repeal of the Stamp Act. In his speeches on that occasion, Pitt declared himself in favor of a great constitutional settlement on the basis that the correctness of the principle advanced by the Americans, that they could not be taxed by Parliament, should be admitted by the State of Great Britain, in consideration that the Colonies should admit that the British Parliament had complete legislative power over them, whether represented therein or not, in every respect save that of taxation. As Pitt then was, and for many years had been, the acknowledged leader of the Whig party, and the greatest statesman in Great Britain, this proposition, to which, under penalty of loss of his leadership, he had practically pledged the whole Whig party of Great Britain, was of the utmost consequence; and all discussion was immediately focussed on his plan of settlement and the points made by him in supporting it. 


\section{74 The Administration of Dependencies}

In his first speech he said:

Taxation is no part of the governing or legislative power. The taxes are a voluntary gift or grant of the Commons alone. In legislation, the three Estates of the Realm are alike concerned, but the concurrence of the Peers and the Crown to a tax is only necessary to close with the forms of law. The gift and grant is of the Commons alone. In ancient days, the Crown, the Barons and the Clergy possessed the lands. In those days, the Barons and the Clergy gave and granted to the Crown. They gave and granted what was their own. At present, since the discovery of America, and other circumstances permitting, the Commons are become the proprietors of the land. The Crown has divested itself of its great estates. The Church (God bless it!) has but a pittance. The property of the Lords, compared with that of the Commons, is as a drop of water in the ocean; and this House represents those Commons, the proprietors of the lands; and those proprietors virtually represent the rest of the inhabitants. When, therefore, in this House, we give and grant, we give and grant what is our own. But in an American tax, what do we do? We, your Majesty's Commons of Great Britain, give and grant to your Majesty, what? Our own property?-No, we give and grant to your Majesty the property of your Majesty's Commons in America.

The distinction between legislation and taxation is necessary to liberty. The Crown, the Peers, are equally legislative powers with the Commons. If taxation be a part of simple legislation, the Crown, the Peers, have rights in taxation as well as yourselves; rights which they will claim, which they will exercise, whenever the principle can be supported by power.

In his speech in reply to objections, he said:

I maintain that the Parliament has a right to bind, to restrain America. Our legislative power over the Colonies is sovereign and supreme. When it ceases to be sovereign and supreme, I would advise every gentleman to sell his lands and 


\section{Plans of Settlement, I $765-1767$}

embark for that country. When two countries are connected together, like England and her Colonies, without being incorporated, one must necessarily govern; the greater must rule the less, but so rule it as not to contradict the fundamental principles that are common to both.

If the gentleman does not understand the difference between internal and external taxes, I cannot help it; but there is a plain distinction between taxes levied for the purposes of raising a revenue, and duties imposed for the regulation of trade, for the accommodation of the subject; although in the consequences, some revenue might incidentally arise from the latter.

Upon the whole, I will beg leave to tell the House what is really my opinion. It is, that the Stamp Act be repealed absolutely, totally and immediately; that the reason for the repeal be assigned, because it was founded on an erroneous principle. At the same time, let the sovereign authority of this country over the Colonies be asserted in as strong terms as can be devised, and be made to extend to every point of legislation whatsoever;-that we may bind their trade, confine their manufactures, and exercise every power whatsoever, except that of taking their money out of their pockets without their consent.

In the House of Lords, Lord Camden (afterwards Lord Chancellor), during the debates on the repeal of the Stamp Act, insisted upon the distinction between taxation and other kinds of governmental power, in terms even more emphatic than those used by Pitt.

Dr. Franklin, the Agent of the Province of Pennsylvania, in his hearing before the House of Commons in February, I766, in opposition to the Stamp Act, following Pitt in the idea that all external taxation (that is, by customs duties) was essentially a regulation of trade, as. sured the House that the Colonies only objected to internal taxation, and that any external taxation would be entirely satisfactory to them, and persisted in this 


\section{76 The Administration of Dependencies}

statement even when members of the House pointed out to him that taxation by duties was, so far as they could see, equally objectionable with any other kind of taxation.

When the Stamp Act was repealed, however,-on March 18, I766,-Pitt's advice was not followed. The preamble, instead of stating that it was repealed "because it was founded on an erroneous principle," declared that the repeal was due to the conclusion of Parliament that "the continuance of the said Act would be attended with many inconveniences and may be productive of consequences greatly detrimental to the commercial interests of these Kingdoms"; and the Peers who dissented from the repeal, filed written reasons for their dissent, one of which was:

Because the reason assigned in the public resolutions of the Provincial Assemblies in the North American Colonies, for their disobeying the Stamp Act, viz., "That they are not represented in the Parliament of Great Britain," extends to all other laws of what nature soever which Parliament has enacted, or shall enact to bind them in times to come, and must (if admitted) set them absolutely free from any obedience to the power of the British Parliament.

However, the repeal was regarded as a triumph for Pitt, and as an admission that Great Britain would make a constitutional settlement with the Colonies on the basis proposed by him, if they would agree.

Along with the Act repealing the Stamp Act, there was passed, on the same day, the famous Declaratory Act of 1766 , which was apparently intended to fit the case whether it should be thought best later on to declare Great Britain the Imperial State of the British Empire or to declare the Empire abolished and a British Realm substituted in its stead, governed by a Parliament in which the inhabitants of the "Realm " outside of Great Britain were "virtually" represented. 


\section{Plans of Settlement, I 765-1 767}

This remarkable Act, which has never yet been repealed, is the foundation-stone on which the British Empire rests. Its purpose was to declare the power of Great Britain and its Parliament, consisting of King, Lords and Commons, over all the dependencies. Though it related, on its face, solely to the American Colonies, Mr. Alpheus Todd, in his Parliamentary Government in the British Colonies, the standard work on British colonial jurisprudence, says that it was the intention of Parliament that it should " be declaratory of the legislative authority of Parliament over the colonies of the British Crown"-over India and the West Indies, as well as over the American Colonies. It was entitled "An Act for the Better Securing the Dependency of his Majesty's Dominions in America upon the Crown and Parliament of Great Britain," and read as follows:

Whereas several of the Houses of Representatives in his Majesty's Colonies and Plantations in America, have of late, against law, claimed to themselves, or to the General Assemblies of the same, the sole and exclusive right of imposing duties and taxes upon his Majesty's subjects in the said Colonies and Plantations, and have, in pursuance of such claim, passed certain votes, resolutions, and orders, derogatory to the legislative authority of Parliament, and inconsistent with the dependence of the said Colonies and Plantations upon the Crown of Great Britain: May it therefore please your most excellent Majesty that it may be declared; and be it declared by the King's most excellent Majesty, by and with the consent of the Lords Spiritual and Temporal, and Commons, in this present Parliament assembled, and by the authority of the same; That the said Colonies and Plantations in America, have been, are, and of right ought to be, subordinate unto and dependent upon the Imperial Crown and Parliament of Great Britain; and that the King's Majesty, by and with the advice and consent of the Lords Spiritual and Temporal and Commons of Great Britain, in Parliament assembled, had, 


\section{78 The Administration of Dependencies}

hath, and of right ought to have, full power and authority to make laws and statutes of sufficient force and validity to bind the Colonies and people of America, subjects of the Crown of Great Britain, in all cases whatsoever.

In so far as this statute declared that the Colonies were subordinate unto and dependent upon the Imperial Crown and Parliament of Great Britain, it was a proper declaration of the existence of the British Empire, and of the power of Great Britain, as the Imperial State. In so far as it declared that the British Parliament had full power and authority to make laws and statutes of sufficient force and validity to bind the Colonies and their inhabitants in all cases whatsoever, it was a denial of the existence of the British Empire and a declaration that all the region over which the Crown and Parliament had power constituted a single British Realm.

The claim was of "legislative" authority. The theory of the "legislative" authority in Great Britain was, that it was the same power which all the people of Great Britain, if assembled together as a legislature, would have. Such a power is unlimited and unconditioned in any constitutional sense, being without specific limits or conditions, but it is self-limited and self-conditioned by the interests of the units against the mass. Acts of Parliament relating to the American Colonies, which were limited and conditioned only by the ratification of the people of Great Britain, acting according to their will and non-expertly, were, of course, to all intents and purposes, so far as the Colonies were concerned, unlimited and unconditioned, because the people of Great Britain were as external to the Colonies as was the Parliament, and there was no possibility of their power being self-limited and self-conditioned by the self-interest of the individual units, since no individual in Great Britain would have an interest, distinct from the mass, in seeing that the 


\section{Plans of Settlement, I765-1767 179}

dependencies were fairly treated. In other words, a claim of the British Parliament to exercise " legislative" authority over the Colonies was a claim to exercise unlimited and unconditional power, while a claim of legislative authority over Great Britain was a claim to exercise power without any specific limits and without any specific conditions laid down as a prerequisite, but subject to be limited because it was exercised with the distinct understanding that the exercise of it was valid only so long as it should continue to be ratified by the acquiescence of the people of Great Britain.

The next Act of Parliament relating to America showed that the Declaratory Act of 1766 was intended to be put in full force. In 1767 , Parliament suspended the sitting of the General Assembly of New York because it had failed to supply money sufficient to pay for the quartering of British troops in the Province under the provisions of the annual Acts, which permitted the quartering of troops in inns and public houses, and, in case such accommodations were insufficient, in uninhabited houses and barns, allowed the seizing of wagons, and required the soldiers so quartered to be furnished with food, drink, and lodging at the expense of the Colony.

Another Act, passed also in 1767 , imposed taxes on glass, lead, painters' colors, paper, and tea imported into the Colonies. The House of Commons, in this, as in the Tariff Act of 1764 and the Stamp Act, "gave and granted" to the King the duties provided in the Act. In the preamble, it was declared that the purpose of the Act was to raise a revenue

for making a more certain and adequate provision for defraying the charge of the administration of justice, and the support of the civil government, in such Provinces where it shall be found necessary, and towards further defraying the expenses of defending, protecting and securing the said dominions. 


\section{80 The Administration of Dependencies}

In the body of the Act, it was provided that the net proceeds of the tax should be applied, in the first place, to meeting the expenses of the local administration in those Colonies in which the Assemblies did not make sufficient provision for this purpose, and that the residue should be kept separate in the British Treasury to be used for the Imperial defence in the Colonies.

In I767, also, an Act was passed establishing a Board of Commissioners of Customs for America, who were to act as inquisitors and prosecutors in the enforcement of the Tariff Acts.

Pitt, in his speech on the repeal of the Stamp Act, had made himself, in a sense, the Commissioner of Great. Britain to negotiate with the Colonies. He had made a definite proposition to them for a constitutional settlement, and his great political influence made it likely that if the Colonies accepted it, it could be carried through Parliament. Franklin had gone far towards committing the Americans to an acceptance of it.

Upon the passage of these Acts, the Americans naturally turned to Dickinson, the author of the reso. lutions of the Stamp Act Congress, as their Commissioner to answer the proposition of Pitt (who had meanwhile been made Earl of Chatham), according to which Parliament, in passing the Acts, was strictly acting. This answer Dickinson made in his Letters from a Pennsylvania Farmer, otherwise called The Farmer's Letters, published in 1767 , which were reprinted in England and France and went through several editions in those countries and the American Colonies.

His answer was, in effect, first, a protest against a settlement being made on any such basis, since the Americans claimed that provisions ought to be made, in any constitutional settlement, whereby the power over the dependencies should be exercised expertly and only according to the necessity in each case; and, secondly, a 
counter-proposition to the effect that, if a settlement could be made only on the basis that Parliament was to have a certain sphere of jurisdiction and the Colonies another, the Colonies could consent to Parliament having power over them only for the regulation of their external commerce.

While Dickinson did not, in The Farmer's Letters, insist upon a constitutional settlement on the basis that the administration of the Colonies in Great Britain should be in the hands of an expert tribunal, his argument inevitably made for a settlement on that basis. He said:

" As the happiness of these Provinces indubitably consists in their connection with Great Britain, any separation between them is less likely to be occasioned by civil discords, if every disgusting measure is opposed singly, and while it is new: for in this manner of proceeding, every such measure is most likely to be rectified. On the other hand, oppressions and dissatisfactions being permitted to accumulate, if ever the governed throw off the load, they will do more. A people does not reform with moderation. The rights of the subject therefore cannot be too often considered, explained or asserted: and whoever attempts to do this, shows himself, whatever may be the rash and peevish reflections of pretended wisdom and pretended duty, a friend to those who injudiciously exercise their power, as well as to them, over whom it is so exercised.

Had all the points of prerogative claimed by Charles I. been separately contested and settled in preceding reigns, his fate would in all probability have been very different; and the people would have been content with that liberty which is compatible with regal authority. But he thought it would be as dangerous for him to give up the powers which at any time had been by usurpation exercised by the Crown, as those that were legally vested in it. This produced an equal excess on the part of the people. For when their passions were excited by multiplied grievances, they thought it would be as dangerous for them to allow the powers that were legally vested in the Crown, as those which 


\section{I82 The Administration of Dependencies}

at any time had been by usurpation exercised by it. Acts, that might by themselves have been upon many considerations excused or extenuated, derived a contagious malignancy and odium from other acts, with which they were connected. They were not regarded according to the simple force of each, but as parts of a system of oppression.

If the Parliament succeeds in this attempt, other statutes will impose other duties. Instead of taxing ourselves, as we have been accustomed to do, from the first settlement of these Provinces, all our usual taxes will be converted into Parliamentary taxes on our importations; and thus the Parliament will levy upon us such sums of money as they choose to take, without any other limitation than their pleasure.

We know how much labor and care have been bestowed by these Colonies, in laying taxes in such a manner, that they should be most easy to the people, by being laid on the proper articles; most equal, by being proportioned to every man's circumstances; and cheapest, by the method directed for collecting them.

But Parliamentary taxes will be laid on us without any consideration, whether there is any easier mode. The only point regarded will be, the certainty of levying the taxes, and not the convenience of the people on whom they are to be levied; and therefore all statutes on this head will be such as will be most likely, according to the favorite phrase, " to execute themselves."

Taxes in every free State have been, and ought to be, as exactly proportioned as is possible to the abilities of those who are to pay them. They cannot otherwise be just.

I mention these particular cases, as striking instances how far the late Act is a deviation from that principle of justice, which has so constantly distinguished our own laws on this continent, and ought to be regarded in all lazes.

Of course, if it was necessary that " every disgusting measure should be opposed singly and while it was new," if " all points of prerogative" claimed by Great Britain 
were to be "separately contested and settled," and if the acts of the British Government were "to be regarded according to the simple force of each," Parliamentary government of the Colonies was out of the question. The business of Parliament could not stop in order to hear the representatives of the Colonies on each proposed measure or on each measure enacted by Parliament. If it legislated, it must legislate in the usual manner.

If it was necessary that the action of the British Government should take place only "after consideration" of what was "the easier mode" for the colonists and what would suit their " convenience," Parliamentary government was out of the question, because a great body like Parliament was concerned so fully with its own interests that it could not " judiciously exercise its power" over communities external to Great Britain, and its Acts relating to such communities were likely to contain " deviations from justice."

This reasoning necessarily led to the conclusion that the power of the Imperial State over the Colonies could never properly and constitutionally be exercised according to mere will, but must always be exercised according to principles ascertained by experts after hearing the parties interested.

Having thus protested against all non-expert exercise of the power of Great Britain, as contrary to the true principles of Imperial government, he proceeded to specify the limits within which, in his opinion, America could, for the sake of a present settlement of the matters in dispute, accept the non-expert exercise of the power, saying:

The Parliament unquestionably possesses a legal authority to regulate the trade of Great Britain, and all her colonies. Such an authority is essential to the relation between a mother country and her colonies, and necessary for the common 


\section{84 The Administration of Dependencies}

good of all. He, who considers these Provinces as States distinct from the British Empire, has very slender notions of justice, or of their interests. We are but parts of a whole; and therefore there must exist a power somewhere to preside, and preserve the connection in due order. This power is lodged in the Parliament; and we are as much dependent on Great Britain, as a perfectly free people can be on another.

I have looked over every statute relating to these Colonies, from their first settlement to this time; and I find every one of them founded on this principle, till the Stamp Act administration: All before, are calculated to regulate trade, and preserve or promote a mutually beneficial intercourse between the several constituent parts of the Empire; and though many of them imposed duties on trade, yet those duties were always imposed with design to restrain the commerce of one part, that was injurious to another, and thus to promote the general welfare. The raising a revenue thereby was never intended.

These Colonies require many things for their use, which the laws of Great Britain prohibit them from getting anywhere but from her. Such are paper and glass.

That we may legally be bound to pay any general duties on these commodities, relative to the regulation of trade, is granted; but we being obliged by her laws to take them from Great Britain, any special duties imposed on their exportation to us only, with intention to raise a revenue from us only, are as much taxes upon us, as those imposed by the Stamp Act.

What is the difference in substance and right, whether the same sum is raised upon us by the rates mentioned in the Stamp Act, on the use of paper, or by these duties, on the importation of it? It is only the edition of a former book, shifting a sentence from the end to the beginning.

Suppose the duties were made payable in Great Britain. It signifies nothing to us, whether they are to be paid here or there. Had the Stamp Act directed that all the paper should be landed at Florida, and the duties paid there, before it was brought to the British Colonies, would the Act have raised less money upon us, or have been less destructive of 
our rights? By no means: for as we were under a necessity of using the paper, we should have been under the necessity of paying the duties. Thus, in the present case, a like necessity will subject us, if this Act continues in force, to the payment of the duties now imposed.

Dickinson's argument on this phase of the question necessarily proceeded, as did Pitt's, upon the theory that there was an essential difference between taxation and all other kinds of legislation. He endeavored to prove this exactly as Pitt had done, by showing that such a distinction had always existed in the English political practice and science - taxes being regarded as grants of money from the people to the Crown, and legislation as grants of privileges by the Crown to the people.

The difficulty with this argument was, that it took no account of the changed conditions of government. In the days when the King was a personality apart from the people, who made laws for them without their consent, the only control the people had over him was to decide upon the amount of public money which he should handle, and the amount of the recompense he should have for his services. But in 1767 the King was fighting for his existence as the superior and expert governmental agency of the Realm and Empire, vainly trying, by fair means or foul, to prevent the people, through Parliament sitting as the Constitutional Convention, from taking away his proper powers in the performance of that agency. The Commons no longer needed to give and grant to him money, because they gave and granted to him his office, and the salary was a mere incident to the office. From the instant that the Act of Settlement was an accomplished fact, taxation was only one form of legislation, all legislation being thenceforth the act of the House of Commons, checked by the King and the House of Lords.

The position taken by Pitt and followed by Dickinson, 
that the settlement should proceed on the basis that the Colonies should not be taxed by Great Britain, was proper enough as the basis of a truce or a modus vivendi. but not as the basis of a constitutional settlement. The State of Great Britain, as the Imperial State, or Sovereign, of the American Colonies, claimed the right to make laws, without their consent, given in any manner whatever, and even without their deliberation and advice, as a personality apart from them, self-appointed for that purpose. So long as it did that, it was necessary, as a matter of political warfare, to make the distinction between taxation and other kinds of legislation, and to insist, as the people of England did under like circumstances with their Kings, that as long as the Kings made such a claim to legislate without their consent and without their deliberation and advice, they would, without the King's consent, and without his deliberation or advice, fix the amount of money which he should have and should handle.

The distinction between taxation and other forms of legislation was a distinction necessitated, therefore, not by a state of internal peace in the Empire, but by a state of distrust of the Imperial State on the part of the dependencies. It furnished a ground for the suspension of hostilities, but provided no assurance against hostilities breaking out at any time on questions other than those of taxation. It left the British Empire in a condition of inefficiency as a political organism, and compelled Great Britain either to exploit its dependencies, or to pay the whole expense of the Empire.

Dickinson vehemently repudiated, in The Farmer's Letters, any intention of saying anything which might tend to break off the constitutional connection between Great Britain and the Colonies, and insisted that his only purpose was to bring about a constitutional settlement satisfactory to both parties. In the third Letter, he said: 
The prosperity of these Provinces is founded in their dependence on Great Britain; and when she returns to her "old good humour, and her old good nature," as Lord Clarendon expresses it, I hope they will always think it their duty and interest, as it most certainly will be, to promote her welfare by all the means in their power.

In a note to the last Letter, he said:

If any person shall imagine that he discovers, in these Letters, the least dislike of the dependence of these Colonies on Great Britain, I beg that such person will not form any judgment on particular expressions, but will consider the tenor of all the Letters taken together. In that case, I flatter myself, that every unprejudiced reader will be convinced that the true interests of Great Britain are as dear to me, as they ought to be to every good subject. If I am an enthusiast in any thing, it is in my zeal for the perpetual dependence of these Colonies on their Mother Country, - a dependence founded on mutual benefits, the continuance of which can be secured only by mutual affections.

Comparing Dickinson's counter-proposition with Lord Chatham's proposition, it will be seen that they differ materially. Lord Chatham's proposition may thus be stated:

Great Britain will agree that it has no right to tax the American Colonies; this admission is not, however, to affect its right, by Act of its Parliament, to impose external or customs duties, which right Great Britain claims and reserves to itself; provided the American Colonies will agree that, except as above agreed and admitted, Great Britain has the right, by Act of its Parliament, to legislate in all cases whatsoever for the Colonies, and to cause its legislation to be executed.

Dickinson's counter-proposition may thus be stated:

The American Colonies, protesting that the question is not of the right of Great Britain to tax them, but of the character 


\section{I88 The Administration of Dependencies}

and extent of all its powers over them and the principles on which those powers rest, but being willing to enter into a constitutional settlement which will relieve the present situation, will agree that Great Britain has the right, by Act of its Parliament, to regulate the trade and commerce of the Colonies to the extent and in the manner practiced prior to the Tariff Act of 1764 , provided Great Britain will agree that it has no right to tax the Colonies, and that this agreement shall be construed as an admission that it has no right to levy customs duties except as an incident to the regulation of commerce and to the extent necessary for that purpose.

Dickinson did not fail to point out the violations committed by Parliament, otherwise than by way of taxation, of the constitutional rights of the inhabitants of the Colonies, and of the Colonies as States. The provision of the Tariff Act of 1767 , by which the proceeds of the taxes were to be used "for making a more certain and adequate provision for defraying the charge of the administration of justice and the support of civil government in such Provinces where it shall be found necessary," he particularly criticised as an attack upon the statehood of the Colonies, demanding, in their behalf, a Local Administration and a Local Judiciary responsible to the people of the Colonies. Particularly, he demanded a Colonial Judiciary which, though appointed by the Crown, should be secured in office during good behavior, and whose salaries should be such as the Colonial Legislatures should determine.

Franklin had an edition of The Farmer's Letters published in England, and they were translated and printed in France and went through several editions in both countries. Richard Henry Lee had an edition printed in Virginia, and another was published in Boston.

Dickinson's counter-proposition met with almost universal approval throughout the Colonies. Jefferson, speaking of the situation in Virginia in 1768 , in his 
Autobiography, while declaring that, in his view, the relation between Great Britain and the American Colonies was " exactly the same as that of England and Scotland after the accession of James and until the Union, and the same as her present relations with Hanover," frankly adds:

In this doctrine, however, I had never been able to get any one to agree with me but Mr. Wythe. He concurred in it from the first dawn of the question, "What was the political relation between us and England ?" Our other patriots, Randolph, the Lees, Nicholas, Pendleton, stopped at the half-way house of John Dickinson, who admitted that England had a right to regulate our commerce, and to levy duties on it for the purposes of regulation, but not of raising revenue.

In Massachusetts, the approval took an organized form. At a town-meeting held in Boston on March 14, 1768, it was voted " that the thanks of the Town be given to the ingenious author of a course of letters published at Philadelphia and in this place, signed 'A Farmer,' wherein the rights of American subjects are clearly stated and fully vindicated," and a committee, of which John Hancock and Samuel Adams were members, was appointed " to prepare and publish a letter of thanks accordingly." In the letter which was accordingly prepared and which was adopted at a town-meeting held ten days later, the Town of Boston declared that to Dickinson "America is obliged for a most seasonable, sensible, loyal and vigorous vindication of her invaded rights and liberties," and added :

Nor is this Western world alone indebted to your wisdom, fortitude and patriotism; Great Britain also may be confirmed by you that to be truly great and successful, she must be just; that to oppress America is to violate her own honor, defeat her brightest prospects and contract her spreading Empire. 


\section{I90 The Administration of Dependencies}

Thus in all sections of America, Dickinson was recognized as the Commissioner for the Colonies to treat with Great Britain, and his counter-proposition for a constitutional settlement approved by what was virtually a. plebiscite. At the time The Farmer's Letters were published, however, Lord Chatham was out of power, and the disposition of the Ministry was to adopt temporizing measures, in the hope of avoiding a constitutional settlement with the Colonies. 


\section{CHAPTER XI}

\section{IMPERIAL UNITY, I768}

\section{$\mathrm{A}^{\mathrm{s}}$}

a result of the consideration given to the question of the relationship between Great Britain and the Colonies prior to 1768 , two distinct views of the unity of the British Empire were beginning to be held, according to one of which the Empire was a permanent Union of States, in which the Imperial State governed the others according to its mere will, except in so far as it had agreed not to govern them at all; and according to the other, a temporary Union of States which might be converted, at the option of Great Britain, into a Unitary State-that is, an aggregation of lands and persons under the British Government. Of the first view Governor Bernard was the principal exponent. In a letter of January 28, I768, published in his Select Letters on the Trade and Government of America, he used the expression "Imperial State" to describe Great Britain and the expression "dependent States" to describe the Colonies, and used language which showed that he regarded the relationship as a permanent one. In this letter he said:

When the dispute has been carried so far as to involve in it matters of the highest importance to the Imperial Sovereignty ; when it has produced questions which the Sovereign State cannot give up, and the dependent States insist upon as the terms of a reconciliation; when the Imperial State has so far given way as to let the dependent States flatter themselves that their pretensions are admissible; whatever terms of reconciliation time, accident or design may produce, if they 


\section{The Administration of Dependencies}

are deficient in settling the true relation of Great Britain to her Colonies and ascertaining the bounds of the Sovereignty of the one, and the dependence of the other, conciliation will be no more than a suspension of animosity; the seeds of which will be left in the ground ready to start up again whenever there shall be a new occasion for the Americans to assert their independence of the authority of Parliament; that is, whenever the Parliament shall make ordinances which the Americans shall think not for their interest to obey.

Ex-Governor Pownall, in the fourth edition of his book The Administration of the Colonies, in 1768 , took the position that, whether or not the Colonies had ever been related to Great Britain as States, nevertheless, when Parliament elected to tax them, they were thereby incorporated into the British Realm and their inhabitants merged with the inhabitants of Great Britain. He criticised the language of the Declaratory Act of 1766, in which the British Government had taken the position that the Colonies and their inhabitants were dependent upon the Imperial Crown of Great Britain, because, as he claimed, it contained an admission that the Colonies were outside the Realm. He reasoned that in the expression "the Imperial Crown of Creat Britain," it was necessarily implied that the State of Great Britain was the Sovereign of the dependencies and their inhabitants, and that, since the State of Great Britain, as Sovereign, necessarily acted through its whole Government, consisting of King, Lords, and Commons, that whole Government constituted the Imperial Crown. If so, he argued that, since the powers of the whole British Government must be determined by the powers of the British State, as King or Sovereign of the Colonies and their inhabitants, and since the powers of the British State, as Sovereign, over the Colonies, must be conditioned and limited in the same way that the powers of any natural person, as Sovereign, would be conditioned and limited, this theory 
inevitably led to a conditioned and limited power of Parliament over the Colonies. He said:

At this day the constitution and rights of the Colonies, in the actual exercise of them, are unsettled; the relation in which they stand connected with the Realm and with the King, is disputed; and Parliament, as well as Ministers, are balancing in opinion what is the true, legal, and constitutional mode of administration by which those Colonies are to be governed. Whether the Colonies be demesnes of the Crown, without the Realm, or parts and parcels of the Realm, whether these foreign dominions of the King be as yet annexed to the Realm of England, whether the colonists be subjects of the King in his foreign dominions, or whether they be subjects of, and owe allegiance to the Realm, has been at various times, and is at this day called into dispute. This question is now no longer of curiosity and theory; it is brought actually into issue. It is now by deeds and overt acts discussed, and must be decided.

From the uncontroverted and universal idea of the subordination of the Colonies to the Government of the Mother Country, this power, by which the Parliament makes laws that shall be binding on the Colonies, has been constantly exerted by the Government of England, (afterwards Great Britain) and submitted to by the Colonies. The fundamental maxim of the laws of those countries, is, that first, the common law of England, together with such statutes (the ecclesiastical laws and canons excepted) as were enacted before the Colonies had Legislatures of their own; secondly, the laws made by their own Legislatures; together with, thirdly, such Acts of Parliament as by a special clause are extended to America, since that time,- are the laws of each Province or Colony. The jurisdiction and power of every court established in that country, the duty of every civil officer, the process of every transaction in law and business there, is regulated on this principle. Nay further, every Act of Parliament passed since the establishment of the Colonies, which respects the general police of the Realm, or the rights and liberties of the subjects 


\section{I94 The Administration of Dependencies}

of the Realm, although not extended by any special clause to America by Parliament, although without the intervention, or express consent of their own respective Legislatures or Representatives, has been considered, and I may venture to say, adopted as part of the law and constitution of those countries; but by what principle of our Constitution, by what maxim of law, this last practice has been established, is not so easy to ascertain, any more than it will be easy to fix any rule, when the Colonies shall adopt, or when they may refuse those kinds of laws of the Mother Country. This arises, as I have said, from some vague indecisive idea that the Colonies are of, or some parts of the Realm; but how or what parts, or whether any parts at all, has never yet been thoroughly examined.

We have seen what was, in reality, the dependence and. subordination of the colonists to the King, while they were supposed to be subject to him in a Seignoral capacity. We have seen what must have been the same subordination, while they were supposed to be subject to the two Houses of Lords and Commons, as Sovereign in the same capacity.

Let us take up the next idea, that while they are not of the body of the Realm, are no parts or parcel of the same, but bodies corporate and politic, distinct from and without the Realm, "they are nevertheless, and of right ought to be subordinate unto, and dependent upon the Imperial Crown of Great Britain, (i.e. the Realm,) and that the King's Majesty, by and with the advice and consent of the Lords Spiritual and Temporal and Commons of Great Britain assembled in Parliament, had, hath, and of right ought to have full power and authority to make laws and statutes of sufficient force and validity to bind the Colonies and people of America, subjects of the Crown of Great Britain, in all cases whatsoever." In this idea we have a very different state of the relation, namely, the Imperial Crown of Great Britain, the King, I.ords and Commons, collectively taken, is stated as Sovereign on the one hand, and the colonists as subjects on the other.

There is no doubt, but that in the nature, reason, justice and necessity of the thing, there must be somewhere, within the body politic of every Government, an absolute power. 
The political freedom of Great Britain consists in this power's being lodged nowhere but in King, Lords and Commons in Parliament assembled. This power is absolute throughout the Realm, and yet the rights and liberties of the subject are preserved, as the Communitas Papuli is the body, of which this Imperium is the soul, reasoning, willing, and acting, in absolute and entire union with it, so as to form one political person.

There can be no doubt but that this power is absolute throughout the dominions of the Realm; yet in the exercise of this power, by the Imperial Crown of Great Britain,- - that is, by the King's Majesty, with the Lords and Commons in Parliament assembled,-towards the Colonies, if they are not of this body of the Realm, but are still to be considered as distinct bodies, foreign or extraneous parts, without the Realm and the jurisdiction of this Kingdom, there is surely some attention due to the nature of this absoluteness in this case.

If the people of the Colonies are no part of the people, or of the body, of the Realm of Great Britain, and if they are to be stated in the argument, as subject to the King, not as the head of that compound political person, of which they are in part the body, sed ut caput alterius populi, - as wearing the Imperial Crown of Great Britain, as the head to which the Realm of Great Britain is the body, and of which body the Parliament is the soul, but of which the Colonies are no part,- then this Imperial Supreme Magistrate, the collective power of King, Lords and Commons, may be stated as Sovereign on the one hand, while the people of the Colonies stand as subjects on the other.

Taking the relation of the Colonies to the Mother Country in this view, when the argument is stated in this manner, we surely may say with exactness and truth, that if the colonists, by birthright, by nature or by establishment, ever were entitled to all the rights, privileges, liberties and franchises of an Englishman, the absolute power of this Sovereign must have some bounds; must from its own nature, from the very nature of these rights of its subjects, be limited in its extension and exercise. Upon this state of the case, questions will necessarily arise, which I will not take upon me to decide, 


\section{I96 The Administration of Dependencies}

whether this Sovereign can disfranchise subjects, so circumstanced, of their rights, because they are settled beyond the territorial limits of the Realm; whether these subjects, thus circumstanced, can, because they are supposed not to be of the Realm, lose that interest in the Legislative Power, which they would have had if they were of, or within the Realm; whether this natural right which they have to personal liberty and to political freedom is inherent in them "to all intents and purposes, as though they had been born within the Realm," or whether "it is to be understood, with very many and very great restrictions" ; whether these people, from the nature of these inherent rights and liberties, are entitled to have, and have a right to require a constitution of the same political liberty as that which they left, or whether "the whole of their constitutions are liable to be new modelled and reformed" at the will of this Sovereign; whether the legislative part of their constitution is, they being distinct, although subordinate, dominions, and no part of the Mother Country, an inherent right of a body of Englishmen, so circumstanced, or whether it can be suspended, or taken away at the will of this Sovereign. In stating these doubts, I do not here add the question, which in time past has been raised, on the right which this Sovereign has, or has not, to impose taxes on these subjects, circumstanced as above stated, without the intervention of their own free will and grant; because, let these other questions be decided howsoever they may, this stands upon quite other grounds, and depends upon quite other principles.

So long as the Government of the Mother Country claims a right to act under this idea of the relation between the Mother Country and the Colonies, so long as the Colonies shall be esteemed in this relation, as " no part of the Mother Country," so long will the colonists think they have a right to raise these questions, and that it is their duty to struggle in the cause which is to decide them; and so long will there be faction and opposition, instead of government and obedience.

This amounted to saying that Parliament, in the Declaratory Act of I766, had contradicted itself, in that, 
after having declared that the Colonies and their inhabitants were subordinate to and dependent upon the Imperial Crown and Parliament of Great Britain,-which necessarily implied that the Colonies were dependent states, that the relationship between them and Great Britain was subject to constitutional conditions and limitations, and that the powers of Parliament over the Colonies and their inhabitants were measured by those which the Imperial State had, by the Constitution of the Empire, to legislate and to execute legislation, - it had immediately proceeded to declare that Parliament had unconditioned and unlimited power over the Colonies and their inhabitants.

He claimed that Parliament ought not to have declared that Great Britain was the Imperial State and the Colonies its dependencies, and that, therefore, it ought to withdraw that declaration and substitute for it another to the effect that Great Britain was an integral part of the Realm, and the Colonies another integral part, and that the Colonies were entitled to be represented in Parliament.

Since no Colony had ever sent representatives to Parliament, it was necessary, in order to prevent such a declaration as Pownall proposed from amounting to a charge of ignorance or wilful oppression of the Colonies by Great Britain in the past, and of ignorant or weak submission by the Colonies to wrong-doing by Great Britain, to give some reason why the Colonies had not been theretofore represented in Parliament. The reason advanced by him was, that the right of the Colonies to representation first began when Parliament considered them as objects of taxation. He said:

The Colonies, from their remote distance and local circumstances, could not have been incorporated into any county, city or borough, - at least, so it is said: and yet, at the same 


\section{The Administration of Dependencies}

time they are supposed to be, and are considered as within the Diocese of London. The colonists were considered as having gone forth from, and having quitted the Realm; as having settled on land without the Realn.

The Colonies thus remote and separate from the Realm, were formed and incorporated into distinct communities; were erected into Provinces; had the jura regalia granted to them; were, in consequence thereof, to all intents and purposes Counties Palatine, in like and as ample manner as the County Palatine of Durham was, some matters of form excepted. They were dominions of the King of England; although, according to the language of those times, "not yet annexed to the Crown." They were under the jurisdiction of the King upon the principles of feudal Sovereignty, although considered as "out of the jurisdiction of the Kingdom." The Parliament itself doubting, at that time, whether it had jurisdiction to meddle with those matters, did not think proper to pass bills concerning America. The Colonies had, therefore, Legislatures peculiar to their own separate communities, subordinate to England, in that they could make no laws contrary to the laws of the Mother Country, but, in all other matters and things, free, uncontrolled and complete Legislatures, in conjunction with the King or his Deputy, as part thereof.

When the King, at the Restoration, participated in the Sovereignty over these his foreign dominions, with the Lords and Commons, the Colonies became, in fact, the dominions of the Realm,- - became subjects of the Kingdom. They came, in fact, and by an actual constitutional exercise of power, under the authority and jurisdiction of Parliament. They became connected and annexed to the State. By coming as parts of the British Realm, not as a separate Kingdom, (which is the case of Ireland), under subjection to the Parliament, they became participants of the rights and liberties on which the power of Parliament is founded. By the very act of extending the power of Parliament over the Colonies, the rights and liberties of the Realm must be also extended to them, for, from the nature of the British Constitution, from the constitution of Parliament itself, they, as parts, can be subject by no 
other mode, than by that in which Parliament can exercise its Sovereignty; for the nature of the power and the nature of the subjection must be reciprocal. They became therefore annexed, although perhaps not yet united parts of the Realm. But to express all that I mean, in a proposition that can neither be misunderstood nor misinterpreted, they from that moment, (whatever was their prior situation), stood related to the Crown and to the Realm literally and precisely in the same predicament in which the County Palatine of Durham stood, -that is, subject to be bound by Acts of Parliament in all cases whatsoever, and even "liable to all rates, payments and subsidies granted by Parliament," although the inhabitants of these countries, " have not hitherto had the liberty and privilege of sending knights and burgesses to Parliament of their own election." And, in the same manner, also, because, in that the inhabitants of the County Palatine of Durham were liable to all rates, payments and subsidies granted by Parliament, and were therefore concerned, with others the inhabitants of this Kingdom, to have knights and burgesses in Parliament, of their own election, to represent the condition of their country, as the inhabitants of other countries had, it was by Act of Parliament enacted, that they should have such,-in the same manner, I say, whenever these Colonies shall be considered, in Parliament, as objects of taxation, and be rendered liable to rates, payments and subsidies granted by Parliament out of their property, they will become concerned equally with others the inhabitants of this Kingdom, to have knights and burgesses in Parliament, of their own election, to represent the condition of their country, as the inhabitants of other countries have, and of right ought to have. Although a right in Parliament to make laws for governing and taxing the Colonies, may and must, in the order of time, precede any right in the Colonies to a share in the Legislature, yet there must arise and proceed pari passu, a right in the Colonies to claim, by petition, a share in the representation, by having kniglts and burgesses in Parliament, of their own election, to represent the condition of their country. And as, in such circumstances, this right shall arise 


\section{The Administration of Dependencies}

on one hand, so on the other, it may become a duty in Government to give them power to send such representatives to Parliament; nay, could one even suppose the Colonies to be negligent in sending, or averse to send such representatives, it would in such case, as above settled, become the duty of Government to require it of them.

As the proposition that the Colonies became entitled to representation in Parliament whenever it began to tax them necessarily implied, unless qualified, that all the existing Tariff Acts relating to the Colonies were unconstitutional and invalid, Pownall had to give some reason by which the validity of these Acts could be upheld. This he did in the following language:

Although from the spirit and essence of our Constitution, as well as the actual laws of it, "the whole body of the Realm, and every particular member thereof, either in person or by representation, (upon their own free election) are, by the laws of the Realm, deemed to be present in the High Court of Parliament," yet, as the circumstances of the several members of this body politic must be often changing, as many acquisitions and improvements, by trade, manufactures and colonies, must make great changes in the natural form of this body; and as it is impossible, both from the gradual nature of these changes, and from the mode of the representative body, that this representative body can, in every instance and moment, follow the changes of the natural passibus aquis; it must necessarily at times, from the nature of things, not be an actual representative, although, from the nature of the constitution of government, it must, in the interim, continue to be a just and constitutional representative. And hence, from the laws of nature, as well as from the nature of our own laws and Constitution, arises the justice and right, which Parliament always has had to render the several members of the Realm liable to rates, payments and subsidies, granted by Parliament, although such members have not, as yet, had the liberty and privilege to send knights and burgesses to Parliament, of 
their own election. Yet on the other hand, as the principle that no free people ought to be taxed but by their own consent, freely originating from, and given by themselves or their representatives, is invariable, absolute and fixed in truth and right, so the mode of the representation in Parliament has from time to time altered, so as to extend to, and to suit the mode under which the represented were, from time to time, found to exist. Hence it was, that many towns, boroughs, counties, and even dominions, which from anything that did exist, or was to be found in their antiquas libertates, and liberas consuetudines, were not previously represented by members of Parliament of their own election, have, as they acceded to the Realm, or increased within the Realm, so as to be equally concerned to have knights and burgesses in Parliament, of their own election, to represent them equally as other inhabitants of the Realm, according to such modes as were at the time admitted to be legal and constitutional, been called to a share in the Common Council of the Realm. Hence it was that the County Palatine of Durham, after many trials, and a long struggle, was admitted to the privilege of sending knights and burgesses to Parliament.

Having thus cleared away, as he thought, the historical obstacles which stood in the way of a declaration that Great Britain and the Colonies constituted a single Unitary State, he proceeded to argue that to make such a declaration was simply to recognize existing facts and conditions, saying:

It is therefore the duty of those who govern us, to carry forward this state of things to the weaving of this lead [i.e., the leadership in matters of common and general interest] in to our system, that Great Britain may be no more considered as the Kingdom of this Isle only, with many appendages of provinces, colonies, settlements, and other extraneous parts, but as a grand Marine Dominion consisting of our possessions in the Atlantic and in America united into a one Empire, in a one center, where the seat of government is. 
Would statesmen doubt for a while the predetermined modes which artificial systems prescribe, would they dare to look for truth in the nature of things, they would soon adopt what is right, as founded upon fact; they would be naturally led into the true system of government, by following, with the powers of the State, where the actual and real powers of the system of things lead to; they would see, that, by the various and mutual interconnections of the different parts of the British dominions throughout the Atlantic and in America, by the intercommunion and reciprocation of their alternate wants and supplies, by the combination and subordination of their several interests and powers, by the circulation of their commerce, revolving in an orbit which hath Great Britain for its center, - that there does exist, in fact, in nature, a real union and incorporation of all these parts of the British dominions, an actual system of dominion; which wants only to be avowed and actuated by the real spirit in which it moves and has its being, by that spirit which is the genuine spirit of the British Constitution, by that spirit from which the British Government has arisen to what it is, by the spirit of extending the basis of its representative Legislature through all the parts to wheresoever the rights, interest or power of its dominions extend,so as to form (I cannot too often inculcate the idea) a grand Marine Dominion, consisting of our possessions in the Atlantic, and in America, united into a one Empire, in a one center, where the seat of government is.

Pownall's proposition to convert the British Empire into a Unitary State is one which, ever since his time, has recrudesced at intervals, and which seems likely to recrudesce frequently in the future. As an apparently logical necessity from the doctrine of "representative government," so-called, the proposition has an extraordinary fascination for that great body of persons who look upon that doctrine as the cure-all for political ills, and who regard as political heresy every suggestion that government by an elected assembly has its limitations, beyond which it becomes a political curse instead of a political blessing. 
As he stated the objections to his own proposition with very considerable completeness and attempted to answer them, it may be worth while to quote his words. $\mathrm{He}$ said :

To this measure, not only the Briton but the American also now objects, that it is unnecessary, inexpedient and dangerous. But let us consider their several objections.

The Briton says that such measure is unnecessary, because the power of Parliament extends to all cases and purposes required. Be it allowed that this power does, in right and theory, thus extend; yet surely the reasoning, the precedents, the examples, and the practice of administrations do show, that something more is necessary in this case.

The American says it is unnecessary, because they have Legislatures of their own, which answer all their purposes. But each Colony having rights, duties, actions, relations, which extend beyond the bounds and jurisdiction of their respective communities, beyond the power of their respective Governments, the Colonial Legislature does certainly not answer all purposes,-is incompetent and inadequate to many purposes. Something more therefore is necessary, either a common union amongst themselves, or a one common union of subordination, under the one General Legislature of the State.

The Briton says that it would be inexpedient to participate with, and communicate to the colonists, the rights and privileges of a subject living and holding his property within the Realm, - to give these rights to people living out of the Realm, and remote from it, whose interests are rival and contrary, both in trade and dominion, to those of this Realm. But the scheme of giving representatives to the Colonies, annexes them to, and incorporates them with the Realm. Their interest is contrary to that of Great Britain, only so long as they are continued in the unnatural artificial state of being considered as external Provinces; and they can become rivals only by continuing to increase in this separate state. But their being united to the Realm, is the very remedy proposed.

The American says, that this measure is inexpedient; 
because, if the Colonies be united to the Realm, and have participation in the Legislature, and communication of the rights and privileges of a subject within the Realm, they must be associated in the burden of the taxes, and so pay a share of the interest and principal of the national debts, which they have no concern in. This is literally the objection which was made by the Scots, at the proposal of the Union of the two Kingdoms; and came indeed with reason and propriety from an independent sovereign Kingdom, which had no concern in the debts of England. But the like objection can never be made with propriety, reason or justice, by Colonies and Provinces which are constituent parts of a trading nation, protected by the British marine. Much less can it be said, that they have no concern in these debts, when they are debts contracted, by wars entered into, the first for the preservation of the Protestant interest and independency of the sovereignty of the Mother Country; the two latter, solely in defence, and for the protection of the trade and actual existence of the Colonies. However, if the Colonies could, on any reasonable grounds of equity or policy, show any inequality, or even inexpediency in their paying any part of the taxes which have a retrospect to times before they were admitted to a share in the Legislature, there is no doubt but that the same moderation and justice which the Kingdom of England showed towards Scotland, in giving that an equivalent, would be extended to the Colonies, by the Kingdom of Great Britain. And I cannot but think, that it would not be more than such equivalent, that the Government should grant them a sum of money sufficient to pay off all their debts which were contracted in consequence of the last war, and are still outstanding; unless Great Britain engaged from henceforth to consider these as the debts of the State in general. I cannot but think that it would not be more than such equivalent, that the Crown should give up all its right to quit-rents, and that every Act, whereby any special revenue was raised upon the Colonies, should be repealed.

The Briton says that this measure would be dangerous; as it might prove a leading step to the finally removing of the 


\section{Imperial Unity, I 768}

seat of empire to America; to which the true answer is that the removal of the seat of empire to America or not, depends on the progressive increase of the territories, trade and power of the American Colonies;- if continued in the same unnatural, separate, rival and dangerous state in which they are at present, that this is an event not to be avoided. But this measure of uniting the Colonies to the Realm, and of fixing the Legislature here in Britain, is the only policy that can obviate and prevent this removal. For, by concentring the interest and power of the several parts in this Island, the Empire must be fixed here also. But if this removal cannot finally be prevented, is it better that a new Empire should arise in America, on the ruins of Great Britain, or that the regalia of the British Empire extending to America, should be removed only to some other part of the dominions, continuing, however, in the same Realm ?

The American says that this measure might be dangerous to their liberties; as this calling the American representatives to a Parliament sitting in Great Britain would remove their representatives at too great a distance from their constituents, for too long a time, and consequently from that communication and influence which their constituents should have with them; and therefore transfer the will of the Colonies out of their own power, involving it, at the same time, in a majority, against which their proportion of representatives would hold no balance. This objection, if it has any ground for its fears, is a direct answer to the British objection last mentioned. But it proves too much, as, according to this argument, no remote parts of a State ought to send representatives, as the seat of empire is also remote. The truth and fact is, that the mutual situation of Great Britain and America very well allows every communication which a member of Parliament ought to have with his constituents; and any influence beyond that, is unparliamentary and unconstitutional.

As to all objections which arise from apprehensions of what effect such an additional number of members, acceding all at once to the House of Commons, might have on the politics, conduct and internal management of that body: . . . 


\section{The Administration of Dependencies}

The Americans fear that the number of representatives which will be allowed to them, will have no power proportionable to their share of interest in the community, that this union to the British Legislature will only involve them in the conclusions of a majority, which will thence claim a right to tax them, and to restrain their trade, manufactures and settlements as they please. The Briton fears that these representatives may be an united phalanx, firmly opposing every tax proposed to be laid upon the Colonies, and every regulation meant to keep their actions and interest in due subordination to the whole; that they will be a party, a faction, a flying squadron, always ready, and in most cases capable, by uniting with opposition to Administration, or with commercial factions, to distress Government and the landed interest of the Kingdom. The Americans again, on the other hand, fear that some future British Ministry, in some future days of corruption, will succeed in bribing their representatives, against which the Colonies will have no remedy, but must submit to the betraying consequences. These are objections which, on the very supposition, mutually counteract and destroy one another. They are objections which have had fair trial upon experience, in the case of the Scots members, and are directly contradicted by truth and fact.

Neither Bernard's nor Pownall's proposition seems to have ever made any impression either in America or Great Britain.

For the Colonies to have exchanged their positions as States constituting component parts of the British Empire, subordinated to Great Britain, and its Government, as a Central Tribunal sitting to determine, through experts, on just principles, their rights and the rights of their inhabitants, in the great political organism, before which Tribunal they were represented by their Agents, who were heard before any dispositions made affecting their interests became final, for a position in which they would have been States in a condition of contractual subjection to the mere will of Great Britain, and its Government, ex- 
cept in so far as it had agreed they should not be, or for a position in which their inhabitants would have constituted an integral part of the whole population subject to the unconditioned and unlimited will of a Parliament, in the Lower House only of which they were represented, sitting three thousand miles away in England,-would have been for them to commit political suicide.

Nor had England anything to gain from the adoption of either Bernard's or Pownall's idea of the relationship. The relationship advocated by Bernard would have lasted exactly as long as the Colonies were too weak to require something better. That any population should in any respect submit to the unconditional and unlimited power of any body of people over which they had no control, if they could help it, was inconceivable. If the Colonies should ever become the stronger party, it was likely to go hard with Great Britain. The relationship of Great Britain to the Colonies advocated by Pownall was plainly dangerous for Great Britain, as he himself admits, for it based the whole power, in the long run, on population, or on wealth and population combined, and, if America ever exceeded Great Britain in wealth and population, inevitably resulted in the removal of the Seat of Empire to America.

Under the Imperial Federal Unity that really existed, Great Britain could retain its position as the Imperial State so long as its Government was best fitted to act as the Central Tribunal for the Colonies as States - that is, so long as it was best fitted to make dispositions concerning their affairs, and needful rules and regulations respecting them and their inhabitants in accordance with its dispositions. 


\section{CHAPTER XII}

\section{THE IMPERIAL SECRETARIAT, I768}

$\mathrm{T}^{\mathrm{H}}$

HOUGH Pownall's work was ineffective in so far as he tried to convert the English and American people to the idea that that which had existed for a century and a half as the British Empire was really a British Unitary State, it had, in another direction, an immediate and direct result. The real purpose of his book, as it was originally written, was to advocate a reform in the Home Administration of the Empire. The important point that he made was that the business of the British State relating to the Empire in Americathat is, the relations between Great Britain and the Colonies-ought properly to be in the charge of a Secretary of State. This amounted to saying that the relations with the Colonies were, by the nature of things, differentiated from both the domestic and the foreign relations of Great Britain, since a Secretariat of State is one of the great and fundamental Departments of the business of the State, which exists because of the permanent and fundamental differences in the functions of the State in some of its relations from those which it has in other relations. This proposition of Pownall's brought into clear light a distinction regarding the functions of the State, which, though acted upon from the time when the relations with the dependencies were placed in the advisory charge of a Committee of the Privy Council distinct from the Committee having charge of either the domestic or foreign affairs of the State, had never been clearly stated. It 
meant that thereafter the British State was to be recognized as the subject and object of a new class of obligations. Up to that time, only two classes of obligations to which the State was subject in time of peace had been recognized - obligations which it owed to its own inhabitants and municipal corporations, which it performed through the instrumentality of a Secretary or a Secretarial Board for Home Affairs, and those which it owed to foreign States and their inhabitants and municipal corporations, which it performed through the instrumentality of a Secretary or Secretarial Board for Foreign Affairs. The obligations of the State to its own inhabitants and municipal corporations were determined by its Constitution, by the unwritten law, and by the will of its Legislature; its obligations to foreign States and their inhabitants and municipal corporations were determined by treaty or by the rules of international law. The proposition to place the relations between Great Britain and the American Colonies in the charge of a Secretariat of State, therefore necessarily implied that the Colonies were neither integral parts of the Realm nor foreign States, and that the relations between them were neither domestic nor foreign relations, but were of a different kind from either, to be determined neither by the Constitution, the unwritten law, or the statutes of the State, nor by treaties or the international law, but by an equity derived from all these, as principles.

At the time Pownall wrote, though the difference in functions between the Home Department and the Foreign Department was recognized, there did not exist in Great Britain a Home Secretary and a Foreign Secretary having charge of the respective duties of these Departments. There were two Principal Secretaries of State, but their duties were determined arbitrarily and geographically, instead of rationally and scientifically. One Secretary had charge of what was called the Northern 


\section{Io The Administration of Dependencies}

Department, including Denmark, Flanders, Germany, the German Principalities and States, Holland, Poland, Saxony, Prussia, Russia, and Sweden; and the other of the Southern Department, which included England, Scotland, Ireland, the Channel Islands, the Isle of Man, the other islands near Great Britain, the American and West Indian Colonies, the East Indian establishments, France, Spain, Portugal, Switzerland, Italy, the Barbary States, and Turkey. The Secretary of State for the Southern Department was thus the Secretary of State for Home and Imperial Affairs and in part for Foreign Affairs; and the Secretary for the Northern Department the Secretary in part for Foreign Affairs.

In advocating the establishment of a Secretariat of State to have charge of the relations with the Colonies, Pownall said:

The forming some general system of administration, some plan which should be (whatever may be the changes of the Ministry at home, or in the Governors and officers employed abroad) uniformly and permanently pursued by measures founded on the actual state of things as they arise, leading to this great end, is, at this crisis, the precise duty of Government.

To enable the British nation to profit of these present circumstances, or of the future events, as they shall successively arise in the natural procession of effects, it is necessary that the Administration form itself into such establishments for the direction of these interests [the British commercial interests] and powers, as may keep them [the Colonial commercial interests then beginning to arise] in their natural channel, as may maintain their due connections with the Government, and lead them to the utmost effect they are capable of producing towards this grand point.

The first spring of this direction, the basis of this government, is the Administration at home. If that Department of 
the Administration which should have the direction of these matters, be not wisely and firmly bottomed, be not so built, as to be a practical-be not so really supported by the powers of the Government, as to be an efficient Administration, all measures for the administration of these interests, all plans for the government of these powers are vain and self-delusive; even those measures that would regulate the movements and unite the interests under a practical and efficient Administration, become mischievous meddling impertinences where that is not, and must either ruin the interests of these powers, or render a breach of duty necessary to the Colonies that they may avoid that ruin.

That part of the Government, which should administer this great and important branch of business, ought, in the first place, to be the center of all information and application from all the interests and powers which form it; and ought from this center, to be able, fully, uniformly, and efficiently, to distribute its directions and orders. Wherever the wisdom of State shall determine that this center of information shall be fixed; from whatever Department all appointments, orders, and executive administration shall issue, it ought somewhere to be fixed, known, of record, and undivided. That it may not be partial, it ought to extend to all times, and all cases. All application, all communication, all information should center immediately and solely in this Department. This should be the spring of all nominations, instructions, and orders. It is of little consequence where this power of administration is placed, so that the Department be such as has the means of the knowledge of its business, is specially appropriated to the attention necessary to it, and officially so formed as to be in a capacity of executing it. Whether this be a Secretary of State, or the Board of Trade and Plantations, is of no consequence; but it ought to be entirely in either the one or the other. Where the power for the direction is lodged, there ought all the knowledge of the Department to center; therefore all officers, civil or military, all servants of the Government, and all other bodies or private persons ought to correspond immediately with this Department, whether it be 


\section{I 2 The Administration of Dependencies}

the Secretary of State or the Board of Trade. While the military correspond with the Secretary of State, the civil in one part of their office with the Secretary of State, in another with the Board of Trade; while the navy correspond in matters not merely naval with the Admiralty, while the engineers correspond with the Board of Ordnance, officers of the revenue with the severai Boards of that branch, and have no communication with the Department which has, or ought to have, the general direction and administration of this great Atlantic and American, this great commercial interest, who is to collect-who does, or ever did collect-into a one view, all these matters of information and knowledge? What Department ever had, or could have, such general direction of it, as to discuss, compare, rectify and regulate it to an official real use? In the first place, there never was yet any one Department formed for this purpose; and in the next, if there was, let any one acquainted with business dare to say, how any attempt of such Department would operate on the jealousies of the others. Whenever, iherefore, it is thought proper, (as most certainly it will, some time or other, though perhaps too late), to form such Department, it must (if I may so express myself) be sovereign and supreme, as to every thing relating to it; or to speak plainly out, must be a Secretary of State's office in itself. When such is formed, although the military, naval, ordnance, and revenue officers should correspond, in the matters of their respective duties, with the Departments of the Government to which they are more immediately subordinate and responsible, yet, in general matters of information, or points which are matters of government, and the department of this State Office, they should be instructed to correspond and communicate with this Minister. Suppose that some such Minister or Office now existed, is it not of consequence that he should be acquainted with the geography of our new acquisitions? If, therefore, there have been any actual surveys made of them, should not such, or copies of such, be sent to this Minister or Office? If a due and official information of any particular conduct in our Colonies, as to their trade, might lead to proper regulations therein, or mighti 
point out the necessity of a revision of the old laws, or the making further provision by new ones, would it not be proper that the Custom House officers settled there should be directed to correspond and communicate with this Minister, or Office, on these points? Would it interfere with their due subordination, as officers of the revenue, to the Commissioners of the Customs? If there were any events arising, or any circumstances existing, that might affect the state of war or peace, wherein the immediate application of military operations were not necessary or proper, should not the military and naval officers be directed to communicate on these matters with this Minister, or Office? Should not, I say, all these matiers of information come officially before this Minister, if any such State Minister, or Office, was established?

As of information and knowledge centering in a one Office, so also of power of executing, it should spring from one undivided Department. Where the power of nominating and dismissing, together with other powers, is separated from the power of directing, the first must be a mere privilege or perquisite of office, useless as to the King's business or the interest of his Colonies, and the latter must be inefficient. That Office, which neither has the means of information, nor can have leisure to attend to the official knowledge produced thereby, nor will be at the trouble to give any official directions as to the ordinary course of the administration of the American matters, must certainly be always, as it is, embarrassed with the power of nomination, and fettered with the chain of applications which that power drags after it. On the other hand, what effect will any instructions, orders or directions have from that Board, which has not interest to make or dismiss one of the meanest of its own officers? This, which is at present the only official channel, will be despised; the Governors, nay, every the meanest of the officers in the Plantations, looking up solely to the giving power, will scarce correspond with the directing, - nay, may perhaps contrive to make their court to the one, by passing by the other. And in any case of improper conduct of these officers, of any neglect of duty, or even of misdemeanor, what can this directing power do, but 


\section{I4 The Administration of Dependencies}

complain to the Minister who nominates, against the officers appointed by him? If there be no jealousies, no interfering of interests, no competitions of interfering friends, to divide and oppose these two Offices to each other; if the Minister is not influenced to continue, upon the same motives upon which he first appointed; if he does not see these complaints in a light of opposition to his nomination and interest, - some redress may, after a due hearing between the party and the Office, be had, the authority of the Board may be supported, and a sort of remedy applied to the special business, but a remedy worse than the disease, - a remedy that dishonors that Board, and holds it forth to the contempt of those whom it ought to govern.

Although Pownall had expressed, in the words above quoted, his conviction that it made no difference whether the Secretariat for Imperial Affairs were vested in a single individual or in a Secretarial Board, he showed, in the first edition of his book, a plain preference for a Secretarial Board, and made a strong argument in favor of converting the Board of Trade and Plantations into this Secretarial Board. On this subject his words were:

It is not only from the natural impracticability of conducting this administration under a divided state of power and direction, that the necessity of forming a some one State Office, or Minister of State, for the executing it, arises: but the very nature of the business of this Department, makes the officer who is to administer it a State Officer, a Minister for that Department, and who ought to have immediate access to the closet. I must here repeat, that I am no partisan of the Secretary of State's office, or for the Board of Trade: I have ceased to have any connection of business with either, and have not the least degree of communication with the one or the other. Without reference, therefore, to either, but with all deference to both, I aim to point out, that the Department of the Administration of Trade and Plantations, be it lodged where it may, should be a State Office, and have a Minister 
of State. That Office, or Officer, in a commercial nation like this, who has the cognizance and direction (so far as the Government can interfere) of the general trade of the Kingdom-whose duty it is to be the depository and reporter of the state and condition of it, of everything which may advance or obstruct it, of the state of manufactures, of the fisheries, of the employment of the poor, of the promoting the labor and riches of the country, by studying and advising every advantage that can be made of every event which arises in commercial politics and every remedy which can remove any defect or obstruction,-who is officially to prepare every provision or revision necessary in the laws of trade, for the consideration of Parliament, and to be the conductor of such through the necessary measures,-is certainly an Officer of State, if the Secretary of State, so-called, is. That Office, or Officer, who has cognizance and direction of the Plantations in every point of government, in every matter judicial or commercial, - who is to direct the settlements of colonies, and to superintend those already settled,- who is to watch the Plantations in all these points, so far as they stand related to the government, laws, courts and trade of the Mother Country -is certainly an Officer of State, if the Secretary of State, so-called, is. That Office, or Officer, who is to report to his Majesty in Council on all these points, whose official fiat, or negative, will be his Majesty's information in Council as to the legislature in the Colonies, is certainly an Officer of State. That Office, or Officer, who is to hear and determine on all matters of complaint, and maladministration, of the Crown officers and others, in the Plantations, and can examine witnesses on oath, is surely an Officer of State. That Office, or Officer, who is to correspond with all the servants of the Crown on these points, and to be the issuer of his Majesty's orders and instructions to his servants, on these many, great, and important points of State-is certainly his Majesty's Secretary, and certainly a Secretary of State.

But if it be considered further, who the persons are, that are of this very great and extensive Commission of the Board of Trade and Plantations, - namely, all the great Officers of 


\section{The Administration of Dependencies}

State for the time being, with the Bishop of London, the Secretaries of State for the time being, and those more especially called the Commissioners of Trade, it will be seen, that it is no longer a doubt or a question, as to its being an Office of State. It is actually so, and has, as an Office, as a Board, immediate access to his Majesty in Council, even to the reporting and recommending of officers. This was the plan whereon it was originally founded, at its first institution, by Lord Somers.

That great statesman and patriot saw that all the powers of the Government and the several Departments of Administration disunited, were interfering with, and obstructing each other on this subject, and not they only here in England, but that the respective Officers of these several Departments carried all this distraction into the detail of their business in the Colonies, which I am afraid is too much the case even at this day: he saw that this administration could not be conducted but by an entire union of all the powers of the Government, and on that idea formed the Board of Trade and Plantations, where, and where alone, these powers were united in a one Office, - in which Office, and in which alone, all the business of the Colonies ought therefore to be administered; for if such union be necessary, here alone is that official union. Unhappily for the true interest of the Government, partly from an entire neglect of this administration in time past, and partly from the defective partial exercise of it, since some idea of these matters began again to revive, this great and wise plan hath been long disused; but it is fortunate for the public in this important crisis, that such is the temper of particulars, such the zeal of all for his Majesty's service, such the union of his servants, that the spirit of service predominates over these natural defects: so that all who wish well to the interest of this country, in its trade and colonies, may hope to see that union, at present only Ministerial, become Official in this business, and revive again that great, wise, and constitutional plan of Office, actuated under the real spirit of it.

The only question at present is, who shall be the Executive Officer of this Department of State; whether the Secretary of 
State, properly so-called; or the First Lord, and other Commissioners, properly called the Board of Trade; or whether it shall remain divided, as it is, between the several great Departments of Administration; or whether some more official and practical division of this administration may not be made.

Suppose now, it should be thought proper, that this administration be placed in the Secretary of State's office, all the administration of the Plantations may be given to the Southern Department: yet the great object of the general trade of Great Britain must be divided between the Southern and the Northern, as the matters of consideration happen to lie in the one or in the other Department; and how will the Southern Department act, when any matter of commerce arises in the Plantations, that has special connections or interferings with the Dutch, Hamburg, Danish or Russian trade?

It cannot lie in the Board of Trade, properly so-called, until it be found proper, and becomes a measure of the Government, to erect that Board into a Secretary of State's Office for this Department, which, first or last, it most certainly will do. That, therefore, the great business of Trade and Plantations may not run into confusion, or be at a stand, that it may be carried to the effect proposed, held forth, and desired by the Government, and necessary to it, - all that can be done at present is, to put the whole executive administration, the nomination, correspondence, issuing of instructions, orders, \&c., under the Secretary of State, if he has leisure to attend to it, and can undertake it; and to make the Board of Trade a mere Committee of Reference and Report; instead of reporting to the King in Council, to report to the Secretary of State, who shall lay the matters before his Majesty, and receive and issue his orders, - who shall refer all matters to this Committee, for their consideration, and shall conduct through the Legislature all measures necessary to be determined thereby. If this be not practicable, there is no other alternative, than to do directly what ought to be done, and what, some time or other, must be done,-the making the Officer who conducts this Department a Minister for that Department, with all the powers necessary thereto. For until a 


\section{I 8 The Administration of Dependencies}

practical and efficient Administration be formed, whatever the people of this country may think, the people of the Colonies, who know their business much better than we do, will never believe the Government is in earnest about them, or their interest, or even about governing them; and will, not merely from that reasoning, but from necessity of their circumstances, act accordingly.

In I768, Pownall had evidently perceived that the Committee of the Privy Council for Plantation Affairs was a factor in the situation which had to be considered, and that, since it had the immediate access to the King, it must be abolished, either directly, or indirectly by converting it into the Secretarial Board, since so long as it. remained in existence in the form in which it then was, with the right and duty of advising the King concerning matters of Imperial administration, any individual or body of individuals having charge of the administration of the Imperial affairs would be nothing more than an under-Secretary. As that Committee was too old an institution to be abolished, except by the indirect method of increasing its powers and thus converting it into a Secretarial Board, his final conclusion seems to have been that the proper course was to give to the Committee of the Privy Council for Plantation Affairs administrative as well as deliberative functions and to make it the Secretarial Board for Imperial Affairs, and to retain the Board of Trade and Plantations as the under-Secretarial Board with duties of examination, reference, and report. In the fourth edition of his book, therefore, he added the following:

Until an effective administration for Colony affairs be established by the Government, all plans for the governing of those countries under any regular system of policy, will be only matter of speculation, and become mere useless opprobrious theory. All official information given and transmitted by 
those whose duty it is to give it, will, as accident shall decide, or as the connections of parties shall run, be received or not; nay, it may so happen, that those officers who should duly report to the Government the state of these matters, will, as they find themselves conscientiously or politically disposed, direct that information to those who are in, or to those who are out of the Administration. Every leader of every little flying squadron will have his runner, his own proper channel of information, and will hold forth his own importance in public, by bringing his plan for American affairs before it. All true and regular knowledge of these affairs being dispersed, will be evaporated; every Administration, even Parliament itself, will be distracted in its councils by a thousand odds and ends of proposals, by a thousand pieces and parcels of plans, while those surely, who are so deeply concerned as the Americans themselves are, will not be excluded from having their plan also; they will have their plan also, for however peaceably they may submit to the direction of the powers of the Government, derived through a regular established permanent mode of administration, they will, by any means that they can justify, refuse to have their interests directed and disposed of by every whim that every temporary empiric can force into execution. If therefore we mean to govern the Colonies, we must previously form at home some practical and efficient administration for Colony affairs.

Before the erection of the Board of Trade as a particular Office, the business of the Colonies was administered with efficiency; the King himself in Council administered the government of his Colonies; each State Officer, in his proper Department, was no otherwise Minister than as ministerially executing the orders which he received, or officially reporting, from his respective Department, the information which he had to lay before the King in Council. Since the establishment of that Office called the Board of Trade, the administration of the Colonies has either laid dormant, or been overlaid; or, if taken up, become an occasion of jealousy and struggle for power between that Board and every State Officer who hath been deemed the Minister for the time being. From this 


\section{The Administration of Dependencies}

jealousy and this struggle, this Board has been supposed to interfere at different times with every other Office, while at one time it has had the powers and held the port of a Minister's Office, and at another has become a mere Committee, in efficient as to execution, unattended to as reporting. The Colonies, and the officers of the Colonies, have one while been taught to look up to this Board as the Minister for their affairs, and at another, have learned to hold it in that contempt which inefficiency gives; which contempt, however, has not always stopped there.

To prevent, on this critical occasion, all such appearances, on one hand, from misleading those who are to be governed, and to put an end, on the other, to all interfering amongst those who are to govern in this line of business, the Board of Trade should either be made what it never was intended to be, a Secretary of State's Office for the Plantations, or be confined to what it really is, a Committee of Reference for examination and report, for stating and preparing business, while the affairs of the Co:onies are administered solely by the King in Council, really acting as an efficient Board for that purpose. Somewhere there ought to be an efficiency, and in this Supreme Board is the proper residence of it. To place it here would be really and in fact the establishing of an Administration for Colony Affairs.

This conclusion of Pownall's - that the Committee of the Privy Council for Plantation Affairs should be converted into the Secretarial Board for Imperial Affairs, and the Board of Trade and Plantations declared the underSecretarial Board to examine into Imperial questions on their own motion or on reference and to report to the Secretarial Board-was a strictly scientific solution of the whole problem. It of course required, in order to complete the organization of the Government, the establishment of a Secretariat for Home Affairs and a Secretariat for Foreign Affairs-the Home Secretariat ultimately responsible to the House of Commons, the Imperial Sec- 
retariat responsible both to the $\mathrm{King}$ and the whole Parliament as representatives of the Imperial State, and the Foreign Secretariat responsible to the King.

This final recommendation of Pownall's came too late, for on February 27, I768, Lord Hillsborough, who had previously been the President of the Board of Trade and Plantations, was commissioned as "Secretary of State for the Colonies" - not because it was the intention of the British Government to recognize the Colonies as States united, as such, in a relationship of political subordination, to the State of Great Britain, and forming with it a Federal Empire, and to provide for the application of just principles to the exercise of the functions of Great Britain, as the Imperial State, but because, as the Letters Patent containing the Commission stated, "the public business of the Colonies and Plantations increasing, it is expedient to appoint one other Principal Secretary of State, besides the two ancient Principal Secretaries."

As the Committee of the Privy Council for Plantation Affairs and the Board of Trade and Plantations were still left in existence, the only effect of the appointment of a Secretary of State for the Colonies was to make this Secretary an under-Secretary for Imperial Affairs, along with the Board of Trade and Plantations, except in so far as he could succeed in inducing the King to act directly on his advice, -which meant that he had to induce the King to prevent certain matters from being considered by the Committee of the Privy Council for Plantation Affairs. This was, of course, a difficult matter, and as the Secretary of State for the Colonies was a member of the Cabinet, and as the Cabinet was tending every day to become responsible to the House of Commons, the Secretary for the Colonies was interested, for his own aggrandizement, to regard the affairs of the Empire as the affairs of the Realm and thus, by throwing the management of them 


\section{The Administration of Dependencies}

into the hands of Parliament, to free himself from the interposition of the Committee of the Privy Council for Plantation Affairs.

The title given to the incumbent of the office-the Secretary for the Colonies-was unfortunate, since it tended to make the British public consider the Colonies as mere appendages or appurtenances of the Realm, and to make the Americans regard them as States foreign to Great Britain. Had the officer been called the Secretary for Imperial Affairs, and the Federal Empire of Great Britain thus recognized, the duties of the Secretary would have been understood by all to be, to ascertain the rules and regulations equitably and justly necessary for the common welfare of the component parts of the whole Empire, considering the Constitution, laws and economic conditions of the Imperial State and the charters, laws, customs, and economic conditions of the Colonies, and to advise the King and Parliament so that they, as the representatives of the Imperial State, might cause such rules and regulations to be put in force.

Pownall's proposition that the political organism theretofore called the British Empire was a Unitary State was exactly contradictory of his proposition that there ought to be a special Secretariat of State having charge of the relations with the Colonies. If the Colonies were integral parts of the British State, there was no more reason why the relations with them should be placed in charge of a Department of the Government of Great Britain, than that the relations with any County in England should be made a Department of the Government. If, therefore, Pownall was right when he claimed that the affairs of the Colonies ought to be in the charge of a Secretary of State's office, he was wrong when he claimed that the Colonies were integral parts of the British State, and vice versa.

The British Government followed exactly the same 
course of inconsistency. The Secretary of State for the Colonies was appointed, and at the same time the Colonies were treated by Parliament as integral parts of the Realm. 


\section{CHAPTER XIII}

\section{AMERICA'S POSITION CRITICISED, I 769}

I $\mathrm{N}_{1769}$, there appeared in England an anonymous pamphlet, entitled The Controversy between Great Britain and the Colonies Reviewed, which was in fact written by William Knox, who had been attached to the Colonial Government of Georgia in the year I760, assisted by Hon. George Grenville, who had been Prime Minister when the Stamp Act was passed. By this pamphlet the arguments in favor of the proposition that the British Empire was a Unitary State were put as strongly as they possibly could be. It was, in fact, a defence of the whole policy of the Grenville Ministry, and its purpose was to show that that Administration was right, and that its successor, the Rockingham Ministry, in procuring the repeal of the Stamp Act, had committed a constitutional error.

The propositions advanced by the Stamp Act Congress, as modified by those advanced by Dickinson in his Far mer's Letters, were considered and answered in consecutive order. Criticising the first resolution of the Stamp Act Congress, - that "his Majesty's subjects in these Colonies owe . . all due subordination to that August Body, the Parliament of Great Britain," the authors of the pamphlet pointed out that in the expression "August Body," there was necessarily contained the implication that Great Britain was a foreign State, and that this proposition was contradictory of the proposition contained in the other resolutions-that the inhabitants of the Colonies were entitled to all the rights and liberties 
of Englishmen-because they could only have the rights of Englishmen in case they were members of the population of the State of Great Britain, and in that case Parliament would be the "Supreme Legislature" of the Colonies and their inhabitants, to the will of which they would owe "obedience," -not an "August Body," to which they would owe "due subordination." The argument on this subject was a follows :

The title of "August Body," which they give the Parliament, is another subterfuge for seeming to respect its authority, whilst they mean to disavow it. An "August Body" it certainly is, and foreigners frequently call it so; but the subjects of the Realm know it by another title, that of Supreme Legislature. That title would, however, have implied obedience to its laws in those who gave it; but the committees, not intending to acknowledge such obedience, avoided giving it that title.which is only proper from subjects, and gave it one which implied no relation or dependence on it, and yet carried so much the appearance of respect, that it might be mistaken to mean it.

The distinction they mark in their resolutions between the people of America and the people of England, by terming the one " his Majesty's liege subjects in the Colonies," and the other " his natural-born subjects," or his " subjects born within the Realm," plainly, though indirectly, declares it to be their opinion, that the people in the Colonies are not the King's " natural-born subjects," or his "subjects born within the Realm." They cannot therefore claim the rights and privileges of Englishmen from their being British subjects in common with the people of England, or the subjects born within the Realm; and yet no other title to those rights do any of them pretend, than that such are the rights and privileges of Englishmen or British subjects. For they go on to resolve " that it is inseparably essential to the freedom of a people, and the undoubted right of Englishmen, that no taxes be imposed on them but with their own consent, given personally, or by their representatives;"- " that trial by jury is the inherent 


\section{The Administration of Dependencies}

and invaluable right of every British subject in these Colonies; -also, "that it is the right of the British subjects in these Colonies to petition the King or either House of Parliament." This is all very true and very sensible; but who those "Englishmen " or "British subjects" in the Colonies are, to whom, and to whom only, these rights belong, cannot easily be discovered. They cannot be the inhabitants of the Colonies, or those who have been born there; for the former resolutions say that the Colonies are " not within the British Realm," and that the people who are born there are not the "natural-born subjects" of the King, "born within the Realm."

Having thus seen upon what sort of foundations the different Colony Assemblies build their several titles to the rights and privileges of Englishmen, and that each superstructure, at the approach of reason, vanishes like "the baseless fabric of a vision," I will not fatigue the reader with a discussion of the arguments introduced by the Colony advocates in support of the Assemblies' resolutions. Whatever they can urge in behalf of the Colonies' claim to the rights and privileges of Englishmen, whilst they deny that they are subjects of the Realm, or natural-born British subjects, and that the Colonies are within the Realm, must be obnoxious to the same charges of inconsistency and absurdity to which the Assemblies' resolutions are so palpably liable; and the simplest of my countrymen can easily detect the most artful American sophister, by insisting upon his answering this plain question-Are the people in the Colonies British subjects, or are they aliens or foreigners?

The Assemblies and their advocates, aware of this dangerous dilemma, have never directly and explicitly declared, as the reader must have observed, that they are, or that they are not, British subjects; that is, subjects of the British State or community. They avoid that declaration by every artifice and subterfuge that words can supply them with,- they are at one time "Englishmen," at another "the children, and not the bastards of Britons," they are "free Britons," "the King of Great Britain's liege subjects," "they owe the same fealty and allegiance to his Majesty that is due to him from his subjects 
in Great Britain," -and numberless other equivocal professions, which serve to elude the main question. At the same time, as if under each character they had defined their condition to be that of British subjects, they boldly draw the consequence, that " they are entitled to all the rights and privileges of natural-born subjects in common with the people of England." That they cannot, however, maintain their title to those rights upon any other ground than that of their being British subjects, born and inhabiting within the Realm, is, I think, sufficiently evident; and therefore, that they may fail in proving that they are not British subjects, and that the Colonies lie without the Realm, is the most friendly wish I can give them.

There was no answer to this criticism, in so far as it charged that the resolutions were inconsistent with each other. The rights, privileges, and immunities of the Colonies and their inhabitants arose out of the character of the people of the Colonies and the geographical relationship of the Colonies to Great Britain, and were determined by the principles of the general public law. Because the Imperial State happened to have a constitution under which the inhabitants enjoyed a high degree of political freedom, it did not necessarily follow that the American Colonies were entitled to the same freedom. The British Constitution was, of course, in force in the Colonies except in so far as it was rendered inapplicable by their local conditions and circumstances, but the inhabitants of the Colonies were entitled to the same rights, privileges, and immunities as the inhabitants of the State of Great Britain only in case their conditions and circumstances were the same as those of the people of England. The fact that the most of the original American colonists were English did not necessarily give them the rights, privileges, and immunities of Englishmen. If they had colonized a tropical instead of a temperate region, these very colonists might, after a century 


\section{The Administration of Dependencies}

and a half, by reason of the local conditions and circumstances, have been wholly unfitted to exercise the same political rights as Englishmen at home. That the Americans were entitled to the same rights and liberties as the inhabitants of Great Britain was undoubtedly true, because they were, as matter of fact, on a par with the inhabitants of Great Britain in civilization. That they owed "due subordination" to Parliament as an "August Body," and not "obedience to its laws" as their "Supreme Legislature," was undoubtedly also true, but this arose from their geographical situation with respect to Great Britain, which rendered impossible a merger of their populations with that of Great Britain so as to form a Unitary State.

The distinction between internal and external taxes was very gingerly touched upon by the authors of the pamphlet,- - evidently because they saw that there was a very large truth underlying this distinction, namely, that the principal function of the Central Government in a Federal State, and of the Imperial State in a Federal Empire, is to attend to the external affairs of the Member-States, since it is with regard to these affairs that there is principally needed a guidance and direction in the common interests. They passed over this subject with the remark that the distinction had been abandoned by the Americans themselves, saying:

However cautious the Colonies have been in admitting that they are British subjects in any sense whatever, they do not nevertheless, as yet, reject the authority of Parliament to bind them in any case, save in the article of taxation; and, against even this right in Parliament, they do not urge that they are not British subjects, and consequently not within the jurisdiction of the supreme British Legislature, because that plea would involve every other right of jurisdiction in the decision of that question; and it is the artifice of the managers 


\section{America's Position Criticised, I769}

on behalf of the Colonies, to avoid general questions, and to keep back and conceal consequences, lest the unsuspecting people of England should too soon catch the alarm, and resolve to withstand their first attempts at independency.

When the repeal of the Stamp Act was their object, a distinction was set up between internal and external taxes; they pretended not to dispute the rights of Parliament to impose external taxes, or port duties, upon the Colonies, whatever were the purposes of Parliament in laying them on, or however productive of revenue they might be. Nay, Doctor Franklin tells the House of Commons, that "they have a natural and equitable right to some toll or duty upon merchandises carried through that part of their dominions, viz. the American seas, towards defraying the expense they are at in ships to maintain the safety of that carriage." This, however, was only the language for I $_{76} 6$ and I 766 ; but when Parliament seemed to adopt the distinction, and waiving for the present the exercise of its right to impose internal taxes, imposed certain duties on merchandises imported into the Colonies, and carried through those seas which the Parliament was told were [its dominions], the distinction between internal and external taxes is rejected by the Colony advocates, and a new one devised between taxes for the regulation of trade, and taxes for the purpose of revenue.

The authors of the pamphlet next proceeded to criticise the distinction which they claimed that Dickinson had made in his Farmer's Letters, between taxation for the regulation of trade and taxation for purposes of revenue, by showing that the admission by the Colonies of an unconditioned and unlimited power in Parliament to regulate the trade of the Colonies was a far more serious matter for them than would be an admission that Parliament had the right to tax them, since taxation implied permission to exercise all activities on condition of paying a tax, and the exercise of them to the greatest extent so as to produce the greatest revenue, whereas regulation 


\section{The Administration of Dependencies}

of trade might extend to the entire prohibition of activities. They said on this subject:

This new distinction, however, between taxes for the regulation of trade, and taxes for the purpose of revenue, as far as it respects the right of Parliament to impose the one, but not the other, is, of all absurdities, the most ridiculous that ever was contended for. It is saying, in other words, that Parliament has a right to impose a heavy tax, but not a small one. It may lay one so grievous, that nobody can afford to pay it; but it has no authority to impose one which may be easily borne.

I believe it is the first time that the Colonies of any State. have complained of the injustice of the Mother Country in laying taxes upon them which were not sufficiently heavy; nor was it ever before discovered that the proper means to redress the grievances of any people, were to increase their taxes. And yet this is certainly the case in the present instance between Great Britain and her Colonies; for, if Parliament had augmented the duties upon foreign molasses, instead of reducing them, or had it laid on another shilling upon black teas exported to the Colonies, instead of taking one off, the right to do so would have been admitted. But (says Mr. Dickinson) the heavy tax would have operated as a prohibition, which is a regulation of trade; the light tax is intended to be paid, and is laid for the purpose of revenue.

It is the purpose of Parliament in laying the tax, which, it seems, gives it the right of laying it. Curious reasoning this! Now, should it happen that Parliament was at any time mistaken in its purpose, and that a tax which it imposed with an intention that nobody should pay it,- that is, that it should operate as a prohibition,- - should really turn out to be such a tax as the commodity on which it was charged could bear, and the people in the Colonies were willing to purchase it at the price the tax had raised it to, what should we do then? If the tax be paid, it then becomes a revenue tax, and no longer a prohibitory one; and is thenceforward a grievance, and an 


\section{America's Position Criticised, I769 23I}

infringement of the rights of the Colonies. On the other hand, suppose Parliament should be mistaken in a tax it laid for the purpose of revenue, and it turned out a prohibition, would the tax then become a constitutional one?

Nevertheless, say the Colony advocates, the essential distinction between the two sorts of taxes will subsist in the purpose for which the tax is laid, no matter how it may operate; and for this essential distinction we are referred to our old statutes. Let the reasoning of Parliament in the preamble to the $5^{\text {th }}$ of Charles the Second, chapter the eleventh, be the measure of this distinction, and then we shall see where the boundary line is to be drawn.

"In regard," says this statute, " that his Majesty's Plantations, \&c. beyond the seas, are inhabited and peopled by his subjects of this his Kingdom of England, for the maintaining a greater correspondence and kindness between them, and keeping them in a firmer dependence upon it, and rendering them yet more beneficial and advantageous to it, in the further employment and increase of English shipping and seamen, vent of English woolen, and other manufactures and commodities, rendering the navigation to and from the same more safe and cheap, and making this Kingdom a staple, not only of the commodities of those Plantations, but also of the commodities of other countries and places; for the supplying of them, be it enacted, \&c." These several purposes are therefore to be deemed regulations of trade; and to whatever tax or duty which may be imposed with any of those purposes, the Colonies ought to submit, notwithstanding a revenue should incidentally arise from them. Be it so. One purpose, then, it appears, is, the making the Colonies a "vent" for British "manufactures." Now if the British manufacturers are heavily taxed, and the American manufacturer pays no taxes, or very small ones, the British manufactures must come much dearer to the consumer in the Colonies than American manufactures, and consequently the British manufactures will not sell there, and the Colonies will no longer be a vent for them. To prevent which, there can be no means so evident or effectual, as taking off taxes from the British manufacturers 


\section{$23^{2}$ The Administration of Dependencies}

and laying them on the American manufacturers. With this view, and with this purpose, of securing a "vent" for the British " manufactures," an Act of Parliament, laying a polltax upon all manufacturers of linen or wool, or a heavy tax upon all kinds of manufactures which should be made, in the Colonies, would be extremely proper. For this purpose also, all materials for manufactures should be taxed, unless exported to Great Britain; as should all tools and instruments for manufacturing. The encouragement of English navigation likewise opens another vein for drawing off the life-blood of the Colonies, as they call their money. Tonnage duties upon all ships and vessels built in the Colonies; duties upon all materials for ship-building, of the product of the Colonies, or imported there; and, in short, there is scarcely a tax, internal or external, which the people of England are liable to, that might not be imposed on the Colonies for some of these purposes. Besides, if we enter thoroughly into the matter, we shall find that it is always an argument of the want of finance ability in the Minister who proposes any tax which is not intended to operate beneficially as a regulation, as well as to produce revenue.

A land-tax is a judicious regulation, inasmuch as it excites the land-owner to cultivate and improve his lands; and with this very view, taxes are laid upon unimproved lands in America, by the Colony Assemblies. Thus our East India duties are many of them calculated to promote our own manufactures, as well as to raise a revenue. Thus the duties upon French goods were imposed with a view to check the trade of France, to encourage our own manufactures, and, at the same time, to raise a fund for defraying the public expenses. So likewise are a multitude of our taxes upon articles of luxury and of extravagance in our home consumption; so likewise are the taxes upon many of our exports, to prevent the manufacture of our raw material abroad, and to encourage it at home.

The double tax upon the Roman Catholics was laid with a view to weaken that interest, as well as to raise a revenue; and it was considered and urged as the strongest motive for 


\section{America's Position Criticised, I 769}

laying on the British stamp duties upon licenses to keep alehouses, to sell wine and spirituous liquors, and even those upon all law proceedings, and upon the admission of attorneys, and many others, that those duties would greatly operate to discourage and diminish what was wished to be checked, as well as produce a public revenue.

Upon this principle, even the Stamp Act in America might have been considered as a regulation; for it was intended likewise to prevent or detect the forgery of deeds, wills, or other instruments; to discourage, by à high duty, the grant of large quantities of land to one person; to make all law proceedings and instruments in the English language, and thence incite the foreign subjects to learn it; to discourage a spirit of unnecessary litigation in the Colonies; to prevent disorders which frequently happen from tippling-houses in remote places, and from selling spirituous liquors to the Indians in the woods; to make the entries and clearances of ships more regular; and to prevent false cockets, and several things of the like nature.

This boasted distinction between taxes for the regulation of trade, and taxes for the purpose of revenue, we therefore see is without a difference, and will in no sort serve to protect the Colonies from Parliamentary internal and external taxation, however it may serve for a pretence, under which to strip Parliament of all jurisdiction over the Colonies.

Evidently realizing that they had gone farther than they ought in interpretating the Farmer's Letters as advocating a distinction between taxes for the regulation of trade and taxes for the purposes of revenue, the authors next attempted to show that what Dickinson had unquestionably advocated, namely, that the sole power of Parliament was to regulate trade otherwise than by taxation, made no difference in the principle. This they did by arguing that there were practically no regulations of trade for the Colonies conceivable which would not be subject to all the objections of a tax. They claimed that 


\section{The Administration of Dependencies}

Dickinson had in effect admitted this when he said, in the Farmer's Letters, that "an Act of Parliament, commanding us to do a certain thing, if it has any validity, is a tax upon us for the expense that accrues in complying with it." After quoting this passage and others of like purport from the Farmer's Letters, they proceeded:

If we take the sense of these several passages together, we shall find that the exercise of sovereign authority over the Colonies is connected so intimately with the right of taxation, that the one cannot subsist without the other in any case whatsoever. The impressing wagons or boats for the transportation of troops or their baggage; the quartering them even upon public houses; their trampling down a man's fences in their march, or encamping upon his grounds; their passage over ferries or toll-bridges - are all taxes, it seems; for in all these cases, something is furnished to the troops, or something is done by them, or something is commanded to be done for them, from whence some expense will accrue to the people in the Colonies. And if Parliament has no right to require any of these things to be done, without the consent of the Colonies, it can have no right to keep up any troops in the Colonies, or to march them through the country without their consent, which is repugnant to every idea of sovereignty on the one part, and of dependence on the other; besides, there can be neither restraints nor regulations of trade but what must fall within some of these descriptions of taxes. To oblige a planter to carry his products to a port of entry, when a vessel can take them in at his own landing-place, nay, to oblige a merchant to ship his goods from the Custom House quay, when another wharf is more convenient to him, is to command the planter and merchant to do certain things from whence expense will accrue. The fees paid the officers of the customs for entries and clearances, are also expenses charged upon the Colonies, and consequently taxes. Confining the Colonies to purchase commodities or manufactures in Great Britain, when they could purchase them at a cheaper rate elsewhere, is taxing them, in this way of reasoning; obliging the Colonies to 


\section{America's Position Criticised, I769 235}

sell their products in Great Britain, or to land them there before they carry them to another market, is likewise a tax upon them; for in all these cases, they are commanded to do something from whence expense accrues.

All the taxes which are paid by the people in England, inasmuch as they serve to raise the price of labor or materials, and thereby raise the price of manufactures, are all taxes upon the people of the Colonies, who are obliged to purchase those manufactures at our prices, and may not get them from other countries.

It would be endless to trace this doctrine of taxes through all its consequences. I have already gone far enough to show that, upon Mr. Dickinson's principles, where they cannot be imposed, there can be neither restraints upon trade, nor exercise of sovereign authority; and that if Great Britain does not possess the right of taxing the Colonies, she has no right to exercise any jurisdiction over them; but that the Colonies are, as Mr. Dickinson says they are, of themselves, "a distinct community, or one political body of which each Colony is a member, separated from the rest of the world," and especially from Great Britain. Yet, notwithstanding these are clearly the consequences which must follow from his premise, and that such are the consequences the Colonies mean should follow from them, Mr. Dickinson, not caring to discover the whole of their purpose so fully at present, in the beginning of his second Letter, thus expresses himself: "The Parliament unquestionably possess a legal authority to regulate the trade of Great Britain and all her Colonies; such an authority is essential to the relation between a Mother Country and her Colonies, and necessary for the common good of all. $\mathrm{He}$ who considers these Provinces as States distinct from the British Empire, has very slender notions of justice, or of their interests; we are but parts of a whole, and therefore there must exist a power somewhere to preside and preserve the connection in due order. This power is lodged in the Parliament." Again, in the same Letter, he says, "that we [the Colonies] may be legally bound, by Act of Parliament, to pay any general duties on these commodities, that is, paper and 


\section{The Administration of Dependencies}

glass \&c., relative to the regulation of trade, is granted." How it comes to pass that these general duties do not occasion an expense to the people who pay them, Mr. Dickinson has not told us, or in what manner the Parliament of Great Britain can exercise its legal authority to regulate the trade of the Colonies, and preside over the whole, and preserve the connection in due order, without a power of commanding the Colonies to furnish a single article for such part of the national forces, as it may, for these purposes, be thought fit to station among them; or what sort of regulations of trade Parliament can devise, from the observance of which no expense will accrue to the Colonies, are matters which he has not thought proper to explain.

The authors of the pamphlet did not fail to point out that the main and real objection to Dickinson's proposition that Parliament had power to regulate the trade of the Colonies otherwise than by taxation, but had no other power over the Colonies, was, that there was necessarily implied in this that the powers of Parliament in the Colonies and in Great Britain were not identical, and that, the instant that was admitted, it was admitted that the Colonies were not "of the same community with England," - that is, were dependent States, and no one could tell what the power of Parliament over them was, or whether it had any power over them at all. Their words were:

Whatever impeaches the jurisdiction of Parliament over the Colonies, however insignificant in itself, becomes of importance from its consequences; for if the authority of the Legislative be not in one instance equally supreme over the Colonies as it is over the people of England, then are not the Colonies of the same community with the people of England. All distinctions destroy this union; and if it can be shown in any particular to be dissolved, it must be so in all instances whatever. There is no alternative: either the Colonies are a part of the community of Great Britain, or they are in a state of 
nature with respect to her, and in no case can be subject to the jurisdiction of that legislative power which represents her community, which is the British Parliament.

However faint any line of partition may be attempted to be drawn between the people in England and the people in the Colonies, it is not to be endured, if we would preserve the union between them as one community, and the supremacy of Parliament over all as the representative of that community.

This, no doubt, was also intended as an answer to the suggestion which the Stamp Act Congress itself had made, in its Address to the House of Commons, when it submitted to that House "whether there be not a material distinction, in reason and sound policy at least, between the necessary exercise of Parliamentary jurisdiction in general Acts, and the common law and the regulations of trade and commerce through the whole Empire, and the exercise of that jurisdiction by imposing taxes in the Colonies," which was a definite suggestion that the power of Parliament in the Realm was different in character and extent from its power in the Empire-different in character because to be exercised only according to the necessity for its interference, and different in extent because in the matter of taxation of the Colonies, at least, it was wholly without power.

The alternative seemed to Knox and Grenville to be that Great Britain and the Colonies either constituted a Unitary State of which the British Parliament was the Legislature and the British King the Executive, or that Great Britain was a State foreign to the American Colonies, in which case they were "in a state of nature" with relation to it, and subject to its will as much as if they were its mere conquests.

Nor was this position wholly unpraiseworthy. It was, in one sense, a manifestation of the Imperial spirit with which the English State has always been imbued-a spirit 
which has its basis in the sense of the personality of the English State. The English idea always was that the English State might incorporate other States or communities into itself, but that it could never confederate with other States or be incorporated by another State into itselfthat any union with other States must result so that the English State was the Central and Governing Power of the whole organism. All communities not incorporated into the English State so as to form a part of its personality were considered to be " in a state of nature" with respect to it - that is, subject to its will, which, if not yielded to, was to be executed by force. The Union with Scotland in 1707 had been an incorporating merger of the Scotch population with the English under such terms that the population of Scotland was in fact segregated and made dependent on the population of England acting through the majority in Parliament, and hence, practically, dependent on the State of England, except that trade and intercourse between them was free from imposition or tax.

It was only natural, therefore, that any Englishman should look with suspicion upon any interpretation of the Constitution of the British Empire according to which it was to be regarded as a federal organism, in which Great Britain-that is, England-was the Central Government, and the American Colonies the Member-States. Such an arrangement, no doubt, seemed to Englishmen to place England in an equivocal position with relation to the Colonies, since it would be their agent, delegate, or representative, even though it had power to adjudicate upon the limits of its own jurisdiction.

Knox and Grenville did the Colonies a service in demolishing the position that the rights of their inhabitants were the rights of Englishmen, and compelling them to base their rights on general principles; and also in pointing out that the moment they claimed that the power of 
Parliament was different in the Colonies from what it was in Great Britain, they declared themselves to be States distinct from the State of Great Britain, and compelling them to base their rights upon an interpretation of the existing relationship between themselves as States, and Great Britain.

The criticism contained in this pamphlet changed the whole course of political thought in America. It had been shown that the rights of the Colonies did not arise from their ancestors having been Englishmen and were not derived through any rights pertaining to individuals, but arose out of the nature of things, which made it just and necessary that political communities external to a State and so far distant or distinct from it that a merger of their populations with that of the State was impossible, should be regarded and should regard themselves as States, in a constitutional relationship of subordination to the Imperial State, and as constituting, with it, a Federal Empire. It forced the Colonies to base their claims upon their rights as States, and to found their claim of right to statehood to the extent of exclusive self-taxation, upon their capacity for governing themselves as States and upon the existence of a moral sense which would have made it repugnant to the populations of the Colonies to refuse to abide by the solemn and impartial adjudications of Great Britain concerning the limits of its jurisdiction, or to make use of the services of Great Britain as the Central Government, having the function of protection and co-ordination of all the parts of the whole organism, without paying for these services. In other words, in so far as the Colonies had attempted to work out their rights from the rights of their inhabitants, as individuals, the American position (involving as it did the proposition that the British Empire was a Unitary State) was demolished; but in so far as it was attempted to work out the rights of the 


\section{The Administration of Dependencies}

inhabitants of the Colonies from the rights of the Colonies, as Member-States of the British Empire, it was uninjured, because impregnable,-the British Empire being, in fact, a federal organism.

Had the resolutions of the Stamp Act Congress been remodelled so as to meet this criticism, they would have read, it would seem, somewhat as follows:

Resolved: That the American Colonies, as dependencies of Great Britain, are Member-States and component parts of the British Empire as a Federal Empire, of which Great Britain is the Imperial State and Central Government, with power to determine expertly and on just principles the limits of its own jurisdiction. To such adjudications, whether made through the King in Council or through the King, Lords, and Commons in Parliament assembled, the Colonies owe the respect and reverence which is properly and rightly due to tribunals of so august a character.

That all the dependencies of Great Britain are justly entitled to the highest degree of member-statehood consistent with their highest development and the highest development of the whole Empire.

That it is inconsistent with the degree of member-statehood to which the American Colonies are justly entitled and to which they have been heretofore recognized as being entitled, that they should not have exclusive control of their internal and external taxation.

That the British Constitution is in force in the Colonies except in so far as it is rendered inapplicable by local conditions and circumstances, and that the local circumstances and conditions in the Colonies are not such as to require the abolition, to any extent, of the right of trial by jury.

No opportunity occurred for reviewing the resolutions of the Stamp Act Congress until the Continental Congress met in 1774. When that Congress met, it was evident that the criticism of Knox and Grenville had had its effect, and that the Colonies had profited by it. 


\section{CHAPTER XIV}

REALM,-NOT EMPIRE, I769-I 774

$\mathrm{T}^{\mathrm{H}}$

HE work done by Knox and Grenville, in the pamphlet, The Controversy between Great Britain and the Colonies Reviewed, was not wholly negative and critical of the American propositions. A large part of it was devoted to an attempt to prove affirmatively that Great Britain and the Colonies constituted a single Unitary State-that there was no British Empire, but only a British Realm, of which the Colonies were integral parts.

Their first point was that the Parliament of Great Britain was the Supreme Legislature of every person subject to the power of the State of Great Britain, on the theory that every individual within that State, by becoming and remaining subject to its power, had tacitly assented that Parliament should be the Supreme Legislature. They said on this subject:

The subjects of Great Britain [in the Colonies] are not without their representatives, though the members who compose the House of Commons cannot be said to be distinctly so. Neither are they bound by laws, nor is their money taken from them without their own consent given by their representatives. The King, Lords, and Commons are their representatives; for to them it is that they have delegated their individual rights over their lives, liberties, and property; and so long as they approve of that form of government, and continue under it, so long do they consent to whatever is done by those they have intrusted with their rights. 


\section{The Administration of Dependencies}

"Laws they are not (says Hooker) which public approbation hath not made so. But approbation not only they give, who personally declare their assent by voice, sign, or act, but also when others do it in their names, by right originally at the least derived from them. And to be commanded we do consent, when that society whereof we are part hath at any time before consented, without revoking the same after by the like universal agreement." And Mr. Locke, who followed this learned investigator of the rights of mankind, in his answer to Sir Robert Filmer, after having shown that the origin of all power is from the people only; that every form of government, whether a democracy, an oligarchy, an elective or hereditary monarchy, is nothing more than a trust delegated by the society to the person or persons so appointed, lays it down as a fundamental maxim in all Governments: " That the Legislative is the joint power of every member of the society, given up to that person or assembly which is legislator; and that even the Executive, when vested in a single person, is to be considered as the representative of the Commonwealth." And he then adds: "Nobody doubts but an express consent of any man entering into society makes him a perfect member of that society, a subject of that Government. The difficulty is what ought to be looked upon as a tacit consent; and to this I say, that every man that hath any possessions or enjoyment of any part of the dominions of any Government, doth thereby give his tacit consent, and is as far forth obliged to obedience to the laws of that Government during such enjoyment, as any one under it."

Upon this principle, the King and the two Houses of Parliament, are by our Constitution representatives of the Legislative, as the King alone is of the Executive power of the Commonwealth; and upon this principle, every subject of Great Britain, when he is taxed by Parliament, is taxed by his own consent, for he is then taxed by consent of those whom the society has impowered to act for the whole; and every member of that community must therefore subscribe his tacit consent to all such taxes as may be imposed, or other legislative acts that may be done by those whom the society 
has appointed, as long as the form of government subsists. This is the British Constitution; and if the British subjects in America still continue to be part of our community, it follows that they also are represented by the British Legislative, and equally bound by its laws.

The answer to this argument, so far as it is founded on the theories of Hooker and Locke, is now easy, but it was not in 1769 , because political thought had not then evolved to the point where the State as organized for the purposes of war, was distinguished from the State as organized for the purposes of peace. In the State as organized for the purposes of war, only one Legislature and Executive was possible, and, for the most effective exercise of the power of the State, it was necessary that all power should be in the hands of one individual. For a long time after the condition of peace came to be the normal condition of the State, and the Sovereign became a body of persons instead of a single individual, the theory that the power of the supreme governing person or body was indivisible, remained undisputed. It was not until the American Revolution that it was perceived. that the will of the people was the supreme power, and that all governmental power was an agency for them, which they might divide in time of peace between two or more governmental agents, so that each should exercise a supreme governmental agency within its sphere. When Hooker and Locke wrote, the conception of divided supreme governmental agency, on which was based the claim of the Colonies to be Member-States of the British Federal Empire, was unknown.

The next argument was that, because the rights of the Colonies were originally derived from the Crown through charters or commissions granted by it, which necessarily implied an original submission to Parliament as the Supreme Legislature, the Colonies could not claim to be 


\section{The Administration of Dependencies}

Member-States of a Federal Empire, because this would imply a subsequent dispensation by the Crown, by which the Colonies were in whole or in part released from the supreme legislative authority of Parliament, which the Crown had never purported to give and which it could not have given, especially since the Act of Settlement of 1689, by which the King recognized that he had no power to dispense with statutes. They said:

That the first inhabitants of the Colonies were part of the British community, and bound to obey its legislative power in all respects, as any other subjects at the time of the establishment of those Colonies, will not be denied. How then has that obedience been altered or released? Those Colonies were all created by charters or temporary authorities, from the Executive Power of this community, except in the cases of Jamaica, New York, and the late acquisition of Quebec, the Ceded Islands, and the two Floridas, which were conquests made by this community upon foreign powers, and such of their subjects as remained were incorporated with us under our laws and obedience. And it cannot, we have seen, be pretended, that this obedience has been altered or released by charters or authorities from the Executive Power; for, on the contrary, the obedience to the laws of Great Britain, without any restriction, is expressly reserved in every one of them, and particularly the right of taxation is mentioned and reserved to the Parliament of Great Britain by the Charter of Pennsylvania, in which Colony Mr. Dickinson wrote his Farmer's Letters.

This argument was difficult to answer in 1769 . The character of the Colonies as Member-States of the Federal Empire arose neither from the act of King or Parliament, but in part from their being under the power of the State of Great Britain, and in part from the nature of things. The acts of the Crown derived their force not merely from the fact that they were expressions of the 
will of the King or of the State of Great Britain, but also and principally because they were adjudications made by the King under expert advice, concerning the character and extent of the rights of member-statehood which the Colonies ought, on just principles, to have in the Federal Empire. The question, therefore, was not of the right of the Crown to release or discharge the Colonies, in whole or in part, from the power of Parliament, but of the right of the Crown to adjudicate in what manner, and to what extent, the Colonies were, in the nature of things, released and discharged, in time of peace, from the power of the State of Great Britain.

The authors also claimed that, in the case of the inhabitants of the Colonies, there was a special reason why they should be considered as an integral part of the population of the British State, namely, that the proprietary title to the soil itself, as well as the governmental authority over the soil, had been originally vested in the State of Great Britain by discovery, and that the inhabitants had recognized this original and paramount title in many ways, and particularly by paying to the Crown, i.e., to the State of Great Britain, rents, called quit-rents, reserved by it, in lieu of the military or other service which the occupant of the land would otherwise owe. The argument on this point was as follows:

It is however pretended, that the lands in America lying without the Realm, and appertaining to the King only, their possessors cannot, from those circumstances, be subject to the jurisdiction of Parliament, whose authority is necessarily confined within the limits of the Realm. This plea, it is presumed, cannot be made by the inhabitants of such lands as were conquered by the forces of the British State from foreign powers, or ceded to Great Britain by treaty. Those conquests or cessions are surely the dominions of the Crown of Great Britain, not the private property of the King, which have 


\section{The Administration of Dependencies}

thus been acquired by the efforts, the blood, and treasure of the community; and indeed Mr. Dickinson puts these out of the question in all that he says of the rights of the Colonies.

But does the discovery of countries by the subjects of the British State, or the cession of them by the natives, make those countries more particularly the private property of the King, than would the conquest of them by force of arms from a foreign Prince, or the acquisition of them by treaty? The difference only lies in the change of the term, the Crown for that of the King; but that change has been made without authority, either of reason or fact. The Kings of England never had personally, nor ever claimed to have any property in the lands in the Colonies. Those of them who carried their claims of prerogative the highest, never pretended to have any other title to those lands than what they derived from their possession of the Crown of England, and they granted them under that title to their present possessors, or their ancestors; for all grants of lands in the Colonies have been made under the Great Seal of England, or by authority derived under the Great Seal of England, which is the same thing, from the first discovery of America to this day.

No man, at least no lawyer, will pretend, that the Great Seal of England is the Private Seal of the King. It is the Seal of the State, and distinguishes the acts of the State from the private acts of the King; now, had the Kings of England claimed to hold the lands in the Colonies as their own private estate, they would have granted them of their own private authority, and passed them under their own Private Seal, and not under the Great Seal of England. The very nature of the grant or charter is therefore an undeniable proof that the lands in the Colonies are, and always have been, the possessions or dominions of the Crown of England, and not the private personal property of the Kings of England. And it is an equally undeniable consequence, that those who hold those lands under such grants or charters, or by whatever title which derives its authority originally or immediately under the Great Seal of England, hold them of the Crown of England, and as a part and parcel of the Realm; for the Crown's estate must 
necessarily be within the Realm, since it is the estate or dominions of the Crown (though not of the King) which make the Realm.

In so far as this argument showed that the soil of the Colonies belonged to the State of Great Britain as its "property," it was unanswerable, but the conclusion drawn from this premise was wholly wrong, as it is now possible to see. To conclude from the premise that the soil of the Colonies was the property of the State of Great Britain, and, as such, subject to the unconditioned and unlimited power of that State, that the people of the Colonies were subject to the unconditioned and unlimited power of that State, necessitated a minor premise to the effect that the people on the soil of the Colonies were a part of the soil.

The argument, put in the form of a syllogism, would be :

The soil of the Colonies is the property of the State of Great Britain, and, as such, subject to its unconditioned and unlimited power.

The people on the soil of the Colonies are a part of the soil of the Colonies.

Therefore the people of the Colonies are the property of the State of Great Britain, and, as such, subject to its unconditioned and unlimited power.

The truth of this minor premise, under any circumstances, would now be denied, according to the practically unanimous sentiment of the civilized world, though the principle contained in it is still, unfortunately, the underlying basis of much political action. The difficulty with the syllogism, however, reaches back to the major premise, which is itself too broad, because not making a difference in the kind and degree of property which a State has in the soil of countries external to itself, accord. ing as they are occupied by human beings or not. If the 


\section{The Administration of Dependencies}

soil of a country external and belonging to a State is occupied by human beings, the region is its "property," but it is its qualified property - that is, its property subject to a lien, incumbrance, or diminution of power, in favor of the human beings occupying the soil, to the extent necessary for their highest development.

The modern view, stated in the form of a syllogism, would be :

The soil of the Colonies is the property of Great Britain, subject to its unconditioned and unlimited power when unoccupied by human beings, but subject, when occupied by human beings, to disposition according to the rules of the general public law founded on reason and the nature of things, so as to effect the highest development of the inhabitants both of Great Britain and the Colonies. As an incident of this right of disposition and to the extent necessary to effectuate this purpose, Great Britain has the right to regulate the actions of the inhabitants of the soil.

The soil of the Colonies is occupied by human beings.

Therefore the soil of the Colonies is subject to disposition according to the rules of the general public law, founded on reason and the nature of things, so as to effect the highest development of the inhabitants both of Great Britain and the Colonies; and, as incidental to this right of disposition, and to the extent necessary to effectuate this purpose, Great Britain has the right to regulate the actions of the inhabitants of the soil.

The proposition that all the lands subject to the power of a State were integral parts of the State in spite of its wish or the wish of the inhabitants of the lands to the contrary, and in spite of the separation of the lands from the lands occupied by the State, was simply a conclusion based on the proposition that a State is an aggregation of lands and not a person occupying a certain amount of space on the earth's surface. The whole syllogism would be : 


\section{Realm,-not Empire, I 769-I 774}

Great Britain is an aggregation of lands subject to a Central Power.

The Colonies are lands subject to this Central Power.

Therefore the Colonies constitute an integral part of the State of Great Britain.

In the light of modern knowledge the syllogism would be framed thus:

Great Britain is a legal and political person,- that is, a corporation and a state,-composed of all the individuals inhabiting certain lands, which may unite to itself or merge in itself the individuals inhabiting other lands, provided such union or merger is not impossible in the nature of things on account of the separation of the lands by great distance, or on account of the individuals inhabiting the lands being incapable of fusion with the individuals composing the Corporation and State of Great Britain.

The lands inhabited by the individuals composing the Colonies are separated by a great distance from the lands inhabited by the individuals composing the Corporation and State of Great Britain.

Therefore the Colonies are not, and can never be, integral parts of the Corporation and State of Great Britain.

The arguments of Knox and Grenville were of a kind which could not be answered by reference to English precedents, because English history furnished no precedents. In order to answer them, it was necessary to appeal to what was then called "the law of nature and of nations," to use the title adopted by Pufendorf in 1672 , or to "the general public law," to use the title adopted by Bluntschli in I880, which concerns itself with the rights and duties of the State towards its inhabitants and towards its dependent, associated, and federated States and their in: habitants. In 1769 , however, the thought on the subject had not reached the point where this necessity was evident. Lord Chatham and Dickinson were silent. 


\section{The Administration of Dependencies}

Bernard's scheme for a Constitutional Convention of the Empire was unpopular on both sides of the water, each party fearing that the other would get the better of it in a constitutional settlement. Pownall's scheme for Imperial Unity was equally unpopular, the British being unwilling to convert the British Parliament into an Imperial Parliament, and the Americans being unwilling to send representatives to an Imperial Parliament because they realized that the British Parliament would in fact control it, and that they would thus have forever committed themselves to the non-expert government of the British House of Commons, which was the supreme governmental agent within the British State.

From March I2, I770, when the British troops were removed from Boston, until the destruction of the tea in Boston Harbor, on December I8, I773, the situation between Great Britain and the Colonies remained unchanged. The advantage in the debate was on the side of Great Britain, since the burden was plainly upon the Colonies to show that the power of Parliament in the Colonies was different from its power in the Realm, and the points of difference which they had suggested had been pretty well demolished by the argument of Knox and Grenville.

This condition of quiescence was largely due to the conciliatory resolution adopted by the Ministry on May I, 1769, which was given out by L.ord Hillsborough, as Secretary of State for the Colonies, in a circular letter to the Colonial Governors, in which it was declared:

It is the unanimous opinion of the Lords present . . . that no measures should be taken which can in any way derogate from the legislative authority of Great Britain over the Colonies, but that the Secretary of State, in his correspondence and conversation, be permitted to state . . . that it is by no means the intention of Administration, nor do they think it expedient, or for the interest of Great Britain 
or of America, to propose or consent to the laying of any further taxes upon America, for the purpose of raising a revenue, and that it is at present their intention to propose, in the next Session of Parliament, to take off the duties upon paper, glass and colors imported into America, upon consideration of such duties having been laid contrary to the true principles of commerce.

This quiescence in the Colonies was, however, wholly external. None of the causes of the original irritation were removed except the most burdensome of the taxes. There never was an instant when Great Britain did not impose some taxes on the Colonies and when it did not keep in existence in the Colonies a complete set of officials and machinery for the collection of taxes. The taxation was so light, however, that the organized resistance by non-importation agreements came to an end in the fall of I770, it having been found, as time passed, that they. were being violated by so many individuals and communities that the rest were obliged to yield.

Neither the Tariff Act of 1764 nor that of 1767 was repealed, all that was done being to change the duties levied under them, leaving in existence all the objectionable provisions of those Acts, which appropriated the proceeds of the taxes to defraying the charge of the administration of justice and the support of civil government in the Colonies, and which legalized writs of assistance and permitted taxes to be recovered by actions in Courts of Admiralty or in a general Court of Vice-Admiralty for all America, in actions triable without a jury.

As showing that the British Government was in earnest about the establishment of a general Court of ViceAdmiralty for all America, the action of the $\mathrm{King}$ in commissioning the Governors of several of the Colonies by the title of "Governor and Vice-Admiral" is signifi- 


\section{The Administration of Dependencies}

cant. This made it possible for the Governors to sit as Courts of Vice-Admiralty and to adjudicate upon cases arising from alleged breaches of the customs laws without a jury. The Act of $\mathrm{i} 767$, providing for the establishment of Commissioners of Customs in America, appointed by the King also, continued in force during all this period. These Commissioners, like the Commissioners of Customs in Great Britain, were both inquisitors to ascertain breaches of the customs laws, and prosecutors in customs cases. By the establishment of this Board and the Court of the Governor sitting as Vice-Admiral, there were provided instrumentalities of the most searching and rigorous kind for the collection of taxes.

During the period from I 770 until the outbreak of the Revolution, taxes were imposed and collected, under the Act of 1766 , on syrups and molasses imported from any place except the Island of Dominica, and on coffee or pimento (allspice) imported from any British Colony, and on tea, and the Navigation Act restricting the commerce of the Colonies to Great Britain remained in force.

There were, however, many statutes in force in the Colonies and actually put into execution there, during the period from I 770 to 1774 , which could not by any stretch of the imagination be classed as taxing or traderegulating statutes or as statutes incidental to the exercise of the power of taxation, or the power to regulate trade, to which the Americans strenuously and properly objected. The annual statutes providing for the quartering of troops in America at the expense of the Colonies, in public-houses, uninhabited dwellings, and barns, when the barracks were insufficient, and for the furnishing of supplies to the troops partly at the expense of the Colonies, and for the impressing of wagons, etc., continued to be passed, and the suspension of the sittings of the General Assembly of New York for two years, until it complied with the statute, had made it evident that the 


\section{Realm,-not Empire, I769-I774 253}

British claim in this respect was intended to be enforced. After the withdrawal of the troops from Boston on March I2, I770, consequent upon the Boston Massacre, care was taken to dispose the troops so that they should not come into collision with the people, but this was the only concession made. The Act of 1764 , prohibiting the issue of bills of credit by the Colonies, continued in force except as modified in favor of $\mathrm{New}$ York in 1770 ; and the Act of 1773 , permitting the Colonies to make bills of credit a legal tender for taxes and public dues, did not alter the hostility of the Colonies to this kind of regulation. The claim made by the British Government, in I 769, of a right to have persons charged with treason in the Colonies tried in England, under a statute of Henry VIII., was renewed by the Act of 1772 , which permitted the King in Council, by order, to require any person charged with destroying any British dockyard, magazine, ships, ammunition, or stores, to be tried in England. The statute of 1765 , relating to the Post Office, fixing the rates of postage on letters and packages between points wholly within the Colonies, continued in force during all this period, and was objected to by the Colonies as an interference with their constitutional rights.

In order to make a successful defence against these various acts of the British Government which the Americans regarded as infringements of their constitutional rights, it was plainly necessary for them to base their argument upon some ground which would be equally good against tax legislation and every other kind of legislation which they regarded as objectionable. The proposition that they were entitled to the same rights as if they were Englishmen had been shown by the British Government to be fallacious, by reducing the tariff on the Americans so that they were taxed less by tariff duties than Englishmen were. If the Americans were entitled to the rights of Englishmen, they certainly could 


\section{The Administration of Dependencies}

not complain if they were treated by the British Government better than Englishmen. This was particularly the case with tea. In 1767 , by the Tariff Act, the tariff on tea was reduced below the tariff which Englishmen had to pay, and by another Act of the same year, tea was allowed, for five years from July 5,1767 , to pass through Great Britain to America without any duty, so that from July 5, 1767, until July 5, 1772, when this arrangement expired, the Americans got their tea at a less price than Englishmen. After the expiration of this arrangement, the Americans still paid less than Englishmen, for though they had to pay the tariff on importation both into England and into America, Englishmen had to pay the tariff on importation into England and an inland duty exceeding the amount of the duty on importation into America.

The tax on the tea imported into America in the fall and winter of 1773 , in the ships chartered by the East India Company, was smaller than the Americans had been paying on tea for more than a year, since under the Act of 1773 the tariff on importations of tea into England was repaid or released by the Government on the exportation of the tea to America. In searching for the intense antipathy manifested by the American Colonies to this importation of tea, therefore, it is necessary not to lay too much stress on the fact that it was taxed by the British Government. It was quite as much because the tea imported was equitably owned by the State of Great Britain, so that the act of importation was the virtual establishment of a monopoly in America, as because it was taxed, that its importation was objectionable.

The facts out of which arose the equitabie ownership by the British Government of the tea attempted to be imported were as follows: The East India Company, which was the successor of companies which had traded under royal charters since 1600 , existed in 1773 , not 
under a royal charter, but under a charter granted by Act of Parliament originally enacted in 1709 , and continued by Acts of I712, I730, and I769, which conferred upon the Company powers of government to some extent. It was not a guild, but an ordinary joint-stock corporation, in which any one could be a member who should purchase its shares. By Clive's victory at Plassy in I757, over the forces of the East Indians and French, the Company had obtained territorial rights in and near Calcutta by possession growing out of conquest, which, in 1765 , were, by the recognition or grant of the Mogul Emperor, converted into rights of fiscal and judicial administration over a large region. By other victories over the French, followed by the Treaty of Paris in $17 \sigma_{3}$, the French power in India ceased to exist. In 1772 , the affairs of the Company, for several different reasons, became much involved, its principal debts being one of $£ 600,000$ to the State of Great Britain for duties unpaid, and one of the same amount to the Bank of England for money borrowed; and, as it could not raise money from private sources to tide it over the difficulty, it became necessary for it either to go into bankruptcy or to be supported by a loan from the State of $£ I, 400,000$. Great Britain could not afford to let the Company fail, as the Company was acting as its officer in the part of India over which it had obtained governmental power. The native population was acquainted with the Company and feared it, and the Company was acquainted with the ways of the natives. The situation required that the Company should not be abolished, but that the enterprise should become partly public and partly private, both in order that the Government might have a hand in the management of the Company so as to protect the interests of Great Britain as creditor, and in order that it might cause to be fulfilled the obligations of Great Britain, as the Imperial State, in the part of India which had, to some 


\section{The Administration of Dependencies}

extent, become dependent upon Great Britain. Consequently, by an Act of the year I773, Great Britain loaned $\notin \mathrm{I}, 400,000$ to the Company, on the security of all the tea then in the Company's English warehouses, amounting to I7,000,000 pounds, and by the Regulating Act for India of 1773 , so called, entitled "An Act for Establishing Certain Regulations for the Better Management of the Affairs of the East India Company," provided for governmental supervision of the affairs of the Company, though the control of its affairs in the first instance was left in the hands of the Board of Directors of the Company. The Regulating Act put an end to the practice of electing the whole Board of Directors annually, and required that only one fourth of the Board of twenty-four members should be elected each year, so as to prevent radical changes of policy which might endanger both the British power and the British loan to the Company, and required monthly repoits from the Board of Directors to the head of the Treasury respecting all matters relating to the revenues of the Company, and to the Secretary of State for the Southern Department respecting all matters relating to civil and military affairs and government. In addition to this, a Supreme Court of Judicature was created to sit at Calcutta, for the part of India under the jurisdiction of the East India Company, the judges of which were to be appointed by the Crown.

Contemporaneously with the Loan Act and the Regulating Act, and as a part of the same transaction, Parliament passed another Act, which permitted the duties collectible on importation of tea into Great Britain to be drawn back or released as respects teas taken from the warehouses to be exported to America, doubled the deposit required of persons buying tea at auction from the warehouses, making it $£ 4$ per chest instead of $£ 2$,- - thus discouraging private individuals from buying at auction for exportation, - and provided as follows: 


\section{Realm,-not Empire, I 769-I $774 \quad 257$}

That it shall and may be lawful for the Commissioners of his Majesty's Treasury, or any three or more of them, upon application made to them by the said United Company of Merchants of England Trading to the East Indies, to grant a license or licenses to the said United Company, to take out of their warehouses, without the same having been put up to sale, and to export to any of the British Plantations in America, or to any parts beyond the seas, such quantity or quantities of tea as the said Commissioners of his Majesty's Treasury or any, three or more of them, or the High Treasurer for the time being, shall think proper and expedient, without incurring any penalty or forfeiture for so doing . . . and to export such tea to any of the British Colonies or Plantations in America, discharged from the payment of any duties or customs whatsoever.

After the passage of this Act, the Ministry insisted that the East India Company should send cargoes of tea to America. The officers of the Company remonstrated, on the ground that they could not safely do so unless the Company paid the duty in advance and landed the goods duty free, but the Ministry insisted that the consignees in America should pay the duty, partly, no doubt, because they feared that such a course as that suggested by the Company would prejudice the claim of Great Britain to tax the Colonies, and hence, as they believed, to legislative supremacy over them, but principally because it was a part of their plan to make the collection of the duty certain, by requiring tea to be imported in cargo lots which could not possibly be smuggled. The tea in the English warehouses equitably belonged to Great Britain, and, had the cargoes of the tea-ships been landed in the Colonies and sold there, all the proceeds, and not merely the three pence per pound duty, would have gone into the British Treasury. It was for the interest of Great Britain, under such circumstances, that it should get as high a price as 


\section{The Administration of Dependencies}

possible for the tea, and that as many people in the Colonies as possible should buy tea, since the more there was realized, the sooner would it collect from the Company what was owing. The situation was, therefore, the same in effect as if the State had granted to the Company the monopoly of supplying tea to the inhabitants of America, and had pledged itself to foster the monopoly by every direct and indirect means. As the consumption of tea by the people of the Colonies would have pecuniarily benefited Great Britain, consumers of tea would have been regarded by the British Government as its friends and non-consumers as its enemies, and the people of the Colonies would have been, in effect, subject to sumptuary. regulations of the British Government, enforced through the instrumentality of spies and informers. That it was this monopoly feature which made the importation of the tea particularly odious is shown by an extract from a Philadelphia newspaper of January 3, 1774, quoted in the Principles and Acts of the Revolution by Hezekiah Niles, which read:

Upon the first advice of this measure, a general dissatisfaction was expressed that, at the time when we were struggling with this oppressive Act imposing a duty on tea, and an agreement not to import tea while subject to duty, our fellow subjects in England should form a measure so directly tending to enforce that Act and again embroil us with our parent State. When it was also considered that the proposed mode of disposing of the tea tended to a monopoly, ever odious in a free country, a universal disapprobation showed itself throughout the city.

The importation of the tea, under the circumstances, was a definite attack upon the member-statehood of the Colonies in the Federal Empire in four different ways: first, it was an execution of a taxing statute passed by the Central Government of Great Britain under a claim 
that, as the Central Government of the British Empire, it had unconditional and unlimited power; second, it was an attempt to collect money from the Colonies to be expended for the maintenance of their Local Governments; third, it was an attempt to establish a monopoly of supplying tea to the Colonies in favor of an English corporation; and fourth, it was an attempt to subject the people of the Colonies to indefinite sumptuary regulations, enforced through spies and informers.

The Act for closing the port of Boston and for depriving the Province of Massachusetts Bay of its House of Representatives and elected Council, passed in the early part of 1774 , and the other acts and measures for the coercion of the Colonies, were war measures, and are hence of little consequence from a constitutional aspect, except so far as they showed a determination, on the part of the British Government, to enforce its policy of depriving the Colonies of their member-statehood in the Federal Empire, and to convert them into mere integral and unrepresented parts of a Unitary State.

The Act of 1774, by which the Province of Quebec,which, under the Proclamation of 1763 , included only what is now the continental part of the Dominion of Canada,-was enlarged so as to include the whole of what was afterwards known as the Northwest Territory, and was given a government by a royal Governor and Council, and by which the Roman Catholic religion was placed under governmental protection, was regarded in the Colonies as a direct attack upon their member-statehood in so far as it deprived them of the benefit of free expansion into the Western region and the control of it for the purposes of their own development, and as an indirect. attack, in so far as it almost surrounded them with a Government directly dependent on the British Government, in which the people had no representation whatever.

Thus, in the spring of 1774 , it was no longer open to 


\section{The Administration of Dependencies}

doubt but that the British Ministry would convert the British Empire into a British Realm unless the Colonies could prevent it. Under these circumstances, the Congress at Philadelphia, to devise measures for concerted action, became a political necessity. 


\section{CHAPTER XV}

\section{THE FEDERAL EMPIRE"DEFINED, I774}

D

URING the quiescent period from I770 to I774, the most noteworthy contribution to the thought on the subject of the constitutional relationship between Great Britain and the Colonies was a pamphlet written by James Wilson of Philadelphia (who afterwards became an Associate Justice of the Supreme Court of the United States at its first formation), entitled Considerations on the Nature and Extent of the Legislative Authority of the British Parliament.

In this pamphlet, written when Wilson was twentyeight years of age and a student in the office of John Dickinson, he took the ground that the King was the sole representative of the State of Great Britain, for the administration of its relations with the Colonies, thus denying any power whatever to Parliament in this respect. After arguing that the liberties of the people of America could not, in the nature of things, be derived from the will of the people of England, but were natural rights, and that they could not be derived from the adjudication of the people of England, because they were interested parties and an incompetent and partial tribunal, he concluded, after an examination of the cases and of the methods of administration of the Colonies theretofore practiced, that the dependence of the Colonies was wholly upon the King, and that, in the performance of his functions, the King had legislative powers within a definite sphere. These legislative powers Wilson derived from 


\section{The Administration of Dependencies}

the principle of allegiance. As it is now apparent that the whole doctrine of allegiance has nothing to do with the question of constitutional relationship between political communities in the time of peace, and has its sole significance only as bearing on the relations between the State and its inhabitants arising out of war, present or prospective, it is unnecessary to consider what he said on this subject. The closing words of the essay, on the subject of the relationship of the King to the Colonies, were as follows:

Now we have explained the dependence of the Americans. They are the subjects of the King of Great Britain. They owe him allegiance. They have a right to the benefits which arise from preserving that allegiance inviolate. They are liable to the punishments which await those who break it. This is a dependence, which they have always boasted of. The principles of loyalty are deeply rooted in their hearts; and there they will grow and bring forth fruit, while a drop of vital blood remains to nourish them. Their history is not stained with rebellious and treasonable machinations; an inviolable attachment to their Sovereign, and the warmest zeal for his glory, shine in every page.

From this dependence, abstracted from every other source, arises a strict connection between the inhabitants of Great Britain and those of America. They are fellow-subjects; they are under allegiance to the same Prince; and this union of allegiance naturally produces a union of hearts. It is also productive of a union of measures through the whole British dominions. To the King is intrusted the direction and management of the great machine of government. He therefore is fittest to adjust the different wheels, and to regulate their motions in such a manner as to co-operate in the same general designs. He makes war: he concludes peace: he forms alliances: he regulates domestic trade by his prerogative, and directs foreign commerce by his treaties with those nations, with whom it is carried on. He names the officers of government; 


\section{The Federal Empire Defined, I774 263}

so that he can check every jarring movement in the administration. He has a negative on the different Legislatures throughout his dominions, so that he can prevent any repugnancy in their different laws.

The connection and harmony between Great Britain and us, which it is her interest and ours mutually to cultivate, and on which her prosperity, as well as ours, so materially depends, will be better preserved by the operation of the legal prerogatives of the Crown, than by the exertion of an unlimited authority by Parliament.

To Wilson's essay there was appended, in the printed pamphlets, the following note, which, though not signed, was evidently written by Dickinson, since, in his next published pamphlet, to which reference will hereafter be made, Dickinson showed a decided tendency toward Wilson's view in the modified form suggested by this note, and since Wilson's essay was published almost contemporaneously with Dickinson's pamphlet in which these views were expressed:

After considering, with all the attention of which I am capable, the foregoing opinion-that all the different members of the British Empire are distinct States, independent of each other, but connected together under the same Sovereign in right of the same Crown-I discover only one objection that can be offered against it. But this objection will, by many, be deemed a fatal one. "How," it will be urged, "can the trade of the British Empire be carried on, without some power, extending over the whole, to regulate it? The legislative authority of each part, according to your doctrine, is confined within the local bounds of that part: how, then, can so many interfering interests and claims, as must necessarily meet and contend in the commerce of the whole, be decided and adjusted?"

Dickinson's criticism, it will be perceived, amounted to his asking the question: Granted that the functions of 


\section{The Administration of Dependencies}

Great Britain, as the Imperial State, toward the Colonies, are such as can be performed properly only by the expert branch of the British Government, how can these functions be performed except through the medium of legislation, and how can the King legislate?

To this Wilson replied in a note which, in the pamphlets, was printed immediately below Dickinson's. This note was as follows:

Permit me to answer these questions by proposing some others in my turn. How has the trade of Europe-how has the trade of the whole globe, been carried on? Have those widely extended plans been formed by one superintending power? Have they been carried into execution by one superintending power? Have they been formed-have they been carried into execution, with less conformity to the rules of justice and equality, than if they had been under the direction of one superintending power?

It has been the opinion of some politicians, of no inferior note, that all regulations of trade are useless; that the greatest part of them are hurtful; and that the stream of commerce never flows with so much beauty and advantage, as when it is not diverted from its natural channels. Whether this opinion is well founded or not, let others determine. Thus much may certainly be said, that commerce is not so properly the object of laws, as of treaties and compacts. In this manner, it has been always directed among the several nations of Europe.

But if the commerce of the British Empire must be regulated by a general superintending power, capable of exerting its influence over every part of it, why may not this power be intrusted to the King, as a part of the royal prerogative? By making treaties, which it is his prerogative to make, he directs the trade of Great Britain with the other States of Europe : and his treaties with those States have, when considered with regard to his subjects, all the binding force of laws upon them. (r. Bl. Com. 252.) Where is the absurdity in supposing him vested with the same right to regulate the commerce of the distinct parts of his dominions with one another, which he has 


\section{The Federal Empire Defined, I $774 \quad 265$}

to regulate their commerce with foreign States? If the history of the British Constitution, relating to this subject, be carefully traced, I apprehend we shall discover, that a prerogative in the Crown, to regulate trade, is perfectly consistent with the principles of law. We find many authorities that the King cannot lay impositions on traffic; and that he cannot restrain it altogether, nor confine it to monopolists; but none of the authorities, that I have had an opportunity of consulting, go any farther. Indeed many of them seem to imply a power in the Crown to regulate trade, where that power is exerted for the great end of all prerogative-the public good.

If the power of regulating trade be, as I am apt to believe it to be, vested, by the principles of the Constitution, in the Crown, this good effect will flow from the doctrine; a perpetual distinction will be kept up between that power, and a power of laying impositions on trade. The prerogative will extend to the former; it can, under no pretence, extend to the latter: as it is given, so it is limited, by the law.

Dickinson's criticism thus forced Wilson finally to take the position that the King of Great Britain had, and of right ought to have, under a proper constitution of the British Federal Empire, the right to legislate to the extent necessary to enable the State of Great Britain to fulfil its functions as the Imperial State. This conclusion was strictly logical, so long as Parliament persisted in its claim that its power in the Empire, as well as in the Realm, was unconditioned and unlimited. As that claim could not be allowed by the Colonies, they necessarily had to find an Imperial Legislature somewhere in the whole political organism composed of Great Britain and the Colonies, which could exercise powers of legislation to the extent necessary to effectuate the dispositions regarding the Colonies made by the King in Council, or to admit that they were seeking independence. Such an Imperial Legislature Wilson found in the $\mathrm{King}$ in Council. 


\section{The Administration of Dependencies}

Such a doctrine was dangerous, in that it tended to weaken the hold which the people of England had over the King, under the Act of Settlement of 1689, by admitting him to have legislative power otherwise than in subordination to Parliament, and because it tended to lead to the belief that the Colonies stood in that slight and shadowy relation toward Great Britain which is now known as "personal union," which exists when two independent States have the same person as Chief Executive, but are otherwise entirely distinct from one another.

Those to whom Wilson showed his essay, when it was first written, evidently thought it dangerous on these accounts. Wilson stated, in the "Advertisement," printed at the beginning of the pamphlet, that the essay was originally written "during the late non-importation agreement; but that agreement being dissolved before the sheets were ready for the press, it was judged unseasonable to publish them." The non-importation agreement in Philadelphia was dissolved in September, I770. It was evidently considered wiser by Dickinson, Wilson's preceptor, that, just at the time that matters were becoming quiescent, a pamphlet should not be published in America which so greatly aggrandized the King at the expense of Parliament, and which might so easily be misconstrued into a claim of entire legislative independence on the part of the Colonies.

One of the most important pamphlets brought out during the discussion in the year 1774 , which arose on account of the retaliatory acts of the British Government after the destruction of the tea in Boston Harbor, was Governor Bernard's Select Letters on the Trade and Govcrnment of America, from which extracts have already been quoted. From the preface of this pamphlet, it appears that his opinions expressed in 1765 had undergone some modification, and that, in 1774 , he was inclining to the opinion that, if the Americans were admitted to be 


\section{The Federal Empire Defined, I774 267}

heard in Parliament, it ought to be as parties or witnesses summoned in order that Parliament might inform itself of the circumstances before making an adjudication and disposition concerning the rights of the respective Colonies, and not as participants in a legislative or contractual act. Bernard's final conclusion seems to have been that it was the business of Parliament to make " settlements of the Governments of the Colonies," according to which the governmental power should be divided, in distinct spheres, between Great Britain and the Colonies. In this preface he said:

At the time of the passage of the Act of Parliament for raising money in America by a stamp duty, there was no fixed idea of the relation between Great Britain and America; not one of the Governments there had, what not one of them should have been without, a Parliamentary Constitution. And therefore it is not to be wondered at that, when they were called upon to pay money to the order of Parliament, they should answer-" We know not what is the relation between you and us, that authorizes you to raise money from us or our lands."

And, indeed, it may afford cause of wonder that, in the course of one hundred and fifty years, (for so many it is, at least, since Governments were first constituted in America), there never has been a Parliamentary settlement of the American Governments, or any adjustment of the nature of the subjection, and the mode of subordination, that was due to, or expected from the dependent Governments to the Imperial State. Before the Revolution [of 1688 ], this neglect is to be accounted for; the rights of Government were then not well understood in England, and in America they were wholly misconceived. The lands acquired by the English there, and the government of them, were supposed to be the absolute property of the King, and were disposed of accordingly. The Parliament was scarce allowed to have anything to do with them, and interfered very little in their government. 


\section{The Administration of Dependencies}

But at the Revolution [of r688], when the rights of Government were well understood and formally settled; when the power of Parliament was greatly enlarged, and allowed to extend over all the dependencies of the Crown of Great Britain, as well as its own Kingdom; at that time, and ever since, it has been an unfortunate omission of policy that the constitutions of the Govcrnments of America were not settled in Parliament, and the rights of the Imperial State over them acknowledged, with such regulations and limitations as the several natures of them, upon constitutional principles and good policy, should require; that we might not, at this time of day, when the Empire is so greatly enlarged, and is still increasing, be at a loss for principles upon which the connection of its subordinate Governments with the Imperial State may be best preserved, and the union of the whole maintained and continued.

But no care has been taken of this important business; and America has been left to that miserable servitude where law is uncertain and unknown. Instead of a certain constitutional law, adapted to the nature of the Governments established by the dependent or subordinate States, America has been hitherto governed by temporary expedients, which have sometimes been allowed to have the force of laws, and have sometimes been refused it. In this state of things, it was impossible but the time would come when the authority of Great Britain over America would be brought into question.

Bernard had nearly thought out the Federal Empire. The Imperial State, according to him, was, through its Parliament, to "settle" the "constitutions of the American Governments," and to abide by such "settlements." Such " settlements" could not fail to partake of the nature of adjudications. Such Acts of Parliament were not acts of legislation in the ordinary sense; they were acts of disposition or adjudication, and of legislation to effectuate the adjudication.

Edmund Burke, in his speech in opposition to American taxation, delivered in Parliament on April 19, I774, 


\section{The Federal Empire Defined, I774 269}

distinguished between the unconditioned and unlimited power of Parliament within the Realm of Great Britain, and its power as the representative of Great Britain, as the Imperial State, so conditioned and limited as to be only a power of "provident and beneficent superintendence" of the Colonies. In that speech he said:

What is to become of the Declaratory Act asserting the entireness of British legislative authority, if we abandon the practice of taxation?

For my part, I look upon the rights stated in that Act, exactly in the manner in which I viewed them on its very first proposition, and which I have often taken the liberty, with great humility, to lay before you. I look, I say, on the Imperial rights of Great Britain, and the privileges which the colonists ought to enjoy under these rights, to be just the most reconcilable things in the world. The Parliament of Great Britain sits at the head of her extensive Empire in two capacities: one as the Local Legislature of this Island, providing for all things at home, immediately, and by no other instrument than the Executive power. The other, and I think her nobler capacity, is what I call her Imperial character, in which, as from the throne of heaven, she superintends all the several inferior Legislatures and guides and controls them all without annihilating any. . . . It is necessary to coerce the negligent, to restrain the violent, and to aid the weak and deficient, by the overruling plenitude of her power. She is never to intrude into the place of others, whilst they are equal to the common duties of their institution. But in order to enable Parliament to answer all these duties of provident and beneficent superintendence, her powers must be boundless.

Such, Sir, is my idea of the Constitution of the British Empire, as distinguished from the Constitution of Britain.

It has been noticed that Dulany, in I $76_{5}$, first used the word "superintendence" to describe the power of the Imperial State, and that he applied it to the power over the American Colonies exercised by the British Parliament, 


\section{The Administration of Dependencies}

as the representative of Great Britain; and that Wilson, in his note in answer to Dickinson's criticism, had used the expression "superintending power" to describe the power of Great Britain, as the Imperial State, exercised by the King in Council. The distinction between the "superintending power" of Parliament acting as agent for Great Britain as the Imperial State, and the "legislative power" of Parliament acting as the "Local Legislature" of Great Britain, was, therefore, American, not British.

Burke, however, added to the previous thoughts by pointing out that the power of the Imperial State was a conditioned, as distinguished from a limited power, when he said: "In order to enable Parliament to answer all these duties of provident and beneficent superintendence, her powers must be boundless." A power of "provident and beneficent superintendence" is necessarily a power without specific limits predetermined by an external human power, but it is conditioned upon the holder of the power adjudicating the limits of his own powers according to his own opinion of the necessity for his interference in each particular case as it arisês, in order that the whole organism under his superintendence may most perfectly and beneficently perform its functions.

On July 18, I774, the inhabitants of Fairfax County, Virginia, at a meeting presided over by George Washington, as chairman, adopted a series of resolutions, prepared by George Mason, which showed that in Virginia the conception of the British Empire as a federal organism was beginning to manifest itself. In these resolutions it was declared:

That the Colony and Dominion of Virginia cannot be considered as a conquered country; and if it was, that the present inhabitants are the descendants, not of the conquered, but of 


\section{The Federal Empire Defined, I774 27I}

the conquerors. That the same was settled at the national expense of England, but at the private expense of the adventurers, our ancestors, by solemn compact with, and under the auspices and protection of the British Crown; upon which we are in every way as dependent as the people of Great Britain, and in the same manner subject to all his Majesty's just, Jegal and constitutional prerogatives.

As the inhabitants of the American Colonies are not, and from their situation cannot be represented in the British Parliament, that the legislative power here can of right be exercised only by our own Provincial Assemblies or Parliaments, subject to the assent or negative of the British Crown, to be declared within some proper limited time. But as it was thought just and reasonable that the people of Great Britain should reap advantages from these Colonies adequate to the protection they afforded them, the British Parliament have claimed and exercised the power of regulating our trade and commerce, so as to restrain our importing from foreign countries such articles as they could furnish us with, of their own growth and manufacture, or exporting to foreign countries such articles and portions of our produce, as Great Britain stood in need of, for her own consumption or manufactures. Such a power, directed with wisdom and moderation, seems necessary for the general good of that great body politic, of which we are a part; although in some degree repugnant to the principles of the Constitution. Under this idea our ancestors submitted to it; the experience of more than a century, during the government of his Majesty's royal predecessors, has proved its utility, and the reciprocal benefits flowing from it produced mutual uninterrupted harmony and good will, between the inhabitants of Great Britain and her Colonies, who, during that long period, always considered themselves as one and the same people; and though such a power is capable of abuse, and in some instances has been stretched beyond the original design and institution, yet to avoid strife and contention with our fellow-subjects, and strongly impressed with the experience of mutual benefits, we always cheerfully acquiesced in it, 


\section{The Administration of Dependencies}

while the entire regulation of our internal policy, and giving and granting our own money, were preserved to our own Provincial Legislatures.

That it is the duty of these Colonies, on all emergencies, to contribute, in proportion to their abilities, situation, and circumstances, to the necessary charge of supporting and defending the Bricish Empire, of which they are a part.

Washington, in giving his assent and approbation to resolutions which, while not going deeply into the details of the exercise of the power of Imperial State, went to the very bottom of the first and vital question, What was the character and extent of the power?-showed his characteristic wisdom and good sense. No one was more ardently devoted than he to the connection with Great Britain. With him, as with the vast body of thinking people of America, the sole question was, What kind and degree of power oughc Great Britain, as the Imperial State of the British Empire, to exercise over the Colonies under a just Constitution of the Empire? His answer was: "A power directed with wisdom and moderation, such as is necessary for the general good of that great body politic of which we are a part," - that is, a power exercised expertly and only to the extent necessary in each particular case. Such a power is exactly that which an Imperial State exercises in a Federal Empire.

The most important contribution, however, which was made by any one during the whole discussion preceding the Revolution, concerning the constitutional relationship between Great Britain and the Colonies, was that made by Dickinson, in July, I774, in his pamphlet entitled, A New Essay on the Constitutional Power of Great Britain over the Colonies in America.

The New Essay was originally intended to be a part of the Instructions which the Pennsylvania Legislature were 


\section{The Federal Empire Defined, I774 273}

to give to the delegates to the Continental Congress. The Instructions were recommended by the Committee of Safety of Pennsylvania, on the report of a subcommittee of which Dickinson was chairman. It was thought best by the Committee of Safety that the "Essay" should be separated from the Instructions, but they ordered it published and voted Dickinson their thanks for his labors. Wilson was a member of the Committee of Safety and united in this action.

In the Instructions it was said:

We acknowledge the prerogatives of the Sovereign, among which are included the great powers of making peace and war, treaties, leagues and alliances binding us-of appointing all officers, except in cases where other provision is made by grants from the Crown, or laws approved by the Crown-of confirming or annulling every act of our Assembly within the allowed time-and of hearing and determining finally, in Council, appeals from our courts of justice. "The prerogatives are limited," as a learned judge observes, - " by bounds so certain and notorious, that it is impossible to exceed them, without the consent of the people on the one hand, or without, on the other, a violation of that original contract, which, in all States impliedly, and in ours most expressly, subsists between the Prince and the subject. For these prerogatives are vested in the Crown for the support of society, and do not intrench any farther on our natural liberties, than is expedient for the maintenance of our civil."

Elaborating this thought in the New Essay, and treating the powers of the Crown as the powers of the State of Great Britain, Dickinson said:

The Colonies have no other head than the King of England. The person who by the laws of that Realm is King of that Realm, is our King.

When it is considered that the King, as King of England, 


\section{The Administration of Dependencies}

has a power in making laws-the power of executing themof finally determining on appeals-of calling upon us for supplies in times of war, or any emergency-that every branch of the prerogative binds us, as the subjects are bound thereby in England - and that all our intercourse with foreigners is regulated by Parliament, - colonists may "surely" be acknowledged to speak with truth, and precision, in answer to the " elegantly" expressed question-" what King it is," \&c., by saying that "his most gracious Majesty, George the Third," is the King of England, and therefore, "the King," they profess themselves to be "loyal subjects of."

We are aware of the objection, that, "if the King of England is therefore King of the Colonies, they are subject to the general legislative authority of that Kingdom." The premises by no means warrant this conclusion. It is built on a mere supposition, that the Colonies are thereby acknowledged to be within the Realm, and on an incantation expected to be wrought by some magic force in those words.

To be subordinately connected with England, the Colonies have contracted. To be subject to the general legislative authority of that Kingdom, they never contracted. Such a power as may be necessary to preserve this connection she has.

The authority of the Sovereign, and the authority of controlling our intercourse with foreign nations, form that power. Such a power leaves the Colonies free. But a general legislative power, is not a power to preserve that connection, but to distress and enslave them. If the first power cannot subsist, without the last, she has no right even to the first, - the Colonies were deceived in their contract-and the power must be unjust and illegal; for God has given to them a better right to preserve their liberty, than to her to destroy it. In other words, supposing, King, Lords and Commons acting in Parliament, constitute a Sovereignty over the Colonies, is that Sovereignty constitutionally absolute or limited That States without freedom, should by principle grow out of a free State, is as impossible, as that sparrows should be produced from the eggs of an eagle. The Sovereignty over the Colonies, must be 


\section{The Federal Empire Defined, I774 275}

limited. . . To argue on this subject from other instances of Parliamentary power, is shifting the ground.

The connection of the Colonies with England is a point of an unprecedented and delicate nature. It can be compared to no other case; and to receive a just determination, it must be considered with reference to its own peculiar circumstances. The common law extends to colonies; yet Mr. Justice Blackstone says: "Such parts of the law as are neither necessary or convenient for them, as the jurisdiction of the spiritual courts, etc., are therefore not in force." If even the common law in force within the Realm of England when the colonists quitted it, is thus abridged by the peculiar circumstances of colonies, at least equally just and constitutional is it, that the power of making new laws within the Realm of England should be abridged with respect to colonies, by those peculiar circumstances.

As to the power of regulating our trade, our opinion is, that it is legally vested in Parliament, not as a Supreme Legislature over these Colonies, but as the Supreme Legislature and full representative of the parent State and the only judge between her and her children in commercial interests, which the nature: of the case, in the progress of their growth, admitted. It has been urged, with great vehemence against us, and seems to be thought their fort by our adversaries, "that a power of regulation is a power of legislation, and a power of legislation, if constitutional, must be universal and supreme in the utmost sense of the words." It is therefore concluded, that the colonists, by acknowledging the power of regulation, have acknowledged every other power. On this objection we observe, that according to a maxim of law, "it is deceitful and dangerous to deal in general propositions."

It seems from many authorities, as if almost the whole power of regulating the trade of England was originally vested in the Crown. One restriction appears to have been, that no duty could be imposed without the consent of Parliament. Trade was little regarded by our warlike ancestors. As commerce became of more importance, and duties and severities were judged necessary additions to its first simple state, Parliament 


\section{The Administration of Dependencies}

more and more interfered. The Constitution was always free, but not always exactly in the same manner. By the feudal law, all navigable rivers and havens were computed among the regalia, and were subject to the Sovereign of the State. And in England it has always been held, that the King is lord of the whole shore, and particularly is guardian of the ports and havens, which are the inlets and gates of the Realm; and therefore, so early as the reign of King John, we find ships seized by the King's officers, for putting in at a place that was not a legal port. These legal ports were undoubtedly at first assigned by the Crown; since to each of them a court of portmote is incident, the jurisdiction of which must flow from the royal authority. The erection of beacons, lighthouses, and sea-marks is also a branch of the royal prerogative. The powers of establishing public marts, regulating of weights and measures, and the giving authority to, or making current, money, the medium of commerce, belong to the Crown. By making peace or war, leagues and treaties, the King may open or stop trade as he pleases. The admiralty courts are grounded on the necessity of supporting a jurisdiction so extensive, though opposite to the usual doctrines of the common law. The laws of Oleron were made by Richard the First, and are still used in those courts. In the "Mare Clausum" are several regulations made by Kings. Time forbids a more exact inquiry into this point: but such it is apprehended, will on inquiry be found to have been the power of the Crown, that our argument may gain, but cannot lose. We will proceed on a concession that the power of regulating trade is vested in Parliament.

A power of regulating our trade involves not in it the idea of a Supreme Legislature over us. The first is a power of a preserving, "protecting" nature. The last, as applied to America, is such a power as Mr. Justice Blackstone describes in these words, "whose enormous weight spreads horror and destruction on all inferior movements."

The power of regulation was the only band that could have held us together; formed on one of those "original contracts," - which only can be a foundation of just authority. Without 


\section{The Federal Empire Defined, I774 277}

such a band, our general commerce with foreign nations might have been injurious and destructive to her. Reason and duty reject such a license. Thus our duty resembles that of children to a parent. The parent has a power over them: but they have rights, which the parent cannot take away.

It seems as if the power of regulation might not inaptly be compared to the prerogative of making peace, war, treaties, or alliances, whereby "the whole nation are bound, against their consent": and yet the prerogative by no means implies a Supreme Legislature. The language held in " the Commentaries" on this point is very remarkable: "With regard to foreign concerns, the King is the delegate or representative of the people; and in him, as in a center, all the rays of his people are united; and the sovereign power quoad hoc is vested in his person." Will any Englishman say these expressions are descriptive of the King's authority within the Realm? Is the sovereign power within that vested in his person? He is styled Sovereign indeed. "His Realm is declared by many Acts of Parliament an Empire, and his crown Imperial." But do these splendid appellations, the highest known in Europe, signify that sovereign power is vested in his person within the Realm? We have a full answer in the Commentaries. "The meaning of the Legislature, when it uses these terms 'Empire' and 'Imperial,' and applies them to the Realm and Crown of England, is only to assert, that our King is equally sovereign and independent within these his dominions; and owes no kind of subjection to any potentate upon earth."

Thus we maintain that with regard to foreign affairs, the parent original State is the delegate or representative of the entire dominions: the sovereign power quoad hoc is vested in her. Her acts under this power irrevocably bind the whole nation. But yet this power by no means implies a Supreme Legislature.

The exercise of this power by statutes was absolutely necessary: because it was, and could only be lodged, as the laws of the parent State stand, in the Supreme Legislature of that State, consisting of King, Lords, and Commons; and statutes are the modes by which these united sentiments and resolutions are expressed. 


\section{${ }_{278}$ The Administration of Dependencies}

The power of the Imperial State, therefore, according to Dickinson's final opinion, was:

A power of enforcing the observance of " the common law" in the Colonies, "abridged by the peculiar circumstances" of the Colonies;

A power exercised by the Imperial State as "the only judge" between itself and its dependencies "which the nature of the case admitted";

A power, therefore, which, if exercised at all by Parliament, consisting of King, Lords, and Commons, was exercised only in substitution for the King, so that Parliament could not exceed the power exercised by the King by virtue of his "prerogative"-that is, by virtue of his constitutional right. As the reason why the British Constitution vested in the Crown the powers enumerated by Dickinson was, plainly, so that they might be exercised expertly, and not submitted to the decision of a large non-expert body, the proposition that the powers of Parliament over the dependencies were measured by the powers of the Crown, was essentially a proposition that the dependencies were entitled to a central expert government and administration;

A power exercised by the whole Central Government of the Imperial State, and ultimately by statutes enacted by Parliament-the Imperial State being "the delegate or representative of the entire dominions," and "the exercise of this power by statutes" being "absolutely necessary";

A power " such as may be necessary to preserve the connection" between the Imperial State and its dependencies;

A power, therefore, by which the State of Great Britain was, under some circumstances, authorized to bind the individual inhabitants of the Colonies without their individual consent expressed by natural persons elected by them as their representatives, because the Colonies, as political 


\section{The Federal Empire Defined, I774 279}

persons, were so related to the State of Great Britain, that that State, as a political person, was their delegate and representative for managing the common concerns of the great political organism composed of the State of Great Britain and the Colonies, constituting the British Empire, under a condition that the power should be exercised through some expert instrumentality, and that in extent and sphere it should be limited by the necessity growing out of the common interests of the whole organism.

By the statement of Dickinson's that Great Britain was "the delegate or representative of the entire dominions," in whom "the sovereign power" for the purposes of the agency was "vested," - whose "acts under this power irrevocably bind the whole nation,"--whose power was, nevertheless, a power to "judge" between itself and the Colonies in those matters in respect to which its interests necessarily conflicted with those of the Colonies, because it was "the only judge which the nature of the case admitted," the Federal Empire may be said to have emerged. The instant it was declared that Great Britain, as a State, was "the delegate or representative" of the Colonies, the Colonies were declared to be Member-States of the British Federal Empire. 


\section{CHAPTER XVI}

\section{AMERICA'S ULTIMATUM, I774}

$\mathrm{W}^{\mathrm{H}}$

HEN the Congress met at Philadelphia for its first session, on September 4, I774, the sentiment of the delegates was unanimous that the Colonies were States, and that they were in a relationship of voluntary union with the State of Great Britain under an unwritten Treaty or Compact of Union. Concerning the character of the Union, however, there was a decided difference of opinion. Dickinson refused to become a delegate until it should appear what position the Congress would take; but, residing, as he did, in Phila. delphia, his great reputation doubtless gave him as much influence as if he had been a delegate. John Adams and Dickinson represented the extremes of sentiment.

Adams regarded the Union as a Union on terms of equality, and the Compact of Union as a mere Treaty of Alliance and Commerce between equal and independent States. A clear expression of his views on this subject is found in the pamphlet entitled Novanglus and Massachusettensis, which was a reprint of letters printed in newspapers, during the latter part of I774 and the early part of 1775, written by Adams, under the name of Novanglus, and by William Leonard, under the name of Massachusettensis. In a letter of March 6, 1775, Adams said :

Distinct States may be united under one King. And those States may be further cemented and united together by a treaty of commerce. This is the case. We have, by our own 
express consent, contracted to observe the Navigation Act: and by our implied consent, by long usage and uninterrupted acquiescence, have submitted to the other Acts of Trade, however grievous some of them may be. This may be compared to a treaty of commerce, by which these distinct States are cemented together in perpetual league and amity. And if any further ratifications of this pact or treaty are necessary, the Colonies would readily enter into them, provided their other liberties were inviolate.

In this view, Acts of Parliament were merely propositions to change the terms of the Treaty or Compact of Alliance and Commerce, which were of no effect until assented to by the Houses of Representatives of the respective Colonies, representing the people of the Colonies, when they became amendments to the Treaty or Compact. Such a Union was merely temporary and inorganic. The King was the Chief Executive of a number of separate States, exercising inconsistent functions in his various official capacities. The Union was through the $\mathrm{King}$ as a natural person, not through the $\mathrm{King}$ in his official capacity. One man was simply exercising the functions which would usually be committed to several men on account of the inconsistency between the functions so exercised. In this view, any State of the Union had the right, in case of dissatisfaction, to withdraw from the partnership or voluntary association (or, to express it technically in the language of the public law, to secede from the Union), and there was no British Empire. The advocates of this view were anti-Imperialists.

Dickinson, on the other hand, starting with the same proposition that the Colonies were originally States (and hence originally independent and equal with the State of Great Britain), contended that, simultaneously with the origin of the Colonies as States, the people of the Colonies had entered into a compact with the people of Great Britain, evidenced by the Charters authenticated by the 


\section{The Administration of Dependencies}

signature of the King, that the Colonies, though States, should be and remain in a permanent and organic Union of subordination to the State of Great Britain on terms just to both parties. In this view, this whole original Treaty or Compact of Union had the effect to form the people of Great Britain and the people of the Colonies into a single political organism or State, composed of Great Britain, as the Imperial State, and of the Colonies, as subordinate Member-States, and called the British Federal Empire. The Treaty or Compact was the supreme law, or, in other words, the Constitution of the Empire,- supreme over every governmental action of the States of the Empire, whether legislative or executive, and hence supreme over Acts of Parliament. In this view, no State of the Empire had any right to secede from the Empire. A change from member-statehood to independent statehood could result only from a dissolution and dismemberment of the State known as the British Federal Empire. The advocates of this theory were Federal-Imperialists.

Jefferson and Hamilton, neither of whom were members of the Continental Congress at its first session, expressed views in pamphlets which placed the former in the antiImperialist and the latter in the Federal-Imperialist party, though neither took an extreme view. Jefferson, in his Summary View of the Rights of British America, while taking generally the anti-Imperialist view, regarded the King as "the only mediatory power between the States of the British Empire."

On September 24, it was voted "that the Congress do confine themselves, at present, to the consideration of such rights as have been infringed by Acts of the British Parliament since the year 1763 ." This was a declaration that it was the purpose of Congress to demand only a restoration of the Constitution of the British Federal Empire as it existed at the close of the war in 1763 . 
Having thus narrowed the issue, the Congress proceeded to narrow it still further by determining the specific Acts of Parliament, the repeal of which they regarded as absolutely necessary to a settlement between the Colonies and Great Britain. The vote on this subject, which was, under the circumstances, a vote concerning the ultimatum which was to be addressed by the Colonies to Great Britain, was taken on October 5, on that day, Congress passed the following resolution:

Resolved: That the Committee appointed to prepare an Address to his Majesty be instructed to assure his Majesty that, in case the Colonies shall be restored to the state they were in at the close of the late war, by abolishing the system of laws and regulations for raising a revenue in America, for extending the powers of Courts of Admiralty, for the trial of persons beyond sea for crimes committed in America, for affecting the Colony of Massachusetts Bay, and for altering the government and extending the limits of Canada, the jealousies which have been occasioned by such acts and regulations of Parliament would be removed and commerce again restored.

In the Declaration of Rights and Grievances of October $\mathrm{I} 4$, the terms of this ultimatum were followed, with the addition of a demand for a discontinuance of the annual statutes which Parliament had been in the habit of enacting, providing for the quartering of troops in America at the expense of the Colonies.

The declaration concerning the constitutional relationship between Great Britain and the Colonies was contained in the fourth, fifth, sixth, seventh, ninth, and tenth resolutions, which were as follows:

4. That the foundation of English liberty and of all free government is a right in the people to participate in their legislative council: and as the English colonists are not 


\section{The Administration of Dependencies}

represented, and from their local and other circumstances cannot properly be represented in the British Parliament, they are entitled to a free and exclusive power of legislation in their several Provincial Legislatures, where their right of representation can alone be preserved, in all cases of taxation and internal polity, subject only to the negative of their Sovereign, in such manner as has been heretofore used and accustomed: But from the necessity of the case, and a regard to the mutual interests of both countries, we cheerfully consent to the operation of such Acts of the British Parliament, as are bona fide restrained to the regulation of our external commerce, for the purpose of securing the commercial advantages of the whole Empire to the Mother Country, and the commercial benefits of its respective members; excluding every idea of taxation, internal or external, for raising a revenue on the subjects in America without their consent.

5. That the respective Colonies are entitled to the common law of England, and more especially to the great and inestimable privilege of being tried by their peers of the vicinage, according to the course of that law.

6. That they are entitled to the benefit of such of the English statutes as existed at the time of their colonization; and which they have, by experience, respectively found to be applicable to their several local and other circumstances.

7. That these, his Majesty's Colonies, are likewise entitled to all the immunities and privileges granted and confirmed to them by royal charters, or secured by their several codes of Provincial laws.

9. That the keeping a standing army in these Colonies in times of peace, without the consent of the Legislature of that Colony in which such army is kept, is against law.

Io. That it is indispensably necessary to good government, and rendered essential by the English Constitution, that the constituent branches of the Legislature be independent of each other; that, therefore, the exercise of legislative power in several Colonies by a Council appointed, during pleasure, by the Crown, is unconstitutional, dangerous and destructive to the freedom of American legislation. 


\section{America's Ultimatum, I 774}

Of these resolutions, the fourth and sixth were passed by less than a unanimous vote, though the record does not show the exact character of the vote.

The declaration concerning the rights of the individual inhabitants of the Colonies against the British Imperial Government were contained in the first, second, third, and eighth resolutions, all of which were adopted by a unanimous vote, and which were as follows:

I. That they are entitled to life, liberty and property: and they have never ceded to any foreign power whatever, a right to dispose of either without their consent.

2. That our ancestors, who first settled these Colonies, were at the time of their emigration from the Mother Country, entitled to all the rights, liberties and immunities of free and natural-born subjects within the Realm of England.

3. That by such emigration they by no means forfeited, surrendered or lost any of those rights, but that they were and their descendants now are entitled to the exercise and enjoyment of all such of them, as their local and other circumstances enable them to exercise and enjoy.

8. That they have a right to peaceably assemble, consider of their grievances, and petition the King; and that all prosecutions, prohibitory proclamations, and commitments for the same, are illegal.

It was declared by the Congress, in a subsequent part of the Declaration of Rights, that these rights of the Colonies and their inhabitants existed "by the immutable laws of nature, the principles of the English Constitution, and the several charters or contracts."

It is noticeable that in this Declaration, the principal ground on which the claims of the Colonies were based was "the laws of nature." While "the principles of the English Constitution" and "the several charters or contracts" were relied upon, the reliance was upon them only 


\section{The Administration of Dependencies}

so far as they were not inconsistent with the principles of justice and good government.

The first resolution, by necessary implication, contained a claim that the Colonies were Member-States of a Federal Empire. Great Britain was described, in that resolution, by necessary implication as a "foreign power" which had some right of disposition over the life, liberty, and property of the inhabitants of the Colonies, but which had not "a right to dispose of either without their consent." This consent, it was intimated, could only be evidenced by some "act of cession" by the inhabitants of the Colonies, or by the Colonies, to Great Britain, as a foreign power. This resolution was, in fact, a declaration. that Great Britain, as the Imperial State of the Federal Empire, had a right to "dispose of " the life, liberty, and property of the inhabitants of the Colonies, to the extent to which they had ceded to it that right.

The language of the fourth resolution, it will be noticed, was wide enough to include both theories of the relationship between Great Britain and the Colonies. The fact that the Colonies " cheerfully consented " to the operation of certain Acts of Parliament was not necessarily inconsistent with the proposition that Parliament had a constitutional right to pass these Acts, though, of course, it was also consistent with the proposition that the power of Parliament rested wholly on the assent and acquiescence of the Colonies. The admission that the consent was given "from the necessity of the case and a regard to the mutual interests of both countries" was very nearly an admission that Parliament had a constitutional right. A " consent" founded on " the necessity of the case" is the basis of all constitutional right of all governors over the governed. It can well be seen that the resolution could not have satisfied either the anti-Imperialists, who believed that the relationship was one of temporary inorganic alliance, or the Federal-Imperialists, who believed 
that the relationship was one of such constitutional dependency on the State of Great Britain that it might exercise powers over the Colonies, on certain conditions and with certain limitations, through its whole Government or any designated instrumentality of government adapted for the purpose. The resolution was evidently the result of a compromise, and the lack of unanimity was evidently caused by the holding out of some of the extremists.

The fifth and sixth resolutions are interesting as showing that, had there been no question concerning the power of Parliament to make statutes to bind the Colonies, there would never have been any doubt but that those parts of the common law, statutes, and charters of Great Britain which establish great general principles of government, and form what is called "The British Constitution," were in force in the Colonies in so far as the Colonies had "by experience, respectively found them to be applicable to their several local and other circumstances."

Dickinson evidently regarded the resolutions as showing a clear intention, on the part of Congress, to seek only the restoration of the Colonies to their constitutional relationship of dependency on Great Britain, for, on the next day after the adoption of the Declaration (Saturday, October 15), he was elected a delegate to the Congress by the Pennsylvania Legislature, and on Monday, October 17 , took his seat in the Congress.

The Declaration of Rights and Grievances made by the Congress of 1774 was, in fact, a Declaration of Dependence, in answer to the British Declaration of Dependence of 1766 . Great Britain had declared that, as the Imperial State, it had, under the Constitution of the British Empire, a right to pass laws to bind the dependencies in all cases whatsoever. America had declared that under the Constitution of the British Empire, Great Britain, 


\section{The Administration of Dependencies}

as the Imperial State, had the right to pass laws to bind the dependencies in all cases where " a proper regard to the mutual interests" made it " necessary" that supreme legislation should be enacted, and that it exercised this right, as a "foreign power," because the Colonies had "ceded" to it the right.

In the Address to the People of Great Britain, adopted by the Congress on October 2I, it was made perfectly clear that all that the Colonies demanded was a restoration of the situation as it existed at the close of the war in $176_{3}$, - that is, the restoration of the Federal Empire. In that Address they said:

Permit us to be as free as yourselves, and we shall ever esteem a union with you to be our greatest glory and our greatest happiness, we shall ever be ready to contribute all in our power to the welfare of the Empire, we shall consider your enemies as our enemies and your interest as our own.

But if you are determined that your Ministers shall wantonly sport with the rights of mankind, if neither the voice of justice, the dictates of the law, the principles of the Constitution or the suggestions of humanity, can restrain your hands from shedding human blood in such an impious cause, we must then tell you that we will never submit to be hewers of wood or drawers of water for any Ministry or Nation in the world.

Place us in the same situation as we were at the close of the last war and our former harmony will be restored.

In the Address to the King of October 26, which was drafted by Dickinson, Great Britain was described as "that nation in whose parental guidance on all important affairs we have hitherto, with filial reverence, constantly trusted." In this Address, the ultimatum of the Colonies was thus formally worded:

We ask but for peace, liberty and safety. We wish not a diminution of the prerogative, nor do we solicit the grant of 
any new right in our favor. Your royal authority and our connection with Great Britain we shall always carefully and zealously endeavor to support and maintain.

Filled with these sentiments of duty to your Majesty and of affection to our parent State, deeply impressed by our education and strongly confirmed by our reason, and anxious to evince the sincerity of these dispositions, we present this petition only to obtain redress of grievances and relief from fears and jealousies, occasioned by the system of statutes and regulations adopted since the close of the late war for raising a revenue in America, extending the power of Courts of Admiralty and Vice-Admiralty, trying persons in Great Britain for offences alleged to be committed in America, affecting the Province of Massachusetts Bay, and altering the government and extending the limits of Quebec; by the abolition of which system the harmony between Great Britain and these Colonies, so necessary to the happiness of both, and so ardently desired by the latter, and the usual intercourses, will be immediately restored. In the magnanimity and justice of your Majesty in Parliament we confide for a redress of our other grievances, trusting that when the causes of our apprehensions are removed, our future conduct will prove us not unworthy of the regard we have been accustomed, in our happier days, to enjoy.

The American ultimatum was, therefore, essentially a demand for the restoration of the Constitution of the British Federal Empire, as it existed at the close of the war of 1763 . The only Acts of Parliament the repeal of which was declared to be an absolute prerequisite had been passed since 1763 , and each of them violated, in some clear and unmistakable way, the Constitution of the Empire as it then existed. Those Acts concerning which there was the least doubt were left open for amicable adjustment, after the general principles of the relationship should have been fixed by a formal restoration of that Constitution. 


\section{The Administration of Dependencies}

The form which the Congress gave to the instruments by which this ultimatum was declared was exactly consistent with the theory which the Federal-Imperialist majority held concerning the political relationship between the Colonies and Great Britain.

In order to appreciate the meaning of these instruments, it is necessary to consider the form which the action of Congress would inevitably have taken under the two theories concerning the relationship.

If the Colonies were States in a temporary inorganic Union with the State of Great Britain, as the anti-Imperialist party in America contended, so that Acts of Parliament had no effect as legislation in the Colonies and were merely propositions of the State of Great Britain to change the terms of the Treaty or Compact of Union, the ultimatum of the Colonies, in case the State of Great Britain insisted, by Acts of Parliament or otherwise, on changing the terms of the Treaty or Compact of Union against the wish of the Colonies, would have been delivered in an Address by the people of the Colonies assembled to the people of the State of Great Britain. The $\mathrm{King}$, in such a case, would have been disqualified, by conflict of interest, from acting as the Chief Executive of either the State of Great Britain or the Colonies, and could have acted only as a friendly third person, or mediator. He would have had no "authority" over the opposing parties, but only an "influence" with them. In such an ultimatum, the Colonies would have notified the State of Great Britain that, if its terms were not complied with, they would secede from the Union.

If the Colonies were States in permanent organic Union with the State of Great Britain, as the Federal-Imperialist party in America contended, so that they all together constituted a single political organism, that is, a State, called a Federal Empire, under a permanent unwritten Constitution conceived of as emanating from all 
the people of the Empire assembled, which was supreme throughout the whole organism, the ultimatum of any Member-State in the Empire, against the Imperial State or against another Member-State, for committing any governmental act inconsistent with the Constitution of the Empire, would have been addressed to the person or body of persons in the Empire whose function it was to interpret and adjudicate the terms of the unwritten Constitution of the Empire, and to cause the Constitution, as so interpreted and adjudicated, to be executed throughout the Empire. If this person were the King, the ultimatum of the Colonies would have been delivered to him, if it were the House of Lords, to that body, if it were the House of Commons, to that body, if it were the whole Parliament, consisting of King, Lords, and Commons assembled, to that body. The person or body of persons so addressed would have been petitioned to exercise his or their "power" or "authority" to adjudicate and declare the Constitution of the Empire, to enjoin and prevent the execution of all acts inconsistent with the Constitution, and to execute the Constitution by affirmative acts. Such an ultimatum would virtually have been a suit in court, and it would not have been necessary for the complaining party to state what it would do if its complaint were fairly adjudicated against it, since it would have gone without saying that it would submit to such an adjudication. If the officer or tribunal designated as the proper official to adjudicate and execute the Constitution refused to act as such and was supported in its refusal by the opposing party, the Empire would be ipso facto dissolved.

The Address to the King was plainly based on this last: theory. He was not asked to use his influence as a friendly third person, by way of mediation, but he was asked to exercise power and authority to adjudicate, declare, and execute the unwritten Constitution of the: Federal Empire, as the sole official of the Empire upon 


\section{The Administration of Dependencies}

whom that function rested. As the power of adjudication, accompanied by the power of execution, is exactly the power of disposition, the King was addressed as the Disposer of the affairs of the Empire.

The King was implored "as the loving father of his whole people, connected by the same bonds of law, loyalty, faith and blood, although dwelling in various coun. tries," not to "suffer the transcendent relation formed by these ties to be further violated." $\mathrm{He}$ was petitioned to "redress the grievances" of the Colonies, by using his "royal authority and interposition" for the "relief" of the Colonies against a "system of statutes and regulations" of the British Parliament alleged to be a wrongful action. on the part of Great Britain toward the Colonies. The Colonies declared that they "wished not a diminution of the prerogative," nor "solicited the grant of any new right in their favor," and that "they should always carefully and zealously endeavor to support and maintain the King's "royal authority" over them and their "connection with Great Britain."

An "authority" of the King to "interpose" so as to prevent the execution of the legislation of the State of Great Britain was essentially, the same power as the King's Chancellor exercised in suits between private persons when he enjoined the performance of a threatened act because in violation of a contract for personal services. The State of Great Britain was regarded in the Address to the King as a person which had entered into an un. written contract with the Colonies, as persons, to perform services for them. It was complained of as a party defendant in a judicial action because it was threatening to insist upon performing services for the Colonies which were not included in the contract, which the Colonies did not desire, and which were not for their benefit. The King was prayed to interpret the terms of the contract, and, on its being determined by him that Great Britain 


\section{America's Ultimatum, I $774 \quad 293$}

had violated the terms of the contract, to enjoin the further performance or attempt to perform the services not included in it. This unwritten contract was described in the Address as "the transcendent relation formed by the ties of law, loyalty, faith and blood," which was the supreme law governing the relations of the States of the Empire to each other.

The purpose of the Address to the People of Great Britain was, in part, to urge them to settle the matter out of court and thus avoid the necessity of having the matter go to final judgment, and in part to notify them that, if they persisted in supporting their Parliament in the position that the Empire was not a federal organism and thus making it impossible for the King to adjudicate and execute the unwritten Constitution of the Empire, the Colonies would regard the Empire as dissolved by the act of the people and State of Great Britain. In this Address it was declared that the statutes complained of were violations of the "rights of the whole Empire," - that is, of the unwritten Constitution of the Federal Empire. The people of Great Britain were declared to be addressed as "fellow-subjects" of the same King, - that is, as subject to the adjudication and execution, by the King of Great Britain, as ex officio the Disposer of the affairs of the Empire, of the terms of the Constitution of the Empire. An appeal was made to their "justice and magnanimity" to compel the Parliament to repeal the statutes which were in excess of the constitutional powers of the State of Great Britain, and thus remove the necessity for an adjudication and execution of the Constitution of the Empire by the King.

The ultimatum of America therefore was, in a word, that the British Empire be recognized, by the State of Great Britain, as a Federal Empire. 


\section{CHAPTER XVII}

\section{BRITISH PROPOSITIONS, I775}

$\mathrm{T}^{\mathrm{H}}$

HE decision in the case of Campbell $v$. Hall, rendered November 28, I'774, after four arguments, by the Court of Kings Bench, presided over by Chief Justice Mansfield, recognizing as it did that the King had legislative power over dependencies arising by conquest, and that such power was conditioned and limited so that he could make no laws which were "contrary to fundamental principles, or excepting from the laws of trade or authority of Parliament, or granting privileges [to inhabitants of the Colonies] exclusive of his other subjects," gave a new trend to thought on both sides of the water, and particularly in America. Thenceforward, though the Court in that case had recognized Parliament as the Supreme Legislature of the Empire, there was a distinct and increasing tendency in America to regard the King - that is, the King in Council-as the Supreme Head of the Empire, and to deny to Parliament all power in the Empire.

The exact question involved in that case was; whether the King, after having granted, by Proclamation in Council, to the Island of Grenada, in the West Indiesone of the countries ceded by France to Great Britain by the Treaty of Paris of February 4, I763, upon the close of the war-the right to have an elected House of Representatives as a part of its General Assembly, could, by a subsequent Proclamation in Council, lay a tariff duty on articles imported into the Island. The Court held that 
the King would have had power to levy the tax, had he not granted Grenada the right to have an elective branch of its Legislature, but that by such grant he had precluded himself from levying the tax.

In the argument on behalf of the Crown, Attorney General Thurlow (afterwards Lord Chancellor) said:

My reason for stating that dominion and property were acquired over Grenada by conquest was, because I shall infer that the Constitution has intrusted the King with the disposition of the property, and with the ordering of that dominion conquered; subject to the legislation of the country $[i$.e., of Great Britain].

The King, both in conquests and colonies, has had this right. There has not been an instance in which the King has not exercised the disposition of the laws and property of the conquered country.

Lord Mansfield, delivering the opinion of the Court, said :

If the King has power (and when I say the King, I mean in this case to be understood "without concurrence of Parliament") to make new laws for a conquered country, this being a power subordinate to his own authority as a part of the Supreme Legislature in Parliament, he can make none which are contrary to fundamental principles, none excepting from the laws of trade or authority of Parliament, or [granting] privileges exclusive of his other subjects.

The present proclamation [of July $20, \mathrm{I} 764$, levying the tax] is an act of this subordinate legislative power. If made before the $1 \mathrm{ith}$ of October, I $76_{3}$ [the date of the proclamation granting to Grenada the right to have a Legislative Assembly], it would have been made on the most reasonable and equitable grounds; putting the Island of Grenada on the same footing as the other Islands. . . . The only question which remains then is, whether the King had power, after the 4th of February, ${ }_{17} 6_{3}$, of himself, to impose the duty. 


\section{The Administration of Dependencies}

It is not to be wondered at that an adjudged case in point is not to be found; no dispute ever was started before upon the King's legislative right over a conquest. It never was denied in a court of law or equity in Westminster Hall, never was questioned in Parliament.

Upon full consideration, we are all of opinion that before the 20 th of July, I 764 , the King had precluded himself from an exercise of the legislative authority by virtue of his prerogative, which he had before over the Island of Grenada. . . .

We therefore think that, by the two proclamations [of October II, I $76_{3}$, and March 26, I764, the latter inviting settlers to the Island] and the commission to Governor Melville [of April 29, 1764$]$, the King had immediately and irrevocably granted to all who did or should inhabit, all who had or should have property in the Island of Grenada-in general, to all whom it may concern-that the subordinate legislation over the Island should be exercised by the Assembly and the Governor and Council, in like manner as in the other Provinces under the King.

And, therefore, though the right of the King to have levied taxes on a conquered country, subject to him in right of his Crown, was good, and the duty reasonable, equitable and expedient, and according to the finding of the verdict paid in the Barbadoes and all the other Leeward Islands; yet, by the inadvertency of the King's servants, the order in which the several instruments passed the office (for the patent of the 20 th of July, for raising the impost stated, should have been first), the order is inverted and the last we think contrary to and a violation of the first, and therefore void.

However proper soever the thing may be respecting the object of these letters patent, it can only now be done... . by act of the Assembly of the Island, or by the Parliament of Great Britain.

While the British looked upon this case as supporting the claim of Parliament over the Colonies, the Americans, on the other hand, disregarded this feature of it (which was, in fact, a mere dictum), and laid stress upon the 
point actually decided, namely, that the King-that is, the King in Council-had legislative power over the dependencies of Great Britain, but that his legislative power was conditioned and limited.

As Blackstone, in his Commentaries, had regarded the American Colonies as conquests, the effect of this decision, if his proposition was correct, was to declare that the King had legislative power over the American Colonies. Though the Americans vigorously denied Blackstone's proposition, they seem to have accepted the statement of Attorney General Thurlow, in the argument. of the case, that the power of the King was the same " both in conquests and in colonies."

After that decision, the only question left, as the Americans looked at it, was whether the King or the Parliament was the Supreme Head of the Empire-that is, whether Parliament had no power over the Colonies or whether it had power over them under the same conditions and limitations as the King, in the exercise of which, however, it was supreme over the King.

If the Colonies were true States, the only bond of union between them and the State of Great Britain was logically the King, since the King was the representative of that State in its dealings with foreign States. If the Colonies were municipal corporations, Parliament was the representative of the State of Great Britain in dealing with them, and its powers were the same as it exercised in the Realm. If they were neither true States nor true municipal corporations, the question arose whether they most nearly resembled States or municipal corporations. The Colonies claimed that they so nearly resembled States that the King was the sole representative of the State of Great Britain as respected them. Some persons in the Colonies stopped here, and denied all power to Parliament; others took the position that, while the King was the usual and proper representative of the State of 


\section{The Administration of Dependencies}

Great Britain in its relations with the Colonies, the Parliament was, within the same sphere of action as the King, supreme over him and hence over the Colonial Legislatures.

The difference in view concerning the respective powers of the King and Parliament was really a difference in view concerning the character of the British Empire. If it was a federal organism, the power of both the King and Parliament over the Colonies was the same in character and extent, except that the King was the superior and Parliament the supreme governmental agency of the Empire. If the British Empire was a unitary organism, the power of Parliament was different from the power of the King, equally in the Realm and in the Empire.

Among the persons in Great Britain who, in the early part of 1775 , had grasped the American conception of the British Empire as a federal organism, was Lord Chatham. When, therefore, the Houses of Parliament were, during the last days of January, I775, considering the American Papers laid before them by the Ministry on January 20, and the Ministry was attempting to procure the adoption of an Address to the King, declaring the Colonies in a state of rebellion, Lord Chatham applied himself to the preparation of a Bill which should embody the principles underlying the British Empire as a federal organism, counselling with Franklin concerning the details, and on February I, I775, introduced his Bill in the House of Lords.

The Bill showed, from its titie, that it was based on the theory that the British Empire was a federal organism. It was entitled "A Bill for a Provisional Act for Settling the Troubles in America and for Asserting the Supreme Legislative Authority and Superintending Power of Great Britain over the Colonies." The authority and power over the Colonies, according to this title, was vested in the State of Great Britain, from which it necessarily 
follows that the Colonies were related to the State of Great Britain as States and that the powers of both King and Parliament were measured by the powers which the State of Great Britain had, under the contract or constitution existing between itself and the Colonies as States.

The full text of the Bill was as follows:

Whereas, by an Act, 6 Geo. III., it is declared that Parliament has full power and authority to make laws and statutes to bind the people of the Colonies in all cases whatsoever: And whereas reiterated complaints and most dangerous disorders have grown, touching the right of taxation claimed and exercised over America, to the disturbance of peace and good order there, and to the actual interruption of the due intercourse from Great Britain and Ireland to the Colonies; deeply affecting the navigation, trade and manufactures of this Kingdom, and of Ireland, and announcing farther an interruption of all exports from the said Colonies to Great Britain, Ireland, and the British islands in America: Now, for the prevention of these ruinous mischiefs, and in order to an equitable, honorable, and lasting settlement of claims not sufficiently ascertained and circumscribed; May it please your most excellent Majesty that it may be declared, and be it declared, by the King's most excellent Majesty, by and with the consent of the Lords Spiritual and Temporal, and Commons, in this present Parliament assembled, and by the authority of the same, that the Colonies of America have been, are, and of right ought to be dependent upon the Imperial Crown of Great Britain, and subordinate unto the British Parliament; and that the King's most excellent Majesty, by and with the advice and consent of the Lords Spiritual and Temporal, and Commons, in Parliament assembled, had, hath, and of right ought to have, full power and authority to make laws and statutes of sufficient force and validity to bind the people of the British Colonies in America, in all matters touching the general weal of the whole dominion of the Imperial Crown of Great Britain, and beyond the competency of the Local Representative of a distinct Colony, and most especially an indubitable and in- 


\section{The Administration of Dependencies}

dispensable right to make and ordain laws for regulating navigation and trade throughout the complicated system of British commerce, - the deep policy of such prudent acts upholding the guardian navy of the whole British Empire,-and that all subjects in the Colonies are bound in duty and allegiance duly to recognize and obey (and they are hereby required so to do) the supreme legislative authority and superintending power of the Parliament of Great Britain, as aforesaid.

And whereas, in a petition from America to his Majesty, it has been represented that the keeping a standing army within any of the Colonies, in time of peace, without consent of the respective Provincial Assembly there, is against law: Be it declared by the King's most excellent Majesty, by and with the advice and consent of the Lords Spiritual and Temporal, and Commons, in this present Parliament assembled, that the declaration of right, at the ever-glorious Revolution, namely, " that the raising and keeping a standing army within the Kingdom, in time of pence, unless it be by consent of Parliament, is against law," having reference only to the consent of the Parliament of Great Britain, the legal, constitutional, and hitherto unquestioned prerogative of the Crown to send any part of such army, so lawfully kept, to any part of the British dominions and possessions, whether in America or elsewhere, as his Majesty, in the due care of his subjects, may judge necessary for the security and protection of the same, cannot be rendered dependent upon the consent of a Provincial Assembly in the Colonies, without most dangerous innovation and derogation from the dignity of the Imperial Crown of Great Britain. Nevertheless, in order to quiet and dispel jealousies and fears, be it hereby declared, that no military force, however raised and kept according to law, can ever be employed to violate and destroy the just rights of the people.

Moreover, in order to remove, forever, all causes of pernicious discords, and in due contemplation of the vast increase of possessions and population in the Colonies; and having at heart to render the condition of so great a body of industrious subjects there, more and more happy, by the 


\section{British Propositions, I 775}

sacredness of property, and of personal liberty, and of more extensive and lasting utility to the parent Kingdom, by indissoluble ties of mutual affection, confidence, trade and reciprocal benefits; be it declared and enacted by the King's most excellent Majesty, by and with the advice and consent of the Lords Spiritual and Temporal, and Commons, in this present Parliament assembled, and it is hereby declared and enacted, by the authority of the same, that no tallage, tax or other charge for his Majesty's revenue, shall be commanded or levied from British freemen in America, without common consent, by act of Provincial Assembly there, duly convened for that purpose.

And it is hereby further declared and enacted by the King's most excellent Majesty, by and with the advice and consent of the Lords Spiritual and Temporal, and Commons, in this present Parliament assembled, and by the authority of the same, that it shall and may be lawful for delegates from the respective Provinces, lately assembled at Philadelphia, to meet in general Congress at the said Philadelphia, on the ninth day of May next ensuing, [the day preceding the day on which the Congress was to reassemble, it having adjourned on October 26, I774, to meet again at Philadelphia on May 10 , 1775$]$, in order then and there to take into consideration the making due recognition of the supreme legislative authority and superintending power of Parliament over the Colonies, as aforesaid; and moreover, may it please your most excellent Majesty, that the said delegates to be in Congress assembled in manner aforesaid, may be required, and the same are hereby required, by the King's Majesty sitting in his Parliament, to take into consideration, (over and above the usual charge for support of civil government in the respective Colonies) the making a free grant to the King, his heirs and successors, of a certain perpetual revenue, subject to the disposition of the British Parliament, to be by them appropriated, as they in their wisdom shall judge fit, to the alleviation of the national debt: no doubt being had, but the just, free aid will be in such honorable proportion, as may seem meet and becoming from great and 


\section{The Administration of Dependencies}

flourishing Colonies towards a parent country, laboring under the heaviest burdens, which (in no inconsiderable part) have been willingly taken upon ourselves and posterity, for the defence, extension and prosperity of the Colonies.

And to this great end, be it hereby further declared and enacted, that the general Congress (to meet at Philadelphia aforesaid) shali be, and is hereby authorized and empowered, (the delegates composing the same being first sufficiently furnished with powers from their respective Provinces for this purpose) to adjust and fix the repartitions and quotas of the several charges to be borne by each Province respectively, towards the general contributary supply; and this in such fair and equitable measure as may best suit the abilities and due convenience of all. Provided always, that the powers for fixing the said quotas, hereby given to the delegates from the old Provinces composing the Congress, shall not extend to the new Provinces of East and West Florida, Georgia, Nova Scotia, St. John's, and Canada; the circumstances and abilities of the said Provinces being reserved for the wisdom of Parliament in their due time. And in order to afford necessary time for mature deliberation in America, be it hereby declared that the provisions for ascertaining and fixing the exercise of the right of taxation in the Colonies, as agreed and expressed by this present Act, shall not be in force, or have any operation, until the delegates to be in Congress assembled, sufficiently authorized and empowered by their respective Provinces to this end, shall, as an indispensable condition, have duly recognized the supreme legislative authority and superintending power of the Parliament of Great Britain over the Colonies as aforesaid. Always understood, that a free grant of an aid, as hereinbefore required and expected from the Colonies, is not to be considered as a condition of redress, but as a just testimony of their affection.

And whereas divers Acts of Parliament have been humbly represented, in a petition to his Majesty from America, to have been found grievous, in whole or in part, to the subjects of the Colonies, be it hereby declared, by the King's most excellent Majesty, by and with the advice and consent of the Lords 
Spiritual and Temporal, and Commons, in this present Parliament assembled, and by the authority of the same, that the powers of Admiralty and Vice-Admiralty Courts in America shall be restrained within their ancient limits, and the trial by jury, in all civil cases, where the same may have been abolished, restored; and that no subject in America shall, in capital cases, be liable to be indicted and tried for the same, in any place out of the Province wherein such offence shall be alleged to have been committed; nor be deprived of a trial by his peers of the vicinage; nor shall it be lawful to send persons indicted for murder, in any Province of America, to another Colony, or to Great Britain, for trial. And it is hereby declared and enacted, by the authority aforesaid, that all and every the same Acts, or so much thereof as are represented to have been found grievous, namely, the several Acts of 4 Geo. III. ch. I5 [the Tariff Act of 1764 ], and ch. 34 [the Colonial Bills of Credit Act of I764], 5 Geo. III. ch. 25 [the Post Office Act of 1765 ], 6 Geo. III. ch. 52 [the Tariff Act of ${ }_{7} 766$ ], 7 Geo. III. ch. 4I [the Commissioners of Customs Act of ${ }_{1767}$ ] and ch. 46 [the Tariff Act of ${ }_{7767}$ ], 8 Geo. III. ch. 22 [the Vice-Admiralty Court Act of 1768 ], I2 Geo. III. ch. 24 [the Trial for Treason Act of $\mathrm{I}_{772}$ ], with the three Acts, for Stopping the Port and Blocking up the Harbor of Boston, for Altering the Charter and Government of Massachusetts Bay, and that entitled "An Act for the Better Administration of Justice, \&c.;" also the Act for Regulating the Government of Quebec; and the Act, passed in the same session, relating to the Quarters of Soldiers-shall be, and are, hereby suspended, and not to have effect or execution, from the date of this Act. And be it moreover hereby declared and enacted by the authority aforesaid, that all and every the before-recited Acts, or the parts thereof complained of, shall be, and are, in virtue of this present Act, finally repealed and annulled from the day that the due recognition of the supreme legislative authority and superintending power of Parliament over the Colonies shall have been made on the part of the said Colonies.

And for the better securing due and impartial administra- 


\section{The Administration of Dependencies}

tion of justice in the Colonies, be it declared and enacted, by the King's most excellent Majesty, by and with the advice and consent of the Lords Spiritual and Temporal, and Commons, in this present Parliament assembled, that his Majesty's judges in the courts of law in the Colonies in America, to be appointed with salaries by the Crown, shall hold their offices and salaries, as his Majesty's judges in England, quamdiu se bene gesserint. And it is hereby farther declared by the authority aforesaid, that the Colonies in America are justly entitled to the privileges, franchises, and immunities granted by the several charters or constitutions, which ought not to be invaded or resumed, unless for misuse, or some legal ground of forfeiture. So shall true reconcilement avert impending calamities, and this most solemn national accord between Great Britain and her Colonies stand an everlasting monument, of clemency and magnanimity in the benignant Father of his People; of wisdom and moderation in this great nation, famed for humanity as for valor; and of fidelity and grateful affection from brave and loyal Colonies to their parent Kingdom, which will ever protect and cherish them.

In the account given in the Parliamentary History of the proceedings in the House of Lords of February $I$, it is said:

The Earl of Chatham rose. His Lordship began with reminding the House, that the last time he had the honor of imparting his sentiments to them, he had informed them, that with their indulgence, he would submit certain propositions to their consideration, as a basis for averting the dangers which now threatened the British Empire; and that in performance of his promise, he had sketched the outlines of a Bill, which he hoped would meet with the approbation of every side of the House. He proceeded to state the urgent necessity of such a plan, as, perhaps, a period of a few hours might forever defeat the possibility of any such conciliatory intervention. $\mathrm{He}$ represented Great Britain and America as drawn up in martial array, waiting for the signal to engage in 
a contest, in which it was little matter for whom victory declared, as ruin and destruction must be the inevitable consequence to both parties. He wished, from a principle of duty and affection, to act the part of a mediator. He said, however, that no regard for popularity, no predilection for his country, not the high esteem he entertained for America on one hand, nor the unalterable steady regard he entertained for the dignity of Great Britain on the other, should at all influence his conduct; for though he loved the Americans, as men prizing and setting the just value on that inestimable blessing, Liberty; yet, if he could once bring himself to be persuaded that they entertained the most distant intentions of throwing off the legislative supremacy and the great constitutional superintending power and control of the British Legislature, he should be the very person himself who would be the first and most zealous mover for securing and enforcing the power by every possible exertion this country was capable of making. $\mathrm{He}$ recurred to his former arguments on the great constitutional question of taxation and representation; insisted they were inseparable, and planted so deeply in the vital principles of the Constitution, as never to be torn up, without destroying and pulling asunder every band of legal government and good faith, which formed the cement that united its several constituent parts together. He entreated the assistance of the House to digest the crude materials which he presumed to now lay before it, and bring it and reduce it to that form which was suited to the dignity and importance of the subject, and to the great ends to which it was ultimately directed. $\mathrm{He}$ called on them to exercise their candor on the present occasion, and deprecated the effects of party or prejudice, of factious spleen, or a blind predilection. He avowed himself to be actuated by no narrow principle, or personal consideration whatever; for though the present Bill might be looked on as a Bill of Concession, it was impossible but to confess at the same time that it was a Bill of Assertion.

The Bill was read the first time, and a motion to lay it on the table was made. The Earl of Sandwich, for the 


\section{The Administration of Dependencies}

Government, moved an amendment, "that the said Bill be rejected." The Earl of Gower, speaking in favor of its rejection, said "that it fell in with the ideas of America in almost every particular."

The Bill was debated at some length. Towards the close of the debate, the Earl of Chatham, in reply to the opponents of the Bill, said:

The indecent attempt to stifle this measure in embryo may promise consequences the very reverse of what I am certain will be the case if the Bill is admitted. The friends of the present amendment may flatter themselves that the contents of the Bill will sink into silence and be forgotten, but I believe they will find the contrary. This Bill, though rejected here, will make its way to the public, to the nation, to the remotest wilds of America; it will in such a course, undergo a deal of cool observation and investigation; and whatever its merits or demerits may be, it will stand or fall by them alone. It will, I trust, remain a monument of my poor endeavors to serve my country; and, however faulty or defective, will at least manifest how zealous I have been to avert those impending storms which seem ready to burst on it, and forever overwhelm it in ruin.

In spite of Lord Chatham's protest, the resolution for rejection was adopted by a vote of 6 I to 32 .

An examination of Lord Chatham's Bill shows that it was carefully framed as an answer to the American ultimatum. Every point made by the Americans was met. Where it seemed to him compatible with just principles, he yielded the point; where it seemed to him that the Americans had asked more than was.just, he advanced a counter-proposition, yielding all he thought proper.

The claim of right to tax the dependencies, he yielded, so far as the American Colonies were concerned, reserving to Parliament the determination of its rights in this respect with regard to the other dependencies. He thus placed the American Colonies in a class by themselves, 
as entitled to a special régime by reason of the fact that they had elective Legislatures.

By the Bill, every Act of the British Parliament which Congress, in its Declaration, had named as a grievance was to be repealed. On the question of quartering troops on the Colonies, he yielded all that was really necessary by declaring that no military force should ever be employed to violate or destroy the just rights of the people.

In the most important particular, namely, the basis on which the power of Parliament rested, the resolutions of Congress and Lord Chatham's Bill, though apparently at variance, were really very close together, as will appear by a comparison of the one with the other.

Congress had, by its resolution, practically based the power of Parliament over the Colonies, as has before been noticed, on the necessity of the case, since "consent" given to an act "from necessity of the case" is simply a yielding to the necessity. The rightfulness of the act in such a case is determined by the necessity for it, and not by the consent given. Granted that the extent of the power of Parliament in the Colonies was to be determined "by the necessity of the case," Lord Chatham's description of the power of Parliament was unexceptionable when he called it a power "to make laws and statutes of sufficient force and validity to bind the people of the British Colonies in America in all matters touching the general weal of the whole dominion of the Imperial Crown of Great Britain, and beyond the competency of the Local Representative, [i.e., the Local Government], of a distinct Colony," - especially when he further qualified the power by describing it "as the supreme legislative authority and superintending power." Superintendence necessarily implied that the action of Parliament should be based upon "the necessity of the case," to be determined expertly in each particular case as it arose. 


\section{The Administration of Dependencies}

The Bill showed that Lord Chatham had advanced in thought far beyond the position he had taken during the debates on the Stamp Act, and that the American conception, worked out by Dickinson, of the British Empire as a federal organism, of which Great Britain, as the Imperial State, was the Central Government, and the American Colonies, Member-States, had been accepted by him. Only as influenced by this conception could he have declared the power of Parliament to be "a supreme legislative authority and superintending power" - that is, a superintending power accompanied by a supreme legislative authority sufficient to effectuate it. In making this declaration, he had to break with the Declaratory Act of 1766 , and with the dictum of the highest court of England, presided over by Lord Mansfield, a Chief Justice of exceptional ability.

In recognizing the Congress of the Colonies as a body competent to bind them, the Bill recognized the right of dependencies to be united or federated in any way that the common interests of any group might dictate.

In recognizing the right of dependencies which were so far advanced in density of population and in civilization as to be able to manage their local affairs through an elected legislature, to tax themselves for local purposes, and to determine the amount of their contribution for Imperial purposes after advising with the Imperial authorities, and in insisting upon the right of the Imperial State to determine the amounts of Imperial and local taxation in dependencies not advanced to the stage of having an elected legislature, the Bill preserved the respective principles for which the Americans on the one side and the British on the other were contending, so far as each principle could be preserved, consistently with the interests of the Empire.

The provisions regarding the security of charter rights and the separation of the Imperial Judiciary from the 


\section{British Propositions, I 775}

Colonial Judiciary and the responsibility of the Colonial Judiciary to the people of the Colonies, were corollaries from the proposition that the power of Parliament, as the Imperial Parliament, "was a superintending power, different from that exercised by it as the Local Legislature of Great Britain, and different from that exercised by the Local Legislatures of the Colonies.

In less than a week after Lord Chatham's Bill was rejected-on February 7, 1775-both Houses united in an Address to the King, procured by the managemen $i$ of Lord North and his Ministry, which was virtually a permission to the King to make a declaration of civil war. In this Address they said:

We find that a part of your Majesty's subjects in the Province of Massachusetts Bay have proceeded so far to resist the authority of the Supreme Legislature, that a rebellion at this time actually exists within the said Province; and we see with the utmost concern that they have been countenanced and encouraged by unlawful combinations and engagements entered into by your Majesty's subjects in several of the other Colonies. . . . We can never so far desert the trust imposed on us as to relinquish any part of the sovereign authority over all your Majesty's dominions, which by law is vested in your Majesty and the two Houses of Parliament. . . .

We ever have been, and always shall be ready to pay attention and regard to any real grievance of any of your Majesty's subjects which shall, in a constitutional manner, be laid before us; and whenever any of the Colonies shall make a proper application to us, we shall be ready to afford them every just and reasonable indulgence. At the same time, we consider it our indispensable duty, humbly to beseech your Majesty that you will take the most effectual measures to enforce due obedience to the laws and authority of the Supreme Legislature; and we beg leave in the most solemn manner to assure your Majesty that it is our fixed resolution, at the hazard of our lives and properties, to stand by your Majesty, against all 


\section{Io The Administration of Dependencies}

rebellious attempts, in the maintenance of the just rights of your Majesty and the two Houses of Parliament.

The dissenting members of the House of Lords, eighteen in number, united in a written protest against this Address, in which they declared that it "amounted to a declaration of war' against the Colonies.

On February 27, I775, the House of Commons, in Committee of the Whole, adopted a report dictated by Lord North, in behalf of the Ministry, making a proposition to the American Colonies. The report read:

That it is the opinion of this Committee, that when the General Council and Assembly, or General Court, of any of his Majesty's Provinces or Colonies in America, shall propose to make provision according to the condition, circumstance, or situation of such Province or Colony, for contributing their proportion of the common defence (such proportion to be raised under the authority of the General Court or General Assembly of such Province or Colony, and disposable by Parliament) and shall engage to make provision for the support of the civil government and the administration of justice in such Province or Colony, it will be proper, if such proposal shall be approved by his Majesty and the two Houses of Parliament, and for so long as such provision shall be made accordingly, to forbear, in respect of such Province or Colony, to lay any duty, tax or assessment, except only such duties as it may be expedient to continue to levy or impose for the regulation of commerce ; the net produce of the duties last mentioned to be carried to the account of such Province or Colony respectively.

This proposition was objectionable for many reasons. It was merely tentative and bound Great Britain to nothing; it denied the right of the dependencies of the British Empire to be federated or united in such a way as the interests of a particular group might require; and it was based on the theory that Great Britain, as the Imperial State, had an unconditional and unlimited power 


\section{British Propositions, I 775}

of legislation in the dependencies, which it might suspend temporarily in return for a consideration which it deemed adequate.

Burke perceived the futility of Lord North's Proposals, and while they were in process of being transmitted to America, introduced in the House of Commons, on March 22, I775, his Resolutions for Conciliation with the Colonies. These resolutions had, for their sole object, the restoration of the Constitution of the Empire, as it existed at the close of the war in $176_{3}$. They declared the right of the American Colonies to tax themselves, the expectation being expressed that they would grant "subsidies and public aids for his Majesty's service, according to their abilities," because "it has been found by experience that the manner of granting the said supplies and aids by those General Assemblies has been more agreeable to the inhabitants of the said Colonies, and more beneficial and conducive to the public service than the mode of giving and granting aids and subsidies in Parliament, to be raised and paid in said Colonies." The resolutions further proposed to repeal all the objectionable Acts of Parliament, to allow all judges appointed by the Crown in the Colonies to hold office during good behavior, and to regulate the Courts of Admiralty in the Colonies " in such a manner as to make the same more commodious to those who sue or are sued in those courts."

The resolutions were immediately rejected by a vote of 270 to 78 .

In his speech in support of these resolutions, Burke said :

The proposition is peace; not peace through the medium of war; not peace to be hunted through the labyrinth of intricate and endless negotiations; not peace to arise out of universal discord, fomented from principle, in all parts of the Empire; 


\section{The Administration of Dependencies}

not peace, to depend upon the juridical determinations of perplexing questions, or the precise marking of the shadowy boundaries of a complex government. It is simple peace, sought in its natural course, and in its ordinary haunts. It is peace sought in the spirit of peace, and laid in principles purely pacific. I propose, by removing the ground of difference, and by restoring the former unsuspecting confidence in the Mother Country, to give a permanent satisfaction to your people, and (far from a principle of ruling by discord) to recover them to each other, in the same act, and by the bond of the very same interest which reconciles them to the British Government.

Perhaps, Sir, I am mistaken in my idea of an Empire, as distinguished from a single State or Kingdom. But my idea of it is this: that an Empire is the aggregate of many States, under one common Head; whether this Head be a monarch, or a presiding republic. It does, in such constitutions, frequently happen (and nothing but the dismal, cold, dead uniformity of servitude can prevent its happening) that the subordinate parts have many local privileges and immunities. Between these privileges and the supreme common authority, the line may be extremely nice. Of course disputes-often, too, very bitter disputes-and much ill blood, will arise. But though every privilege is an exemption (in the case) from the ordinary exercise of the supreme authority, it is no denial of it. The claim of a privilege seems rather, ex vi termini, to imply a superior power; for to talk of the privileges of a State or of a person, who has no superior, is hardly any better than speaking nonsense. Now, in such unfortunate quarrels, among the component parts of a great political union of communities, I can scarcely conceive anything more completely imprudent, than for the Head of the Empire to insist, that if any privilege is pleaded against his will, or his acts, his whole authority is denied, instantly to proclaim rebellion, to beat to arms, and to put the offending Province under the ban. Will not this, Sir, very soon teach the Provinces to make no distinctions on their part? Will it not teach them that the Government, against which a claim of liberty is tantamount 
to high treason, is a Government to which submission is equivalent to slavery? It may not always be quite convenient to impress dependent communities with such an idea.

"We are, indeed, in all disputes with the Colonies, by the necessity of things, the judge. It is true, Sir. But I confess that the character of judge in my own cause is a thing that frightens me. Instead of filling me with pride, I am exceedingly humbled by it. I cannot proceed with a stern, assured, judicial confidence, until I find myself in something more like a judicial character. I must have these hesitations as long as I am compelled to recollect, that, in my little reading upon such contests as these, the sense of mankind has at least as often decided against the superior as the subordinate power.

My idea, without considering whether we yield as matter of right, or grant as matter of favor, is to admit the people of our Colonies into an interest in the Constitution; and by recording that admission in the Journals of Parliament, to give them as strong an assurance as the nature of the thing will admit, that we mean forever to adhere to that solemn declaration of systematic indulgence.

Burke's resolutions were apparently based on the theory that the British Constitution did not "extend to the Colonies," - to use a modern expression. He apparently proposed to solve the difficulty by "extending the Constitution" to them for some purposes and to some extent. The people of the Colonies were to be "admitted into an interest in the Constitution," as if they had never had any interest in it before. When he distinguished his plan of settlement from those which aimed at a peace which was "to depend upon the juridical determination of perplexing questions, or the precise marking of the shadowy boundaries of a complex government," or which was "to be hunted through a labyrinth of intricate and endless negotiations," he was apparently disparaging the efforts of Dickinson and Lord Chatham, 


\section{I4 The Administration of Dependencies}

as well as of many others, who were attempting to work out the just relationship between Great Britain and the Colonies as a problem of political science and of the general public law.

Those, however, who were contending that the Constitution of the Empire could only be ascertained by "the juridical determination of perplexing questions and the precise marking of the shadowy boundaries of a complex government" and by "intricate negotiations," were necessarily and inevitably acting on the theory that the people of the Colonies had always been "admitted to an interest in the Constitution" since the inception of the Colonies, in the sense that the British Constitution had always been in force in the Colonies except so far as it was rendered inapplicable by the local circumstances and conditions. It was this fact, and this fact only, which made the government of the Empire " complex" and the questions of its Eovernment " perplexing," which made the boundaries of its government " shadowy," which made it impossible that these boundaries should be marked except as the result of "intricate and endless negotiations" and the "juridical determination" of the questions which arose. Burke saw that the Constitution of the British Empire was based on different principles from the Constitution of Great Britain, and that what was true in this case was true in every Empire founded on just principles, but if one were to judge entirely from the expression "to admit the Colonies into an interest in the Constitution," it would appear that he had not seen that the Constitution of the British Empire had always and necessarily been related to the British Constitution so that the Colonies had an "interest" in it, ever since the British Empire was established.

Perhaps, however, it is unjust to Burke to lay too much stress on the word "admit," since, in the course of his speech, he used expressions which seem necessarily 
to imply that he regarded the Colonies as always having had an interest, in the nature of things, in the British Constitution. If, in all "disputes with the Colonies" Great Britain "by the necessity of things" was a "judge" sitting as "a judge in its own cause," its action necessarily was directed toward "the juridical determination of perplexing questions and the precise marking of the shadowy boundaries of a complex government," and such determination could only be made as the result of "intricate and endless negotiations." It is possible that he used the word "admit" rather with the purpose of cutting off discussion concerning the existing relationship than as implying that, up to that time, the people of the Colonies had had no interest in the British Constitution.

The last attempt which was made towards a conciliation with the Colonies was that of David Hartley, who, on March 27, I775, introduced resolutions for this purpose in the House of Commons, the first of which was as follows :

That an humble address be presented to his Majesty, that he will be graciously pleased to give orders that letters of requisition be written to the several Provinces of his Majesty's Colonies and Plantations in America, to make provision for the purpose of defending, protecting and securing the said Colonies and Plantations; and that his Majesty will be pleased to order all such addresses as he shall receive in answer to the aforesaid letters of requisition to be laid before this House.

Hartley's other resolutions provided for the suspension, during a period of three years, of the Acts "for Blocking up the Port of Boston," "for the Impartial Administration of Justice," and "for Regulating the Government of the Province of Massachusetts Bay."

A form of letter of requisition was made a part of the first resolution, which, had it been adopted by Parliament and followed by the King, would have contained 


\section{The Administration of Dependencies}

an offer to the Colonies, in case they contributed equitably to the Imperial defence by money or troops and made "an ostensible contribution to the general supply," that the King would recommend to Parliament a relaxation of the restrictions on their trade, and would allow them "to spread into the continent of America."

Hartley's idea, like Burke's, seems to have been to accomplish exactly the same purpose as Lord Chatham had aimed at in his Bill, but to avoid an express definition of the power of Great Britain or of Parliament or of the King, leaving it open for definition by events as they should arise in the future. His prime object was to secure the recognition by the Colonies of some power to be exercised by Parliament, leaving it free to Great Britain to claim that its power was more than that exercised, in case it should be found necessary in the future to exercise greater power.

In explaining his resolutions, Hartley said:

My motion originates in the House of Commons, to desire the King, as the Executive Magistrate, to put their plan into effect. If the power of making requisitions to the Colonies is not in the King, my motion is to give the authority and sanction of Parliament to this measure. It is so far from being my proposition, to enable the Crown to raise what supply it can in America, independent of Parliament, that my motion is the very first which has ever had in contemplation to lay a Parliamentary control upon that power, and to require that all answers from America shall be laid before this House for the very purpose of controlling that power in the Crown. I have so doubly guarded that point that my motion is not even for the Crown to demand a supply from America, but for services to be performed in America, for the defence, security and protection of the Colonies themselves.

Hartley's resolutions met the same fate as Lord Chatham's and Burke's. Neither House of Parliament would 


\section{British Propositions, I 775}

admit, directly or indirectly, that the power of Parliament over the Colonies was anything less than a power to bind them "in all cases whatsoever."

Dickinson, Lord Chatham, and Burke all concurred in the conclusion that the Imperial State in the Federal Empire must, from the necessity of the case, adjudicate the rights of the Member-States, and incidentally, also, the limits of its own jurisdiction. Dickinson said, in his New Essay, that Parliament was "the supreme Legislature and full representative of the parent State, and the only judge between her and her children in commercial interests, which the nature of the case, in the progress of their growth, admitted." Lord Chatham, in his Bill, called the power of Parliament, sitting as the Parliament of the Empire, a "supreme legislative authority and superintending power"; and Burke, after having described the power of the Imperial Parliament as a power of "provident and beneficent superintendence" in his speech on American Taxation, said in his speech on Conciliation: "We are, indeed, in all disputes with the Colonies, by the necessity of the case, the judge."

Hartley, too, was enthusiastically in favor of Lord Chatham's plan of settlement, if it could have been brought about, and brought forward his resolutions in the hope of accomplishing the same result at which Lord Chatham was aiming.

It may, therefore, be said that every British plan of settlement, proposed in 1775 , aimed at the restoration or the declaration of the Federal Empire. 


\section{CHAPTER XVIII}

\section{THE FINAL ISSUE, I775-I776}

\section{$\mathrm{L}$}

ORD CHATHAM'S Bill, by describing the power of the State of Great Britain in the Empire as a power of "superintendence," inevitably precipitated a second debate, in the second session of Congress, which began on May IO, I775, concerning the character and extent of the power of the Imperial State in the Empire. Lord North's Proposals, by providing for a Parliamentary determination, having in some respects the form of an adjudication, of the amounts of the contributions of the respective Colonies to the Imperial defence (and hence providing, by necessary implication, for Parliamentary adjudication of all the rights of the Colonies), inevitably precipitated a second debate concerning the respective functions of the King and the Parliament in the Empire. These were the two fundamental questions, if the British Empire was a political organism.

Before reaching the consideration of these questions, however, there had to be a second discussion and settlement of the preliminary question-whether the British Empire was a political organism, or State, from which withdrawal of any of the Member-States was impossible except upon dissolution by mutual consent, or whether it was a mere Alliance of States, from which one or more might secede at any time.

It has already been noticed that, at the first session of the Congress, this question had been strenuously debated, and that, as the result, the majority had been in favor of the Federal-Imperialist view, in which it was necessariiy 


\section{The Final Issue, I775-1776}

implied that the British Empire was a State. In the recess between the first and the second sessions of Congress, however, the anti-Imperialist or Secessionist minority had shown themselves quite unreconciied to the view of the majority. The most pronounced anti-Imperialist utterance of John Adams was made during this recess, shortly before the news of Lord Chatham's Bill could have reached America. When that news arrived, it evidently cut the ground from under the feet of this minority. Lord Chatham's Bill was virtually an adjudication of the whole dispute between the Colonies and Great Britain, by the one man in whom the Colonies possessed absolute confidence, and who was recognized as the greatest statesman of his day.

Jefferson has borne witness to the profound effect which the Bill had upon the thought of America. On May 7, I775, he wrote to Dr. Wm. Small:

When I saw Lord Chatham's Bill, I entertained high hope that a reconciliation could have been brought about. The difference between his terms and those offered by Congress might have been accommodated, if entered on by both parties with a disposition to accommodate.

In the Address to Governor Dunmore from the House of Burgesses of Virginia, of June I2, I775,-in answer to Lord North's Proposals, - which Jefferson, in his Autobiography, says that he drafted, it was said:

There was, indeed, a plan of accommodation offered in Parliament which, though not entirely equal to the terms we had a right to ask, yet differed but in a few points from what the General Congress had held out. Had Parliament been disposed sincerely, as we are, to bring about a reconciliation, reasonable men had hoped that by meeting us on this ground, something might have been done. Lord Chatham's Bill on the one part, and the terms of Congress on the other, would have 


\section{The Administration of Dependencies}

formed a basis for negotiations which a spirit of accommodation on both sides might, perhaps, have reconciled. It came recommended, too, from one whose successful experience in the art of government should have insured it some attention from those to whom it was intended. He had shown to the world that Great Britain, with her Colonies united under a just and honest government, formed a power which might bid defiance to the most potent enemies.

Upon the reassembling of Congress for the second session, there were two elements of the situation which made for unanimity, - the appreciation of the fact that the Colonies could not hope to succeed if they were divided among themselves, and the influence of Lord Chatham's opinion in favor of the Federal-Imperialist majority. The result was a partial yielding on both sides, which brought the anti-Imperialists into substantial accord with the Federal-Imperialists, and which led the latter to take an enlarged and more correct conception of the character of the Federal Empire. The circumstances of the yielding of the anti-Imperialist party to the general views of the Federal-Imperialists are narrated by Jefferson and were as follows:

On June 23, I775, Congress appointed a committee to prepare a Declaration on Taking up Arms. The first draft, prepared by John Rutledge, was unsatisfactory to Congress, and the report was recommitted and Jefferson and Dickinson added to the committee. Jefferson prepared a draft, but it was not satisfactory to the committee, and finally, by their request, Dickinson wrote a draft incorporating some parts of Jefferson's, which was accepted by the committee and by Congress. Jefferson in his Autobiography says of his draft:

It was too strong for Mr. Dickinson. He still retained the hope of reconciliation with the Mother Country, and was unwilling it should be lessened by offensive statements. He was 
so honest a man, and so able a one, that he was greatly indulged even by those who could not feel his scruples. IVe therefore requested him to take the paper, and put it in a form he could approve.

Jefferson, in his draft, said:

Our forefathers established civil societies with various forms of constitution. To continue their connection with the friends whom they had left, they arranged themselves by charters of compact under the same common King, who thus completed their powers of full and perfect legislation, and became the link of union between the several parts of the Empire. Some occasional assumptions of power by the Parliament of Great Britain, however unacknowledged by the constitution of our Governments, were finally acquiesced in through warmth of affection.

Dickinson appended to Jefferson's draft a query whether "it might not be proper to take notice of Lord Chatham's Plan, mentioning his great abilities."

In the Declaration drafted by Dickinson, as finally adopted by Congress, it was said :

Our forefathers . . . effected settlements in the distant and inhospitable wilds of America, then filled with numerous and warlike nations of barbarians. Societies or Governments, vested with perfect Legislatures, were formed under Charters from the Crown, and an harmonious intercourse was established between the Colonies and the Kingdom from which they derived their origin. . . . Towards the close of the late war, it pleased our Sovereign to make a change in his counsels. From that moment the affairs of the British Empire began to fall into confusion. . . . Parliament was influenced to adopt the pernicious project [of subduing and plundering the Colonies], and, assuming a new power over them, have in the course of eleven years given such decisive specimens of the spirit and consequences attending this power as to leave no doubt concerning the effects of acquiescence under it. . . . 


\section{The Administration of Dependencies}

But why enumerate our injuries in detail ? By one statute it is declared that Parliament can "of right make laws to bind us in all cases whatsoever." What is to defend us against so enormous, so unlimited a power? Not a single man of those who assume it, is chosen by us, or is subject to our control or influence; but on the contrary, they are all of them exempt from the operation of such laws, and an American revenue, if not diverted from the ostensible purposes for which it is raised, would actually lighten their own burdens in proportion as they increase ours.

At the same time that this conversion of the anti-Imperialists to the general principles of the Federal-Imperialists occurred, a decided change occurred in the views of the Federal-Imperialists. The anti-Imperialists had evidently insisted that, if the British Empire was a political organism, or State, under a Constitution, the matter of money contributions of any part of the State to the defence and welfare of the whole State could not be excepted out of the matters over which the Imperial State, as the Central Government, had power, and the FederalImperialists had evidently been unable to answer this proposition. The anti-Imperialists had evidently insisted, also, that if the British Empire was a State composed of States, there was no reason why the subordinate Member-States should not unite or federate among themselves in any way not inconsistent with their subordination to the Imperial State which might be best in their own interests; and the Federal-Imperialists had evidently assented to this proposition. When this point was reached, it evidently became clear to both parties that the real question at issue was whether the British Empire was a Federal Empire or a Unitary State, and that no settlement was possible except one which went to the root of the matter and settled that question once for all.

That this change of view on the part of the FederalImperialists regarding the matter of the money contri- 
butions of the Colonies to the Imperial defence and welfare did, in fact, occur, and that it resulted in a substantial unanimity of sentiment in Congress that Great Britain, as the Imperial State, ought to have, under a just and proper Constitution of the Empire, a superintendence over this matter, can be affirmed on no less authority than that of Jefferson and Madison. Writing, at the request of M. Soulés, on September 13, I786, in criticism of the proof sheets of his Histoire des Troubles de l'Amerique Anglaise, Jefferson, said, speaking of the issues on' which the American Revolution was fought:

Dickinson acknowledged, in his Farmer's Letters, that [Parliament] could levy duties, internal or external, payable in Great Britain or in the States. He only required that these duties should be bona fide for the regulation of commerce, and not to raise a solid revenue. He admitted that they might control our commerce, but not tax us. This mysterious system took for a moment in America as well as in Europe. But sounder heads saw in the first moment that he who could put down the loom could stop the spinning-wheel, and he who could stop the spinning-wheel could tie the hand which turned it. They saw that this flimsy fabric could not be supported. Who were to .be judges whether duties were imposed with a view to burthen and suppress a branch of manufacture or to raise a revenue? If either party, exclusively of the other, it was plain where that would end. If both parties, it was plain where that would end also. They saw, therefore, no clue to lead them out of their difficulties but reason and right. They dared to follow them, assured that they alone could lead to defensible ground. The first elements of reason showed that the members of Parliament could have no power which the people. of the several counties had not-that these had naturally a power over their own farms, and collectively over all England -that if they had any over countries out of England, it must be founded on compact or force. No compact could be shown, and neither party chose to bottom their pretensions on force. 


\section{The Administration of Dependencies}

It was objected that this annihilated the Navigation Act. True, it does. The Navigation Act, therefore, becomes a proper subject of treaty between the two nations. Or, if Great Britain does not choose to have its basis questioned, let us go on as we have done. Let no new shackles be imposed, and we will continue to submit to the old. We will consider the restrictions on our commerce now actually existing, as compensations yielded by us for the protections and privileges we actually enjoy, only trusting that if Great Britain, on a revisal of these restrictions, is sensible that some of them are useless to her and oppressive to us, she will repeal them. But on this she shall be free. Place us in the condition we were when the King came to the throne, let us rest so, and we will be satisfied. This was the ground on which all the States very soon found themselves rallied, and there was no other which could be defended.

Madison, speaking reminiscently in the Convention for framing the Constitution of the United States, on August 13, 1787, said:

When the contest was first opened with Great Britain, their power to regulate trade was admitted, their power to raise revenue rejected. An accurate investigation of the subject, afterwards, proved that no line could be drawn between the two cases.

And in a letter to Jefferson of October 24, I787, Madison said:

How long has it taken to fix, and how imperfectly is yet fixed, the legislative power of corporations, though that power is subordinate in the most complete manner? The line of distinction between the power of regulating trade and that of drawing revenue from it, which was once considered the barrier of our liberties, was found, on fair discussion, to be absolutely untenable.

The documents which evidenced the change in the views of Congress on these three different subjects, - 


\section{The Final Issue, I $775^{-1} 776$}

namely, the right of the Imperial State, as the Central Government, to adjudicate the contributions to the Imperial defence and welfare; the right of the Colonies, as subordinate Member-States, to federate or unite; and the necessity for a general settlement which should finally determine the character of the Empire as a federal organism, as opposed to a settlement relating solely to the existing grievances, - were the second Address to the King, of July 8, drafted by Dickinson, as chairman of the committee, the second Address to the People of Great Britain, of the same date, prepared by a committee of which Richard Henry Lee was chairman, and the resolutions on Lord North's Proposals, of July 31, prepared by a committee of which Franklin was chairman, and Jefferson, John Adams, and Richard Henry Lee members.

In the Address to the King, the relationship between Great Britain and the Colonies was called "the Union between the Mother Country and the Colonies," Great Britain was described as "the Sovereign and Parent State," and the Parliament was spoken of as "that august Legislature, the Parliament."

In this Address, the Congress said:

Attached to your Majesty's person, family and government with all devotion that principle and affection can inspire, connected with Great Britain by the strongest ties that can unite societies, and deploring every event that tends in any way to weaken them, we solemnly assure your Majesty that we not only most ardently desire the former harmony between her and these Colonies may be restored, but that a concord may be established between them upon so firm a basis as to perpetuate its blessings, uninterrupted by any future dissensions, to succeeding generations in both countries.

We beg leave to assure your Majesty that notwithstanding the sufferings of your loyal colonists during the course of this present controversy, our breasts retain too tender a regard for 


\section{The Administration of Dependencies}

the Kingdom from which we derive our origin, to request such a reconciliation as might in any manner be inconsistent with her dignity and welfare. These, related as we are to her, honor and duty, as well as inclination, induce us to support and advance; and the apprehensions that now oppress our hearts with unspeakable grief being once removed, your Majesty will find your faithful subjects on this continent ready and willing, at all times, as they have ever been, with their lives and fortunes, to maintain the rights and interests of your Majesty and of our Mother Country.

We therefore beseech your Majesty that your royal authority and influence may be graciously interposed to procure us relief from our afflicting fears and jealousies occasioned by the system [of statutes and regulations adopted for the administration. of the Colonies] before mentioned, and to settle peace through every part of your dominions, with all humility submitting to your Majesty's wise consideration whether it may not be expedient for facilitating those important purposes that your Majesty may be pleased co direct some mode by which the united applications of your faithful colonists to the throne, in pursuance of their common counsels, may be improved into a happy and permanent reconciliation.

For by such arrangements as your Majesty's wisdom can form, for collecting the united sense of your American people, we are convinced your Majesty would receive . . . satisfactory proofs of the disposition of the colonists towards their Sovereign and Parent State.

In the Address to the People of Great Britain, it was said:

It is alleged that we contribute nothing to the common defence. To this we answer, that the advantages which Great Britain receives from the monopoly of our trade far exceed our proportion of the expense necessary for that purpose. But should these advantages be inadequate thereto, let the restrictions on our trade be removed, and we will cheerfully contribute such proportion when constitutionally required. . . .

A plan of accommodation (as it has been absurdly called) 
has been proposed by your Ministers to our respective Assemblies. . . What is submitted to our consideration? We contend for the disposal of our property. We are told that our demand is unreasonable, that our Assemblies may indeed collect our money, but that they must at the same time offer, not what your exigencies or ours require, but so much as shall be deemed sufficient to satisfy the desires of a Minister and enable him to provide for favorites and dependents. A recurrence to your own Treasury will convince you how little of the money already extorted from us has been applied to the relief of your burdens. To suppose that we would thus grasp the shadow and give up the substance, is adding insult to injuries.

We have nevertheless again presented an humble and dutiful petition to our Sovereign, and to remove every imputation of obstinacy, have requested his Majesty to direct some mode by which the united applications of his faithful colonists may be improved into a happy and permanent reconciliation. We are willing to treat on such terms as can alone render an accommodation lasting.

Yet conclude not from this that we propose to surrender our property into the hands of your Ministry, or vest your Parliament with a power which may terminate in our destruction.

In the resolutions of Congress of July $3 \mathrm{I}, 1775$, relating to Lord North's Proposals, drafted by Jefferson, it was said :

We think the attempt unnecessary to raise upon us, by force or by threats, our proportional contributions to the common defence, when all know, and themselves acknowledge, we have fully contributed whenever called upon to do so in the character of freemen.

We are of opinion that it is not just that the Colonies should be required to oblige themselves to other contributions while Great Britain possesses a monopoly of their trade. This, of itself, lays them under heavy contribution. To demand, therefore, additional aids in the form of a tax, is to demand the double of 


\section{The Administration of Dependencies}

their equal proportion. If we are to contribute equally with the other parts of the Empire, let us, equally with them, enjoy free commerce with the whole world. But while the restrictions on our trade shut to us the resources of wealth, is it just that we should bear all other burthens equally with those to whom every resource is open?

We conceive that the British Parliament has no right to intermeddle with our provisions for the support of civil government or administration of justice. The provisions we have made are such as please ourselves and are agreeable to our own circumstances. They answer the substantial purposes of government and of justice; and other purposes than these should not be answered. We do not mean that our people shall be burthened with oppressive taxes, to provide sinecures for the idle or wicked, under color of providing for a civil list. While Parliament pursue their plan of civil government within their own jurisdiction, we also hope to pursue ours without molestation.

We are of opinion the proposition is altogether unsatisfactory because it imports only a suspension of the mode, not a renunciation of the pretended right to tax us; and because it does not propose to repeal the several Acts of Parliament [describing them]. Nor do they renounce the power of suspending our owon Legislatures, and of legislating for us themselves in all cases whatsoever. On the contrary, to show that they mean no discontinuance of injury, they pass Acts, at the very time of holding out this proposition, for restraining the commerce and fisheries of the Provinces of New England, and for interdicting the trade of other Colonies with foreign nations and with each other. This proves unequivocally they mean not to relinquish the exercise of indiscriminate legislation over us.

Upon the whole, this proposition seems to have been held up to the world, to deceive it into a belief that there was nothing in dispute between us but the mode of levying taxes; and that the Parliament having now been so good as to give up this, the Colonies are unreasonable if not perfectly satisfied: whereas in truth, our adversaries still claim a right of demand- 
ing ad libitum, and of taxing us themselves to the full amount of their demand if we do not comply with it. This leaves us without anything we can call property. But what is of more importance, and what in this proposal they keep out of sight, as if no such point was now in contest between us, they claim a right to alter our charters and established laws, and leave us without any security for our lives or libertics.

It is noticeable that the method adopted by the Congress for modifying the terms of the ultimatum so as to conform to the change of sentiment was exactly the same as the method adopted in the original transmission of the ultimatum. The first Address to the King had not expressly claimed that Great Britain had not, under the Constitution of the Empire, any power whatever over the contributions of the Colonies to the Imperial defence and welfare. It had simply claimed that Acts of Parliament taxing the Colonies, without previous adjudication and without any hearing of them, and under a claim of Parliament to legislate so as to bind the Colonies in all cases whatsoever, were violations of the Constitution of the Empire. The Colonies had not in the least altered their views in this respect, but they had so expressed the first Address that it gave the impression that their contention was that the King of Great Britain had only the power to annul these unconstitutional Acts of Parliament, and had not the power of himself, in his official capacity as Disposer of the Empire, to make rules and regulations in execution of his adjudications concerning the rights of the Imperial State and the Colonies, as Member-States, under the Constitution of the Empire. The second Address was necessary to make it clear that the Colonies were not denying the whole power of the State of Great Britain, as the Central Government of the Empire, over their contributions to the Imperial defence and welfare, and that they admitted that that State had a conditional and limited 


\section{The Administration of Dependencies}

power in that respect, as in all others, which, according to their view (though they did not insist upon their view if the King thought otherwise and could arrange for proper and constitutional action by Parliament), should be exercised by the King in his official capacity-in which he would necessarily act under the advice of a suitable expert tribunal appointed by him-by making and causing to be executed the needful rules and regulations.

The prayer of the Address to the King was accordingly enlarged so as to ask the King, as Disposer of the Empire, not merely to give negative relief by way of injunction, but to give affirmative relief by decreeing the specific performance of the contract between the parties and also to specifically perform it, making all needful rules and regulations for this purpose, as the expert representative of Great Britain, acting as the Imperial State. He was thus asked to act as "judge in his own cause," to use the words of Burke, and to conform his action as party litigant to his own decision as judge. Such a proposal that the King should exercise inconsistent functions was not a novel idea. The King of Great Britain, as does the Chief Executive of every State, necessarily executed every day a great variety of inconsistent functions. The whole conception of the King, as the Crown, was of the King exercising a great variety of inconsistent functions and harmonizing them all towards a common end. It was this inherent inconsistency of his various functions which required the functions to be distributed to expert officers and tribunals, whose actions the King, advised by men most expert in the science of government, harmonized and directed.

In this Address, the Congress took occasion to declare themselves a constitutional body. The King was asked "to direct some mode by which the united applications of [his] faithful colonists to the throne, in pursuance of [their] common counsels, [might] be improved into a 
happy and permanent reconciliation," and to make "such arrangements as [his] Majesty's wisdom can form, for collecting the united sense of [his] American people." If the Congress was a constitutional body, it could only be such on the theory that the Colonies had a right, under the Constitution of the Empire, to unite or federate as their interests might require, provided no injury was done to the whole Empire thereby, and provided the union or federation was not on terms inconsistent with the performance by the Imperial State of its proper functions in the Empire. This was a following out of the idea of Lord Chatham, whose Bill had provided for the recognition of the Congress as a permanent constitutional body.

The King was by this second Address petitioned not merely to "interpose" his "royal authority and influence" to procure the Colonies "relief," and to "restore harmony," but also to "establish" a permanent "concord," and, for this purpose, to "direct a mode" of action which would lead to a "happy and permanent reconciliation." The Congress had realized that a settlement which purported merely to restore the situation as it existed at the close of the war in 1763 would be ineffectual, since the discussion had developed three distinct and different views concerning the character of the political relationship which existed in 1763 between Great Britain and the Colonies, - the British view, the American Federal-Imperiaiist view, and the American anti-Imperialist view. This demand of Congress was also an adoption of Lord Chatham's opinion of the necessities of the political situation. He had shown, by his Bill, that he regarded as useless a settlement which did not expressly declare the power of Great Britain to be a "superintending power" accompanied by the "supreme legislative authority" necessary to execute it, thus recognizing the statehood of the Colonies and, in effect, declaring the British Federal Empire. 


\section{The Administration of Dependencies}

The change of view in Congress concerning the contri. butions of the Colonies to the Imperial defence and welfare was expressed in the second Address to the People of Great Britain-Parliamentary taxation of the people of the Colonies being carefully distinguished from an apportionment of the shares of the expenditure necessary for the Imperial defence and welfare among the States of the Empire, adjudicated by the King. The power of Parliament, so long as it persisted in its claim of unconditional and unlimited power, was denied, as was also the power of the Ministry - they being regarded as officials who were nominally the King's advisers, but who were actually under the dictation of the House of Commons, which was persistent in the claim of unconditional and unlimited power for Parliament. The statement that, upon withdrawal by Parliament of its restrictions upon the trade of the Colonies, the Colonies would "cheerfully contribute their necessary proportion to the common defence when constitutionally required" was followed by a statement that "to remove every imputation of obstinacy," they had petitioned the King to suggest a plan of "permanent reconciliation," adding that they were "willing to treat on such terms as can alone render an accommodation lasting."

In the resolution concerning Lord North's Proposals occurred a plain statement by the Colonies that the British Parliament could exercise power, under the Constitution of the Empire, only within a certain sphere of jurisdiction-in other words that the Acts of the British Parliament relating to the Colonies were to be measured by the Constitution of the Empire, and, if in excess of the powers granted to Parliament by that Constitution, were null and void. The statement that Parliament must "pursue their plan of civil government within their own jurisdiction" unmistakably fixed the character of the pro. ceedings of the Congress as a suit in equity brought by 
Member-States of the Federal Empire, against the Imperial State, as a Member-State, before the King of Great Britain, as ex officio the Disposer of the Empire, having authority to finally interpret, adjudicate, and execute the unwritten Constitution of the Empire, through an expert tribunal as his adviser, and to finally determine the constitutionality of any act of any Member-State, by virtue of power and authority granted to him by the people of the whole Empire.

The proposition of the Congress that in case Parliament would repeal the laws taxing the Colonies and would remove or decrease the restrictions on their trade, they would contribute directly to the Imperial defence a sum equal to the amount so saved to them, was a testproposition. Had Parliament accepted it, the acceptance would have been an admission that the Colonies were Member-States of the Empire, which were already paying indirectly to the State of Great Britain for its services as the Protector and Disposer of the Empire a sum which both parties agreed to be fair and just, under a contract, or Constitution of the Empire, which provided that Great Britain should perform these services, and should be paid therefor a reasonable compensation. The proposition, when accepted, would have been a contract, operating as an amendment to the original contract, or Constitution of the Empire, and would have been, by necessary implication, a recognition of the British Empire as a federal organism and a State, existing under a Constitution, supreme for Imperial purposes over the Constitution of the State of Great Britain. Had this proposition been accepted, Great Britain could not logically have refused to have the unwritten Constitution of the Empire interpreted by the King, as the Head of the expert part of its own Government, in case it disagreed with the Colonies concerning the proper interpretation, and the Colonies would have accomplished the real result at 


\section{The Administration of Dependencies}

which they were aiming, - as Congress stated in their resolutions concerning Lord North's Proposals, - namely, an admission that Great Britain had no right "to alter our charters and established laws, and leave us without any security for our lives and liberties."

That both parties in Congress were united in the hope that these last Addresses might lead to a reconciliation is shown by two letters of Jefferson, the latter written a month after news of the rejection of the second Address to the King, called the "Olive Branch" petition, reached America, but before the rejection by Parliament of all plans for conciliation.

In a letter to John Randolph, written August 25, I775, he said:

I am sincerely one of those who wish for a reunion with their Parent Country, and would rather be in dependence on Great Britain, properly limited, than on any other nation on earth, or on no nation. But I am one of those who, rather than submit to the rights of legislating for us, assumed by the British Parliament, and which late experience has shown they will so cruelly exercise, would lend $\mathrm{my}$ hand to sink the whole Island in the ocean.

On November 29, I775, Jefferson again wrote to Randolph :

Believe me, dear Sir, there is not in the British Empire a man who more cordially loves a union with Great Britain than I do. But, by the God that made me, I will cease to exist before I yield to a connection on such terms as the British Parliament propose; and in this, I think, I speak the sentiments of America.

It was not " dependence," therefore, to which Jefferson, in 1775 , objected, but the "cruel exercise" of power by Great Britain, claimed by it to be "legislative," and 
the "terms proposed by the British Parliament," for the continuance of the connection.

Burke, on November 16 , during the debate on the Bill to Prohibit Trade and Intercourse with America, proposed by the Ministry, renewed his previous measures for conciliation, by introducing a Bill intended to restore the Colonies to the situation in which they were at the close of the war in 1763 . The Bill was immediately rejected.

On December 7, 1775, Hartley, in the House of Commons, offered resolutions providing for the acceptance of the proposition of Congress that the Colonies should contribute to the Imperial defence in proportion as the restrictions on their trade were removed, provided the Acts taxing them were repealed, adding to them a proviso that the several Colonial Legislatures should, as a prerequisite to the repeal of the Acts of Parliament taxing the Colonies, register an Act of Parliament to the effect that "every slave in North America should be entitled to his trial by jury in all criminal cases," as an evidence of the submission of the Colonies to the exercise of some degree of power by Parliament of its own mere will,- - his purpose evidently being to counteract in this way the implication which would have arisen from an unqualified acceptance of the proposition of Congress, that the Empire was a Federal Empire, and thus to avoid a definition of the power of Parliament. In his speech in support of his resolutions he said:

The House having heard this most dutiful and affectionate petition to the King from their fellow-subjects in America, humbly supplicating his Majesty to become the mediator of peace between them and their Parent State, I hope that this, added to all the remembrance of our former friendships, to all the ties of consanguinity and derivation from one common stock, by which we claim a joint inheritance and equal right to peace, liberty and safety, will carry some favorable influence upon the heart of this House. 


\section{The Administration of Dependencies}

In these circumstances, it should seem well becoming the magnanimity and moderation of Parliament to endeavor to point out some definite mode and terms of reconciliation, in compliance with the prayer of that petition, pursuing the same spirit of peace which breathes through every line of it, and as a merited return for that confidential and respectful deference, by which they refer implicitly to his Majesty's wisdom and justice the mode and terms of accommodation, declaring in the most unreserved manner that, notwithstanding all their sufferings, they retain too tender a regard for the Kingdom from which they derive their origin, to request such a reconciliation as might in any manner be inconsistent with her dignity or welfare, and that his Majesty will find his faithful subjects in America ready, at all times, as they have ever been; with their lives and fortunes, to assert and maintain the rights and interests of his Majesty and of their Mother Country.

In the course of his speech, he made the following plea in favor of accepting the plan proposed by Congress, which, though based wholly on expediency, would have been equally pertinent and true if he had based it upon the requirements of justice, in view of the unwritten compact between Great Britain and the Colonies, as States, forming the Constitution of the Empire:

The introduction of requisitions in the time of peace is novel, and therefore must be expected to be attended with many consequential alterations in the constitutional connection of the Colonies with this country. I mean, upon the restrictions of their trade, which have hitherto been always accepted as an equivalent to pecuniary contributions. If we should put the Colonies upon a new footing of money contribution, in the time of peace, there can be no doubt but that this country will think them entitled to relaxations in trade, in proportion as they contribute. I have no doubt but that, in future times, we shall come to be convinced of the narrowness of that policy which thinks to cherish trade by restrictions. We shall see many of these poor expedients 
in the same light as we now do the little policy of Queen Elizabeth's reign, about corporations, apprentices, poor laws \&c. Therefore, though I might not have been the first supporter of this new system of contributions to peace requisitions, yet I think it promises to open a more liberal system than we are attached to now. The intercourse of one common cause in the common defence of the whole Empire, may form a new and salutary connection between Great Britain and her Colonies, instead of that connection by grievous restraints, which will become more galling, and appear more absurd every day. We shall have at least the choice of two modes of receiving their assistance, which we may exercise according to the discretion of the case, sometimes through the channel of trade, sometimes through supply. The option may easily be adjusted, without either strangulating the hand of industry, or closing the hand of contribution. Ireland, besides providing for its own internal establishment, provides annually, for the common defence, a considerable number of men in the land service. America may contribute the naval supply, being that part of the common concern which forms the common bond of connection between us. Seamen, ships or naval stores may be the contribution in America.

These resolutions of Hartley's met the same fate as those originally introduced by him.

The then existing political situation in Great Britain made it impossible for the British Government to accept any such view as the Congress proposed, of the powers of the King and the Parliament in the Empire. The Constitution of Great Britain was an unwritten Constitution, conceived of, it is true, as emanating from the whole people of that State, and distinguished from action merely legislative and executive, but it was only morally the supreme law of that State. A written Constitution, formed by a Constitutional Convention of the people of a State and legally supreme over all legislative and executive action within the State, was yet an experiment. British legislation and the British Constitution were 


\section{The Administration of Dependencies}

legally one and the same thing, - that is, the Acts of Parliament were legally the supreme law of the State of Great Britain,- as they still are.

Burke, although he admitted that there was a Constitution of the Empire (that is, a fundamental law conceived of as emanating directly from the people of the Empire), which was distinct from the Constitution and laws of Great Britain, and which it was the function of Great Britain, as the Imperial State of the Empire, to adjudicate and declare, held that this power was to be exercised ultimately by the British Parliament. As the House of Commons, by virtue of its power to dictate to the King the choice of the Ministry, was the ultimate power in Parliament, this proposition meant that the House of Commons was to adjudicate and execute the Constitution of the Empire-that that House, and not the King, was the Disposer of the Empire.

Lord North, while not admitting that there was any Constitution or laws of the British Empire distinct from the Constitution and laws of Great Britain, seems to have agreed that, if there was, Burke's theory was correct. This doubtless appeared to him to be a logical necessity from the proposition (which he was the first Prime Minister to admit) that the House of Commons had power to dictate to the King the choice of the Ministry. If that power was proper to be exercised by that House, it could only be because the House of Commons was the ultimate unconditioned and unlimited power in the State of Great Britain, and was, in legal contemplation, the people of the State of Great Britain assembled, and not their agent, - and hence was entitled to control the King in the exercise of all his functions, even his judicial functions, his treaty-making functions, and the functions which he exercised ex officio in the British Empire. That the unconditional and unlimited power of the House of Commons in the State of Great Britain appeared to him to be 
an insuperable obstacle to the adoption of the American theory of the conditional and limited power of the King and the Parliament in the Empire, as ex officio representatives and agents of the State of Great Britain acting as the Imperial State, was made evident in a speech delivered by him in the House of Commons on November 20 , 1775 , in which, while expressing his readiness to accept any reasonable plan of settlement, he said, as reported in the Parliamentary History:

That there were two grounds upon which every Minister ought to stand; the first was, that the King had an undoubted right of naming his own servants; the second, which formed the happiness of this country, that if the people, by their representatives, did really disapprove the measures of any Minister, to that degree that they would not go along with him, the King, however he might approve such Minister, could not carry on business by him, and must part with him.

The Congress took the position that a "Constitution" of the Empire which was not legally supreme for Imperial purposes over the Constitution of Great Britain was not a Constitution at all, but only special legislation of the British Parliament, and hence claimed that the Constitution of the Empire and all legislation and action in execution thereof were, in the nature of things, supreme for Imperial purposes over the Constitution and laws of Great Britain.

From this, the Congress deduced the corollary that, because the Constitution and laws of the Empire must necessarily conflict with the Constitution and laws of the State of Great Britain, and be supreme in all cases in which they so conflicted, the British Parliament, which was charged with the duty of adjudicating and declaring the Constitution of Great Britain and of enacting legislation in execution thereof, was necessarily disqualified from adjudicating and declaring the Constitution of the 


\section{The Administration of Dependencies}

Empire, and that the King of Great Britain, as the Chief Executive of the Imperial State, and ex officio the Chief Executive of the Empire, had the sole power and duty of adjudicating and causing to be executed, by appropriate legislation and executive action, the Constitution of the Empire. For the purpose of such executive legislation, they regarded the British Parliament, within the sphere allotted by the Constitution of the Empire to the Chief Legislature of the Empire, as being ex officio the Chief Legislature of the Empire.

The Congress recognized that the Constitution, laws, and customs of the State of Great Britain were in force in the Colonies except to the extent to which they were rendered inapplicable by the local circumstances and conditions, - as the Charters of the respective Colonies provided. The Constitution of the British Empire was, as they believed, based on the Constitution of the State of Great Britain-that is, on the great principles of justice and good government recognized and declared, at various times, and in various ways, in the history of the English and British people; and they also believed that the laws and customs of Great Britain, by which these great principles had been worked out in Great Britain, were to be considered as a guide in making Imperial dispositions, but were not to be binding on the Colonies where their local circumstances and conditions required a different working out of these principles.

The King, from the British standpoint that the power of the State of Great Britain was a power of legislation, or of adjudication of the terms of the Constitution of the Empire by Parliamentary action, was obliged to refuse to receive the petitions contained in the two Addresses of Congress to him. He was petitioned as the Chancellor or the Disposer of the Empire, having jurisdiction to enjoin the breach of the contract for personal services between the State of Great Britain and the Colonies, as 


\section{The Final Issue, I $775^{-1} 776$}

States. Had he received the petitions (or, to use a legal phrase, had he allowed the petitions to be filed in court), against the objection of the opposing party, he would have admitted that he had jurisdiction to give the relief prayed for, and would have been in duty bound to adjudicate the questions raised in the petitions. Upon such adjudication, it would have been the duty of Parliament and the Colonial Assemblies to conform their legislation to the decision, and, in case they refused to do so, it would have been the duty of the King to refuse to execute or to allow to be executed any Acts of Parliament or of the Colonial Assemblies inconsistent with the Constitution as so adjudicated and declared. This would have been for the King to oppose himself, as the ultimate power in the British Empire, to the House of Commons, the ultimate power in the British State. Lord North undoubtedly felt that he could not advise the King to enter into such a struggle with the House of Commons, which might endanger the peace of the State of Great Britain itself.

Such was the situation when the Declaration of Independence was framed. It was evident, that, in stating the causes of the dissolution of the political relationship between Great Britain and the Colonies, the refusal of the King to act as the Disposer of the Empire in adjudicating the terms of the unwritten Constitution of the Empire must be made the principal cause. Accordingly the Declaration was framed as a Bill of Impeachment of the then reigning $\mathrm{King}$ of Great Britain for nonfeasance and malfeasance in office as Disposer of the Empire.

Had the Declaration of Independence been drawn at the present day, when we are accustomed to the conception of the Federal State, composed of federally-equal States, and of the Federal Empire, composed of an Imperial State and federally-subject States, and of a "Constitution" as distinct from a "law" or a "statute," it would have been drawn as follows: 


\section{The Administration of Dependencies}

First: There would have been a preamble, in which the Colonies would have declared themselves to be and to have always been States in a permanent contractual relationship of subjection to the State of Great Britain, from whence it would have been inferred that the State of Great Britain and the Colonies constituted a Federal Empire under an unwritten Constitution, and that that unwritten Constitution was necessarily supreme over the Constitution of Great Britain as the Imperial State for Imperial purposes, and over the Constitutions of the respective Colonies as Member-States; and that the interpretation of this unwritten Constitution was, by the nature of things, vested in the King of Great Britain, as $e x$ officio. the Chief Executive of the Empire, acting through a suitable tribunal of experts; and that these adjudications were to be executed by the needful rules and regulations made by the King or by the legislation of Parliament acting within the sphere of action of the Imperial State as determined by the Constitution, and by the Colonial Assem. blies, acting within the spheres of action of subordinate Member-States, as so determined; and that the people of Great Britain, as the ultimate source of all authority in the Imperial State, were ultimately responsible to the Colonies for the failure of the King to adjudicate and of the King and the Parliament to execute the Constitution of the Empire.

Second: There would have followed this preamble a Bill of Impeachment of the King, charging him with refusal to acknowledge himself to be the Disposer of the Empire, charged with the duty of ultimately adjudicating and executing the Constitution of the Empire.

Third: There would have followed this Bill of Impeachment, a Bill of Impeachment of the People of Great Britain for acquiescing in the King's refusal.

Fourth: There would have followed these two Bills of Impeachment a Declaration of Dissolution of Political 
Copartnership between the State of Great Britain and the Colonies as States, for breach of the Articles of Copartnership-the Constitution of the Empire-by the State of Great Britain.

An examination of the Declaration shows that it contains exactly all these elements, though the facts and conclusions of the imaginary preamble above written are not contained in the preamble of the Declaration, but are scattered through it in various places. The declaration of the federally-subject statehood of the Colonies was necessarily implied in the statement of the Declaration that the British Parliament had attempted "to extend an unwarrantable jurisdiction over us." Jefferson originally wrote this clause "to exercise jurisdiction over these our States." As, however, the Declaration as originally adopted was entitled "A Declaration by the Representatives of the United States of America, in Congress Assembled," and was entitled as engrossed, "The Unanimous Declaration of the Thirteen United States of America," the word "us" meant "the Thirteen United States," and the expression "these our States" would have been tautological.

The whole passage in which this expression occurred, as originally drafted by Jefferson, expressed plainly the anti-Imperialist view of the political relationship. His words were :

Nor have we been wanting in attention to our British brethren. We have warned them from time to time of attempts of their Legislature to extend a jurisdiction over these our States. . . . We have reminded them . . . that, in constituting, indeed, our several forms of government, we had adopted one common King, thereby laying a foundation for perpetual league and amity with them; but that submission to their Parliament was no part of our Constitution, nor ever in idea, if history may be credited. 


\section{The Administration of Dependencies}

This was changed by the Congress so as to express the Federal-Imperialist view, and was made to read:

Nor have we been wanting in attention to our British brethren. We have warned them from time to time of attempts by their Legislature to extend an unwarrantable jurisdiction over us. We have reminded them of the circumstances of our emigration and settlement here.

The failure of the preamble to directly claim that the Constitution of the Empire was legally supreme in the Empire was also supplied by subsequent statements in the Declaration. The statement that the British Parliament was exercising an "unwarrantable jurisdiction" over. the Colonies inevitably implied a Constitution of the Empire supreme over the Acts of the British Parliament. Only by assuming the existence of a supreme Constitution of the Empire could the British Parliament be regarded as having "jurisciiction" over the Colonies; only by this assumption could the exercise of power in certain respects be regarded as the exercise of "unwarrantable jurisdiction," and in other respects as the exercise of "warranted jurisdiction." The Declaration declared that the King had "combined with others" (referring to the two Houses of Parliament and the Ministry) "to subject us to a jurisdiction foreign to our Constitution and unacknowledged by our laws; giving his assent to their acts of pretended legislation," for various purposes which were specified. The characterization of any Acts of Parliament as "acts of pretended legislation" inevitably implied that Parliament exercised its powers in the Empire under a Constitution which was the supreme law of the Empire. On that theory, and on that theory alone, could any Act of Parliament be called "an act of pretended legislation." If it was in excess of the powers granted to the Imperial State, or to Parliament, as its representative, by the people of the Empire assembled, in 
their Constitution, it was a pretence and a nullity and not legislation, because not in execution of the supreme law of the Empire.

The King was impeached by the Declaration for his refusal to act as the Disposer of the Empire. It charged that the Colonies had "petitioned" the King for "redress," and that he had not only refused, but had done many overt acts wholly inconsistent with his functions as Disposer of the Empire. A large part of the Declaration is occupied with the specification of these acts of the King, evidencing his refusal.

John Adams objected to describing King George III. in the Declaration as a tyrant, giving as his reason that he always believed him "to be, in his official capacity only, cruel."

The people of Great Britain were impeached by the Declaration because, though having the power to compel the King to fulfil his functions as Disposer of the Empire, they had acquiesced in his nonfeasance and misfeasance.

The Empire was, by the Declaration, declared to be dissolved on the initiative of Great Britain, and the independence of the Colonies, and their consequent existence as States, having full rights of sovereignty, was declared to have resulted from the dissolution.

Everything in the original draft which tended to show that the Colonies based their right to independence on a claim of right to political equality with Great Britain, or on a claim of right to secede from the Union with Great Britain, was stricken out, and words were inserted by Congress which conveyed the idea that the Colonies had always been subordinate Member-States in the British Federal Empire, and were willing and anxious to remain such; and that they were merely acquiescing in the abdication, by the State of Great Britain, of its functions as the Imperial State in the Federal Empire. 


\section{The Administration of Dependencies}

In the original draft, the first sentence began thus:

When in the course of human events it becomes necessary for a people to advance from that subordination in which they have hitherto remained, etc.

The change, in Jefferson's handwriting, made it read, as it finally read:

When in the course of human events it becomes necessary for one people to dissolve the political bands which have connected them with another, etc.

For Jefferson's words, "reject and renounce," as applied to the allegiance of the colonists to the King of Great Britain, Congress substituted the words "are absolved from," and for the words "dissolve and break off," as applied to the political connection, the words "is dissolved."

As Jefferson originally wrote the last clause of the Declaration, it read:

We, therefore, the representatives of the United States in Congress assembled, do . . . reject and renounce all allegiance and subjection to the Kings of Great Britain and all others who may hereafter claim by, through, or under them, and utterly dissolve and break off all political connection which may heretofore have subsisted between us and the people or Parliament of Great Britain, and finally we do assert and declare these Colonies to be free and independent States.

This language was rejected by the Congress, and they substituted the following:

We, therefore, the representatives of the United States in Congress assembled . . . do . . . solemnly publish and declare, that these United Colonies are, and of right ought to be, free and independent States; that they are ab- 
solved from all allegiance to the British Crown, and that all political connection between them and the State of Great Britain is, and ought to be, totally dissolved.

By changing Jefferson's words "the political connection between the representatives of the United States in Congress assembled and the people and Parliament of Great Britain" to "the political connection between these United Colonies and the State of Great Britain," Congress, in effect, declared that the British Empire in America, as it had formerly existed, had been a Federal Empire.

The blame for the whole situation was placed by the Declaration wholly on the King. He was recognized as the representative of Great Britain ultimately responsible for the performance of its functions as the Imperial State, and he was declared to have abdicated his functions, with the consent of the people of Great Britain; from whence it was concluded that the State of Great Britain had abdicated, as the Imperial State.

The Declaration of Independence was, therefore, a Declaration concerning Dependence. It opposed the Federal Empire, as the ideal of America, to the Unitary State, as the ideal of Great Britain. The British Declaration of Unconditional Dependence of I 766 was answered in 1776 by an American Declaration of Federal Dependence. The Declaration of Independence did not announce the proposition that all States are free and equal. It merely announced that all States are born free and equal, and hence not only capable of contracting, but incapable of entering into any relationship which is not contractual-that is, federal.

It was based on the theory that States, like individuals, may rightfully, and, under some circumstances, ought voluntarily to enter into a contract to submit to such judicious leadership and control, under proper conditions 


\section{The Administration of Dependencies}

and limitations, of a State qualified by its mental and physical endowment to lead and control, as may result in the general good of the States immediately concerned, and of the world at large.

It is interesting, as possibly showing how and when the word "disposition" came to be adopted in the American public law to express the function of the Imperial State in a Federal Empire, to notice that in the Proclamation of Congress of June I2, I775, appointing Thursday, July 20, I775, as a day of humiliation and prayer, issued shortly after Lord Chatham's Bill and Burke's and Hartley's resolutions must have reached America, the power of the Deity was described as a "supreme, universal, and superintending providence," and $\mathrm{He}$ is called "the Disposer of all events."

The Proclamation read in part:

As the great Governor of the world, by His supreme and universal providence, not only conducts the course of nature with unerring wisdom and rectitude, but frequently influences the minds of men to serve His wise and gracious purposes by His providential government; and it being at all times our indispensable duty devoutly to acknowledge His superintending providence; . . .

This Congress therefore, considering the present critical, alarming and calamitous state of these Colonies, do earnestly recommend that Thursday, the 2oth day of July next, be observed by the inhabitants of all the English Colonies on this Continent, as a day of public humiliation and prayer, that we may . . . offer up our joint supplications to the all-wise, omnipotent and merciful Disposer of all events. . . . that all America may soon behold a gracious interposition of Heaven for the redress of her many grievances, the restoration of her invaded rights $[$ and $]$ a reconciliation with the Parent State on terms constitutional and honorable to both.

In the Address to the People of Ireland of July 28, I775, the Deity was spoken of as "the Supreme Disposer of all human events." 
As William Hooper, of North Carolina, was chairman of the Committee which framed this Proclamation and also of that which framed this Address, the honor of having restored to the public law the word "dispose" as signifying the power to adjudicate and execute the judgment, seems to belong to him.

The final issue between Great Britain and the Colonies was, therefore, generally, whether or not the British Empire was a Federal Empire, and specifically whether or not there was a Constitution of the British Empire, and a law of the British Empire in execution thereof, which were supreme, for Imperial purposes, over the Constitutions and laws of the Imperial State and of all its dependencies.

The Colonies claimed that there was such an Imperial Constitution, and, as it was unwritten, they claimed that it necessarily followed as a corollary, that it was to be adjudicated and declared by the King of Great Britain, as ex officio the Supreme Disposer of the Empire, and was also to be executed by him, in the same capacity, by means of rules and regulations made by him and administrative acts done by and under him; and that the British Parliament, as ex officio the Chief Legislature of the Empire, had also the power, within the sphere allotted to it by the Constitution as so adjudicated and declared, to make rules and regulations, in the form of statutes, in execution of the Constitution.

As Great Britain did not admit that the British Empire was a Federal Empire, and hence did not admit that there was a Constitution of the Empire supreme, for Imperial purposes, over the Constitution of Great Britain, it did not admit the corollary. 


\section{CHAPTER XIX}

\section{THE AMERICAN EMPIRE PIANNED, I 776}

$\mathrm{W}^{\mathrm{H}}$

HEN it is recalled that it was Franklin who made the first draft of Articles of Confederation which was considered by the Congress, it is not surprising to find that it contained provisions establishing an American Empire, in which the American Confederation was to be the Imperial State. It was Franklin who made the original draft of the Plan of Union, which, as has been already noticed, provided for the establishment of an American Empire much more completely and distinctly than it did for the establishment of an American State. He was the foremost expansionist of his times. He published a Plan for Settling Two Colonies West of the Allegheny Mountains, in 1757, and by his Canada Pamphlet in 1762 saved Canada to Great Britain, when men of experience and influence in England, alarmed by the spirit of expansion in America shown by the Pian of Union, were advising that it should be yielded back to France in return for the diminutive, but highly cultivated and productive island of Guadaloupe.

In this first draft, presented to Congress on August 20, I775, Franklin inserted Articles securing to the Indian tribes the rights of uncivilized States dependent on the Confederation, and providing for the "planting of new colonies, when proper," by the Confederation. By another Article, which showed his remarkable faith in the possibility of the unlimited extension of a Confederation of States acting by a Congress of elected delegates, he provided for receiving into the Confederation, not only all the other British Colonies on the American Continent 


\section{The American Empire Planned, I776 351}

(Quebec,-then including Canada and the Northwest Territory,-St. John's and Nova Scotia, East and West Florida), but also the West Indies, the Bermudas, and even Ireland!

The Articles of this draft on these subjects read:

Article XI. A perpetual alliance, offensive and defensive, is to be entered into as soon as may be with the Six Nations; their limits to be ascertained and secured to them; their land not to be encroached on, nor any private or Colony purchases made of them hereafter to be held good; nor any contract for lands to be made, but between the Great Council of the Indians at Onondaga and the general Congress. The boundaries and lands of all other Indians shall also be ascertained and secured to them in the same manner, and persons appointed to reside among them in proper districts; and shall take care to prevent injustice in the trade with them; and be enabled at our general expense, by occasional small supplies, to relieve their personal wants and distresses. And all purchases from them shall be by the Congress, for the general advantage and benefit of the United Colonies.

Article V. That the power and duty of the Congress shall extend to . . . the settling all disputes and differences between Colony and Colony, about limits or any other cause, if such should arise, and the planting of new colonies when proper. The Congress shall also make such general ordinances as, though necessary to the general welfare, particular assemblies cannot be competent to, viz., those that may relate to our general commerce, or general currency; the establishment of posts; and the regulation of our common forces.

Article XIV. Any and every Colony from Great Britain upon the Continent of North America not at present engaged in our Association, may, upon application and joining the said Association, be received into the Confederation, viz., Ireland, the West India Islands, Quebec, St. John's, Nova Scotia, the Bermudas, and the East and West Floridas; and shall thereupon be entitled to all the advantages of our Union, mutual assistance and commerce. 


\section{$35^{2}$ The Administration of Dependencies}

The draft of Articles of Confederation reported on July 12, I776, by the committee appointed by Congress for the purpose, consisting of one member from each State, was, as we are told by Madison, and as the Secret Fournals state, written by Dickinson. It contained full and carefully drawn provisions intended to cover all the problems which then confronted the United States, growing out of their relations with external communities subject to their control. These provisions were as follows:

Article XIV. No purchases of lands, hereafter to be made of the Indians, by Colonies or private persons, before the limits of the Colonies are ascertained, to be valid. All purchases of lands not included within those limits, when ascertained, to be made by contracts between the United States assembled, or by persons for that purpose authorized by them, and the Great Councils of the Indians, for the general benefit of all the United Colonies.

Article XVIII. The United States assembled shall have the sole and exclusive right and power of . . . Regulating the trade, and managing all affairs with the Indians: Limiting the bounds of those Colonies which, by Charter or Proclamation, or under any pretence, are said to extend to the South Sea; and ascertaining the bounds of any other Colony that appear to be indeterminate: Assigning territories for new colonies; either in lands to be separated from Colonies and heretofore purchased or obtained by the Crown of Great Britain from the Indians, or hereafter to be purchased or obtained from them: Disposing of all such lands for the general benefit of all the United Colonies: Ascertaining boundaries in such new colonies within which forms of government are to be established on the principles of liberty.

Article XX. Canada, acceding to this Confederation, and entirely joining in the measures of the United Colonies, shall be admitted into, and entitled to all the advantages of the Union. But no other Colony shall be admitted into the same unless such admission be agreed to by the delegates of nine Colonies. 


\section{The American Empire Planned, I776 353}

In order to appreciate the significance of these words, it is necessary to understand the situation which existed at the time between "the Unired States assembled" and the regions which were in fact or in expectation under its control.

The five matters to be decided in the government of these regions were:

First.-The arrangements which were to be made with the Indian tribes. These tribes at the outbreak of the Revolution were, by treaty, under the protection of the State of Great Britain, but the protectorate was of that peculiar kind which is now described as a "protectorate over uncivilized regions" or a "constitutional protectorate" - that is, a political relationship between a State and an external community of so low a degree of civilization as to be unfitted for any form of government except a tribal form, under which the minor community is permitted to keep the form and ceremony of a half-sovereign State, while the dominant State has, in fact, the powers over the minor community which it would have if that community were a dependency of itself as an Imperial State-which powers, however, it refrains from exercising except upon emergency. This relationship is allowed to exist by the dominant State in order to carry on the government of the minor community with the least friction possible, until it arrives at a point of development where it can either be converted into a true dependency, or where its land and population can be incorporated with those of the dominant State.

Second.-The arrangements to be made with the Land Companies. The Vandalia Company, which Franklin had promoted, claimed two million five hundred acres just west of the Allegheny Mountains northeast of Virginia, by grant from the British Crown. A charter had been prepared, giving powers to the company as a colonizing company, which was ready except for the affixing 


\section{The Administration of Dependencies}

of the seals when the war broke out. Many Englishmen were interested in the company. The Ohio and Indiana Companies, which had been promoted by Arthur Lee and Samuel Wharton, claimed lands in the same region, under grants from Virginia and from the Indian tribes, which had been recognized by the Crown and merged in the grant to the Vandalia Company. The Illinois Company and the Wabash Company claimed large and indeterminate amounts of land on the Illinois and Wabash Rivers, by grant from the Indians. These Land Companies were inchóate colonies-“" new colonies."

Third. - The arrangements to be made for the part of the North American Continent which was dependent on the State of Great Britain at the outbreak of the Revolution, not included within the limits of any Colony or Land Company. These lands were "lands to be separated from Colonies and heretofore purchased or obtained by the Crown of Great Britain from the Indians, or hereafter to be purchased or obtained from them."

The charter-limits of some of the thirteen Colonies extended to "the South Sea," that is, to the Pacific Ocean; but the British Government, by the Proclamation of the King in Council of 1763 (issued soon after the Treaty of I763, which fixed the western boundary of the British possessions in America at the Mississippi River) had claimed that those provisions of the Charters which made the South Sea the western boundary were rescinded, and by that Proclamation had, by forbidding grants of land by the Colonies beyond the ridge of the Allegheny and Appalachian Mountains, practically fixed the western boundaries of these Colonies along the ridge of those mountains. These Colonies had, however, prior to the Proclamation of $176_{3}$, in fact "appropriated" land beyond the ridge of the mountains by including it within the boundaries of their counties and other municipalities. Virginia, in its Constitution adopted June 29, 1776, made 
an express claim to jurisdiction, as the Imperial State of an Empire, westward of the mountains to the Mississippi River, by declaring that its western boundary should be as fixed by the Virginia Charter of 1609 and the Treaty of 1763 "unless, by Act of the Legislature [of Virginia], one or more Governments be established westward of the Allegheny Mountains." By Dickinson's draft of the Articles of Confederation, Congress was to be given the power, which the King in Council had claimed, of "limiting the bounds" of the Colonies which claimed to the South Sea, and of "separating from" them the lands westward of the bounds so limited. The lands thus to be "separated from Colonies" constituted an enormous region extending from the Mississippi River on the west to the ridge of the Allegheny and Appalachian Mountains on the east, and from near the Gulf of Mexico on the south to the present northern boundary of the United States. It was realized by the Congress from the outset that if this region should be brought into a state of dependence on any European Power, it would be a menace to the existence of the Confederation, and if it should be kept permanently in dependence on the Confederation, or on a State or States of the Confederation, it would raise problems in government of the most serious kind. That it must, however, be held in a state of dependence during its settlement was evident. The proper provision to be made in the Articles of Confederation regarding this region was necessarily the most difficult. matter to be decided in the framing of the Articles.

The theory of Dickinson's draft was that this region belonged to the United States by manifest destiny and anticipated conquest, or by the Indian treaties. It did not claim the region under the Charters of the Colonies. The expression was: "Limiting the bounds of those Colonies which, by Charter or Proclamation, or under any pretence, are said to extend to the South Sea"- - the claims 


\section{The Administration of Dependencies}

under the Charters of the Colonies being thus treated as without foundation. The treaties with the Six Nations, by which they placed themselves under the protection of Great Britain, had been made with the King of Great Britain, but the United Colonies had been a party to these treaties, and the Committee of Thirteen seem to have treated the King as acting for the benefit of the United Colonies in making them.

Fourth. - The arrangements to be made in the case of Vermont, which had separated itself from New York, New Hampshire, and Massachusetts. On July 8, I777, a Convention in Vermont adopted a Constitution forming a permanent Government "on the principles of liberty,." which placed Vermont under the "direction" of Congress. The clauses relating to this subject were as follows :

It is absolutely necessiry, for the welfare and safety of the inhabitants of this State, that it should be, henceforth, a free and independent State; and that a just, permanent, and proper form of government should exist in it, derived from, and founded on, the authority of the people only, agreeable to the direction of the honorable American Congress.

The people of this State have the sole, exclusive, and inherent right of governing and regulating the internal police of the same.

Vermont was "a new colony within which forms of government are to be established on the principles of liberty." Doubtless, also, the Kentucky and Maine districts were regarded as falling within this description.

Fifth.-The arrangements which were to be made with the British and French settlements on the North American Continent and in the Bermudas and the West Indies, in case they should come to the United States as conquests resulting from the war, and with the Colonies in the Western region when they should have advanced 


\section{The American Empire Planned, I 776}

to a stage which entitled them to admission into the Union. These settlements were included under the description "Canada" and "any other Colony" not in the Union.

Article XVIII. of Dickinson's draft took up the first four problems in order.

First.-With respect to the Indian tribes, "the United States assembled," as the Imperial State, was to have the sole and exclusive right and power of regulating the trade and managing all affairs with them. These were exactly the powers that had been exercised over them by the State of Great Britain, through the King in Council. The regulations of the King in Council had extended only to the actions of white men with the Indians. The British Government had never attempted to regulate the dealings of Indians with white men, but had held the whole tribe responsible for the acts of each individual Indian. It had never regarded the agreements made with the Indian tribes as strictly treaties, but rather as fictitious treaties resembling actual treaties to the same extent as the Indian tribes resembled States. Such treaties were properly described as "affairs with" the Indians, which "the United States assembled" was "to manage" as the State of Great Britain had previously managed them.

In this specification of the powers of Congress over the Indian tribes, there was necessarily implied a recognition of the statehood of these tribes and of their federal union with "the United States assembled," as the Imperial State, in a relationship of subordination, each agreeing to isolate itself from the other because the two populations were on such different planes of civilization that free trade and intercourse would be harmful to both, and particularly to the weaker party.

The principle upon which this treatment of the Indian tribes was justified was the general principle, which the American Colonies had admitted throughout their contest 


\section{$35^{8}$ The Administration of Dependencies}

with Great Britain, that the Imperial State had the right, in its disposition of the affairs of the Empire, to isolate its dependent States from itself and from each other, by restrictions on trade and intercourse, to the extent necessary for the good of the States of the Empire immediately concerned, of the whole Empire, and of the world at large.

Second.-With respect to the Land Companies described as "new colonies," "the United States assembled," as the Imperial State, was given the sole and exclusive right and power of " assigning territories" for them. This was a power which had been exercised by the State of Great Britain, through the King in Council. As so many British citizens were interested in the Indiana and Vandalia Companies, it was evidently thought proper (as was afterwards actually recommended by the committee of Congress on the subject) that the grants should be cut down so as to be proportioned in size to the proportion of the interest of American citizens. The Indian grants to the Illinois and Wabash Companies were so indeterminate that they could not properly be recognized. For fear, therefore, lest the general provision giving governmental power over the region might operate as a recognition of the validity of these grants in full, it was evidently thought necessary to give this special power.

By describing the power of "the United States assembled" over the Land Companies as a power of "assigning territories" for them, their dependent statehood was recognized-the word "territories" being applicable solely to lands over which a State exercises its governmental power.

Third.-With respect to the parts of the American continent claimed by the United States, which were occupied by the Indians or which had been bought from them by the State of Great Britain and not yet appropriated to settlement,--which, as has been seen, included 
the whole of the unsettled parts of North America east of the Mississippi and northward to the Canadian frontier, -the provision was as follows:

The United States assembled shall have the sole and exclusive right and power of . . . disposing of all . . . lands [to be separated from Colonies and heretofore purchased or obtained by the Crown of Great Britain from the Indians, or hereafter to be purchased or obtained from them], for the general benefit of all the United Colonies.

The addition of the words "for the general benefit of all the United Colonies" was necessary from the fact that a large part of this region was claimed by particular States of the Union. Had this not been the case doubtless the expression "disposing of all lands" would have been left unqualified.

The region thus described as that which "the United States assembled" should have the power to "dispose of " was exactly the region which the American Colonies had regarded as within their Empire ever since 1750. According to the Plan of Union of 1754 , it was to be colonized by them, not by Great Britain. The prohibition by Great Britain of their colonization of the region, initiated by the Proclamation of 1763 and consummated by the Quebec Act of I774, was a common grievance of the Colonies which did more to unite them in opposition to Great Britain than any other infringement of what they believed to be their rights as Member-States of the British Empire. The words which the Congress should adopt to express the power of "the United States assembled," as the Imperial State of the American Empire, over this region, had to be chosen with the greatest care, in order that Great Britain might not charge the United Colonies before the whole world with bad faith in their protestations of a desire to continue parts of the British Empire as a Federal Empire. Had the words "the power of 
governing" or "the power of legislating for" the Western lands been used, the United Colonies, as United States, would have placed themselves before the whole world in a most disagreeable light. After claiming that they declared themselves independent on the sole ground that Great Britain had wrongfully claimed that its Central Government had unconditional and unlimited power in the British Empire, they would have immediately created an American Empire in which the Central Government of the American Confederation had unconditional and unlimited power, and their subsequent action would have belied their former.

The power of the King in his official capacity-that is, of the King in Council-over the Western region was described in the Annual Register of $17 \sigma_{3}$, in the passage heretofore quoted, as a power of "disposition." The power which the King exercised over "colonies and conquests" had been described by Attorney-General Thurlow, in the case of Campbell v. Hall, as a power "of disposition of the laws and property" of the country, and the Court in that case had held that this power of the King over conquests was conditioned and limited exactly as the Americans claimed that the power of the State of Great Britain over the American Colonies ought to be.

The power which the King, as the representative of the State of Great Britain, exercised over the American Colonies had been regarded by the Congress, in the Declaration of Independence, and the proceedings leading up to it, as a power to adjudicate and execute the unwritten Constitution of the Empire, which was exactly a power . to "dispose of" the affairs of the Empire. The King, in the exercise of these functions, was regarded by the Colonies as ex officio the Chief Executive of the Empire because actually the Chief Executive of the State of Great Britain. Nothing was more natural than that the Congress, which was the Chief Executive of the Confed- 


\section{The American Empire Planned, I776 36r}

eration, should be given the same powers in the American Empire that the King of Great Britain would have exercised in the British Empire had he actually performed in that Empire the functions which the Colonies considered it his duty to perform. By such a grant of powers the American Confederation would have been recognized as the Imperial State of an American Federal Empire, exercising its powers through the Congress as its Chief Executive. The functions of the Congress would have been to adjudicate and execute the Constitution of the American Federal Empire-a Constitution founded on the Constitution of the Confederation, but which differed from it to the extent that the local circumstances and conditions of the dependent States in the Western region might require.

"The coupling of the word "lands" with the expression "dispose of " did not confine the power of "the United States assembled" to merely making dispositions of the soil. Lands owned by the State differ from lands owned by a private individual. The latter owns only the "property" in the lands; the State owns both the "property" and the "jurisdiction." The power of the State to dispose of lands owned by it, is, therefore, both a right to dispose of the soil of the lands-of the right of property in them-and to dispose of the jurisdiction over them.

Considering, therefore, the immense significance that the expression used to describe the power of the United States over the Western region had; considering, also, that the draft of Articles of Confederation in which the power of the United States was defined to be a power "to dispose of the lands" in this region, was written by Dickinson, who was the originator of the conception of the Federal Empire; considering, also, that the expression "to dispose of " was the only expression in the English language which exactly expressed the character and 


\section{The Administration of Dependencies}

extent of the powers of the Imperial State in a Federal Empire, and that it was consecrated by a usage of more than a century and a half to express exactly a governmental power of this kind, it seems there can be no doubt but that the intention of the Committee of Thirteen was to declare to all the world, by the use of this expression, that the American Empire, which they were establishing over the Western region, should forever be and remain a Federal Empire, in which "the United States assembled" should be the Imperial State.

Anticipating the narrative somewhat, it is perhaps proper here to notice a somewhat striking corroboration of the interpretation which has here been placed upon the expression "to dispose of," as describing the power of "the United States assembled" over the lands to be acquired from the Indians in the Western region, by one who would naturally have been careful not to extend the proper meaning of the word-Thomas Jefferson. In a letter to James Monroe, of July 9, I786, Jefferson said, speaking of the plan for the government of the Northwest Territory:

With respect to the new States, were the question to stand simply in this form, How may the ultramontane territory be disposed of, so as to produce the greatest and most immediate benefit to the inhabitants of the maritime States of the Union, the plan would be more plausible, of laying it off into two or three States only.

Fourth.-With respect to the Vermont, Kentucky, and Maine districts, "the United States assembled" was given power to "ascertain" their "boundaries." The special difficulty with these cases was the ascertainment of boundaries. The question of the boundaries of Vermont had already become a pressing one. The States of New York, New Hampshire, and Massachusetts claimed, first, that Vermont had no existence as a distinct Govern. 


\section{The American Empire Planned, I776 363}

ment for any purpose, and, secondly, that, if it had, the boundaries claimed by it were unreasonable. The same difficulty existed with respect to the Kentucky and Maine districts, though to a lesser degree, since they were not so nearly surrounded by the existing States. This clause, if it had been adopted, would have recognized Vermont as a colony of the United States by describing it under the designation of "new colonies within which forms of government are to be established on principles of liberty."

There was contained in the expression "ascertaining boundaries" a recognition of the personality and dependent statehood of such "colonies." This expression was exactly the same as would have been used in a suit between individuals where boundaries of lands were in dispute. A State "alters" the boundaries of its municipalities. An international tribunal or an Imperial State "ascertains" the boundaries of States.

Fifth.-With respect to the British and French settlements on the North American Continent and in the Bermudas and West Indies, and with respect to the colonies of the United States in the Western region, the States of the Union-not "the United States assembled" were recognized as having the power to "admit into the Union," by a vote of nine out of thirteen. The case was met by Article XX. of Dickinson's draft, which, while allowing Canada to enter the Union "on joining in the measures" of the States of the Union, provided that "no other Colony shall be admitted in to the Union, unless such admission be agreed to by the delegates from nine Colonies."

"Admission into the Union" meant admission to representation in the Congress. Thus this Article related to an entirely different subject from the two preceding Articles. The "disposing of" the Western region, the "regulating of commerce and managing all affairs with" 


\section{The Administration of Dependencies}

the Indian tribes, the "assigning territories" for colonizing companies, the "ascertaining boundaries" for existing Colonies which had placed themselves under the protection of the Union, implied administration by the American Union, as the Imperial State, of States external to itself and forming with it a Federal Empire under an unwritten Constitution, of which Empire the Congress was the Chief Executive with such Chief-Legislative powers as were necessary to execute the Constitution of the Empire. Admission of Colonies into the Union meant an incorporation of them, as States, into the body and personality of the Union, so that they were represented by elected delegates in the Congress of the Union. The representation of Colonies admitted to the Union as States might, however, be unequal, as compared to the representation of the States originally in the Union, and thus a relationship between the original Union and the Colonies admitted on such unequal terms (called an unequal Union) might be formed which would, in many respects, resemble a relationship of dependency.

The condition of affairs between the United States and Canada at that time throws considerabie light on this Article. The situation was briefly this:

Among the many "Addresses" issued by the Continental Congress was one to " the People of Canada," urging them to join the Confederation. In the early part of 1776 , Franklin, Charles Carroll, and Samuel Chase (the two latter from Maryland), accompanied by Rev. John Carroll, a Jesuit priest from Maryland (afterwards Bishop of Baltimore), went to Canada, as Commissioners from Congress, to induce it to form a revolutionary Government and to join the Confederation. Their Instructions, given by Congress, permitted them to sign an agreement admitting Canada to the Union on the same terms as the other Colonies, and required them, in case it refused to come into the Union on these terms, to report 


\section{The American Empire Planned, I776 365}

any propositions which it might make for entering the Union on other terms. The various "Addresses" issued by the Congress were drawn by different hands, and, as it so happened, the Roman Catholic religion was bitterly attacked in all of them except the one to the people of Canada, à propos of the Quebec Act of I774, which had assured to the French inhabitants full liberty in the exercise of the Roman Catholic religion. When the Commissioners arrived, they found that they had to deal with the Roman Catholic priests entirely, they having full charge of the interests of the French inhabitants. The priests called attention to the attacks of the Americans on their religion and to the security they enjoyed under British rule, and politely refused to listen to the Commissioners. Franklin returned in advance of the other Commissioners, in time to take part in the signing of the Declaration of Independence, reporting that only one Canadian in five hundred could read, and advising that, if another Commission were sent, it be composed wholly of schoolmasters. After the Commissioners reported, there was no further idea of holding Canada except as a dependency.

On July I2, I776, when Dickinson's draft was reported by the Committee, though any equal union with Canada was hopeless, it was plainly necessary to renew, in the Articles of Confederation, the offer which had been made in the Address of Congress to the People of Canada.

Canada was, by the provisions of Article XX., to be " admitted into the Union" and also " to be entitled to all the advantages of the Union," that is, it was to be admitted on equal terms. "Any other Colony" was simply "to be admitted into the Union" in case such admission should be agreed to by nine States. The plain meaning of this was that the American Confederation might admit Canada into the Union on unequal terms, if it refused to accept equal terms, and that the Confederation might admit any other Colony except Canada 
into the Union on any terms whatever, and hence on unequal terms, if the Congress saw fit.

The word "Colony," in this Article, was evidently used in its most inclusive sense. The Article is plainly a revision of the Article in Franklin's draft on the same subject, in which he provided for receiving into the Union "any and every Colony from Great Britain upon the Continent of North America not at present engaged in our Association." The omission of all these qualifying words could only have been for the purpose of giving the word "Colony" its widest meaning. It meant, practically, any political community external to the American Union, which was under the governmental control of a European Power or of the American Union, as its Imperial State, and which was dependent for its existence in a condition of statehood upon the protection of its Imperial State. The word "Colony," therefore, referred to the States expected to arise in the Western region, as well as to all others. It applied also to States dependent on the United States which might become such by conquest, by cession, or by voluntary union in a relationship of dependency.

Over against the contrary view expressed by Madison in Chapter 43 of The Federalist, may be set the view of Jefferson expressed in his draft of the Plan of Government for the Northwest Territory, to which reference will be made hereafter, that the word "Colony" in this Article was intended to apply to the new States in the Western region. Jefferson was a member of the Continental Congress at the time the Articles of Confederation were debated. Madison did not become a member until after the Articles were adopted.

Dickinson's draft was debated in Congress, in Committee of the Whole, on parts of thirteen days between July 22 and August 20, I776, with the result that, on August 20, a new draft was reported by the Committee 


\section{The American Empire Planned, I776 367}

of the Whole, in which Article XIV. and all the part of Article XVIII. above quoted, except that clause giving power to Congress to regulate trade and manage the affairs with the Indians, were wholly omitted, and Article $\mathrm{XX}$. retained with certain verbal changes which did not affect its meaning.

The words of Article XVIII. which were stricken out were:

Limiting the bounds of those Colonies which, by Charter or Proclamation, or under any pretence, are said to extend to the South Sea; and ascertaining the bounds of any other Colony that appear to be indeterminate: Assigning territories for new colonies, either in lands to be separated from Colonies and heretofore purchased or obtained by the Crown of Great Britain from the Indians, or hereafter to be purchased or obtained from them; Disposing of all such lands for the general benefit of the United Colonies: Ascertaining boundaries in such new colonies within which forms of government are to be established on the principles of liberty.

These were the very words, and all the words of Dickinson's draft which related to the administration of dependencies - that is, which were intended to declare the existence of the American Federal Empire, and the powers of "the United States assembled" as the Imperial State of that Empire.

With these provisions omitted, the sole power of Congress over the whole question of the relationship between the American Confederation and other political communities related to it was contained in the words of Article XX., as amended, "but no other Colony shall be admitted into the Union except such admission be agreed to by nine States."

The principal reason for the rejection of these provisions seems to have been that the States were agreed 


\section{The Administration of Dependencies}

that there ought not to be any provision in the Articles which would give Congress power to determine the boundaries of any State of the Union, as between it and the Union. The Congress, as the representative of the Union, was, in such a case, disqualified by interest to act judicially. As there was no absolute necessity for inserting a provision in the Articles relating to the administration of dependencies unless the Union, as distinct from the States composing it, had or was immediately to have dependencies to administer, and as the Western region was the only region which it was reasonably to be expected would soon become dependent on the Union, there would have been an almost necessary implication, if any provision relating to the administration of dependencies had been inserted in the Articles, that it related to the Western region, and the Congress might very properly have claimed, under such a provision, the right to determine the boundaries between the Western region and the States of the Union, as an incident to its power to administer the region as a dependency.

It seems, however, that there was another good reason which induced the Congress to refrain from defining the powers of the Union over the Western region. The Congress, in framing the Articles of Confederation, was, in fact, sitting as the Constitutional Convention of the people of the Union. The Articles of Confederation were to be the permanent Constitution of the Union. This was particularly the case with respect to any provisions concerning the powers of the Union over communities external to itself. A policy in this respect outlined in the Articles of Confederation would bind the Union and its successors for all time. In attempting to define the powers of the Union in this respect, the question immediately arose whether the principles governing the political relationship between widely separated countries like Great Britain and America governed the politica! 


\section{The American Empire Planned, I776 369}

relationship between adjacent countries like the Union and the Western region.

It was recognized that the problem was a difficult one, and substantially the problem of the proper relationship between Great Britain and Ireland, - that is, the problem how a strong State can justly deal with a State, naturally dependent on it, whose manifest destiny is, at some time, either to have its land and population incorporated with the land and population of the stronger State so as to form a Unitary State, or to be admitted to an equal federal union with the stronger State or its component States, by equal representation in a common Parliament or Congress, so as to form a Federal State, but which is unfitted and will necessarily continue for many years to be unfitted for such an incorporation or admission to equal union. The new States which were expected to arise in the Western region were certain to be of this kind-naturally dependent on the American Confederation and manifestly destined at some time in the future for admission into the Confederation, on an equality with the old States in the matter of representation in the Congress, but certain to be unfitted for a longer or shorter period, by reason of their local circumstances and conditions, for equal union. In trying to work out this problem, England and Great Britain, though with unconditional and unlimited powers, had failed; and it undoubtedly seemed to the majority in Congress presumptuous to commit the Confederation to any policy whatever which, by restricting its powers, might embarrass it in working out the problem. Congress itself declared in its resolution of September 6, I 780, that the discussion of the question of the power of the Union over the Western region "was declined, on mature consideration, when the Articles of Confederation were debated."

The entire absence of any provision in the draft of 


\section{The Administration of Dependencies}

August 20, 1776 , determining the power of the Union over the soil and jurisdiction of the Western region, caused a delay in the agreement by Congress upon Articles of Confederation for a year and three months. The whole matter lay dormant from August 20, I776, until October I5, I777. On that day, three resolutions relating to the subject of the administration of dependencies were proposed, and, although all were lost, they were, in fact, the foundation of the whole policy of the United States towards the communities in the Western region, and were, in substance, acted upon subsequently as if they had been incorporated into the Articles of Confederation.

The first of these resolutions read:

That in order to render the present Union and Confederacy firm and perpetual, it is essential that the limits of each respective territorial jurisdiction should be ascertained by the Articles of Confederation; and therefore it is recommended to the Legislatures of every State to lay before Congress a description of the territorial lands of each of their respective States, and a summary of the grants, treaties, and proofs, upon which they are claimed, or established.

The yeas and nays were taken, and only New York, Pennsylvania, and Maryland voted in favor of the resolution.

This resolution was evidently regarded as the prerequisite to any statement in the Articles regarding the kind of power which the Confederation should exercise over the dependencies, because, although two resolutions were immediately offered expressing alternative theories of the policy to be pursued by the Union in the administration of the Western region, both were lost, and the yeas and nays were not taken, - the rejection of them evidently being considered a foregone conclusion after the vote on the first resolution. 


\section{The American Empire Planned, I776 37r}

The second resolution was:

That the United States in Congress assembled shall have the sole and exclusive right and power to ascertain and fix the western boundary of such States as claim to the South Sea; and to dispose of all land beyond the boundary so ascertained for the benefit of the United States.

Evidently this resolution expressed the view of the Federal-Imperialist party in Congress, who held to the theory of Dickinson that the Congress was the successor of the King in the Empire and, as such, had power over the dependencies, which they described as a power of "disposition."

The third resolution was:

That the United States in Congress assembled shall have the sole and exclusive right and power to ascertain and fix the western boundary of such States as claim to the Mississippi, or South Sea, and lay out the land beyond the boundary so ascertained into separate and independent States, from time to time, as the numbers and circumstances of the people thereof may require.

This resolution expressed the anti-Imperialist theory that the "States" were to "arise" in the Western region without the assistance or supervision of the Union, except that it should fix the boundaries of these "States," "from time to time, as the numbers and circumstances of the people thereof may require." This resolution, if it had been adopted, would have put the United States. in the power of the communities of the Western region, with the single reservation that it might gerrymander the country, from time to time, so as to divide or isolate, and thus weaken, those communities which persisted in acting adversely to the general interests.

As will be seen, the final policy was a compromise resulting from a modification of the plan proposed in the 


\section{The Administration of Dependencies}

first resolution, and a combination of the theories expressed in the last two resolutions.

The Articles of Confederation were agreed upon by Congress on November I5, I777, and on November I7, copies signed by the President of Congress were ordered sent to the Legislatures of the respective States for ratification. All reference to civilized dependencies of the Confederation was omitted, except so far as they were referred to in the Article relating to Canada and "other Colonies," which was retained as Article XI., and which read :

Canada acceding to this Confederation, and joining in the measures of the United States, shall be admitted into, and entitled to all the advantages of this Union; but no other Colony shall be admitted into the same, unless such admission be agreed to by nine States.

The Articles contained very elaborate provisions giving power to Congress to determine controversies between the States, but none giving it power to determine controversies between the Confederation and a State, and in order to prevent a proceeding for determining a dispute between States from being made a pretext by Congress for adjudicating the claims of territory as between the Confederation and a State, it was provided that "no State shall be deprived of territory for the benefit of the United States."

The only provision relating to the administration of uncivilized dependencies was contained in the power of "regulating the trade and managing all affairs with the Indians, not members of any of the States." In order to prevent Congress from determining territorial limits as between the Confederation and the States under pretext of "regulating the trade and managing all affairs with the Indians," it was made a proviso to this power 


\section{The American Empire Planned, I776 373}

that "the legislative right of any State within its own limits be not infringed or violated."

In spite of the fact that Congress "declined to discuss" the question of the administration of the dependencies of the Union at the time the Articles of Confederation were debated, the work of the Committee of Thirteen on this subject was not lost. They had, in fact, planned the American Federal Empire, and their plans were finally adopted. 


\section{CHAPTER XX}

THE AMERICAN EMPIRE DECLARED, I778

IF any proof is needed, other than Franklin's and Dickinson's drafts of Articles of Confederation, that it was the purpose of the United Colonies, from the moment when their independence became a matter of necessity, to form themselves into a Union of States which should be the Imperial State of an American Empire, all doubt on the subject is removed by the Treaties of Alliance and Commerce with France, signed February 6, I778, and ratified by Congress on May 5, I778. The Treaty of Alliance shows, beyond a doubt, that the American Union intended to reduce to its possession by conquest, and to hold permanently, all those parts of the American Continent external to the Union, which then belonged to Great Britain, and also the Island of Bermuda, as dependencies of the Union, or to incorporate these regions, as States, into the Union, according to its discretion-all conquests from Great Britain in the West Indies being set apart to France, to be held as its dependencies. The purpose of Congress in this respect was made clear so early as December 30, I776, by its Instructions to the Commissioners at the Court of France, directing them to secure, if possible, a clause in the treaty they were endeavoring to negotiate, which should provide that in case Cape Breton, Newfoundland, and Nova Scotia should be "reduced," "the Province of Nova Scotia, Island of Cape Breton, and the remaining part of Newfoundland" (one half) should be "annexed to the territory and government of the United States." 


\section{The American Empire Declared, I 778}

\section{In the Treaty of Alliance it was provided:}

Article V. If the United States should think fit to attempt the reduction of the British power remaining in the northern parts of America, or the Islands of Bermudas, those countries or islands, in case of success, shall be confederated with or dependent upon the said United States.

Article VI. The most Christian King renounces forever the Islands of Bermudas, as well as any part of the Continent of North America which, before the Treaty of Paris in $176_{3}$, or in virtue of that Treaty, were acknowledged to belong to the Crown of Great Britain, or to the United States, heretofore called British Colonies, or which are at this time, or have lately been, under the power of the King and Crown of Great Britain.

Article VII. If his most Christian Majesty shall think proper to attack any of the islands situated in the Gulf of Mexico, or near that Gulf, which are at present under the power of Great Britain, all the said isles, in case of success, shall appertain to the Crown of France.

Article XI. The two parties guarantee, mutually, from the present time and forever, against all other powers, to wit, the United States to his most Christian Majesty, the present possessions of the Crown of France in America, as well as those which it may acquire by the future treaty of peace; and his most Christian Majesty guarantees, on his part, to the United States, their liberty, sovereignty, and independence, absolute and unlimited, as well in matters of government as of commerce, and also their possessions, and the additions or conquests that their Confederation may obtain during the war, from any of the dominions now or heretofore possessed by Great Britain in North America, conformably to the fifth and sixth Articles above written.

In the Treaty of Commerce which accompanied the Treaty of Alliance and in the Instructions of Congress on which the Treaty of Commerce was based, the expression "subjects of the United States" was used-in the 


\section{The Administration of Dependencies}

latter, repeatedly. In the Instructions the phrase was "subjects, people, and inhabitants of the United States." In the Treaty the word "subjects" was coupled with the word " citizens" and "inhabitants." In the ninth Article, reference was made to the " states, provinces, and dominions of each party," thereby implying that the United States had or might have "provinces" or "dominions." In the seventh Article mention was made of places "within the jurisdiction of the United States or any of them," thus distinguishing between places within the jurisdiction of the United States and places within the jurisdiction of the respective States.

The Treaty of Alliance was a Declaration of the American Empire, supplementing the Declaration of Independence, which was a Declaration of the American State. The Treaty of Alliance was also an international recognition of both the American State and the American Empire, The French Commissioners objected to recognizing the sovereignty and independence of the United States, fearing that France would be embroiled in the disputes of the several States. The American Commissioners assured them that the Treaty should be construed as recognizing the sovereignty and independence of the American Union. The facts concerning this conference are narrated by Arthur Lee, one of the Commissioners, in his diary of the negotiations. This action of the Commissioners was quite in accordance with the action of the Commissioners appointed by Congress in September, I776, at the solicitation of Lord Howe, to confer with him under authority given him, as Commander-in-Chief of America, by the Act Prohibiting Trade and Intercourse with America. These Commissioners, under the Instructions of Congress, refused to confer except as Commissioners of the Union, and the conference came to an end. 
From the moment the French Treaties were signed, therefore, the American Union existed as an independent State de jure, for all international and Imperial purposes, and the American Empire existed in posse.

Had the American Empire rested wholly upon the foundation of the Declaration contained in the Treaty of Alliance, its character as a federal organism might well have been open to question. The contemporaneous public statement made by the Congress, however, on rejecting the proposals of the British Government for conciliation, in which were announced the principles which the American Union believed to be the true principles on which the administration, by any State, of its dependencies ought to be based, limited the meaning of the expression "dependent upon the United States" in the Treaty of Alliance, so that the American Union was thereafter inevitably and forever committed to the establishment of an American Empire which should be a federal organism. The proposals of the British Government and the action of the Congress upon them were, therefore, of such importance as facts bearing on the Constitution of the American Empire, that it is necessary to go into the history of them with some care. The facts were as follows:

The British Government, upon receipt of the news of the signing of the French Treaties, set themselves in earnest to the work of conciliation which they had had for some: time under consideration. Copies of the Bills agreed upon by the Ministry were sent, so as to arrive in advance of the Treaties, to Sir Henry Clinton, who had been appointed to succeed Lord Howe, as Commanderin-Chief of the British forces in America. The Bills were printed and authenticated by order of the British Commander-in-Chief, and were circulated in Philadelphia and elsewhere. General Washington sent printed copies of these Bills to Congress, which was then sitting at 


\section{The Administration of Dependencies}

York, and they were laid before that body on April 2I, I778. At that time Congress had no knowledge of the French Treaties, their first knowledge of them being obtained when the messenger arrived with them from France on May 2. They therefore regarded the drafts of Bills as containing an informal proposition from the British Commander-in-Chief under the Act Prohibiting Trade and Intercourse with America, and realizing that the Colonies were as yet only States de facto, being without international recognition, they considered the proposition on its merits-for this purpose referring the drafts of Bills to a committee of which Gouverneur Morris was made the chairman.

As Morris was the author of the clause in the Constitution of the United States relating to the administration of dependencies, a special interest attaches to his connection with the proceedings of Congress in rejecting the British proposals, considering in how vital a manner this action of Congress related to the American Empire. Morris was, at that time, a delegate from the State of New York, having been elected in the year preceding, when he was only twenty-five years of age. He was a member of a family which for many years had held a high social position in the city of New York, and which was noted for its conservatism. He had travelled extensively abroad as a young man, was a fine French scholar, and, as an ardent patriot, had, from the very first, thrown himself into the study of the true theory of the relationship between Great Britain and the Colonies. As a member of the New York Convention of 1774 , he had had an important, if not a leading part in bringing about the adoption of very conservative resolutions-equalled, indeed, in their conservatism, only by those of Pennsylvania, drafted by Dickinson-which based the whole power of Great Britain over the Colonies upon "necessity" and the nature of things, by the declaration: "That, from the necessity 


\section{The American Empire Declared, I 778}

of the case, Great Britain ought to regulate the trade of the whole Empire for the general benefit of the whole, and not for the separate interest of any particular part." He was a firm believer in a strong, dignified and orderly government. Upon his election to Congress, he immediately became a leader, especially in matters involving the foreign relations of the Union. As chairman of the committee appointed to report on the informal proposition contained in the published drafts of the Bills for Conciliation, he wrote the report of the committee, and the report was adopted by Congress.

The first Bill was entitled "A Bill for Declaring the Intentions of the Parliament of Great Britain, concerning the Exercise of the Right of Imposing Taxes within his Majesty's Colonies, Provinces and Plantations in North America." By the terms of this Bill it was to be "declared and enacted":

That from and after the passing of this Act, the King and Parliament of Great Britain will not impose any duty, tax or assessment whatsoever, payable within any of his Majesty's Colonies, Provinces and Plantations in North America, except only such duties as it may deem expedient to impose for the regulation of commerce; the net produce of such duties to be always paid and applied to and for the use of the Colony, Province and Plantation in which the same shall be respectively levied, in such manner as other duties collected by the authority of the respective General Courts, or General Assemblies, of such Colonies, Provinces or Plantations, are ordinarily paid and applied.

The second Bill was entitled "A Bill to Enable his Majesty to Appoint Commissioners with Sufficient Powers to Treat, Consult and Agree upon the Means of Quieting the Disorders now Subsisting in Certain of the Colonies, Plantations and Provinces of North America." 


\section{The Administration of Dependencies}

It provided for the appointment of Commissioners by the King with the following powers:

To treat, consult and agree with such body or bodies political and corporate, or with such assembly or assemblies of men, or with such person or persons, as in their wisdom and discretion they shall think meet, of and concerning any grievances or complaints of grievances existing or supposed to exist in the government of any of the said Colonies, Provinces or Plantations respectively, or in the laws and statutes of this Realm respecting the same; and of and concerning any aid or contribution to be furnished by all or any of the Colonies, Provinces or Plantations respectively, for the common defence of this Realm and the dominions thereunto belonging; and of and concerning such other regulations, provisions, matters and things, as upon mature deliberation of the said Commissioners shall be thought necessary and convenient for the honor of his Majesty and the common good of all his subjects: Provided, also, and be it further enacted and declared, That no regulation, provision, matter or thing so proposed, treated, consulted or agreed, shall have any other force or effect, or be carried further into execution, than is hereinafter mentioned and provided, until the same shall have been approved by Parliament.

By the proposed Bill, the Commissioners were to have power to proclaim a suspension of hostilities and to suspend the operation of all or any of the Acts of Parliament relating to the Colonies passed since the close of the war in $\mathrm{I} 76_{3}$, to grant pardons, and to appoint in each Colony a Governor and Commander-in-Chief, "to have, hold and exercise, during his Majesty's pleasure, the said offices of Governor and Commander-in-Chief in and for such Colony or Plantation respectively, with all such powers and authorities as any Governor of such Province heretofore appointed by his Majesty might or could have exercised."

In the report of the committee submitted the next day -April 22, I778-which was adopted by Congress, it was 


\section{The American Empire Declared, I778 38I}

recommended that the propositions contained in the Bills be rejected for the following reasons, among others:

The first of these Bills appears, from the title, to be a declaration of the intentions of the British Parliament concerning the exercise of the right of imposing taxes within these States. Wherefore, should these States treat under the said Bill, they would indirectly acknowledge that right, to obtain which acknowledgment the present war has been avowedly undertaken and prosecuted on the part of Great Britain.

Should such pretended right be acquiesced in, then, of consequence, the same might be exercised whenever the British Parliament should find themselves in a different temper and disposition; since it must depend upon those and such like contingencies, how far men will act according to their former intentions.

That the said first Bill, in the body thereof, contains no new matter, but is precisely the same with the Motion beforementioned [Lord North's Proposals of $\mathrm{r} 775$ ], excepting the following particular, viz., that by that Motion actual taxation was to be suspended so long as America should give as much as Parliament might think proper: Whereas, by the proposed Bill, it is to be suspended as long as future Parliaments continue of the same mind with the present.

From the second Bill it appears that the British King may, if he pleases, appoint Commissioners to treat and agree with those whom they please about a variety of things therein mentioned; but such treaties and agreements are to be of no validity without the concurrence of the said Parliament, except so far as they relate to the suspension of hostilities and of certain of their Acts, the granting of pardons, and the appointing of Governors to these sovereign, free and independent States. Wherefore, the said Parliament have reserved to themselves, in express words, the power of setting aside any such treaty and taking advantage of any circumstances which may arise to subject this continent to their usurpations.

The inhabitants of these States being claimed by them as subjects, they may infer, from the nature of the negotiation 


\section{The Administration of Dependencies}

now pretended to be set on foot, that the said inhabitants would of right be afterwards bound by such laws as they should make. Wherefore any agreement entered into on such negotiation might at any future time be repealed.

The Bills were introduced into Parliament by Lord North on February I7, and were passed on March 9. The first Act differed from the draft in the respect that it was entitled: "An Act for Removing all Doubts and Apprehensions concerning Taxation by the Parliament of Great Britain in any of the Colonies, Provinces and Plantations in North America and the West Indies," and that it contained a clause repealing the duties on tea.

The second Act differed from the draft in the respect that the general clause in the draft, authorizing the Commissioners to treat concerning "any other regulations, provisions, matters and things, necessary or convenient for the honor of His Majesty, and for the common good of all his subjects," was changed so that they were given power to treat concerning "any other regulations, provisions, matters and things, necessary or convenient for the honor of his Majesty and his Parliament, and for the common good of all his subjects" - thus prohibiting the Commissioners from conducting any negotiations which did not proceed upon the basis that Parliament had some power in the Empire. With the two Conciliatory Acts was enacted a separate Act repealing the Act of I774, which had deprived the Province of Massachusetts Bay of its elected House of Representatives.

The Declaratory Act of 1766 , which declared the power of Parliament to pass laws to bind the Colonies and their inhabitants "in all cases whatsoever," it was decided, after discussion in Parliament, not to repeal.

After the passage of the Conciliatory Acts, the text of the French Treaties was made known by the Ministry to Parliament, and the question was raised of authorizing 


\section{The American Empire Declared, $1778 \quad 383$}

the Commissioners to acknowledge the independence of the American States, it being perceived at once that the Congress would, in all probability, insist on that condition. Many who favored giving this authority to the Commissioners were influenced by the economic theories of Adam Smith, contained in his Inquiry into the Nature and Causes of the Wealth of Nations, published in 1776. In this work the mercantile system was denounced in toto, and universal free trade advocated. This extreme and radical view of the economic relationship between Great Britain and the American Colonies naturally led Smith to take an equally extreme and radical view of the political relationship. He advocated absolute independence for the Colonies, or if this were impracticable, the absolute incorporation of their lands and populations into the land and population of Great Britain, by granting them representation in Parliament, proportioned to their contributions to the Imperial defence and welfare. The latter alternative was substantially Pownall's plan, which, upon its proposition in 1768 , had been immediately rejected both by Great Britain and the Colonies.

Lord Chatham, on the day when this proposition was to come up in the House of Lords, - April 7, - had him. self carried to the House from a bed of sickness and suffering, and after making a magnificent protest against the proposed dismemberment of the British Empire, fell, stricken by apoplexy, as he rose to reply to his opponents. His death occurred about five weeks later-on May I I.

Lord Chatham was consistent to the last. In the previous November he had moved in the House of Lords an Address to the King for a cessation of hostilities in America, carefully limiting the purpose of it to the restoration of the relationship of dependency which existed in 1763 . On that occasion he said:

My Lords, no man wishes for the due dependence of Amer- 


\section{The Administration of Dependencies}

ica on this country more than I do. To preserve it, and not confirm that state of dependence into which your measures hitherto have driven them, is the object which we ought to unite in attaining. . . . In a due constitutional dependency, including the ancient supremacy of this country in regulating their commerce and navigation, consists the mutual happiness and prosperity both of England and America.

On June IO, I778, the three British Commissioners, the Earl of Carlisle, William Eden, and George Johnstone, sent to Congress copies of the Conciliatory Acts and of their Commission, together with a letter signed by them, which were received by Congress on June 13 . In this letter the Commissioners spoke of the French Treaties as "the insidious interposition of a power which has, from the first settlement of these Colonies, been actuated with enemity to us both," and proposed that the United States rescind the Treaties, because "it is notorious that they were made in consequence of the plans of accommodation previously concerted in Great Britain, and with a view to prevent our reconciliation and to prolong this destructive war." They proposed to enter into an "arrangement " on the following basis:

To consent to a cessation of hostilities, both by sea and land.

To restore free intercourse, to revive mutual affection, and renew the common benefits of naturalization, through the several parts of this Empire.

To extend every freedom of trade that our respective interests can require.

To agree that no military forces shall be kept up in the different States of North America, without the consent of the General Congress or particular Assemblies.

To concur in measures calculated to discharge the debts of America, and to raise the credit and value of the paper circulation.

To perpetuate our union by a reciprocal deputation of an 


\section{The American Empire Declared, I $778 \quad 385$}

Agent or Agents from the different States, who shall have the privilege of a seat and voice in the Parliament of Great Britain; or, if sent from Britain, in that case to have a seat and voice in the Assemblies of the different States to which they may be deputed respectively, in order to attend the several interests of those by whom they are deputed.

In short, to establish the power of the respective Legislatures in each particular State to settle its revenue, its civil and military establishment, and to exercise a perfect freedom of legislation and internal government, so that the British States throughout North America, acting with us in peace and war under one common Sovereign, may have the irrevocable enjoyment of every privilege that is short of a total separation of interests or consistent with that union of force, on which the safety of our common religion and liberty depends.

To this the Congress, through the President, replied on June I7:

Nothing but an earnest desire to spare the further effusion of blood could have induced [the Congress] to read a paper containing expressions so disrespectful to his most Christian Majesty, the great and good ally of these States; or to consider propositions so derogatory to the honor of an independent nation.

The Acts of the British Parliament, the Commission from your Sovereign, and your letter, suppose the people of those States to be subjects of the Crown of Great Britain, and are founded on the idea of dependence, which is utterly inadmissible.

The letter concluded by stating the disposition of Congress to negotiate regarding "a treaty of peace and commerce, not inconsistent with treaties already subsisting," when Great Britain should withdraw its fleets and armies or should explicitly acknowledge the independence of the States.

To this the Commissioners replied in a letter received 


\section{$3^{86}$ 'The Administration of Dependencies}

in Congress June 18,1778 , in which they said, speaking of the requirement that as preliminary, to any negotiation, the independence of the States should be acknowledged :

We are not inclined to dispute with you about the meaning of words; but so far as you mean the entire privilege of the people of North America to dispose of their property, and to govern themselves without any reference to Great Britain, beyond what is necessary to preserve that union of force in which our mutual safety and advantage consist, we think that, so far, their independency is fully acknowledged in the terms of our letter of the Ioth of June. And we are willing to enter upon a fair discussion with you, of all the circumstances that may be necessary to ensure or even to enlarge that independency.

We assure you that nu circumstance will give us more satisfaction than to find that the extent of our future connection is to be determined on principles of mere reason and the considerations of mutual interest, on which we are willing likewise to rest the permanency of any arrangements we may form.

Congress immediately resolved "that no answer be given to the letter of the British Commissioners."

The Commissioners, on October 3, I778, issued a "Manifesto and Proclamation" to be transmitted to the Assemblies of the respective States, in which they said:

To the members of the Congress, we again declare that we are ready to concur in all satisfactory and just arrangements for securing to them and their respective constituents the reestablishment of peace, with the exemption from any imposition of taxes by the Parliament of Great Britain, and the irrevocable enjoyment of every privilege consistent with that union of interests and force on which our mutual prosperity and the safety of our common religion and liberty depend. 


\section{The American Empire Declared, I778 387}

In the Proclamation, it was claimed that the Congress should have transmitted the proposals of the Commissioners to the General Assemblies of the several States. The French Treaties were referred to as "pretended foreign treaties which [the Congress] know are delusively framed in the first instance, and which have never yet been ratified by the people of this continent."

To the General Assemblies of the several States it was declared :

We offer to the Colonies at large, or separately, a general or separate peace, with the revival of their ancient Governments, secured against any future infringements, and protected forever from taxation by Great Britain. And, with respect to such farther regulations, whether civil, military, or commercial, as they may wish to be framed and established, we promise all the concurrence and assistance that his Majesty's Commission authorizes and enables us to give.

The Proclamation contained an offer of amnesty and pardon on yielding submission. It was, by its terms, to be in in force forty days- until November I I, 1778.

As soon as this Proclamation was brought to the attention of Congress, they issued a "Manifesto and Proclamation" in reply, which was practically a general denial that the Commissioners had ever made or could make a proposition which, if accepted, would have the result which they had claimed in their Manifesto; and, on October 26, I778, Congress appointed a committee consisting of Gouverneur Morris, as chairman, and William Henry Drayton and Richard Henry Lee, "to superintend the publication of such matters relating to the disputes, petitions and negotiations to and with the Court of Great Britain, and such notes and explanations thereon, as to them shall appear proper."

As chairman of this committee, Morris prepared a statement which, when printed, made a pamphlet of 122 


\section{The Administration of Dependencies}

pages. The pamphlet was entitled Observations on the American Revolution, and set out in detail all the Acts of Parliament and Congress, explaining their bearings one on the other, and showing that the denial by Great Britain of all moral or legal obligation in the exercise of its power over the Colonies, contained in the Declaratory Act of 1766 , which it was not proposed to repeal, stood in the way of any dignified relationship between that State and the Colonies.

From this pamphlet it is made clear beyond a doubt that the American States were willing, at all times, to treat for a return to a position of dependence on the State of Great Britain, on the terms that the British Empire should be declared to be a federal organism. After the French Treaties were signed on February 6, 1778, and especially after they were ratified on May 5, 1778, the Union, and its component States, were independent States de jure by international recognition, and could not have treated for a return to dependence except on the basis that the international obligations assumed by those Treaties should be fulfilled. The statement of Congress on this subject was as follows:

It is to be observed, that a circumstance had intervened between the resolutions of the $22 \mathrm{nd}$ of April and the receipt of the letter from the Commissioners. This was the arrival of the copies of Treaties entered into with his most Christian Majesty [the King of France], which was the first intelligence which had been received from Europe in the space of a year. The resolutions of the House, therefore, on the 22nd of April were founded simply on the firm determination, under no change of fortune whatever to recede from the Declaration of Independence of July, $\mathrm{I} 776$, and for this reason, as a preliminary to any treaty, it was required that Great Britain should either acknowledge our independence or withdraw her fleets and armies, because upon no other principle could America be said to possess that degree of equality and freedom which is essential 


\section{The American Empire Declared, I778 389}

to the validity of national compacts. The Treaty with France being out of the question, had these preliminaries been complied with, we should have been bound in honor, as we certainly were by inclination and the principles of humanity, to enter upon a conference for the purpose of sheathing the sword. But since by that Treaty the United States could not, upon a certain contingency, make either peace or truce without the consent of her ally, it became necessary to provide that any treaties to be made should not be inconsistent with the Treaties already subsisting.

In this pamphlet, the proposals of the Commissioners were taken up separately and criticised. Parliamentary regulations of trade, it was claimed, would inevitably be unfair to the Colonies and in the interest of Great Britain. The proposition not to keep a military force in America without the consent of Congress or the Colonial Assemblies was objected to because one Parliament could not bind a succeeding Parliament in this respect. The proposition concerning the debts of the Colonies was declared to be insufficient because furnishing no security that they would not ultimately be required to participate in the payment of the British debts. The proposition to allow reciprocal representation of Great Britain in the Colonial Assemblies and of the Colonies in Parliament was denounced in the following language:

The fourth offer is . . . to perpetuate our slavery, by taking from us, on the one hand, the objection against their tyrannous acts, that we were not represented in the Legislature which passed them, though in fact such representation would be merely illusory and ineffectual; and on the other, by sending Ministerial Agents, artful, plausible and wicked, to influence the debates of our Legislatures, and give a voice among the immediate representatives of the people on matters even of the most internal nature. No greater insult was ever offered to the common sense of mankind. Had the proposal, particularly the latter part of it, been made before the 
commencement of the contest, it was sufficient in itself to have roused us to arms.

The proposition to establish the powers of the Colonial Legislatures in certain respects was objected to because the claim of unconditional and unlimited power of Parliament was not given up, and a subsequent Parliament might overturn any Colonial legislation.

All these objections reduced themselves to two-that the Colonies would never consent to form component parts of the British Empire, so long as Great Britain claimed unconditional and unlimited power over them, and that they would never, under any circumstances, consent to be represented in the House of Commons or to have Great Britain represented in the Colonial Houses of Representatives. This was simply another way of saying that the States of the American Union would never again become component parts of the British Empire, unless that Empire was declared to be a federal organism, of which the States of the Union were MemberStates, and would never, under any circumstances, consent that their lands and populations should be merged with the land and population of Great Britain.

The proposition of the British Government was a proposition to convert the British Empire into a decentralized unitary organism - that is, into an organism in which the dependencies would derive all their rights from the will and grant of the Parliament of Great Britain, (not from the nature of things), but in which the general principle of local self-government would be recognized, so far as the Parliament saw fit. The American Union, through its Congress, insisted that the rights of the American Colonies were natural rights to be political persons, that is, States, and were not derived from the will and grant of the Parliament or the State of Great Britain; and that the only power of Great Britain was to adjudi- 


\section{The American Empire Declared, I 778}

cate and execute the unwritten Constitution of the Empire, which defined the character and extent of their rights, as States; and therefore refused to assent to become parts of the British Empire on the terms proposed.

The negotiation resulted in the perception of the great and fundamental distinction upon which the whole conception of the Federal Empire was based-the distinction between conditional and limited power. The power of the Imperial State in the Federal Empire was recognized as being not a limited, but a conditional power, by defining the "subjection" of the American Colonies to Great Britain to be a "conditional subjection."

The whole philosophy of the Federal Empire, as a political organism, was summed up in the first pages of the pamphlet in the following words:

The right of a State over its own members has been brought into question; and there are not wanting authorities to show that citizens who renounce allegiance and protection may fly from the territories of the State, and erect new independent Governments in new countries. Be this as it may, the point is clear, that when the consent of Government is obtained, the individuals are again in a state of nature; alike free either to submit to a society existing, or to establish one, as their interest or their inclination may prompt. Here then is the situation of those who, wearied with the contentions and oppressions of the old world, boldly threw themselves upon the protection of Providence to explore the new, and traversed the ocean to inhabit a wilderness amid nations of barbarous foes. These first adventurers, inspired by freedom, supported by industry, and protected by Heaven, became inured to toil, to hardship, and to war. In spite therefore of every obstacle, they obtained a settlement; and then turned their attention to the security of those equal rights for which they had encountered so many perils and inconveniences. For this purpose they framed independent Constitutions; and these, however different in form, were all inspired by the same spirit, 


\section{The Administration of Dependencies}

and all founded on that eternal maxim of free Governments, that no man can be bound by laws to which he does not consent. These little republics soon began to flourish with a vigor and beauty adequate to the radical energy of their first principle. Of consequence they became a desirable object to that genius of enterprise which had animated the monarchies of Europe. On the other hand, their weakness required some ancient trunk to support them for a while in the storm of ambition. Our ancestors, therefore, stimulated by their necessities, and seduced by ancient habits and the remembrance of former friendships and connections, were easily prevailed on to subject themselves to the King of England, in consequence of his solemn promise to afford them protection, in common with all his other subjects, against foreign force and internal violence. The British Colonies then, under that name, were in fact so many independent States, whose only political connection with each other, and with the several. parts of the British Empire, was by means of a common Sovereign.

As a free people, we could not be bound by the arbitrary edicts of the Prince: by still stronger reasons we could not be bound by the more arbitrary edicts of our fellow-subjects: and of consequence, although the Prince and our fellowsubjects should join against us whatever force they might acquire, they could acquire no right by the union.

We had, on every principle, a right to become independent, particularly if the Crown should violate those contracts which formed the basis of a union. For let us suppose that when our ancestors quitted Europe, they went on the general principle of disclaiming allegiance to and protection from the several States of which they were subjects, or that they came hither with the permission of those States, and even under a contract with the King of England. And when they arrived here, let us suppose that they established independent Governments which afterwards became subject by agreement, or that a conditional subjection was interwoven in their frame;-still the existence of the contract remains unimpeached; or even 
on a supposition that they had actually bargained for unconditional submission, still that bargain would have been from its very nature void as to them, or if not to them, at least to their offspring; and of consequence from the principle of all free societies, the contract will still result. And it being evident that the two countries not only had not, but really could not have (on free principles) any political connection but thro' the Prince, so that right [of resistance to arbitrary power] exercised in the Revolution of England, demonstrated since, and generally admitted, must necessarily draw with it the right to independence, which is above stated.

This statement may thus be summarized:

If the Colonies were, from the first instant of their settlement, independent States (which was the anti-Imperialist theory held by the American radicals), their subjection to the State of Great Britain was necessarily the result of a contract between them and the State of Great Britain, which, being made between free and equal political persons, and intended to create a permanent relationship between them, was conclusively presumed to have been made on terms just and beneficial to both. Their continuance in the relationship of subjection was, therefore, conditional upon both parties agreeing concerning the just terms of the contract, or, in case of disagreement, upon a just and impartial adjudication of its terms and a fulfilment of the contract, as so adjudicated, by the State of Great Britain.

If the Colonies were, from the first instant of their settlement, dependent States - if "a conditional subjection was interwoven in their frame "- (which was the Federal-Imperialist theory held by the American conservatives), their subjection was under a contract "implied in fact," that is, implied from the circumstances, upon the same terms as would have been agreed upon by the parties, had they treated on an equality, and was conditional in exactly the same way as if the contract had been between equal parties.

If the Colonies were States which, at the time of their settlement, agreed to unconditionally subject themselves to the will 


\section{The Administration of Dependencies}

of the State of Great Britain (which was the theory of the British Government), this contract was either entirely void, or void as to the successors of those who made it, and a contract "resulted," that is, was implied by law and justice, out of the existing circumstances, as the result of the avoidance of the original contract, on the same terms as would have been agreed upon by the parties had they treated on an equality. Their subjection in this case, also, was conditional in exactly the same way as if the contract had been between equal parties.

The relationship was therefore not through the King as a natural person, who, in case of disagreement between the parties concerning the terms of the various contracts and the common contract, forming the Constitution of the Empire, could only exercise the influence of a friendly third person or Mediator, but through the King in his official capacity- "the Prince" or "the common Sovereign," as Morris expressed itwho had actual power in adjudicating the terms of the contracts forming the Constitution of the Empire, as the Disposer of the affairs of the Empire, and of executing them on betalf of the State of Great Britain, by analogy to the power of making, interpreting and executing treaties with foreign States, which he exercised as the expert part-the Crown-of the State of Great Britain.

As the Parliament of Great Britain was not inentioned in this statement, it was necessarily implied that its only power was to effectuate, by rules and regulations in the form of laws, the adjudications of the Crown concerning what was needful to be done by Great Britain, as the Imperial State, in the performance of its part of the contract with the Colonies, as Member-States, and that it had no direct power to interpret or change the contract, being from its nature unfitted to perform functions of a kind requiring expert knowledge and investigation. It was equally implied in the statement, however, that the Colonial Assemblies could not interpret or change the terms of this contract, they being 
likewise unfitted from their nature to perform functions of this kind.

This definition of the "subjection" of the Colonies as a "conditional subjection" by Gouverneur Morris entitled him to be regarded as the leader of thought in all matters respecting the American Empire. He had gone deeper than any one else, and had stated the universal principle. The power of the Imperial State was conditional, he said, over independent States which became dependent. Hence it was conditional over States which were voluntarily dependent. It was conditional, he said, over those which were dependent from their first settlement. Hence it was conditional over colonies. It was conditional, he said, even over States which had once accepted a relation. ship of absolute and unconditional submission. Hence it was conditional over conquests.

This conditional or contractual subjection which Morris claimed was the ultimate result of every possible theory of the original relationship between Great Britain and the American Colonies was a conditional or contractual subjection of them, as States-that is, a federal subjection, since "federal" is the word particularly appropriated to express the idea of "contractual between States." The final word of the American Union to Great Britain, therefore, was a Declaration that the States of the Union would never consent to anything less than a federal subjection to the State of Great Britain-that is, a contractual or conditional subjection, not of the inhabitants of the States of the Union to the State of Great Britain, or to its Government, or to its inhabitants, but of the States of the Union, as States, to the State of Great Britain.

By this Declaration, made almost contemporaneously with the Declaration contained in the French Treaty of Alliance that the American Union proposed to hold its conquests as dependencies, the American Union bound itself and its successors, forever, by all the obligations 


\section{The Administration of Dependencies}

of national good faith, to treat every community external to and connected with the Union, as a State in a relationship of federal subjection.

The statement of the reasons upon which the Colonies declared themselves independent contained in the Observations on the American Revolution, and approved by Congress, may be called the Declaration of Independence of I778. As a later document, it interprets and governs the Declaration of 1776 , where that document is ambiguous, as it is in the much-discussed passage of the preamble which states, as a self-evident truth, that, in order to secure to the individual the natural rights of life, liberty, and the pursuit of happiness, "Governments are instituted among men, deriving their just powers from the consent of the governed."

This statement is capable of being interpreted as meaning that Governments derive their just powers from the mere will of the governed, or that they derive their just powers from an agreement, compact, or contract (consensus) between the Government and the governed. The Declaration of 1778 settled this ambiguity, by declaring that the theory of America was that all Governments derive their just powers from an agreement, compact, or contract between the Government and the governed. The Declaration of 1776 stated the axiom of the original freedom and equality of all human beings, and advanced from that to the corollary that Governments derive their just powers from the consent of the governed. The Declaration of $\mathrm{I} 778$ supplied the intermediate corollaries between the axiom and that corollary. Because all men were originally free and equal, it followed as a corollary (since the proposition that a free and equal human being could ever be subject to the mere will of another free and equal human being is a self-evident contradiction and absurdity), that all human relationships resulted from a meeting of wills, - that is, from a compact or contract 
between the persons in relationship. As Governments were human beings and the governed also human beings, it necessarily followed that all relations between Governments and the governed were founded on agreement, compact, or contract (consensus) between the Government and the governed.

The Declaration of 1778 also declared that the contract which was the basis of the relationship between the Government and the governed might (like every other contract creating a human relationship) be express or implied -and, in the nature of things, any contract may be written or unwritten.

An agreement between the Government and the governed is a "Constitution" of government. Though written Constitutions usually are given the unilateral form, so that they appear as powers of attorney from the governed to the Government, they would more properly be given the bilateral form. They are, in fact; given this bilateral form when they provide for the formal acceptance, by the Government, of the Constitution, by requiring the persons who form the Government to take an oath to fulfil the Constitution.

The Declaration of 1778 admitted, by necessary implication, that, if the Constitution was reduced to writing, the terms of the writing governed as in other cases of contracts. If not, the contract was to be proved by the words and acts of the parties or was to be implied out of the circumstances, and in case of disagreement between the parties concerning the interpretation of the contract, or concerning what was just and reasonable, when the parties left the terms indefinite, it was to be interpreted and adjudicated by an impartial expert tribunal.

As applied to the American Empire, the statement in the Declaration of Independence that, in order to secure to the individual his natural rights, "Governments are instituted among men, deriving their just powers from the 


\section{The Administration of Dependencies}

consent of the governed," required that the State of America (whether called by the name of "the American Union," " the United States assembled," or " the United States of America," or by any other name), when occupying the position of the Government for other States, as its dependencies, should regard itself as being in a relationship of constitutional connection with them, so that all together would constitute a Federal Empire, in which the American Union would be the Imperial State and would act under an unwritten Constitution of the Empire, supreme, for Imperial purposes, over its own Constitution and the Constitutions of the Member-States, which it was obligated to interpret, adjudicate, and execute, for the benefit of all parties concerned.

Neither the Declaration of Independence of 1776 nor that of 1778 had anything to say concerning the manner in which the Government should be distinguished from the governed. They did not say that Governments derived their original existence from the will and act of the governed, but only that they derived their " just" powers from the "consent" of the governed. In both these instruments, the relationship of Government and governed was taken for granted, and they were merely concerned with declaring the duties of Governments. They therefore had nothing to say concerning whether, in a given case, the American Union should or should not act as the Government for other States. They declared, however, that if Great Britain had been willing to admit that its powers over the American Colonies were exercised under an unwritten Constitution securing to the Colonies their rights as States, and to the inhabitants of the Colonies their rights as individuals, and had in fact so exercised them, its exercise of power over the Colonies would have been just. As Great Britain had elected itself the Imperial State of the British Empire, the Declaration of Independence necessarily implied that the American 


\section{The American Empire Declared, I 778399}

Union might justly elect itself the Imperial State of the American Empire if it saw fit, provided the American Empire were recognized as a Federal Empire.

From the moment of the issuance of the Declarations of Independence of 1776 and 1778 , the obligations of the American Union could not be fulfilled by merely granting to its dependencies, of its mere will and favor, local self-government as municipal corporations, but could only be fulfilled by recognizing them as States having, by the nature of things, the fullest and most complete rights of statehood consistent with the welfare of the whole American Federal Empire, composed of the American Union, as the Imperial State, and its dependencies. How complete the rights of statehood of the federally-subject Statesthe Member-States of the American Federal Empire,should be, it was for the American Union, as the Imperial State, to adjudicate, and by its dispositions, made by its impartial and expert tribunal, fairly and after opportunity of the federally-subject States to be heard, they were bound, in equity and good conscience. 


\section{CHAPTER XXI}

THE, DISPOSITIVE POWER, I779-I 783

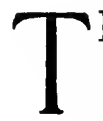

HE Congress of the American Union came into existence as a body of delegates from the Colonies, assembled to devise means for making an effectual protest against the claims of Great Britain, as the Imperial State. After the Declaration of Independence, it was continued by common consent, and without any express definition of its powers. What its powers were could only be ascertained from a consideration of what the powers of such an assembly, under such circumstances, ought, in the nature of things, to be. There seems, however, to have been little doubt felt, in the Congress itself, concerning the nature of its powers. It seems to have been the unanimous sentiment that the Congress was the successor of the King of Great Britain in his official capacity. It is beyond the limits of the study here undertaken to show how this conception of the power of Congress was applied as between the Congress and the States of the Union, though that it was applied admits of no doubt, - the powers given to Congress by the Articles of Confederation being almost exactly those which the King in Council exercised or had exercised in the State of Great Britain. Bancroft, in his History of the United States, has referred to this fact, in his chapter on the Articles of Confederation. Prefacing his examination of the Articles, he says:

According to the American theory, the unity of the Colonies had, before the Declaration of Independence, resided in the 


\section{The Dispositive Power, I779-I783 40 I}

British King. The Congress of the United States was the King's successor, and it inherited only such powers as the Colonies themselves acknowledged to have belonged to the Crown.

That the Congress regarded itself as authorized to exercise the same powers over the dependencies of the Union as were exercised by the King in Council over the American Colonies prior to 1763 is proved by various acts and documents.

The memorial of the Indiana Company filed September I4, I779, asked that Congress direct an order against Virginia

to stay the sale of the lands in question, till Virginia, as well as the memorialists, can be heard before this honorable House and the whole rights of the owners of the said tract of land called Vandalia, of which Indiana is a part, shall be ascertained in such a manner as may tend to support the Sovereignty of the United States and the rights of individuals therein.

The committee of Congress reported, on the remonstrance of Virginia, that they could not find " any such distinction between the question of the jurisdiction and the merits of the cause, as to recommend any decision upon the first separately from the last "-in other words, that the whole question was one of jurisdiction.

Franklin, in his memorial on behalf of the Vandalia Company, filed in February, I780, used the word "Sovereignty" to describe the power of the Union over the Western region. His words were:

As your Honors have now succeeded to the Sovereignty of the territory in question, your memorialists confide that you will think it just and reasonable to consider the said lands as subject to such contracts and dispositions as were made concerning them while they confessedly belonged to the British Crown; and that your memorialisis and their associates, who have ever 


\section{The Administration of Dependencies}

been ready to fulfil their parts of the said contract, may not suffer such great injury by the change of Sovereignty as to be deprived of their equitable rights to the said lands.

He asked that the lands be granted to the persons interested in the Vandalia Company either upon the terms and conditions of their contract with Great Britain approved by order of the King in Council (which contract, as has been said, was ready for delivery with the exception of affixing the seals when the Revolution broke out), " or upon such other terms as may be convenient to the interests of the United States and not injurious to your memorialists and their associates."

The form of this memorial was exactly such as might have been addressed to the King in Council before the Revolution, and the word " Sovereignty" plainly meant the power which the King, as Sovereign, had previously exercised and not "sovereign power" in the sense of unlimited, unconditional power.

The first statement of the Congress on this subject was contained in the Instructions given by it on October I7, I780, to the Ministers Plenipotentiary of the United States at the Courts of France and Spain, regarding the claims of Spain to the Western region. These Instructions were reported by a committee consisting of James Madison, John Sullivan of New Hampshire, and James Duane of New York. Spain, on January 31, I780, through the French Minister, had expressed a willingness to enter into a treaty of alliance with the United States and France, providing the United States would admit that the western limits of the Confederation extended only so far as there had been actual settlements from the Colonies prior to the Proclamation of the King made in I763, closing the Western region to settlement. Spain based its claim on the propositions that the United States had no possession of the region beyond those limits be- 


\section{The Dispositive Power, I779-I 783403}

fore the Revolution and that they could not claim " in the right of sovereignty of Great Britain " because they had "abjured the dominion" of that country.

To this the Ministers at the Courts of France and Spain were instructed to reply that the Mississippi was the boundary of the United States on the west because " by the definitive Treaty of Paris of I763, Article Seventh, all the territory now claimed by the United States was expressly and irrevocably ceded to the King of Great Britain; and the United States are, in consequence of the revolution in their government, entitled to the benefits of that cession."

The Instructions then proceeded:

The first of these positions is proved by the Treaty itself. To prove the last, it must be observed that it is a fundamental principle in all lawful Governments, and particularly in the Constitution of the British Empire, that all the rights of Sovereignty are intended for the benefit of those from whom they are derived, and over whom they are exercised. It is knowm also to have been held for an inviolable principle by the United States, while they remained a part of the British Empire, that the Sovereignty of the King of England, with all the rights and powers included in it, did not extend to them in virtue of his being acknowledged and obeyed as King by the people of England, or of any other part of the Empire, but in virtue of his being acknowledged and obeyed as King of the people of America themselves; and that this principle was the basis, first of their opposition to, and finally of the abolition of his authority over them. From these principles it results, that all territory lying within the limits of these States, as fixed by the Sovereign himself, was held by him for their particular benefits, and must, equally with his other rights and claims in quality of their Sovereign, be considered as having devolved on them, in consequence of their resumption of the Sovereignty to themselves.

As further evidence in support of the opinion of the Congress that their powers were the same as those 


\section{The Administration of Dependencies}

exercised prior to the Revolution by the King in Council, there may be cited the report made on August I6, I782, of a committee consisting of Daniel Carroll of Maryland, Edmund Randolph of Virginia, and Joseph Mont. gomery of Pennsylvania, appointed to report facts and observations to be referred to the Secretary for Foreign Affairs, "to be by him digested, completed and transmitted to the Ministers Plenipotentiary for negotiating a peace, for their information and use." In their report, the committee said:

If the vacant lands cannot be demanded upon the titles of individual States, they are to be deemed to have been the property of his Britannic Majesty, as Sovereign of the thirteen Colonies immediately before the Revolution, and to be devolved upon the United States collectively taken. The character in which he was so seized was that of King of the thirteen Colonies collectively taken. Being stripped of this character, his rights descended to the United States for the following reasons: I. The United States are to be considered in many respects as one undivided independent nation, inheriting those rights which the King of Great Britain enjoyed as not appertaining to any one particular State, while he was what they are now, the Superintending Governor of the whole. 2. The King of Great Britain has been dethroned as King of the United States, by the joint efforts of the whole. 3. The very country in question has been conquered through the means of the common labors of the United States.

While this report was not adopted, it is evident that it was not because it did not state the views of Congress, but because it was not thought proper at that time, while the States were still hesitating about ceding their rights in the Northwest Territory, for Congress to take a definite stand, which might prejudice the claims of the States against the Union. There is every reason to believe that if the claims of the States had not at the 


\section{The Dispositive Power, I 779-I 783405}

moment conflicted with those of the Union, this declaration of the rights of the Union over the Northwest Territory would have been unanimously adopted.

Gouverneur Morris, in a letter of January I, I783, to John Jay, who was then in Paris, and who was acting with Adams and Franklin in negotiating the definitive Treaty of Peace with Great Britain, said:

You and I differ about the Western country, but you and your Sovereign are of the same opinion.

On September I3, I783, while Congress was considering the report on the conditional cession of $178 \mathrm{I}$ made by Virginia, and there appeared to be some probability that it would yield to the conditions, Maryland presented a remonstrance of its Legislature, in which it was declared:

The United States have succeeded to the Sovereignty over the Western territory, and are thereby vested as one undivided and independent nation, with all and every pozerer and right exercised by the King of Great Britain over the said territory.

In the latter part of 1784 and the early part of 1785 , treaties were made with the Indians whereby a strip of land constituting about the east quarter of the present State of Ohio was opened to settlement by the extinguishment of the Indian title. The principal one, which was with the Wyandot, Delaware, Chippewa, and Ottawa Indians, was expressed in language which showed that the American Union regarded itself as a single nation, acting as the Sovereign and Imperial State over the Indian tribes, as native States, which stood to it in the relationship of constitutional protectorates. The second Article of the Treaty provided that:

The said Indian nations do acknowledge themselves and all their tribes to be under the protection of the United States, and of no other Sovereign whatsoever. 
John Jay, as Secretary for Foreign Affairs, on October 3,1786 , in a report to Congress concerning the right of the States to interfere with the execution of the provisions of the Treaty of Peace, said:

The rights to make war, to make peace, and to make treaties appertaining exclusively to the National Sovereign-that is, to Congress-your Secretary is of opinion that the thirteen State Legislatures have no more authority to exercise these powers or pass acts of Sovereignty on these points, than any thirteen individual citizens.

On April 13, I787, the Congress agreed to a letter, drafted by Jay, to be sent to the Legislatures of the States, in which it was said:

The thirteen independent sovereign States have, by express delegation of powers, formed and vested in us a general, though limited Sovereignty, for the general and national purposes specified in the Confederation. In this Sovereignty they cannot participate, except by their delegates, nor with it have concurrent jurisdiction; for the ninth Article of the Confederation most expressly conveys to us the sole and exclusive right and power of determining on war and peace and of entering into treaties and alliances etc.

Treaties derive their sole obligation from being compacts between the Sovereign of this and the Sovereign of another Nation.

It seems, therefore, to be clear beyond a doubt that the theory of the Congress and of the separate State Legislatures was that the American Union was the Sovereign - the Sovereign State-of the Western region, and that the Congress, as the sole agent and representative of the Sovereign State, fulfilled its functions and was, therefore, the effective and actual Sovereign of the Western region. The power of the Union over this 


\section{The Dispositive Power, I779-I 783407}

region measured the power of the Congress over the region, on the theory that the Union could grant to the Congress as its agent only such power as it itself had. As all power exercised by a Sovereign was recognized as being conditional power, the power of the Union, and of the Congress as its agent and representative, over the Western region, was recognized as being conditionalthat is, as being a power of disposition.

That the Congress regarded itself, at least from the moment that the Articles of Confederation were signed, as the constitutional Sovereign of the Union, exercising powers over the States of the Union, as persons, and over their inhabitants, which were in their character essentially judicial and conditional, is shown by the names which they adopted, immediately upon the signing of the Articles of Confederation, to designate their official acts. These names were "ordinances" and "resolutions." The former was used to designate those actions of the Congress which were of general and public interest, while the latter was used to designate those actions which related to matters of special or local interest, or which expressed the sentiments of the Congress on any subject.

The first action of the Congress which it described as an "ordinance" was taken on March 27, I78I, less than a month after the Articles of Confederation were signed. The preamble of this ordinance, which was entitled "An Ordinance Relative to the Capture and Condemnation of Prizes," was worded in such a manner as to show that the Congress regarded its powers as essentially judicative. It read :

The United States in Congress assembled, taking into consideration the implacable war waged against them by the King of Great Britain, and judging it inconsistent with their dignity as a free and independent nation any longer to continue the 
indulgence and exemptions to any of the subjects of their enemy, who is absolutely bent upon their destruction or subjugation, have thought it proper to ordain and order, and it is hereby ordained and ordered that henceforward general reprisals be granted against the ships, goods and subjects of the King of Great Britain.

The word "ordinance" is plainly a translation of the French word ordonnance. The Grand Vocabulaire François, says that the word ordonnance came into common use in 1287, during the time of Philippe le Bel. It adds that "it has been finally established in usage to express in general every law made by the Sovereign (le Prince)." In another place it says:

Ordonnance is used particularly of the laws and constitutions of the Sovereign Prince (Prince Souverain) . . . The power of making new ordinances . . . and of changing and modifying them, belongs in France to the King only. But as one cannot pay too much attention to the framing of ordinances, our Kings have the custom of taking the advice of learned and distinguished persons who are of their Council.

The ancient ordinances were made in two ways: some were resolved upon and decreed (arrêtées) in the Privy and Secret Council of the King; those which appeared to be more important were deliberated (deliberées) in Assemblies of larger number.

The Grand Vocabulaire gives as the original meaning of the word ordonnance the following: "[Latin] 'dispositio.' Disposition, arrangement (disposition, arrangement)." It gives as the original meaning of the verb ordonner, "[Latin] 'disponere.' To arrange, dispose, set in order (ranger, disposer, mettre en ordre)."

The word "resolution" was a plain translation of the French word "arrêté," which meant, literally, a thing de- 


\section{The Dispositive Power, I779-I783 409}

termined upon after deliberation, by an assembly which was advisory to the King, or by an administrative official or body, as preliminary to administrative action. The word "arrête" bore a close relationship to the word "arrêt," meaning the judgment or decree of a court of law or equity, both being derived from the same verb, "arrêter," meaning, literally, "to arrest or bring to a stop," and derivatively, "to resolve, to determine, or to decide."

The Congress, by adopting the words "ordinances" and "resolutions" to describe its acts, therefore, adopted the French view that every act done by it as the Sovereign was an act done in pursuance of an unwritten supreme law, which it was under obligation to adjudicate and execute.

The adoption of the expression "dispose of " to describe the power of the Union over its dependencies seems to have come about in the following manner:

On May 21, I779, Maryland, which was the only State which at that time had not signed the Articles of Confederation, filed in Congress a Declaration, together with Instructions to its delegates in Congress, adopted by its Legislature. In the Instructions the Legislature said:

We are convinced, policy and justice require that a country unsettled at the commencement of this war, claimed by the British Crown, and ceded to it by the Treaty of Paris, if wrested from the common enemy by the blood and treasure of the thirteen States, should be considered as a common property, subject to be parcelled out by Congress into free, convenient and independent Governments, in such manner and at such times as the wisdom of that Assembly shall hereafter direct.

Thus convinced, we should betray the trust reposed in us by our constituents, were we to authorize you to ratify on their behalf the Confederation, unless it be farther explained. We - . do instruct you not to agree to the Confederation, 


\section{4ro The Administration of Dependencies}

unless an Article or Articles be added thereto in conformity with our Declaration. Should we succeed in obtaining such Article or Articles, then you are fully empowered to accede to the Confederation.

The word " independent" cannot, of course, be read literally. To parcel out a common property into independent Governments, using "independent" in its ordinary sense, is a self-evident absurdity, since the conception of parcelling out is inevitably associated with the idea of dependence. "Independent" here plainly means " conditionally dependent," or " federally dependent," and not "wholly without dependence," which is its usual meaning. This same ambiguity in the word "independent" will be noticed frequently in the language of the period.

In the Declaration, the Legislature of Maryland said:

We will accede to the Confederation, provided an Article or Articles be added thereto, giving full power to the United States in Congress assembled to ascertain and fix the western limits of the States claiming to extend to the Mississippi or South Sea, and expressly reserving or securing to the United States a right in common in and to all the lands lying to the westward of the frontiers as aforesaid, not granted to, surveyed for, or purchased by individuals at the commencement of the present war, in such manner that the lands be sold out, or otherwise disposed of, for the common benefit of all the States.

These two statements made by the Legislature of Maryland regarding the explanatory Article which Maryland wished to have added to the Articles of Confederation evidently cover the same ground. It seems clear, therefore, that the Legislature of Maryland considered that an Article which should provide that "the United States in Congress assembled" should "dispose of" the lands in the Western region "for the common benefit of 


\section{The Dispositive Power, I779-I783 4II}

all the States," would include a power in "the United States in Congress assembled" to "parcel out" that region "into free, convenient, and independent Governments, in such manner and at such times as the wisdom of that Assembly shall hereafter direct."

The description of the power of "the United States in Congress assembled " over the Western region as a power to "dispose of " the "lands" in that region, was evidently preferred by the Legislature of Maryland, because such a power included the power both to dispose of the soil of which the Union owned the primary title and to dispose of the jurisdiction over the Western region, and it was regarded as just and proper that, as the region was unsettled, "the United States in Congress assembled" - that is, the American Union, considered as a State, and as the Imperial State of the American Empire-should have the benefit arising from the sale of its primary title to the soil. It was doubtless because of the fact that the American Union, as a State, owned the primary title to the soil in the Western region,-it not having been appropriated to private ownership, - that the word "lands" was uniformly coupled with the expression "dispose of " in the proceedings of Congress. Had the Western region been in part appropriated to private ownership and in part unappropriated, the Congress would undoubtedly have used the expression "the territory and lands""territory" having the meaning, as has been above noticed, of lands appropriated to private ownership and under the governmental control of the State.

It will have been noticed that Maryland, in its Instructions, demanded that the Articles of Confederation be "explained." It demanded also that this explanation should be by a "new Article or Articles." If, however, the Articles had only to be "explained," a "new Article or Articles" was unnecessary, since the proposition that the Articles required explanation implied that they 


\section{I2 The Administration of Dependencies}

already contained an ambiguous or uncertain provision on the subject, (which they undoubtedly did by providing for the admission of "Colonies" into the Union in Article XI.), and it was the function of Congress to explain the Articles.

Congress acted upon the basis that the Articles covered the subject and that all that was necessary was to "explain" them, as regarded the Western region. With this purpose, it adopted, on September 6, I780, the report of a committee in which it was recommended that Congress should "press upon those States which can remove the embarrassments respecting the western country a liberal surrender of their territorial claims, since they cannot be preserved entire without endangering the stability of the general Confederacy"; and Congress thereupon resolved:

That is be earnestly recommended to those States who have claims to the Western country, to pass such laws, and give their delegates in Congress such powers, as may effectually remove the only obstacle to a final ratification of the Articles of Confederation; and that the Legislature of Maryland be earnestly requested to authorize the delegates in Congress to subscribe the said Articles.

Had the Congress acceded to the request of Maryland, by adopting a new Article to be added to the Articles of Confederation, this would have required the Articles, as amended, to have been resubmitted to the Legislatures of all the States, and would have opened the way for the other States to demand other amendments. If the Articles had only to be explained, that could be done equally as well by a resolution of Congress as by a new Article. The Congress, accordingly, on October Io, I780, adopted the following resolution:

Resolved: That the unappropriated lands that may be ceded or relinquished to the United States, by any particular State, 


\section{The Dispositive Power, I779-I783 4I3}

pursuant to the recommendation of Congress on the 6th day of September last, shall be disposed of for the common benefit of the United States, and be settled and formed into distinct republican States, which shall beconie members of the Federal Union and have the same rights of sovereignty, freedom, and independence, as the other States; that each State which shall be so formed shall contain a suitable extent of territory, not less than one hundred nor more than one hundred and fifty miles square, or as near thereto as circumstances will admit.

That the said lands shall be granted or settled at such times and under such regulations as shall hereafter be agreed on by the United States in Congress assembled, or any nine or more of them.

This resolution explained that Article XI. of the Articles of Confederation, which provided that "no other Colony [except Canada] shall be admitted into the [Union], unless such admission be agreed to by nine States," included a Colony of the Union, and defined a Colony of the Union as a "distinct State," which was to be "disposed of" by the Congress, according to "regulations" made by the Congress.

The resolution related simply to "the unappropriated lands that may be ceded or relinquished to the United States, by any particular State," and hence related exclusively to the Western region. By the resolution, all these general powers of the Union were carefully qualified as respects this region. The right of disposition was subject to the proviso that the disposition was to be "for the common benefit of the United States," and with a view to the ultimate admission of the Colonies into the Union, as States, on equal terms with the rest. The right of making regulations was qualified so that it extended only to regulations made relating to the granting of the title to the soil or to the actual settlement of the region. The right of statehood on the part of these 


\section{I4 The Administration of Dependencies}

Colonies in the Western region was subject to the proviso that the statehood should be "republican" in character, - that is, that the people of each of these Colonies in that region should be regarded as the ultimate depositary of the political power for local purposes, and should act through elected representatives.

If the resolution had been divided into two, one expressing the general principles and the other defining the method of application of those general principles to the Western region, the one expressing the general principles would have read as follows:

Resolved: That the American Union has the right, and is subject to the obligation, to dispose of all lands and populations external to it and subject to its control, it being understood that this power of disposition includes the power of regulation, and that it implies a right to statehood of all populations naturally adapted to exist as distinct States.

The resolution relating to the application of these general principles to the Western region would have read:

Resolved: That in applying these principles to the Western region, they shall be subject to the following modifications:

First: The power of disposition shall be exercised by the Union so as not to be for the benefit of any particular State, but so as to be for the common benefit of the Union, and with a view to fit the Colonies for ultimate admission into the Union, as States, on equal terms with the other States.

Second: The power of disposition shall be construed as giving the Congress the right to make only such regulations as may be necessary for the orderly granting of the primary title of the Union to the soil, and for effecting the original settlement of the region.

Third: The right of the Colonies to be distinct States shall, for the protection of the Union, be subject to the proviso that they shall all be republican States. 


\section{The Dispositive Power, I779-I 783 4I5}

It was evidently the common understanding at the time the resolution of October IO, I780, was adopted, that it applied to dispositions made by the Union of its jurisdiction over the Western region as well as to dispositions made of its primary title to the soil of unoccupied lands. Thus the deed of cession of the State of New York of March I, I78I, granted the "right, title, jurisdiction, and claim" of the State to the lands beyond the western boundary of the State as described in the deed, "to and for the benefit of such of the States as are or shall become parties to the Articles of Confederation. . . . to be granted, disposed of, and appropriated in such manner only as the Congress of the said United States shall direct." The Act of cession of the State of Massachusetts of November 13, I784, authorized the Commissioners who were to make the deed to impose the condition that the land ceded should " be disposed of for the common benefit of the United States, agreeably to a resolve of Congress of October IO, I780 "; and the Commissioners, by their deed, ceded " all right, title and estate of and in, as well the soil as the jurisdiction, which the said Commonwealth hath to the territory" ceded "to the uses in a resolve of Congress of the tenth of October, I 780 , mentioned."

The committee of Congress appointed to consider the questions which had arisen concerning the Western country reported, on May $\mathrm{I}, \mathrm{I782}$, in favor of accepting the cession of the State of New York, holding that that State had the best title to the soil and jurisdiction of the Northwest Territory occupied by the Six Nations and their tributaries, because " all the lands belonging to the Six Nations and their tributaries have been in due form put under the protection of the Crown of England, as appendant to the late Government of New York, so far as respects jurisdiction only," and that " the Crown of England has always considered and treated the country 


\section{The Administration of Dependencies}

of the said Six Nations and their tributaries, inhabiting as far as the $45^{\text {th }}$ degree of north latitude, as appendant to the Government of New York." They concluded that " by Congress accepting this cession, the jurisdiction of the whole Western territory, belonging to the Six Nations and their tributaries, will be vested in the United States." The power of the United States over the region inhabited by Indians under the protection of the United States was called " jurisdiction," showing that the committee considered the region occupied by the Indian tribes as essentially a dependency, though under the outward form of a protectorate.

There seems to have never been any question in Congress but that the Congress was the successor of the King of Great Britain both as respects the States of the Union, and as respects the regions external to the Union and subject to its control. Nor does there ever seem to have been any question but that the power of the Congress, as the Disposer of the affairs of the Union, extended only to the making of rules and regulations for the common interest and benefit of all the States of the Union. The difficulty arose concerning the application of these principles to the administration of the dependencies of the Union. The party which in the years 1775 and 1776 had been the anti-Imperialist party on account of their devotion to the principle of States' Rights, were inclined to the opinion that the power of the Union over the dependencies extended only to the making of dispositions respecting them as if they were States of the Union, and hence extended only to the making of regulations concerning the common interests of the whole political organism consisting of the States and the dependencies of the Union. If the power of the Congress was only this, it could make no regulations even for the purpose of granting the title to the soil in the dependencies or relating to the settlement of unoccupied regions 


\section{The Dispositive Power, I779-I783 4I 7}

belonging to the United States, since it could certainly do neither of these things in any of the States. The provision, therefore, in the resolution of October io, I780, that the lands in the Western region should be "granted or settled at such times and under such regulations" as should thereafter "be agreed on by the United States in Congress assembled, or any nine or more of them," was a concession forced, by the necessity of the case, from the anti-Imperialist party, and a yielding by them, to that extent, to the Federal-Imperialist view.

When it came to be a question of the Congress making regulations for other purposes than these, the anti-Imperialists evidently blocked the way. The disposition to be made concerning the claims of the Land Companies to portions of the Western region was forced upon the attention of Congress by petitions of these Companies, in I 779 and 1780 , and the Congress, by its committee, adjudicated these claims in 1783 , and reported in favor of recognizing them in part, but never made any regulation "assigning territories" to them. So in the case of Vermont, the Congress in I784, on the application of Vermont, adjudicated, by a committee, the question both of its right to a distinct existence and of its boundaries; but, though a decision was made that it was entitled to a distinct existence and though the boundaries were ascertained, no regulation was made in execution of the adjudication. So far as the Indian tribes were concerned, the power of disposition was exercised, under the provisions of the Articles of Confederation, not through regulations made by Congress in the form of legislation, but by regulations made in the form of treaties with the tribes.

By the resolution of October IO, I780, therefore, the power of the Union, as the Imperial State of the American Empire, over its dependencies, was declared to be the power of disposition-the dispositive power. The antiImperialist party, however, evidently fearing that such 


\section{The Administration of Dependencies}

power exercised by a popular representative body like the Congress might, in practice, come to be virtually a power of legislation with a mere pretence of previous adjudication, insisted that the power should be construed as strictly as possible against the Congress and against the Union, in so far as it included power to make rules and regulations in execution of adjudications. Though, in joining in the resolution of October IO, I780, the antiImperialists admitted that the power of disposition, from its very definition, implied the power to make rules and regulations, they had at the same time succeeded in having the power of regulation separated from the power of disposition, so as to leave it doubtful whether the regulations which were to be made in execution of the adjudications of Congress were to be made by the Congress or made by the dependencies themselves. Since to allow the dependencies to make such regulations was practically to have no regulations made at all, the effect of the resolution of October IO, I780, was, in fact, to give the Congress power over the Western region only for the purpose of granting the primary title to the soil and for the purpose of colonizing the region. Thenceforward, the question was whether or not the power of Congress to regulate the Western region was a limited one, so that, although it was its duty to adjudicate all matters arising between the Union and the dependencies, it had power to make rules and regulations only in a restricted class of cases, - in a word, it became a question of the extent of the regulative power of the Union over its dependencies.

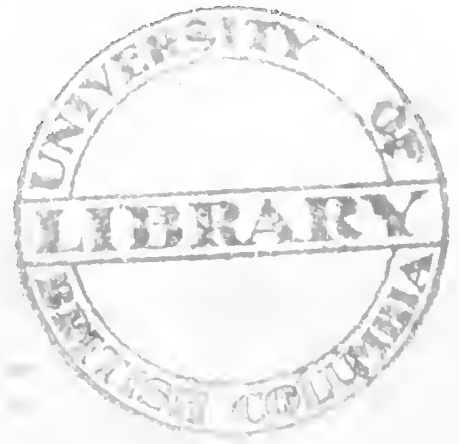




\section{CHAPTER XXII}

THE REGULATIVE POWER, I 783-I 787

$\mathrm{T}^{\mathrm{H}=\mathrm{a}}$

$\mathrm{HE}$ committee of Congress appointed to consider and report on the general policy to be pursued toward the Western region, in their report made October 14,1783 , proposed a resolution for the appointment of a committee to consider the expediency of " laying out a suitable District within the said territory and erecting it into a distinct Government," and recommended that this committee be instructed, in case they were in favor of laying out such a District,

to devise a plan for the government of the inhabitants and the administration of justice, until their number and circumstances shall entitle them to a place among the States of the Union, when they shall be at liberty to form a Constitution for themselves, not inconsistent with the republican principles which are the basis of the Constitutions of the respective States of the Union.

A plan "for the government of the inhabitants and the administration of justice" in the Western dependencies until they were admitted to the Union would have been a plan based on the mere will of Congress. The Union would have "governed" these dependencies during the whole period that they were without representation in Congress.

Elbridge Gerry, of Massachusetts, proposed an amendment to this resolution, which was adopted, and which declared it to be the intention of Congress " to erect a 


\section{The Administration of Dependencies}

District of the Western territory into a distinct Government, as soon as circumstances shall permit, and "in the interim to appoint a committee to report a plan, consistent with the principles of the Confederation for connecting with the Union, by a temporary form of government, the purchasers and inhabitants of the said District."

A plan "for connecting [the District] with the Union, by a temporary form of government," was a plan based on the theory that a compact existed between the Union and the District. It was not a pian to allow the populations in the Western region to form their own Government and then enter into a treaty with the Union concerning the powers which it should exercise over them. The temporary form of government was itself to be of such a kind as to "connect" the dependencies with the Union, but "connection," by its very definition, necessarily implies a contractual, that is, a federal relationship.

The " circumstances" referred to in Gerry's resolution, which were to permit the devising of a plan of government, were a satisfactory cession by Virginia and the extinguishment of the Indian title. The first of these circumstances occurred on March I, I784, when the cession of Virginia was accepted by Congress. A committee of Congress was immediately appointed to devise a plan of government for the Western region, of which Thomas Jefferson was the chairman, and David Howell, of Rhode Island and Samuel Chase, of Maryland members. On March II, I784, this committee reported a resolution which, in an amended form, was adopted April 23, I784, which became known as the Resolution of I784 for the Government of the Northwest Territory. The Resolution, after providing that the region to be ceded by the States to the Union should be "divided into distinct States," which were described by boundaries, made the following provisions for the "temporary and 


\section{The Regulative Power, I 783-I $78742 \mathrm{I}$}

permanent Government" to be established in the ceded region :

The settlers within the territory so to be purchased [from the Indians] and offered for sale shall, either on their own petition or on the order of Congress, receive authority from them, with appointments of time and place, for their free males of full age to meet together for the purpose of establishing a temporary Government, to adopt the Constitution and laws of any of these States, so that such laws, nevertheless, shall be subject to alteration by their ordinary Legislature, and to erect, subject to like alteration, counties or townships for the election of members for their Legislature.

Such temporary Government shall only continue in force in any State until it shall have acquired twenty thousand free inhabitants, when, giving due proof thereof to Congress, they shall receive from them authority, with appointments of time and place, to call a convention of representatives to establish a permanent Constitution and Government for themselves ;

Provided, That both the temporary and permanent Governments be established on these principles as their basis:

First: That they shall forever remain a part of this Confederacy of the United States of America.

Second: That they shall be subject to the Articles of Confederation in all those cases in which the original States shall be so subject, and to all the acts and ordinances of the United States in Congress assembled, conformable thereto.

Third: That they in no case shall interfere with the primary disposal of the soil by the United States in Congress assembled, nor with the ordinances and regulations which Congress may find necessary for securing the title in such soil to bona fide purchasers.

Fourth: That they shall be subject to pay a part of the Federal debts contracted or to be contracted, to be apportioned on them by Congress, according to the same common rule and measure by which apportionment thereof shall be made on the other States. 


\section{The Administration of Dependencies}

Fifth: That no tax shall be imposed on lands the property of the United States.

Sixth: That the respective Governments shall be republican.

Seventh: That the lands of non-resident proprietors shall in no case be taxed higher than those of residents within any new States, before the admission thereof to a vote by its delegates in Congress.

The Plan provided that each of the new States in the ceded region, under both the temporary and permanent Government, was to be connected with the Union through the medium of a delegate in Congress, who was to have the right to debate, but not to vote. Such a delegate corresponded almost exactly to the Colonial Agent which each of the American Colonies, prior to the Revolution, had sent to the British Court, to represent the Colony diplomatically before the King in Council. The Congress thus recognized itself as the Sovereign of the American Union, at whose Court the dependent States in the Western region were entitled to have diplomatic representatives.

The following clause was inserted at the end of the Resolution :

The preceding Articles shall be formed into a Charter of Compact, shall be duly executed by the President of the United States in Congress assembled, under his hand and the seal of the United States, shall be promulgated, and shall stand as Fundamental Constitutions between the thirteen original States, and those now newly described, unalterable but by the general consent of the United States in Congress assembled, and of the particular State within which such alteration is proposed to be made.

Had a plan of government for the Western region been adopted, according to which all the provisions were made a "Charter of Compact" between the Confederation and 


\section{The Regulative Power, I $783-1787 \quad 423$}

each of the dependencies in that region, each of them would have been recognized as a State, equal with and independent of the Confederation, and as having granted to the Confederation the right, license, or privilege of performing services for the benefit of the dependency. The adoption of such a plan of government would have made it forever impossible for the Confederation to exercise other powers than those granted unless the dependencies saw fit to make an additional grant of powers. This would have been "States' rights" carried to the extreme.

The Resolution recognized that the "Districts" or "States" in the Western region, until their admission into the Confederation on equal terms, were "Colonies" within the meaning of Article XI. of the Articles of Confederation. It provided that:

Whenever any of the said States shall have, of free inhabitants, as many as shall then be in any one the least numerous of the thirteen original States, such State shall be admitted by its delegates into the Congress of the United States, on an equal footing with the said original States; after which the assent of two-thirds of the United States in Congress assembled shall be requisite in all those cases, wherein by the Articles of Confederation the assent of nine States is now required; provided the consent of nine States to such admission may be obtained according to the eleventh of the Articles of Confederation.

The eleventh of the Articles of Confederation was the one which permitted the entrance of Canada into the Union upon joining in the measures of the Confederacy, and which provided that " no other Colony shall be admitted into the same unless such admission be agreed to by nine States."

In the Resolution as originally reported from the committee, the second condition was worded as follows: 


\section{.424 The Administration of Dependencies}

That they shall be subject, in their persons, property, and territory, to the government of the United States in Congress assembled, and to the Articles of Confederation in all those cases in which the original States shall be so subject, and to all the acts and ordinances of the United States in Congress assembled, conformable thereto.

On April 20, I784, when the Resolution was brought before Congress for discussion, after having been previously recommitted, the words "to the government of the United States in Congress assembled" were, on motion, stricken out, only the State of Maryland voting in favor of their retention.

Had these words been allowed to remain in the Resolution, the "Districts" or "States" in the Western region would have been subject, by express contract, to the mere will of "the United States in Congress assembled," except in so far as the latter had agreed in the "Charter of Compact" not to exercise its will. They would have bargained for a limited subjection, but also for an unconditional subjection outside the limits, and the case would have fallen within the principle of the third class of cases of federal subjection of States mentioned in the Observations on the American Revolution-where a State had "actually bargained for unconditional submission "-and, according to the theory of the United States as therein declared, "that bargain would have been from its very nature void as to [the people of the new States]; or if not to them, at least to their offspring; and, of consequence from the principles of all free societies, the contract [for a conditional subjection] would result."

When the provision that made the temporary and permanent Governments " subject to the government of the United States in Congress assembled," was stricken out, the effect was to leave the dependencies in the Western 
region, after the formation of temporary Governments, subject only " to the Articles of Confederation in all those cases in which the original States shall be so subject," and to take away all possibility of any control of them by Congress from the moment the temporary Governments should be formed. What power the Congress should have until the temporary Governments were formed, was left indefinite.

A resolution covering the power of Congress until such time as the settlers should form a temporary Government was soon introduced, which assumed that Congress ought to have the same powers as those claimed by the British Parliament by the Declaratory Act of I766. This resolution read:

That till such time as the settlers aforesaid shall have adopted the Constitution and laws of some one of the original States as aforesaid, for their temporary Government, they shall be ruled by magistrates to be appointed by the United States in Congress assembled, and under such laws and regulations as the United States in Congress assembled shall direct.

This resolution failed to receive the vote of seven States, and three days later Congress adopted a resolution, offered by Gerry, the author of the original resolution of October I4, I783, committing Congress to the FederalImperialist theory until a temporary Government should be formed, and declaring its power, until that time, to be conditional, fiduciary, and conservative, - that is, a power of disposition. This resolution read:

That measures not inconsistent with the principles of the Confederation, and necessary for the preservation of peace and good order among the settlers in any of the new States, until they shall assume a temporary Government as aforesaid, may from time to time be taken by the United States in Congress assembled. 


\section{The Administration of Dependencies}

This provision was inserted before the last clause of the Resolution and hence was made a part of the "Charter of Compact."

As the Resolution stood, even after Gerry's amendment, the moment a community in the Western region adopted even a " temporary Government," it was considered as a distinct political personality, or State, external to the Confederation, over which the Confederation had no power except as such power had been granted to it by the express treaty made between it and the new State, formulated in and evidenced by the Resolution.

The Resolution of 1784 , therefore, was, as a whole, in accordance with the anti-Imperialist theory that all relations between States are the result of an express contract. Had it ever gone into effect, it would have constituted a written Imperial Constitution between the American Union, as the Imperial State, and the dependencies in the Western region, from the moment that they assumed even temporary Governments, and would have given the Union the same limited powers over them as it exercised over the States of the Union, which powers, however, it could have exercised without any condition whatever as to the manner of its exercise. For the dispositive power, it would have substituted a power of managing the foreign relations of the dependencies, and an exceedingly limited power to legislate for the common interests, as soon as even temporary Governments should be formed by these dependencies.

The Resolution of 1784 was never put in force. Providing, as it did, that the communities in the Western region should ultimately be admitted as States of the Confederation on equal terms with the other States, in which respect it conformed to the resolution of October IO, I780, and the Virginia and Massachusetts deeds of cession, a difficulty arose from the fact that the resolution and deeds required that each State formed in the West- 


\section{The Regulative Power, I 783-I787 427}

ern region should be not less than one hundred nor more than one hundred and fifty miles square.

If the Northwest Territory alone had been divided into States one hundred and fifty miles square, eleven States would have been formed in it; if of one hundred miles square, twenty-five. The resolution of October 10, I780, however, by which these maximum and minimum dimensions were fixed, related to all the Western region which should be ceded by the States to the United States, and promised to each State formed in the region admission into the Confederation on equal terms. In that which was actually ceded, there could have been formed twenty States one hundred and fifty miles square, or forty-five one hundred miles square.

As the power to admit new "States" was based on Article XI. of the Articles of Confederation, a new "State" could be admitted by vote of any nine States of the Confederation. As soon as more than three new States were added, the original States would have been at the mercy of any coalition between these three and a minority of themselves, and as soon as more than five new States were admitted, even nine of the old States voting together could not have prevented the admission of as many new States as the remainder might have seen fit. The original States were slow to adopt a plan which seemed certain to throw the power into the hands of the Western States. In the Resolution as amended on recommittal and as adopted by Congress, the difficulty was attempted to be cured by requiring each new State on its admission to agree that no State should be subsequently admitted except by a vote of two thirds of the States then members of the Confederation; but this was plainly an attempt to amend Article XI. in an indirect way, and its validity was doubtful.

It was doubtless largely owing to this difficulty that the subject of the disposition to be made of the Western 


\section{The Administration of Dependencies}

region was before Congress for more than three years before final action was taken, and that there arose, as there evidently did, between the United States and the inhabitants of the Northwest Territory a decided hostility in the years 1786 and 1787 . There was a practical deadlock. Congress could not give the "Districts" or "States" a régime guaranteeing them ultimate admission as States of the Union, without exposing the original States to the power of the Western States, in number at least eleven and perhaps forty-five; and yet to have given them a régime which did not so guarantee, would not only have alienated them from the Union, but would have driven them to intrigue with Great Britain or Spain for the purpose of establishing an independent Confederation.

Matters were rapidly drifting into a dangerous situation. The British troops had refused to evacuate the posts in the Northwest Territory and were ready to reoccupy the region in case the United States should fail, after a reasonable time, to effectively occupy it. Spain claimed the whole region between the Mississippi and the Alleghenies as far north as the Ohio. Madison, in the Madison Papers, gives a detailed account of a number of interviews which he had, in the spring of 1787 , as a member of the Committee on Foreign Relations, with Guardoqui, the Spanish Minister, who was seeking recognition of the Spanish claim to close the Mississippi, in one of which the Minister distinctly claimed for Spain the whole region above described. By vote of seven States, Congress authorized a treaty to be made, granting to Spain the right to close the navigation of the Mississippi for twenty-five years, but the validity of a majority vote on such an important subject was denied by the other States, and the treaty was not consummated.

Washington, writing to Governor Benjamin Harrison, of Virginia, less than six months after the Resolution of 
I 784 was adopted, on his return from a journey through the Western region, said that the communities there stood, "as it were, upon a pivot. The touch of a feather would turn them any way."

The Ordinance of 1787 for the Government of the Northwest Territory evidently had its origin in the conviction of some of the delegates in the Congress, that it was absolutely necessary to the safety of the Confederation that the Congress should recognize itself as having the utmost power possible over the Western region, consistently with the position which the American Colonies had taken against Great Britain during the Revolution. It was realized that if the Confederation should actually commit itself to the theory of the Resolution of 1784 , that it had no power over the communities in the Western region except as the result of an express contract, this practically would give the Confederation only so much power over these communities as they chose to allow it to have, and would allow them to rescind the contract and secede from the Empire whenever they were dissatisfied. Secession of the Western States from the American Empire, it was realized, would mean possibly the destruction of the Confederation itself by a new Confederation of Western States, aided by foreign influence, and certainly a serious loss of prestige to the existing Confederation. The effect of the representations of the delegates who held this view was to gradually bring the whole Congress to this way of thinking, and Congress set itself to the task of establishing a régime for the Western region which should go as far as possible in the direction of keeping the power in the hands of the Confederation, and yet not be inconsistent with the position taken by the American Colonies in the contest with Great Britain. Such action had to be taken in secret. The popular mind was so full of the "rights of man" theories that demagogues had become popular idols and 


\section{The Administration of Dependencies}

easily persuaded the people that all government except that by demagogues was oppression. "Shays' Rebellion," so-called, which occurred in Massachusetts in I786, was but an evidence of the general disrespect for all government, and particularly of government by the Congress. Evidently it was due to the political situation that Congress left no record on its Fournals except of appointment of committees and of its completed action.

The Fournals of Congress show that on March 24, I786, a report was made by a Grand Committee of the House, to whom had been referred a motion of James Monroe, then one of the delegates from Virginia, on the subject of the Western territory. They also show that, on May IO, I786, a report was made by a Committee of which Monroe was chairman and Johnson of Connecticut, King of Massachusetts, and Kean and Pinckney of South Carolina were members, to whom a motion made by Dane of Massachusetts, for considering and reporting the form of a temporary Government for the Western territory, had been referred. Though the originals of these motions and reports are not in existence, so far as is known, Monroe has left a statement of their main characteristics. Writing to his friend and preceptor, Jefferson, who was then in Paris, on the very next day after this report was made (May I I, I786), he said:

A proposition, or rather a report, is before Congress, recommending it to Virginia and Massachusetts to revise their acts so as to leave it to the United States to make what division of the [Northwest Territory] future circumstances may make necessary, subject to this proviso, "that the said territory be divided into not less than two nor more than five States." The plan of a temporary Government to be instituted by Congress and preserved over such District until they shall be admitted into Congress is also reported. The outlines are as follows: Congress are to appoint, as soon as any of the lands 


\section{The Regulative Power, I783-I 787 431}

shall be sold, a Governor, Council, Judges, Secretary to the Council, and some other officers; the Governor and Council to have certain powers until they have a certain number of inhabitants, at which time they are to elect representatives to form a General Assembly, to consist of the Governor and Council and said House of Representatives. It is, in effect, to be a Colonial Government similar to that which prevailed in these States previous to the Revolution, with this remarkable and important difference that when such District shall contain the number of the least numerous of the thirteen original States for the time being, they shall be admitted into the Confederacy. The most important principles of the Act at Annapolis are, you observe, preserved in this report. It is generally approved of, but has not yet been taken up.

"The Act at Annapolis" was the Resolution of I784, -Congress being in session at Annapolis at the time that Resolution was adopted.

It was entirely consistent with the position taken by the American Colonies against Great Britain for the Confederation to establish "a Colonial Government similar to that which prevailed in these States previous to the Revolution." The ultimatum of the American Colonies had been a demand for the restoration of the British Empire in America as it existed in 1763 , - that is, "previous to the Revolution."

To this letter Jefferson replied from Paris on July 9, I786, saying that the question which Congress ought to consider was, "How may the territories of the Union be disposed of, so as to produce the greatest degree of happiness to their inhabitants ?"-using the word "territories" as applying both to the States of the Union and the dependencies of the Union. He opposed this question to that which he said Congress was really considering, namely, "How may the ultramontane territory be disposed of, so as to produce the greatest and most immediate benefit to the inhabitants of the maritime 


\section{The Administration of Dependencies}

States?" saying that, if that were the real question, "the plan would be more plausible, of laying it off into two or three States only."

His argument was that as the real question was how the territory should be disposed of so as to produce the greatest degree of happiness to its inhabitants, a division of it into States of moderate size was necessary. He said:

There will surely be a division of that country into States of a small, or at most, of a moderate size. If we lay them off into siuch, they will acquiesce; and we shall have the advantage of arranging them so as to produce the best combinations of interest. . . Upon this plan we treat them as fellow: citizens; they will have a just share in their own government; they will love us, and pride themselves on a union with us. Upon the other, we treat them as subjects; we govern them, and not they themselves; and they will abhor us as masters, and break off from us in lefiance.

Jefferson had, therefore, arrived at the conclusion that the power of the Union was a power of "disposition "; that it was proper that it should " arrange " the dependencies " so as to produce the best combinations of interest" ; that statehood, as applied to dependencies, meant that the inhabitants should have "a just share in their own government."

It is noticeable that he made no comment on Monroe's statement that the Government proposed for the Northwest Territory was to be " in effect, a Colonial Government, similar to that which prevailed in these States previous to the Revolution" until the Colony should be admitted as a State into the Union on equal terms. This is not surprising when we remember that in 1775 he wrote to John Randolph: "I am sincerely one of those who wish for a reunion with their parent country, and would rather be in dependence on Great 
Britain, properly limited, than on any other nation on earth, or than on no nation."

The report of Monroe's Committee was recommitted, after being amended, on July 13, I786. He failed to be re-elected upon the expiration of his term in the summer of 1786 , and on September I9, I786, the Committee was reconstituted, Johnson becoming the chairman and the other members being Pinckney, Smith of New York, Dane, and Henry of Maryland. They were directed to prepare a "plan of temporary government for such Districts or new States as shall be laid out by the United States upon the principles of the Acts of Cession from individual States and admitted into the Confederacy." On April 26, 1787, this Committee reported "An Ordinance for the Government of the Western Territory," which was read a second time and amended on May 9, and assigned for third reading the next day. The third reading was, however, postponed by vote of the House on May IO. These proceedings of the Congress (which was then sitting in New York) were the last in which those members participated who had been elected as delegates to the Convention to frame the Constitution of the United States which met in Philadelphia on May 14. Among those who thus came to the Constitutional Convention fresh from the debates in Congress concerning the proper disposition of the Western region was Madison.

The Ordinance as reported is not given in the Fournals of Congress. It was, however, kept among the files and was brought to light by Peter Force in I848. From an inspection it is evident that no material change had been made in the Ordinance as reported by Monroe's Committee. It was still unmistakably an Ordinance establishing "a Colonial Government similar to that which prevailed in these States previous to the Revolution."

By the terms of the Ordinance as reported, the whole 28 


\section{The Administration of Dependencies}

of the Northwest Territory was created into a District or Province, under a Governor and Council appointed by the Congress. The Governor was at the same time the Commander-in-Chief of the militia of the region, with power to appoint and commission all officers below the rank of general officers, these latter being appointed and commissioned by Congress. He was to hold office for three years, unless his commission was sooner revoked by Congress.

Until the organization of the General Assembly, the Governor had power to lay out counties and townships and to make proper divisions of the District for the convenient execution of civil and criminal process. He had the entire power to appoint all " such magistrates and other civil officers, in each county or township, as he shall find necessary for the preservation of peace and good order in the same." In the performance of all these duties of disposition of the jurisdiction of the region, he acted absolutely according to his own will and pleasure, subject only to removal by Congress.

In the matter of legislation, his powers were limited, and he had no power of adjudication between individuals, except where military law was applicable. For purposes of legislation there were associated with him three men who were also "Judges." The fear of Congress that even the Governor and Judges themselves might fall in with some of the many schemes of government which were then prevalent in the Northwest region is shown by the very peculiar limitation which they placed upon the legislative power to be exercised by the Governor and the Judges. As a Legislative Assembly, these four men were limited to simply making a choice of " such laws of the original States, criminal and civil, as may be necessary and best suited to the circumstances of the District," and even these were subject to the disapproval of Congress. 
The provision for associating the Judges with the Governor to form the Legislative Council of the District in its first grade seems to have been inserted for the purpose of evidencing the dispositive character of the Government of the District appointed by Congress, as a Substituted and Trustee Government. It was the evident intention of Congress to form a body which should legislate only after investigation and after weighing the Constitutions and laws of the States as against the local circumstances and conditions of the District for the purpose of harmonizing the legislation of the District, so far as practicable, with that of the States.

The Judges held office during good behavior. They had " a common law jurisdiction." No provision was made for the exercise of an equitable jurisdiction, and the necessary implication is that such jurisdiction must have remained in Congress, since if not vested somewhere, great injustice was certain to accrue to litigants.

The District was permitted to advance from the first to the second grade when its free male inhabitants numbered five thousand. If they "gave proof to the Governor" of this fact, they were entitled to " receive authority with time and place, to elect Representatives from their counties or townships, to represent them in General Assembly." There was to be one Representative for each five hundred of free male inhabitants until the number should reach twenty-five, when the number and proportion was to be regulated by the Legislature. The right to hold the office of Representative was carefully hedged about by restrictions, and it was distinctly assumed that there was no " citizenship of the United States" and that the persons in the Western region were divided into only two classes, namely, " citizens of one of the United States" and "residents of the District." This is shown by the clauses relating to eligibility to office and to the voting franchise. 


\section{$43^{6}$ The Administration of Dependencies}

The provision as to eligibility to the office of Representative was as follows:

Provided, That no person be eligible or qualified to act as a Representative unless he shall be a citizen of one of the United States or have resided within the District three years, and shall likewise hold in his own right, in fee simple, two hundred acres of land within the same.

The provision as to eligibility to vote for Representative was:

Provided also, That a freehold in fifty acres of land in the District, if a citizen of any of the United States, and two. years residence in the District, if a foreigner, in addition, shall be necessary to qualify a man as an elector for said Representatives.

The provision contained in the Resolution of $i 784$ which permitted the Colonies in the Western region to have a delegate in Congress with power to debate but without the power to vote was omitted. Provision was made for the admission of the Colonies to the Union as States when any one of them should have a population equal to one thirteenth of the population of the original States.

The provision concerning the General Assembly of the District was as follows:

The General Assembly shall consist of the Governor, a Legislative Council, - to consist of five Members, to be appointed by the United States in Congress Assembled, to continue in office during pleasure, any three of whom shall be $a$ quorum, - and a House of Representatives, who shall bave $a$ legislative authority complete in all cases for the good government of the said District."

The Congress, however, was most cautious in reserv- 


\section{The Regulative Power, I $783-\mathrm{I} 787$}

ing to itself complete control of the whole Colonial Government. In the first place, it was provided that the Governor, Judges, Legislative Council, Secretary, and all other officers except the Representatives in the Lower House of the Legislature should be appointed by Congress and should take "an oath or affirmation of fidelity; the Governor before the President of Congress, and all other officers before the Governor." All legislation enacted by the Governor and Judges was to be transmitted to Congress and was to be subject to its disapproval. The Governor was given an absolute power of veto over all laws passed by the Legislature, by the provision according to which " no Bill or Legislative Act whatever shall be valid or of any force without his consent," and also a power "to convene, prorogue and dissolve the General Assembly, when in his opinion it shall be expedient." As the Governor had thus full power to prevent or nullify all objectionable Colonial legislation, and as Congress had full power over the Governor by virtue of its ability to revoke his commission at any time, the ultimate control was kept in the hands of Congress.

In addition to these reservations of power, Congress had the power of modifying or rescinding the whole Ordinance by amendment or repeal. It did not purport to be a "Charter of Compact," in whole or in part. It was merely an "Ordinance." The action of Congress in I784 had been by a "Resolution" which, when accepted by the District, was to become a "Charter" - that is, the evidence-of a "Compact." The Ordinance of 1787 , as originally contemplated by Congress, was to be an act emanating exclusively from Congress and subject to modification or rescission without consulting the District. According to the Ordinance as reported, therefore, Congress reserved to itself the right, even after the District had formed its own partly elective Government, to destroy the elective part of the Government and place the 


\section{The Administration of Dependencies}

District under the charge of a Government wholly appointed by Congress. The theory of the Ordinance as reported was, therefore, that the Congress, as the representative of the Confederation, had power to make all rules and regulations for the District that it might think proper.

On July 9, the Committee was again reconstituted, Carrington of Virginia being made the chairman, and the other members being Dane, Richard Henry Lee, Kean, and Smith. The Committee immediately set to work in hot haste to amend the Ordinance, and in two days had brought it into substantially the form in which it was finally adopted. The action of Congress upon the. report of this Committee was as prompt as the action of the latter had been. On the second day after the Committee reported (July I3), the Ordinance was adopted.

Carrington's Committee ameliorated, in some small details, the general régime according to which the Northwest Territory was to be administered until the Districts were admitted into the Union. The Governor and other officers and the Representatives and their electors were required to be residents of the District, and the House of Representatives was allowed to nominate persons to Congress from whom the members of the Legislative Council were to be selected. The District was allowed to have a delegate in Congress, with power to debate but not to vote. Still, the Government provided for in the Ordinance was unmistakably "a Colonial Government similar to that which existed in these States previous to the Revolution." The great change in the Ordinance made by this Committee consisted in adding to it six sections which were declared to be "Articles of Compact between the original States and the people and States in the said territory," which were to "forever remain unalterable, unless by common consent."

It had evidently been objected to the Ordinance as re- 


\section{The Regulative Power, I783-1787}

ported that it did not sufficiently qualify and limit the power of the Confederation over the dependencies, so as to make it clear that the relationship between them was founded on compact and not on the mere will of the Confederation, and was hence a power of disposition; and that it did not make it sufficiently clear on what principles Congress intended to act in negativing the action of the General Assembly of the District.

The first of the objections was met by inserting provisions in the Articles of Compact, by which certain of the implied terms and conditions of the compact growing out of the relationship were reduced to writing and agreed to be permanent unless changed by mutual consent. The relationship was thus recognized as founded on contract between States and hence as a federal and constitutional relationship.

The second objection was met by making the Articles of Compact the basis upon which the power of the Confederation to negative Colonial legislation should proceed.

The position of the American Colonies on the subject of the right of the Imperial State, through its Sovereign, to negative colonial legislation was perfectly clear. In the Declaration and Resolves of the Continental Congress of October I4, I774, it had been declared:

[The Colonies] are entitled to a free and exclusive power of legislation, in their Provincial Legislatures, . . . in all cases of taxation and internal polity, subject only to the negative of their Sovereign, in such manner as has been heretofore used and accustomed.

As the Congress, acting for the Confederation, was recognized as the Sovereign of the Northwest Territory, it followed that it might rightfully exercise the power to negative Colonial legislation, consistently with the principles for which the American Colonies stood in the Revolution. 


\section{The Administration of Dependencies}

It was important, in the interests of harmony, however, to arrange that all action of the Confederation, by its Congress or by its officials, having the effect to negative Colonial legislation, should occur under such conditions as to make acquiescence in it by the Colonies as likely as possible. This was accomplished by inserting such of the conditions of the relationship as the Confederation was willing to recognize as permanent in the Articles of Compact, and by making the validity of all legislation of the Colonial Assembly conditional upon its not being "repugnant to the principles and articles in this Ordinance established and declared." The Congress did not in any way commit itself to the proposition that the conditions of the relationship contained in the Articles of Compact were the only conditions on which it would insist, or the only conditions on which the District might properly insist. It was provided simply that "The following Articles shall be considered as Articles of Compact," etc.

The first two Articles were a declaration that individuals within the District should have the natural rights of life, liberty, and property. The third provided for the encouragement of education and forbade mistreatment by the District of the Indians. A violation, by a legislative act, in a dependency, of any of these principles would justify an Imperial State, in the exercise of its power of disposition, in negativing such act even though there were no Articles of Compact between it and the dependency giving it this power, but, as it was possible to cover this ground by an express contract, this was done.

The fourth Article provided that the Northwest Territory should "forever remain a part of this Confederacy of the United States of America, subject to the Articles of Confederation and to such alterations therein as shall be constitutionally made, and to all the Acts and Ordi- 


\section{The Regulative Power, I783-I787 44I}

nances of the United States conformable thereto." To "forever remain a part of this Confederacy" meant that they were to be either "parcel of the Realm in tenure" or "parcel of the body of the Realm," to use the old distinction used in Calvin's Case, to which reference is evidently made-that is, that they were forever to remain either in the position of dependencies of the Union or of States admitted into the Union by representation in its Central Government, and were not to have the right of secession either from the Federal Empire or from the Federal State. This was unnecessary, since the power of the Confederation was recognized as being a power of disposition. Still it was an important matter and proper to be made the subject of an express contract.

The fourth Article also provided that the District should be subject to pay its proportional part of the federal debts and of the current expenses of the whole Government. An Imperial State exercising the power of disposition might properly have imposed this obligation upon a dependency situated as was the District, but it was a matter about which disputes might arise and hence properly settled by express contract. The same may be said of the provisions of the fourth Article according to which the proprietary title of the Confederation to the soil of the unappropriated parts of the District was to be recognized by the District, by which this land was to be free from taxes, by which non-residents were not to be taxed higher than residents, and by which the navigable rivers in the District were declared to be free and common highways. These were questions about which a difference of opinion was possible and hence properly the subject of an express contract.

The fifth Article recognized the obligation of the United States under the resolution of October IO, I780, to lay out the Western region into distinct republican States and to admit them into the Union on equal 


\section{$44^{2}$ The Administration of Dependencies}

terms. Such contractual obligations would of course be recognized by any State or tribunal exercising dispositive power, but it was advisable to formally recognize a direct obligation existing between the Confederation and the District by means of a document evidencing the contract.

Incidentally it may be noticed that this Article finally solved the problem raised by the provision of the resolution of October IO, I780, which required that the new States in the Western region should be not less than one hundred nor more than one hundred and fifty miles square. It provided that not less than three nor more than five States should be laid out in the region, but made this provision conditional on the consent of Virginia, which had made its cession conditional on the fulfilment by the Union of the resolution of October IO, I780; and Virginia subsequently consented to this change.

The sixth Article forbade slavery in the District. An Imperial State exercising a power of disposition would not have been likely to permit slavery in a region situated as was the Northwest Territory. Still, considering the violence of the dispute on the subject, it was eminently proper to take advantage of the power of the Confederation to enter into express contracts with its dependencies and thus settle the question.

The Ordinance was thus a compromise between the Resolution of 1784 and the Ordinance as reported in 1786 and again on April 26, I787. The former had pushed the principle that the relationship between the Confederation and its dependencies was a relationship founded on compact to an absurdity, by assuming that the relationship could not exist except as the result of an express contract. The Ordinance as reported in 1786 and on April 26, I 787, had left it doubtful whether the relationship was founded on compact at all. The Ordinance as finally adopted proceeded on the theory that the rela- 


\section{The Regulative Power, I 783-I 787 443}

tionship was wholly founded on an implied contract, but that the Imperial State and any dependency might, by an express contract, reduce the conditions, in any respects they saw fit, to writing and agree that in these respects no change should be made except by mutual consent, the dispositive power of the Imperial State remaining unchanged as respects matters not reduced to the form of express contract.

It has been shown that the Ordinance as adopted recognized, first, that the power of the Confederation was a power of disposition, whether its action was constructive and positive or destructive and negative, and, secondly, that the power of disposition implied the power to contract with a dependency. The Ordinance had, however, another very important effect,-it recognized that the power of the Confederation over the dependencies was plenary-that it was a power to dispose of them "in all cases whatsoever," and to regulate them accordingly. None of the provisions relating to the form of government of the dependencies in the Western region, or to the powers to be exercised by the Union over these dependencies until their admission into the Union as States on equal terms were incorporated in the Articles of Compact. They were all in the part of the Ordinance which was a regulation made under the power of disposition. These provisions were, of course, subject to modification or rescission by Congress at any time. Congress, by thus carefully leaving these provisions out of the Articles of Compact, in effect declared that the powers of the Confederation over the dependencies, being powers of disposition based on an implied contract, were in the nature of things limited only by the necessity of each case, and that the Confederation had the right to finally determine what the necessity in each case demanded, subject to any express contract of the Union relating to the manner of disposition. Where the Union, by express contract, had 


\section{The Administration of Dependencies}

obligated itself to exercise its powers of disposition in a certain manner, necessity of course demanded that in its regulations it should act in this manner. The plenary nature of the regulative power which was implied in the dispositive power was thus declared. The Union was declared to have power to make necessary or needful rules and regulations in all cases whatsoever.

The Ordinance, therefore, settled the question concerning the character and extent of the regulative power of the Union over its dependencies. It recognized the Union as having power to make rules and regulations in execution of and necessarily incidental to its power of disposition in all cases whatsoever, subject to all express contracts of the Union with foreign States, with the States of the Union, or with the dependencies of the Union-that is, as a power to make all needful rules and regulations respecting the dependencies. 


\section{CHAPTER XXIII}

THE IMPERIAL POWER, I 787

$\mathrm{T}^{\mathrm{N}}$

$\mathrm{HE}$ first resolution adopted by the Convention for framing the Constitution of the United States, which was the basis of all its subsequent action, read, according to the report of Madison, in his Fournal of the Federal Convention, as follows:

Resolved: That a National Government ought to be established, consisting of a Supreme Legislative, Executive, and Judiciary.

If the American Confederation was to be reorganized so as to be a true "Nation" - that is, a State-with a Chief Executive, it was plainly necessary, if traditions were to be observed, that the Executive should administer the dependencies of the State under the superintendence of the Legislature. The power of disposition was a power neither strictly executive nor legislative, but which more closely resembled the executive than the legislative power, since it was essentially judicative in its character. Still, though the American Colonies, during their contest with Great Britain, had uniformly insisted that the political connection between them and the State of Great Britain was through the Executive of Great Britain, who was ex officio the Disposer of the Empire, the antiImperialists had never succeeded in committing the Colonies to the proposition that the Legislature of Great Britain had no power in the Empire. Dickinson had prevented the adoption of the statement to this effect in 
Jefferson's draft of the Declaration on Taking up Arms, and the Federal-Imperialists had prevented the adoption of a similar statement in his draft of the Declaration of Independence. The American Union was, therefore, in a position, thanks to the Federal-Imperialists, where it could place the responsibility for the habitual performance of its Imperial obligations either on the Executive, as the expert branch of the Government, subject to the superintendence of the Legislature, or on the Legislature, as the popular branch of the Government, subject to the superintendence of the Executive. It could not, however, without national self-stultification, after having insisted that the Chief Executive of the State of Great Britain had power to nullify Acts of Parliament relating to the American Colonies as "pretended" and "unwarrantable" legislation, confer upon its own Legislature the exclusive power to administer the dependencies of the Union, or even require the Chief Executive to execute the will of the Legislature relating to the dependencies in all cases.

In examining the proceedings of the Convention, relating to administration of the dependencies, therefore, the prime interest naturally attaches to its action concerning the powers of the Chief Executive of the Union.

Randolph's resolutions, which were taken as the basis of the action of the Convention, contained the following three provisions bearing on the subject of the administration of the dependences:

6. That the National Legislature ought to be empowered to enjoy the legislative rights vested in Congress by the Confederation; and moreover to legislate in all cases to which the separate States are incompetent, or in which the harmony of the United States may be interrupted by the exercise of individual legislation.

7. That a National Executive be instituted; . . . and 


\section{The Imperial Power, I 787}

that besides a general authority to execute the National laws, it ought to enjoy the executive rights vested in Congress by the Confederation.

Io. That provision ought to be made for the admission of States lawfully arising within the limits of the United States, whether from a voluntary junction of government and territory, or otherwise, with the consent of a number of voices in the National Legislature less than the whole.

The expression "rights vested in the Confederation" was wide enough to include both those vested in Congress by the Articles of Confederation and those vested in it by the resolution of October I0, 1780 and the cessions of the States made in pursuance of that resolution.

Considering the character of the power exercised by the Confederation in administering its dependencies, it was doubtful whether this power was intended to have been granted to the National Legislature by the sixth resolution as a "legislative right," or to the National Executive, under the seventh resolution, as an "executive right." As all the rights exercised by the Congress of the Confederation had been recognized as being essentially executive rights, and as it had claimed that it was the successor of the King of Great Britain for the purpose of administering the Western region, the natural inference would seem to be that it was intended to make the Chief Executive the acting representative of the Union in the administration of the dependencies, subject to the superintendence of the Legislature.

The word "arising" in the tenth resolution was a word of sufficiently broad meaning to cover the case of the creation of a State by the action of the squatters or settlers on the public lands in joining themselves, their families, their possessions and lands, and uniting under a common authority (which was the case of the State of Franklin and the State of Vermont), or of the creation 


\section{The Administration of Dependencies}

of a State by the authority and direction of a State (which was the case of the District of Kentucky); yet it rather implied that such communities were essentially distinct personalities, growing like individuals by their own exertions, and not things moulded into shape by a force from without.

These words "lawfully arising," in connection with the general powers of legislation given to Congress, were, it seems, considered sufficient for a considerable time to designate the theory of the administration of dependencies. The word "arising" was doubtless used to satisfy the anti-Imperialist faction in the Convention, and the word "lawfully" to satisfy the Federal-Imperialist faction.

The Congress, in Committee of the Whole, unanimously agreed that all the legislative powers of the existing Congress ought to be transferred to the National Legislature, and the Committee of the Whole reported Randolph's sixth resolution with the single change of the word "possess" for the expression "empowered to enjoy." The provision with regard to the National Executive was, however, changed so as to read as follows:

Resolved: That a National Executive be instituted, to consist of a single person; to be chosen by the National Legislature, for the term of seven years; with power to carry into execution the National laws; to appoint to offices in cases not otherwise provided for; to be ineligible a second time; and to be removable on impeachment and conviction of malpractices or neglect of duty; to receive a fixed stipend by which he may be compensated for the devotion of his time to the public service, to be paid out of the National Treasury.

Madison, on June I, attempted to have a clause added which should provide that the Executive should be empowered "to execute such other powers not legisia- 
tive or judiciary in their nature, as may from time to time be delegated by the National Legislature," but the clause was stricken out on Pinckney's objection that this power was included in the power to carry into effect the National laws; Massachusetts, Virginia, and South Carolina voting in favor of the retention of the clause.

In the Committee of the Whole, the tenth resolution relating to "new States lawfully arising" was left unclianged.

The Committee of the Whole reported on June 13. The debate on this report continued until July 26 , when the resolutions of the Committee of the Whole, as amended, were referred to a Committee on Detail, composed of Rutledge, Randolph, Gorham, Ellsworth, and Wilson. During this debate, on July $\mathrm{I} 7$, the provision relating to the National Legislature was amended so as to read:

That the National Legislature ought to possess the legislative rights vested in Congress by the Confederation; and, moreover, to legislate in all cases for the general interests of the Union, and also in those to which the States are separately incompetent, or in which the harmony of the United States may be interrupted by the exercise of individual legislation.

The provision relating to the Executive was amended by striking out the clause making him ineligible for re-election. That relating to the admission of new States into the Union was not changed at all.

As the resolutions went to the Committee on Detail, therefore, they either gave the Congress the exclusive power of legislating for the dependencies, as a part of "the general interests of the Union," or they left the whole subject of the respective powers of the Legislature and the Executive in the administration of the depend. encies to be implied from the words "lawfully arising." 


\section{The Administration of Dependencies}

The Committee on Detail seem to have taken the latter view, for they reported a draft of Constitution in which was substituted, instead of the general grant of powers to the Legislature contained in the resolution, a specification of its powers substantially like that contained in Article I., Section 8, of the Constitution as adopted, in which specification no power was given to the Legislature respecting the dependencies.

In the draft, the Committee on Detail inserted a clause evidently intended to dignify the office of Executive and to render it independent of the Legislature to a proper extent. During the debates on the resolutions reported by the Committee of the Whole, it had been recognized that it would not do to subordinate the executive wholly to the legislative part of the Government-that the real question was how to balance the Executive, as the expert part of the Government, as against the Legislature, the popular part. The question of the character of the Executive was one of the last questions discussed before the reference to the Committee on Detail, and during this debate the tendency of tl:e Convention towards making the Executive responsible to the people, rather than to the Legislature, was clearly evident. The proposition that the Executive should be chosen by the Legislature was warmly debated, and passed by a vote of six States to three, Pennsylvania, Delaware, and Maryland voting against it, Massachusetts, New York, and Rhode Island not voting, and Virginia being dividedWashington and Madison voting against it.

The Committee on Detail reported a clause relating to the executive power which read, in part, as follows:

The executive power of the United States shall be vested in a single person. His style shall be "The President of the United States of America," and his title shall be "His Excel. lency." 
As the draft made by the Committee on Detail stood, the President was given the exclusive power of disposition of the dependencies. The powers of Congress were distinctly specified in that draft, and no power whatever was given to it over the dependencies. The only two references in that draft to the administration of dependencies were contained in the two following paragraphs:

As the proportions of numbers in different States will alter from time to time; as some of the States may hereafter be divided; as others may be enlarged by addition of ierritory; as two or more States may be united; as new States will be erected within the limits of the United States, - - the Legislature shall, in each of these cases, regulate the number of representatives by the number of inhabitants, according to the provisions hereinafter made, at the rate of one for every forty thousand.

New States lawefully constituted or established within the limits of the United States may be admitted by the Legislature into this Government. . . . If a new State shall arise within the limits of any of the present States, the consent of the Legislature of such States shall be also necessary to its admission.

The power of the American Union over its dependencies was thus declared, in this draft, a power " to erect new States" and "to constitute or establish new States." The constitution and establishment of new States was recognized as an act to be done under the Constitution, not only by the meaning of the words "erected," "constituted," and "established," but also by the coupling of the word "lawfully" with the words "constituted and established."

That the Executive was to have powers which the Congress itself was to execute by its legislation was shown by the clause in this draft, after the general specification of the powers of Congress, which provided that the Congress should have power: 


\section{$45^{2}$ The Administration of Dependencies}

To make all laws which shall be necessary and proper for carrying into execution the foregoing powers, and all other powers vested by this Constitution in the Government of the United States, or in any Department or Office thereof.

It may be noticed, in passing, that this provision was incorporated in the Constitution as adopted, with the single change of the word "office " to "officer."

In the draft of August 6, reported by the Committee on Detail, the general provisions as to the legislative, executive, and judicial powers were as follows:

The legislative power shall be vested in a Congress, to consist of two separate and distinct bodies of men, a House of Representatives and a Senate.

The executive power of the United States shall be vested in a single person. His style shall be "The President of the United States of America," and his title shall be "His Excellency."

The judicial power of the United States shall be vested in one Supreme Court, and in such inferior courts, as shall, when necessary, from time to time, be constituted by the Legislature of the United States.

In the Constitution, as adopted, these general powers are granted in the following words:

All legislative powers herein granted shall be vested in a Congress of the United States, which shall consist of a Senate and a House of Representatives.

The executive power shall be vested in a President of the United States of America.

The judicial power of the United States shall be vested in one Supreme Court and such inferior courts as the Congress may from time to time ordain and establish.

Between the time of the report of the Committee on Detail, therefore, and the close of the Convention, the 
general words relating to the powers of the National Legislature were restricted, while those relating to the National Executive were enlarged. The general words relating to the powers of the National Judiciary were not changed.

These changes were made by the Committee on Style and Arrangement, appointed September Io, which consisted of Johnson, Hamilton, Gouverneur Morris, Madison, and King.

The President, therefore, is authorized to exercise "the executive power," while the Congress is authorized to exercise only "all legislative powers herein granted," -the word "herein" apparently referring to Article I. of the Constitution, in which occurs the specification of the "legislative powers" of Congress. The character and extent of the executive power, therefore, is to be determined according to the principles of the general public law, and by the fundamental principles and traditions of the American Union; while the character and extent of the legislative power is to be determined by the express words of specification in the grant. All powers which are strictly "legislative" in their nature granted by the Constitution to Congress are undoubtedly vested in Congress to the exclusion of the President, but powers not legislative are not vested in it exclusively. The power of the American Union over its dependencies, not being legislative in its nature, may therefore, it would seem, be exercised by the President, as a part of "the executive power."

After the draft of August 6 was reported by the Committee on Detail, the question plainly was whether or not the Congress should have any power whatever in the administration of the dependencies. There were several reasons which doubtless operated to induce the Convention to give it power in this respect.

The first was that it was realized that since the power 
of the American Union over its dependencies was the power of a State over other States, and essentially neither legislative, executive, nor judicial in its character, it was immaterial by what instrumentality the Imperial State exercised its powers, provided it exercised them justly and expertly. It might therefore exercise them through its Legislature-the popular branch of its Governmentor its Executive-the expert branch-or by both, according as experience should show that one method of action or the other produced the best results in the particular case.

The second was that the Western region had been ceded to "the United States in Congress assembled," and the Congress of the Confederation had already made a disposition of the region. To have provided that the power over the Western region should be exercised by the President would have been a reversal of policy which would have been likely to weaken the authority of the Union.

Another reason was that it was perceived that a region situated with relation to a State as was the Northwest Territory to the American Union might properly be subjected to the will of the popular branch of the Government. Such a region must first of all be held strongly to the State. If not, it is likely to be a base of operations against the State. As it is ultimately to form a part of the body and personality of the State, its institutions must be assimilated to those of the State. If not, it is likely to cause trouble when admitted into the body and personality of the State. For these purposes, the control of the Congress over the Northwest Territory was to be preferred to that of the President. Though quite contrary to the principles on which the American Colonies had acted in the Revolution, such a course of action was evidently regarded as justified by the circumstances, which were entirely dif- 
ferent from those which existed between the American Colonies and Great Britain.

The resolution giving Congress power in the administration of the dependencies was introduced by Madison. It will be remembered that he had just come from Congress, where, as member of the Committee on Foreign Relations, he had had many interviews with the Spanish Minister, Guardoqui, which had shown him the disaffection of the Western region and the danger of its loss by the combined action of Great Britain and Spain. He doubtless realized the hostility of the Western region provoked by the action of the delegates of seven States in authorizing a treaty with Spain allowing that nation to control the navigation of the Mississippi for twenty-five years, and felt that unless the Congress under the Constitution were to be given power over the Western region, the American Union could not fulfil the trust which it had assumed by its declaration of trust of October IO, I780, and that the Western region was lost to the United States. He knew, too, that while he was in Congress it had been thought necessary to convert the whole Western region into a Province of the United States under a Governor and other officers appointed by Congress, and that since he had left Congress this plan had been carried out by the enactment of an Ordinance for this purpose.

On August i8, while the Article of the draft containing the specifications of the legislative powers of Congress was under discussion, Madison "submitted, in order to be referred to the Committee on Detail, the following powers, as proper to be added to those of the General Legislature "':

To dispose of the unappropriated lands of the United States;

To institute temporary Governments for new States arising therein. 


\section{$45^{6}$ The Administration of Dependencies}

These specifications of powers were a part of a list of powers contained in the resolution "as proper to be added to those of the General Legislature," in which list were included the power to regulate Indian affairs, to legislate for the Federal District, to grant charters of incorporation, to grant copyrights and patents, to establish a university and to acquire and maintain forts and public buildings. It was evidently his intention that the powers over the dependencies should be put on exactly a par with the other powers of Congress.

On August 22, the Committee on Detail reported a clause covering the ground of Madison's propositions, to be inserted in the specifications of the powers of the Legislature just before the clause giving the Legislature power "to make all laws which shall be necessary and proper for carrying into execution the foregoing powers," which read:

The Legislature of the United States shall have power to provide, as may become necessary, from time to time, for the well-managing and securing the common property and general interests and welfare of the United States in such manner as shall not interfere with the government of individual States, in matters which respect only their internal police or for which their individual authority may be competent.

The words " to provide, as may become necessary from time to time, for the well-managing and securing the common property and general interests" were plainly a mere paraphrase of the expression "to dispose of the common property and general interests." They imposed a condition and trust upon the power of Congress, requiring Congress to "provide" for the "well-managing" of the common property and general interests. They also implied that the power of Congress was to be a supervisory or superintending nature-that the Presi- 
dent was to "manage" and "secure" the common property and general interests, and that the Congress was to "provide," so that under his management, the common property and general interests should be "well-managed" and "secured."

The words "individual States" plainly referred to the dependencies, and the purpose of the clause " in such manner as shall not interfere with the government of individual States, in matters which respect only their internal police or for which their individual authority may be competent " was evidently intended to convert the dependencies into constitutional protectorates as soon as they had attained even a "temporary form of government." In passing, it is noticeable that the phrase "in matters which respect only their internal police" seems to have been suggested by the terms of the protectorate exercised by the United States over Vermont, as shown by its Constitution, in which, after placing the State "under the direction of the honorable American Congress," it was declared " that the people of this State have the sole, exclusive, and inherent right of governing and regulating the internal police of the same."

The terms of such a constitutional protectorate would have been impracticable. The Federal Government would have been powerless to enact a law, even after the most careful study and investigation had proved that it was necessary for the "well-managing and securing" of the dependencies, and even after the dependency interested had refused to enact such a law itself, if the subject-matter of the law were such that it related to " the internal police" of the dependency or if it were such that the "individual authority" of the dependency were " competent" to its enactment.

Such a limitation as this would have been a legal limitation on the power of Congress. It would have limited Congress to a distinct sphere of governmental action in 


\section{$45^{8}$ The Administration of Dependencies}

the dependencies, and the governments of the dependencies would have been constitutionally independent of it in their own spheres. In determining the limits of such spheres of action, innumerable opportunities for dispute would have arisen, which would doubtless have resulted either in the loss of the dependencies to the Union, or in the abandonment of the limitation.

When the Article of the draft of the Committee on Detail relating to the admission of new States was reached in the regular order, on August 30, an amendment, offered by Gouverneur Morris, was unanimously adopted, which read:

The Legislature shall have power to dispose of and make all needful rules and regulations respecting the territory or other property belonging to the United States.

This provision was incorporated in the Constitution verbatim except that the word "Legislature" was changed to "Congress."

The clause recommended by the Committee on Detail was never referred to after Morris's motion was adopted.

In the previous chapters, it has been noticed how the expression "to dispose of " the dependencies had come to be the generic expression to describe the Imperial power and trust, and why it became necessary to add the words "and make all needful rules and regulations respecting" the dependencies. By these words, therefore, the Imperial power and trust undertaken by the American Union and its people were granted to and imposed upon Congress, and it shared the responsibility with the President.

The clause, by referring to "territory or other property belonging to the United States," recognized the American Empire. It has already been pointed out that the expression "belonging to," when relating to lands and 
population under the control of a State, was uniformly used, both in British and American politics and public law, as meaning "dependent upon." A somewhat striking example of this technical meaning of the expression "belonging to" is found in the Principles of Law and Polity Applied to the American Colonies, published by Sir Francis Bernard in 1764 . In that work, he thus defined the British Empire:

The Kingdom of Great Britain has, belonging to and depending upon it, divers external dominions and countries; all which, together with Great Britain, form the British Empire.

By the use of the expression "dispose of and make all needful rules and regulations respecting," the American Empire was recognized as a Federal Empire. By these words the American Union assumed the obligation of recognizing all the natural rights of the dependencies and their inhabitants, and hence assumed the responsibility of recognizing the natural right of statehood, on the part of communities external to itself and under its control, to the degree and within the area required by their conditions and circumstances.

The use of the words "rules and regulations" was doubtless due to the fact that the Convention perceived that the power which an Imperial State exercises over a dependency is a power exercised by one State for and over another. The thought underlying these words evidently is that the acts of an Imperial State respecting a dependency are rules and regulations to which its local governmental action is conformed, and not strictly legis. lation or executive action.

Doubtless the principal reason why the word "needful " was preferred to the word "necessary" or the words "necessary and proper," was that they limited the poiver of Congress, in general, to the power of supervision or 
superintendence. The President, being vested with the executive power, was assumed to have power to make all rules and regulations which were necessary and proper in the exercise of the power of disposition, and Congress was limited in its action to the cases where there existed a need or emergency for interposition. In this respect, the clause adopted followed the one proposed by the Committee on Detail.

Another reason why the word "needful," seems to have been preferred to the word "necessary" or the words "necessary and proper" was, in order to particularize the acts of disposition, and to make it certain that the power of disposition extended to the power of making different dispositions for the different dependent States as might be necessary. With the same purpose of particularizing the acts of disposition, the word "respecting" was evidently preferred to the word "concerning," the word "respecting" having the meaning of "concerning respectively."

The word "needful" has not only the meaning of "necessary" but the meaning of "adapted to specific human needs." By its use, therefore, the Congress was by necessary implication forbidden to assimilate the dependencies to the American Union, except so far as the local circumstances in each were the same, and was obliged to recognize each dependency as a State entitled to a régime adapted to the local circumstances.

The word "needful" in the sense of "adapted to needs" gave to the words "rules" and "regulations" the same meaning as ordonnances and réglements. It may be surmised that the word "rules" was considered preferable to either " ordinances" or "orders" or "laws" because if the first had been used, it might have given rise to a claim that the power of Congress over the dependencies was exactly that exercised by the King of France, if the second, that it was exactly that exercised by the 
King of Great Britain, and if the third, that it was exactly the same as that claimed by Parliament. While the intention of the framers of the Constitution, as shown by the words used in this clause, was to model, in a general way, the power of Congress over the dependencies upon the powers exercised in this respect by the King in France, and the King in Council in Great Britain, and while the claim of Parliament to the extent that it was a claim that the Parliament had the superintending legislative power over the dependencies was admitted, it is equally clear that it was the intention that Congress should not be required to exactly follow the theory or the practice of either of them. The King of France, in his disposition of the dependencies by "ordinances and regulations," did not limit his action to such only as was needful, but claimed the right to paternally interfere even in the details of the internal life of the dependencies; and the then reigning King of Great Britain, in his disposition of the British dependencies by "orders in Council " or " regulations in Council," while exercising a more general control than the French King, had exercised his powers as if he were under no condition or moral obligation to exercise them according to principles or according to the advice of expert men. The power claimed by Parliament, in the Declaratory Act of I766, of making "laws and statutes," was a power without condition or limitation, or moral obligation of any kind, - a power "to make laws and statutes of sufficient validity to bind the dependencies in all cases whatsoever."

The use of the expression " needful rules and regulations" made it clear that, while the power of the United States over the dependencies was to resemble the powers exercised by the King in France and Great Britain in that it was to be a power of disposition, and was to resemble that claimed by Parliament in that it was to be 


\section{The Administration of Dependencies}

exercised by the Chief Legislature of the Imperial State, it was to differ from that exercised by the King of France in being limited to the necessity of each case and not paternal, from that exercised by the then reigning King of Great Britain by being exercised according to principles determined by expert advisers, and from that claimed by Parliament in being exercised with full realization of the condition, limitation, and obligation attached to it and for the purpose of supervision or superintendence.

The use of the word "all" before "needful" made it certain that there was no limitation upon the power of the Union other than that implied in the word "needful." It thus made it certain that the Union, in administering its dependencies, was not confined to any specific sphere of action-that, if a proposed "rule" or "regulation " was plainly "needful" in the exercise of the dispositive power, it was immaterial whether it interfered with the "internal police" of the dependency to which it related, or not. It also made it impossible for any one to claim that the power of the Union over its dependencies was limited in its duration. Madison had suggested a provision which would have confined the Union to the power to "institute temporary Governments" for certain dependencies. The Convention, thus having before them the question whether all administration of dependencies by the Union was to be "temporary" - that is, with a view to their ultimate admission into the Union or their ultimate independence, declared that the power of the Union was without limit as to time, and was only limited by the necessity of each case.

The expression "territory or other property" was equally complete and inclusive with the expression "to make all needful rules and regulations respecting." It has been noticed that, from the time of the Commonwealth, the dependencies of Great Britain, when described as forming with Great Britain the British Empire, were 
invariably divided into two classes. It is true that different names were adopted for the two classes, but duality in the classification occurred uniformly. Scientific study has confirmed this duality. There are inevitably two classes, and only two classes, of dependencies -one manifestly destined, by nature, to be incorporated, at some time, into the body and personality of the Imperial State, and the other manifestly destined never to be so incorporated. The word "territory," as has been already noticed, is, according to its literal meaning, the word most appropriate, in the English language, to denote a dependent region of the former class. It means a region so near to a State that the State is able without difficulty to reduce it, at any time, to complete submission-to terrorize the region, or act as its Territor.

The words "or other property" were those most appropriate to describe all the regions external to the Union and subject to its disposition, which were manifestly destined never to be incorporated into its body and personality. They, of course, implied that "territory belonging to the United States" was "property" of "the United States of America." This at first glance seems to be a harsh and brutal statement of the relationship between the American Union and its dependencies. As a matter of fact, though cold and scientific, it is neither harsh nor brutal. The original basis of the power of a State over any community external to it is that the land occupied by that community "belongs to" the State as its "property," and is not a part of its body. The power of a State over external populations is a power incidental to and derived from its power over external lands. A power, therefore, "to dispose of, and make all needful rules and regulations respecting territory or other property belonging to " a State inevitably carries with it, as an incident, power to dispose of and make all needful rules and regulations respecting the populations inhabiting the 


\section{The Administration of Dependencies}

"territory or other property." Instead of being harsh and brutal, therefore, this statement in the Constitution is exactly the reverse. Instead of basing the power of the American Union over external populations upon a relationship assumed to exist between them directly, it bases the power upon a relationship assumed to exist indirectly -namely, through a paramount title to the lands occupied, vested in the American Union. In other words, the theory of the Constitution is, that the inhabitants of the dependencies are not slaves of the American Union, nor even its wards, (except in certain cases where guardianship is necessary), but that they are permanent tenants of land of which the American Union owns the paramount title for public purposes.

This conception was, as has been noticed, nothing novel or original. It runs through the whole of the English and American public law from the very inception of the American Colonies. The power of England over its American Colonies was in almost every case derived from a grant of the soil occupied by the Colonies to a person or persons in trust for the Colony. The Constitution simply universalized this conception, so as to commit the Union to the theory that its power over all its dependencies, whether arising from voluntary action on

- the part of a foreign State in consenting to become dependent, or from the cession by a foreign State of a part of its territory, or from a grant of unoccupied land to a colonizing society, or from conquest, was based upon its ownership of the paramount title, for public purposes, of the land thus subjected to its disposition.

The description of the Imperial power as a power "to dispose of and make all needful rules and regulations respecting " the dependencies, though expressly applied in the Constitution to the power exercised by the Union through the Congress necessarily also qualified the power exercised by the Union through the President, since the 
power of an acting agent and the superintending agent must necessarily be the same in character.

The Constitution not only universalized the conception of the Imperial power and obligation of the American Union by imposing it upon the whole Government of the Union, and by making it clear that the power to be exercised over every kind of dependency, whether arising by voluntary action, by colonization, by cession, or by conquest, was to be a power of disposition, but it also provided for an intermediate relationship between the American Union and external communities which was neither a relationship of dependency nor an incorporation into its body. The provision which now appears in Article IV., Section 3, of the Constitution, and which reads, "New States may be admitted by the Congress into this Union,"-which was also drawn by Gouverneur Morris and accepted unanimously by the Convention,-was carefully framed, as the debates show, in this very general and unlimited form, with the express purpose of allowing States to be admitted into the Union on unequal terms, in respect to their representation in Congress or in any other respects which the Congress might think desirable, as compared with the States originally in the Union. Such a relationship of unequal union partakes both of the nature of incorporation and dependence. It resembles incorporation, because the States which are in such a situation are actually represented in the Central Government of the Union by Representatives in the Lower House at least, and they may possibly have a Senator and may participate in the election of the President. It resembles dependence, because the State so unequally represented, or which is taken into the Union on terms which place it on a permanent inequality as respects the other States, is, to the extent of the inequality, subject to the legislation or disposition of the other States acting as the Imperial State. 
The Constitution, therefore, provided for every possible relationship between the American Union and the rest of the world. By the treaty-making power, vested in the President and Senate, as the Chief Executive for this purpose, the American Union was recognized as capable of entering into a treaty with another State by which the latter should become a protectorate of the Union, and of entering into treaties by which foreign States should obligate themselves not to make conquest of regions under the control of the Union to some extent, but not yet effectively occupied by it, and thus establish the "sphere of influence" of the Union over those regions. By the power to admit new States into the Union on equal or unequal terms, vested in the Congress, the American Union was authorized to incorporate any foreign or dependent State into its body and personality on any terms it saw fit. By the power of disposition and regulation vested in the President and the Congress, it was authorized to allow every relationship known to general public law to exist between itself and its dependent States and between each dependent State and each and all the others. In no respect was the Constitution more complete or more scientifically accurate, universal, and inclusive than in the two clauses which read: "New States may be admitted by the Congress into this Union" and "The Congress shall have power to dispose of and make all needful rules and regulations respecting the territory or other property belonging to the United States."

The clause relating to the administration of dependencies was adopted by the Convention as an amendment, or more exactly, an "addition" to the clause relating to the admission of new States into the Union. As has been already noticed, Madison had intended to have the clause on this subject inserted in the specification of the legislative powers of Congress, and the Committee on 
Detail had expressed the same intention in respect to the clause reported by them. The Committee on Style and Arrangement, of which Morris was a member, considered that the clause relating to the administration of dependencies had no place in the specification of the legislative powers of Congress-plainly because they recognized that the power granted was not legislative in its nature, and that it ought in some cases to be exercised by the Congress and in some cases by the President. They therefore left it in the same Article with the clause permitting Congress to admit new States into the Union on equal or unequal terms. This was strictly logical. The power to admit new States into the Union was not a legislative power, but a power to make a contract or treaty with the State to be admitted, which should establish a permanent relationship on express and definite terms between the parties to the contract. The power to dispose of and make all needful rules and regulations was not a legislative power, but a power to fulfil an implied and indefinite contract of trust or agency, by which the State was under an obligation to perform services for the benefit of another State, in pursuance of a relationship existing between them. These powers were not to be exercised in the same way as the ordinary powers of legislation. The power to admit new States was to be exercised by means of a proposition made by one party and accepted by the other; the power to dispose of the dependencies was to be exercised by a decree, ordinance, and disposition made after careful consideration of the principles applicable to a statement of facts ascertained by an expert investigation.

Against one easily possible misconception, namely, that admission into the Union was to be the ultimate and expected goal of all States dependent on the Union, the Convention carefully guarded. Instead of following the usual form in the Article relating to 


\section{The Administration of Dependencies}

admission of States into the Union, according to which it would have read, "The Congress shall have power to ad. mit new States into the Union," this form (which was actually proposed by Luther Martin) was rejected by the Convention in favor of Morris's form, "New States may be admitted by the Legislature into the Union," from which it was made absolutely clear that the admission or non-admission of States into the Union was to depend entirely upon the will of the Union, and that it did not recognize any natural right in any of its dependent States to be admitted into its body and personality. This idea was further carried out by the arrangement, in the Constitution, of this clause and the clause relating to the administration of dependencies so that the former preceded the latter, - the Committee on Style and Arrangement following Morris's ideas in this respect.

If the order had been reversed, an argument of considerable convincing force might have been made, that it was the understanding of the framers of the Constitution that all dependent statehood was but a mere stepping-stone to admission of the dependent States into the Union, first on unequal and finally on equal terms with the original States. By placing the clause permitting Congress to admit new States into the Union before the clause relating to the administration of dependencies, it was forever rendered impossible to use the Constitution itself as an argument in favor of any such unpractical and disastrous proposition.

At the same time that Morris was engaged in framing these two most important clauses of the Constitution, he took upon himself to see to it that the expression "the United States of America" or "the United States," wherever it occurred in the Constitution, should certainly have the meaning of "the Federal State composed of the States forming the original Union and those subsequently admitted into the Union." The moment the words 
"the territory or other property belonging to the United States" were inserted in the Constitution, the expression "the United States" was inevitably confined to the Federal State composed of the States so united and admitted, and the United States, together with "the territory or other property belonging to " it, inevitably formed the American Empire. The expression "within the limits of the United States," which had been inserted by the Committee on Detail in the clause relating to the admission of new States, was omitted because the expression "the United States" there meant "the American Empire." Thenceforth "the United States " was understood to mean the American Union and not the American Empire. The Committee on Style and Arrangement therefore struck out the words "of the United States" as qualifying the executive power, so as to make it evident that the executive power extended throughout the American Empire. They confined the exercise of the legislative power to the American Union by limiting the powers of Congress to the "legislative powers herein [in Article I.] granted," and by inserting the specification of legislative powers in Article I. They also inserted in the specifications of powers relating to taxation and to legislation concerning bankruptcy and naturalization, which it was desirable should be uniform, a proviso that such legislation should be "uniform throughout the United States." Their evident purpose was thus to prevent the "legislative powers" of Congress from conflicting with the power "to dispose of and make all needful rules and regulations respecting" the dependencies, and to keep the legislative power and the Imperial power forever distinct. They left the words "of the United States" as qualifying the grant of the judiciary power to the Supreme Court and the "inferior Courts," in order to make it certain that that power was confined to the American Union, and that these Courts 


\section{The Administration of Dependencies}

were to be entirely distinct from the Courts of the American Empire and from the local Courts of the American dependent States.

It has been supposed that the power "to dispose of " the dependencies includes the power to sell the rights of the American Union over them to a foreign State. There is, however, contemporaneous evidence of the highest character against this construction. In the Convention of the State of Virginia which met on June 2, 1788 , to consider the question of the ratification of the Federal Constitution, an amendment was proposed which provided as follows:

No treaty ceding, contracting, restraining or suspending the territorial rights or claims of the United States, or any of them . . . shall be made, but in cases of the most urgent and extreme necessity, nor shall any such treaty be ratified without the concurrence of three-fourths of the whole number of the members of both Houses respectively.

Governor Edmund Randolph, who, as already noticed, had headed the Virginia delegation in the Convention and presented the Virginia resolutions, opposed this proposed amendment, saying :

Of all the amendments, this is the most destructive, which requires the consent of three-fourths of both Houses to treaties ceding or restraining territorial rights. . . . There is no power in the Constitution to cede any part of the territories of the United States. But this amendment admits, in the fullest latitude, that Corrgress have a right to dismenber the Empire.

It has also been supposed that the provision of Article VI. which makes the Constitution and the laws of the United States made in pursuance thereof "the supreme law of the land" has some reference to the administra- 
tion of dependencies. In Magna Charta the provision in which the expression "the law of the land" occurs reads as follows:

No free man shall be taken or imprisoned or dispossessed or outlawed or banished or in any way destroyed, nor will we go upon him, nor send upon him, except by the legal judgment of his peers or by the law of the land.

The words "the law of the land" here undoubtedly mean the law of England. This provision of Article VI. is almost verbation in the words of Pinckney's draft of the Constitution, with the single exception that the words "the Constitution of the United States" are added. In that draft, the Congress was given no power whatever in the administration of dependencies, and yet all Acts made by the Legislature of the United States pursuant to the Constitution were declared to be "the supreme law of the land." The Constitution and laws of the United States are the supreme law of the land in the American Union; they are only the basis of the supreme law of the land in the dependencies of the American Union, because these dependencies are under an unwritten Constitution based on the Constitution and laws of the United States.

That the clause presented by Gouverneur Morris relating to the administration of dependencies should have been accepted so promptly by the Convention was not surprising. By his action in conducting the negotiations between the Congress and the British Government in I778, followed by his masterly statement, in his Observations on the American Revolution, of the whole position taken by the American Colonies in their contest with Great Britain, he had made himself the leading authority in America upon all Imperial questions. In crowding into one short sentence a complete description of the 


\section{$47^{2}$ The Administration of Dependencies}

Imperial power and obligation, as America claimed it to be, he had but fulfilled what the Convention had expected of him. Evidently they recognized instantly that there was no room for debate or criticism-that the clause was complete and perfect in itself.

From the exercise of power subject to the Imperial obligation, the District of Columbia was excepted. In that dependency, Congress was given power "to exercise exclusive legislation in all cases whatsoever," and this specification of power was placed in the list of specifications of the "legislative powers" of Congress. Within the District of Columbia, the Congress has exactly the same powers as were claimed by the British Parliament. over the American Colonies by the Declaratory Act of I 766, - - power "to make laws and statutes of sufficient force and validity to bind [the District] and its inhabitants in all cases whatsoever." The District of Columbia has no inherent right of statehood. The political rights are only such as Congress shall grant of its mere will, as a "privilege" or "indulgence." This is necessary, in order that Congress and the President may be free from local influence. The very fact that the two kinds of power are so separated and distinguished in the Constitution serves to show the great distinction between the powers themselves. The power to "legislate" for the District of Columbia is the Magisterial power to command and govern: the power to "dispose of and make all needful rules and regulations respecting " the other dependencies is the Imperial power to administer and govern.

It will be remembered that Grotius, in the passage which has been already quoted, said:

It is well worth our observation that what the Latins express by the word imperare, to command, the Greeks more modestly express by the word $\tau \alpha \sigma \sigma \sigma \varepsilon \nu$, to dispose or set in order. 
The British had expressed the Imperial power in the same way as had the Latins. The Americans repudiated this definition of the Imperial power, but did not fall into the mistake into which the Greeks had fallen. The too great haughtiness of the Romans had resulted in a loss of power through excessive centralization. The too great modesty of the Greeks had resulted in an entire absence of power because of the lack of centralization. The Americans chose the middle ground. That which the Romans called the power to command and which the Greeks called the power to dispose or set in order, the Anericans called the power to dispose or set in order and to command accordingly. 


\section{CHAPTER XXIV}

\section{EUROPEAN ADMINISTRATION, I787-I9O2}

IUST at the moment that the Constitution of the United States was being framed, France entered upon a period of experimentation in the matter of the administration of its dependencies. Louis XVI., in March, 1787, granted to the Provinces of France ihe right to elect local Parlements, with restricted and rrovisional powers of legislation; and in June, $178 \%$, he granted the same right to the French Colonies is the West Indies. The consequence was that when the Revolution broke out, these Colonies demanded represertation in the General Assembly of France, taking the sround that, as the principles of liberty, equality, anc fraternity were universal, France and its dependencie constituted a Unitary State, and that the dependences could not be excluded from proportionate representaton in the General Assembly. On July 4, I789, deput:s elected by the Colonial Legislature of San Doming' presented themselves in the Assembly and demanded tk: full rights of deputies from the domestic Provinces. After a long debate, their demand was granted. On ctober 14, in the same year, deputies from Martinique rade a similar demand, and were admitted, and their exmple was followed July 7, I790, by deputies from Gadaloupe, with the same result. In March and April, 190, the General Assembly took up the colonial question $1 d$ resolved that:

While this Assembly considers the Colries as a part of the French Empire and desires to grant them en enjoyment of the 
fruits of the happy regeneration which is now going on, it has never intended to include them in the Constitution which it has decreed for the Realm, and to subject them to laws which might be incompatible with their local and particular requirements and customs.

The General Assembly, therefore, authorized the Colonies, through their deputies, "to make known their wishes in regard to the Constitution, the legislation, and the administration which would be best adapted to their needs," and permitted them to elect Local Assemblies whose powers should be on this basis of relationship. A Colonial Committee of twelve members was named, charged with drawing up a plan for a Constitution which should serve as a model for all the Colonial Constitutions, but which should be merely for the guidance of the Colonial Assemblies, they having full permission either to use it only in part or not to use it at all, as they saw fit. The committee reported a guide-plan as directed, and by order of the Constituent Assembly it was sent to the Colonies on June I 5 , I79r.

Meantime, in May, I79I, political rights as citizens had been granted by the Constituent Assembly to free negroes, and the negroes in the West Indian Colonies had become excited by the prospect of freedom held out to them by the speeches of the Revolutionary radicals and by the actions and publications of the French Society for the Abolition of Slavery. Before the permission had arrived from France to form Colonial Assemblies on the new basis, they had been formed by the white populations, in the interest of the whites; and an organization was immediately formed among the white populations to start a reactionary movement which would make the Colonies independent of France and thus prevent the abolition of slavery, on which institution they felt the prosperity of both the white and the black population 


\section{The Administration of Dependencies}

depended. By the time the too liberal terms of relationship offered by the French National Assembly were transmitted to the West Indian Colonies, these Colonies were not only in a state of organized rebellion against France, but in a state of civil war between the whites and the negroes.

In the Constitution of September, I79I, it was provided that:

The Colonies and French possessions of Asia, Africa, and America, although they form a part of the French Empire, are not comprised in the present Constitution.

This Constitution fixed the number of representatives at 745, "independently of those which may be allowed to the Colonies." To the General Assembly of France was reserved the decision of questions relative "to the exterior régime of the Colonies, to the organization of the courts, to the defence of French interests, and to the carrying out of engagements between the French traders and planters and the natives "-all other matters being left to be finally determined by the Colonies themselves.

The abolition of slavery throughout France and all its dependencies by vote of the Convention, in 1794 , removed the last obstacle to the universal application of the principle of equality between individuals, and accordingly, in order both to make the application of the principle universal and to put an end to all the hopes of the planters that a separation of the Colonies from France might be brought about, the political organism composed of France and its dependencies was declared to be a Unitary State by the Convention, in the Constitution of $\mathrm{I} 795$, in the following language:

The French Colonies are integral parts of the Republic and are subject to the same constitutional law. . . . They shall be divided into Departements. 
All laws enacted under this Constitution were to be ipso facto applicable, without distinction, to the Colonies then belonging to France. Some Colonies, theretofore separate, were united so as to form a single Departement; but San Domingo, where the race war between the whites and the blacks was raging most fiercely, and where the local organization was most complete, was divided into several Départements.

In I798, by statute, this principle of uniformity was extended so as to assimilate the colonial Departements to the domestic Départements in all matters of finance and taxation, and the system of elective judges and jury trial in force in France was extended to the Colonies.

During this period of uniformity and assimilation, the Colonies were proportionally represented in the Assemblies of France.

Speaking of the effect of this policy, M. Arthur Girault, in his work, Les Principes de Colonisation et de Législation Coloniale, published in 1895 , says:

In spite of this, the Colonies made lively opposition to all the measures which the Assemblies adopted in relation to them. They accepted the advantages of assimilation, but they were unwilling to submit to its burdens, being of a mind to govern themselves. . . . In fact, moreover, our Colonies, altogether too far distant for the Revolutionary Government to be able to make its will respected among them, passed through a period of trouble and confusion. Some, like Martinique, were in the hands of the English. San Domingo was devastated by a frightful civil war. Toussaint l'Ouverture and Victor Hugues did as they pleased there. In the Colony of Réunion, the Colonial Assembly governed the island according to its whim. It was anarchy.

With the consulate of Napoleon came the reaction against the Revolutionary sentiments, and the political 


\section{The Administration of Dependencies}

organism composed of France and its dependencies was again recognized as an Empire. The Constitution of I 800 provided that :

The régime of the French Colonies shall be determined by special laws.

Two years later, the Legislature delegated to Napoleon its power over the Colonies for ten years by an Act which provided that:

All previous laws to the contrary notwithstanding, the régime of the Colonies is submitted, for ten years, to the regulations which shall be made by the Government.

The moral obligation of France to exercise its functions towards these dependencies in an expert manner, and the federal nature of the Empire composed of France and its dependencies, was immediately recognized by Napoleon, by the establishment of a Colonial Council at Paris, composed in part of persons appointed by the French Government and in part by persons elected by the appointed Legislatures of the dependencies. France was convinced, for all time, that popular government of aggregations of communities was limited to those which are contiguous and homogeneous, and from that time forward never departed from the proposition that the dependencies were entitled to a special and particular administration differing from that of France.

The Constitution of I8I4 provided that: "The Colonies shall be ruled by particular laws or regulations "- the word laws (lois) referring to the action of the Parliament, and the word regulations (réglements) to the action of the Executive. The administration of the dependencies, under this Constitution, drifted inevitably into the hands of the Executive, and during the period from 1814 to 
I830, a great number of careful and scientific regulations for the Colonies were made by royal ordinances. In I830, the jealousy felt by the Legislature of the Executive, due to the claims of arbitrary power in France made by Louis XVIII. and Charles X., led to a return to administration of the dependencies by the French Parliament. In the Constitution of 1830 , the words "and regulations" were omitted, so that the provision read: "The Colonies shall be governed by particular laws."

By the Constitution of $\mathrm{I} 848$, it was provided:

The territory of Algeria and the Colonies is declared French territory, and shall be ruled by particular laws until a special law places it under the régime of the present Constitution.

In the Constitution of 1852 , the provision was: "The Senate shall rule the Constitution of Algeria and the Colonies by senatus-consultes"-that is, by action taken by the Senate alone as a deliberative and legislative body.

The constitutional laws of France which since 1875 have formed its Constitution do not specifically cover the case of the dependencies, and the sénatus-consultes made under the provisions of the Constitution of 1852 are still considered to be in force, though not to the extent of preventing the operation of the general rule that a law of Parliament controls every other law or regulation.

The Colonies of France remained under the direction of the Minister for the Marine until I88I. In that year, the administration of the Colonies was committed to the Minister for Commerce, and placed in the special charge of an Under-Secretary for the Colonies. A little later, the administration was again attached to the Ministry for the Marine; later it was again attached to the Ministry for Commerce; and still later was again attached to the Ministry for the Marine. Meanwhile the business of the administration of the Colonies had fallen under the 


\section{The Administration of Dependencies}

charge of a permanent Under-Secretary, and had become independent of both the Ministry for the Marine and the Ministry for Commerce. On March 20, I894, by a law of the French Parliament, the administration of the French dependencies was placed in the charge of a Minister for the Colonies. This action was taken with great deliberation, and after a very careful examination of the whole subject by the members of the House and Senate familiar with the requirements of colonial administration. Neither Algeria, Tunis, Madagascar, nor the protectorates of Indo-China were included within the jurisdiction of the Minister for the Colonies. Algeria was placed within the jurisdiction of the Minister for the Interior, and Tunis, Madagascar, and the protectorates of Indo-China within the jurisdiction of the Minister for Foreign Affairs.

In the year I883, while the administration of the French Colonies was in the hands of the Minister for the Marine, there was established, by decree of the President, an Imperial Council, attached to the Under-Secretary for the Colonies, called Le Conseil Supérieur des Colonies, composed of persons expert in colonial administration, whose duties were to advise the Under-Secretary. This Council was remodelled in I890, as the result of the action of the French National Colonial Congress, held at Paris in December, I889, and February, I890, which arose out of the International Colonial Congress held in August, 1889, in connection with the Universal Exposition. The action of the Congress was expressed by the following resolution:

The Congress-considering that the representation in the National Parliament of some of the Colonies requires, as a logical correlative, the establishment, for the benefit of the Colonies not represented, of a special system of consultation; considering, also, that the former régimes applied to the Colonies gave to them the necessary guaranties in this respect, either by the institution of Local Legislatures invested with 
power to manage their purely internal affairs, or by the organization in the Imperial State of Councils-General, in which the decisions of the Government might be debated before being put in force in these countries-express the opinion that an organic law should be enacted, instituting, in connection with the administration of the Colonies, a Superior Council of the Colonies, composed as follows:- etc.

In accordance with this resolution, the Superior Council for the Colonies as remodelled by decree of the President, was composed of the Senators and Deputies of the Colonies represented in the French Parliament, delegates from the other Colonies, seventeen barristers having special knowledge of administrative law, persons nominated by the French Government because of their expert knowledge of colonial affairs and administration, delegates from the Chambers of Commerce of the principal French cities, and delegates from societies formed for the study of colonial and geographical questions. When the office of Minister for the Colonies was established in 1894, this Council was continued and was attached to this Ministry.

M. Boulanger, the first Minister for the Colonies, in a report to the President of the Republic, of May 5, I894, speaking of the functions of France, as the Imperial State, towards its dependencies, said:

In establishing a Ministry for the Colonies, the Parliament has recognized the necessity of making certain important modifications in the workings of the Central Administration, in order that it may fulfil the heavy task imposed upon it by the extension of our Colonial domain.

The principal divisions of this Ministry ought to be so constituted as to accomplish the following results:

In the first place, it is necessary to assure to our possessions an administration which is actuated by the highest sentiments of order, of justice, and of scrupulous equity, which shall give to persons who immigrate into the Colonies and to the natives 3r 


\section{The Administration of Dependencies}

a knowledge and understanding of their rights and a respect for their duties, which shall let it be known to all the world that France, however far distant, proposes to exercise upon its Colonies its moral and civilizing influence. It is important that the administration should be decentralized enough not to interfere with the initiative of the Colonies and to prevent their free development, but it is necessary that it should conserve the sovereign authority necessary to safeguard the general interests of the whole political organism composed of France and its dependencies (les intérêts généraux du pays), to protect, whenever necessary, our foreign possessions against their own weakness, and to maintain at every point on the earth's surface where the French flag floats the unity of purpose indispensable to the prosperity of the Colonies.

In the second place, the administration ought to have for its object the procuring for our different possessions the enjoyment of institutions suitable to the nature of each, of countenancing and supervising the exploitation of their natural resources, and of placing and keeping their relations with the Imperial State upon a just, coherent and orderly basis.

It was obviously implied in this statement that the "sovereign authority" of France over its dependencies was not unconditional and unlimited, but only such a power as was "necessary" to safeguard the general interests of the Empire, to protect the respective dependencies from their own inherent weaknesses, and to maintain a unity of purpose throughout the whole political organism composed of France and its dependencies.

Some of the recent French writers on the administration of dependencies admit only two possible views of the power of a State over its dependencies-the first, that it is the same as its power over the integral parts of the State; and the second that it is the same as that exercised by the State in or for an independent State, under a treaty with that State. In either view, the condition of dependence is a temporary one, and for the purpose 


\section{European Administration, I 787-I902 483}

of preparing the dependency either for complete independence or for complete incorporation into the body and personality of the State. These two conceptions of the power of the State are the only ones admitted by Professor Edouard Petit, in his monumental work entitled Organisation des Colonies Françaises et des Pays de Protectorat, published in I895. Other writers, notably M. Arthur Girault, in his essay entitled "Théorie Générale de la Colonisation," printed as a preface to his Principes de Colonisation et de Législation Coloniale, published in I895, admit a third conception, namely, that the power of the State is a power over the individual inhabitants of the dependencies, who, if not of French origin or entitled to rights by treaty, have no political rights as against France and only the fundamental civil rights. A State which is devoted to the first conception of its powers is said to be devoted to the policy of assimilation (l'assimilation); one devoted to the second conception is said to have the policy of autonomy (l'autonomie); and one devoted to the third, the policy of assubjectization (l'assujetissement).

$M$. Girault is of the opinion that none of the three conceptions is exactly correct, and that, while the general principle of the second is correct, the true conception is arrived at by combining all three conceptions. He thus closes his essay:

This policy [of assimilation], of the principle of which we approve, must be both moderated and eclectic-by "moderated" I mean disengaged from certain unfortunate exaggerations, and carefully distinguished from a uniformity contrary to the nature of things, and by " eclectic," borrowing from the two other systems what is good in them, namely, the unity of authority from the principle of assubjectization, and extended local liberties and wide decentralization from the principle of autonomy.

It is an interesting fact that the recognition of the 


\section{The Administration of Dependencies}

Imperial power as a power of assubjectization by writers on French colonial policy was due to the representations made by the delegates from Holland to the International Colonial Congress of I889. Devoted as is the State of Holland to the principle of individual liberty and of statehood for all communities destined by nature for a distinct existence, it has adopted, in the management of tropical dependencies, the principle that its power is a power of assubjectization. The States-General fix by an organic law the Constitutions of the dependencies and establish by statute the most important rules and regulations. Details of the administration are provided for by the decrees of the Queen or by resolutions (arrêtés) of the local Governor-General, who acts after advising with an Executive Council of experts. The inhabitants of the dependencies are not consulted, and no question of allowing them representatives in the States-General has ever been raised.

In I 895, the French Government made a statement of its views on the subject of the relations of France to its dependencies which went far beyond the views of any of . the writers on the subject. This statement was made in support of a project of law proposed by the French Cabinet to the Parliament for an Act to be passed declaring Mada. gascar, which was then in the military occupation of France (it having been previously a half-sovereign State under protection of France by treaty, and a revolt having occurred which France had suppressed), to be annexed to France as a French Colony. It was objected that annexation would imply that the French Constitution and laws were in force in Madagascar exactly as they were in France.

In opposition to this, the Minister for the Colonies made a statement before the Committee of the Chamber of Deputies in which he said:

The project of law presented by the Government does not 


\section{European Administration, I 787-I902 485}

carry with it, as a necessary consequence, any modification in the administration of the country or require the immediate application of French legislation in its entirety to the different tribes which are scattered over the vast territory of the island.

In other words, the expression, "French Colony," as applied to Madagascar does not necessarily imply the creation of a complicated administration, because it is possible to administer and organize our new Colony by utilizing the assistance of the local authorities and institutions. . . . This measure is not such as amounts to substituting, ipso facto, the institutions of the Imperial State for those of the dependent country, because the well-defined policy of the Government is toward a progressive amelioration in the legislation of the natives, by borrowing (empruntant) from our own legislation, in proportion to the needs and according to the circumstances, whatever it contains which is applicable to populations of different races, which are for the most part very far removed as yet from our ideas of civilization.

The law in project, from an international point of view, annuls the personality of the Madagascan State, which will disappear as a juridical entity, and become a dependency of the French sovereignty; but it cannot have the effect to annihiate the personal status of the natives, who cannot reasonably be subjected, without a period of transition, to the exigencies of our "civil life," nor can it abrogate the local laws or usages.

The report of the Committee, after quoting, as above, the words as of the Minister for the Colonies, proceeded as follows :

It is wrong to confound annexation and assimilation. Annexation is the act of incorporating, whether by cession, conquest, or purchase, new territory into the national domain; giving to it, or leaving to it the government which best suits its needs. Assimilation is a form of administration in all respects conforming to that of the Imperial State. This latter method of administration, which is applicable only when 


\section{The Administration of Dependencies}

populations of the same origin, which have arrived at the same degree of civilization, are concerned, would not be at all suited to natives having different manners and customs.

This statement came very near to recognizing that the French dependencies have an inherent right of statehood. The French Government, in making the statement, necessarily denied that by annexation of territory the Constitution and laws of France become the Constitution and laws of the annexed territory, They admitted that the "legislation of the natives" continued after annexation, and that French legislation, in so far as it operated as legislation within the dependency, operated by a process of "borrowing," - the borrowing extending only to such parts as were "applicable," considering the local "needs" and "circumstances" of the dependency. It seems not too much to say that this statement, followed as it was by the passage by Parliament, in 1896 , of the Act projected, committed France to the proposition that its power over its dependencies is a power distinct and different from its power as exercised within the State of France, and conditioned and limited so as to be properly described as a power of disposition.

The proposition that the dependencies of France are subject only to a conditional and limited power of the State of France is but a natural extension of the French theory concerning the nature of all governmental power. According to the French view, all governmental power except that exercised by an elected representative Assembly is regarded as the result of a previous expert investigation and adjudication. The acts of the President of the Republic are called decrees (décrets). The regulations made by a Minister for the purpose of carrying into effect the laws of Parliament or the decrees of the President are called arrêtés, while the judgment of a court is called arrêt-both words containing the idea of adjudication 
and decision. The tendency, throughout all administration emanating from or affected by French ideas, to regard all administrative functions as having a judicial aspect is well known. The institution, known as the Council of State, which exists in France as a court of last resort in all cases involving the application of the public law to the individual and as an advisory council for the Parliament and the President, unconnected with the Ministry except as the Ministry follows its advice given on matters referred to it, is but an evidence of the French theory which has survived from the earliest times.

The establishment of the Colonial School in Paris by decree of the President, of November 23, I889, was a recognition of the Imperial power as a power of disposition. This school, which is attached to the Ministry for the Colonies and administered by a Council named by the Minister for the Colonies, is an institution partly public and partly private, being supported in part by grants made by France and by the Colonies, in part by private donations and legacies, and in part by tuition charges. It is open both to young men from the Colonies and from France. The purpose is to fit the inhabitants of the French dependencies for their own government, and to fit the French Government to most expertly perform its functions as the Imperial Government, by training up young men to perform these different functions.

Though Algeria is a dependency so near to France that its ultimate incorporation into France might under some circumstances be practicable, yet the great difference between the native population and the French renders it extremely improbable that such incorporation can ever occur. Since 1870 , it has been represented in the French Parliament on the basis of the French population of Algeria,- - that is, on unequal terms as compared with the Départements of France.

Since I866, the Colonies of Réunion, Martinique, and 


\section{The Administration of Dependencies}

Guadaloupe have each been represented in the Chamber of Deputies of France by two Deputies and in the Senate by a Senator. French India has one Deputy and one Senator, and Senegal, Guiana, and Cochin China have each a Deputy.

In spite of this representation, however, all legislation of the French Parliament is not ipso facto in force in the dependencies. If Parliament by express words extends a law to some or all the dependencies, it is in force accordingly. As respects native-born Frenchmen residing in the dependencies, all laws of France protecting the person and property are regarded as being in force ipso facto.

While France allows to some of its dependencies a very considerable autonomy, -even permitting some of them, under its supervision, to regulate their own tariffs, and while it respects the privilege of Colonial Assemblies to grant taxes, yet every act of the dependencies is under the supervision and control of the French Government. In theory, the dependencies are yet only "prolongations of the soil" of France, to use the expression of M. Girault. Napoleon's epigram, "Là oì est le drapeau, là est la France," is taken as an axiom, while at the same time the march of events is contradicting it. The administration of Tunis, since I88I, as a protectorate of France under such conditions that it may perhaps be called a "constitutional protectorate," though having the form of an "international protectorate," is an illustration of the advantage to be derived from treating dependencies as entitled to inherent rights of statehood, and preserving, to the urmost degree consistent with the general interests, the local habits and customs. The same system of constitutional protectorate has been applied by France in the management of some of its African and East Indian possessions which it was necessary to isolate.

It thus appears that the present tendency in France is towards the solution of the problem of the administration 
of dependencies by. a compromise between popular and expert government, according to which the right of representation is extended to even very remote dependencies, while at the same time the dependencies so represented are actually given an expert administration through an Imperial Department.

At the same time, there undoubtedly exists an opposing tendency which makes for a more and more complete differentiation of the dependencies from the Imperial State. Even in the case of Algeria, the policy of assimilation which prevailed unquestioned from i 860 to I 885 is now regarded as a general plan, not likely, in the immediate future, to result in the incorporation of Algeria into the body and personality of France-or, to use the words of M. J.-C. Paul Rougier, in his Précis de Législation et d'Économie Coloniale, published in 1895, "a plan indicative of the end to be obtained and to which we shall attain only after centuries spent in changing the character and transforming the moral conscience of the Mussulman society." The recent statements of the French Government seem also to indicate a trend of thought which, if carried to its logical outcome, can only result in the conception of the French Empire as a federal organism.

Germany, like the United States, began its experience as an Imperial State by being obliged to control an adjacent population which was not capable of immediate assimilation but which was manifestly destined to incorporated into the body and personality of Germany. The acquisition of Alsace-Lorraine, as the result of the FrancoGerman War, in $187 \mathrm{I}$, raised a problem which, in its general features, resembled the problem which the United States worked out by the Ordinance of 1787 for the 


\section{The Administration of Dependencies}

government of the Northwest Territory. The reasons why the populations of the adjacent regions could not be immediately assimilated were entirely different, but the fact of this impracticability was the same in both cases.

In passing, it may be noticed that the description of the political organism composed of the German States, as "the German Empire," was a recognition of the principle underlying the description of a State and its dependencies as a Federal Empire-it being an organism composed of States, of which Prussia was the Imperial State for some purposes.

Some German and Swiss writers, following the classification originally suggested by Dr. J.-G. Bluntschli, in his Geschichte des Schweitzerischen Bundesrechts, published between I 848 and I859, regard Germany as a Federal Empire (Bundesreich). Dr. Edward A. Freeman, in his essay entitled "Bases of National Unity," printed in a volume of essays entitled Britannic Confederation, edited by Mr. A. S. White, published in 1892 , also took this view. His words were:

The position . . . of the State of Prussia quite cuts off [Germany] from being reckoned as a real Federation. If anything, it is rather a Federal Empire, an Empire in the shape of a Federation.

By "Federation," in this extract, is really meant, as the context shows, "Federal State."

Germany, however, differs from a true Federal Empire in having a representative Central Government, and therefore most writers classify it as a Federal State. M. Louis LeFur, in his État Fédéral et Confédération d'États, published in 1896 , takes this view, and intimates that the term Federal Empire is only properly applicable to "a State formed by the union of a Sovereign State and one or more dependent States." 
Upon the acquisition of Alsace-Lorraine, the German Government, recognizing it as a dependency destined for ultimate incorporation into the body and personality of Germany as a State of the Union, but not capable of immediate incorporation because of the hostility of the inhabitants and their devotion to French customs and traditions, gave to the region of Alsace-Lorraine the name and description of Reichsland, "the land of the Empire" or "land belonging to the Empire," distinguishing it from the Schutzgebiete, "the foreign protected dominions." Both Houses of the German Parliament withdrew from all active participation in the administration in behalf of Germany, by uniting in the enactment of a law of June 9, I87I, which provided that the political power should be exercised in Alsace-Lorraine by the Emperor. By the Constitution of Germany, the Emperor exercises all political power "in the name of the Empire" - that is, in the name of the State of Germany. The Imperial Chancellor, who is the immediate official adviser of the Emperor, became the Minister for the administration of the relations between Germany and Alsace-Lorraine, it being recognized that the charge of the administration of the region could not properly be given to any of the Executive Departments. A Local Government was established in Alsace-Lorraine in which the people of that region had some participation. On December 30, I87I, by Act of Parliament, a Governor, with full powers of internal administration, and an elective Council to assist him, were provided. On July 4, I879, the local administrative power over Alsace-Lorraine was, by Act of Parliament, taken away from the Imperial Chancellor and vested in the Governor assisted by his Council, and the Governor was made directly responsible to the Emperor. As the Emperor, in administering the affairs of Alsace-Lorraine, acts as the representative of the State of Germany, the action of the German 


\section{The Administration of Dependencies}

Parliament, in placing the local administration of AlsaceLorraine in the charge of a Governor appointed by the State of Germany, assisted by an elected Council, was a recognition of the dependent statehood of AlsaceLorraine, and of a federal relationship between it and Germany.

Between 1871 and 1873 , there was much discussion in Germany concerning the relation of the Constitution of the State of Germany to the administration of AlsaceLorraine. On June 25, I873, a law was passed by the German Parliament providing that the Constitution of Germany should be in force in Alsace-Lorraine on and after January I, I874. Alsace-Lorraine was not, however, allowed to be represented in the German Parliament.

Professor Paul Laband, in the last (French) edition of his Das Staatsrecht des Deutschen Reiches, now in course of publication, speaking of the present situation in AlsaceLorraine, arising out of the putting in force of the Constitution in Alsace-Lorraine by the Act of 1873 , admits that it is very difficult to understand exactly what effect this action had. He says :

By the laws of May 2, 1877 , and July 4, I879, the provisions of the law of June 25 , I 873 , were completed and modified, with the result that the principles which govern the exercise of the governmental power in Alsace-Lorraine are actually very complicated.

Since the putting in force of the Constitution in AlsaceLorraine, the German Parliament has, in general, exercised the same powers as it exercises over the States of Germany, but it has not hesitated to exercise such other powers of supervision and control as it has thought necessary.

In Germany, as in France, the theory prevails that all the rights of the German dependencies arise from 
the mere will and grant of Germany, as the Imperial State. Thus, Professor Laband says of the relationship of Alsace-Lorraine to Germany:

Alsace-Lorraine is not a monarchy, because it has no personal Sovereign; nor, on the other hand, is it a republic, because the people of Alsace-Lorraine are not the depositaries of the political power. It is an integral part or province of Germany. The depositary of power in Alsace-Lorraine is Germany, that is to say, the body of States united to form Germany, in their theoretical unity, in their political personality.

The Constitution of Germany recognizes the class of dependencies manifestly destined, by reason of their remoteness in distance and civilization, never to be incorporated into the State of Germany under the name of Schutzgebiete - "foreign protected dominions." Such dependencies are, by the Constitution, placed in the immediate control of the Emperor, who by its terms exercises "the protective power" over them. The administration of the foreign protected dominions is in charge of the Imperial Chancellor, in his capacity as Secretary of State for Foreign Affairs, there being in the Ministry for Foreign Affairs a special division devoted to this branch of administration. Nearly all the foreign protected dominions consist of tropical or semi-tropical lands and populations, and the original occupation by Germany of these regions has usually arisen out of the occupation of merchants, followed by the occupation of colonizing and exploiting companies. These companies have, in most cases, surrendered to Germany the governmental powers which they have assumed or obtained by conquest or treaty from the natives. Professor Laband calls the Schutzgebiete "protectorates under the general public law," as distinguished from "protectorates under the international law." 


\section{The Administration of Dependencies}

Almost simultaneously with the reorganization of the Colonial Council in France (on October IO, I890), there was created, by a decree of the Imperial Chancellor, an advisory Council of experts, attached to the division of the Foreign Office having charge of the administration of the foreign protected dominions. This Council is composed of an undesignated number of persons having special knowledge and experience in colonial administration, named by the Imperial Chancellor, together with representatives of those colonizing and exploiting companies which are formally under the protection of Germany through letters of protection issued to them by the Emperor, or which are engaged in operations of importance without formal protection.

By Act of Parliament of March 30, I892, the budget of each foreign protected dominion is required to be kept separate from the budget of Germany, and from that of Alsace-Lorraine, and from those of the other foreign protected dominions, so that the tax and revenue laws of each dependency are adjusted to its own budget. Thus in this most important respect of financial isolation, the statehood of the German dependencies is preserved.

Professor Laband, speaking of the relation of the foreign protected dominions to Germany, says :

The Schutzgebiete are not foreign territory as respects Germany; they belong to Germany. . . . They are not incorporated into Germany; they do not form part of that portion of the earth's surface which constitutes the material basis of the political personality of Germany; they are not elements, but dependencies of the territory of Germany.

It is proper to say that the territories of the Schutzgebiete are "foreign" when one is speaking of the force and application of the laws of Germany, of the jurisdiction of officers, 
and of the effect of administrative acts and decisions, for in this sense the word "foreign" is not used to describe that which is subjected to a foreign political power, but to describe territory other than that which the Constitution has set apart in order to make of it a juridical unity.

The most recent German writer on general public law, Dr. Georg Jellinek, in his book entitled Das Recht des Modernen Staates, published in I900, recognizes the distinction between dependencies destined for incorporation into the Imperial State and those destined never to be so incorporated, by dividing all dependencies into two great divisions, one of which he calls land als integrirend Staatsglied,_- "land as an integral part of the State," - and the other nebenland. He describes land als integrirend Staatsglied (which, it is at once evident, corresponds to the Reichsland of Germany and the "Territories" of America) as follows :

A region of this kind is, in greater or less degree, subordinated to the State and is organized with reference to the exclusive interest of the State, as a province, whose participation in the corresponding life of the State is limited.

Dr. Jellinek thus describes the nebenland:

To a region of this kind, from its nature, there pertains a separate political existence, so that it can have no participation in the life of the dominant State. This is the case with all Schutzgebiete and Colonies, to which no participation in the Parliamentary deliberations of the collective State is allowed; whose administration shows a wide differentiation from that of the State, so that they appear, not as integral and constituent parts, but rather as mere connected parts of the State; and which, for this reason, without coming into contact with its inner life, may be almost entirely separated from it.

The possibility of regarding dependencies as States in a 


\section{The Administration of Dependencies}

federal relationship with the Imperial State has not escaped the attention of the German scholars, but they unanimously oppose such a conception as applied to the Schutzgebiete. Professor Georg Meyer, in his Die Staatsrechtliche Stellung der Deutschen Schutzgebiete, published in I888, denied their statehood, and he was supported in this position by Professor Carl von Stengel in his Die Deutschen Schutzgebiete, ihre rechtliche Stellung, Verfassung und Verwaltung, published in 1895 , and by Laband and Jellinek.

It thus appears that though, in Germany, as in France, the dependencies are regarded as deriving their political existence and rights from the will and grant of Germany, they are nevertheless being treated more and more exactly as they would be if they were considered to have inherent rights of statehood-in other words, that, although the German Empire (meaning by this term Germany and its dependencies, and not the State of Europe which calls itself "the German Empire"), is in theory a unitary organism, it is in practice a federal organism. Even the tropical dependencies, whose populations are wholly without the ability to govern themselves except, in some cases, under a tribal form, are treated as States, and the State of Germany recognizes its right and its duty to isolate these States economically, and to some extent socially, from German contact and influence, and to hold the administrators of these dependencies to the most stringent obligation to account, as a Substituted and Trustee Government for the people of these States, to the State of Germany concerning their trusteeship.

Summarizing the results of this investigation of the theory and practice of the States of continental Europe, it appears that the conception of the dependencies of a State as themselves States is steadily forcing its way from the very necessity of the case, since experience has proved that only upon this basis can dependencies 
European Administration, I787-1902 497

be successfully administered. As the theory is yet in process of formation, no consideration has been given to the very important corollaries which would flow from its acceptance,- - such as, for instance, the corollaries that the Imperial power is a trust arising out of an implied contract between the Imperial State and the dependent States, which rests upon the Legislature and the Executive of the Imperial State alike; and that therefore the Federal Empire composed of a State and its dependencies is subject to an unwritten Constitution distinct from the Constitution of the Imperial State. 


\section{CHAPTER XXV}

\section{BRITISH ADMINISTRATION, I780-I9O2}

N I780, Burke introduced a Bill in Parliament for reducing the expenses of the Civil List, which provided for the abolition of the office of Secretary of State for the Colonies and of the Board of Commissioners for Trade and Plantations, as unnecessary and useless. As. Great Britain had insisted, not only at the inception of the American Revolution, but even in 1778 , after the war had been going on for three years, that its dependencies were mere counties of the Realm, and its Parliament the Supreme Legislature which "granted" to the dependencies the "privilege" or "indulgence" of "self-government," there was no more need for a Secretary of State for the Colonies or for a Board of Commissioners for Trade and Plantations, which was, in effect, an UnderSecretarial Board, than there was for a Secretary of State and an Under-Secretary of State for the County of Durham. The King yielded and himself abolished the two offices attacked by Burke. By an Act passed in I782, the offices were formally abolished.

Burke, though insisting upon the unconditional and unlimited power of Great Britain over the dependencies, was a great believer, as has already been noticed, in granting "privileges" or "indulgences" to them. By his influence, in I782, the "privilege" or "indulgence" of entire exemption from Parliamentary control was granted to Ireland, by the repeal of the Act of 1720 " for the better securing of the dependency of Ireland upon the Crown of Great Britain," in which it had been declared: 
That the said Kingdom of Ireland hath been, is, and of right ought to be subordinate unto and dependent upon the Imperial Crown of Great Britain, as being inseparably united and annexed thereunto; and that the King's Majesty, by and with the advice and consent of the Lords Spiritual and Temporal, and Commons of Great Britain, in Parliament assembled, had, hath, and of right ought to have full power and authority to make laws and statutes of sufficient force and validity to bind the Kingdom and people of Ireland.

Two years later, in 1783 , when the Irish objected to cases going on appeal from the highest courts of Ireland to the Judicial Committee of the Privy Council, the Parliament settled this matter by granting Ireland the "privilege" and "indulgence" of entire exemption from this appellate jurisdiction, in an Act which provided:

That the right claimed by the people of Ireland to be bound only by laws enacted by his Majesty and the Parliament of that Kingdom in all cases whatever, and to have all actions and suits at law or in equity, which may be instituted in that Kingdom, decided by his Majesty's courts therein finally, and without appeal from thence, shall be, and it is hereby declared to be, established and ascertained forever, and shall at no time hereafter be questioned or questionable.

The Irish people, instead of arguing from this action of Parliament that Great Britain and Ireland constituted a Federal Empire, of which Great Britain was the Sovereign State for which the King acted, argued that Ireland was a State independent of Great Britain, though the same person was King of both States. If the King of Great Britain was merely the King of Ireland, it necessarily followed that when a Regent had to be named, Ireland might name him as well as Great Britain, and if they could not agree, Ireland might name its own King and become entirely independent. This was actually 
attempted in 1788 . At the time the Constitution of the United States was being framed, Ireland, released from Parliamentary control, was in a state of anarchy and was a menace to the peace and safety of Great Britain; and it was evident that the Act of $\mathrm{r} 782$ had been a serious mistake. It seems probable that the failure of this experiment had much to do with the practically unanimous sentiment which seems to have prevailed in America in I 787 that the Northwest Territory could not safely be exempted from the control of Congress.

In I 782, when Burke's Act was passed, there was no regularly organized Committee of the Privy Council for Trade and Plantations. The administration of the British dependencies, therefore, rested with the King and the Parliament (except where, as in the case of Ireland, the Parliament had voluntarily withdrawn), acting through the Secretary of State for the Southern Department, who then began to be recognized as the Secretary of State for Home Affairs. Until i 786, the immediate charge of the administration of the dependencies was vested in a Bureau or Division of the Home Office, known as "the Plantations Branch of the Home Office." The Committee of the Privy Council for Trade and Plantations was revived in 1784 , and in 1786 the business of the Plantations Branch of the Home Office was transferred to this Committee.

Under this arrangement, the Committee of the Privy Council for Trade and Plantations was, in effect, the Secretarial Board for Imperial Affairs. The Secretary of State for the Southern Department was also Secretary for Imperial Affairs. There were therefore two Secretaries of State having the same functions, acting under an arrangement which did not expressly subordinate either of them to the other. It was inevitable that one should supplant the other. The Committee of the Privy Council for Trade and Plantations, being less effective than 


\section{British Administration, I780-I902 501}

the single Secretary, gradually dropped into desuetude, and by the year I 800 had practically ceased to have any connection with the administration of the dependencies.

In 1794, it evidently being realized that the business of the administration of the dependencies had no proper connection with the administration of the Home Affairs of Great Britain, the administration of the dependencies was placed in the charge of the War Department, and the Secretary of State for War became nominally the Secretary of State for the Colonies.

The policy of legislative independence for Ireland, initiated by Great Britain in 782 during the Radical reaction, which had resulted in nothing but anarchy for Ireland, was brought to a close by the Union between Great Britain and Ireland which was consummated August 2, I 800 .

By Pitt's Act, in I79I, Canada was divided into two Provinces-Lower Canada being set apart so as to include the French settlements, and Upper Canada so as to include the regions into which there was English immigration. Each Province was given a Lower House which was elective, and the form of government in each was assimilated as nearly as possible to that of the British Government. The French population, however, did not wish to be assimilated, but insisted on retaining their own habits and customs, and a bitter feeling arose between the two populations. The French majority in Lower Canada, unused to expressing themselves through a popular Assembly, soon fell under the influence of socialistic leaders.

The crisis was reached between the years 1835 and 1840. The Radicals in Lower Canada demanded a Colonial Executive dependent for its tenure of office on the vote of the popular branch of the Colonial Assembly. This was, in effect, a demand that Lower Canada should be recognized as an independent State, having no 


\section{The Administration of Dependencies}

connection with Great Britain except by treaty. It was substantially the same as the demand of the antiImperialist party in the American Colonies just prior to the Revolution.

Warned by its experience with the American Colonies, and acting under the advice of Lord Durham, who was sent out under a commission by which he was appointed not only Governor of Lower Canada, but also "High Commissioner for the adjustment of certain important questions depending in the Provinces of Lower and Upper Canada respecting the form and future government of said Provinces," Great Britain adopted the principle of "responsible government" for both Upper. and Lower Canada. Lord Durham thus described the characteristics of "responsible government" in his Report on the Affairs of British America, published in I839:

The responsibility to the Colonial Legislature of all officers of the Government, except the Governor and his Secretary, should be secured by every means known to the British Constitution. The Governor, as the representative of the Crown, should be instructed that he must carry on his government by Heads of Departments in whom the Colonial Legislature shall repose confidence; and that he must look for no support from home in any contest with the Legislature, except on points involving strictly Imperial interests.

I would not impair a single prerogative of the Crown; on the contrary, I believe that the interests of the people of these Colonies require the protection of prerogatives which have not hitherto been exercised. But the Crown must on the other hand submit to the necessary consequence of representative institutions; and if it has to carry on the government in unison with a representative body, it must consent to carry it on by means of those in whom that representative body has confidence. 
Perfectly aware of the value of our colonial possessions and strongly impressed with the necessity of maintaining our connection with them, I know not in what respect it can be desirable that we should interfere with their internal legislation in matters which do not affect their relations with the Mother Country. The matters which so concern us are very few. The constitution of the form of government, - the regulation of foreign relations, and of trade with the Mother Country, the other British Colonies, and foreign nations,- and the disposal of the public lands, are the only points on which the Mother Country requires a control. This control is now sufficiently secured by the authority of the Imperial Legislature; by the protection which the Colony derives from us against foreign enemies; by the beneficial terms which our laws secure to its trade; and by its share of the reciprocal benefits which would be conferred by a wise system of colonization.

In accordance with Lord Durham's suggestion, Upper and Lower Canada were united under a single legislative Assembly, and this Assembly, on September 3, I84I, adopted the following resolutions, which are interesting as containing a definition of "responsible government" from the point of view of the population of a highly intelligent British dependency:

That the Head of the Executive Government being, within the limits of his Government, the representative of the Sovereign, is responsible to the Imperial authority alone; but that, nevertheless, the managen ent of our local affairs can only be conducted by him, by and with the assistance, counsel, and information of subordinate officers in the Province.

That in order to preserve, between the different branches of the Provincial Parliament, that harmony which is essential to the peace, welfare, and good government of the Province, the chief advisers of the representative of the Sovereign, constituting a Provincial Administration under him, ought to be 


\section{The Administration of Dependencies}

men possessed of the confidence of the representatives of the people; thus affording a guarantee that the well-understood wishes and interests of the people, which our gracious Sovereign has declared shall be the rule of the Provincial Government, will, on all occasions, be faithfully represented and advocated.

That the people of the Province have, moreover, a right to expect from such Provincial Administration the exertion of their best endeavors that the Imperial authority, within its constitutional limits, shall be exercised in the manner most consistent with their well-understood wishes and interests.

According to this statement, the purpose of "responsible government" is to "guarantee that the well-understood wishes and interests of the people [of the dependency] will, on all occasions, be faithfully represented and advocated " before the tribunal representing the Imperial State, in order that it may make a disposition concerning them. "The well-understood wishes and interests" of the people of the dependency are, according to this statement, to be regarded as "the rule of the Provincial Government," and a denial of these wishes and interests is to occur only as an exception and for good cause. The "responsibility" of the Imperial State, according to this statement, is to "the people" of the dependency considered as an organized body capable of having and expressing their "wishes and interests" as a distinct political unit or State. The admission, by an Imperial State, of the principle of "responsible government" for a dependency is therefore nothing more or less than the recognition of the dependency as a State in a permanent relationship to the Imperial State of such a kind that the Imperial State renders services as a Judge and Ruler under an implied contract-that is, under an unwritten Constitution.

During the period from 1800 to $184 \mathrm{I}$, great attention 


\section{British Administration, I 780-I902 505}

was given to the economic problems of the administration of dependencies, particularly by William Huskisson, who was Secretary of State for War and the Colonies in 1827 , with the result that the statehood of the dependencies for economic purposes was recognized by the British Government. Mr. Egerton, in his History of British Colonial Policy, thus sums up the history of this period:

Amidst the confusion of particular enactments we note a general tendency. For the theory of monopoly a new theory has been substituted, that of reciprocity, to be ever connected with the name of Huskisson.

Inasmuch as a State cannot perform an act of reciprocity except toward another State, the acceptance by the State of Great Britain of the theory of Huskisson was an acceptance, to that extent, of the conception of the British dependencies as dependent States.

With the admission of the principle of "responsible government," as the basic principle of the political relationship between Great Britain and its dependencies and of "reciprocity" as the basic principle of the economic relationship, came the perception that the British Empire was a permanent political organism-a State, federal in form, and permanent in its nature, founded in the necessities of human nature, and subserving a beneficent purpose.

Herman Merivale, who was Under-Secretary of State for the Colonies for many years and a profound student of colonial administration, in the last of his series of lectures on "Colonization and Colonies" delivered at Oxford University in the years I839, I840, and I84I, said :

It does not follow as a necessary consequence that the attainment of domestic freedom is inconsistent with a continued dependence on the Imperial sovereignty. . . . Union might be preserved, for any reason which theory has to show 


\section{The Administration of Dependencies}

against it, long after the sense of necessary dependence is gone. . . . The union must more and more lose the protective, and approximate to the federative character; and the Crown may remain, at last, in solitary supremacy, the only common authority recognized by many different Legislatures, by many Nations politically and socially distinct.

Lord Elgin, in 1850 , while Governor-General of Canada, expressed the conception of the British Empire as a federal organism, existing permanently and for beneficent objects, in a letter in which he declared:

You must renounce the habit of telling the Colonies that the colonial is a provisional existence. You must allow them to believe that, without severing the bonds which unite them to Great Britain, they may attain a degree of perfection and of sociai and political development, to which organized communities of free men have a right to aspire.

In I849, Lord Grey, then Secretary of State for War and for the Colonies, revived the Committee of the Privy Council for Trade and Plantations. This Committee had been in existence, but it had had no concern for many years with colonial subjects. The occasion of this revival was the difficulties into which he had fallen in attempting to recommend legislation relating to Australia. It was necessary that a disposition of the matter should be made by an expert tribunal, whose decision would 'meet with' acceptance. The Committee of the Privy Council for Trade and Plantations was enlarged so as to include several men expert in colonial administration, and in fact adjudicated the whole subject of the relations between Great Britain and Australia. The Bill recommended by them for adoption by Parliament went to the utmost extent in regarding the different colonial communities as States. Though the Bill was passed and met with the approval of the Australian Colonies, this 


\section{British Administration, I780-I902 507}

practice (which was in fact a substitution of a Committee of the Privy Council for the Secretary of State for the Colonies) was not continued, it evidently being perceived that, though most valuable as an exceptional practice, it would lead to conflict and confusion if applied habitually.

In I 852 , the principle of "responsible government" was applied to the Maori tribes of New Zealand, they being treated as dependent States under a "constitutional protectorate." The preamble of the Act of Parliament was thus worded:

Whereas it may be expedient that the laws, customs and usages of the Maori tribes should for the present be maintained for the government of themselves . . . and that particular districts should be set apart within which such laws, usages and customs should be preserved, etc.

By the Act, power was given to the Crown to make provision for the purposes aforesaid, " any repugnancy of such native laws . . . to the law of England . . . notwithstanding." The Crown delegated its powers under this statute to the Governor of New Zealand.

In 1854 , a separate Secretariat for the Colonies was established. The conception of the British Empire as a permanent federal organism, requiring an administration different from that of Great Britain and in which the relations between the component States were entirely different from the relations between Great Britain and foreign States, was thus accepted by the British Government. "Responsible government" for all the dependencies having an elective legislative Assembly was thenceforth rapidly converted into the conception of "responsible government" for all dependencies. Each Local Government was recognized as a Government substituted by the power of Great Britain for the Local Government which the dependency would have formed 


\section{The Administration of Dependencies}

for itself, had it been an independent State capable of having and expressing distinct "wishes and interests."

The universality, in the British Empire, of the principle of "responsible government," using this expression as meaning "government responsible to the people of each dependency," is illustrated in the administration of India.

It had been perceived by the French, during the time of their administration in India, that the only possible function which the representatives of a European State in India could successfully perform was that of a Central Government for the native States, and during the last part of their administration they had acted on this theory with great success, keeping in existence the native States. as far as practicable. Clive adopted this policy on his conquest of the French in. I757, and his policy was followed by his successors. In the Regulating Acts for India, enacted by Parliament in 1773 and 1784 , the "Presidencies" establisned by the East India Company in regions coterminous with the boundaries of native States were recognized. In I793, by the India Act of that year, the direct responsibility of Great Britain to the people and States of India was recognized by giving the Governor-General of the Presidency (that is, the dependent State) of Bengal limited authority over the Governments of the two other Presidencies, Madras and Bombay. By the Act of 1833 , the Governor-General in Council of Bengal became the Governor-General in Council of India, vested with the "superintendence, direction, and control of the whole civil and military Governments of all the said territories and revenues in India." This Act was due very largely to the efforts of Thomas B. Macaulay (afterwards Lord Macaulay) who, during his period of office as a member of Parliament from 1830 to 1835 , had made a special study of the characteristics of India and of the needs of the States and populations of India in the matter of government. 
India thus became a Federal State under an unwritten Constitution. The legislative powers of each Presidency were vested in the native people of each Presidency, and were exercised, not by a representative Assembly elected by the people, but by a Local Government appointed by the State of Great Britain and acting as a Substitute and Trustee Government, following in part British principles, and in part the unwritten and written traditions and customs of the native populations. Under this system, the functions of the Supreme Government of India were essentially dispositive. Whatever legisiative powers they possessed were powers of executive legislation. They were fulfilling the implied contract of trust and agency between the State of Great Britain and the people of each Presidency.

Macaulay's work in behalf of the people of India, while he was a member of the Council of the GovernorGeneral, during the years from 1835 to 1838 , was based on a recognition by him of the dispositive functions of the Indian Government. In recommending a Penal Code, which was afterwards prepared chiefly by him, and which is justly famous for its simplicity and completeness and for its adaptation to the situation, he announced the theory on which it should be based as follows:

This code should not be a mere digest of existing rules and regulations, but should comprise all the reforms which the Commission may think desirable. It should be framed on two great principles-the principle of suppressing crime with the smallest amount of suffering, and the principle of ascertaining the truth at the smallest possible cost of time and money.

By the Act of 1853 , a body was established in India called "the Legislative Council of India," composed of a Governor-General, the four members of the Executive Council, four persons nominated by the Governor of 


\section{5 ro The Administration of Dependencies}

each of the four Presidencies, the Chief Justice and the Puisne Judge of the Supreme Court of Calcutta, and two persons chosen by the Governor-General. It was not long before this body showed the effect of their description as a "Legislative Council." They reasoned that if they were, in fact, a Legislative Council, their powers were powers of legislation and not of disposition, and that they were not obliged to execute the Constitution of the Empire or the Constitution of Great Britain, or the will of the native inhabitants, and that their true function was to execute their own will. They therefore proceeded to criticise and oppose both the wishes of the British Government and the wishes of the native populations. In I86I, Parliament put an end to this system, and re-established a Central Government in India with distinctly dispositive powers. By the Act of I86I, the number of ordinary members of the Executive Council, which was thenceforth called "the Council of the Governor-General," was increased from four to five-one to be a barrister of five years' standing, with the Commander-in-Chief, as before, an extraordinary member. In addition, the Governor-General was to nominate not less than six nor more than twelve additional members, one half of whom were to be persons not in the service of the Government. All legislative acts of the Council, before becoming operative, were to receive the assent of the Governor-General or to be reserved by him for the assent of the King. Power was also given to the Governor-General, in cases of emergency, to pass ordinances having the force of laws.

By the same Act, the division of functions between the members of the Governor-General's Council so as to make it the Cabinet of India was legalized, and the Local Governments of the Presidencies of India were reorganized and made subject to the disposition of the Governor-General in Council. By subsequent Acts, 


\section{British Administration, I780-I902 5 I I}

changes have been made in the composition of the Council of the Governor-General, and of the Local Councils, but there has never been any departure from the principle established by the Act of $186 \mathrm{I}$, which is that the instrumentalities of government in India are to be so constituted as to most justly and expertly adjudicate and execute the unwritten Constitution of the British Empire in India, which is based in part upon the Constitution of Great Britain and in part upon the traditions and customs of the respective natural divisions of the lands and populations of India, regarded as States.

In 1858 , the instrumentalities of the British Government in Great Britain were remodelled for the express purpose of accomplishing the same result-namely, the proper and orderly adjudication and execution of the Constitution of the British Empire, as applied to India. By an Act passed in that year, all governmental powers were taken from the East India Company and vested in the Crown, which was to act through a Secretary of State for India, for whose advice there was provided a Council for India. Though the Secretary of State for India was required to act on his own responsibility in advising the King, he was obliged to consult the Council for India before acting at all and before advising the King.

Sir George Chesney says of this Council, in his Indian Polity :

The necessity for maintaining a permanent Council or body of some sort, unconnected with the ebb and flow of party politics, will be universally recognized, and the constitution of this body will equally be considered a matter of importance. The number of Councillors was fixed at fifteen in the first instance, in order to admit of its being fairly representative of knowledge and experience gained in the different parts of India and of the different interests to be dealt with; and making 


\section{The Administration of Dependencies}

allowance for the proportion of dull men who will always find their way into such a body, it is certainly not too large for the purpose. Whether the Council, as established, is turned to the best account, will depend on the procedure laid down for its working. One of the most important points to be provided for is the protection of the people of India, the taxpayers, from the infliction of improper and unfair charges. This was, no doubt, the object aimed at in the provision of the Act of 1858 , that "no charge should be placed upon the revenues of India without the sanction of a majority of the Council."

Speaking of the relation of the Council to the Secretary of State for India, he says:

The Secretary of State should undoubtedly have power to override his Council. It could not be allowed that the policy of the British Governmen: should be liable to obstruction by any other body than the Parliament which places it in power; but the interests of India demand that the Cabinet should at least be placed in possession of the opinions of those who are best qualified to judge of the effect of any measures proposed which will involve a financial burden on India.

He admits that since it must be recognized that "in dealing with measures involving military operations, secrecy is a necessary condition, and that the maintenance of secrecy is not compatible with the deliberation of a large body," the Secretary of State for India must be allowed to control such operations without the necessity of advising with the whole Council, and he approves the general principle of the Act of 1858 which allowed a part of the Council to act as a Secret Committee in cases requiring secrecy.

The question has been agitated from time to time of replacing the existing Government of India, which is essentially an executive Government, by a Government 
which should have strictly legislative powers. It has even been seriously proposed that the seat of such a legislative Government should be in Great Britain. Speaking of this subject, Sir George Chesney says:

Hitherto the India Office, recognizing that its proper function is that of a court of review, and that India can be properly governed only by the Government in that country, has as a rule laudably abstained from direct interference in administrative details. . . . The Secretary of State for the time being has usually been scrupulous in maintaining this dividing line of the respective functions of the two authorities. There have indeed been exceptions to the rule, as in the case of the reorganization of the army after the Mutiny, when a quite impractical scheme was sent forth from the India Office cut and dried to be carried out in India. These and similar attempts to transfer the initiation of affairs from India to England have served to bring more clearly to light the soundness of the policy of abstention.

The maintenance of this principle, that India must be administered by the Government in India-with the development lately set in motion of local institutions, the advancement of the people of that country to a larger share in its administration through the expansion of the Legislative Councils, and their extended employment in all branches of the public service-becomes now more than ever a vital necessity, and makes it superfluous to discuss the proposals put forward from time to time for the replacement of the existing Council of India by a larger body. Anything in the shape of an Assembly debating in public is, from the nature of the case, out of the range of serious consideration. Indians could not be brought to this country to serve on it, at any rate in sufficient numbers to be representative of the people of India; and the idea that persons so placed, whether Englishmen or Indians, should be in a position to advance opinions, still more to carry resolutions, for the result of which they would not be wholly responsible, 


\section{I4 The Administration of Dependencies}

will not be entertained by any one who has the most elementary acquaintance with the conditions of that country or with representative institutions. If, in the $\operatorname{dim}$ and distant future, the time should ever arrive when a Parliament of any sort is possible for India, it must be set up in that country and not in this.

Sir John R. Seeley, in his Expansion of England, speaking of the British Empire in India, says:

We call this Empire a conquest, in order to mark the fact that it was not acquired in any degree by settlement or colonization, but by a series of wars ending in cessions of territory by the native Powers to the East India Company. But let us be careful how we take for granted that it is a conquest in any more precise sensè of the word.

India therefore may be called a possession of England in a sense which is not applicable to the Colonies. Nevertheless the word conquest, which, like most of the vocabulary of war, has come down to us from primitive barbaric times, may easily be misunderstood. We may still ask in what sense England can be said to possess India. What we possess we devote in some manner to our own enjoyment. If I own land, I either take the profits of the harvest, or, if I let the land to a farmer, I get rent from it. And in primitive times the conquest of a country was usually followed by possession in some literal sense. Sometimes the conquerors actually became landlords of the conquered territory or of part of it, as in that conquest of Palestine which we read of in the Book of Joshua, or in those Roman conquests where a certain extent of confiscated land was often granted out to a number of Roman citizens. Now assuredly India is not a conquered country in this sense. England has not seized lands in India, and after displacing the native proprietors assigned them to Englishmen.

There is another sense in which we may conceive the condition of a conquered country. We may think of it as tribu- 
tary or paying tribute. . . . Taxes are raised of course in India, as taxes are raised in England, but India is no more tributary than England itself. The money drawn from India is spent upon the government of India, and no money is levied beyond what is supposed to be necessary for this purpose.

The truth is that, though the present relation between India and England was historically created by war, yet England does not, at least openly, claim any rights over India in virtue of this fact. In the Queen's Proclamation of Ist November, I 858 , by which the open assumption of the government by the Queen was announced, occur the express words, "We hold ourselves bound to the natives of our Indian territories by the same obligations of duty which bind us to all our other subjects." That is, conquest confers no peculiar rights, or India is not for practical purposes a conquered country.

What is unprecedented in the relation of England to India is the attenipt to rule, not merely by experts, but by a system founded on public opinion, a population not merely distant, but wholly alien, wholly unlike in ways of thinking, to the sovereign public. Public opinion is necessarily guided by a few large, plain, simple ideas. When the great interests of the country are plain, and the great maxims of its government unmistakable, it may be able to judge securely even in questions of vast magnitude. But public opinion is liable to be bewildered when it is called on to enter into subtleties, draw nice distinctions, apply one set of principles here and another set there. Such bewilderment our Indian Empire produces. It is so different in kind both from England itself and from the Colonial Empire that it requires wholly different principles: of policy. And therefore public opinion does not know what to make of it, but looks with blank indignation and despair upon a Government which seems utterly un-English, which is bureaucratic and in the hands of a ruling race, which rests mainly on military force, which raises its revenue, not in the European fashion, but by monopolies of salt and opium, and 


\section{The Administration of Dependencies}

by taking the place of a universal landlord, and in a hundred other ways departs, from the traditions of England.

If we combine all the facts $I$ have hitherto adduced in order to form a conception of our Indian Empire, the result is very singular. An Empire similar to that of Rome, in which we hold the position not merely of a ruling but of an educating and civilizing race; this Empire held at arm's length, paying no tribute to us, yet costing nothing except through the burden it imposes on our foreign policy, and neither modifying nor perceptibly influencing our busy domestic politics; this Empire nevertheless held firmly and with a grasp which does not slacken but visibly tightens; the union of England and India, ill-assorted and unnatural as it might seem to be, nevertheless growing closer and closer with great rapidity under the influence of the modern conditions of the world, which seem favorable to vast political unions; - all this makes up the strangest, most curious, and perhaps most instructive chapter of English history. It has been made the subject of much empty boasting, while those who have looked deeper have often been disposed to regard the whole enterprise with despondency, as a kind of romantic adventure which can lead to nothing permanent. But, as time passes, it rather appears that we are in the hands of a Providence which is greater than all statesmanship, that this fabric so blindly piled up has a chance of becoming a part of the permanent edifice of civilization, and that the Indian achievement of England as it is the strangest, may after all turn out to be the greatest, of all her achievements.

The government of India has been called despotic and paternal, but it is not. Despotism implies an imposition of the mere will of one person upon another. Paternal. ism is the same thing except that the person who imposes his will on the other is assumed to have a benevolent purpose in so doing. The reason why the English government of India has been successful is that it has been, on the whole, neither despotic nor paternal, but expert. 
The distinction between expert government and despotic or paternal government cannot be insisted upon too strongly. Expert government is inconceivable except as the outgrowth of republicanism and democracy. It implies that the depositaries of power are the agents of all the people of the community, and hence responsible to the people in the last resort; and that they stand in the same relation to the people as the physician to his patient or the lawyer to his client. The patient may refuse to follow the law of health ascertained and declared to him by his physician, and the client may refuse to follow the law of human commerce and intercourse ascertained and declared to him by his lawyer, but the more the mind of the individual is enlightened, the more willing and anxious is he to obtain expert advice and to follow it. Expert government has its final sanction, therefore, in the free will of the governed.

The individual in India has never been made to feel that he was merely a thing or that he was a mere lump of human clay which was either to be moulded into an Englishman or to be destroyed. His traditions, his wishes, and his ideals have been respected to the utmost extent consistent with the common welfare. The advice of the enlightened mind of India has been sought and given its full weight. The people of India have participated in their own government-not by popular elections of local officials, but by a method entirely dignified and such as the most highly civilized community might properly adopt. The government of India has proceeded upon the recognition of and a respect for the natural rights of men-even the natural rights of communities to distinct statehood. Districts and provinces are organized with reference to natural conditions, and the respective districts and provinces are given a separate political personality as far as it is possible consistently with the general welfare. Government by mere will exists 


\section{The Administration of Dependencies}

nowhere where British rule prevails. Government preceded by an investigation of rights and duties and by a decision based on this investigation exists wherever British rule prevails. The duty of the Imperial Government to refrain from acting is recognized as being equally important with its duty to act, and when action is taken, it is not allowed to go beyond the necessity of the case. The British power in India is uniformly recognized as being a power of disposition-not a power of legislation, and the Executive is conclusively bound by the judgments of the courts. It is a reign of law, not a reign of will.

The system of government which now prevails in India is plainly a development of the general conception of the Empire as a political organism composed of States in a relationship of federal union under an unwritten Constitution. It is, in fact, "responsible government." The responsibility of the Governments in India appointed by Great Britain is not, it is true, to the local representative Assemblies, but to the people of the States of India,that is, to the States of India.

The British Empire of the present day is federal in practice even when it is examined from the standpoint of its workings in those dependencies sparsely inhabited or inhabited by mixed or barbarous races, in which any degree of popular government is yet impossible, and which are called Crown Colonies or Constitutional Protectorates. Even in these dependencies, administrative districts are formed with the view of maintaining all proper distinctions between separate communities growing out of diversity of race, tradition, and language, and the British Administrators recognize and enforce as far as possible the natural rights of men and consult the enlightened public will of the community, so far as any such exists.

In the working of the British Empire since it has become a federal organism in fact, two distinct tendencies 
are noticeable: first, a tendency on the part of the dependencies to regard federal dependence too much in the light of independence; and second, a tendency in Great Britain, either to admit that federal dependence and independence are one and the same thing, or to counteract the tendency of the dependencies to regard themselves as independent by converting the British Federal Empire into a British Federal State under the control of an elective body, composed of representatives both of Great Britain and its dependencies.

The first tendency was most observable during the period from I 86 I to I 885 . Mr. Egerton calls this period "the period of the zenith and decline of the laissez-aller principles."

Sir P. Wodehouse, the Governor of the Cape Colony, in his speech at the opening of the Cape Parliament in I870, said :

People in England, knowing little of the Colonies and to whom their proper position is not brought home, are fascinated by the notion of extending British institutions. . . . They do not perceive that the very principle of responsibility is opposed to the existence of the Colony, . . . that the day must come for a collision, that . . . the issues [may] be delayed, but, sooner or later, it is inevitable; that this form is suitable only to communities who desire or look forward to a severance at no distant day from the Mother Country, whether by transfer to another power or by the establishment of an independent State.

Lord Blachford, who, as Sir F. Rogers, was Permanent Under-Secretary of State for the Colonies from I860 to I $87 \mathrm{I}$, wrote, in 1885 :

I have always believed, - and the belief has so confirmed and consolidated itself that I can hardly realize the possibility of any one seriously thinking the contrary,-that the destiny 


\section{The Administration of Dependencies}

of our Colonies is independence; and that, in this point of view, the function of the Colonial Office is to secure that our connection, while it lasts, shall be as profitable to both parties, and our separation, when it comes, as amicable, as possible.

The period from I 886 to the present day, which Mr. Egerton calls " the period of Greater Britain," was marked, at its beginning, by a too violent reaction against the laissez-aller doctrines. It was at this period that the doctrine which became known as "Imperial Federation" took such strong possession of a large part of the thinking population of Great Britain. The purpose of this movement was to convert the British Empire into a Federal State under a central representative Assembly sitting in England, composed of delegates both from Great Britain and its dependencies. The advocates of this theory seem to have admitted that it was wholly inapplicable to India. Perhaps there would have been a substantial agreement among them that the plan was applicable only to dependencies having elected representative Assemblies.

The British Government, however, seems never to have been so much affected by these doctrines as it was by the laissez-aller doctrines. Independence for the Colonies was regarded as a practicable proposition, but the conversion of the British Empire into a Federal State was regarded as both impracticable in itself and as wholly out of the question because it involved the abdication of Great Britain,- that is, the abdication of England,-from its proud position as the Disposer of the affairs of the British Empire. At the Colonial Conference held in London in I887, Lord Salisbury, speaking of the doctrines of the Imperial-Federationist faction, thus rebuked their lack of political sagacity:

These are grand aspirations. . . . They are doubtlessly hazy, but they are the nebulous matter that, in the course of 
ages,-in much less than ages, - will cool down and condense into material from which many practical and business-like resolutions may very likely come.

The opinion of the British Government concerning the impracticability of Imperial Federation was ultimately adopted by the conservative thought of England. Dr. Edward A. Freeman, in his essay on The Bases of $\mathrm{Na}$ tional Unity, published in 1892 , to which reference has heretofore been made, gave voice to the Imperial spirit of the English State which makes "Imperial Federation," as a substitute for the British Empire, forever impossibie except as a matter of necessity, when he said:

I am no lover of "empire"; I am not anxious for my country to exercise lordship over other lands, English-speaking or otherwise. But I will not, so far as one man can hinder it, have my country ruled over by any other power, even by a power in which my country itself has a voice. If it is proposed that the great and historic Assembly which King Edward called into existence in $\mathbf{2} 295$ shall keep its six hundredth anniversary by sinking to the level of the Legislature of a Canton of a Britannic Confederation, then I shall be driven, however much against the grain, to turn Jingo and sing "Rule, Britannia."

The trend of the conservative thought of England for the past twenty-five years has undoubtedly been toward the formation of an Imperial Council in England, composed of experts, which shall be advisory to the British Crown and Parliament, when acting as the representative of Great Britain as the Imperial State.

Mr. Charles Walter Eddy, writing in 1874 on the subject, "What are the best means of drawing together the interests of the United Kingdom and the Colonies, and of strengthening the bonds of union?" (his paper on this 


\section{The Administration of Dependencies}

subject being read, shortly after his death in I874, before the Royal Colonial Institute of London), said:

Mr. W. Jardine Smith, of Melbourne, and other Colonial writers, have advocated the formation of a Supreme Council of the Empire, for the consideration of the external affairs, and others in which the whole Empire is interested; and this project of a Council, rather than of a United Parliament, is clearly the favorite idea of colonists. It is one which is greatly favored and facilitated by the appointment of AgentsGeneral in London to represent all the larger Colonies, and these are in some instances surrounded by a court of advisers similar to the Indian Council. This plan is evidently taking root, and expanding and growing with the healthy growth of all English institutions which experience shows to be congenial and useful.

In furtherance of this project of a Supreme Council, I some time ago submitted to an assembly of colonists a scheme which was received with a certain amount of favor, though it was acknowledged to be hopeless to put it before the Government of the day. Of this I will, with your leave, in conclusion, reproduce the heads. It is one that has received the approval of so profound a student of constitutional history as $\mathrm{Mr}$. Froude, who wrote on it as follows: "The machinery of the Privy Council is, as you say, made to the hand for a judicious reconstruction of our Colonial relations."

My proposal was not to attempt to create de novo a power unknown to the Constitution that we all revere, but still planting our footsteps on her ancient and well trodden paths, to take advantage of the machinery provided by that venerable institution, " the Queen's most honorable Privy Council," by reviving in a manner suited to the present and prospective exigencies of our Colonies that department of it which was formed under the name of the Committee of Privy Council for Trade and Foreign Plantations, and so constituting a branch of the Council for advice on the general concerns of the whole Empire, in like manner as the Judicial Committee of the Council is constituted as the Court of Final Appeal on 


\section{British Administration, I780-I902 523}

legal matters. I showed that the Cabinet, whose only legal status is that it consists only of Privy Councillors, and [which] is, in fact, a committee of that body, may be regarded as the Standing Committee for general purposes, and is supposed to represent the prevailing public opinion of the Kingdom for the time being; that it is necessarily in harmony with the House of Commons, but with that only; and that an analogous Committee for counsel and advice, in which the Colonies as well as the Mother Country should be represented, would apparently provide the whole machinery necessary for the government of the Empire.

The sphere of this Committee would be confined to advice on a few simple but grand subjects,-peace, war, diplomacy, the marshalling of the forces in time of war, the proper quota or contingent of forces to be furnished by each Colony for Imperial purposes, and the distribution of the Imperial garrisons and ships.

Holding as I do that a legislative union of the Empire is at present impossible, yet I believe that a Federal Union is quite practicable, and may be accomplished without difficulty by the formation of a Federal Council such as I have indicated.

Mr. George R. Parkin, in his book on Imperial Federation, published in 1892 , while advocating the conversion of Great Britain and its self-governing Colonies into a Federal State under an elected representative Parliament, supreme over the Parliament of Great Britain and over the Parliaments of the respective self-governing Colonies, frankly confessed that that idea was not acceptable to the leading statesmen of Great Britain, and gave the following impartial summary of the various propositions advanced for the establishment of an Imperial Council, which should be advisory to the Crown and Parliament when acting as the Imperial Executive and the Imperial Legislature. He said: 


\section{The Administration of Dependencies}

I have found that practical statesmen throughout the Empire, even those most devoted to the cause of national unity, while recognizing that the difficulties constantly tend to diminish, look upon the immediate realization of this ideal as impracticable, or as involving too great a political effort, too sweeping a change in the existing machinery of national government. They turn themselves to the consideration of measures which will by gradual steps and a process of constitutional growth lead up to the desired end.

Prominent among such measures must be placed the proposal to summon periodical conferences of duly qualified representatives of the great Colonies to consult with the Home Government and with each other on all questions of common concern. The public recognition of the right of consultation; the formal summoning of such conferences by the head of the State, would of itself be a signal proof to the outside world of the reality of national unity, a decisive step towards its complete attainment. By bringing the leading statesmen of the Colonies from time to time into immediate contact with those of the Mother-Land, the opportunity would be furnished for that personal understanding which becomes more and more necessary in the conduct of politics and diplomacy. In proportion as dignity is given to these conferences, and as their decisions are carried into effect, their influence on the policy of the Empire would increase till, it is believed, they would either themselves develop into an adequate Federal Council, or would have gained an authority and experience entitling them to indicate the lines on which such a Council could be created.

But conferences are occasional, and it would still be necessary to provide some means of more continuous contact between the thought of the Governments of the Colonies and that of the Mother Land. On this point of an adequate constitutional nexus we have many important suggestions, to a few of which reference should be made.

Sir Frederick Pollock, in an article contributed to an 
English journal in March, r89r, says: "Is there not any way, short of a gigantic constitutional experiment, of providing a visible symbol and rallying-point for the feeling of Imperial patriotism which has so notably increased within the last ten years? I think there is. One part of our Constitution retains, not only in form, but in fact, the vigor of perpetual youth, and is capable of indefinite new growth as occasion may require, without doing violence to established usage. I mean the Privy Council. From the Privy Council there have sprung within modern times the Board of Trade, the Judicial Committee, the Education Department, the Universities Committee, and virtually, though not quite formally, the Local Government Board, and the several commissions now merged in the Agricultural Board. Why should there not be a Colonial and Imperial Committee of the Privy Council, on which the interests of the various parts of the Empire might be represented without the disturbance of any existing institution whatever, and whose functions might safely be left, to a large extent, to be moulded and defined by experience?

It might be summoned to confer with the Cabinet, the Foreign or Colonial Minister, the Admiralty, or the War Office, at the discretion of the Prime Minister or of the Department concerned; and its proceedings would be confidential.

It is hardly needful to mention the Agents-General of the self-governing Colonies as the kind of persons who should be members of the Committee now suggested, being, of course, first made Privy Councillors. . . . I believe that such a Committee might give us something better than a written Constitution for the British Empire; it might become the centre of an unwritten one."

Lord Thring, looking at the question as a constitutional expert, has stated in his opinion that the best way in which the Colonies could at present directly intervene in the general policy of the Empire would be by elevating the position of Agents-General to one akin to that of a Minister of a foreign State, and by giving them in addition, as members of the Privy Council, the right of constitutional access to the British Government. This, he thinks, would satisfy the immediate 


\section{The Administration of Dependencies}

necessities of the case, and would pave the way for the fuller representation which must come with the fuller acceptance of national responsibility.

Nothing can more fully show the change that has come over the public mind than the fact that proposals such as these are now made by constitutional authorities and responsible public men. It illustrates a complete reversal of the policy which was assumed without question by the statesmen of the last generation. The discussion has become one not of the principle of unity, but of ways and means to arrive at the most satisfactory constitutional nexus between the Mother Land and her offshoots.

Sir Charles Dilke, in the second edition of his Problems of Greater Britain, published in 1890 , disapproved the proposition to convert the Agents-General of the self-governing Colonies into an Imperial Council and made the following pertinent suggestion concerning the authority which such a Council would have as compared with an Imperial Council composed of English Privy Councillors:

A Colony may be disinclined to allow the Mother Country to declare that a thing cannot be done on account of Imperial interests or Imperial treaties, but each Colony would admit the validity of such a declaration from the Mother Country more readily than she would tolerate interference from the representatives of other Colonies. At the same time, while it is difficult to make a Council of the Agents-General, there is no reason why we should not give them a nominal position which would correspond in dignity with the services that they already render. They are, in fact, taken individually, among the most trusted of the councillors of the Empire, and those who have held for some years the position, and who have had the confidence of successive Governments, might well be placed formally in the Imperial Privy Council.

Lord Brassey, in a speech delivered at Leeds on March 
I3, I89I, which is reprinted in his Papers and Addresses on Imperial Federation and Colonization, said:

The appointment of a Colonial Council to advise with the Secretary of State for the Colonies, as the Indian Council advises with the Secretary of State for India, is a more limited proposal [than that for Imperial Federation], and for this the time is near at hand, if it has not already come. As an example of what it seems practicable to do, I might refer to the recent Presidential decree under which a Colonial Council has been created in France, with provision for the representation of the Colonies, in association with other members possessing special knowledge and qualifications.

Hon. Joseph Chamberlain, the present Secretary of State for the Colonies, in a speech to the Premiers of the selfgoverning Colonies, delivered at the time of the second Queen's Jubilee in I897, advocated the establishment of an Imperial Council advisory to the British Government in which the self-governing Colonies should be represented. His words were:

I feel that there is a real necessity for some better machinery of consultation between the self-governing Colonies and the Mother Country, and it has sometimes struck me-I offer it now merely as a personal suggestion-that it might be feasible to create a Great Council of the Empire to which the Colonies would send representative Plenipotentiaries, - not mere delegates who were unable to speak in their name without further reference to their respective Governments, but persons who by their position in the Colonies, by their representative character, and by their close touch with Colonial feeling, would be able, upon all subjects submitted to them, to give really effective and valuable advice. . . .

To a Council of this kind would be committed, in the first instance, the discussion of all minor subjects of common interest, and their opinion would be taken and would weigh 


\section{${ }_{528}$ The Administration of Dependencies}

most materially in the balance before any decision were come to either by this country or by the Legislatures of the several Colonies in regard to such matters.

Now, gentlemen, in connection with this subject we have already made a small advance, upon which I congratulate myself, since it was accomplished during my term of office, though it was prepared by my predecessors; and it may have in the future important results. The Judicial Committee of the Privy Council is the great Judicial Court of Appeals of the Empire. It is the nearest approach, the closest analogy, to the Supreme Court of the United States. It is a body of almost universal and world-wide reputation and authority, and it is our desire naturally, in pursuit of the ideas which I am venturing to put before you, to increase its authority, if that be possible, and to give it a more representative character, and with that view we have most gladly secured the appointment, as Privy Councillors, of distinguished Judges from the courts of Canada, of Australia, and of South Africa, and they now will take their seats on equal terms with the other members of the Judicial Committee.

The magnitude and importance of the great States of Canada and Australia make it necessary for English statesmen, when speaking of such an Imperial Council, to speak of it as if it were to be a representative Assembly. It seems, however, that such a representative Assembly would be opposed to the true character of a Federal Empire, unless it shall prove possible to form a Federal Empire under a written Constitution. So long as the Constitution of the Federal Empire is unwritten (and an unwritten Constitution seems at present necessary in a Federal Empire), the function of the Imperial Council would be to represent the Imperial State in the fulfilment of its dispositive functions. If the Member-States were to be represented in this Imperial Council, the Imperial State would be relieved to this extent from its Imperial 
obligations, and division of responsibility would inevitably lead to a weakening of its authority. The Agents of the dependencies should come before the Imperial Council as the Agents for independent States come before an International Tribunal. They should come as a matter of choice and as a matter of right, but they should come to present the case at issue and not to decide it. When the decisions of the Imperial Council cease to command respect and to be followed implicitly by the States whose rights are adjudicated by it, the Federal Empire must be replaced by a Federal State under a Central Legislature having supreme power within a sphere carefully defined by a written Constitution. An Imperial Council which should be in part an Interstate Tribunal and in part an Imperial Parliament is perhaps possible, but whether it would be surcessful in its operation is exceedingly doubtful. Instead of decreasing friction and jealousies between the different parts of the Empire, it seems that it would be likely to increase them. Dispositive and legislative functions are opposed to each other in the nature of things, and experience seems to prove that a representative Assembly can habitually exercise only the power of legislation.

It seems, therefore, that the present tendency of thought in England is toward the solution of the problems growing out of the relationship between Great Britain and those of its dependencies which have the highest degree of acknowledged statehood, through the instrumentality of an Imperial Council, the function of which it shall be to adjudicate the political rights of Great Britain and these dependencies, and the civil rights of their inhabitarits as against the Empire, and to assist the King and the Parliament, acting as the Imperial Executive and Legislature, in making all needful rules and regulations and in taking all necessary measures to effectuate the disposition of the affairs of the Empire. 


\section{The Administration of Dependencies}

The Imperial Council is to be neither co-ordinate with nor subordinate to the Secretary of State for the Colonies nor advisory to him, since an investiture of such a Committee with co-ordinate power would lead to conflict and paralysis of both, and investiture with subordinate or advisory power would have the effect to weaken its prestige as an Imperial Council. It is apparently to be an Interstate Tribunal for superintending the Secretary of State for the Colonies by reviewing his adjudications upon the application of persons interested. It is to be the ultimate adviser of the Crown and Parliament when acting as the Imperial Executive and Legislature.

The great problem of the British Empire at the present. time is to discover some just basis upon which self-governing colonies, so called,-that is, colonies whose statehood has been definitely' recognized,--may contribute to the expense of the Imperial defence and welfare. Neither the Declaratory Act of 1766 , under which Great Britain claimed the right to legislate, by Acts of its Parliament, according to its mere will, so as to bind the people of all the dependencies, whether selfgoverning or not, "in all cases whatsoever," nor the Act of 1778 , by which it was declared that "from and after the passage of this Act the King and Parliament of Great Britain will not impose any duty, tax, or assessment whatsoever, payable in any of his Majesty's Colonies, Provinces and Plantations, in North America or the West Indies, except only such duties as it may be expedient to impose for the regulation of commerce" has ever been repealed; and these statutes have stood from that day to this as a barrier to prevent Great Britain from obtaining, in any manner, any contribution from any self-governing Colony toward the expense of the Imperial defence and welfare. In the second edition of Alpheus Todd's Parliamentary Government in the British Colonies, published in 1894 , it is said: 
The Declaratory Statute of 1766 , with the proviso agreed to in 1778 , that it shall not be construed to sanction taxation for revenue purposes, is still to be regarded as embodying the constitutional assertion of the supreme authority which is exercisable by the Imperial Parliament over all the Queen's dominions, notwithstanding that they may be in possession of Local Legislatures with powers for local self-government.

So long as these statutes remain, every British dependency-even the Dominion of Canada and the Commonwealth of Australia -is, theoretically, on no higher grade than a county or parish of England under exemption from payment of taxes for the support of the State Government of Great Britain. Theoretically the power of Great Britain over Canada and Australia is unconditional and unlimited except in the matter of taxation, and it is due only to its grace and favor that it does not reduce both these enormous States to a condition of absolute subjection. Under such a theory, every dependency must, out of self-respect, refuse to contribute to support the power of the dominant State over them.

The power which Great Britain has actually exercised in the British Empire for more than half a century has been a power of disposition, and not a power of legislation; yet rather than admit this to be the fact, the British Government to-day professes itself to be in favor of a union, at some future time, between Great Britain and its self-governing Colonies, in which necessarily England will sink to a level with all the rest the of members of the Union, and all the affairs of the Federal State thus formed will be managed by a common Parliament. Only in this way does even Mr. Chamberlain see any hope of obtaining any contribution towards the expense of the Imperial defence and welfare. In the speech from which the above extract is taken he said: 


\section{$53^{2}$ The Administration of Dependencies}

It may be that the time has come, and if not I believe it will come, when the Colonies will desire to substitute for the slight relationship which at present exists a true partnership, and in that case they will want their share in the management of the Empire which we like to think is as much theirs as it is ours. But, of course, with the privilege of management and control will also come the obligation and the responsibility. There will come some form of contribution toward the expense for objects which we shall have in common.

The reason for the insistence upon the theory that the power of Great Britain over its dependencies is the power of legislation is, undoubtedly, that the British Government fears, as it has always feared, that an admission that it was not would involve an admission that the British Parliament had no power in the Empire. If, however, the British Empire were recognized as a Federal Empire, this would necessarily imply that the State of Great Britain. was the Protector and Disposer of the Empire, and that it might act through any instrumentality of its Government that it saw fit, and hence through the Parliament. While it is undoubtedly true that a great body like the British Parliament, in which the Lower House is composed of the elected representatives of the people of Great Britain, is, by its nature, unfitted for the steady and constant adjudication of the delicate questions which arise in the course of the relation between Great Britain and its dependencies, there exists, on occasions, the necessity for submitting certain great questions in the administration of the Empire to a tribunal for final settlement; and on such occasions of emergency the British Parliament and the people of Great Britain must undoubtedly settle the question and, if necessary, support their decision by force and arms.

Admiral Sir John Colomb in his article entitled "A Survey of Existing Conditions," printed in the volume 
of essays entitled Britannic Confederation, to which reference has already been made, said:

Nominally the Parliament of the United Kingdom, as well as the Crown, retains supreme authority over the Parliaments of self-governing Colonies. Practically, the power of Parliament is a reserve force, to be called out of abeyance only in great emergencies.

Lord Chancellor Norton (formerly Baron Adderley), in an article entitled "How Not to Retain the Colonies," in the Nineteenth Century for July, I879, said:

There is no dispute as to the entire control which all selfgoverning British Colonial communities have over matters of their own internal and local concern. The Imperial Parliament would never think of interfering in exclusively Colonial legislation, nor could the Sovereign constitutionally withhold the royal assent from responsible Ministers possessing the confidence of the Parliament passing such measures.

The legislative authority of the Imperial Parliament is in theory transcendent, and extends over Colonies and all dominions of the Sovereign; but in Colonies under government responsible to their own representative Legislatures, it is practically never directly exerted at all. If it were, it would reduce constitutional government, recognized and established in a Colony, to a fiction, sham, and delusion, fraught with mischief alike to the bastard Colony, and to the Mother Country so degrading herself abroad. . . . There are, however, subjects of legislation which cannot be considered of exclusive interest to any Colony, affecting the interests of the whole Empire; or based on universal principles, which may be looked on as a sort of common law or even jus gentium; or comprised within great Imperial statutes and decisions, which would be violated by contrary legislation in the Colony.

In the second edition of Alpheus Todd's Parliamcntary Government in the British Colonies, it is said: 


\section{The Administration of Dependencies}

The Colonial possessions of the British Crown, howsoever acquired and whatever may be their political constitution, are subject at all periods of their existence to the legislative control of the Imperial Parliament. But in practice, especialiy in the case of Colonies enjoying representative institutions and responsible government, the Mother Country, in deference to the principle of self-government, has conceded the largest possible measure of local independence, and practically exerts its supreme authority only in cases of necessity, or when Imperial interests are at stake.

If the British Empire were to be formally recognized by the British Government as a Federal Empire, and the power of the State of Great Britain hence recognized as a power of disposition, the present position of the British Parliament in the Empire would not be altered, and the actual administration of the affairs of the Empire would be changed only in the single respect that the State of Great Britain could then claim the right to adjudicate, by an expert tribunal, along with all other questions, the amount and manner of the contributions of the dependencies to the Imperial defence and welfare, and the dependencies could with dignity and propriety contribute according to such dispositions.

Nothing stands in the way of such a recognition except two statutes repudiated by the United States of America, when they were Colonies of Great Britain, as violations of the Constitution of the British Empire.

There is evident, in the most recent thought in England, a tendency to renounce the old theory of the unconditional and unlimited power of Great Britain over its dependencies, and to substitute for it the theory embodied in the American Constitution, that the Imperial power is conditional and limited and essentially a trust or agency to be performed by the Imperial State for the benefit of its dependent States. Mr. Spencer Wilkinson 
(the collaborator of Sir Charles Dilke in their recent work on Imperial Defence) says, in his book entitled The $N a$ tion's Awakening, published in I896, which Sir Charles Dilke approves in his recent book, The British Empire:

The title of Empire and the quality of a British possession or dependency give to the work of Great Britain in India a certain amount of ambiguity. There is about a government of this kind a tinge of vain-glory which lends itself to the unamiable pride of race. The perfect type of the kind of work which is carried on in India is to be seen in Egypt, where a similar task has been undertaken without any outward show. The British administrators in Egypt are true rulers because they are truly the servants of the Egyptians. Englishmen whose pride in their country consists in the pleasure which they derive from the excellence of the work done by the nation care little for names and titles. They do not want to call Egypt a British possession or even a British protectorate, and are content that the work done for that country should be such as commands the approval of impartial judges. . . . Lord Cromer and his assistants are the representatives of the noblest work that has ever been undertaken by any nation, and in carrying on that work, they personify the spirit of the British Empire.

The conception which we have formed of empire, that it consists in services rendered to the races over whom it is extended, is inconsistent witi a desire for a monopoly. England may justly insist, as far as her opportunities offer, that no European nation shall found an Empire for the exclusive bersefit of its own subjects. We may be content that France in her Colonies shall spread the spirit of French institutions; that Russia shall Russify the inhabitants of the Steppes of Central Asia, and that the German Colonies in Africa shall be administered according to German traditions and in accordance with German ideas. But we may fairly demand the general recognition of the canon which we have set up for ourselves, that a community capable of self-government shall regulate its affairs zeithout restriction 


\section{The Administration of Dependencies}

according to its judgment, but that where we are acting as trustees for a race subject to our rule, we have no right to exclude the trade or the intercourse of other nations.

Mr. Chamberlain's views of the mission of the British Empire are well known. According to him, the purpose of the exercise, by England, of the Imperial power is to extend the Pax Britannica over all the people of the Empire, and to keep the peace by arbitrating disputes with and between the strong Colonies, and equalizing economic conditions between all parts of the Empire. In a speech before the Royal Colonial Institute, delivered in 1897 , he declared that with respect to the self-govern-. ing Colonies "the sense of possession has given place to the sentiment of kinship "; and that with respect to those not capable of self-government, "the sense of possession has given place to the sense of obligation." Speaking of this obligation, he said:

We feel now that our rule over these territories can be justified only if we can show that it adds to the happiness and prosperity of the people. . . . Such a mission involves great responsibility. . . . Great is the task, great is the responsibility, but great is the honor; and I am convinced that . . . we shall be able to fulfil the mission which our history and national character have imposed upon us.

Upon the whole, it seems not too much to say that the sentiment of the English people for humanity and justice has rendered obsolete the theory for which England stood in the war with the American Colonies, and that the British Empire of to-day is a Federal Empire. 


\section{CHAPTER XXVI}

\section{AMERICAN ADMINISTRA'TION, I787-I9O2}

$T$

HE first Congress which assembled after the adoption of the Constitution, by an Act passed at its first session in the year 1789 , recognized that it was its duty to withdraw from the direct administration of the dependencies in the Northwest Territory. Although, under the Ordinance of 1787 , the reports of the Governor were required to be made to the Congress, and the Congress had power to appoint and remove all the officers concerned in the Local Government of the Northwest Territory, Congress, by this Act, recognized that these functions ought properly to be performed by the President. The officers of the Local Government of the Northwest Territory were not considered to be "officers of the United States" which, under the Constitution of the United States, the President was authorized to appoint by and with the advice of the Senate. If they had been, no Act of Congress would have been necessary. The provisions of the Constitution would have controlled, and would have superseded the inconsistent provisions of the Ordinance of 1787 . The preamble stated that the purpose of the Act was to "adapt" the Ordinance of 1787 to the Constitution. If the Constitution had controlled the Ordinance, it would not have been proper to speak of "adapting" the Ordinance to the Constitution. The Ordinance was plainly recognized as a "needful rule and regulation respecting" the Northwest Territory, made in the exercise of the power of 


\section{$53^{8}$ The Administration of Dependencies}

disposition, and forming a part of the Imperial Constitution relating to the Northwest Territory, and the purpose of the Act was to "adapt" the Imperial Constitution to the Constitution of the American Union-that is, to apply a similar rule where the local conditions and circumstances of the Union and its dependencies were the same, and a different rule where the local conditions and circumstances of each were different. Only that which is coordinate with another thing can be "adapted" to it.

During the period from I 787 to I 799 , the Governor and Judges, acting as the Local Legislature, framed laws such as they considered to be adapted to the needs of the inhabitants of the Territory, the provision of the Ordinance which required them to select laws from the laws of some one of the States having been found to be impracticable. Thougn these laws were obviously void, Congress refrained, after careful consideration, from taking any action to nullify them, and in 1799 they were re-enacted by the General Assembly, upon the establishment of the Temporary Government. During all this period Congress also refrained from enacting any local legislation for the Northwest Territory, thus recognizing the statehood of this dependent region, and recognizing the Governor and Judges as the Substituted and Trustee Government for the people of the region, as a dependent State.

The same system of government which was applied to the Northwest Territory by the Ordinance of 1787 , as adapted to the Constitution by the Act of 1789 , was applied to the dependencies southeast of the Ohio River as they were formed, it being made a condition in the deeds of cession from North and South Carolina and Georgia that this system should be applied, with the exception of the anti-slavery provision.

When the Louisiana Purchase was being discussed in Congress in December, I 803, Henry W. Livingston, then a Member of Congress from New Jersey, wrote to Gou- 


\section{American Administration, I787-1902 539}

verneur Morris to obtain from him his views concerning the scope and meaning of the clauses of the Constitution relating to the disposition of the dependencies, and to the admission of new States into the Union. Morris replied that the Convention intended both these clauses to have an inclusive and universal meaning. Relating to the former, he wrote:

I always thought that when we should acquire Canada and Louisiana it would be proper to govern them as provinces and allow them no voice in our councils. In wording the third section of the fourth Article I went as far as circumstances would permit to establish the exclusion. Candor obliges me to add my belief that, had it been more pointedly expressed, a strong opposition would have been made.

After Jefferson had once become satisfied that Louisiana had, by the operation of the treaty of cession, become a dependency of the American Union, he seems to have felt no doubt but that the power of the Union over Louisiana was unconditional and unlimited. The Act of 1804, entitled "An Act Erecting Louisiana into Two Territories and Providing for the Temporary Government thereof," in fact provided for the government of that region, without any reference to any specific period of duration, by a more absolute form of government than was ever imposed by Great Britain upon any of the American Colonies. The whole political power in the Local Government of the region was vested in a Governor and a Council of thirteen members, all appointed by the President, by and with the advice and consent of the Senate. The Governor and his Council constituted a Legislative Assembly, with legislative powers extending to all rightful subjects of legislation, except that no law was to be valid that was inconsistent with the Constitution of the United States. Certain specified Acts of 


\section{The Administration of Dependencies}

Congress were to be regarded as in force in the region, and Congress assumed that it had the right to make laws of sufficient force and validity to bind the inhabitants of the region in all cases whatsoever, according to its mere will.

The coinmittee of the House of Representatives appointed to consider and report upon the petition of the inhabitants of Louisiana to be relieved from some of the more arbitrary provisions of the Act of 1804 , in their report, made January 25 , 1805 , said:

Relying on the good sense of the people of Lcuisiana to point out to them that the United States cannot have incurred a heavy debt in order to obtain the Territory, merely with a view of exclusive or especial benefit of its inhabitants, your committee at the same time earnestly recommend that every indulgence not incompatible with the interests of the Union may be extended to them. Only two modes present themselves, whereby a dependent province may be held in obedience to a Sovereign State - force and affection. The first of these is not only repugnant to all our principles and institutions of government, but it could not be more odious to those on whom it would operate than it would be hostile to the best interests as well as the dearest predilections of those by whom, in this instance, it would have to be exercised. The United States . . . form the patrimony of a free and enlightened people who control, while they constitute the fund from which men and money, of which military power is composed, can be drawn.

It can never be the interest, therefore, of the people of the United States to subject themselves to the burthens and their liberties to the dangers of a vast military force, for the subjugation of others. The only alternative, then, which presents itself, is believed to be not more congenial to the feelings than to the best interests of the Union.

Government by "affection" as the only alternative to a government by "force" had been expressly repudiated 


\section{American Administration, I 787-I902 54I}

by the Continental Congress in its resolution of April I4, I778, concerning the proposition of the British Government to give the Colonies a government founded on "affection," at the same time that it claimed that the Imperial power of the British State was unconditional and unlimited.

They saw, in an instant, that a government by affection was a government by force in disguise, and that the only permissible alternative to government by force was, as Jefferson well said, in his letter of September I3, I786, to M. Soulés, a government by "compact," which com. pact, as Gouverneur Morris showed in his Observations on the American Revolution, might be express or implied, written or unwritten. More than that, the Continental Congress had refused to admit that government by force, in time of peace, whether undisguised or disguised in the form of government by affection, was permissible at all, and had claimed that every possible relationship between a State and its external communities was a relationship between itself as a State and them as States, founded on a compact between them.

In an Act passed three days previous to the Act providing for the government of Louisiana, relating to the Bank of the United States, it was provided:

That the President and Directors of the Bank of the United States shall be and they are hereby authorized to establish offices of discount in any part of the territories or dependencies of the United States.

At the same session Congress passed an Act, relating to the exemplification and proof of public records, which extended the previous Act on this subject to

the Public Acts . . . of the respective territories of the United States and countries subject to the jurisdiction of the United States. 


\section{The Administration of Dependencies}

In the year 1808 , in the case of Rose v. Himely, 4 Cranch, 24I, where the question was whether a judgment of condemnation of a vessel by the Colonial Court of San Domingo for violation of regulations made by Napoleon, as First Consul of France, was valid, though the Court was not a Court of admiralty jurisdiction, it was held that the condemnation was valid, because in violation of a law which was a municipal regulation of France. The island of San Domingo was treated exactly as if it were an integral part of France, and the European view, that all the rights of dependencies were derived from the will and grant of the Imperial State, was adopted by the Supreme Court.

In I810, the Supreme Court, speaking by Mr. Chief Justice Marshall, in a case involving the question of the jurisdiction of the courts in the Territory of Orleans (Sere v. Pitot, 6 Cranch, 366), gave countenance to the British and European theory of the administration of dependencies by saying:

The power of governing and legislating for a Territory is the inevitable consequence of the right to acquire and hold territory. Could this position be contested, the Constitution of the United States declares that " Congress shall have power to dispose of and make all needful rules and regulations respecting the territory or other property belonging to the United States." Accordingly we find Congress possessing and exercising the absolute and undisputed power of governing and legislating for the Territory of Orieans. Congress has given them a Legislative, an Executive, and a Judiciary, with such powers as it has been their will to assign to those departments generally.

In the year 1820 , the question of the relationship between the United States and its external communities had incidentally to be considered by the Supreme Court, in the case of Loughborough v. Blake, 5 Wheaton, 3I7, 
which was brought to test the validity of the imposition of direct taxes, by Congress, on the inhabitants of the District of Columbia. The claim was made by counsel, on the argument, in behalf of the inhabitants of the District, that such taxation was taxation without representation and hence contrary to the fundamental principles upon which the government of the United States was founded. The Court differentiated the case of the District of Columbia and the regions dependent on the American Union, on the North American continent and immediately adjacent to the Union, colonized or expected to be colonized from the population of the Union, and manifestly destined for admission into the Union as States, from all regions, remote or insular, or inhabited by populations of diverse race and civilization, and held that dependencies of the former class (called "Territories") were subject to the mere will of Congress "under the restrictions of our Constitution," and that they had no right of representation in Congress. The language of the Court was:

The difference between requiring a continent with an immense population to submit to be taxed by a Government having no common interest with it, separated from it by a vast ocean, restrained by no principle of apportionment, and associated with it by no common feelings, and permitting the representatives of the American people, under the restrictions of our Constitution, to tax a part of the society which is either in a state of infancy advancing to manhood, looking forward to complete equality as soon as that state of manhood shall be attained, as is the case of Territories, or which has voluntarily relinquished the right of representation and has adopted the whole body of Congress for its legitimate Government (like the District of Columbia), is too obvious not to present itself to the minds of all.

By the decision, the government of the Territories by 


\section{The Administration of Dependencies}

the Congress of the United States, which was, as to them, a mere oligarchy of foreigners, acting according to its mere will except so far as the people of the American Union (also foreigners) had restrained them from so doing by the terms of the written Constitution of the United States, was justified by the Court on two grounds: first, that this foreign oligarchy was "under the restrictions of our Constitution" concerning the extent of its powers (though under none in regard to the manner of exercising them); and second, because the Territories were in a state of weakness which prevented them from making any successful opposition to what this foreign oligarchy might do, and the foreign oligarchy would be likely to give them a government by affection instead of a government by force because the people of the United States and the people of the Territories were "a part of the same society" and were "associated by common feelings." The government of the District of Columbia by the Congress of the United States as an oligarchy of foreigners, acting according to its mere will, under the restrictions of the Constitution, was justified because the District had "voluntarily relinquished the right of representation and adopted the whole body of Congress for its legitimate Government."

In further justification of its decision, the Court distinctly adopted the British view, that the Territories and the District of Columbia were mere external municipalities of the United States, so that they were all comprehended in one political organism, or State, called "the United States of America." Speaking of the name "the United States of America," the Court said:

Does this term designate the whole or any particular part of the American Empire? Certainly this question can admit of but one answer. It is the name given to our great Republic, which is composed of States and Territories. The District of 


\section{American Administration, I787-1902 545}

Columbia, or the territory west of the Missouri, is not less within the United States than Maryland or Pennsylvania.

The Court thus considered that the whole political organism, composed of the American States and the American Territories, was both an American Republicthat is, an American State-and an American Empire. They considered the American Empire to be a Unitary State, in which the Federal State, composed of the States represented in Congress-the American Union,-was not only the Imperial State of the Territories, as its dependencies, but the Supreme Legislature, the Supreme Executive and the Supreme Judiciary of the Territories as mere municipalities. This Imperial State was regarded as having power to make laws and statutes of sufficient validity to bind the Territories and their inhabitants in all cases whatsoever, subject to "the restrictions of our Constitution." What these restrictions were the Court did not specify. The principles of the British Empire were applied to America, with some indefinite modifications.

The Court, while giving the preference to this conception of the American Empire, did not base its decision wholly upon this conception. Recognizing that the American Empire was capable of being conceived of as a federal organism so that the powers of Congress in the Territories were powers of disposition only, they held that the levying of the taxes in the particular case was, since they were uniform with those levied in the States of the Union, a "needful rule and regulation respecting" the District of Columbia, saying:

It is not less necessary, on the principles of our Constitution, that uniformity in the imposition of imposts, duties, and excises should be observed in the [States] than in the [District of Columbia and the Territories].

Had the decision made a distinction between the 35 


\section{The Administration of Dependencies}

District of Columbia and the Territories and regarded the power over the District as a power of limited legislation, -a power in Congress to act according to its mere will "subject to the restrictions of our Constitution,"-and the power over the Territories and other dependencies as a power of conditional legislation-a power of disposition,no fault could be found with it. The District of Columbia is undoubtedly "within the United States," since by the Constitution the Congress is made its Supreme Legislature. The Territories are however expressly described by the Constitution as external States "belonging to" the United States, and the American Union - "the United States "-is given the Imperial power to dispose of them as their Sovereign and to enact executive legislation.

In the case of Johnson v. McIntosh, 8 Wheaton, 589, in the year 1823 , the question was concerning the validity of grants of lands in the dependent regions external to the Union, made by Indians or by Indian tribes to individuals in the years 1773 and $\mathrm{I} 775$, while the Indian tribes were under the protection and disposition of the British Crown, and while the British Crown claimed the right of pre-emption of all Indian lands. It was held that the local circumstances and conditions of the Indian tribes were such that they justified the American Union in refusing to recognize the grants as valid, although it was admitted that, under ordinary circumstances, the private rights of individuals in the dependencies were inviolable by the Central Government of the Union to the same extent as similar rights of inhabitants of the Union. The argument of the opinion was that the local circumstances and conditions of the Indians required their complete isolation from the whites, under their own government, and a restriction of the region occupied by them, which could be accomplished in an orderly and peaceful manner only if all grants of land to individual white men were for- 


\section{American Administration, I787-I902 547}

bidden and it was required that the Indians should sell only to the Imperial State. The Court, speaking by $\mathrm{Mr}$. Chief Justice Marshall, said:

The British Government, which was then our Government, and whose rights have passed to the United States, asserted a title to all the lands occupied by Indians, within the chartered limits of the British Colonies. It asserted also a limited sovereignty over them, and the exclusive right of extinguishing the title which occupancy gave to them. These claims have been maintained and established as far west as the Mississippi, by the sword. The title to a vast portion of the lands we now hold originates in them. It is not for the courts of this country to question the validity of this title or to sustain one which is incompatible with it.

Although we do not mean to engage in the defence of those principles which Europeans have applied to Indian title, they may, we think, find some excuse, if not justification, in the character and habits of the people whose rights have been wrested from them.

The title by conquest is acquired and maintained by force. The conqueror prescribes its limits. Humanity, however, acting on public opinion, has established, as a general rule, that the conquered shall not be wantonly oppressed, and that their condition shall remain as eligible as is compatible with the objects of the conquest. Most usually, they are incorporated with the victorious nation, and become subjects or citizens of the government with which they are connected. The new and old members of the society mingle with each other; the distinction between them is gradually lost, and they make one people. Where this incorporation is practicable, humarity demands, and a wise policy requires, that the rights of the conquered to property should remain unimpaired; that the new subjects should be governed as equitably as the old, and that confidence in their security should gradually banish the painful sense of being separated from their ancient connections and united by force to strangers.

When the conquest is complete, and the conquered inhabi- 


\section{The Administration of Dependencies}

tants can be blended with the conquerors, or safely governed as a distinct people, public opinion, which not even the conqueror can disregard, imposes these restraints upon him; and he cannot neglect them without injury to his fame and hazard to his power.

But the rribes of Indians inhabiting this country were fierce savages, whose occupation was war, and whose subsistence was drawn chiefly from the forest. To leave them in possession of their country was to leave the country a wilderness; to govern them as a distinct people was impossible, because they were as brave and high-spirited as they were fierce, and were ready to repel by arms every attempt on their independence.

What was the inevitable consequence of this state of thingsं? The Europeans were under the necessity either of abandoning the country and relinquishing their pompous claims to it, or of enforcing those claims by the sword and by the adoption of principles adapted to the condition of a people with whom it was impossible to mix and who could not be governed as a distinct society, or of remaining in their neighborhood and exposing themselves and their families to the perpetual hazard of being massacred.

Frequent and bloody wars, in which the whites were not always the aggressors, unavoidably ensued. European policy, numbers, and skill prevailed. As the white population advanced, that of the Indians necessarily receded. The country in the immediate neighborhood of agriculturists became unfit for them. The game fled into thicker and more unbroken forests, and the Indians followed. The soil, to which the Crown originally claimed title, being no longer occupied by its ancient inhabitants, was parcelled out according to the will of the sovereign power, and taken possession of by persons who claimed immediately from the Crown, or mediately, through its grantees or deputies.

That law which regulates, and ought to regulate in general, the relations between the conqueror and conquered, was incapable of application to a people under such circumstances. The resort to some new and different rule, better adapted to 


\section{American Administration, I787-1902}

the actual state of things, was unavoidable. Every rule which can be suggested will be found to be attended with great difficulty.

However extravagant the pretension of converting the discovery of an inhabited country into conquest may appear, if the principle has been asserted in the first instance and afterwards sustained; if a country has been acquired and held under it; if the property of the great mass of the community originates in it, it becomes the law of the land and cannot be questioned. So, too, with respect to the concomitant principle, that the Indian inhabitants are to be considered merely as occupants, to be protected, indeed, while in peace, in the possession of their lands, but to be deemed incapable of transferring the absolute title to others. However this restriction may be opposed to natural right, and to the usages of civilized nations, yet, if it be indispensable to that system under which the country has been settled, and be adapted to the actual condition of the two peoples, it may, perhaps, be supported by reason, and certainly cannot be rejected by courts of justice.

This case recognized a third class of dependenciesthose adjacent to the American Union, but manifestly destined never to be incorporated as States into the Union and unfitted for free commerce and intercourse with the Union. Such dependencies were to be administered not "under the restrictions of our Constitution," not even by " the rule which regulates or ought to regulate, in general, the relations between the conqueror and the conquered," but by "some new and different rule, better adapted to the actual state of things."

The right of pre-emption of soil claimed by a State against uncivilized dependencies is a right growing out of the natural right of a State to isolate its dependencies from itself to the extent necessary for the good of the whole Empire composed of itself and them, and to use all reasonable and proper means to accomplish this end. 


\section{$55^{\circ}$ The Administration of Dependencies}

So far as the case of Johnson v. McIntosh justifies the isolation of dependent uncivilized tribes under their tribal government, it is undoubtedly in accord with the general public law of the civilized world. The Constitution, laws, and customs of the Imperial State form a part of the Consticution of the Empire only so far as they are applicable, considering the local circumstances and conditions of the dependencies; but these local circumstances and conditions may be so diametrically opposite from those which exist in the Imperial State as to require the temporary or partial suspension of principles which, in the Imperial State, are regarded as so fundamental as to be almost axiomatic.

In the case of American Insurance Company v. Canter, I Peters, 449, decided in 1828 , it became necessary for the Supreme Court to remove the misapprehension which had arisen from its decision in the case of Loughborough v. Blake. Because the Supreme Court had held that the whole political organism consisting of the American States and Territories, was, in one aspect, a State, it argued that it was a Federal State, of which the Territories were Member-States, though without representation in the Central Government, and not an Empire. Consequently it was claimed that all courts in the Territories were United States Courts, of the same kind as those which the Congress was, by the Constitution, authorized to establish in the States. If so, as the jurisdiction of these courts was established by the Constitution, it was argued that every court in the Territories had the jurisdiction of a United States Court. This required the Supreme Court to decide whether the political organism composed of the American Union and the Territories was a Federal State or a Federal Empire. The Court decided that it was not a Federal State. The courts in the Territories, they said, were not United States Courts, though the Congress might, if it saw fit, 


\section{American Administration, I 787-I902 55I}

establish courts in the Territories which would have the same jurisdiction and be related in the same way to the Territories as the United States Courts in the States were related to the States. They held that Congress might establish such courts in the Territories as it saw fit, without reference to the provisions of the Constitution relating to the courts of the United States, and might confer upon them any kind of jurisdiction it thought proper.

In the opinion of the Supreme Court, delivered by Chief Justice Marshall, it was said:

[The inhabitants of Florida] do not . . . participate in political power; they do not share in the government [of the United States] till Florida shall become a State. In the meantime, Florida continues to be a Territory of the United States, governed by virtue of that clause in the Constitution which empowers Congress "to make all needful rules and regulations respecting the territory or other property belonging to the United States."

Perhaps the power of governing a Territory belonging to the United States which has not, by becoming a State, acquired the means of self-government, may result necessarily from the facts that it is not within the jurisdiction of any particular State and is within the jurisdiction of the United States. The right to govern may be the inevitable consequence of the right to acquire territory. Whichever may be the source whence the power is derived, the possession of it is unquestioned.

These courts, then, are not Constitutional courts, in which the judicial power conferred by the Constitution on the General Government can be deposited. They are Legislative courts, created in virtue of the general right of Sovereignty which exists in the Government, or in virtue of that clause which enables Congress to make all needful rules and regulations respecting the territory belonging to the United States. The jurisdiction with which they are invested is not a part of that judicial power which is defined in the third Article of the 


\section{$55^{2}$ The Administration of Dependencies}

Constitution, but is conferred by Congress, in the execution of those general powers which that body possesses over the Territories of the United States. Although admiralty jurisdiction can be exercised in the States in those courts only which are established in pursuance of the third Article of the Constitution, the same limitation does not extend to the Territories. In legislating for them, Congress exercises the combined powers of the General and of a State Government.

Prior to 1850 , the usual provision relating to the power of the Legislatures of the Territories was:

The legislative powers shall extend to all the rightful subjects of legislation; but no law shall be valid which is inconsistent with the Constitution and laws of the United States. The Governor shall publish throughout the said Territory all the laws which shall be made, and shall from time to time report the same to the President of the United States, to be laid before Congress; which, if disapproved by Congress, shall thenceforth be of no force.

This was the exact language used in the Act of March 26, I804, establishing a Temporary Government for Louisiana. These same words were used to describe the power of territorial legislation in the Act of Congress of March 30, 1822, establishing a Territorial Government in Florida. In the Act of April 20, 1836 , establishing a Territorial Government in Wisconsin, and in the Act of June I2, I838, establishing a Territorial Government in Iowa, in the Act of August 14, I848, establishing a Territorial Government in Oregon, and in the Act of March 3, I849, establishing a Territorial Government in Minnesota, the same formula was used, except that the words "but no law shall be valid which is inconsistent with the Constitution and laws of the United States" were omitted. The omission was, however, supplied by other provisions in the Acts, placing these Territories under 


\section{American Administration, I787-1902 553}

the regime of the Ordinance for the Government of the Northwest Territory (according to which, they were "subject to the Articles of Confederation and to such alterations therein as shall be constitutionally made, and to all the Acts and Ordinances of the United States in Congress assembled, conformable thereto"), and extending over the Territory the laws of the United States, "so far as the same, or any provision thereof, may be applicable." Mississippi, Indiana, Michigan, Illinois, and Alabama were, by the terms of the cession, under the régime applicable to the Northwest Territory.

There can be no doubt, therefore, that, up to March 3, I849, the undisputed theory prevailed throughout the American Union and its dependencies that it and its dependencies constituted an American Empire, under an unwritten and "flexible" constitution, of which the provisions of the Constitution and laws of the American Union which were applicable to the respective dependencies, considering their local conditions and circumstances, formed a part.

In I849, Calhoun revived the theory which had been repudiated by the Supreme Court in the case of American Insurance Company v. Canter, that the Territories were imperfect Member-States of the American Union, so that the Constitution of the American Union was in force in the Territories in exactly the same sense that it was in force in the States. Benton, in his Historical and Legal Examination of the Dred Scott Case, published in I 857 , quotes the following language used by Calhoun in the Senate in support of his proposition, speaking of the treaty with Mexico, ceding New Mexico and California:

I deny that the laws of Mexico can have the effect attributed to them-that of keeping slavery out of $\mathrm{New}$ Mexico and California. As soon as the treaty between the two countries is ratified, the sovereignty and authority of Mexico in the terri- 


\section{The Administration of Dependencies}

tory acquired by it becomes extinct, and that of the United States is substituted in its place, conveying the Constitution with its overriding control over all the laws and institutions of Mexico inconsistent with it.

The distinction between Calhoun's theory and the previous theory seems to be this: Calhoun claimed that the Territories were to be treated as external municipalities, but were to be assimilated as closely as possible to the States of the Union, regardless of their wishes and regardless of their local conditions and circumstances. The previous theory was that they were entitled to such a régime of autonomy and statehood as wouid have been given them had they been free and equal States which had entered into a compact with the American Union, made on a basis of equality and in which full account was taken both of the Constitution of the United States and of their local conditions and circumstances, by which they had voluntarily entered into a relationship of permanent dependency on the Union. Calhoun's theory substituted a government by force in the Territories for an administration of them based on compact.

In the Organic Act of New Mexico in I850, accepting the cession of New Mexico by the State of Texas, a section was inserted providing:

That the Constitution, and all laws of the United States which are not locally inapplicable, shall have the same force and effect within the said Territory of $\mathrm{New}$ Mexico as elsewhere within the United States.

This same provision was inserted in the Organic Acts of Colorado and Dakota (I86I), of Arizona and Idaho (I863), of Montana (I864), of Wyoming (I868), and of Oklahoma (i 890).

The Organic Act of Utah of 1850 , however, contained the following provision : 


\section{American Administration, I787-I902 555}

That the Constitution and laws of the United States are hereby extended over and declared to be in force in said Territory of Utah, so far as the same, or any provision thereof, may be applicable.

Between the New Mexico Act and the Utah Act, there was the most fundamental difference. In the former, the Constitution was declared to be literally in force in the Territory; in the latter, to be in force only "so far as the same, or any provision thereof, may be applicable." In the former, it was declared to be a written Constitution imposed upon the Territory without its consent; in the latter, it was declared to be the basis of an unwritten Constitution of an Empire of which the Territory formed a part.

The plain purpose of the above-quoted provision of the New Mexico Act, which was in exact conformity with Calhoun's theory, was, of course, to strengthen the claim of the Southern States that Congress had power to impose slavery upon the Territories. If the Constitution of the United States was in force in the dependencies only so far as its provisions were applicable, considering the local circumstances and conditions, and the Local Governments of the Territories had power to make all laws not inconsistent with the Constitution and laws of the United States, it was possible to claim that Congress, in exercising the power to make municipal regulations for the Territories, acted in substitution for the Local Government, and that its powers were only such as the Local Government would exercise if it were the Government of a free and equal State in a voluntary relationship of permanent dependency on the Union, in which case it was exceedingly doubtful whether Congress could impose slavery upon any of the Territories, and it was certain that it could not impose it upon all of them. It was for the interest of 


\section{The Administration of Dependencies}

the Southern States, therefore, to have the Territories treated as nearly like the States of the Union as possible, and then to have Congress regard itself as a substitute for a State Government. The result was to require Congress to exercise its powers in the Territories "subject to the restrictions of the Constitution," one of which restrictions was, as the slaveholding States claimed, that Congress should not only not deprive persons of their property in slaves, but should recognize and protect this alleged right of property.

Beginning with the Act of September 9, I8jo, establishing a Territorial Government in Utah, and until the Act of May 2, I890, establishing a Temporary Government in Oklahoma, every Act of Congress establishing a Territorial Government, with one exception, provided that the legislative power of the Territory should "extend to all rightful subjects of legislation, consistent with the Constitution of the United States." The one exception was the Act of March 2, I853, establishing a Territorial Government in Washington Territory, which followed the old formula - that the Territorial legislation should be "not inconsistent with" the Constitution and laws of the United States. Since I890, the old formula has been followed.

In the Dred Scott Case (Scott v. Sandford, I9 Howard, 393) decided in 1857 , the relationship between the Constitution of the United States and the Constitution of the American Empire was again examined, and two distinct views developed: the first, that all the restrictions (both express and implied) imposed by the Constitution upon either the National Government or the State Government were literally in force in the dependencies; and second, that only the express prohibitions of the Constitution were in force. It was not suggested by any of the Judges that the Constitution was in force "so far as the same, or any provision therof, might be applicable." 
The whole Court attempted to treat the Constitution of the United States as if it were actually the written Constitution of the Empire, instead of being the basis of the unwritten Constitution of the Empire. Realizing that it was impossible, in the nature of things, to treat it literally and totally as the Constitution of the Empire, they attempted to take a part of it and declare that to be the written Constitution of the Empire.

Mr. Chief Justice Taney, in that case, attempted to read out of the Constitution the clause giving Congress the power "to dispose of and make all needful rules and regulations respecting" the dependencies by confining it entirely to the Northwest Territory, and others of the Judges attempted to destroy its effect by interpreting it as having reference only to dispositions of the primary title to the soil in the dependencies, but the majority of the Court in that case did not adopt either of these constructions, and there is nothing to prevent the Supreme Court, at the present time, from giving to the clause its most universal meaning.

From the time of the decision of the Dred Scott Case until the present time, the question of the relationship between the Constitution of the United States and the Constitution of the American Empire has been under consideration by the Supreme Court. That the Constitution of the United States and the Constitution of the American Empire are not, and cannot be one and the same thing, is evident from the most casual inspection of the Constitution of the United States, which contains numerous provisions which cannot by any possibility be regarded as applicable to the Territories or other dependencies of the United States. There is in this Constitution hardly a single provision which any judicious person would be willing to say was applicable to every dependent community, whatever might be the character of its civilization and whatever might be its local conditions 


\section{The Administration of Dependencies}

and circumstances. Yet that there must be some relationship between the Constitution of the Imperial State and the Constitution of the Empire, whether the Constitution of the Imperial State be written or unwritten, and whether the Imperial State be unitary or federal in character, is a proposition which hardly any judicious person at the present time doubts.

The view taken by the Supreme Court in the Dred Scott Case, that the American Union had unconditional and unlimited power over its dependencies "subject to the restrictions of the Constitution," was followed in a long course of decisions until the year I 889.

One of the most notable cases on this subject during this period was the case of National Bank v. County of Yankton, IOI U. S., I29, decided in I879. Mr. Chief Justice Waite, delivering the unanimous opinion of the Court, upholding the power of Congress to disapprove and annul Territorial legislation, said:

The Territories are but political subdivisions of the outlying dominion of the United States. Their relation to the General Government is much the same as that which counties bear to the respective States, and Congress may legislate for them as a State does for its municipal organizations. The organic law of a Territory takes the place of a Constitution as a fundamental law of the Local Government. It is obligatory and binds the Territorial authorities; but Congress is supreme, and for the purposes of this department of its governmental authority has all the powers of the people of the United States, except such as have been expressly or by implication reserved in the prohibitions of the Constitution.

Congress may not only abrogate laws of the Territorial Legislature, but it may itself legislate directly for the Local Government. It may make a void Act of the Local Legislature valid, and a valid Act void. In other words, it has full and complete legislative authority over the people of the Territories and all the Departments of the Territorial Govern- 
ments. It may do for the Territories what the people, under the Constitution of the United States, may do for the States."

As further illustrating the view taken by the Supreme Court during this period, there may be quoted the following language of the Court in the case of Murphy v. Ramsey, I 44 U. S., I 5, decided in 1884, which involved the question of the power of Congress to disapprove and annul certain legislation of the Territory of Utah-the opinion being delivered by Mr. Justice Matthews:

The people of the United States, as sovereign owners of the National Territories, have supreme power over them and their inhabitants. In the exercise of this sovereign dominion, they are represented by the Government of the United States, to whom all the powers of government over that subject have been delegated, subject only to such restrictions as are expressed in the Constitution, or are necessarily implied in its terms, or in the purposes and objects of the power itself; for it may well be admitted in respect to this, as to every power of society over its members, that it is not absolute and unlimited. But in ordaining government for the Territories and the people who inhabit them, all the discretion which belongs to legislative power is vested in Congress; and that extends, beyond all controversy, to determining by law, from time to time, the form of the local Government of a particular Territory, and the qualification of those who shall administer it. It rests with Congress to say whether, in a particular case, any of the people, resident in the Territory, shall participate in the election of its officers or the making of its laws; and it may therefore take from them any right of suffrage it may previously have conferred, or at any time modify or abridge it, as it may deem expedient.

The personal and civil rights of the inhabitants of the Territories are secured to them, as to other citizens, by the principles of constitutional liberty which restrain all the agencies of government, State and National; their political 


\section{The Administration of Dependencies}

rights are franchises which they hold as privileges in the legislative discretion of the Congress of the United States.

In I889, in the case of The Mormon Church v. The United States, I 36 U. S., I, the Supreme Court, finding it necessary, in the interests of justice and good government, to justify an Act of Congress confiscating the property of the Mormon Church in the Territory of Utah, and recognizing that the Act could not be sustained if the express prohibitions of the Bill of Rights bound Congress in its disposition of the Territories, announced a doctrine which meant nothing else than that the American Empire, consisting of the American Union and its dependencies, was under an unwritten Constitution of which the Constitution of the United States was the basis. Speaking by Mr. Justice Bradley, the Court said:

Doubtless Congress, ir legislating for the Territories, would be subject to those fundamental limitations in favor of personal rights which are formulated in the Constitution and its amendments, but these limitations would exist rather by inference and the general spirit of the Constitution, from which Congress derives all its powers, than by any express and direct application of its provisions.

The limitations upon the power thus declared are at the same time very indefinite and very extensive. According to the theory of this opinion, no provision whatever of the Constitution protecting the personal rights of citizens of the States applies expressly and directly to the power of the American Union and its Central Government over the dependencies, but every provision of the Constitution in favor of personal rights may possibly apply, if its application can be justified "by inference and the general spirit of the Constitution." A power which is limited by inference is not the kind of power which is usually conferred on a representative 


\section{American Administration, I787-I902 561}

Legislature. It is not the usual function of a Legislature composed of necessarily non-expert delegates to inquire whether the circumstances and conditions of communities which none of the delegates represent, but to which the powers of the Legislature extend, are the same as those of communities represented, and from hence to "infer" that express limitations upon the power of the Legislature in the latter are, according to "the general spirit of the Constitution," applicable in the former. If a representative body has, in fact, as a part of its duties, to occupy itself with such "inferences," its duties are essentially expert, and its powers of legislation are incidental to its power of disposition. It is acting under an unwritten Constitution.

In the case of McAllister v: The United States, I4I U. S., I74, which involved the question of the power of Congress over the Judges of Territorial Courts with respect to their term of office, suspension, or removal, the Court, speaking by Mr. Justice Harlan, in upholding the power of Congress in this respect, said:

How far the exercise of [the plenary power of Congress over the Territories of the United States] is restrained by the essential principles upon which our system of government rests, and which are embodied in the Constitution, we need not stop to inquire, though we may repeat what was said in Mormon Church v. United States, I36 U. S. I, 44: "Doubtless Congress, in legislating for the Territories, would be subject to those fundamental limitations in favor of personal rights which are formulated in the Constitution and its amendments; but these limitations would exist rather by inference and the general spirit of the Constitution from which Congress derives all its powers, than by any express and direct application of its provisions."

Here was another enormous step forward. The power of the American Union over its dependencies is, it was 36 


\section{The Administration of Dependencies}

intimated, "restrained by the essential principles upon which our system of government rests, and which are embodied in the Constitution." This was a very different proposition, indeed, from that advanced in the Mormon Church case - that the power was restrained by "those fundamental limitations in favor of personal rights which are formulated in the Constitution and its amendments." The suggestion plainly is that every provision of the Constitution is, in principle and so far as applicable, a restriction upon the power of the American Union and its Central Government over the dependencies. At last the Supreme Court returned to the principle of the old English Colonial Charters-that all governmental action relating to the dependencies should "not be repugnant to, but agreeable, as nearly as may be, to the Constitution, laws and customs" of the Imperial State, "considering the circumstances and conditions" in the dependency, and the Congress of the United States was declared to stand substantially in the same relation to the dependencies as the King in Council did to the American Colonies, though possessing, in addition, full powers of legislation and execution, in aid of its jurisdiction - that is, to have the power of disposition of the dependencies.

Though Mr. Chief Justice Fuller, Mr. Justice Field, and Mr. Justice Lamar dissented in the Mormon Church Case, and Mr. Justice Field, Mr. Justice Gray, and Mr. Justice Brown in the McAllister Case, their dissent did not go to the statement of the majority regarding the effect of the Constitution in the Territories.

In the case of Dorenes v. Bidruell, one of the so-called Insular Tariff Cases, decided May 27, I90I, and reported in 182 U. S., 244, involving the validity of the special tariff for the island of Porto Rico, established by Act of Congress on April 12, 1900, the whole question of the relationship of the Constitution of the United States to the 


\section{American Administration, I 787-1902 563}

Constitution of the American Empire was again considered, and the power of the Union to establish this special tariff was upheld by a majority of the Court. Five of the Judges were of the opinion that the Constitution of the United States is the basis of the unwritten Constitution of the American Empire, so that the American Union is at liberty to treat its dependencies as having natural rights of statehood and as entitled to a régime either of autonomy or of assimilation according to the local conditions and circumstances of each; and four were of the opinion that the Constitution of the United States, or some part of it, is actually the written Constitution of the American Empire, so that the Union can recognize no right in the dependencies to a régime of autonomy, but is obliged to force upon them, to an extent not specified, a régime by which they shall be assimilated, as nearly as possible, to the States of the Union regardless of their local conditions and circumstances. Because the Constitution provides that all taxes, duties, and imposts shall be "uniform throughout the United States," the dissenting Judges were of opinion that they must be likewise uniform throughout the American Empire.

The régime which the French call the régime of assimilation, the majority of the Supreme Court in the Insular Tariff Cases call the régime of "incorporation." The French word seems the more proper. "Incorporation" means "admission into the body and personality" of the State. In the case of a State under popular government, incorporation of lands and populations can only occur by admission of them to a representation in the Legislature on equal terms with the lands and populations already constituting the body and personality of the State, and with equal participation in the vote for the Executive if he is elective. In the case of a Federal State, incorporation of lands and populations can only occur when they 


\section{The Administration of Dependencies}

form a State and that State is admitted into the Union as a State, on equal terms respecting representation in the Congress or Parliament, and with equal participation in the vote for Chief Executive if he is elective. Lands and populations, however, though not incorporated into the State, may be dependent upon the State under a régime similar in all respects except participation in the election of the Central Government to that which prevails in the lands and populations which are actually incorporated into the State. Such a dependency is under the régime of "assimilation," as distinguished from the régime of "autonomy."

Mr. Justice White, speaking also for Mr. Justice Shiras and Mr. Justice McKenna, in his opinion maintaining the proposition that the Constitution of the United States is only the basis of the unwritten Constitution of the Empire, and that the American Union has the right to apply either the régime of assimilation or autonomy, said:

In some adjudged cases, the power to locally govern at discretion has been declared to arise as an incident to the right to acquire territory. In others it has been rested upon the clause of Section 3, Article IV. of the Constitution, which vests Congress with the power to dispose of and make all needful rules and regulations respecting the territory or other property of the United States. But this divergence, if not conflict of opinion, does not imply that the authority of Congress to govern the Territories is outside of the Constitution, since in either case the right is founded upon the Constitution, although referred to different provisions of that instrument.

Whilst, therefore, there is no express or implied limitation on Congress in exercising its power to create Local Governments for any and all of the Territories, by which that body is restrained from the widest latitude of discretion, it does not follow that there may not be inherent, although unexpressed, 


\section{American Administration, I 787-1902 565}

principles which are the basis of all free government, which cannot be with impunity transcended. But this does not suggest that every express limitation of the Constitution which is applicable has not force, but only signifies that even in cases where there is no direct command of the Constitution which applies, there may nevertheless be restrictions of so fundamental a nature that they cannot be transgressed, although not expressed in so many words in the Constitution.

As Congress in governing the Territories is subject to the Constitution, it results that all the limitations of the Constitution which are applicable to Congress in exercising this authority necessarily limit its power on this subject. It follows also that every provision of the Constitution which is applicable to the Territories is also controlling therein.

It is insisted, however, conceding the right of the Government of the United States to acquire territory, that, as all such territory when acquired becomes absolutely incorporated into the United States, every provision of the Constitution which would apply under that situation is controlling in such acquired territory. This, however, is but to admit the power to acquire, and immediately to deny its beneficial existence.

The general principle of the law of nations, already stated, is that acquired territory, in the absence of agreement to the contrary, will bear such relation to the acquiring government as may be by it determined. To concede to the Government of the United States the right to acquire, and to strip it of all power to protect the birthright of its own citizens and to provide for the well-being of the acquired territory by such enactments as may in view of its condition be essential, is, in effect, to say that the United States is helpless in the family of nations, and does not possess that authority which has at all times been treated as an incident of the right to acquire. Let me illustrate the accuracy of this statement. Take a case of discovery. Citizens of the United States discover an unknown island, peopled with an uncivilized race, yet rich in soil, and valuable to the United States for commercial and strategic reasons. Clearly, by the law of nations, the right 


\section{The Administration of Dependencies}

to ratify such acquisition and thus to acquire the territory would pertain to the Government of the United States. Can it be denied that such right could not be practically exercised if the result would be to endow the inhabitants with the citizenship of the United States and to subject them not only to local but also to an equal proportion of national taxes, even although the consequence would be to entail ruin on the discovered territory and to inflict grave detriment on the United States to arise both from the dislocation of its fiscal system and the immediate bestowal of citizenship on those absolutely unfit to receive it?

The result of what has been said is that whilst in an international sense Porto Rico is not a foreign country, since it was subject to the Sovereignty of, and was owned by, the United States, it was foreign to the United States in a domestic sense, because the island had not been incorporated into the United States, but was merely appurtenant thereto as a possession.

Mr. Justice Brown, who was one of the five judges of the majority, in his concurring opinion regarded the unwritten Constitution of the American Empire as being almost wholly divorced from the Constitution of the United States, and as being determined, therefore, by the principles of the general public law of the civilized world. He suggested that there might be some express restrictions upon the power of the American Union in favor of natural rights, contained in the Constitution of the United States, which were of so universal a nature as to be applicable in whatever part of the universe the power of the American Union was exercised.

In his opinion, Mr. Justice Brown made the following suggestion concerning the effect of the Fourteenth Amendment, which has by some persons been supposed to make all persons born or naturalized in the depen- 


\section{American Administration, I 787-1902 567}

dencies of the American Union "citizens of the United States":

The Thirteenth Amendment to the Constitution prohibiting slavery and involuntary servitude "within the United States or any place subject to their jurisdiction" is also significant as showing that there may be places within the jurisdiction of the United States that are no part of the Union. To say that the phraseology of this Amendment was due to the fact that it was intended to prohibit slavery in the seceded States, under a possible interpretation that those States were no longer a part of the Union, is to confess the very point in issue, since it involves an admission that, if these States were not a part of the Union, they were still subject to the jurisdiction of the United States.

The Fourteenth Amendment, upon the subject of citizenship, declares only that "all persons born or naturalized in the United States, and subject to the jurisdiction thereof, are citizens of the United States and of the State in which they reside." Here there is a limitation to persons born or naturalized in the United States which is not extended to persons born in any place "subject to their jurisdiction."

This amounts, of course, to saying that only persons born or naturalized within one of the States of the Union are citizens of the United States, since that was undoubtedly the case before the adoption of the Fourteenth Amendment, and that Amendment establishes no rule to the contrary-in other words, it amounts to saying that the inhabitants of the dependencies of the American Union are not citizens of the United States except so far as some of them may have been born or naturalized in some State of the Union.

Mr. Justice Gray, in his opinion concurring with that of Mr. Justice White, committed himself only to the proposition that the American Union, if it "is not ready to construct a complete Government for the conquered 


\section{The Administration of Dependencies}

territory . . . may establish a temporary Government, which is not subject to all the restrictions of the Constitution."

Mr. Chief Justice Fuller, in delivering the opinion of the dissenting Judges (himself, Mr. Justice Harlan, Mr. Justice Brewer, and Mr. Justice Peckham), denied that the dissenting Judges regarded Porto Rico as "incorporated " into the Union, saying:

Great stress is thrown upon the word "incorporation" as if possessed of some occult meaning, but I take it that the Act under consideration made Porto Rico, whatever its situation before, an organized territory of the United States.

Mr. Justice Harlan, in his separate dissenting opinion, after specifying the various acts of power exercised by the American Union over Porto Rico under the terms of the Porto Rico Act, thus criticised the use of the word "incorporation" in this connection:

It would seem, according to the theory of some, that even if Porto Rico is in and of the United States for many important purposes, it is yet not a part of this country with the privilege of protesting against a rule of taxation which Congress is expressly forbidden by the Constitution from adopting as to any part of the "United States." And this result comes from the failure of Congress to use the word "incorporate" in the [Porto Rico] Act, although by the same Act all power exercised by the Civil Government in Porto Rico is by authority of the United States, and although this Court has been given jurisdiction by writ of error or appeal to reexamine the final judgments of the District Court of the United States established by Congress for that Territory. Suppose Congress had passed this act: "Be it enacted by the Senate and House of Representatives in Congress assembled, That Porto Rico be and is hereby incorporated into the United States as a Territory," would such a statute have 


\section{American Administration, I787-1902 569}

enlarged the scope or effect of the [Porto Rico] Act? Would such a statute have accomplished more than the [Porto Rico] Act has done? Indeed, would not such legislation have been regarded as most extraordinary as well as unnecessary?

I am constrained to say that this idea of "incorporation" has some occult meaning which my mind does not apprehend. It is enveloped in some mystery which I am unable to unravel.

In my opinion, Porto Rico became, at least after the ratification of the Treaty with Spain, a part of and subject to the jurisdiction of the United States in respect of all its territory and people, and Congress could not thereafter impose any duty, impost, or excise in respect to that Island and its inhabitants which departed from the rule of uniformity established by the Constitution.

The theory of the dissenting Judges seems to be that the parts of the Constitution which apply to the dependencies at all apply to them literally. Mr. Chief Justice Fuller, in his opinion, said:

In our judgment, so much of the Porto Rican Act as authorized the imposition of these duties is invalid, and plaintiffs were entitled to recover.

Some argument was made as to the general consequences apprehended to flow from this result, but the language of the Constitution is too plain and unambiguous to permit its meaning to be thus influenced. There is nothing "in the literal construction so obviously absurd, or mischievous, or repugnant to the general spirit of the instrument, as to justify those who expound the Constitution " in giving it a construction not warranted by its words.

If the dependencies of the American Union are not "incorporated into" the body and personality of the Union, as the dissenting Judges insist they are not, and if they are nevertheless subject to the power of the American Government under the express limitations of the Constitution interpreted with the same literalness 


\section{The Administration of Dependencies}

as if it were a question of their operation within the States of the Union, it necessarily follows that the minority Judges regard all the American dependencies as dependencies under a régime of assimilation.

The dissenting Judges criticized the theory of the majority, as a theory according to which the dependencies of the American Union are subjected to "absolute" and "unrestricted" power. They said:

The contention seems to be that if an organized and settled Province of another Sovereignty is acquired by the United States, Congress has the power to keep it, like a disembodied shade, in an intermediate state of ambiguous existence for an indefinite period; and, more than that, that after it has been called from that limbo, commerce with it is absolutely subject to the will of Congress, irrespective of constitutional provisions.

That theory [of the majority of the Court] assumes that the Constitution created a Government empowered to acquire countries throughout the world, to be governed by different rules than those obtaining in the original States and Territories, and substitutes for the present system of republican government a system of domination over distant Provinces in the exercise of unrestricted power.

The plain and necessary meaning of the majority of the Court is, however, that the power of the American Union over its dependencies is neither an absolute power nor an unrestricted power, but a conditional power and a power limited by the necessity for its exercise in the particular case. It is not a power which is exercised by the Government of the American Union without a Constitution, but a power exercised under a trust imposed on the Government of the American Union by the people of the American Union, in their written Constitution, compelling the Government to adjudicate and 


\section{American Administration, I787-1902 57I}

execute an unwritten Constitution. The majority of the Court recognize that a written Constitution is only the best evidence of the unwritten Constitution which it evidences, and that the same rule of the relationship between the Constitution of a State and the Constitution of its Empire applies, whether the Constitution of the State is written or unwritten, - that the Constitution of a State, whether written or unwritten, is in force in its dependencies so far as may be practicable, considering the local conditions and circumstances of each dependency, and to this extent forms a part of the unwritten Constitution of the Empire of the State. There is nothing in this theory which militates against the interposition of the Imperial Judiciary for the protection of private rights. The very definition of the Imperial power in the Constitution as the power of disposition accompanied by a power to make all needful rules and regulations, implies a power existing somewhere to nullify all acts of the American Union which are not acts of disposition, and all legislative acts which are not "needful."

On the other hand, the theory of the dissenting Judges, though apparently based upon a desire to protect the inhabitants of the dependencies against unlimited governmental power, is really based upon the theory that the power of the Imperial State over its dependencies is a power based upon its will, supported by force, and not upon compact. Any régime of assimilation necessarily implies the non-recognition of the wishes and desires of the people of the dependencies, and the claim on the part of the people of the Imperial State that what they consider good for them is good also for the people of the dependencies. The enforcement of limitations on governmental power may be an injustice to the people of the dependencies, where it would be doing justice to the people of the Imperial State. The exercise of governmental power according to the neces- 


\section{The Administration of Dependencies}

sity of the case is the prime necessity of all community life, and to require power to be exercised in a certain manner, which is not the manner dictated by the necessity of the case, is practically to deny to the community the prime necessity of community life, and to exercise power which to all intents and purposes is, so far as the people of the dependencies are concerned, "absolute" and "unrestricted."

By the decision in the Insular Tariff Cases, the purpose of the framers of the Constitution has been at last recognized and fulfilled, and the American Empire is recognized as a Federal Empire.

If the history of the instrumentalities by which the American Union has performed its Imperial obligations is examined, they will be found to reflect the views which have been held, from time to time, concerning the political relationship.

From the beginning of the nineteenth century until very recently, the Congress has regarded itself as the sole representative of the American Union in the exercise of the power over its dependencies. Though, by the Organic Acts of the Territories, the President, by and with the consent of the Senate, has been recognized as having the power to appoint the Territorial Governors and Secretaries and in some cases the Executive and Legislative Councils, he has not been recognized until recently as having any legislative power, except for military purposes or purposes incidental thereto, either negative or affirmative. This power has been claimed and exercised solely by Congress. Though the reports of Territorial Governors, when they have been made, have always been made to the President, through one of his Secretaries, it has been for the purpose of laying them before Congress.

By Act of 1884 , the District of Alaska was given a form of government wholly appointive but without legislative 
powers, the applicable provisions of the laws of Oregon being declared by the Act to be in force in the District. This form of government was continued by the Act of 1900 , providing a code for the District.

By Joint Resolution of July 7, 1898, it was provided:

That the Hawaiian Islands and their dependencies be and they are hereby annexed as a part of the territory of the United.States, and are subject to the sovereign dominion thereof.

By this Resolution it was also provided:

That until Congress shall provide for the government of such Islands, all the civil, judicial, and military powers exercised by the officers of the existing Government in said Islands shall be vested in such person or persons, and shall be exercised in such manner as the President of the United States shall direct; and the President shall have power to remove said officers and fill the vacancies so occasioned.

By the Act of 1900, Hawaii was given a Territorial form of government.

Various provisions having been made in the treatres prior to 1898 by which territory was ceded, concerning the rights of the inhabitants, some of which had led to a claim, by the people of the dependencies in the ceded regions, of a right to be admitted as Member-States of the American Union, this possibility was carefully guarded against in the treaty of cession from Spain of December IO, I898, following substantially the provisions in the treaty with Russia of 1887 ceding Alaska, by a provision which read as follows:

The civil rights and political status of the native inhabitants of the territories hereby ceded to the United States shall be determined by Congress. 


\section{The Administration of Dependencies}

By the Act of 1900 , the Island of Porto Rico was given a Government, under an appointed Governor and Council and an elected House of Representatives, with full powers of local legislation. The Act was so worded as to make it impossible for a claim to be made under it that the American Union was under any obligation to Porto Rico to admit that dependency into the Union.

On April 7, I900, a Philippine Commission of five members was appointed by the President, without authority of any Act or Resolution of Congress, which was, by the Instructions accompanying the President's commission, given the following powers, among others:

Beginning with the Ist of September, 1900 , the authority to exercise, subject to my approval, through the Secretary of War, that part of the power of government in the Philippine Islands which is of a legislative nature is to be transferred from the Military Governor of the Islands to this Commission, to be thereafter exercised by them in the place and stead of the Military Governor, under such rules and regulations as you shall prescribe, until the establishment of the Civil Central Government for the Islands . . . or until Congress shall otherwise provide.

The Instructions required the Commission to admit the natives to as large a share in the Government as possible, provided for putting the Civil Service of the Islands under proper regulations to insure expertness, enjoined legislation conforming as far as practicable to the customs, habits, and prejudices of the people, and authorized the isolation of uncivilized tribes under their tribal governments.

By Act of Congress of March 2, I9OI, it was provided:

All military, civil, and judicial powers necessary to govern the Philippine Islands, . . . shall, until otherwise provided by Congress, be vested in such person or persons and shall be exercised in such manner as the President of the 


\section{American Administration, I 787-I902 575}

United States shall direct, for the establishment of civil government and for maintaining and protecting the inhabitants of said Islands in the free enjoyment of their liberty, property, and religion: Provided, That all franchises granted under the authority hereof shall contain a reservation of the right to alter, amend, or repeal the same.

Until a Permanent Government shall have been established in said Archipelago, full reports shall be made to Congress, on or before the first day of each regular session, of all legislative acts and proceedings of the Temporary Government instituted under the provisions hereof; and full reports of the acts and doings of the said Government, and as to the condition of the Archipelago and of its people shall be made to the President, including all information which may be useful to the Congress in providing for a more permanent Government: Provided, That no sale or lease or other disposition of the public lands or the timber thereon or the mining rights therein shall be made: And provided further, That no franchise shall be granted which is not approved by the President of the United States, and is not in his judgment clearly necessary for the immediate government of the Islands and indispensable for the interest of the people thereof, and which cannot, without great public mischief, be postponed until the establishment of permanent civil government; and all such franchises shall terminate one year after the establishment of such permanent civil government.

The actual condition of affairs with respect to the Philippine Islands, therefore, is that Congress has temporarily withdrawn from the habitual and constant control and has recognized that the President is, for temporary and special purposes, the proper representative of the United States in exercising the Imperial power and performing the Imperial obligations. It exercises the power of superintendence, and claims the power to substitute itself at any time for the President in the habitual and constant exercise of the Imperial power. 


\section{The Administration of Dependencies}

As the President exercises all his powers through Secretaries or Secretarial Boards, it is important to ascertain the Executive Departments in whose charge the business of the relations with the dependencies has been since the adoption of the Constitution.

Until March I, I873, the relations with the Territories were in the charge of the Secretary who is called the Secretary of State, but who is really the Secretary of State for Foreign Affairs, upon whom some of the functions of the Secretariat for Home Affairs were imposed in the year 1789 , for special reasons which no longer exist. The Secretariat was originally created as the Secretariat for Foreign Affairs and the name was changed when the special duties were added. The dependencies were thus treated as "foreign States" and their affairs as "foreign affairs," to quote the language of the original Act creating this Secretariat.

On March I, I873, by Act of Congress, all powers and duties in relation to the Territories "that were, prior to March I, I873, by law or custom exercised and performed by the Secretary of State" were transferred to the Secretary of the Interior.

The Secretary of the Interior has charge, under this statute, at the present time, of the relations with the continental Territories, including Alaska, with Hawaii, and, under special statutes, of some of the relations with Porto Rico.

As matter of fact, the relations between the American Union and the Territories seem to have been almost entirely neglected until a very recent period. The appointed Governors and Secretaries have regarded themselves as responsible entirely to the people and the elected Senate and House of Representatives of the respective Territories, and the delegate in Congress, with the power to debate but not to vote, has been recognized as the link between each Territory and the Union. . At 


\section{American Administration, I787-1902 577}

the present time Governors of Territories report to the Secretary of the Interior, and their reports are laid before the President and Congress.

Upon the establishment of the Secretariat of War in I789, the relations with the Indians were placed in charge of this Department. In 1832, by Act of Congress, a permanent Under-Secretariat in this Department for this purpose was created, in charge of a "Commissioner for Indian Affairs" who was to have "the direction and management of all Indian affairs, and of all matters arising out of Indian relations" and was obliged to act "under the direction of the Secretary of War and agreeably to such regulations as the President may, from time to time, prescribe." The propriety and necessity of leaving the habitual and constant charge of the relations with the Indian tribes in the hands of the President was thus recognized. In I849, by Act of Congress, "the supervising and appellate powers exercised by the Secretary of the War Department " over the Commissioner for Indian Affairs were transferred to the Department of the Interior, where they still remain.

The relations of the American Union with the Philippines are still in the charge of the War Department, in which there has been established a Division, called the Division of Insular Affairs, having the immediate direction of affairs.

In its theory, as declared by the Supreme Court, and in its practice, as shown by the action of Congress and the President, therefore, the American Union is daily recognizing itself as an Imperial State performing Imperial obligations and exercising Imperial power over external States. The American Federal Empire is a fact, and will remain a fact. It remains, therefore, to ascertain its Imperial obligations. 


\section{CHAPTER XXVII}

\section{IMPERIAL OBLIGATIONS}

$\mathrm{A}^{\mathrm{s}}$ SSUMING it to be granted that the people and lands of the American Union and the people and lands of its dependencies constitute a Federal Empire, and that the people of the American Union, by their written Constitution consented to by all the people of the Empire, have divided the governmental power under an unwritten Constitution, so that the Union is the Imperial State as respects the dependencies, standing in a federal and contractual relation to them, and having neither unconditional nor unlimited power over them, but only a power of disposition,-which implies adjudication as a prerequisite, and in which is included the power to execute its adjudications by all needful rules and regulations, - it becomes important to attempt to ascertain the obligations which, in this view, are imposed upon the American Union and its people.

The first obligation undoubtedly is that the two great instrumentalities of government - the Senate and House of Representatives, together constituting the Congress (the President participating in the action of Congress only as a Committee of Revision with power to compel reconsideration, but not to nullify its action), and the President, acting separately and apart from the Congress - shall be properly related to each other in the exercise of the Imperial power.

Considering, first, the question of the propriety of attempting to administer the dependencies wholly through 
the instrumentality of the Congress, it is to be noticed that, if such were the habitual and constant method of administration, it would amount, when viewed from the standpoint of the dependencies, to habitual and constant administration by an oligarchy of foreigners. If the oligarchy were composed of a small body of men, having a unity of view and interest, and familiar with the local circumstances and conditions of the dependencies as well as with those of the Union, such a body might be, perhaps, a very proper and effective instrumentality for the performance of the national trust. As a matter of fact, however, the Congress is not a small but a large body; it has not a unity of view and interest, but is alwrays divided into at least two great parties, and always represents local interests, many of which are opposed not only to the interests of the dependencies, but to the interests of each other; its members are elected primarily for the protection of local interests, secondarily for the protection of the interests of the whole Union, and lastly, when these interests have been protected, to protect the interests of the dependencies. With the best and most honest intentions in the world, a man elected to the Senate or House of Representatives is under a pressure to protect the local interests and the interests of the whole Union, which makes it impossible for him to place the interests of the dependencies on anything like an equality with the other interests.

Moreover, a large body of men is, in the nature of things, disqualified from determining questions where the facts are complicated and are not facts of common knowledge. The theory of legislation is that the members of the Legislature are familiar with the facts, and that they deliberate simply concerning the rule to be applied to established facts. Congressional committees investigate facts, but such investigations are properly for the purpose of settling disputed or doubtful questions of 


\section{The Administration of Dependencies}

fact, and not for the purpose of investigating facts concerning which no knowledge can be had except by a process of investigation. The administration of dependencies, however, requires a continuous investigation of facts, concerning which the members of the Senate and House of Representatives cannot, in the nature of things, have a knowledge as a part of their common and daily experience. For the Congress, therefore, to attempt to act as the representative of the American Union in the fulfilment of its continuous daily and hourly duties, would require it to sit continuously and to be continuously investigating new facts through its committees. There are therefore, obviously, serious objections growing out of the character and composition of the Congress, to the proposition that the American Union can habitually and constantly administer its dependencies through the instrumentality of Congress.

There are, likewise, serious objections against placing the habitual and daily administration of the dependencies in the hands of the President. The President himself is elected by a party, and is likely to be swayed by partisan considerations; he may or may not have a personal knowledge of the local circumstances and conditions in the dependencies; and he may or may not have the capacity of investigating and digesting facts. Further than this, to allow one man, free from supervision and control, to adjudicate the unwritten Constitution of the American Empire and to legislate in execution of his adjudications, even though all the people of the Empire should consent and agree to this, would be to subject the President to a temptation to convert his conditional and limited power into a power practically unconditioned and unlimited, and, judging from history, the temptation would not be withstood.

When the objections to the administration of dependencies by the Congress or by the President are sum- 
marized, it thus appears that the objections to administration by Congress are really objections to the habitual and daily exercise of power for this purpose. Congress can occasionally and in matters of great importance investigate by its committees facts which are wholly outside of common knowledge, and can decide upon those facts, and when the matter is of sufficient importance so that it can afford to give the time necessary to ascertain all the facts and so that the matter may be debated and deliberated, the Congress can give a decision which will be judicious and adequate. The Congress is, therefore, a body admirably adapted for the purposes of general superintendence. A superintending body interferes with the agent body only occasionally, and for the purpose of keeping the agent body within its limits and of compelling it to perform the conditions under which it acts, but when the superintending body acts, its action is final and supersedes and nullifies all contrary action of the agent body.

On the other hand, the objections to administration of the dependencies by the President are really objections to his acting without supervision and control by a superintending body. Because the Presidential office is vested in one man, the President is qualified to act as the habitual and daily administrator of the dependencies. The President, and his assistants, are continuously in the performance of governmental duties. Matters requiring immediate action can receive his immediate attention. $\mathrm{He}$ can be supplied, or can supply himself with expert investigators and advisers on every subject, who will be able to apply themselves continuously to the work. Congress can give these expert advisers power to compel the giving of testimony, and to make personal investigations in any part of the world and may require them to preserve the records of their investigations. The very functions which the Congress is least qualified to perform 


\section{The Administration of Dependencies}

in the administration of dependencies, the President, assisted by expert investigators and advisers, is able perfectly to perform.

It seems, therefore, to be indicated from the very nature of things that the habitual and daily administration of the dependencies of the American Union should be in the charge of the President, assisted by expert in vestigators and advisers, and that the superintendence and final control of the administration should rest with the Congress, subject only to the final judgment of the whole people of the American Union, expressed at the polls.

If the subject is examined from the standpoint of expediency, the same result is reached,-that the habitual and daily administration of the dependencies should be in the charge of the President, and that the Congress should exercise the power of superintendence. Since the administration of dependencies is, in the last analysis, nothing more or less than the performance of a trust which the American Union and its people are under obligation both to adjudicate and to execute, the general principles which are applicable to the administration of private trusts must be also applicable in this case. Experience teaches that there are three conditions which are likely to lead to the maladministration of trustsdivision of responsibility between the trustees, a failure to require records to be kept of all action under the trust, and a failure to make provision for coherency and continuity of administration.

There is a division of responsibility when any one of several trustees is authorized to act, and it is left uncertain whether or not his action binds the others, or when a trustee acts without certainly binding his successors. If Congress were to attempt to habitually and continuously administer the dependencies, there would certainly be a division of responsibility among the trustees of the 
national trust. As one party succeeded another and one Congress succeeded another, each would disclaim responsibility for the actions of its predecessor. A political party has no definite corporate form, and it is hence extremely difficult to fix the responsibility for a party measure. When a party goes before the people in a popular election, the issues which immediately affect the welfare of the American Union are likely to be controlling and the issues affecting the dependencies only subsidiary. The habitual and constant administration of the dependencies by the President concentrates the responsibility for every act, in the first instance, upon him. All persons or communities claiming to have been injured in the administration of the trust know exactly to whom to apply for redress. If Congress were to act as a superintending body to supervise and control the action of the President, this would not operate to divide the responsibility in the sense in which that expression is used. If it is agreed by all parties concerned that one trustee shall act habitually and constantly and the other superintend and control his action, there is no division of responsibility. The trustee who acts habitually and constantly is subject to have his acts nullified by his co-trustee; but if the co-trustee fails to nullify them within a reasonable time, he ratifies them, and both become jointly responsible. The method of dividing the functions of the trusteeship between an acting trustee and a superintending trustee is one frequently adopted for the very purpose of more firmly fixing the responsibility for action. A superintending trustee who should not nullify an act done by the acting trustee which was in violation of the trust would be held as strictly, if not more strictly, responsible than if he had investigated the act of his cotrustee and had approved it. The requirement of good administration of trusts that there should be no division of responsibility is, therefore, complied with if the Presi- 


\section{The Administration of Dependencies}

dent is recognized as the habitual and constant administrator and Congress the superintending administrator.

If Congress were to be regarded as the habitual and constant administrator of the dependencies, there would be no possibility of keeping accurate records concerning the performance of the trust which would be in such shape that they could be easily referred to and understood. It is quite possible for a trustee to maladminister a trust who allows every one to be familiar with all his acts of trusteeship as they occur. If he keeps no records, he is almost certain to maladminister the trust, however good his intentions. The action of Congressional committees, though open to the public, is rarely digested and recorded so as to be convenient for future reference, and, in the multitude of affairs and the haste with which they must be disposed of, it is impossible to keep careful and systematic records. On the other hand, systematic records of the action of the President in the habitual administration of dependencies could be kept, and thus every act of importance exposed not only to the public criticism of the moment, but to the public criticism of the future. Nothing tends to good administration equally with the necessity of making an immediate record of every act as it occurs, for public inspection and criticism.

The requirement of coherency and continuity of administration can, it would seem, never be attained, should Congress undertake the habitual and constant administration of the dependencies. As the exponent of party government, its policy must inevitably change with the change of parties. Proceeding, as it inevitably must, without adequate record of past action and without the opportunity for the patient and slow investigation of complicated facts, each act will stand separate and apart from all previous acts, and will represent only the result of the combined common sense of the particular Con- 


\section{Imperial Obligations}

gress, applied to such facts as it may happen to have before it. On the other hand, it is possible to establish an advisory tribunal to assist the President in his habitual and constant administration of the dependencies, which shall be entirely free from the control of party government and which shall act only after careful investigation of all the facts and keep a record of its investigations and conclusions which can be readily referred to at any time in the future. If coherency and continuity of administration are essential to good administration of dependencies, it seems obvious that the habitual and constant administration of them should be vested in the President.

On this subject, perhaps no one is better qualified to speak than M. Paul Leroy-Beaulieu, the great traveller and student of colonial economic and political problems. $\mathrm{He}$ regards this feature of the administration of dependencies as the most important of all. The final words of his great work, De la Colonisation chez les Peuples Modernes, of which the fourth edition was published in I89r, are these :

It is necessary to bring to this work of the State a great store of reflection and intelligence, much moderation, a profound sentiment of justice, and above all a high regard for coherency and continuity in the administration (et surtout beaucoup $d^{\prime}$ 'esprit de suite). It is a part of the duty of the State to set itself the task of establishing its political direction and control in such manner as to interfere as little as possible with native populations, in such manner as to change them gradually, in such manner that their rights will be respected and wars with them will be avoided.

The relation of the Imperial State to its dependencies is, however, as has been shown, not a mere relationship of trusteeship. It is at the same time a trustee, and the Chancellor which finally adjudicates the terms of the trust. It needs no argument to show that a great body 


\section{The Administration of Dependencies}

of elected representatives is incapable, in the very nature of things, of adjudicating the terms of a private trust which is left indistinct and indefinite as respects the means and instrumentalities which the trustee is to use and even in respect to the end and purpose of the whole trust. It is equally incapable, in the nature of things, of adjudicating the terms of a public trust of this kind. It is one thing, however, to adjudicate the terms of such a trust, and quitc another and different thing to revise, occasionally, the adjudications made concerning the terms of the trust, by some other tribunal. One may successfully superintend a work who has not the technical knowledge sufficient to enable him to solve the habitual and constant problems which are arising in the execution of the work. Moreover, many of the great problems arising in the administration of dependencies are incapable of any solution which can be absolutely said to be correct, and such problems have to be solved according to the educated public sentiment of the whole people of the American Union, with respect to which Congress is peculiarly qualified to speak.

From whatever standpoint, therefore, the matter is viewed, it seems to be logically indicated that the President should be the representative of the American Union in the habitual and constant performance of its Imperial obligations, and that the Congress should represent the Union in the performance of these same obligations as the superintendent of the President. Such an arrangement has no tendency whatever toward monarchy, hereditary or temporary. All power in the Empire is recognized as emanating from all the people of the Empire, who have selected a part of themselves to form an Imperial State which is the Disposer of the affairs of the Empire, and who have divided all governmental power in the Empire between the Imperial State and the remainder of the people of the Empire recognized as States 
formed according to natural circumstances and conditions. All power exercised by the American Union, when acting as the Imperial State, is regarded as emanating directly from all the people of the Union, and indirectly from all the people of the Empire. The President acts primarily as the representative of all the people of the Union and secondarily as the representative of all the people of the Empire. Because the trust which he performs is one requiring continuity and coherency of action, it does not follow that the person who occupies the office of President may not be changed as often as the people see fit. It is only necessary that the President's advisory body, which has the active charge of the administration in behalf of the President, should not change with the President.

If it be the fact, as it seems to be, that the tendency in all States which are engaged to-day in the administration of dependencies is toward placing the immediate and daily charge of them in the hands of the Chief Executive of the Imperial State, this action is due to the fact that the enormous trust undertaken can, according to the enlightened opinion in those States, based on experience, be performed only in this manner.

If it be granted that the trust, in order to be well performed, must be placed in the immediate and direct charge of the President, subject to the supervision and control of Congress, the question of the administration of dependencies becomes simply one of securing an expert administration by the President; and as the President must necessarily act through subordinate advisers and officials, the question becomes one of securing expert official action and expert advice.

In ascertaining the character of the public office which ought to have charge of the administration of the dependencies, it is necessary, of course, to consider the nature of the duties performed by this office. At the present 


\section{The Administration of Dependencies}

time, it is recognized that all the duties of the public offices of the American Government having charge of the administration of affairs in time of peace are divided between various Cabinet officers, all of whom may be classified as falling into two great Departments - the Department for Home Affairs and the Department for Foreign Affairs. The duties of an office which should be charged with the administration of dependencies would be entirely different from the duties of either the Home Office or the Foreign Office. The Home Office is concerned with carrying out the commands of the Constitution and the Congress relating to home affairs, and the Foreign Office in making treaties and contracts with foreign States. The Office having charge of the administration of the dependencies - the Imperial Office -would have the function of executing the trust assumed by the American Union towards distinct external States standing in a permanent and constitutional relationship toward the Union. The function of the Imperial Office - the Department for Imperial Affairs-would therefore be entirely different from the function of either of the other great Departments. The Imperial Department, therefore, should be entirely distinct from all other Departments.

Considering the nature of the duties of the Office-the performance of a trust-it would seem that it should be vested in a single Secretary of State rather than in a Secretarial Board, though this would be a matter to be determined by expediency as experience would dictate.

The Secretary of State for Imperial Affairs would, of course, be the President's representative, and the advisory Council would, of course, be attached to the Imperial Office; and the Imperial Secretary would act, or would advise the President or the Congress regarding action, only after consultation with the Imperial Council, in the same way as the Secretary of State for India in Great 
Britain acts only after advising with the Council for India, the Minister for the Colonies in France after advising with the Conseil Supérieur des Colonies, and the Imperial Chancellor, in Germany, acting as Minister for Foreign Affairs and $e x$ officio as Minister for the Colonies, after advising with the Kolonialrath.

How such an Imperial Council should be composed, what should be the term of office of its members, whether it should be so constituted that its membership should be changed gradually, and other questions of like nature, are matters of expediency which are beyond the scope of this work. The general principles upon which the Council should be constituted are, it would seem, first, that it should always contain persons expert in the general art of government, persons expert in the science of the administration of dependencies and persons actually familiar with local circumstances and conditions in the dependencies, and second, that it should be so constituted as to be removed as far as possible from the influence of party politics.

The placing of the immediate and daily charge of the administration of the affairs of the dependencies in the hands of the President advised by a Council of experts would still leave a most important field of operation for the Congress. It would not only superintend and control the action of the President, but would determine for the Union and for the Empire all the great questions of national and Imperial policy and would give the final ratification to those great Imperial dispositions or settlements, by which the forms of government in the dependencies are established or amended, and by which the dependencies are federated or united as their local interests may dictate. Whenever it acted, it would be the responsible representative of the American Union and the Supreme Disposer of the Empire. It would finally adjudicate and execute the Constitution 


\section{The Administration of Dependencies}

of the Empire, either affirming or disaffirming, in whole or in part, the decrees of the President. It would have the advantage of having had the whole subject carefully gone over by the President and his expert advisers, and could obtain from them the facts within their knowledge and have the benefit of their advice, in the same way that a Supreme Court of Appeals has the benefit of the finding of facts, the opinion and the judgment of the court below.

The Congress, taking up occasionally, and under such circumstances, matters of importance arising in the administration of dependencies, would undoubtedly be able to make as wise a disposition of them as any body of men. Questions so presented to Congress would be presented in such a way that party politics would have the least possible effect upon their decision. A decision by Congress under such circumstances, even though adverse to that of the President, would not necessarily tend to weaken the authority of the American Union or the authority of the President in the dependencies.

As the trust assumed by the American Union towards its dependencies includes the duty to recognize their statehood to the utmost extent possible, it necessarily follows that all Local Governments of the dependencies, except so far as they are elected by the people of the dependencies, are to be regarded as Substituted Governments or Trustee Governments. All the officials in the dependencies appointed by the American Union are responsible to the people of the dependency as cestuis que trustent, and to the American Union as the Disposer and Chancellor of the Empire. All the acts of the Local Government are to be done for the benefit of the people of the dependency. A Local Government substituted for a Local Government emanating from the people of the dependency stands exactly in the position of a conservator of a private individual. It is no more the duty of such 
a Substituted and Trustee Government to act for the benefit of the American Union than it would be for a conservator to act for the benefit of the Chancellor before whom he must render an account. Collusion between the American Union and such a Substituted and Trustee Government to obtain any part of the property of the people of the dependency would be equally as immoral and culpable as collusion between the Chancellor and the conservator of a private individual to procure for the Chancellor a part of the property of the individual under guardianship.

In the Federal Empire, the Governor of a dependency, alone in the Local Government, exercises inconsistent functions. $\mathrm{He}$ is at once responsible to the people of the dependency, and the Vice-Disposer and Vice-Chancellor representing the American Union. This, however, is nothing novel, as the Chief Executive must, in every State, exercise inconsistent functions and harmonize them all toward a common end.

The form of government in dependent States of a Federal Empire may be republican, monarchical, or oligarchical. In such case, the function ordinarily ex. ercised by the Governor of a dependency would be divided between two personalities. The local elective Governor or the local monarch or the local oligarchy would exercise the powers of the local Chief Executive, and an Imperial Governor would guard the Imperial interests.

While the system of administering the dependencies through the President advised by an Imperial Council, under the supervision and control of Congress, is obviously applicable to the administration of the Territories of the United States (by "Territories" meaning the adjacent dependencies on the North American Continent destined by nature for incorporation into the American Union), there are many reasons of expediency for not 


\section{The Administration of Dependencies}

applying it. Congressional government of the Territories, to the exclusion of administration by the President, has been a fact for nearly a century. The Territories have been treated as outlying municipalities of the Union under a régime of assimilation to the utmost extent possible, and have accepted this régime because it was accompanied by the promise of memberstatehood in the Union. Congressional government has, however, consisted in establishing a form of gov. ernment under an express or implied promise of ultimate statehood in the Union and then allowing the Territory to grow up substantially in its own way and according to its own will. Under the circumstances, this policy has perhaps worked as well as any, but the fact that it has worked well would seem to be due to the circumstances, rather than to any virtue in the plan itself. The problem of administering the Territories of the United States, until the acquisition of Alaska in 1867 , was presented in the very simplest form in which a problem in the administration of dependencies could possibly arise. A marvellously rich country lying on the frontier of the Union, unoccupied except by wandering tribes (which have very properly been restricted within certain territorial limits under their tribal governments until such time as they shall be suited for incorporation into the population of a State of the Union) was colonized without difficulty by the population of the Union. Nothing was required of the Union except to fix the boundaries of new States and to prescribe the forms of government adapted to the population of the Territory as it should gradually grow towards statehood in the Union. The principal thing to be done was to incorporate these continental Territories into the American Imperial Tariff-Union, and to compel them otherwise to contribute equally to the common defence and welfare by taxation, which, on account of the peculiar circum- 
stances, it was right and proper to make uniform with similar taxation in the States of the Union. These Territories, being not only under promise of statehood, but under compulsion to become States of the Union whenever the Union saw fit, could properly be treated, in return for this privilege and in consideration of this necessity, as being under the sole control of Congress, even though this resulted in their being taxed according to the mere will of a legislative body in which they were not represented.

Where statehood in the Union for a dependency is doubtful, or where such statehood is certain to be denied and must be denied, in the nature of things, out of mere justice to the dependency, Congressional administration of the dependency loses its sole justification. To ascertain the duty of the American Union towards such a dependency, it is necessary to put ourselves in the place of the dependency by studying the actions and thoughts of our Revolutionary ancestors when they were inhabitants of dependencies of the State of Great Britain, and to supplement this study by an examination of the theory. and practice of those who have had to meet similar problems.

All the insular dependencies of the Union and Alaska are probably destined never to be incorporated into the Union as States, because it is best for them and for the Union that they should permanently remain in a relationship of dependence on the Union. In the latter relationship, they can properly have a higher degree of statehood than in the former. Under a well-balanced and expert administration by the American Union, as their Imperial State, they can have that distinct community life which their isolated position makes necessary. With respect to them, an Imperial Department of the Government of the Union, and an Imperial Council, so arranged as to form and maintain a proper balance $3^{8}$ 


\section{The Administration of Dependencies}

between the interests of all parts of the American Empire and to skilfully adjust the constantly changing relations, is, according to American traditions, a necessity. With respect to them, the work of administration must be done by the President and his advisers, as the expert part of the Government of the American Union, under the superintendence of Congress.

It must be expected that the inhabitants of these dependencies will, if Congressional government is pushed too far, follow the precedent established by the American Colonies in the time of the American Revolution and insist that they are States naturally free and equal with other States, that they are in a federal union with the American Union, that Congress is not their Supreme Legislature, and that their connection with the Union is through the President. It will apparently be the part of wisdom for the American Union to forestall such a state of things by adopting the theory of Dickinson and Lord Chatham and recognizing the President, advised by a Secretary of State for Imperial Affairs and an Imperial Council composed of statesmen and men familiar with colonial affairs, as the habitual and constant administrator of the dependencies, and the Congress as the "august body" or great Interstate Tribunal of the Empire to which the insular and remote dependencies may look for a general superintendence of the affairs of the American Empire.

The District of Columbia, as has been already noticed, stands in an entirely different relation to the Union from any other dependency. By the express provision of the Constitution, the power of the Union over the District is declared to be a power "to exercise exclusive legislation in all cases whatsoever"- that is, to exercise the power of legislation, subject to the restrictions of the Constitution of the United States, to the exclusion of any other Government whatever. The Union, 
therefore, exercises over the District exactly the power which the State of Great Britain, in the Act of $17 \overline{6} 6$, claimed to have the right to exercise over the American Colonies, subject to the restrictions of the Constitution. The District of Columbia, therefore, has no inherent right of statehood, and not even an inherent right of local self-government. Though the inhabitants are protected in their individual rights by the Bill of Rights in the Constitution, their political rights are only such as the Congress may see fit to bestow upon them.

It does not follow, however, that the Congress has the moral right to assubjectize the inhabitants of the District to its own mere will, as respects their political status. They are entitled morally to all political rights not inconsistent with the welfare of the Union. The object of the framers of the Constitution, as the debates in the Continental Congress during the years 1783 and 1784 , and in the Constitutional Convention show, was to prevent the action of Congress from being confused with or influenced by the politics of any city or State in the Union. The politics the effect of which was thus guarded against were the politics arising from local elections of the legislative and executive officers by popular vote, which involved party government and intense partisan feeling. The inhabitants are morally entitled to as much control over the local affairs of the District as it is possible for them to have without popular elections. The only alternative which can justly be applied when popular government is impossible is, as has been seen, expert government. The present form of government, according to which Congress, advised by its Committee for the District of Columbia, composed of members of both the Senate and the House, acts as the Legislature of the District, and by which three commissioners act as the Executive, is a vast improvement over all previous forms of government, according to which the lands and inhabitants of the District 


\section{The Administration of Dependencies}

were first divided into municipalities with elective Governments, and afterwards were made a Territory with an appointed Governor and Council and an elected House of Representatives. Any change in the present arrangements will doubtless not be in the direction of making the Government in any respect elective, but in the direction of recognizing that the habitual and constant charge of the District ought to be in the hands of the President, acting through a Cabinet officer, to whom the present Board of Commissioners shall be an Executive Council, and to whose office there shall be attached a Legislative Council, composed in part of members of the Senate and House, appointed by Congress, and in part of inhabitants of the District appointed by the President, which shall have the power of local legislation for the District, subject to the negative of the Secretary or the President, and subject at all times to the superintending power and supreme legislative authority of Congress.

In what has been said will be found the answer to the question, How, under an unwritten Constitution of the Federal Empire, can the private rights of the inhabitants of the dependencies be protected against the exercise of the Imperial power? As the Imperial power in the Federal Empire is itself essentially a power of adjudication and not a power of legislation, every act implies an adjudication in which private rights are considered and respected. In making such adjudications every provision of the Constitution of the United States which protects private rights is regarded as literally in force in the dependencies when the local circumstances and conditions of the American Union and the dependency in question are the same as respects the matter under consideration, and as in force to the utmost extent practicable under all circumstances and conditions.

But if this is regarded as an insufficient protection of private rights, it is possible to institute a Council of 
Revision for all action of the President or the Secretary for Imperial Affairs in Council, or of Governors of dependencies in Council, which is claimed to violate private rights. Such a Council of Revision ought, of course, to be in possession of all the facts on which the Imperial Council acts, and therefore its members ought to be also members (and the most learned and judicious members) of the Imperial Council-in a word, the Council of Revision to hear private causes arising under the Constitution of the Empire ought to be a Judicial Committee of the Imperial Council.

If the effect of the provision of the Constitution relating to the administration of dependencies is, as it seems to be, to give the Supreme Court jurisdiction of causes arising under the unwritten Constitution of the Empire, because such causes are at the same time causes arising under the Constitution of the United States-the Government of the American Union being responsible both to the people of the American Union and the people of the American Empire to "dispose of and make all needful rules and regulations respecting" the dependenciesan appeal would lie, as, of course, in private causes, from the Judicial Committee of the Imperial Council to the Supreme Court of the United States. As the jurisdiction of all the Courts of the United States except the Supreme Court, in cases arising under the Constitution of the United States, exists at the will of Congress, all jurisdiction of cases arising both under the Constitution of the United States and the Constitution of the Empire should, it would seem, be denied to all the inferior courts of the United States, so that all private causes arising under the Constitution of the Empire may be decided by Imperial Councils, subject only to the revisory power of the Supreme Court of the United States.

The two other questions of the administration of dependencies which are particularly under discussion at the 


\section{The Administration of Dependencies}

present time are concerning the extent to which a depend. ency may be recognized as isolated from the Imperial State, and concerning the method by which the dependencies may justly share with the Imperial State the expense necessary for the Imperial defence and welfare.

Applying, in the attempt to answer these questions, the principles of the Federal Empire, it would appear certain that, in making disposition of the dependencies, the Imperial State may recognize them as isolated from itself to such extent as it may think necessary, considering all the conditions and circumstances. The relationship in the Federal Empire is primarily a relationship between States-not between a Government and individuals; and the fact that a State is a component part of an Empire does not necessarily imply that it must have free trade and intercourse with every other part of the Empire. If a State is admitted into a Federal State, and participates in the election of its Central Government, it does so at the expense of subjecting itself to free trade and intercourse with every other State composing the Federal State. The Member-States of a Federal Empire can properly be recognized as having a much higher degree of statehood than the Member-States of a Federal State, and therefore a State may often prefer to be related to an Imperial State as its dependency rather than to become a Member-State of a Federal State. It results from this that the Imperial State can, by its disposition, give any of its dependencies a special tariff or allow them to make their own tariff, or can enter into a Tariff-Union with them on any terms, and therefore on the terms that trade and intercourse within the TariffUnion shall be free and that the States within the TariffUnion shall exact the same tariff from all the rest of the world. As guardian and conservator, it can allow its ward to do business for itself, or can take it into partnership, according as it may be for the best interests of both. 
Presumptively it would seem that a dependency in a Federal Empire is entitled, as a necessary incident of its member-statehood in the Empire, to its own tariff, which it ought, however, to modify in the interests of its related States, so far as practicable.

Applying the principles of the Federal Empire to the solution of the question concerning the contributions of the different parts of the Empire to the Imperial defence and welfare, many of the difficulties surrounding this question as it has been heretofore discussed, disappear. The Imperial State in the Federal Empire renders services for the dependencies which are not only difficult and dangerous in themselves, but which are necessary for the peace and welfare of the whole community and involve a continuous and immediate outlay of money for the benefit of the dependencies. With the economic aspect of the question, this work is not concerned. Economic benefits, if they accrue at all from the possession of colonies, accrue to individuals, and the benefit to the Imperial State is only indirect. Putting aside, therefore, all question of economic benefits, the question arises, how shall the services of the Imperial State in giving the dependent States physical protection against external interference, in providing them with honest and stable Governments when they are unable to provide themselves with such Governments, and in equalizing commercial conditions between the different parts of the Empire and between the Empire and foreign nations, be compensated?

The American Union is not bound by tradition or otherwise to the proposition that it cannot adjudicate the proportional contributions which the different parts of the American Empire shall make to its support, or to the proposition that it cannot enforce such adjudications by process of execution. It is simply committed to the proposition that it cannot tax dependencies by the action of its own legislative body, acting according to its mere will. 


\section{The Administration of Dependencies}

If, therefore, the American Union accepts the theory for which the American Colonies fought in the Revolution, and admits its power over the dependencies to be only a power of disposition, it may adjudicate the contributions of the different parts of the Empire along with all other matters of Imperial administration, and should it ever become necessary to enforce the payment of such just and reasonable contributions from any part of the Empire, the American Union would be not only justified, but morally obligated to enforce such contribution.

It is undoubtedly true that in making such adjudications, the American Union would be, as Burke said, "a judge in its own cause." It would, however, be a judge in its own cause from the necessity of the case. That it should judge in such a case, therefore, could not be charged to it as a wrong act. Where one is obliged to judge in his own cause, such obligation increases enormously the moral responsibility. It necessitates the reduction of every question which must be so decided to a cold, dry, and scientific basis to the very utmost extent possible. If all questions arising in the administration of the dependencies are in fact decided on such a basis, there is no reason in principle or in tradition why any question should be excepted from the power of the American Union to decide.

The Imperial obligation does not rest upon the President and Congress alone. The ultimate responsibility for the proper execution of the trust is upon the people of the American Union, and means must be provided for educating the public sentiment so that the people of the American Union may be in a position to superintend both the President and the Congress. They must establish institutions for the training of youth in the science of the administration of dependencies, for promoting the interchange of ideas between experts and disseminating these ideas, and for educating public sentiment on this 
subject by object-lessons, through expositions and $\mathrm{mu}$ seums. Perhaps the most important part of the Imperial obligations is that the people should provide for the education of picked men to carry out the details of the trust. Instrumentalities of government, however well arranged, will not alone accomplish a good administration of the dependencies. A good administration of the trust can only be given by experts, and these the people of the American Union must continuously furnish from their midst.

Undoubtedly the performance of Imperial obligations entails a constant effort by the American people. Realizing this, many persons are asking the question, Why should the people of the American Union undertake Imperial obligations? They object that the exercise of the Imperial power, under this conception of the Imperial obligations, is not necessarily profitable from a pecuniary standpoint. This objection is undeniably well taken. The idea of the Imperial power as a power to perform services for other States is wholly inconsistent with the idea of monopoly or exploitation, as Mr. Spencer Wilkinson has well pointed out, in the passage above quoted. It implies opening new markets, not for the Imperial State, but for all the world. To the "merchants" who, to quote Lord Bacon, "look ever to the present gain," it is better to let some other State exercise such Imperial power and for America to take the benefit of the work. But to those who do not "look ever to the present gain" and whose eyes are set on a goal farther off and higher up, there appears to be both a moral compulsion which compels the American Union to perform such obligations when they come upon them in the ordinary course of events, and a pleasure in performing them well. The State which shirks obligations because they are difficult or dangerous pays the penalty of the individual who shirks such obligations $\rightarrow$ it sinks into insignificance. 


\section{The Administration of Dependencies}

But, these considerations aside, there seems to be no alternative. Imperial obligations impose themselves in the very process of community life. The Federal Empire is the outgrowth of democratic and republican principles. The Imperial State recognizes itself as under a trusteeship toward every part of the whole Empire, and hence as the delegate and representative of the dependencies, as political persons or States. Where Imperial States base their actions upon these principles, dependencies which are abundantly strong enough to become independent prefer not to do so, and weak dependencies regard the relationship as one in which they can take pride and satisfaction. Such a consent is equivalent to an election of the Imperial State, by the dependencies, to be their Central Government. Thus the republican principle of representation - that all governors, whether persons or States, are the agents or trustees of the governed -is preserved. The democratic principle is preserved because the whole conception of a State acting through its representative Government as the Central Government of its related political communities is impossible unless the Imperial State is founded on democratic principles; and because all power of the Imperial State is regarded as emanating from a grant made by all the people of the Empire.

The Federal Empire has arisen out of the need for social and economic peace and for equalization of economic conditions, exactly as Confederations and Federal States arose. It is the only form of organism by which the federative principle can be extended beyond the limits of lands occupied by a homogeneous population capable of self-government. Government of widely extended and scattered lands and populations through representative institutions is not to be the ultimate substitute for the administration of dependencies by Imperial States. On the contrary, administration of dependencies by Im- 
perial States is the final and permanent substitute for representative Government, wherever Government must, in the nature of things, extend itself beyond the limits of lands occupied by a homogeneous population capable of self-government.

The Federal Empire is, therefore, not a temporary phenomenon destined to disappear; nor is it a mere incomplete form of a political organism hereafter to disclose itself in a complete form. It is a naturally evolved, permanent, and complete form of political organism, and, if it fails to preserve this form, and divides itself into its constituent parts, this is not the result of the law of progress, but a disintegration due to ignorance and incapacity on the part of the people and the Government of the Imperial State.

A State can have no higher ideal than to perform well its obligations as the Imperial State of a Federal Empire. To be at once both a Judge and a Ruler is to occupy the most exalted position conceivable, and, in its possibilities of territorial extent, the Federal Empire has no limits. The Imperial State in such an Empire may judge and control and equalize between States the most remote possible from each other and the most diverse possible in their languages, traditions, and interests. Its action, always intelligent and judicious, and never going beyond the necessity of each case, is inevitably beneficial and makes for peace and for that better understanding between men under all circumstances and conditions which is the basis of good-will.

That America can temporarily perform the functions of an Imperial State toward a dependent State has been shown in the case of Cuba. It is now necessary to prove that that can be done habitually and constantly which has been so successfully done temporarily and as a matter of emergency. That America will do so there can be no doubt; but it will be done only by hard thinking 
604 The Administration of Dependencies

and hard work. It will not be done by despising the experience of other nations, but by studying it and daring to follow their example where they have succeeded in improving and elevating the peoples whose affairs they have administered. It will not be done by those who blindly worship the Constitution of the United States, but by those who, with the principles of that Constitution as their foundation and their hope, shall apply themselves to the task of patiently evolving the unwritten Constitution of the American Federal Empire. 


\section{INDEX}

\section{A}

Act of Parliament, of 1750 , prohibiting iron mills in American Colonies, I33; of $\mathrm{I} 75 \mathrm{I}$, regulating issue of bills of credit in American Colonies, 133 ; of 1767 , suspending New York Assembly, I79; of I767, imposing tariff on paints, etc., 179 , I 80 ; of 1767 , establishing Commissioners of Customs in American Colonies, I8o ; of I772, for trying in England persons charged with crime in America, 253 ; of 1773 , regulating issue of bills of credit in American Colonies, 253 ; of 1774 , for closing the port of Boston, 259; of 1774 , for regulating government of Quebec, 259

Adams, John, his anti-Imperialist views expressed in the pamphlet, Novanglus and Massachusettensis, 280, 28I

Address to the House of Commons, of 1765 , quotation from, I67, I68

Address to the King, of 1765 , quotation from, I66, I67; of I774, quotation from, 288, 289; of 1775 , quoted and discussed, 325, 326, 329-33I

Address to the People of Canada, of I774, its purpose and effect, 364, 365

Address to the People of Great Britain, of 1774 , quotation from, 288 ; of 1775 , quoted and discussed, 326, 332

Administration of dependencies, theory of, governed by view held concerning their statehood, $8,{ }^{\circ} 9$

Admiralty, Courts of, in American Colonies, r46-r 48

Admission to the American Union, meaning of, 363
Agents for the Colonies, institution and functions of, 89

Alaska, administration of, 573

Albany Congress, of 1754 , suggests American sub-Empire, I35

Albany Plan of Union, of 1754 , provisions respecting dependencies in, I35-I4I

Algeria, in charge of French Minister for the Interior, 480 ; represented in French Parliament, 487; modern views of French policy respecting, 489

All needful rules and regulations, meaning of, in U.S. Constitution, 462

Alsace-Lorraine, character of Germany's problem respecting, 489, 490 ; administration of, by Germany, 49I-493

American dependencies, administration of, 537-577; status of the Local Legislatures and Courts, 550-553; division of administration between Executive Departments, 576, 577; power of American Union to isolate, 597, 598 ; and to adjudicate contributions to the Imperial defence, 599, 600

American Empire, planned by Franklin, 35I; declared by French Treaties of 1778 , 374399 ; recognized by U. S. Constitution, 445-473

American Indians, see Indian Tribes.

American insular dependencies, Presidential administration, under supervision of Congress, necessary, 593, 594

American Insurance Company v. Canter (I Peters, 449), decision of Supreme Court concerning status of Colonial Judiciary, 550, $55 \mathrm{I}$ 
Andros, Sir Edmund, acts of, as Governor-General of New England, 84

Annual Register, of 1763 , quotation from, 143

Anti-Imperialist Party, positions taken by, in Continental Congress, $280,281,290,320-334$; position taken by, regarding Resolution of I784, in Congress of the Confederation, 426

Articles of Confederation, provisions of Franklin's draft of, relating to the Empire, 350, 35I ; of Dickinson's draft, 352 ; reasons for omitting provisions relating to the Empire in, 367-369

Assimilation, policy of, for dependencies, meaning of, in French politics, 483 ; régime of, insisted upon by dissenting Judges in Insular Tariff Cases, 57 I, 572

d'Avenel, Vicomte, quot a t i o n s from: his book, Richelieu et la Monarchie Absolue, II-I3

$\mathrm{B}$

Bacon, Sir Francis, leader in argument in Case of the Postnati, 34 ; assists in procuring Virginia Charter of I606, 36; (Lord Bacon), quotations from his Essay on Plantations, 63, 64, 92

Bancroft, George, quotation from his History of the United States, 400, 401

Belonging to, as meaning "dependent upon," in British-American public law, IIo; in U. S. Constitution, $458,4.59$

Benton, Thomas H., quotation from his Historical and Legal Examination of the Dred Scott Case, 553, 554

Bermuda, Island of, Franklin proposes admission into American Unicn, $35 \mathrm{I}$

Bernard, Sir Francis, quotation from his Select Letters on the Trade and Government of America, 169-r 73, 267, 268

Blachford, Lord, in 1885 regarded British Empire as temporary, 519

Blackstone, Sir William, regarded American Colonies as conquests, 297
Bluntschli, Dr. J. G., in I850 distinguished the Federal Empire from the Federal State, 490

Board of Commissioners for Trade and Plantations, as Under-Secretary of State for Imperial Affairs, $85-88,215,216$; office abolished in 1780,498

Boston Port Bill a war measure, 259

Boulanger, M., statement concerning administration of French dependencies, $48 \mathrm{r}, 482$

Brassey, Lord, views of, concerning an Imperial Council, 527

British Empire, administration of, 49-I5I, I9I-26o, 498-536; the Stamp Act a denial of, I49; conception of, as a permanent organism, 505, 506; essentially a federal organism, 536

British Peace Commissioners of I778, proposals of, $384-387$

British Peace Overtures of 1778 , character of, and causes of rejection of, $377-387$

Burke, Edmund, quotation from his speech on American taxation, 268, 269 ; his resolutions for conciliation, 3II; quotation from his speech on his resolutions for conciliation, 3II-3I3; his views concerning the Imperial power, 313315,338 ; his second conciliatory resolutions, 335 ; in 1780 secures abolition of Imperial Secretariat, $49^{8}$

Burnet, History of his Own Times quoted, 86

\section{C}

Cabinet, (British), distinguished from Privy Council, I28, I29

Calhoun, John C., his theory concerning relationship of the Territories to the American Union, 553,554

Calvin's Case, principles concerning dependencies decided in, 32-35

Camden, Lord, his views concerning taxation, I75

Campbell v. Hall, case of, discussed, 294-297

Canada, Franklin's and Dickinson's proposals to admit into American 


\section{Index}

Canada-Continued

Union, 35I, 352, 356, 363-366 ; declines overtures of American Union for reception into Union, 364,365 ; Articles of Confederation relating to admission of, to Union, 372 ; divided into two Provinces, I79I, 50I ; crisis in, I $835-1840,501,502$

Carolina, characteristics of Charter of $1584,30,31$; of Charter of 1665,83

Case of the Postnati, principles concerning dependencies decided in, 3 I -35

Chamberlain, Hon. Joseph, views of, concerning an Imperial Council, 527,528 ; concerning Imperial power and obligation, 536

Channel Islands, administration of, in 1606,49

Charles I., grants Massachusetts Bay Charter of $I 629,66$; grants Maryland Charter of 1632,66 ; grants Province of Maine, I639, 67, 68; appoints Imperial Council of 1634 , 66

Charles II., appoints Council for Foreign Plantations in 1660 as Imperial Council, 79; in 1672, abolishes this Council and appoints Council for Trade and Plantations as Imperial UnderCouncil, 83, 84

Charter of Compact, meaning of, in Resolution of $1784,422,423$

Chatham, Lord, quotation of his Bill for settlement between Great Britain and the American Colonies, 299-304; his speeches in support of his Bill, 304-306, 308; his speech opposing American independence in $1778,383,384$. See also William Pitt.

Chesney, Sir George, quotation from his Indion Polity, 5I I-5 I4

Citizens of the United States, inhabitants of Northwest Territory not, 435,436 ; inhabitants of American dependencies not, 566, 567

Colomb, Sir John, quotation from his Survey of Existing Conditions, 532,533

Colonial Agents, institution and functions of, 89

Colonial Committee, of French Gen- eral Assembly, prepares plan of Constitution for Colonies, 475

Colonial Council of France, first instituted by Napoleon I., 478; modern, its institution and functions, $48 \mathrm{O}, 48 \mathrm{I}$

Colonial Council of Germany, its institution and functions, 494

Colonial Legislation (British-American), form of enacting clause of, II 7, II 8

Colonial Pact, French theory of, I9-22

Colonies of the American Union, provided for in Franklin's draft of Articles of Confederation, 350, $35 \mathrm{I}$; provided for in Dickinson's draft of Articles of Confederation, 352 ; proposition of 1777 concerning their administration, 370, 37I : provided for in Articles of Confederation, 372; districts of Northwest Territory recognized as, 423

Colonization, by Lords Proprietors, 30 ; by guilds or privileged companies, 52-54

Colony, meaning of, 90-94: meaning of, in Articles of Confederation, 366

Commissioners for making peace with American Colonies in 1778 , their proposals, $384-387$

Commissioners for Trade and Plantations as Under-Secretariat of State for Imperial Affairs, 83, 84, 215,216

Committee of the Privy Councii for Plantation Affairs, as Secretariat of State, 218-220; revived in I784, 500 ; ceased to exist in 1800 , $5 \mathrm{OI}$; temporarily revived in I849, 506,507

Commonwealth Parliament, powers exercised by, respecting the Colonies, 68-79, II4

Conditional power, distinguished from limited power by the Continental Congress of $1778,39 \mathbf{I}-$ 396

Conditional subjection, inhabitants of American dependencies in relationship of, 395

Congress of the American Union, claims to be the successor of the King of Great Britain and Sovereign of Western region, 400-409 
Congress of the Confederation, power of, over the American dependencies, 378-444; power of, to negative colonial legislation, $438-440$

Congress of the United States, power of, respecting the dependencies, 453-473; objections to administration of dependencies by, $578-580$; as a superintending administrator of the dependencies, $58 \mathrm{I}-587$

Connecticut, Charter of 1662 granted, 82 ; Charter forfeited in I687, 84

Conseil Supérieur des Colonies, established in 1883 , remodelled in IS9o, 480, 48r

Consent of the governed, meaning of, in Declaration of Independence, 396-399

Constitution, British-American, of I 750, I 21-I27

Constitution of the British Empire, distinguished by Edmund Burke from British Constitution, 269; also by the Continental Cougress, 344,349

Constitution of the United States, proceedings of Convention for framing, 445-473; “ extended to " the Territories, I $850-1890$, 550 ; its effect in the dependencies, 552-555

Constitutional protectorate, meaning of, 353

Continental Congress, proceedings of, at session of $1774,280-293$; recognized by Lord Chatham's Bill, 30I ; issues and parties at its second session in $1775,318-$ 349 ; its views concerning the power of Parliament, 339, 340 ; it reasons for rejecting informal British peace overtures of $\mathbf{1 7 7 8}$, $38 \mathrm{r}, 382$; rejects proposals of British Commissioners, I 778, 384387

Council for Foreign Plantations (I660-I670), as the Imperial Council, instructions to, 79-82 ; instructions to, of 1670 , regarding Indian tribes, 83

Council for India, in Great Britain,

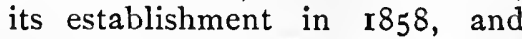
functions, $5 \mathrm{II}-5 \mathrm{I} 4$
Council for Trade and Plantations, of 1672 , as the Imperial UnderCouncil, 83,84

Council of Commerce, of 1650 , as the Imperial Under-Council, 75, 76 ; of I655, as the Imperial Under-Council, 77,78

Council of State, as the Imperial Council, I650-1658, 75-79

Countries subject to the jurisdiction of the United States, meritioned in Act of Congress of I804, 54I ; and in Thirteenth Amendment, 566,567

Courts of Admiralty in the American Colonies, $146-148$

Cromwell, Oliver, appoints Council of Commerce, as Imperial UnderCouncil, 77

Crown, power of the British, over the American Colonies, 244, 245, $264,265,273,277$

\section{D}

Declaration of Independence, principles of colonial relationship underlying, 34I-348; not inconsistent with an American Federal Empire, 396-399

Declaration of Rights and Grievances of 1774 quoted and discussed, 283-285

Declaration of War, between Great Britain and the American Colonies, in $1775,309,310$

Declaratory Act of 1766 , regarding the Imperial power of Great Britain, $176-179$

Delegate in Congress, Territorial, same as Colonial Agent, 422

Department for Imperial Affairs, in United States, proposed, 588

Department of Colonial Affairs (British), proposed in 1764,208 , 223 ; established 1768,498 ; abolished, I 782, 498 ; re-established, r854, 507

Dependencies, defined, 7 ; their characteristics as possessing political personality or not, $6-8$; with the Imperial State constitute an Empire, 8, 9; first use of the term, I08-I IO

Dependencies of the American Union, propositions of 1777 re- 


\section{Index}

Dependencies-Continued

lating to their administration, 370 , $37 \mathrm{I}$; planned to arise from conquest in 1776,374 ; referred to in French Treaties of $1778,374-$ 376

Dependencies of the United States, mentioned in Act of Congress of I 804, 54I

Dependent States, American Colonies so called by Sir Francis Bernard in 1768 , I 91

Dependent upon, this expression used in Act of October 3, 1650, 76

Dickinson, John, his pamphlet, The Late Regulations Respecting the British Colonies on the Continent of America, I57; quotation from $T$ he Farmer's Letters, I80-I89; his criticism of James Wilson's essay, 263 ; quotation from his New $E s$ say on the Constitutional Power of Great Britain over the Colonies in America, 273-277 ; his recognition of the Federal Empire, 279; elected to the Continental Congress and takes his seat, I774, 287 ; his draft of the Declaration on Taking up Arms, I775, 320322 ; provisions relating to the Empire in his draft of Articles of Confederation, 352

Dilke, Sir Charles, quotation from his Problems of Greater Britain, concerning an Imperial Council, 526

Dispose of, meaning of, in English public law, 44-46

Disposition, meaning of, in French public law, I3, I4; in English public law, 39-44; in British politics, 143 ; in British public law, 295; used to describe the Imperial power by the Continental Congress, 348; power of the American Union over its dependencies a power of, 359-362, 40I4I8, 458, 459; power of, includes plenary power of regulation, 419444 ; used by Jefferson as describing the Imperial power in 1787 , $43 \mathrm{I}, 432$; used to describe the Imperial power in United States Constitution, 458, 459 ; power of, does not include power of alienation, 470
District of Columbia, power of Congress over, under United States Constitution, 472 ; administration of, $594-596$

Districts in Western region both "States" and "Colonies," 423

Dominion, meaning of, IOO-IO3

Downes v. Bidzell (I82 U. S., 244), views of the Supreme Court concerning the Imperial power in, 562-570

Dred Scott Case, views of the Supreme Court concerning the Imperial power in, 556,557

Duke of York, patent of 1664 to, 83

Dulany, Daniel, quotation from his Considerations on the Propriety of Imposing Taxes on the British Colonies, I53, I54

Durham, Lord, quotation from his Report on the Affairs of British America (I839), 502, 503

\section{$\mathrm{E}$}

East India Company, reasons for sending tea-ships to America in I 773, 253-257

Eddy, Charles Walter, views of, concerning an Imperial Council, $521-523$

Egerton, Hugh E., quotations from his History of British Colonial Policy, 36, 505, 519, 520

Elgin, Lord, declares British Empire a permanent organism, I 850 , 506

Elizabeth, Queen of England, her policy respecting Parliament, 2628

Emperor of Germany, power of, respecting the dependencies, $49 \mathrm{I}$

Empire, definition of the modern, 8

Empire, the Federal, see Federal Empire.

Enacting clause, of colonial laws, I I , I I 8

English Empire, from I 200 to 1600 , 28

Expansion of the American Union, Franklin's views expressed in his draft of Articles of Confederation, 35 I

Expert government, defined, I ; implies conditional power, 2 ; may 
Expert government-Continued exist in any form of State, 2-4; no modern State wholly under, 4 ; distinguished from despotic or paternal government, $5 \mathrm{I} 7,5 \mathrm{I} 8$

Extension of the Constitution to the Territories, meaning of, 554

\section{F}

Farmer's Letters of John Dickinson, quoted from, their purport and effect, I80-IS9; criticised by William Knox, 229-237

Federal Empire, British Empire of I 750 a, I25; defined, 26I-279; principles of, announced by John Dickinson, I774, 279; the American ultimatum to Great Britain a demand for restoration of, 289 ; recognized by Lord Chatham, I 775, 308; theory of, stated by Gouverneur Morris in his Observations on the American Revolution, 39I-395 ; the modern British Empire essentially a, 536 ; an evolution and a permanent organism, 602,603

Federal-Imperialist Party, in the Continental Congress, 280, 28I ; views of, expressed by the form given American ultimatum, 290294 ; their position at the second session of the Continental Congress, 320-322 ; in the Congress of the Confederation, position of, concerning administration of the Western region, 426, 43I, 433, $439,442-444$

Fourteenth Amendment, effect of, on political status of inhabitants of American dependencies, 566, 567

France, administration of its dependencies by, from 1600 to 1787 , II-24; from I 787 to I9O2, 474489

Franklin, Benjamin, drafts Albany Plan of Union of 1754 , I37 ; quotation from his Reasons and Motives on which the Plan of Union was Formed, r37, 138; examination before the House of Commons in $1766,175,176$; counsels with Lord Chatham concerning latter's Bill, 298; his Canada
Pamphlet, 350 ; his Plan for Settling Two Colonies West of the Allegheny Mountains, 350; regards the Union as the Sovereign of the Western region, $40 \mathrm{I}$

Freeman, Edward A., regards Germany as a Federal Empire, 490; views concerning Imperial Federation, $52 \mathrm{I}$

French Colonial Empire, of 1600 to I 750, 21, 24

French Colonial School, its establishment and objects, 487

French Constitution, of I79I, provisions respecting the dependencies in, 476 ; of 1795 , provisions on same subject in, 476 ; of 1800 , 478 ; of 1814,478 ; of 1830,479 ; of 1848,479 ; of 1852,479 ; of I875, situation respecting dependencies under, 479

French General Assembly, prepares plan for Colonial Constitutions, 475

French Minister for Commerce, in charge of the Colonies between I $88 \mathrm{I}$ and I 890,479

French Minister for the Colonies, appointed in 1894,480

French Minister for the Marine, in charge of the Colonies until after I88I, 479

French National Colonial Congress, of $\mathrm{I} 889$, action regarding French Imperial Council, $48 \mathrm{o}, 48 \mathrm{I}$

French Society for the Abolition of Slavery, effect of, in the. French Colonies, 475

French West Indian Colonies, granted Local Assemblies by Louis XVI., 474 ; Civil Wạr in, 475,477

\section{G}

General Courts of Virginia Company, as Imperial Councils, 57

George III., opposes House of Commions, 130

Georgia, Charter granted in 1732, 88

Germany, character of its Colonial Empire, 490 ; administration of its dependencies by, 489-497

Germany, Emperor of, his powers respecting the dependencies, $49 \mathrm{I}$ 
Gerry, Elbridge, his proposals concerning administration of Northwest Territory, 419, 420, 425, 426

Girault, Arthur, quotation from his Principes de Colonisation et Legislation Coloniale, 93, 477, 483

Government, popular and expert, I-4; division of powers between instrumentalities representing, 46 ; acting and superintending agencies of, 5

Government by affection, as substitute for disposition, 540, 54 I

Grenville, Hon. George, assists IVilliam Knox in writing the pamphlet, The Controversy between Great Britain and the Colonies Reviezued, 224

Grey, Lord, revives Committee of the Privy Council for Trade and Plantations in I849, 506

Grotius, Hugo, his statement in his Peace and $W$ ar, concerning Greek and Roman conception of Imperial power, 44, 472; derivation of "territory," in his Peace and War, $\mathrm{IO}_{3}$

Guadaloupe, granted representation in French General Assembly, 474 ; and in French Parliament, 487, 488

Guilds, their application to colonizing operations, 52-54

\section{$\mathrm{H}$}

Hamilton, Alexander, a FederalImperialist in $\mathbf{I 7 7 4}, \mathbf{2 8 2}$

Hartley, David, his first resolutions for conciliation, 3I5-3I7; his second resolutions, $335-337$

Hawaii, administration of, 572,573

Hillsborough, Lord, first Secretary of State for the Colonies, 221 ; his circular letter to the colonial governors, 250, 25 I

Holland, policy of, respecting its dependencies, 484

Hooper, William, responsible for use of the word "disposition " to express the Imperial power, 349

Hopkins, Stephen, quotation from his pamphlet, The Grievances of the American Colonies Candidly Explained, I54-I56
Huskisson, IVilliam, his views concerning statehood of dependencies, 505

\section{I}

Illinois Company, its claims respecting the Western region, 354

Imperial Council (American), proposed, 588, 589

Imperial Council (British), propositions concerning, 52I-530

Inperial Council (English and British), of 1606 , under Virginia Charter, 36-3 $8,46,47,51$; for Ireland, Lord Bacon's proposition concerning, in $1606,5 \mathrm{I}$; under Virginia Charter of I609, 55-57; under Plymouth Charter Company of 1620,63 ; Privy Council as, under Charles I., 66, 68; appointed by Charles I. in $1634,66-68$; appointed by Lords and Commons in 1643,69 ; ordinance appointing, quoted, 69-72; the Council of State of I650-I65I as, 75 ; the Council of Commerce of I65O as, (Under-Council), 75, 76; Lord Protector's Council of I653 as, 77 ; Council of Commerce of 1655 as, (Under-Council), 77, 78 ; Privy Council as, under Cromwell, 78 ; Council of State of 1658 as, 78 , 79 ; Council of Foreign Plantations of 1660 as, 79-82; Council for Trade and Plantations of 1760 as, (Under-Council), 83-84 ; Committee of Privy Council for Plantations Affairs as, 1670 to I 768 , 84-88 ; Board of Commissioners for Trade and Plantations as, (Under-Council), I696 to I 782 , 84-88; for India in England established in I $854,5 \mathrm{I}$ I-5 I4

Imperial Council (French), its institution and functions, 480, 48I

Imperial Council (German), its institution and functions, 494

Imperial defence, problem of, in British Empire, 530-534; American Union may adjudicate contributions to, 599, 600

Imperial Department, proposed for America, 588

Imperial Federation, movement for, I885-I 895,520 
Imperial obligations, recognition of, by Great Britain, 534-536 ; recognized by U. S. Constitution, 578604

Imperial power, how described by the Greeks and Romans, according to Grotius, 44, 472 ; how described in U.S. Constitution, 445473 ; as described by Congress and the Supreme Court, 537-577

Imperial Secretariat, its functions as described by Pownall, 208-223

Imperial State, expression first used by Sir Francis Bernard, in 1768 , I9I

Imperial Unity, advocated by Pownall in 1764 , $19 \mathrm{I}-207$

India, its political relationship to Great Britain, 508-518; in effect a Federal State under a Substituted Central Government, since 1833, 508, 509 ; Governor-General of, in Council, his dispositive powers, 5 IO, 511 ; Council for, in England, established in $\mathbf{1} 854,5$ I I$5 \mathrm{I} 4$

Indiana Company, its claims respecting the Western region, 354; memorial to Congress of 1779 , 401

Indian tribes in America, instructions to Council for Foreign Plantations of 1670 , concerning, 83 ; British administration of, in 1763 , 142, I43; provisions respecting, in Franklin's draft of Articles of Confederation, 35I ; in Dickinson's draft of Articles of Confederation, $352,353,357,358$; in I784, acknowledged the American Union as their Sovereign, 405; considered by Congress in I 782 to be dependencies of the Union, 4 I 5, 4I6 ; relations with, in charge of Secretary of War from I789 to $\mathbf{r} 849$, in charge of Secretary of the Interior from 1849 to I9O2, 577

Indo-China, French protectorates in, in charge of Minister of Foreign Affairs, 480

Ireland, administration of, from I 495 to I600, 28 ; in I606, 49 ; Lord Bacon's advice concerning colonization of, 50; declared a Province by William III., in I690,
97, 98 ; Franklin's proposal to admit into American Union, 351 ; granted legislative and judicial independence in $1782,498,499$; effect of British concessions on, 499, 500; union of, with Great Britain, I800, 501

Isle of Man, administration of, in I606, 49

\section{J}

James I., proclamation of, relating to Virginia, 64

Jay, John, in $1786-7$, regards Congress as the Sovereign of the American Union, 406

Jefferson, Thomas, his views in 1774 concerning relationship between Great Britain and the American Colonies, I88, I89, 282; his views concerning Lord Chatham's Bill, 319,320 ; his draft of the Declaration on Taking up Arms of 1775 , 320,321 ; his statement of the issues of the American Revolution, 323,324 ; his views in 1775 concerning dependence on Great Britain, 334 ; his draft of the Declaration of Independence remodelled, 343-347; drafts Resolution of 1784 for the government of the Northwest Territory, 420, $42 \mathrm{I}$; his views in 1787 concerning the administration of the Northwest Territory, 431, 432

Jellinek, Dr. Georg, quotation from his work, Das Recht des Modernen Staates, 495

Jersey, Island of, statehood of American Colonies derived from by Pownall, I I I

John, King of England, conception of governmental power in time of, 25,26

Fohnson v. McIntosh (8 Wheaton, 589), decision of Supreme Court concerning political status of the Indian tribes, $547-550$

Judges, legislative powers of, in Northwest Territory, 434, 435

Jurisdiction, meaning of in French. public law, I5

Jurisdiction, meaning of, as applied to the power of a State over its dependencies, $36 \mathrm{I}$ 
$\mathrm{K}$

Kentucky, provisions relating to, in Dickinson's draft of Articles of Confederation, $352,356,362,363$

King in Council, legislative powers of, 264, 265, 273-276, 294, 297

King of France, power of, in administration of dependencies, II-I 8

King of Great Britain, power of, in the American Colonies, I3I, 263$265,273-276,292,293,34 \mathrm{I}-347$; Address of American Colonies to, of $1774,288-293$; of 1775,325 , $326,340,34 \mathrm{I}$

Knox, IVilliam, quotations from his pamphlet, The Controversy between Great Britain and the Colonies Revierved, 225-233, 236, 237

L

Laband, Professor Paul, quotation from his work, Das Staatsrecht des Deutschen Reiches, 492-494

Laisser-aller, period of, in British Colonial policy, 519, 520

Land Companies, provisions concerning, in Dickinson's draft of Articles of Confederation, 353, 354,358 ; their rights adjudicated by Congress in $1783,4 \mathrm{I} 7$

Laud, William, Archbishop of Canterbury, member of Imperial Council of $1634,66,67$

Law of the land, meaning of, in U.S. Constitution, $47 \mathrm{I}$

LeFur, Louis, definition of the Fed. eral Empire in his État Fédéral et Confédération d'États, 490

Legislation, power of Parliament over the American Colonies claimed to be power of, I77I79; power of, distinguished from power to regulate trade by Dickinson, 275-277 ; power of, distinguished from power of disposition in U. S. Constitution, 472 ; power of U. S. Congress over District of Columbia, a power of, 472

Leonard, William, his letters under the name of Massachusettensis, 280

Leroy-Beaulieu, Paul, quotation from his work, De la Colonisation chez les Peuples Modernes, 585

Lewis, Sir George Cornewall, his Government of Dependencies, quoted, 95, 96

Lord Chatham's Bill, quoted, 299304 ; its effect in America, $318-$ 320

Lord North's Conciliation Acts, of I 778, 377-380 ; action of Congress concerning, $380-382$

Lord North's Proposals, of I775, quoted, 309, 310 ; action of Congress concerning, 327-329

Lord Protector's Council, of 1653 , as Imperial Council; 77

Loughborough v. Blake (5 Wheaton, 3I7), Territories distinguished from ultramarine dependencies, 542,543 ; views of Supreme Court concerning the Imperial power expressed in, 543-546

Louis XVI. of France, grants West Indian Colonies local assemblies, 474

Louis XVIII. of France, policy respecting the dependencies, 478 , 479

Louisiana, adminstration of, $\mathrm{ISO}_{4}-$ I $805,539,540$

Lucas, C. P., definition of "province," 95,96

\section{M}

Macaulay, Thomas B., his work in India, 508, 509

Madagascar, in charge of French Minister for Foreign Affairs, $4 \varepsilon_{0}$; statement of French Government regarding effect of annexation of, 484-486

Madison, James, declares American Revolution not based on taxation without representation, 324 ; introduces resolution in Constitutional Convention respecting dependencies, 455, 456

Maine, grant of, by Charles I., 67, 68

Manifesto of 1778 (American), to people of the American Colonies, 387

Manifesto of 1778 (British), to people of the American Colonies, 386 , 387 
Mansfield, Chief Justice, his opinion in Campbell v. Hall, 295, 296

Maori tribes, principle of responsible government extended to, I 852,507

Martinique, granted representation in French General Assembly, 474; represented in French Parliament, 487,488

Maryland, Charter of 1632 granted, 66 ; in $\mathrm{I} 783$ declares American Union the Sovereign of Northwest Territory, 405

Mason, George, views of, concerning powers of Great Britain, 270272

Massachusetts, Act of Cession of November 13, I784, 4I 5

Massachusetts Bay, Charter of 1629 granted, 66, 67; Charter ratified by Imperial Council of 1643,74 ; Charter forfeited in 1684,84 ; Charter of I69I granted, 85 ; as a Province under Charter of I69I, 97 ; in 1692 , claims right to tax itself, I20 ; claim granted b" King in Council in 1735 , 120

Mast-timber Act of r7Io objected to by American Colonies, I2 I

McAllister v. The United States (I4I U. S., I74), view of the Supreme Court concerning the Imperial power in, 561, 562

Mercantile system, acquiesced in by the American Colonies, II9, I2O ; attacked by Adam Smith, I 776,383

Merivale, Herman, quotation from his Lectures on Colonization and Colonies, 505

Meyer, Professor Georg, his views concerning statehood of the German dependencies in Die Staatsrechtliche Stellung der Deutschen Schutzgebiete, 496

Monroe, James, his plan for the government of the Northwest Territory, 430, 43I

Mormon Church v. The United States (1 36 U. S., I), view of the Supreme Court concerning the Imperial power in, 560

Morris, Gouverneur, his characteristics, and his standing in the Continental Congress of 1778,378 , 379; his Observations on the
American Revolution, 388-395; in 1784 regards Congress as the Sovereign of the American Union, 405 ; his resolutions in the Constitutional Convention respecting the dependencies, 458-465; his statement in $\mathrm{I} 804$ regarding the Imperial clause of the U. S. Constitution, 538, 539

Murphy v. Ramsey (I 4 U. S., I5), view of the Supreme Court concerning the Imperial power in, 559

\section{$\mathrm{N}$}

Napoleon I., his policy towards the French Colonies, 477,478

National Bank v. County of Yankton (IOI U. S., 129), view of the Supreme Court concerning the Imperial power in, 558,559

Navigation Act of $165 \mathrm{I}$, its purpose and effect, 76, II9; of 1663 , II9 ; of 1696 , II6, II

Needful rules and regulations, meaning of, in the Imperial clause of the U. S. Constitution, 460-462

New States, power of admission of, into American Union, 465, 466

New York, provisions of deed of cession of March I, I78I, 4I 5

Niles, Hezekiah, quotation from his Princifles and Acts of the Revolution, 258

North Carolina, established in 1729 , 88

North, Lord, his proposals to the American Colonies, 3IO, 3II ; action of Congress concerning, 327329 ; his views concerning responsibility of the Cabinet to the House of Commons, 338, 339; his Conciliation Acts of $1778,377-$ 380 ; action of Congress concerning, $380-382$

Northwest Territory, provisions of Dickinson's draft of Articles of Confederation relating to, 352 . $354-356, \quad 35^{8}-362$; claim of American Union to, 403-405: Resolution of October IO, I780, concerning, 4I2-4I5 ; original report concerning administration of, 4I9; Resolution of 1784 concerning, 420-427; difficulties in 


\section{Index}

Northwest Territory-Continued administration of, 427-429 ; Ordinance of 1787 for the government of, 429-444; adaptation of Ordinance of $I 787$ to.U. S. Constitution by Act of $1789,537,538$; administration of, from 1787 to I 800,538

Norton, Lord Chancellor, quotation from his article How Not to Re. tain the Colonies, 533

\section{$\mathrm{O}$}

Ohio Company, its claims respecting the Western region, 354

Ordinance, meaning of, as used by Congress of the Confederation, 408

Ordinance of $\mathrm{I} 643$, for regulating the Plantations, 69-72

Ordinance of 1787 , for government of Northwest Territory, as originally reported, $433-437$; as amended in Committee and by Congress, 437-440; Articles of Compact in, 440-442; FederalImperialist theories evidenced by form of Ordinance, 442-444

Ordonnance, meaning of, in French public law, 16

Otis, James, quotation from The Rights of the Colonies Asserted and Proved, I5I-I 53

\section{$\mathrm{P}$}

Parkin, George R., quotation from his Imperial Federation concerning an Imperial Council, 523-526

Parliament (British), power of, as claimed by Massachusetts Bay in I646, II3, II4; power exercised by, prior to 1750 , II3-II 7 ; British claims concerning power of, I764, 132; in Tariff Act of I764, r 45 ; in Stamp Act, I49 ; views of James Otis (I764), I5I, I52; of Daniel Dulany (I765), I53, I54 ; of Stephen Hopkins (I 765), I 54I56 ; claim of American Colonies in $1765,159-161$; Declaratory Act of I 766, I 77-I 79; views of John Dickinson (1767), I80-190 ; of Thomas Pownall (I 768), rg6207 ; of William Knox and George
Grenville (I769), 224-247 ; of James Wilson (I774), 262 ; of Edmund Burke (I774), 269 ; of John Dickinson (I 774), 272-279; power of, recognized by Continental Congress (I774), 284, 286; declared by Lord Chatham to have a superintending power (I775), 300, 307 ; views of Edmund Burke concerning power of (I775), 338 ; of Lord North (I775), 338, 339; of the Continental Congress, 339, 340, 394 ; modern views, 532, 533

Parliamentary Settlement, with the American Colonies, advocated ty Sir Francis Bernard, 264, 265

Pennsylvania, Charter granted in I68I, 84; position of General Assembly in 1765 regarding taxation, I57

Personality, dependencies may be conceived of as possessing political, 7, 8 ; claim of American Colonies to political, 239, 395-399

Petit, Edouard, views of, in his Principes de Colonisation et de Législation Coloniale, 483

Petit, Émilien, quotation from his Dissertations sur le Droit Public des Colonies Françoises Espagnoles et Angloises, I 7 ; from his Droit Public ou Gouvernement des Colonies Françoises, 23

Philippine Islands, American administration of, 574,575 ; in charge of Secretary of War, 577

Pitt, William (Earl of Chatham), speech regarding Stamp Act, I73I75; see also Lord Chatham

Plan of Union, of 1754 , its provisions regarding dependencies, I35-I4I

Plantation, meaning of, 92

Plantations Branch of the Home Office (British), administration of the Colonies by, from $\mathrm{I}_{7} 82$ to I 786, 500

Plymouth Company, of 1620 , as an Imperial Council, 63

Pollock, Sir Frederick, views of, concerning an Imperial Council, 524,525

Popham, Lord Chief Justice, drafts Virginia Charter of 1606,36

Popular government, defined, I ; implies unconditional power, 2 ; 
Popular government-Continued may exist in any form of State, 24 ; no modern State wholly under, 4

Porto Rico, special tariff for, held valid, 562, 563; administration of, 574

Post Office Act, of $x 707$, objected to by American Colonies, I 2 I

Pownall, Thomas, quotation from his book, The Administration of the Colonies, III, II2, I92, 2 IO220

Poynings' Law, in Ireland, its provisions, 50

Pradier-Fodéré, M., derivation of " territory" in his Traité de Droit International Public, $\mathrm{IO}_{3}$

President of the United States, his constitutional powers respecting the dependencies, 445-453; powers actually exercised by him, 574 ; properly the active administrator of the insular dependencies, 58r587, 593, 594

Privileged Companies (English), their institution and objects, 5254

Privileged Companies (French), their institution and objects, I8, Io

Privy Council, institution of, 26 ; as Imperial Council under Charles I., 66, 68 ; under Cromwell, 78 ; Committee of, under Charles II., as Imperial Council, 84 ; Committee of, for Plantations Affairs, continued from I675 until I782 as Imperial Council, 88 ; same Committee revived in 1784,500 ; ceased to exist in I800, 50I ; same Committee temporarily revived in I849, 506

Property, dependencies as, of the State, 247, 248; meaning of, as applied to dependencies, 36I ; meaning of, in Imperial clause of U. S. Constitution, 463,464

Protectorate over uncivilized tribes, or constitutional protectorate, meaning of, 353

Providence Plantations, Charter of I644, its provisions, 72, 73

Province, meaning of, 94-100

Pym, John, member of Imperial Council of $1643,69-71,73$
Q

Quebec Act, of $\mathbf{1 7 7 4}$, objections of American Colonies to, 259

R

Raleigh, Sir Walter, as Lord Proprietor of Carolina, 29, 30

Regulation, meaning of, in the public law, I39-r4I

Regulation, plenary power of, included in disposition, 4I9-444

Regulation of trade, power of, distinguished from legislation, 275277

Reichsland distinguished from Schutzgebiete by German Government, 49I

Representation of American Còlonies in Parliament, regarded by them as impracticable, I6r, I62: views of Sir Francis Bernard (I764), I II-I 73; views of Thomas Pownall (I 768), 197-207

Representation on the State of the Colonies, of 1754, quoted, I36, I37

Resolution, meaning of, as used by Congress, 408, 409

Resolutions of Congress, of 1765 , concerning Stamp Act, I59-166 ; of 1774 , declaring rights and grievances, $283-285$; of 1775 , concerning Lord North's proposals, 327-329, 332, 333; of September 6, 1780 , recommending cessions, 412 ; of October Io, I $7 \mathrm{SO}$, regarding disposition of the Western region, 4I2-4I5; of 1784 , for the government of the Northwest Territory, 420-427

Responsible government, definition of by Lord Durham, 1839, 502, 503 ; Canadian view of, in I84I, 503,504 ; principle of, universalized, I854-I902, 507, 508, $5 \mathrm{I8}$; application of principle of, to India, 518

Réunion, Island of, represented in French Parliament, 487, 488

Rhode Island, Charter of 1663 granted, 82

Rose v. Himely (4 Cranch, 24I), view of Supreme Court regarding colonial relationship in, 508 
Rougier, J. C. Paul, quotation from his Précis de Législation et d'Économie Coloniale, 489

Rules and regulations respecting the dependencies, meaning of, in U. S. Constitution, 459

\section{$\mathrm{S}$}

Salisbury, Lord, views of, concerning Imperial Federation, 520, $52 \mathrm{I}$

San Domingo, granted representation in French General Assembly, 474

Sandys, Sir Edwin, assists in argument of Case of the Postnati, 35 ; his actions as Treasurer of Virginia Company, 58-62

Schutzgebiete, administration of, by Germany, 493-495

Scott v. Sand ford (I9 Howard, 393), view of the Supreme Court concerning the Imperial power in, 556,557

Secretary of the Interior (American), acting Secretary for the Territories since 1873,576

Secretary of State for the Colonies, in Great Britain, proposed by Pownall, I764, 208-221; appointed in 1768,221 ; office abolished in 1782,498 ; Secretary of State for Southern Department as acting, I782-I794, 209, 210, 500,501 ; Secretary of State for War as acting, I794-I854, 501 ; office re-established, I854, 507

Secretary of State (for Foreign Affairs), (American), acting Secretary of State for the Territories, $1787-1873,576$

Secretary of State for the Southern Department (British), acting Secretary of State for the Colonies until $\mathrm{I} 768$, and from $\mathrm{I} 782$ to $\mathrm{I}_{794}$, 209, 2 IO, 500, 50I

Secretary of State for War (British), acting Secretary of State for the Colonies, I 794-I854, 50 I

Secretary of War (American), in charge of Indian Affairs, I7S9I894, in charge of affairs with Philippine Islands, I 899-I902, 577

Seeley, Sir John R., quotation from his Expansion of England, regarding India, 5 I4-516
Sere v. Pitot (6 Cranch, 366), views of Supreme Court concerning the Imperial power in, 542

Slavery, effect of abolition of, in French dependencies, 476

Smith, Adam, views of, concerning colonial relationship, in his Inquiry into the Nature and Causes of the Wealth of Nations, 383

South Carolina established in 1729 . 88

Sovereignty, meaning of, as applied to relationship of the American Union to its dependencies, 4OI407

Stamp Act of 1765 , its provisions and their effect, I48-I5O; repeal of, I 76

Stamp Act Congress, its proceedings, $158-168$

State, political personality of the, 6 ; power over external lands and populations as dependencies, 6-8

Statehood of the American Colonies, a fact under American Constitution of 1750,125 ; resolution of Stamp Act Congress a demand for, I6r, 162 ; effect of a criticism of William Knox in strengthening the American position, 238, 239; American ultimatum of 1774 a demand for, 290-293, 329-333

Statehood in American Union, American dependencies not necessarily entitled to, 468

Stengel, Carl von, his views concerning statehood of the German dependencies in his book, Die Deutschen Schutzgebiete, 496

Subjection, declared by Continental Congress to be conditional, 39I395; meaning of, in a Federal Empire, 395

Superintendence, used by Daniel Dulany in $\mathrm{I} 765$ to express the Imperial power, I54 ; used by Burke in 1774,269 ; used by Lord Chatham in 1775, 299-304; used by Committee of the Congress of the Confederation in $17 \mathrm{~S}_{2}, 404$

Supreme Court of the United States, its views concerning the Imperial power of the American Union, $542-552,556-572$; its power as the Supreme Court of the American Empire, 597 
$\mathrm{T}$

Tariff Act, of 1764 , its provisions and effect, I44-148; of $1767,179,180$ Tariff - Union between American Union and its dependenicies permissible, 598, 599

Taxation, of American Colonies, British claims yielded by King in Council in I735, 120; internal and, external, the Pennsylvania view of, in $1765, \mathrm{I} 57$; power of Parliament in matter of, denied, I62-I64; American Colonies consider purpose of, immaterial, $\mathrm{I}_{3}$, I64; views of William Pitt (Earl of Chatham) in 1766, I 73-175; internal and external, distinction advocated by Pitt, I75; internal and external, distinction advocated by Franklin in 1766, I75, I 76 ; views of John Dickinson in I767, r86-I 88 ; views of Thomas Pownall in I768, 197-207; internal and external, argument of William Knox, 228, 229; for regulation of trade and for revenue, argument of William Knox, I769, 230-236; question concerning power of, not the main issue of American Revolution, 323, 324

Tea, connection of East India Company with importation of, 253257 ; Tariff Acts relating to, 254

Territorial Delegate in Congress, same as Colonial Agent, 422

Territories of the United States, distinguished by Supreme Court from other dependencies, 542,543 ; relations with, in charge of Secretary of State (for Foreign Affairs), $1787-1873,576$; in charge of Sec. retary of the Interior, I873-I9O2, 576; Congressional administra. tion of, proper, 59I-593

Territory, meaning of, I03-ro8; meaning of, in U.S. Constitution, 462,463

Thring, Lord, views of, concerning an Imperial Council, 525, 526

Thurlow, Attorney-General, lan. guage used in Camplell v. Hall concerning power of the King in the Empire, 295

Todd, Alpheus, quotations from his book, Parliamentary Government in the British Colonies, 530, 53I, 533,534

Treaties of Alliance and Commerce with France, of 1778 , their recognition of the American Empire, 374-377

Treaty of Paris, of $I_{7} 6_{3}$, provisions respecting America, I4I, I42

Tunis, in charge of French Minister of Foreign Affairs, 480 ; a constitutional protectorate of France, 488

\section{U}

Ulster, colonization of, by Great Britain, 49, 54

Ultimatum of the American Colonies to Great Britain, I774, 280-. 293

United States, meaning of, in U.S. Constitution, 469

\section{V}

Vandalia Company, its claims respecting the Western region, 354 ; its memorial to Congress, of 1779 , 4 or

Vane, Sir Henry, member of Imperial Council of $1643,69-71,73$

Varro, M. Terentius, his derivation of "territory," r04

Vattel, quotation from his Law of Nations, I3, I4, I40

Vermont, provisions concerning, in Dickinson's draft of Articles of Confederation, $352,356,363$; its rights adjudicated by Congress in I784, 4I 7

Virginia, characteristics of Charter of $1606,37-49$; Charter of r6og, its purpose and effect, 55-57; Charter of $16 I I$, its purpose and effect, 57, 58 ; Ordinance of 1621 , recognizing statehood of, 59-6I; forfeiture of Charters in 1624,62 ; called a "Dominion" until r7oo, thenceforward a "Province," 99 ; Articles of Surrender of I65I, II5

W

Wabash Company, its claims respecting the Western region, 354 


\section{Index}

Washington, George, views of, concerning the colonial relationship, 270-273

West India Islands, Franklin's proposal to admit into the American Union, 35I

Wilkinson, Spencer, quotation from The Nation's A wakening, 534-536

William the Conqueror, conception of governmental power in time of, 25

William III., of England, his ad-

ministration of colonial affairs, 84-88

Williams, Roger, agent of Providence Plantations, 68

Wilson, James, quotation from his pamphlet, Considerations on the Nature and Extent of the Legislative Authority of the British Parliament, 26r-263; his reply to John Dickinson, 264, 265

Wodehouse, Sir P., in 1870 regards British Empire as temporary, 519

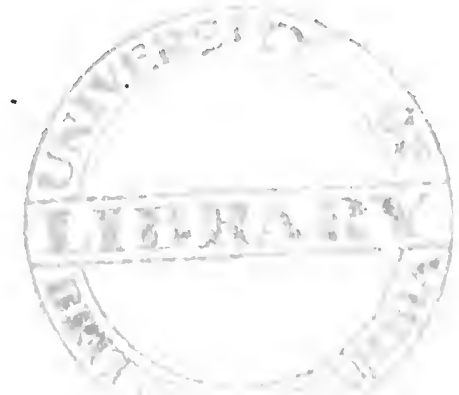






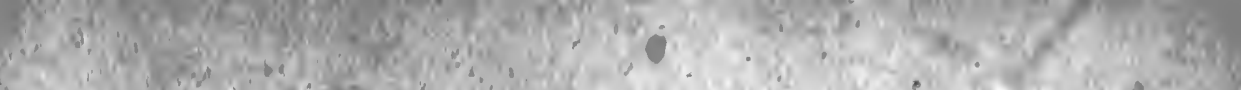

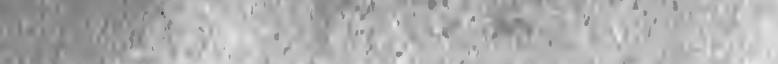

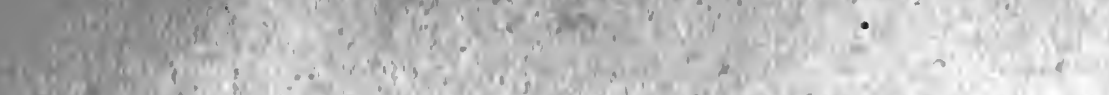

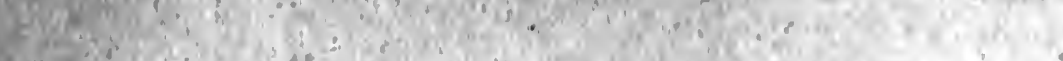
thencis:

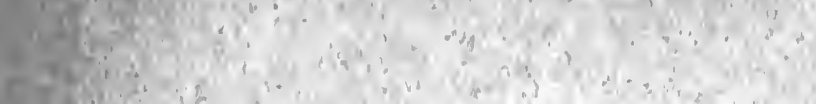

Q.

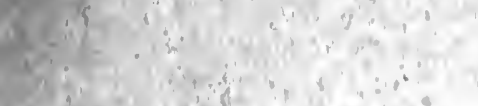

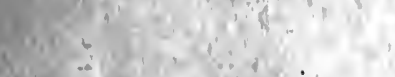

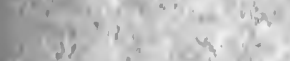

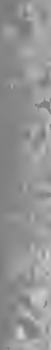

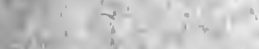

$x^{2}=x^{2}(x)$

as 2.0

scis

as.

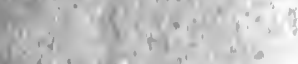

Silicicis is

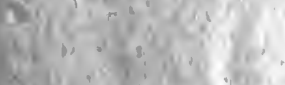

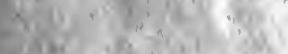

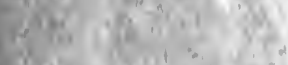

Y.

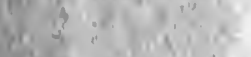

1055: Wh

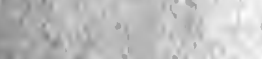

$260,5=2$

is bents?

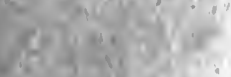

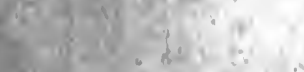

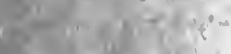

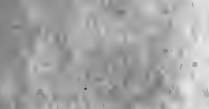

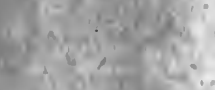

whersin

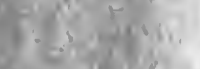

$y^{2}=4 x^{2}=3$

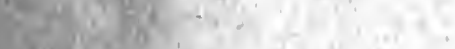

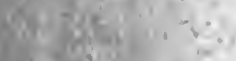

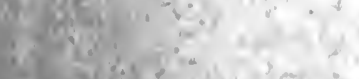

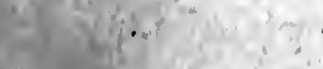

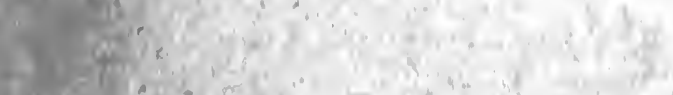

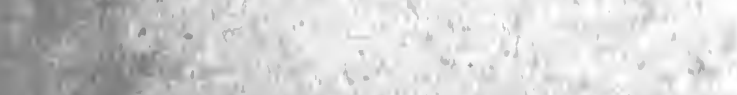
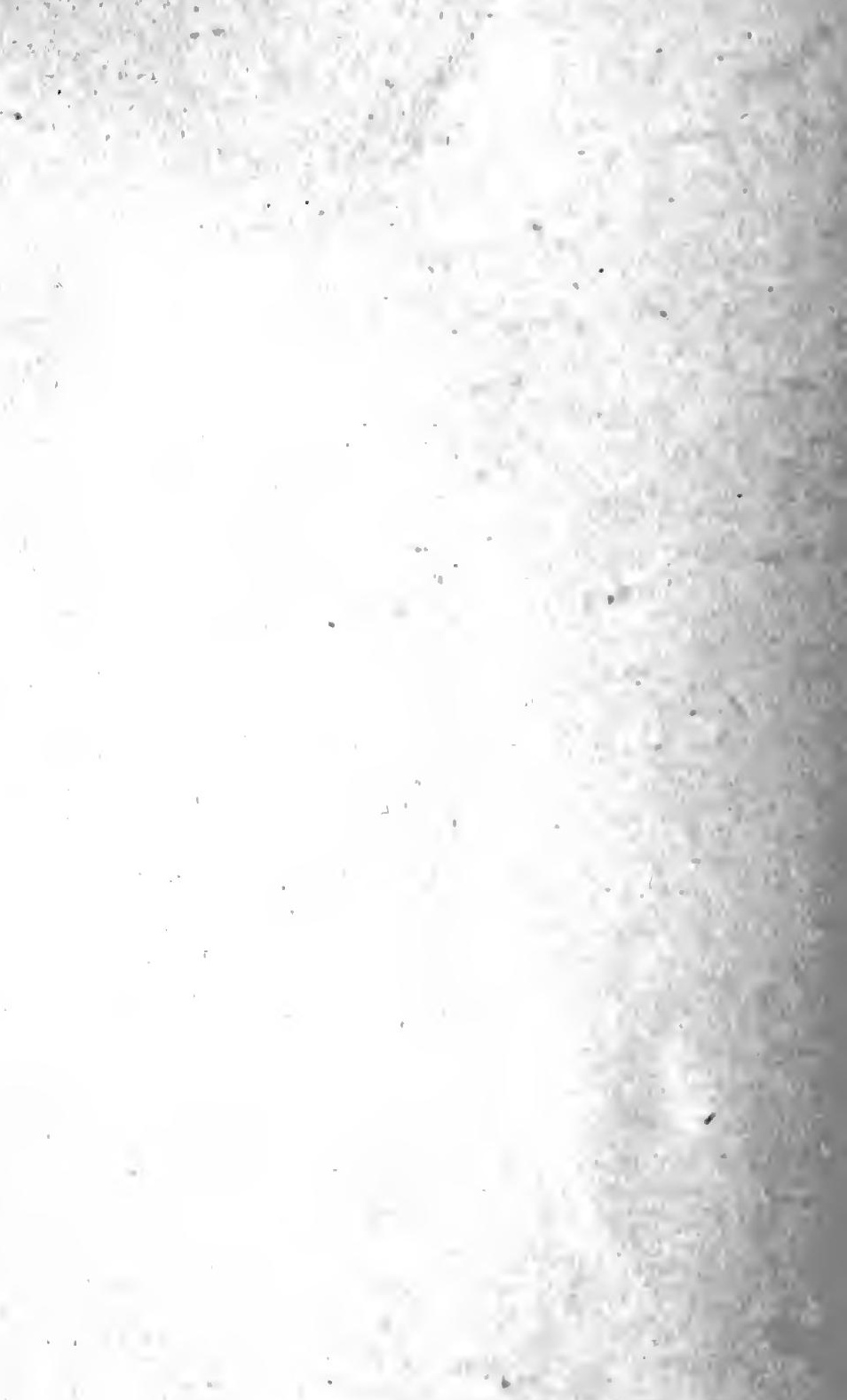

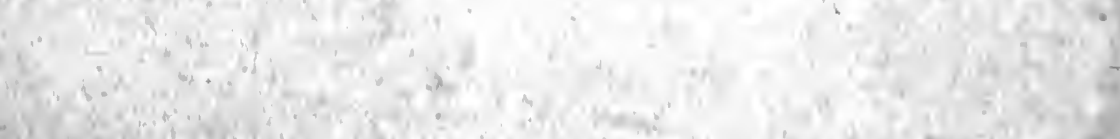

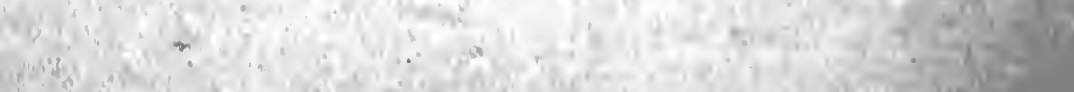

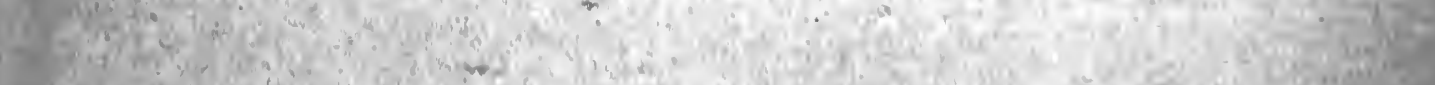

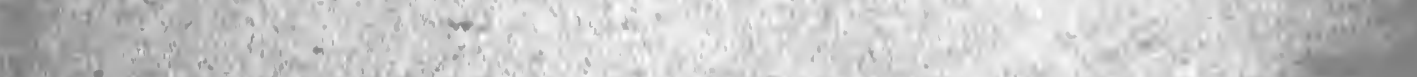

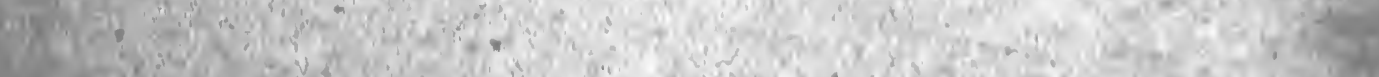

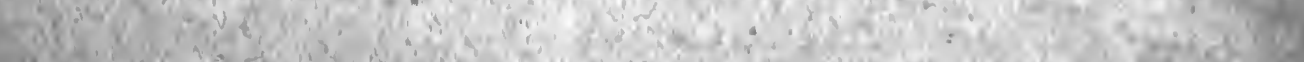
70.

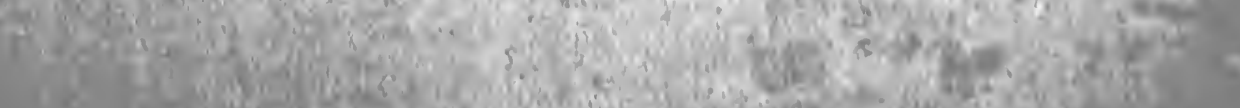

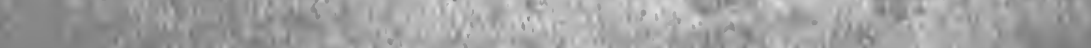
m. 


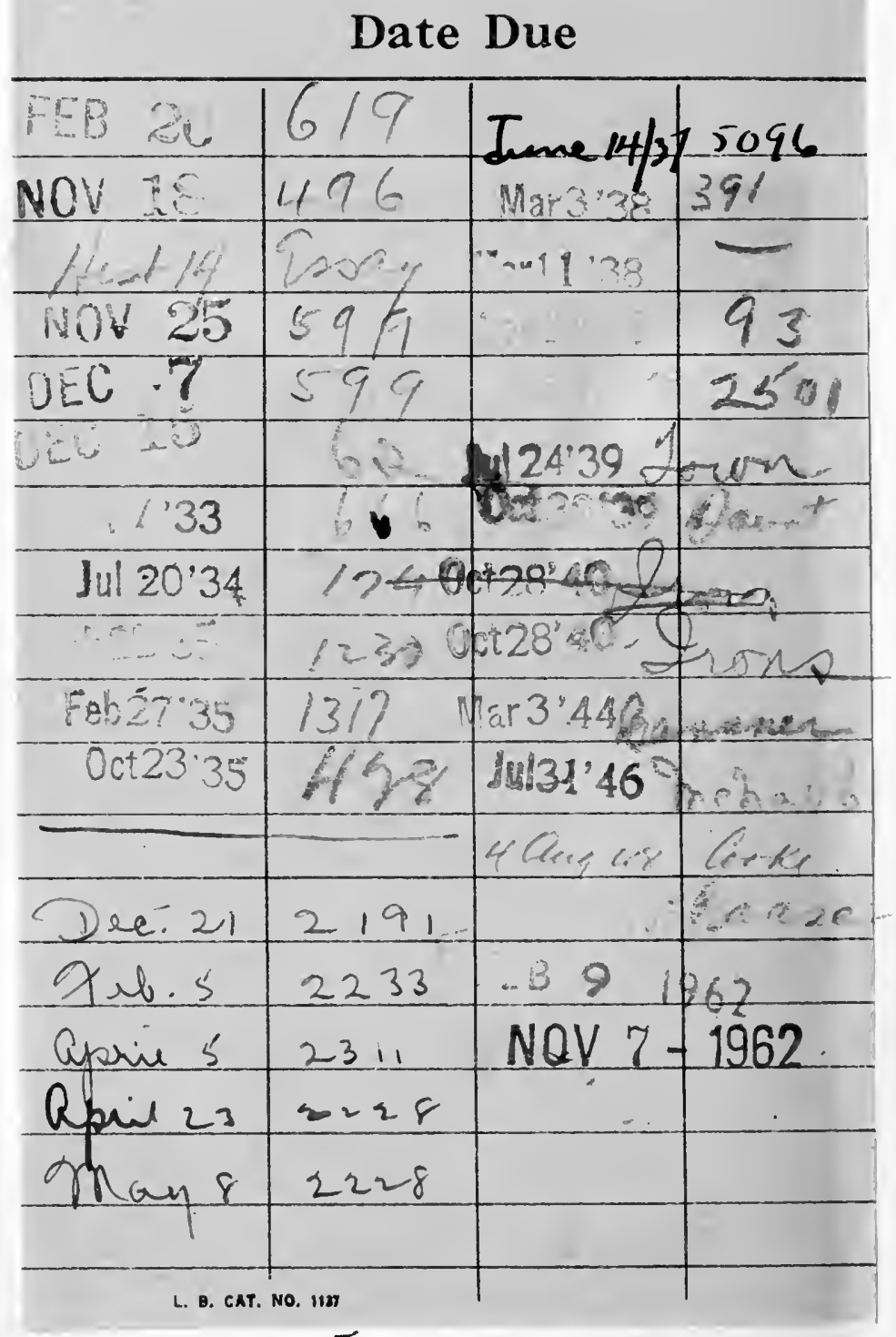



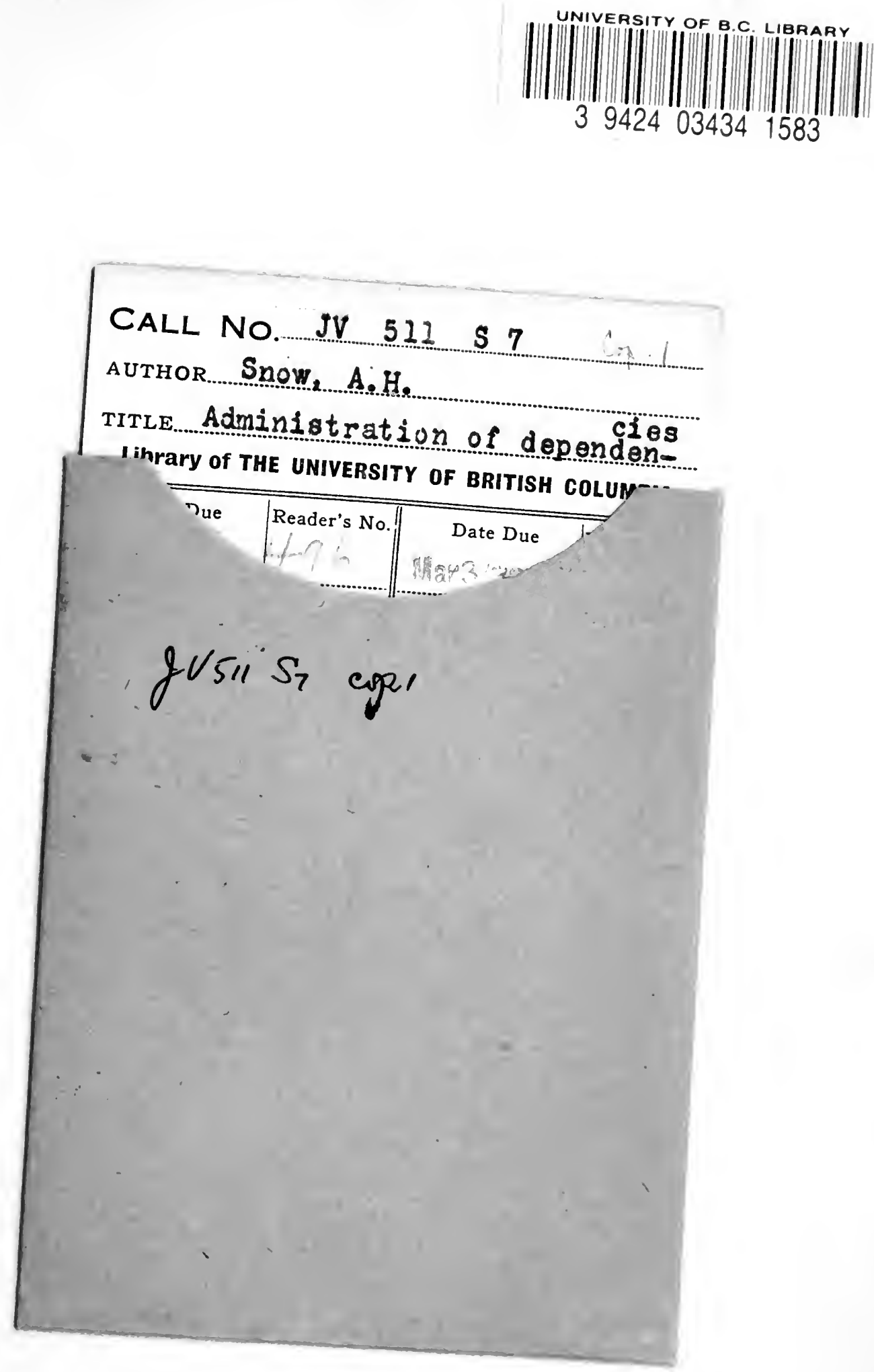
nisitit
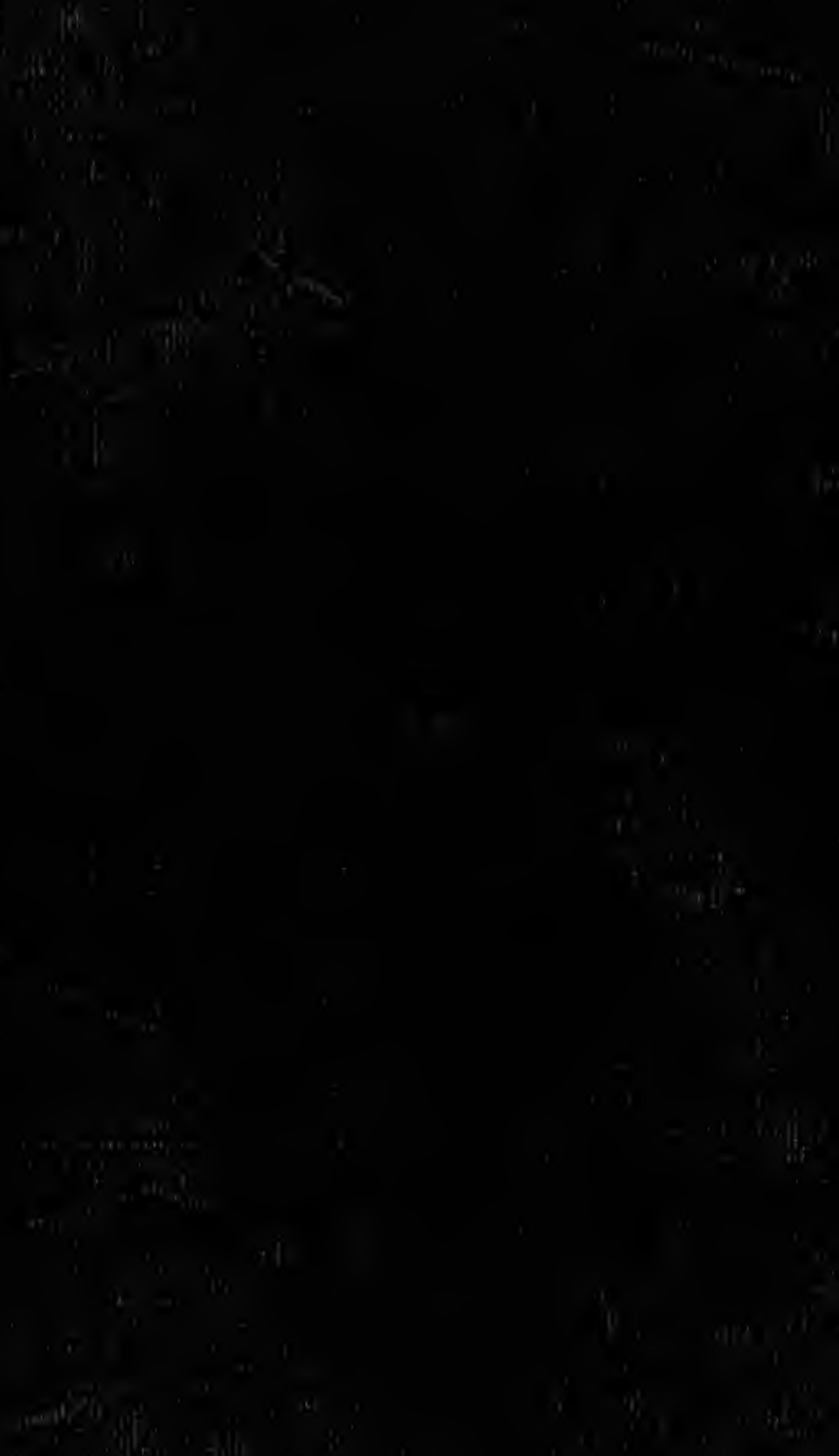